2015

\title{
Maopewa iati bi: Takai Tonqyayun Monyton "To abandon so beautiful a Dwelling": Indians in the Kanawha-New River Valley, 1500-1755
}

Isaac J. Emrick

Follow this and additional works at: https://researchrepository.wvu.edu/etd

\section{Recommended Citation}

Emrick, Isaac J., "Maopewa iati bi: Takai Tonqyayun Monyton "To abandon so beautiful a Dwelling": Indians in the Kanawha-New River Valley, 1500-1755" (2015). Graduate Theses, Dissertations, and Problem Reports. 5543.

https://researchrepository.wvu.edu/etd/5543 


\section{Maopewa iati bi: Takai Toñqyayuñ Monyton "To abandon so beautiful a Dwelling": Indians in the Kanawha-New River Valley, 1500-1755}

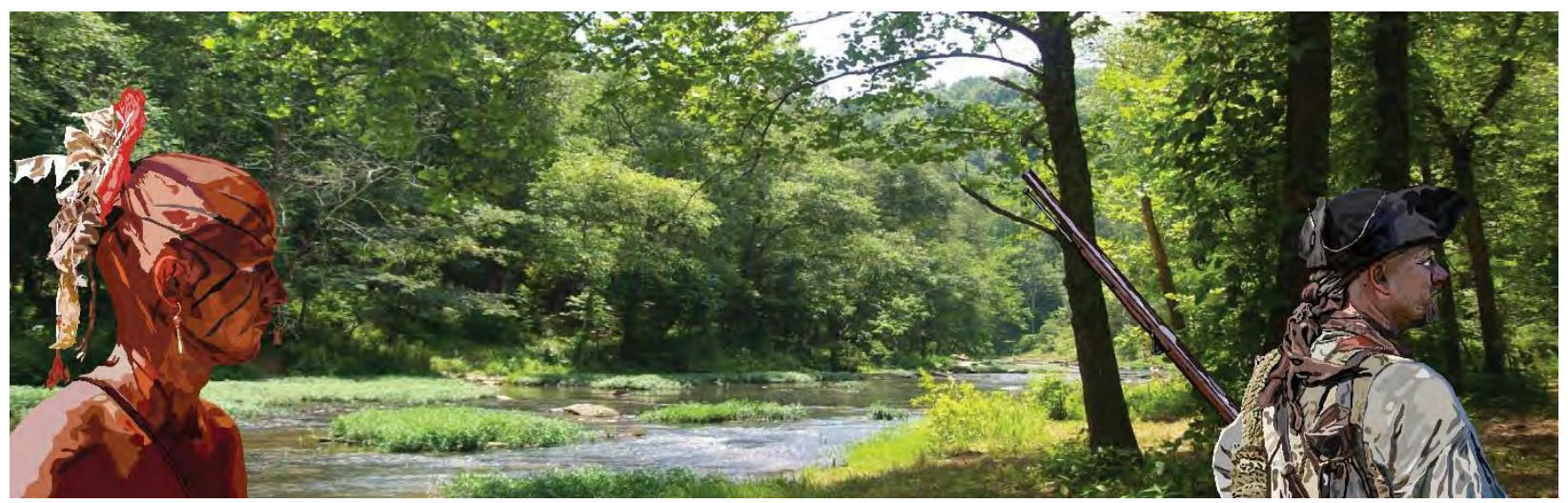

Isaac J. Emrick

Dissertation submitted

to the Eberly College of Arts and Sciences

at West Virginia University

in partial fulfillment of the requirements

for the degree of

Doctor of Philosophy in

History

Tyler Boulware, Ph.D., Chair

Kenneth Fones-Wolf, Ph.D.

Joseph Hodge, Ph.D.

Michele Stephens, Ph.D.

Department of History

$\&$

Amy Hirshman, Ph.D.

Department of Sociology and Anthropology

Morgantown, West Virginia

2015

Keywords: Native Americans, Indian History, West Virginia History, Colonial North America, Diaspora, Environmental History, Archaeology

Copyright 2015 Isaac J. Emrick 


\begin{abstract}
Maopewa iati bi: Takai Toñqyayuñ Monyton

"To abandon so beautiful a Dwelling": Indians in the Kanawha-New River Valley, 1500-1755

Isaac J. Emrick

Maopewa iati bi is a Tutelo translation of William Byrd's eighteenth century quote "To abandon so beautiful a Dwelling." The quotes sets the stage for this examination of the indigenous landscape history of the eastern half of the Middle Ohio River Valley. The region, or Okahok amai, was the homeland of Siouan speakers, but passed from Siouan control into Iroquoian and Algonquian hands around turn of the eighteenth century. Not long afterward Indians, pressured by British and French citizens and governments, were forced to again fight to maintain their hard won new homes. By the middle of the eighteenth century, control and access had begun to shift to the growing number of European settlers gaining a permanent foothold in the former Okahok amai.
\end{abstract}

Residents of the Okahok amai were adept at adapting to ever-changing social circumstances, but they also adapted to economic and environmental processes as well. The environment played a large role in the process of the many diasporas from and through the Middle Ohio Valley. These diasporas stemmed from seventeenth-century demographic and environmental crises, or shatter zones, but also connected the remaining residents to communities across the entire eastern half of North America. These kinship connections became important avenues for survival during the early eighteenth century. Whether Monyton, Tutelo, or Shawnee, the Wahtakai, or Indians as the English referred to them, also remained connected to the former Okahok amai.

Maopewa iati bi also challenges many of the myths of the Ohio region, especially the one that refers to the region as merely a "common hunting ground." While outlining the complicated 
history of Wahtakai in the Okahok amai beginning in the sixteenth century, my research deconstructs the history of the misunderstandings of the "hunting ground" culturally, geographically, and temporally. This alters and complicates the indigenous cultural landscape assumptions of Seven Years' War historiography when the Ohio enters the colonial consciousness.

The story of this part of the Ohio Valley has been obscured through time but has been carefully reconstructed to show that the historical, cultural, and political importance of this region for indigenous peoples was much deeper and more complicated than previously thought. 
Dedication

Si c'est possible, c'est fait; impossible? Cela se fera.

The difficult is done at once, the impossible takes a little longer.

Charles Alexandre de Calonne, Finance Minister to Louis XIV, circa 1783

One fool may ask more than seven wise men can answer.

Torriano, Piazza universal di proverbi italiani, 1666

I dedicate this manifestation of nearly fifteen years of my life first and foremost to the peoples I hopefully represent and give voice to throughout, the Monyton and other residents of the Okahok amai. Through this, and my future endeavors, I hope to return you to the story of the indigenous past of the Americas. But of course there so many people, in the present, that I must include that have come along with me for this ride. My son Kelan was born in the midst of my return to graduate work in 2007 . He has never known me to be without this other world ever present in my mind. He has been amazingly patient. My wife, Rebecca, mo Beannu, came into this in the midst of writing the final roughest chapters of my career so far. Many nights have I cloistered in the basement ranting about the minutiae of people she never knew existed. She has made the many sacrifices that three years have brought to finally finish this project. I also have an extensive and complicated family that I like to dedicate this to. My father and mother, after so many years, I am done with the dissertation, for a few months at least. They have supported me by listening to my often long-winded attempts to explain what the heck I am actually doing. My sister has patiently and lovingly sat through most of these discussions, or kept Kelan occupied through them. LeeAnne, it's done; you were important from the beginning too. Thank you. My final dedication goes to the myriad indigenous peoples I have worked with and talk about in my writings. I am a poor vessel, limited in ability, but I hope to do justice to your histories. I may not be able to correct the injustices of the past, but I hope to not add to them. Thank you for the many whom have put your faith in my work that I can bring these stories back to life. 
Acknowledgements

The historian ought to be the humblest of men; he is faced a dozen times a day with the evidence of his own ignorance; he is perpetually confronted with his own humiliating inability to interpret his material correctly; he is, in a sense that no other writer is, in bondage to that material.

C. V. Wedgwood

So many people have provided assistance in the process of this massive project. I must of course begin with the two advisors I had at West Virginia University, Drs. Mary Lou Lustig and Tyler Boulware. Dr. Lustig shaped my Masters research that became the middle portion of this dissertation, whether it was through grammatical boot-camps or pointing out historical logical fallacies. Dr. Boulware, the chair of my dissertation committee, has provided the freedom to go out on a historical limb and found ways to get me through the difficulties of navigating not only academic but also real world issues. Drs. Silvermoon, Kenneth Fones-Wolf, Joseph Hodge, Ronald Lewis and Barbara Rasmussen all sat with me frequently to make helpful suggestions as I began this project. Bonnie Brown from Native American Studies, and archaeologists Patricia Rice and Dr. Amy Hirshman were pivotal in making sure my science was precise. Martha and Becky, in the History office, offered their frequent assistance helping me navigate the complexities of travel grants, tuition waivers, and occasional photo copies. I am forever indebted to the welcoming family of the History Department graduate students under the stairs. Not only did they share research they thought would help me, but we helped keep each other sane through many long study sessions.

I also received a great deal of support from the Department of Geology and Geography at WVU, especially those working in GIS. Drs. Gregory Elmes and Trevor Harris shaped the development and expectations of my geodatabase work. The technical support provided by Frank Lafone in the GIS Tech Center also guided me through the morass of technical issues I frequently found developing digital history materials. Conversations with Dr. Amy Hessl helped 
steer me through paleoclimatology, avoiding some major pitfalls; I am forever in your debt. The department's many grad students were very patient with the random historian that occasionally showed up asking obvious questions.

I also must thank the staff at Wise Library on the Downtown Campus of West Virginia University. The reference and ILL staff handled my numerous daily requests with great speed often getting materials digitally that I would have missed. Likewise, the staff at the West Virginia collection helped me dig through the archival materials they had to gather the oldest references to Indians.

My second home, another welcoming family, has been the archaeological community in West Virginia. We're a close-knit bunch, and though I am more historian than archaeologist, they welcomed me and provided me access to hard-to-find research materials and forced me to question things in new ways. The members of the West Virginia Archaeological Society and Council of West Virginia Archaeology were invaluable resources. In particular, I must thank Bob Maslowski and Darla Spencer for their continued support and advice. Much of this project is due to their vast research and many questions. West Virginia's State Historic Preservation Office in Charleston provided me frequent access to archaeological site files. The Virginia Department of Historic Resources welcomed me in the summer of 2010 as I was beginning the second phase of my research. The wealth of materials and their continued access to the archaeological site files and databases thankfully solved some major cultural affiliation issues in the West Virginia materials. While visiting Richmond in 2010, I also visited the Virginia Historical Society and the Library of Virginia. The library staff at each facility graciously helped with what probably seemed an odd fishing expedition. The Virginia Historical Society has continued to provide useful documents as I have asked for them to be scanned and emailed. 
At last I come to the greatest supporters of this work, my dear compatriots Jason Roberts, Laura Nelson, Ben Scharff, Jinny Turman, and Kat Fitchel. These five have in their various ways been the sounding boards for all these ideas. Even when they shook their heads and wondered what hair-brained idea I was getting into next, they found ways to keep me grounded. Laura and Jason even went so far as to accompany me on a wild ride through southern West Virginia back roads to capture landscape data and scope out possible village sites.

Finally, I cannot forget two others that have read, edited, and commented on this work. Joe Candillo has with kind words propelled me through the last phases of this process, himself a recent $\mathrm{PhD}$ graduate. Many hours have we batted around the ideas and events contained below. I will end with the invaluable contribution of Rebecca, my wife. Her editing, guidance, prodding, and support have pushed me to be so much better, i.e. done, than I was before I met her. It is a blessed person who knowingly marries an academic historian in the final throws of their dissertation.

So many people have helped me along the way towards completion of this dissertation. I have not even remotely named you all. To all those I have left out, thank you! 
Table of Contents

\begin{tabular}{|c|c|}
\hline Title Page & $\mathrm{i}$ \\
\hline Abstract & ii-iii \\
\hline Dedication & iv \\
\hline Acknowledgements & v-vii \\
\hline Table of Contents & viii \\
\hline List of Maps & ix-x \\
\hline List of Tables & $\mathrm{x}$ \\
\hline List of Diagrams & $\mathrm{x}$ \\
\hline Appendices & $\mathrm{xi}$ \\
\hline Prologue: The Hidden World of the Kanawha-New River & $1-35$ \\
\hline I: Wēhē piwa (Summer) 1500-1650 & 36 \\
\hline Chapter 1: Towards a Monyton Okahok amai, $1500-1650$ & $37-58$ \\
\hline Chapter 2: Europeans on the edge of the Monyton Onqyayun, $1500-1650$ & $59-83$ \\
\hline II: Tañyi (Autumn) 1650-1700 & 84 \\
\hline Chapter 3: Preparing the Monyton Onqyayun Shatter Zone, 1650-1680 & $85-120$ \\
\hline Chapter 4: Monyton Diaspora: Refugees, Captives, and Slaves, $1670-1700$ & $121-150$ \\
\hline III: Wāneni (Winter) 1700-1730 & 151 \\
\hline Chapter 5: Monyton Onqyayun Untended, 1700-1730 & $152-172$ \\
\hline $\begin{array}{l}\text { Chapter 6: New Ethnogeographies in the Okahok amai: Reimagining the } \\
\text { Hunting Ground, } 1700-1730\end{array}$ & $173-203$ \\
\hline IV: Wehahempēi (Spring) 1730-1755 & 204 \\
\hline Chapter 7: Foreigners in an Untidy Garden, $1730-1755$ & $205-249$ \\
\hline Epilogue: Tanachrisson and Jumonville, $1754-55$, Arbiters of the Okahok amai & $250-256$ \\
\hline Future Research and the Modern Implications of the Monyton Diaspora & $257-258$ \\
\hline Maps & $259-297$ \\
\hline Tables & $298-313$ \\
\hline Diagrams & $314-324$ \\
\hline Appendix 1: Language Data & $325-327$ \\
\hline Appendix 2: Physical Landscape Data & $328-333$ \\
\hline Appendix 3: Paleo-Climatology Data & $334-352$ \\
\hline Bibliography & $353-389$ \\
\hline
\end{tabular}




\begin{tabular}{|c|c|c|}
\hline \multicolumn{3}{|c|}{ Maps } \\
\hline 0.1 & World of the Okahok amai & 260 \\
\hline 1.1 & Okahok amai: Geographic labels map & 261 \\
\hline 1.2 & Mentioned Archaeological sites $1500-1650$ & 262 \\
\hline 1.3 & Trails & 263 \\
\hline $1.4 \mathrm{a}$ & Z-Twist Percentages at Middle-Late Woodland Sites & 264 \\
\hline $1.4 \mathrm{~b}$ & Z-Twist Percentages at Late Protohistoric Sites & 264 \\
\hline 2.1 & Archaeological Sites with European Materials & 265 \\
\hline $2.2 \mathrm{a}$ & Spanish exploration 1526-1543 & 266 \\
\hline $2.2 \mathrm{~b}$ & Spanish exploration 1543-1600 & 266 \\
\hline 2.3 & French Dutch exploration 1530-1650 & 267 \\
\hline 2.4 & Tsenacomoco exploration $1607-1650$ & 267 \\
\hline 3.1 & European Influence Circa 1650-1680 & 268 \\
\hline 3.2 & English Exploration, 1650-1680 & 268 \\
\hline 3.3 & Bland Expedition, 1650 & 269 \\
\hline 3.4 & Lederer Expedition, 1669-1670 & 269 \\
\hline 3.5 & Batts and Fallam Reconstructions from 1911 and 1987 & 270 \\
\hline $3.6 \mathrm{a}$ & Batts and Fallam Adjusted Reconstruction & 270 \\
\hline $3.6 \mathrm{~b}-\mathrm{c}$ & Batts and Fallam Reconstruction: Stage 1-2 & 271 \\
\hline $3.6 \mathrm{~d}$ & Batts and Fallam Reconstruction: Stage 3 & 272 \\
\hline $3.6 \mathrm{e}$ & Batts and Fallam Reconstruction: Stage 4 Close-up & 272 \\
\hline $3.6 \mathrm{f}$ & Batts and Fallam Reconstruction: Stage 4 & 273 \\
\hline $3.6 \mathrm{~g}$ & Batts and Fallam Reconstruction: Stage 5 & 273 \\
\hline $3.7 \mathrm{a}$ & Needham-Arthur, 1911 & 274 \\
\hline $3.7 \mathrm{~b}$ & Needham-Arthur, 1987 & 274 \\
\hline $3.7 \mathrm{c}$ & Needham and Arthur Adjusted Reconstruction & 275 \\
\hline 3.8 & Reconstructed FA Movements 1600-1700 & 276 \\
\hline 4.1 & French Exploration 1650-1700 & 276 \\
\hline 4.2 & Seventeenth Century Archaeological Phase Changes & 277 \\
\hline $4.3 \mathrm{a}$ & Monyton Diaspora: Slavery 1630-1690 & 278 \\
\hline $4.3 \mathrm{~b}$ & Monyton Diaspora: Height 1650-1695 & 279 \\
\hline $4.3 \mathrm{c}$ & Monyton Diaspora: Extended Exodus 1695-1795 & 280 \\
\hline $4.3 \mathrm{~d}$ & Monyton Diaspora: Remnant Eastern Siouan Communities & 281 \\
\hline 5.1 & Upper Atmosphere Wind Patterns & 282 \\
\hline $5.2 \mathrm{a}$ & Marmet Catchment Map & 283 \\
\hline $5.2 \mathrm{~b}$ & Man Catchment Map & 283 \\
\hline 5.3 & Regional Salt Brines & 284 \\
\hline 6.1 & European Exploration, 1700-1730 & 285 \\
\hline 6.2 & European Settlement 1700-1720 & 286 \\
\hline 7.1 & Shawnee Migration 1650-1760 & 287 \\
\hline 7.2 & European Exploration, 1730-1750 & 288 \\
\hline $7.3 \mathrm{a}$ & Salley $1741-5$ full & 289 \\
\hline $7.3 \mathrm{~b}$ & Salley $1741-2$ region & 290 \\
\hline 7.4 & Land Titles Ohio-Loyal-Greenbrier & 290 \\
\hline 7.5 & Walker 1749 & 291 \\
\hline
\end{tabular}




\begin{tabular}{|l|l|l|}
\hline $7.6 \mathrm{a}$ & Bienville 1749 & 292 \\
\hline $7.6 \mathrm{~b}$ & Bienville August 14-27, 1749 & 293 \\
\hline $7.7 \mathrm{a}$ & Gist $1^{\text {st }}$ Exp. Oct. 31, 1750-May 20, 1751 & 294 \\
\hline $7.7 \mathrm{~b}$ & Gist $2^{\text {nd }}$ Exp. Nov. 4, 1751-March 29, 1752 & 295 \\
\hline E.1 & European Settlement 1740-1760 & 296 \\
\hline E.2 & Locations mentioned, 1750-1755 & 297 \\
\hline
\end{tabular}

\begin{tabular}{|l|l|l|}
\hline \multicolumn{2}{|c|}{ Tables } \\
\hline 1.1 & Time period/Phase table & 299 \\
\hline 1.2 & Archaeological Sites with Shell Gorgets table & 300 \\
\hline 2.1 & Archaeological Sites with European Materials table & 300 \\
\hline 2.2 & Epidemic table 1500-1699 & 301 \\
\hline 3.1 & Batts and Fallam Calculations Tables & 302 \\
\hline 3.2 & Needham and Arthur Calculation Tables & $303-304$ \\
\hline 4.1 a-b & C14 database & $305-306$ \\
\hline 4.2 & Grave data w/ violent deaths/Diseases data & 307 \\
\hline 4.3 & Chronology of Iroquois Raids & 308 \\
\hline 4.4 & Epidemiology Chart & 309 \\
\hline 4.5 & Fauna in the Okahok amai & 310 \\
\hline 4.6 & Flora in the Okahok amai & 310 \\
\hline 4.7 & Southern Native Americans sold in the British slave trade, 1670-1715 & 311 \\
\hline 5.1 & Invasive plant species & 311 \\
\hline 6.1 & Epidemic table 1700-1760 & 312 \\
\hline 7.1 & Treaties mentioned & 313 \\
\hline
\end{tabular}

\begin{tabular}{|l|l|l|}
\hline \multicolumn{2}{|c|}{ Diagrams } \\
\hline 1.1 & Cross-section of 46Ka0009, 46Lg0007 & 315 \\
\hline $1.2 \mathrm{a}$ & Corncob impressions on rim of Buffalo mampi sherd (46Pu0031) & 316 \\
\hline $1.2 \mathrm{~b}$ & Corncob impressions on rim, Burning Spring mampi sherd (46Ka0142) & 316 \\
\hline $1.2 \mathrm{c}$ & Corncob impressions on rim and strap, Marmet mampi sherd (46Ka0009) & 317 \\
\hline $1.2 \mathrm{~d}$ & Corncob impression on rim of Wells site (44Hr0009) Dan River sherd & 317 \\
\hline $1.3 \mathrm{a}-\mathrm{c}$ & Marginella, Olivella, shells beads & 319 \\
\hline $1.4 \mathrm{a}-\mathrm{c}$ & Shell Gorgets from West Virginia Sites & 318 \\
\hline 4.1 & Clay head from Clover area & 319 \\
\hline 5.1 & Model of Human Ecosystem & 320 \\
\hline 5.2 & Adaptive Social Systems & 320 \\
\hline $5.3 \mathrm{a}-\mathrm{b}$ & Forest-edge spread & 321 \\
\hline 5.4 & Forest Succession & 322 \\
\hline 6.1 & A dish and spoon & 322 \\
\hline $6.2 \mathrm{a}-\mathrm{c}$ & Ngram: hunting ground, Indian hunting ground, common hunting ground & 323 \\
\hline 7.1 & Deer skin trade 1700-1758 & 324 \\
\hline
\end{tabular}




\begin{tabular}{|l|l|l|}
\hline \multicolumn{2}{|l|}{ Appendix 1: Language Data } & $326-327$ \\
\hline 1.1 & Landscape Language table & 329 \\
\hline Appendix 2: Physical Landscape Data & $330-332$ \\
\hline 2.1 & Selected Arable Lands (Slope $0^{\circ}-14^{\circ}$ ) & 333 \\
\hline $2.2 \mathrm{a}-\mathrm{c}$ & Chart of Arable Lands by River-Creek & 335 \\
\hline 2.3 & Slope Calculation of Region & 336 \\
\hline Appendix 3: Paleo-Climatology Data & 337 \\
\hline 3.1 & Selected Sites for Climate Data & 337 \\
\hline 3.2 & Regional Mean Annual Precipitation (Inches) & 337 \\
\hline 3.3 & Regional Mean Spring Precipitation (Inches) & 337 \\
\hline 3.4 & Regional Mean Summer Precipitation (Inches) & 338 \\
\hline 3.5 & Regional Mean Fall Precipitation (Inches) & 339 \\
\hline 3.6 & Regional Mean Winter Precipitation (Inches) & 340 \\
\hline 3.7 & Map of Selected PDSI points & 341 \\
\hline $3.8 \mathrm{a}$ & PDSI: 237-247 1500-1760 & 342 \\
\hline $3.8 \mathrm{~b}$ & PDSI: 237-247 1500-1610 & 343 \\
\hline $3.8 \mathrm{c}$ & PDSI: 237-247 1590-1700 & 344 \\
\hline $3.8 \mathrm{~d}$ & PDSI: 237-247 1690-1760 & 345 \\
\hline 3.9 & Pederson et al 2012 & 346 \\
\hline 3.10 & Central US1000 year summer PHDI & 347 \\
\hline 3.11 & Maxwell et al 2012 & 347 \\
\hline $3.12 \mathrm{ab}$ & Solomon paper: Global Temperature Anomaly: 0-2000 & 348 \\
\hline $3.13 \mathrm{a}$ & PDSI 237-247 w/ Maxwell et al 2012: 1500-1630 & 348 \\
\hline $3.13 \mathrm{~b}$ & Absolute Difference: PDSI 237-247 and Maxwell et al 2012: 1500-1630 & 351 \\
\hline $3.13 \mathrm{c}$ & PDSI 237-247 w/ Maxwell et al 2012: 1630-1760 & 350 \\
\hline $3.13 \mathrm{~d}$ & Absolute Difference: PDSI 237-247 and Maxwell et al 2012: 1630-1760 \\
\hline $3.14 \mathrm{a}$ & NDCD Draft 36: Observed US Temp. Change 1901-1960 vs 1991-2011 & 350 \\
\hline $3.14 \mathrm{~b}$ & NCDC Draft 1604: 1700 Years Global Temp. Proxy Data 300-2000AD & 351 \\
\hline 3.15 & SI: Volcanic Ash Volume, 1500-1760 & 36 \\
\hline & & \\
\hline
\end{tabular}




\begin{abstract}
Prologue: The Hidden World of the Kanawha-New River
What we call the beginning is often the end

And to make and end is to make a beginning.

The end is where we start from....
\end{abstract}

We shall not cease from exploration

And the end of all our exploring

Will be to arrive where we started

And know the place for the first time. ${ }^{1}$

Looking out from the palisades surrounding the houses on the floodplain all you could see were cornfields (mataque in Tutelo) between the village (mampi in Tutelo) and the rounded mountains lining each side of the river. The idyllic location of the settlement that would be called Buffalo mampi (village) by archaeologists over three hundred years later was only one of the large mampi (villages) occupying the eastern half of the middle Ohio River Valley during the seventeenth century. The forests (tahkai in Tutelo), mataque (cornfields), mampi (villages), salt brines, caves, and trails scattered throughout the Ohio region are all but forgotten today. Even the mounds that once towered over the river have either been removed by plowing or have paved walkways to their peaks with benches and trashcans for memorials. Much of the American historiography suggests that the Ohio Valley was forgotten land that was easily and quickly occupied by European-American settlers in the eighteenth- and nineteenth-centuries. The following story concerns a landscape and resident indigenous peoples largely hidden from the gaze of history for the past four hundred years. The region briefly came into the spotlight during the 1670 s but the Wahtakai (Indian people) of the Kanawha-New River Valley remained an enigma. Just as suddenly as they had appeared, the people living in the deep valley tributaries of the Ohio disappeared from not only the historical record but also from the archaeological one.

The Kanawha-New River Valley and the adjacent valleys were, and remain, a distinct region environmentally, historically, and culturally (Map 0.1). Bound by the Little Kanawha

\footnotetext{
${ }^{1}$ T. S. Eliot, Four Quartets: Little Gildings V: Lines 1-4...26-29.
} 
River to the north, the high ridges of the Allegheny Mountains to the east, the Big Sandy River to the south and the Ohio River on the west, this region will be referred to by its Tutelo name of Okahok amai (oh-KAH-hok AH-my), which is translated and discussed below. What follows is largely a landscape history that follows the changes in human occupants, internal environmental conditions, and its relationships to other landscapes within North America. Far from the "no man's land" it is often portrayed as in historical literature, the region hosted thousands of residents and in turn the Okahok amai was molded by them to meet their needs. Much like the changing of the seasons, the residents also came and went in cycles throughout the Okahok amai.

The lands south and east of the Ohio, the Okahok amai, were occupied by a succession of indigenous peoples from 1500 to 1755 when control of the region began to shift towards European intruders. The summer of Siouan control ended with the demographic collapse caused by Iroquois depredations, the Southern Indian slave trade and climactic instabilities that weakened mampi agriculture. The following autumn, the mampi disbanded in a diaspora of individuals and families moving towards extended kinship networks established through marriage, adoption and alliances with neighboring mampi and peoples. As winter overtook the region the land laid fallow for thirty or forty years, left to its own ecological and environmental processes with only sporadic human intervention. By 1730, spring had returned, as Algonquian and Iroquoian peoples colonized the Ohio valley in an effort to escape European pressure in the East. Wahtakai control, maintained for at least 15,000 years, became threatened by the British and French as the last memories of Siouan control passed from the region in 1755.

By 1755 , what had been a palisaded mampi with hundreds of residents had become just another scrubby floodplain trampled by increasing numbers of elk and buffalo. Though the homeland of the Siouan speaking peoples had been maintained for at least a millennia, the 
Okahok amai was relegated to the buried remains deep within the archaeological sites. The river that had been identified as Monyton in 1673 had been renamed numerous times as Wood's River, Chinodaista and Conhaway, which is derived today as the Kanawha. The land had been named and used in a variety of ways and was shifting back towards agriculture by the 1750 s after many years of hunting and gathering. The only constant in the Okahok amai was change. As the age of Wahtakai control began to slip, 1755 marked the first permanent British settlements in eastern valleys of the former Okahok amai.

\section{Problems}

This landscape history of the Okahok amai arose out of the simple, if brazen, question of who used to live there and why did they leave? West Virginia students and long-time residents are taught that the state was a "common hunting ground" and that Wahtakai had an extremely limited claim to the land. This glib disclaimer buried in the first few pages of West Virginia history ignores the tens of thousands of archaeological sites and the numerous Wahtakai who at one point occupied them. After my Master's thesis, “The Monyton Diaspora," I became increasingly aware of the hidden connections this region had to the entire eastern half of North America. Who these people were and where they went remained obscured by limited archaeological analysis. The fluorescence of ethnohistory and archaeological research since 2005 has allowed a closer examination of the Okahok amai and its myriad residents and where they went. $^{2}$

The English, and original, title of this work comes from William Byrd II in 1733 in reference to a Cheraw town along what is now known as the Roanoke River. He remarked on the "great misfortune" that must have "obliged" them to leave. James Merrell took this one step

\footnotetext{
${ }^{2}$ Isaac J. Emrick, “The Monyton Diaspora: A History of the Middle Ohio River Valley, 1640-1700” (master's thesis, West Virginia University, 2005).
} 
further by noting that "the very act of leaving was traumatic" for Wahtakai peoples in the context of the seventeenth-century Southeast. Certainly, some aspects of leaving "so beautiful a dwelling" were traumatic but as the examination of the Monyton Onqyayun, the Kanawha-New River Valley, will show that this was more than just a tragedy. This is not the story of a defeated people crumbling in the face of insurmountable pressures. While the Monyton did leave their homes it was not by force alone, as some willingly left to join far-flung allies and family to better access the shifting indigenous trade networks, or to be protected from the Indian slave trade. The region likewise did "appear" to be abandoned until the late eighteenth century, but the effects of Monyton management continued to be felt by all who travelled through the steep river sides even a century later. The Monyton were compelled to leave and may have looked back with some trepidation and homesickness but nonetheless chose to evacuate. ${ }^{3}$

The effects of this removal on the landscape are equally important to examine. After establishing the long-term management techniques the Monyton practiced, the environmenthuman ecological feedback loop can be fleshed out and a model for what happens when humans cease active management can be developed. The vast literature on fallowing, and second generation growth in forests along with new aerial scanning methods have shown places considered "pristine," such as the Amazon, are showing evidence of previous human management. All the historical accounts concerning the Appalachian Mountains discuss the influence of Wahtakai on the landscape whether as "old fields," abandoned mampi or "Indian roads." This will be discussed as part of the systematic management of the landscape. But how

\footnotetext{
${ }^{3}$ James H. Merrell, The Indians New World: Catawbas and Their Neighbors from European Contact through the Era of Removal, (Chapel Hill: Published for the Institute of Early American History and Culture, Williamsburg, Virginia, University of North Carolina Press, 1989), 26-27. Merrell's Quote: "Whatever course each chose, the very act of leaving was traumatic. A people's village and the surrounding area were vital elements of native identity. Here the past lived." Byrd II Quote: "it must have been a great misfortune to them to be obliged to abandon so beautiful a dwelling."
} 
do we examine a landscape left abandoned for several decades? How do we piece together the effects of fallowing? The answers to these questions lead to a detailed reevaluation of the next stage in the process when the region was reoccupied.

What little is known about eighteenth-century Ohio Valley Wahtakai come from the region's allure leading up to and during the Seven Years War. The people who enter the story here include the Shawnee, Delaware, Mingo, Seneca, English, and French. Why were so many people increasingly interested in the seeming backwater of the Ohio River Valley?

Diplomatically, Wahtakai, mostly the Iroquois, claimed the lands as hunting grounds and territories acquired through conquest. While the Cherokee would claim the land south of the Kanawha-New River as their hunting grounds in the 1768 Fort Stanwix negotiations, these were equally tenuous and optimistic expansions of external influence. Shawnee and Delaware, the new residents, had more systemic and dynamic reasons for their interest. The interests of the Europeans have been well covered in other literature and mattered relatively little to Wahtakai on the ground along the Kanawha-New River. The land was so desirable, beyond its distance from prying European eyes and settlers, for the resources that fueled and deepened many indigenous connections to the Europeans distantly surrounding them. How did Shawnee people view and utilize the landscape of the former Okahok amai? What was a hunting ground and how did this concept manifest during the eighteenth century? What other cultural frameworks could be used to better describe the landscape usage found in the eighteenth-century Okahok amai?

\section{Historiography}

The history of Wahtakai (American Indians) in the Ohio Valley is both deeper and more complicated than the current historiography of the region allows. Much of the history of the region derives from limited or secondhand narratives written in the nineteenth-century and these 
in turn have been accepted by modern authors with little critical analysis. The origins of the “hunting ground" mythology stem from Wills De Hass' brief 1851 account of the Shenandoah Valley during the early eighteenth century. ${ }^{4}$ The Ohio valley may have been unoccupied briefly during the early eighteenth century, but this condition did not stretch indefinitely back in time. The landscape described by Christopher Gist, George Croghan, and even George Washington appeared to be a pristine and untamed wilderness. These descriptions continue to influence current historiography. The current historiography does not sufficiently deal with the Ohio Valley until Europeans began arriving in the mid-eighteenth century. Historians of the eighteenth-century Ohio, such as Jane Merritt, Eric Hinderacker, and Fred Anderson, begin their examinations of the eastern portion of the Ohio Valley stating that it was an unoccupied common hunting ground for the Shawnee, Delaware, Iroquois and the Cherokee. Hinderacker and Anderson admit that the region had been cleared of its seventeenth-century inhabitants, yet they do not evaluate the ramifications of this social and environmental change in their analysis.

Recent Shawnee scholarship by Stephen Warren, Sami Lakomäki and Laura Spero has brought the perceived simplicity of the Ohio into question by examining the pathways that forced the Shawnee from and brought them back to the region. These ecological and demographic perceptions, fostered by historical documents, have been used to paint a misleadingly sparse picture of the precontact Ohio Valley. ${ }^{5}$

\footnotetext{
${ }^{4}$ Wills de Hass, History of the Settlement and Indian Wars of Western Virginia: An Account of the Various Expeditions in the West, Previous to 1795 (Wheeling, WV: H. Hoblitzell, 1851), 33.

${ }^{5}$ Jane T. Merritt, At the Crossroads: Indians and Empires on a Mid-Atlantic Frontier, 1700-1763 (Chapel Hill: University of North Carolina, 2003), 10; Eric Hinderaker, Elusive Empires: Constructing Colonialism in the Ohio Valley, 1673-1800 (Cambridge, 1997), xi; Fred Anderson, Crucible of War: The Seven Years' War and the Fate of the Empire in British North America, 1754-66, (New York: 1st Vintage Books Edition, 2001), 13, 18; Alexander Scott Withers, Chronicles of Border Warfare: or a History of Settlement by the Whites, of North-western Virginia, and the Indians Wars and Massacres in that section of the state with Reflections, anecdotes, \&c (Cincinnati: The Robert Clarke Company, 1895), 44; Michael N. McConnell, A Country Between: The Upper Ohio Valley and Its Peoples, 1724-1774 (Lincoln: University of Nebraska Press, 1992), 9, 19; John A. Williams, West Virginia: a History, $2^{\text {nd }}$ edition (Morgantown, WV: West Virginia University, 2001), 7.
} 
The difficulty of discussing the historiography of the Middle Ohio River Valley is that the region lingers in a major academic blind spot. When historians refer to the Ohio region, they are usually referring to the Upper Ohio Valley from the Little Kanawha River north to the confluence of the Allegheny and Monongahela rivers, which admittedly maintained much higher population densities than the Middle Ohio River valley. Most ethnohistorical research has continued to focus on the Upper Ohio, especially the confluence of the Monongahela and Allegheny River, as in the work of Michael McConnell and Jane Merritt, or in the Southeast, as in the work of Alan Gallay and Robbie Ethridge. Neither set of literature mentions the Middle Ohio River Valley except to briefly mention trade or hunting connections to the region. When the Middle Ohio is discussed in the anthropological literature there is a strong focus on the much heavier populations to the west of the Ohio. The constrained valleys east of the Ohio were physically and culturally distinct but have received little attention. Historically, the surrounding regions were always more populated and thus produced a richer documentary history. The few early travels into the Kanawha River valley, from Thomas Batts and Robert Fallam to Christopher Gist, have not yet been integrated into a single research methodology. By connecting the loose ends of these regional histories, the seemingly minor adventures of Gabriel Arthur and John Lederer become increasingly important and illuminating. ${ }^{6}$

Upper Ohio historiography is quite comprehensive, boosted by systematic archaeology, especially during the eighteenth-century, but even this literature has problems explaining the “changes and conflicts that had cleared the upper Ohio Valley of its first native peoples." In $A t$ the Crossroads, Jane Merritt only mentions the "arrival" of the Iroquois, Delaware and Shawnee

\footnotetext{
${ }^{6}$ Penelope Ballard Drooker, The View from Madisonville: Protohistoric Fort Ancient Interaction Patterns (Ann Arbor: Memoirs of the Museum of Anthropology, University of Michigan, No. 31, 1997); James B. Griffin, "The Chronological position and ethnographical relationships of the Fort Ancient aspect" American Antiquity (1937) 2:273-276. Only amateur and recent conservation archaeology have begun to really open the subject. There are no recent academic syntheses of West Virginia archaeology.
} 
in the Upper Ohio without explaining that the region had been occupied by other peoples. Michael McConnell recognizes "the resettlement of the Ohio Country" as "a creative response to the pressure of colonial settlement and imperial conflict" but ignores the larger implications of this movement to the landscape itself. For him the Delaware arrived "not as invaders but as pioneering newcomers who inaugurated a new phase in a rich and turbulent regional history."7 Fred Anderson in discussing the Seven Years' War was even less concerned with the implications of the Ohio as a new home for the Algonquian and Iroquoian intruders. One of the main problems inherent in the current interpretation of the Ohio origin of the Seven Years' War stems from the deeply ingrained assumptions concerning Native American occupation of the territory. Fred Anderson and Michael McConnell therefore fail to address a larger environmental and cultural issue by ignoring the shift from pre-eighteenth-century Siouan control. While it was true that Wahtakai sought refuge in the Ohio, their occupation was dependent on the latent environmental conditions left behind by Monyton and other previous residents. The Siouan peoples had only recently evacuated, yet the Iroquois claimed conquest rights, therefore the meaning of Delaware and Shawnee occupation of the region must to be reevaluated. ${ }^{8}$

There is a distinct divide between the historiographies of the sixteenth-century and the eighteenth-century that is a product of the switch from primarily Spanish to English settlement and exploration. This also arises from the limited recorded exploration from the 1590s till the 1670s. Just as the developing forgotten century literature fills in the gaps between the sixteenthcentury Spanish explorations and the eighteenth-century British and French fluorescence in lands east of the Mississippi River, this dissertation develops the role of Eastern Siouans in the Appalachian Mountains and shows how they provided the ecological foundation that facilitated

\footnotetext{
${ }^{7}$ McConnell 1992, 9 .

${ }^{8}$ Merritt 2003; McConnell 1992; Fred Anderson 2001.
} 
the eighteenth-century Algonquian occupation of the Ohio. Ohio Siouans, namely the Monyton, join the Tutelo, Saponi, Occanneechi, Catawba, and Monacan as part of the Eastern Siouan peoples. ${ }^{9}$ The field began with the early twentieth-century ethnographic work of James Mooney and John Swanton who proposed the controversial presence of such an Eastern collection of Siouan speakers. ${ }^{10}$ This was followed by the interest of linguists Horatio Hale, Franck Speck, and Wallace Chafe. ${ }^{11}$ The Southeastern archaeologist, Joffre Lanning Coe, further supported the Eastern Siouan historiography in The Formative Cultures of the Carolina Piedmont. The primary historical treatment is James Merrell's The Indians' New World: Catawbas and their neighbors from European contact through the era of removal. This work states that: "After 1700, many of them [upcountry Siouans] drew upon their cultural affinities and their common plight, migrated to the Catawba River valley, and became part of the Catawba Nation, thereby reuniting fragments of the ancient Siouan migration." 12 This dissertation will directly contribute to this discussion by evaluating the model laid out by Merrell and others through study of the Ohio Siouans and their late seventeenth-century diaspora. ${ }^{13}$

Embedded in the return of the Shawnee to the Ohio in the 1730s was a complicated history of their origins and national identity that has seen resurgence in the twenty-first century. Henry Harvey in 1855 produced one of the earliest and most expansive examinations of Shawnee movements and history but contemporary biases against Indians poisoned much of the

\footnotetext{
${ }^{9}$ Little ethnographic material (no linguistic references) remains of the seventeenth and eighteenth century Monacans in order to verify the classification, but modern Monacan oral traditions and archaeological materials seem to support their Siouan heritage. Interview with Robert Rankin, October 2009.

${ }^{10}$ James Mooney, The Siouan Tribes of the East, Smithsonian Institution, Bureau of American Ethnography, bulletin no. 22. (Washington, D.C.: Government Printing Office, 1894); John R. Swanton, The Indians of the Southeastern United States (Washington, D.C.: Smithsonian Institution, Bureau of American Ethnology, Bulletin 137, 1946).

${ }^{11}$ Horatio Hale, The Tutelo language (Bristol, Pa.: Evolution Pub., 2001, 1883); Frank G. Speck, Catawba texts (New York: Columbia University Press, 1934); and Wallace L. Chafe, The Caddoan, Iroquoian and Siouan languages. (The Hague: Mouton, 1976).

${ }^{12}$ Merrell 1989, 10.

${ }^{13}$ Emrick, 2005.
} 
documents. Using William Penn's letters, Harvey placed Shawnee origins far past the Mississippi just below the Missouri River among the Sac and Fox. This "unquestionable" statement has been evaluated frequently over the last one hundred and fifty years. Laura Keenan Spero traced the diaspora of the Shawnee from a variety of locations in her recent dissertation "'Stout, Bold, Cunning and the Greatest Travellers in America': The Colonial Shawnee Diaspora." Her work marks a stark contrast from the European focused histories of Wahtakai of the late-twentieth century as she examines Shawnee movements, some from the Ohio and Cumberland River valleys, as expressions of indigenous needs and culture that were a response to the pressures of not just Europeans but also other Wahtakai. Her focus on the application of diaspora to the movements of the Shawnee was significantly influential to this research. Her dissertation was joined in 2014 by two very different examinations of Shawnee history that weave together the elements of Spero's diaspora with violence studies and national identity issues. Stephen Warren's The World the Shawnees Made largely focuses on the influence and effects of Shawnee involvement across much of Eastern North America but he closely connects the Fort Ancient cultural pattern with Shawnee ancestors. He indicates that "there were many Fort Ancient societies" some of which might have been Siouan. Warren's origin of the Shawnee were not as refined nor based on as close a reading of archaeology as Sami Lakomäki's Gathering Together. Lakomäki stressed that the mampi of the Ohio were multi-ethnic autonomous polities that had constantly shifting relationships with other mampi through alliance, marriage, and trade. The geographic boundaries of Lakomäki's work are inherently fuzzy due to the dispersal of the Shawnee and even when they were active within the eastern portion of the Middle Ohio, the region remains loosely combined into the discussion of the entire Ohio valley. ${ }^{14}$

\footnotetext{
${ }^{14}$ While certainly not the first to include the Shawnee in their history, Henry Harvey, History of the Shawnee
} 
Unlike recent historiography, archaeological research has taken more interest in the Middle Ohio River Valley, but currently lacks the synthetic analysis found in historical literature. The largest portion of research appears as archaeological site reports and focused articles. A broad regional archaeological examination of the Kanawha-New River and the surrounding region has not yet been published. James Griffin in 1937 began describing the cultural pattern identified as Fort Ancient, named for the type site in Ohio. ${ }^{15}$ People practicing the Fort Ancient cultural pattern relied more heavily on maize and beans than wild domesticated plants, as their pottery styles switched from grit to shell tempering and began adding handles and lugs (knobs). Their hunters switched from atl-atl spears to smaller bows and arrows. Each shift contributed to more stable mampi with greatly increased populations but notably absent were markers of rigid social stratification found in nearby Mississippian sites. There have also been some regional surveys like Jeffrey Graybill’s 1981 dissertation “The Eastern Periphery of Fort Ancient (A.D. 1050-1650)." Most of the synthesis of the region has concerned the western side of the Ohio River in the current state of Ohio. Penelope Drooker and Gwynn Henderson have incorporated some material from West Virginia in their research on Fort Ancient sites. ${ }^{16}$ The site report for the Burning Spring Branch site, 46Ka0142, is one of the best overviews of the Kanawha-New River region archaeology. Drooker and Henderson's important analyses are nearly twenty years old and need to be re-evaluated against recent excavations and new anthropological and

Indians, from the year 1681 to 1854, inclusive (Cincinnati: E. Morgan \& Sons, 1855) was the earliest history devoted to the Shawnee. For William Penn's letters see Harvey 1855, 22. I must mention Jerry E. Clark, The Shawnee (Lexington, KY: University Press of Kentucky, 1993) if only to note that historical work continued in the twentieth century with questionable results. Laura Keenan Spero, "'Stout, Bold, Cunning and the Greatest Travellers in America': The Colonial Shawnee Diaspora" (Unpublished PhD Dissertation, University of Pennsylvania, 2010); Stephen Warren, The Worlds the Shawnees Made: Migration and Violence in Early America (Chapel Hill: University of North Carolina Press, 2014); Sami Lakomäki, Gathering Together: The Shawnee People through Diaspora and Nationhood, 1600-1870 (New Haven: Yale University Press, 2014).

${ }^{15}$ The Fort Ancient cultural complex was identified by Griffin after excavations in a village on an upper glacial terrace above the Fort Ancient Earthworks which were built much earlier by Hopewell occupations.

${ }^{16}$ Description from Griffin 1992: 53. Graybill, 1981; Drooker 1997; A. Gwynn Henderson and Emanuel Breitburg, Fort Ancient cultural dynamics in the Middle Ohio Valley (Madison: Prehistory Press, 1992). 
archaeological models to evaluate their cultural identifications.

A primary focus for archaeologists in the 1960s and 1970s was the proper identification of the prehistoric peoples of the Kanawha Valley in relation to modern "tribes." James Griffin proposed in 1952 that the Ohio peoples were Algonquian-speaking ancestors of the Shawnee, countering John Swanton's suggestion in 1943 that they were Siouan speaking peoples more closely related to their Eastern neighbors, the Tutelo and Saponi. ${ }^{17}$ The picture has gotten murkier as sites like Burning Springs and Buffalo have been excavated and exhibited evidence of different ethnic enclaves within mampi. While the ancestors of the Shawnee may have visited the Kanawha Valley, they were part of a diverse set of residents.

The academic blind spot of the Middle Ohio River Valley is both geographic and temporal. The seventeenth-century in the Southeast was identified by Charles Hudson and Carmen Chaves Tesser as a "forgotten century" between the contact with the Spanish and the arrival of English. ${ }^{18}$ Their collected volume of essays begins outlining the late sixteenth- and seventeenth-century indigenous history of not only contacted peoples along the coast but also the interior populations only known through archaeological materials. The Ohio was not included in this volume and remains poorly understood in the early colonial historiography. The analysis below begins to fill in some of these gaps. Even if you look at the very distinct and limited literatures of West Virginia archaeology and the eighteenth-century histories of the same region, it becomes apparent that the Middle Ohio River Valley has been ignored by historians and many archaeologists in order to study more heavily occupied regions. As an initial study of such an academic vacuum, this is as much a story about the region's connections to surrounding

\footnotetext{
${ }^{17}$ James B. Griffin, "Culture Periods in Eastern United States Archaeology" in Archaeology of Eastern United States, ed. James B. Griffin, (Chicago: University of Chicago Press, 1952), 364; John R. Swanton, "Siouan Tribes and the Ohio Valley" American Anthropologist 45 (1943), 49-66.

${ }^{18}$ Charles Hudson and Carmen Chaves Tesser, eds. The Forgotten Centuries: Indians and Europeans in the American South, 1521-1704 (Athens: University of Georgia Press, 1994).
} 
geographies and peoples as it is a story about the Middle Ohio River Valley and its inhabitants.

Often I have had to overcome the gaps noted above by focusing on the historical connections between surrounding regions that crisscross the Middle Ohio River valley, the Okahok amai.

Understanding the collapse of the Siouan presence within this pivotal region is key to explaining the instability of many Native American interactions across eastern North America during the late seventeenth and early-eighteenth century. The Siouan peoples of the Ohio connected the North to the South and the Atlantic Ocean to the Mississippian River through trade, diplomacy, kinship, and even war. But before we can begin to make these connections it is important to identify the theoretical frameworks concerning the work ahead. The frontier framework continues to be applied to Ohio during the seventeenth- and eighteenth-centuries, despite the fact that this concept assumes the vantage point of Europeans and has little utility in the indigenous world that existed. ${ }^{19}$ Europeans entered the Okahok amai as intruders, guests, and usurpers and had to cross other indigenous landscapes beforehand. From an archaeological perspective this world was a nodal network of highly connected peer-polities with surrounding zones of control. ${ }^{20}$ In historical literature this closely resembles the conceptualization of the borderlands examining the friction between two nations or societies as they contest the lands inbetween. The geopolitical landscape of eastern North America consisted of a variety of polities some complex and stratified, like Mississippian chiefdoms, some simple, like the autonomous

\footnotetext{
${ }^{19}$ James D. Rice, Tales from a Revolution: Bacon's Rebellion and the Transformation of Early America (Oxford: Oxford University Press, 2012), 142; John Anthony Caruso, The Appalachian Frontier: America's First Surge Westward (Knoxville: University of Tennessee Press, 2003); Andrew K. Frank, Creeks \& Southerners: Biculturalism on the Early American Frontier (Lincoln: University of Nebraska Press, 2005); Francois Furstenberg, "The Significance of the Trans-Appalachian Frontier in Atlantic History" American Historical Review 113:3 (June 2008), 647-677; Merritt 2003; switching the frontier perspective a bit is David L. Preston The Texture of Contact: European and Indian Settler Communities on the Frontiers of Iroquoia, 1667-1783 (Lincoln: University of Nebraska Press, 2009). For an archaeological analysis: Kent G. Lightfoot and Antoinette Martinez, "Frontiers and Boundaries in Archaeological Perspective" Annual Review of Anthropology 24 (1995), 471-492.

${ }^{20}$ Colin Renfrew and John F. Cherry, eds. Peer Polity Interaction and Socio-Political Change (Cambridge: Cambridge University Press, 1986).
} 
mampi of the Middle Ohio River Valley. The borders between these groups also had variable permeability allowing alliances, marriages, and trade but also permitting warfare, abduction, and reprisals. Borderland frameworks allow for numerous focal points within a single analysis, rather than the dichotomous frontier model of Europeans/Wahtakai. The complex social interactions of a borderland model provide for a much more nuanced view of the geopolitical world of Wahtakai, especially in the Trans-Appalachian region discussed here. Since each mampi had a high degree of autonomy the utilization of overlapping land claims, even within alliances, could become highly contentious. When Europeans settled on the eastern fringe of the Okahok amai in the eighteenth-century, those communities were extensions of a new polity with its own complex and often more rigid borders than the preceding Wahtakai ones. Another benefit of the borderland framework is the historical depth of complex social interactions that it introduces into Robbie Ethridge's shatter zone framework. ${ }^{21}$

Ethridge developed the shatter zone concept as a lens through which to examine the chaos of the late-seventeenth and early-eighteenth centuries. She proposes in 2006 that the Southeast was destabilized as a region due in part to the collapse of the Mississippian chiefdoms but also due to the introduction of deadly European diseases and an increasing connection to European capitalism. The end product of these destabilizing forces was the dual processes of increased intergroup violence and enslavement alongside the formation of coalescent societies

\footnotetext{
${ }^{21}$ A good overview of the Borderlands concept in Daniel H. Usner, Jr., "Borderlands" In A Companion to Colonial America ed. by Daniel Vickers (Malden, MA: Blackwell Publishing, 2006), 408-424. For more specific issues: Helena M. Wall, "Confessions of a British North Americanist: Borderlands Historiography and Early American History" Reviews in American History 25:1 (Mar. 1997), 1-12; Jeremy Adelman and Stephen Aron, "From Borderlands to Borders: Empires, Nation-States, and the Peoples in between in North American History" The American Historical Review 104:3 (Jun. 1999), 814-841; Evan Haefeli, “A Note on the Use of North American Borderlands" The American Historical Review 104:4. (Oct. 1999), 1222-1225; Christopher Ebert Schmidt-Nowara, "Borders and Borderlands of Interpretation" The American Historical Review 104:4 (Oct. 1999); 1226-1228; Bradley J. Parker, "Toward an Understanding of Borderland Processes." American Antiquity 71:1 (Jan. 2006), 77100; Magdalena Naum, "Re-emerging Frontiers: Postcolonial Theory and Historical Archaeology of the Borderlands" Journal of Archaeological Method and Theory, 17: 2 (June 2010), 101-131.
} 
like the Creek and Catawba. The shatter zone, according to Ethridge, is a "descriptive shorthand for this particular time place ... when two asymmetrical worlds met. The Mississippian shatter zone, then, may have been but one of several shatter zones created when the European world collided with other Native worlds." While the cultural chaos of the seventeenth-century Southeast certainly affected the Okahok amai, applying the shatter zone has certain limitations. The region never experienced the collapse of powerful socially stratified settlements, as in the Mississippian Southeast. Instead of a power vacuum filled by violent competition, the region became embroiled in the expansion of Iroquoian boundaries. More importantly, the Siouan residents had only limited exposure to the ravages of European diseases and seemed enticed by the new markets posed by European traders (Table 4.4). The shatter zone model, however, has its uses, as the world of the Monyton residents began to be pulled and pushed out of the Okahok amai, much of what Ethridge found in the colonial Southeast. ${ }^{22}$ The shatter zone that spread northward into the Ohio region pushed and pulled people from their homes and cast them on journeys throughout North America.

There are two additional concepts that apply to the Okahok amai and its various peoples: the status of these refugees and the broader geopolitical effects of the Monyton diaspora.

\footnotetext{
${ }^{22}$ Quote: Robbie Ethridge, From Chicaza to Chickasaw: The European Invasion and the Transformation of the Mississippian World, 1540-1715 (Chapel Hill: University of North Carolina Press, 2010), 4-5. Robbie Ethridge, "Creating the shatter zone: Indian slave traders and the collapse of the southeastern chiefdoms" In Light On The Path: The Anthropology and History of the Southeastern Indians edited by Thomas J. Pluckhahn, and Robbie Ethridge (Tuscaloosa: University Of Alabama Press, 2006), 207-218; Robbie Ethridge, "Introduction: Mapping the Mississippian Shatter Zone" In Ethridge Shuck-Hall, 2009: 1-62; Robbie Ethridge, "Afterword: Some Thoughts on Further Work" In Ethridge Shuck-Hall, 2009, 418-424; Ethridge, 2010; Three particularly important applications of the shatter zone framework mentioned in this analysis are Robin A. Beck, Jr., "Catawba Coalescence and the Shattering of the Carolina Piedmont, 1540-1675" In Ethridge Shuck-Hall, 2009, 115-141; Matthew H. Jennings, "Violence in a Shattered World" In Ethridge Shuck-Hall, 2009: 272-294; Stephen Warren and Randolph Noe, "The Greatest Travelers in America": Shawnee Survival in the Shatter Zone, In Ethridge Shuck-Hall, 2009: 163-187; Joseph M. Hall, Jr., Zamumo's Gifts: Indian-European Exchange in the Colonial Southeast (Philadelphia, University of Penn Press, 2009); Joshua Piker, Okfuskee: A Creek Indian Town in Colonial America (New York: Harvard University Press, 2006); Robert Paulett, An Empire of Small Places: Mapping the Southeastern Anglo-Indian Trade, 1732-1795 (Atlanta: University of Georgia Press, 2012); Denise Ileana Bossy, "Shattering Together, Merging Apart: Colonialism, Violence, and the Remaking of the Native South" $W M Q 3^{\text {rd }}$ ser. 71:4 (October 2014): 611-631 reviewed Ethridge 2010, Ethridge Shuck-Hall 2009, Hall 2009, Paulett 2012.
} 
Diaspora here refers to "any people or ethnic population forced or induced to leave their traditional ethnic homelands being dispersed throughout other parts of the world. ${ }^{23}$ Based in a Jewish or African context, diaspora has increasingly been used by colonial Indian historians such as Laura Keenan Spero to describe the myriad movements of indigenous peoples. Like Spero's work, I examine the pathways travelled by Ohio Siouans, Wahtakai, the meanings of places that were left, their homelands, alongside the shifts in personal and cultural identity as refugees among other peoples. The Monyton's piecemeal and seemingly opportunistic diaspora required individuals and families to be even more flexible with their identities than other groups that moved entire mampi and social structures intact. Wahtakai refugees found themselves seeking new homes in far-flung mampi across the eastern half of North America. ${ }^{24}$

Eastern North America was in cultural and demographic upheaval during the seventeenth- and eighteenth-centuries. Groups were forced to move from their traditional homelands and join with other small refugee bands to form larger polities, or what some scholars have referred to as coalescence. Many of these polities are now recognized as tribes. This process of coalescence requires a detailed examination of the previous positions and interactions of the cultures involved. The Ohio Siouans were closely allied with groups in the South and joined their mampi as refugees during the late-seventeenth century. The genesis of new cultural identities and alliances was a process of the internal and intergroup relationships between indigenous peoples, not merely a product of European interference. Despite the chaos of the shatter zone, Wahtakai peoples found ways, simultaneously opportunistic and traditional, to

\footnotetext{
23 "Diaspora" http://www.thefreedictionary.com/ Diaspora+studies (Nov. 30, 2004).

${ }^{24}$ Spero 2010: 19-20. Gal Allon, Athena S. Leoussi, and Anthony D Smith. The Call of the Homeland: Diaspora Nationalisms, Past and Present (Boston 2010); Robin Cohen, "Solid, ductile and liquid: changing notions of homeland and home in diaspora studies" QEH Working Paper Series: Working Paper Number 156, October 2007; Brent Hayes Edwards, The Practice of Diaspora: Literature, Translation, and the Rise of Black Internationalism (Cambridge and London: Harvard University Press, 2003), 12.
} 
survive on their own terms. ${ }^{25}$

Europeans did change many things for Ohio Siouans even as early as 1600 . The introduction of new trade materials and new diseases dramatically affected the Ohio Wahtakai even without direct contact with Europeans. The combined effort of historians and archaeologists like Richard Aquila, Michael McConnell, Charles Hudson, and Penelope Drooker have shown how new materials were incorporated into pre-existing cultural networks and traditions in surprisingly culturally specific ways. ${ }^{26}$ The process of dealing with disease appeared to be equally as dynamic yet no less demographically devastating. The discussion of the role that Ohio Siouans played in this new cultural landscape will be juxtaposed with the implications of their removal from the Ohio Valley. Their absence had many dramatic effects on the cultural, economic and environmental landscapes within the middle Ohio Valley and the surrounding regions. Half a century after Siouan speaking people left, Algonquian and Iroquoian peoples laid claim to the Ohio Valley. These claims became the conflagration point for the North American theater of the Seven Years' War historiography.

\section{The role of Language and Multi-ethnicty in Indigenous Identity}

There is a great deal of linguistic data that has been collected that points to a complicated cultural framework for the Okahok amai. There were three language families represented in the region, but Siouan was the most frequently spoken within the Monyton Onqyayun. There was a great deal of diversity among the Siouan languages in the Ohio watershed and Mid-Atlantic region during the sixteenth and seventeenth centuries. It has been well established since John Swanton's 1943 "Siouan Tribes and the Ohio Valley" that during the prehistoric and

\footnotetext{
${ }^{25}$ Alan Gallay, The Indian Slave Trade: The Rise of the English Empire in the American South, 1670-1717 (New Haven: Yale University Press, 2002); Merritt, 2003.

${ }^{26}$ Robbie Ethridge and Charles Hudson, eds. The Transformation of the Southeastern Indians, 1540-1760 (Jackson, MS: University Press of Mississippi, 2002); Richard Aquila, The Iroquois Restoration: Iroquois Diplomacy on the Colonial Frontier, 1701-1754 (Lincoln: University of Nebraska Press, 1997); McConnell, 1992.
} 
protohistoric periods there were a number of Siouan linguistic groups in the region. The disagreement over geographic origins and limitations on historical materials make it nearly impossible to pinpoint the boundaries of each language group with any degree of certainty. Siouan linguist Robert Rankin has corroborated some of Swanton's original claims that the "mony-ton" mampi visited by Gabriel Arthur in 1673 spoke a Siouan language closely related to Tutelo. Likewise pulling from Swanton's work, Rankin notes that the glottochronology of Catawban and Tutelo along with Mississippian Siouan languages indicates a possible origin in the Ohio River valley dating back roughly 1000 years, making the Siouan-speaking Monyton of the Okahok amai the last vestiges of more than a millennium of Siouan control. The similarities between their name and Tutelo cognates supports a very strong eastward connection. ${ }^{27}$

In between the Okahok amai and Powhatan's Tsenacomoco was a Siouan dominant language zone, including Tutelo, Saponi, and Occaneechi. The earliest European accounts do not refer to these groups, suggesting a dramatic reconfiguring of the Piedmont and Blue Ridge region from 1607 to 1650 . Booker, Hudson, and Rankin detail many of the complications to identification of these people. This brings up further linguistic support for the multi-ethnicity of most if not all indigenous populations during the late-sixteenth and seventeenth centuries. Booker, Hudson, and Rankin proposed that Wahtakai in the Southeast lived in a linguistic Sprachbünd, an area of highly diffuse and overlapping linguistic traditions. The corollary to this framework is that not only were they linguistically diverse within the populations, but contrary to common assumptions about protohistoric populations, these mampi were multi-ethnic and highly fluid culturally. Even during the sixteenth century, Spanish visitors had constant need and access

\footnotetext{
${ }^{27}$ Swanton, 1943, 49-66; Giulia R. Oliverio and Robert Rankin, "On the Sub-grouping of the Virginia Siouan Languages" In Essays in Algonquian, Catawban and Siouan Linguistics in Memory of Frank T. Siebert, Jr. edited by Blair A. Rudes and David J. Costa, Algonquian and Iroquoian Linguistics. Memoir 16. (Winnipeg: Algonquian and Iroquoian Linguistics, 2003), 165-180; Rankin, 2006, 563-575; Goddard, 2005, 7-10.
} 
to interpreters as they moved through the Southeast. The ubiquity of interpreters, even within a mampi, must be examined further to see how this may be better accounted for in our understanding of indigenous politics during all periods of history. ${ }^{28}$

The second and increasingly more common linguistic group in the Okahok amai was the Algonquian-speaking peoples moving east across the Pelewathipiki, Ohio River. In further support for the presence of a Sprachbünd within especially the western half of the Okahok amai, the shifting pottery traditions and increase of S-twist markings at sites like Orchard and Buffalo is evidence of a great deal cultural mixing (Map 1.4b). ${ }^{29}$ Though equally intrusive within the Middle Ohio Valley, Iroquoian languages also became prominent during the early-eighteenth century. The region was certainly a constantly shifting Sprachbünd throughout the entirety of the early colonial period.

The most interesting social effects of the Sprachbünd are witnessed in the development of individual and group identities. As mentioned before, the shatter-zone, borderlands, and peerpolity model focus on the corporate identities and the individual roles of mampi members. While the specific identity of individuals is difficult to reconstruct, the presence of such a vibrant linguistic landscape paralleled the geopolitical turmoil of the of the seventeenth-century interior. Indigenous peoples often knew three orfour languages, often learned while living among their neighbors in order to perform important political and economic tasks. Combined with the

\footnotetext{
${ }^{28}$ Karen M. Booker, Charles M. Hudson, and Robert L. Rankin. "Place Name Identification and Multilingualism in the Sixteenth-Century Southeast" Ethnohistory, 39:4 (Autumn, 1992), 399-451. To bring in the idea of the Sprachbund and linguistic variety in the Southeast see: Goddard 2005, 1-60; John J. Gumperz, "Types of Linguistic Communities" Anthropological Linguistics, 35:1/4, A Retrospective of the Journal Anthropological Linguistics: Selected Papers, 1959-1985 (1993), 130-142; Sarah Grey Thomason, "Linguistic areas and language history" (Revised version of presentation, Conference on Language Contacts in Groningen, Netherlands, November 1999); Lyle Campbell, "Areal linguistics" Encyclopedia of Language and Linguistics $2^{\text {nd }}$ edition, ed. Keith Brown (Oxford: Elsevier, 2006); Michael Silverstein, "Dynamics of Linguistic Contact" Handbook of North American Indians, Volume 17: Languages ed. by William C. Sturtevant. (Washington, D.C.: Smithsonian Institution, 1996), 117-127. ${ }^{29}$ Siouan: Swanton 1943, 49; Leonard R. Bruguier, The Yankton Sioux Tribe: People of the Pipestone, 1634-1888 (Oklahoma State University Press, 1993), 23-24; Thomas Constantine Maroukis, Peyote and the Yankton Sioux: The Life and Times of Sam Necklace (University of Oklahoma Press, 2005), 6, 332.
} 
captivity and and kinship practices of Wahtakai, the cultural identity of an individual can not be simply stated and frequently adjusted to their religious and geopolitical needs.

Archaeological sites provide, even in the best of circumstances, weak data on ethnic identities, much less which were dominant. This is especially true in the Monyton Onqyayun, as sites exhibit the mixing of cultural traditions from the surrounding regions. It is equally problematic to assume that the ethnic majority maintained group dominance. In Iroquoian towns (kanstaks) in New York during the eighteenth-century, non-Iroquoian birth of an individual did not preclude a person from a role of leadership, as in the case of Tanachrisson, the "Half-King." The meaning of multi-ethnicity in Monyton Onqyayun mampi must be examined with two details in mind. First, the notable lack of social hierarchy within Fort Ancient sites seems coupled with trade alliances within the entire region. Second, the changes of the shatter-zone may have made ethnicity even more fluid than during previous centuries.

Historians and anthropologists have been working on the cultural implications of two customs in protohistoric North America: adoption and captivity. These institutions have direct impact on the issues of identity and must be examined within a closer investigation of archaeological materials. Adoption and captivity must also be understood within the larger context of kinship systems and mampi alliances. As theorized in the peer-polity model, mampi allied politically and socially often solidifying their connections through marriage. Mampi alliances might explain some of the diversity of the sites, but if the seventeenth-century accounts from the surrounding region are any indication, war-captives and adoption also figure heavily into the demographic equation. ${ }^{30}$

\footnotetext{
${ }^{30}$ Adoption war captives in demography: Max Carocci and Stephanie Pratt, "Introduction: Contextualizing Native American Adoption, Captivity, and Slavery" in Native American Adoption, Captivity, and Slavery in Changing Contexts edited by Max Caroccii and Stephanie Pratt (New York: Palgrave MacMillan, 2012), 1-22; Robbie Ethridge, "The Emergence of the Colonial South: Colonial Indian Slaving, the Fall of the Precontact Mississippian
} 
To expand past the assumptions of "affiliation" this work focuses on multiple ethnic factions. Greybill, Fuerst, and Maslowski posed that the Upper Kanawha, New, and Bluestone River sites show evidence of interaction between the Fort Ancient cultural pattern and the Siouan cultural patterns of Piedmont Virginia. As the sixteenth-century progressed, this Late Woodland connection began to weaken. Robbie Ethridge has proposes the existence of a series of shatterzones during the sixteenth- and seventeenth-centuries. She focused her attention on the inherent instability of Mississippian chiefdoms as they responded to additional disruptions of disease and nascent capitalism with intensified inter-group violence. How this worked in the Monyton Onqyayun will be discussed in greater detail in Chapters 3 and 4. Coupled with the idea of shatter-zones is the formative coalescence of Wahtakai into new polities. While Ethridge focuses on the late sixteenth- and seventeenth-centuries for discussions of the shatter zone, the Monyton Onqyayun archaeological record supports the existence of a shatter zone well before the arrival of Europeans into the region. The cultural upheavals of the seventeenth-century might not have been as "unexpected" as portrayed within the Southeastern Indian historiography. Joseph Hall and others have recently examined the political instabilities of Mississippian societies by showing that their collapse in the fifteenth-century led to a massive social reorganization that provided opportunities for groups in the Okahok amai. The fracturing of their Mississippian connections coincides with increased conflict and new alliances with the Monongahela and other Eastern Siouans. ${ }^{31}$

World, and the Emergence of a New Social Geography in the American South, 1540-1730" in Native American Adoption, Captivity, and Slavery in Changing Contexts edited by Max Caroccii and Stephanie Pratt (New York: Palgrave MacMillan, 2012), 47-64; Alan Gallay, Introduction, In Indian Slavery in Colonial America, edited by Alan Gallay (Lincoln: University of Nebraska Press, 2009), 1-32.

${ }^{31}$ Multi-ethnicity in Monyton Onqyayun: Spero 2010, 86; Warren 2014, 20-1; this discussion is also found in Steven C. Hahn, The Invention of the Creek Nation, 1670-1763 (Lincoln: University of Nebraska Press, 2004), 52 concerning the Ochese Creek talwa; Patricia K. Galloway, Choctaw Genesis 1500-1700 (Lincoln: University of Nebraska Press, 1995), 264 concerning Ethnic Boundaries from Material Evidence and Choctaw villages; the 
There have been quite a few identities placed upon the Wahtakai of the Monyton Onqyayun by archaeologists and historians alike. These efforts go back to the 1800 s with suggestions that the region's mounds could not have been created by Wahtakai and therefore were built by the remnants of the Lost Tribes of Israel. Historians and archaeologist have also indicated that the residents were Shawnee, Iroquois, Cherokee, and any number of other groups. Considering the work on multi-ethnic mampi and the cultural coalescence of the late-seventeenth and early eighteenth centuries, this conversation should be reevaluated. Predicated on the search for connections to modern Wahtakai, the speculation concerning Wahtakai identities forces the researcher to generalize complex social processes using language inappropriate to indigenous concepts of identity. The existence and prevalence of multi-ethnic mampi long before Europeans supposedly destabilized the Okahok amai's cultural politics suggests that individual and mampi identities were a great deal more fluid and complicated than assumed in previous historical work.

Admittedly, the ability to reconstruct these indigenous identities is almost impossible. Responses to James Merrell's "Second Thoughts on Colonial Historians and American Indians" testifies to the continuing difficultly of language and the weaknesses of the documentary evidence historians use when it comes to indigenous people. The solution proposed here follows the lead of the peer-polity model of Colin Renfrew and the anthropological work of Max Carocci and Stephanie Pratt concerning captive identity. Since there is little evidence for political centralization in the Monyton Onqyayun at any point, each mampi continued to be politically and

comparative anthropology of ethnicity and identity in Frederick Barth, Ethnic Groups and Boundaries: The Social Organization of Culture Difference (London: Allen and Unwin, 1969).

Jeffrey R. Graybill, “The Eastern Periphery of Fort Ancient” Pennsylvania Archaeologist 54 (1984), 40-50; Jeffrey R. Graybill, "The Eastern Periphery of Fort Ancient (A.D. 1050-1650): A Diachronic Approach to Settlement Variation" (Ph.D. Dissertation, University of Washington, Seattle, 1981); David N. Fuerst, "On the Bluestone Phase of Southern West Virginia" (Paper presented at the New River Symposium, Radford University, Virginia, June 1, 2007). Robert F. Maslowski, "Protohistoric Villages in Southern West Virginia." Proceedings of the Upland Archaeology in the East Symposium 2. Cultural Resources Report No. 5, Michael B. Barber, ed. (US Department of Agriculture, Forest Service Southern Region, Atlanta, 1984). Ethridge 2010; Hall 2009. 
economically independent, allying when needed with nearby mampi. This may mean that languages spoken by these people tended to be restricted to two or three of the dominant ones, such as Tutelo, Yuchi, or even Shawnee. Individuals in village-level societies often spoke two or more languages out of necessity for trade, diplomacy, multi-ethnic marriages, and captive adoption. Diveristy, not homogeneity, provided the best social survival mechanisms as will be discussed at easch stage of the following analysis. The role of language in identity can be seen most powerfully within the development and maintenance of the ethnogeographies within the Okahok amai. $^{32}$

\section{Ethnogeography: The Nexus of Culture, Environment, and Language}

James Merrell in 2012 offered the criticism that the language used to discuss Native Americans is laden with cultural and historical malapropisms. In this piece I have tried to get the reader away from these misconceptions of Wahtakai cultural traditions especially concerning landscape and societal structure by utilizing appropriate Tutelo (Yesanechi) words and phrases. Tutelo was significantly similar to Monyton since there was no need for a translator in 1671. But more practically, Tutelo is the closest language recorded enough to even begin the process of understanding the indigenous ethnogeography. Much like what can be found in Michael Witgen's An Infinity of Nation, my goal is to provide the reader with a more nuanced vocabulary of social and geographic terms removed as much as possible from Eurocentric presumptions and biases so that the landscape can be defined within the context of appropriate historical and anthropological literature. Words like landscape, village, and valley each have historical and culturally-specific meanings and connotations that do not match indigenous linguistic

\footnotetext{
${ }^{32}$ Merrell 2012, 451-512; Renfrew in Renfrew Cherry 1986, 1-18; Carocci Pratt in Caroccii Pratt 2012, 1-22. Archaeologists have been interested in the signatures of multi-ethnicity such as Mark R. Plane, "Catawba Ethnicity: Identity and Adaptation on the English Colonial Landscape" North Carolina Archaeology 53 (Oct. 2004), 60-79; Thomas E. Emerson and Eve Hargrave, "Strangers In Paradise? Recognizing Ethnic Mortuary Diversity On The Fringes Of Cahokia" Southeastern Archaeology 19:1 (Summer 2000): 1-23.
} 
understandings of the environment (Appendix 1.1). When speaking about the main characters of this story, the mountain Siouans living along the Kanawha-New and Staunton Rivers, I use the terms discussed below. Some authors, like Keith Basso, Ramon Gutierrez, and Sami Lakomäki, have begun incorporating such examples of culturally-specific ethnogeography with increasing success. $^{33}$

Ethnogeographic terms can be broken down into two sets. First, there are words for the cultural landscape of the Tutelo (Map 1.1). While hukamai would mean roughly "all the land" according to Horatio Hale's analysis of Tutelo in 1883, the emphatic use of the more formal Okahok amai provides room for the historical, archaeological, geospatial, and ethnographic contextualization discussed below. This term means a great deal more than just "all the land," region, territory or even nation. For the Monyton, the Okahok amai was the landscape they called home and used to survive. It had definite boundaries, as will be shown through the accounts of contact, but these lines on a map are forever lost. The legacy of the Okahok amai remained present in the Kanawha-New River valley well into the eighteenth-century but was presumably carried as part of their cultural-memory as they became refugees abroad. ${ }^{34}$ After the Monyton

\footnotetext{
${ }^{33}$ Connections to Tutelo: Ives Goddard, "The Indigenous Languages of the Southeast" Anthropological Linguistics 47:11 (2005), 1-60, 7-8; Swanton, 1946, 152; Stevan C. Pullins, C. Michael Anslinger, Andrew Bradbury, Alexandra Bybee, Flora Church, Darla Spencer, and William D. Updike, Late Prehistoric, Late Woodland, And Late Archaic/Early Woodland Transitional Occupations At The Burning Spring Branch Site On The Kanawha River, West Virginia Contract Publication Series WV08-22. Prepared for: U.S. Army Corps of Engineers, Huntington District. Prepared by: Cultural Resource Analysts, Inc. CRAI Project No. W04H004, September 5, 2008, 119-121; Landscape-ethnogeography issues: James H. Merrell, "Second Thoughts on Colonial Historians and American Indians" Forum: Colonial Historians and American Indians. WMQ $3^{\text {rd }}$ ser. 69: 3 (July 2012): 451-512; James Taylor Carson, "Ethnogeography and the Native American Past." Ethnohistory 49: 4 (Autumn 2002), 769-788; Keith Basso, Wisdom Sits in Places: Landscape and Language among the Western Apache (Albuquerque: University of New Mexico Press, 1996); Ramón A. Gutié rez, When Jesus came, the Corn Mothers went away: marriage, sexuality, and power in New Mexico, 1500-1846 (Stanford University Press, 1991); Lakomäki 2014; Michael Witgen, An Infinity of Nations: How the Native New World Shaped Early North America (Philadelphia: University of Pennsylvania Press, 2012).

${ }^{34}$ Concepts of landscape: Carson, 2002, 769-788; Julia E. Hammett, "Ethnohistory of Aboriginal Landscapes in the Southeastern United States" Southern Indian Studies 41 (Oct. 1992), 1-50; David, Bruno and Meredith Wilson, eds. Inscribed Landscapes: Marking and Making Place. Honolulu: University of Hawai'I Press, 2002; Basso 1996; Christopher Rodning," Place, Landscape, and Environment: Anthropological Archaeology in 2009" American Anthropologist 112:2 (2010) 180-190; Stephen Adams, The best and worst country in the world: perspectives on the
} 
diaspora, I recognize the removal of Siouan control but also the very real legacy of their millennium of occupation by referring to it as the former Okahok amai.

More specific and concrete in the Okahok amai was the Monyton Onqyayun, literally "beautiful water valley." While the Monyton probably would have referred to the valley as maisonqyayunkai "our valley" or just onqyayun "the valley" I opt for a more formal version, Monyton Onqyayun (mon-E-tun on-KYAY-yun) to distinguish the Kanawha-New River from the other valleys that the discussion travels through. Again, this is more than just the physical space from ridgetop to river to ridgetop of the Kanawha-New River valley. The term implies direct human interaction with and, in some cases, control of the natural environment. In archaeological terms, this is the catchment area, defined by systematic use for food production and cultural activities. Where the Okahok amai was the expansive landscape Monyton identified as their own, the area in proximity to their mampi would be the Monyton Onqyayun. ${ }^{35}$ The Tutelo name for the Ohio River unfortunately has been lost though the Shawnee name was Pelawathipiki. Therefore, for the sake of clarity and historical ubiquity, I continue to use the Iroquois name Ohio.

Another landscape term used throughout this discussion is tahkai (TAH-kai). Its closest translation would be "forest." More than cuqe (suh-KAY) "mountain" or taksita (tak-SEE-ta) "river," forest has proven problematic in Colonial American historiography. Whether discussing the psychological dimensions of English dichotomies of urban-civilization versus forestedwilderness or portraying Wahtakai as forest savages versus English farmers, the word "forest" is laden with a multitude of meanings that complicates the discussions below. Tahkai were wooded

early Virginia landscape (Charlottesville: University Press of Virginia, 2001). Words: Hukamai: Horatio Hale, "The Tutelo Tribe and Language." Proceedings of the American Philosophical Society, 21:114 (Mar., 1883), 1-47, 22-23; Okahok, Ibid, 36; amai: Ibid: 38.

${ }^{35}$ Catchment area: Frank J. Findlow and Jonathon E. Ericson, eds, Catchment analysis: essays on prehistoric resource space (Los Angeles: Dept. of Anthropology, University of California, 1980). Words: maisonqyayunkai: Hale 1883a: 44; our valley: Ibid: 22-23. 
areas within the Monyton Onqyayun with varying degrees of human maintenance. These were not areas of wilderness, expanses of untamed dangerous woods, according to European definitions, contemporary or modern. Tahkai was the outermost area of systematic resource gathering in the Monyton Onqyayun. Tahkai in many ways was the beginning of humanenvironmental interaction, a region where the environment and humans were evenly matched. At the edge of the tahkai was a shorter zone tahkai iñkte (TAH-kai inyk-TAY), "nearby forest," which was marked by the end of large trees and the beginning of second growth plants. Much work has been done on the role of the "edge of the forest" and the cultural rituals and meanings of this zone. The full application of this concept will be discussed later. ${ }^{36}$ Unlike the human-influenced tahkai, mataque (ma-TAH-kay) or fields were entirely human created and artifices of cultural and dietary desires. This zone around the settlements provided a large portion of the food for Wahtakai. I distinguish mataque from European fields to disconnect them from the rowed and highly structured farming system that was practiced on the plantations and small farms maintained by the intruding British and French settlers. Mataque were carefully selected along floodplains that would get flooded yearly. The site selection of

\footnotetext{
${ }^{36}$ Colonial American historiography about forest and dichotomies of civilized-wilderness: According modern definitions a forest is an ecological term for a landscape dominated by trees. A wilderness, though, is an area "untrammeled by man" according to the 1964 Wilderness act. Jim Rice, Wilderness Acts: Environmental Change, Land Use, and the Rise of Chiefdoms in the Potomac Valley, 700 A.D. - 1608 OIEAHC Colloquium Paper, Sept. 12, 2001; Timothy Silver, A new face on the countryside: Indians, colonists, and slaves in South Atlantic Forest, 15001800 (Cambridge: Cambridge University Press, 1990), 104; Kenneth R. Olwig, "Reinventing Common Nature: Yosemite and Mount Rushmore - A Meandering Tale of Double Nature" In Uncommon Ground: Rethinking the Human Place in Nature ed. by William Cronon, (New York: WW Norton Company, 1995), 379-408, 399-401; William M. Denevan, "The Pristine Myth: The Landscape of the Americas in 1492" Annals of the Association of American Geographers 82:3, The Americas before and after 1492: Current Geographical Research (Sep. 1992), 369385; Simon Schama, Landscape and Memory (New York: Vintage Books, 1995). Words: tahkai: Hale 1883a: 39; cuqe: Ibid: 41; taksita: Ibid: 42; inkte: Ibid: 41; also see Chapter 5. Edge of forest: Jon Parmenter, The Edge of the Woods: Iroquoia, 1534-1701 (East Lansing: Michigan State University Press, 2010), Xxxvi; Warren 2014, 12; William T. Stark, ed., The Archaeology of Social Boundaries (Washington, DC: Smithsonian Institution, 1998); Hammett, 1992, 12; Kristen J. Gremillion, "The Role of Plants in Southeastern Subsistence Economies" In The Subsistence Economies of Indigenous North American Societies: A Handbook. Edited by Bruce D. Smith, (Washington, DC: Smithsonian Institution Scholarly Press, 2011), 387-400, 387-390.
} 
mampi was dictated by the availability and location of arable land for mataque, making them a protected resource. As one travels upriver along the Monyton Onqyayun, the valleys become steeper and narrower, limiting the arable lands and restricting mampi settlement to the west of the New River. Mataque would become threatened during the mid-seventeenth century from Wahtakai raiding from the North and South but also the variability of the Little Ice Age climate. $^{37}$

As we move closer to human habitations, we move into the mampi (MAM-pee), or “village." These were collections of people living together, but they were highly fluid polities with mixed language-ethnic families and complicated geopolitical affiliations. Mampi were subject to dramatic fluctuations in the composition as their residents utilized the Monyton Onqyayun seasonally and as war-captives, political marriages, and refugees found their way to the Okahok amai. Each mampi had a lifespan of twenty to thirty years as the tahkai and amai (ground) became exhausted and resources became scarce. After this the mampi would be abandoned and a new location would be occupied often carrying the name from the previous location. This was similar to the movement of Creek talwas and Cherokee towns. The fallowed mampi often would be reoccupied many times. So much like the Wahtakai (WAH-tak-aye), or "people," living within each mampi, these homes had an organic quality. ${ }^{38}$

\footnotetext{
${ }^{37}$ Mataque fields: Gremillion, 2011, 387-390; Parmenter 2010: xxxix-xl; April M. Beisaw, "Environmental History of the Susquehanna Valley around the Time of European Contact" Pennsylvania History: A Journal of Mid-Atlantic Studies 79:4 (2012), 366-376: 366-7.

${ }^{38}$ Social mechanisms of mampi: Pullins et al, 2010, 105; Paul W. Sciulli, "A Survey Of Pathological Conditions in The Southwestern Pennsylvania Monongahela" Archaeology of Eastern North America 30 (2002), 39-57, 41-2; Michael Adler "Negotiating the Village: Community Landscapes in the Late Pre-Historic American Southwest" in Inscribed Landscapes: Marking and Making Place edited by Bruno David and Meredith Wilson, eds. (Honolulu: University of Hawai'i Press, 2002), 200-218; David Pollack and A. Gwynn Henderson, "Toward a model of Fort Ancient Society" in Fort Ancient cultural dynamics in the Middle Ohio Valley edited by A. Gwynn Henderson and Emanuel Breitburg (Madison: Prehistory Press, 1992) 281-294, 286-7; further discussion is found for Cherokee village dynamics in Tyler Boulware, Deconstructing the Cherokee Nation: Town, Region, and Nation Among Eighteenth-century Cherokees (Gainesville: University Press of Florida, 2011); Christopher Rodning, Chapter 9: Community Aggregation through Public Architecture: Cherokee Townhouses. In From Prehistoric Villages to
} 
Inside each mampi were ati, houses. Admittedly, the term house would appear to have the least amount of linguistic baggage. The use of ati is here used in an attempt to distinguish Monyton Onqyayun structures from those of the surrounding regions, whether Siouan, Algonquian or Iroquoian. Ati should not to be confused with gilida (home), which is a much more amorphous cultural and psychological concept. The ati includes the house structure and the burials in the floor of the dwelling, along with food storage and trash pits in the vicinity of the structure. The ati was likely a cultural metaphor for the resident family, much like the political metaphor of the longhouse in Iroquoian tradition. Post molds of ati itañi (large house or special houses) have been found in sites like Buffalo mampi and seem to indicate that this was a political or religious meeting place. As with each of the above, the physical and social structures represented the residents' place within political and cosmological landscapes. ${ }^{39}$

Finally we come to the issue of what to call the residents of the Monyton Onqyayun. Generally speaking, the debate over Native American, American Indian or Amerindian in this microcosm study is solved by using known self-identifiers. I use the Tutelo (Yesanechi) word Wahtakai (WAH-ta-KAI) to distinguish indigenous peoples from Europeans. Keeping with the pattern of self-identification, I do use the term Europeans instead of the Tutelo term for "white people" miha maganaga. I refer broadly to the entire population of indigenous peoples of North America as Indian only when speaking about the European racial construction. ${ }^{40}$ Therefore, it would be Indian trade when with Europeans and Wahtakai trade networks with indigenous neighbors and distant relatives. Yet the regional focus here makes cultural and racial

Cities: Settlement Aggregation and Community Transformation, edited by Jennifer Birch. (New York: Taylor and Francis, 2013).Word: mampi: Hale 1883a: 44.

${ }^{39}$ Anthropology on houses: Gérard Toffin, "Ecology And Anthropology Of Traditional Dwellings" Traditional Dwellings and Settlements Review 5:2 (Spring 1994), 9-20. Word: ati: Hale 1883a: 17-19, 40; ati itañi: Ibid: 18.

${ }^{40}$ Despite the obvious problems with Columbus' mis-identification of the islands and their residents, Indians provides an economy of language and reference. American Indians, Native Americans, and Amerindians all are equally as inappropriate stemming from the reference to America and European control. For more on this see Karen Ordahl Kupperman, "Before 1607” WMQ 3rd ser. 72:1 (January 2015), 3-24. 
generalizations more problematic; therefore I utilize the names that certain groups used to refer to themselves. The name given by Gabriel Arthur in Abraham Wood's 1674 letter, Monyton, literally "beautiful water," probably only applied to that specific mampi. The term refers to the people living in the Kanawha-New River valley till the 1690s. I do not use the term Yesah, "river people," in the context of the Siouan peoples; instead I refer to each group individually as the Monyton, Tutelo, Saponi, Occaneechi, etc. When known, I describe individuals using their tribal affiliation, Mohawk, Seneca, Hitichi, Yuchi, etc. otherwise I revert to Wahtakai. $^{41}$

In the second half of this dissertation, the cultural landscape is altered significantly with the removal of Siouan-speaking peoples from most of the Okahok amai. Progressively, the italicized words will be replaced with their Shawnee, Seneca or English counterparts to convey the fading of the Siouan cultural landscape. The process of Algonquian, primarily Shawnee, takeover of the former Okahok amai in the eighteenth-century places more layers on the cultural landscape obscuring earlier occupations. Therefore, I discuss Algonquian usage of the landscape as an intrusive new pattern rather than applying new landscape terminology. The sole exceptions to this is the case of town-village. In settlements that were dominantly Shawnee, cheelakawtha (chee-lah-KAW-tha); dominantly Delaware, utèney (ew-TE-nay); and dominantly SenecaMingo, kanstaks (ka-naw-ta-kaw). Beyond these, eighteenth-century Iroquoian and European landscape concepts are described using English phrases. ${ }^{42}$

Above and below the layers of cultural information developed by Siouan and other Wahtakai, existed a physical reality, the climatic conditions of the environment. Until recently,

\footnotetext{
${ }^{41}$ People: Yesah, Esaw: Goddard 2005, 18; James H. Merrell, The Catawba, Indians of North America, Frank W. Porter III, ed. (New York: Chelsea House Publishers, 1989a), 25. Words: Wahtakai: Hale 1883a: 27.

${ }^{42}$ These words and concepts, including the explanations above, are based on the limited historical, archaeological, and ethnographic information available. This has been supplemented with theoretical and comparative anthropological literature to get away from the weight of semantic issues of English words for landscape. This is not a claim that these particular Tutelo words were derived from Tutelo documents in these exact contexts. Therefore each term may have semantic flaws hidden by language loss and the historical circumstances of Eastern Siouan speaking peoples.
} 
historians and anthropologists steered away from discussions of the role of the environment in history. This was due partially to the negative consequences of environmental determinism in indigenous history suggesting that Wahtakai were mere products of their environment and had no effect. Increasingly, scholars have circumvented this pitfall by examining the dialectic process between humans and their environment. Works like William Cronon's Changes in the Land, Carolyn Merchant's Ecological Revolutions, and Richard White's The Roots of Dependency described the climate and environment as serious forces within historical human actions and reactions but also began to analyze humans as part of climate-environment processes. Humans shaped the environment as much if not more than they were constrained and altered by it. The fields of environmental and colonial history have joined increasingly with climatologists to supplement problematic human observations with scientific data sets. David Stahle and many others collaborated in 1998 to analyze the droughts of the late-sixteenth and early-seventeenth centuries along the Virginia and Carolina coastline. Their use of cypress tree ring data showed the repeated occurrence of droughts during this seminal period in European settlement of the region. While scientific data sets provide support for the concrete reality of the climate, corroborating these with historical data is fraught with the ambiguities of the data and the subjective nature of human observations during the seventeenth- and eighteenth-centuries. In addition to the examination of droughts, floods and other weather related events, environmental history has become concerned with the global Little Ice Age that began in the late-fourteenth century. Brian Fagan produced an examination of the global instabilities that occurred during the Little Ice Age and noted that the period was hardly uniform across the planet and should be viewed more as a series of globally connected local instabilities. A close examination of the local climatic effects of the Little Ice Age led me to the science of paleoclimatology. ${ }^{43}$

\footnotetext{
${ }^{43}$ William Cronon, Changes in the land: Indians, colonists, and the ecology of New England (New York: Hill and
} 
Initially, this project relied heavily on a paleoclimatic data set that seemed to provide an unprecedented window into yearly changes in both temperature and precipitation. Harold Fritts' dendrochronological reconstruction provided a wealth of yearly figures covering the entire sixteenth, seventeenth, and eighteenth centuries. Sadly, Fritts' measurements have not been able to be duplicated and his presumption that temperature can also be calculated by measuring tree rings has been soundly discredited. By working back in time, dendrochronologists have been able to determine the variation in precipitation that does affect tree ring widths. This has been used to create the Palmer Drought Severity Index (PDSI) that is referred to throughout the document below. Climate played a significant if complicated role in the ability of groups to grow food, but even harsh conditions could be overcome through human ingenuity and adaptation. $^{44}$

Connected to the environmental histories presented above are the anthropological discussions of human ecology. Paul and Hazel Delcourt's Prehistoric Native Americans and Ecological Change continued the work of Shepard Krech and William Denevan concerning the process of indigenous land use and the effects it had on the environment. Far from being mythically "in-tune" with nature, the human residents of almost every ecological niche interacted and altered their environment to suit their own cultural and dietary needs; this often led to an unbalanced ecological system that responded in ways that forced residents to adapt their practices. While environmental history had discussed the ecological problems faced by

Wang, 1983); Carolyn Merchant, Ecological Revolutions: Nature, Gender, and Sciences in New England (Chapel Hill: University of North Carolina Press, 1989); Richard White, The Roots of Dependency: Subsistence,

Environment, and Social Change among the Choctaws, Pawnees, and Navajos (University of Nebraska Press, 1983)

David W. Stahle, Malcolm K. Cleaveland, Dennis B. Blanton, Matthew D. Therrell and David A. Gay, "The Lost Colony and Jamestown Droughts" Science, New Series, 280:5363 (Apr. 24, 1998), 564-567; Brian M. Fagan, The Little Ice Age: how climate made history, 1300-1850 (Basic Books, NY, 2002).

${ }^{44}$ Harold C. Fritts, Reconstructing Large-Scale Climatic Patterns form Tree-Ring Data: A Diagnostic Analysis (Tucson: University of Arizona Press, 1991); R. Stockton Maxwell, Amy E. Hessl, Edward R. Cook, and Brendan M. Buckley, "A Multicentury Reconstruction of May Precipitation for the Mid-Atlantic Region Using Juniperus virginiana Tree Ring” Journal of Climate 25 (Feb. 2012), 1045-1056, 1053. 
colonizing Europeans in works like D. W. Meinig's The Shaping of America, Joyce Chaplin has called on colonial historians to more deeply consider the process from an indigenous perspective. $^{45}$

The multi-disciplinary approach to the landscape history of the Okahok amai, the Middle Ohio Valley, and the Kanawha-New River valley is the beginning of an equally long process of reevaluating the region and the people that called it gilida (home). These various fields provide additional support to the limited historical details of everyday life in the Okahok amai and help to illuminate the significance of this region and its residents.

\section{Chapter Outline}

The story of the Monyton Onqyayun begins in wēhē piwa, the summer of Siouan control of the Kanawha-New River valley, 1500-1650. The cultural fluorescence within the Okahok amai is the focus of Chapter 1. As Monyton navigated the constantly shifting intergroup networks of the sixteenth-century, they revitalized and adapted deeply rooted cultural traditions to cope with social changes. After establishing the complexities of the culturally dynamic mampi within the Okahok amai, the arrival of Europeans began to affect Monyton interactions with their neighbors, as discussed in Chapter 2. The earliest interactions with the Spanish, English, French, and Dutch were far removed from the Monyton Onqyayun, but the effects of those contacts are evident in the archaeological record. Beginning with the accounts of de Soto's and Pardo's Southeastern explorations and ending with the English in Tsenacomoco (Virginia), the chapter focuses on the ripples of changes in trade, language, disease, and weather.

\footnotetext{
${ }^{45}$ Paul A. Delcourt and Hazel R. Delcourt, Prehistoric Native Americans and Ecological Change (Cambridge: Cambridge University Press, 2004); Shepard Krech, III, The Ecological Indian: Myth and History (New York: Norton, 1999); Denevan, 1992, 369-385; D. W. Meinig, The shaping of America: a geographical perspective on 500 years of history (New Haven: Yale University Press, 1986), 205-213.
} 
Summer in the Monyton Onqyayun faded into a tempestuous tañyi, autumn, during the last half of the seventeenth-century. Like the falling of leaves, people began to leave the region. Chapter 3 examines the shattering social networks highlighted by the English as they neared and then entered Monyton. By examining the Virginia-based expeditions from the perspective of the Wahtakai participants, the direct consequences of these contacts become much clearer. With the collapse of the Occaneechi after Nathaniel Bacon's attack in 1676, the Monyton began their final withdrawal from the Okahok amai (Chapter 4). The diaspora of Monyton occurred both by force and voluntarily. Increasing attacks by Iroquois warriors, mainly the Seneca, led to the removal of the Monongahela, a major trading partner of the Monyton. The seventeenth-century mourning war complex combined with a burgeoning Indian slave trade to scatter hundreds of Monyton across the Atlantic seaboard and likely among the Caribbean islands. Those who decided to flee mostly became refugees among the Southeastern Muskogeans, Cherokee, and Catawba. How they incorporated into the cultural and economic landscape of the Southeast is a case study in cultural creativity within the Southeastern shatter zone. While Monyton dispersed on the winds, the seasons changed again in the former Monyton Onqyayun.

From fall to winter, wāneni, the region laid largely untended and unoccupied during the first thirty years of the eighteenth-century, the subject of Chapter 5. The environment of the Okahok amai, left to its own processes without human intervention, became an overgrown garden. Far from "pristine" the long-lasting effects of hundreds of years of human management was hardly undone in a brief thirty year span. Remnants of management like clearings, fields, and former mampi remained accessible and important, especially for fur-bearing animals. Despite the fact that highland archaeological sites show evidence of continued small-scale occupation of the region, the Monyton Diaspora effectively ended roughly two millennia of 
control of the original Siouan homeland from whence all other Siouan-speaking peoples came. Following the examination of ecological panoply is a discussion of the human meaning of this regrowth. Chapter 6 suggests that while Monyton environmental management led to the degradation of the woodland forest ecology it also created the conditions for increases in wildlife populations that would make the region valuable during the eighteenth-century. This region was much more than just a hunting ground, it was an overgrown garden, and remained a home to many. The region was a sparsely inhabited territory but was frequently hunted and fought over by the Cherokee and Iroquois and their satellite groups. This required a sophisticated level of ecological interaction ignored by the hunting ground mythology.

The former Okahok amai woke from the dormancy of winter to wehahempeie, spring, witnessed by small mampi of Shawnee, Delaware, Seneca, Mingo, English, and even French dotting the region. Chapter 7 begins with a closer examination of this reinvigorated interest in the Ohio River valley. Algonquians outgrowing the Upper Ohio began extending southward by 1740. Iroquois and Cherokee maintained overlapping land claims within the Middle Ohio region. Celeron de Bienville, Christopher Gist, and a few European traders frequented the Middle Ohio region by the $1750 \mathrm{~s}$, leading to increasing international tensions. As peoples began earnest occupation of the former Okahok amai, the discussion turns to the language of ownership and environmental conditions. Shawnee and Delaware explanations of landscape utilization and their ecological effects differed greatly from Monyton practices. The increased value of the lands led to violent conflicts over land claims by the mid-eighteenth century that seriously affected Shawnee attempts to occupy the Kanawha-New River valley. The former Okahok amai was again at the center of the geopolitical tinderbox. 
I conclude by examining the meaning of the indigenous landscape in the larger context of Early American environmental and cultural history. The Okahok amai provides a poignant case study of long-duree shatter-zones. It witnessed the shattering of the last vestiges of Siouan control, then Algonquian, then Iroquoian, as British settlers intruded on the Greenbrier Valley in 1755 establishing the first permanent non-Indian settlements in in the former Okahok amai. The epilogue closes with Tanachrisson's well-known final act in the Ohio as it became the conflagration point for a global conflict with deep Siouan cultural hidden meanings. 


$$
\begin{gathered}
\mathrm{I}: \\
\text { Wèhē piwa (Summer) } \\
1500-1650
\end{gathered}
$$




\section{Chapter 1: \\ Towards a Monyton Okahok amai, 1500-1650}

"Our positive knowledge, beyond the date of 1650 , loses itself in vague conjectures. There is abundant evidence in the mounds everywhere abounding, and in the very bones found therein, as well as in articles buried beneath alluvial deposits, to indicate a former occupancy by a people differing socially and physically from the tribes so recently occupying the soil."

People have occupied the Okahok amai for at least 10,000 years but the landscape changed a great deal throughout that time. The occupants of the valley, Wahtakai, to varying degrees had interacted with the environment sometimes confined by it and sometimes actively altering it. It is important here to give a brief explanation of earlier occupations of the Monyton Onqyayun, from $800 \mathrm{BCE}$ to $1500 \mathrm{AD}$. This comprises the permanent settlements within the region beginning in the Woodland period through the Late Prehistoric. The Spanish arrival in the Caribbean did not impact the interior of the Appalachian Mountains; therefore the protohistoric period does not begin until 1540 with the advent of de Soto into the Southeast (Map 2.2a).

Woodland occupations of the Monyton Onqyayun started out as family-sized hamlet with opportunistic seasonal movements but increased in size to large multi-family mampi as they became reliant on the three sisters of agriculture, especially maize, which was introduced around 900 AD. The use of Muskogean cognates for maize among Ohio Valley Siouans, Monyton among them, indicates that the practice of planting maize originated from the South. ${ }^{2}$ The increase in populations and increasing social complexity coincided with the Medieval Warm period. As the populations relied on seasonal agriculture life became more sedentary and structured around mampi life and systematic use of the local landscape. By the end of the late

\footnotetext{
${ }^{1}$ J. R. Dodge, Red Men of the Ohio Valley: An Aboriginal History of the Period Commencing A.D. 1650 and Ending at the Treaty of Grenville, A.D. 1795 (Springfield, Ohio: Ruralist Publishing Co., 1860), 15.

${ }^{2}$ Muskogean cognates for corn among Eastern Siouans: Robert L. Rankin, "Siouan Tribal Contacts and Dispersions Evidenced in the Terminology for Maize and Other Cultigens." In Histories of Maize: Multidisciplinary Approaches to the Prehistory, Linguistics, Biogeography, Domestication, and Evolution of Maize, edited by John E. Staller, Robert H. Tykot, and Bruce F. Benz (Academic Press, 2006), 563-575, 572.
} 
Woodland period around 1000 AD large-scale consolidated mampi had developed throughout the Okahok amai, including the Adena and later Hopewell culture groups and their famous earthworks. Using twine twist information and stylistic differences in pottery, archaeologists have proposed an increase in cultural variation towards the end of the Late Woodland. The development of the Fort Ancient cultural pattern around $1250 \mathrm{AD}$ exhibited further the consolidation of ethnicities into complex mampi. This will be discussed in greater detail below as it pertains to Monyton Onqyayun during the sixteenth-century. ${ }^{3}$

The historiography, especially of the colonial period, has struggled to describe the societies of Wahtakai, assuming that groups were nearly homogenous "tribes." Archaeologists, understandably, also have difficulty discussing the ethnic makeup of mampi and tribal groups. This stems from two semantic issues that must be discarded in the discussion of the peoples of the Monyton Onqyayun. Anthropologists and archaeologists have shown that the rise of consolidated mampi often involved the mixing of ethnicities for mutual survival, protection, and maintenance of intergroup politics. These imagined-communities and their multi-ethnic archaeological signatures must be carefully examined, as ethno-historical literature has begun incorporating in works like The Mississippian Shatter Zone. The generalization, or worse social flattening, that comes from the assumption of homogeneity makes understanding the scattering of peoples from the Monyton Onqyayun during the second half of the seventeenth-century nearly unintelligible. ${ }^{4}$

\footnotetext{
${ }^{3}$ Woodland period: Pullins et al, 2008, 31-81; C. Clifford Boyd, Jr., "The Trigg Site (44MY3) and Other Late Woodland/Contact Period Sites Along the New River Valley in Southwest Virginia" (Paper presented SEAC Conference, Raliegh, NC, November 1993).

${ }^{4}$ As a relatively new framework, the application of shatter zone language is still being tested. The combination of borderlands with the shatter zone framework seems to be very promising for regions like the Monyton Onqyayun stuck very much between the gravitational centers of the Southeast and the Northeast. Ethridge, 2006, 207-218. The discussion has been greatly expanded in Ethridge Shuck-Hall, 2009. See introduction and Map 1.1 for an explanation of the meanings and implications of using "Monyton Onqyayun."
} 
As many historians and anthropologists have noted, the term "tribe" and its assumption of socio-political hierarchies must be carefully evaluated. In the case of the Monyton Onqyayun tribes did not exist. As I advocated in “Monyton Diaspora,” Renfrew's village-based peer-polity model explains the complexities of both archaeological and historical sources. This needs some minor revision considering the suggestion by Jay Custer, studying Appalachian Highland sites that showed a direct correlation between the size of the floodplain and the establishment of more complicated social organization. In regions where mampi grew and fractured due to the floodplain's restricted access and availability of natural resources, splinter groups tended to remain connected and subordinate to the original mampi. Peer polities became more complicated than single mampi, especially in times of need. The peer-polity model also provides for the mutable alliances between mampi in times of economic strife and opportunity. Tribal structures require a certain amount of cultural homogeneity and political centrality that is just not evident within the seventeenth-century Monyton Onqyayun. ${ }^{5}$

The world of the seventeenth-century as a constantly shifting cultural and environmental landscape is far more interesting than previously thought. It leads to a few major questions of the basic assumptions of Wahtakai life during the 1600s. How did ethnic identity and political power play out in these multi-ethnic mampi? How did ethnic identity influence the interactions between mampi?

\section{A brief history of Okahok amai, 1000-1500}

After the developed sites present during the Middle Woodland period (500BC-400 AD) identified as Adena and Hopewell, the Late Woodland seemed relatively quiet in the Okahok

\footnotetext{
${ }^{5}$ Emrick, 2005, 13-14; Colin Renfrew, Introduction: Peer Polity Interaction and Socio-Political Change, in Peer Polity Interaction and Socio-Political Change, eds. Colin Renfrew and John F. Cherry, (New York: Cambridge University Press, 1986), 1-18; Drooker, 1997, 1-14; Jay F. Custer, "A Controlled Comparison of Late Woodland Settlement Patterns in the Appalachian Highlands" In Upland Archaeology in the East: Symposium No. 2. Special Publication No. 38, Part 2. (USDA, Forest Service, Archaeological Society of Virginia, 1984), 75-101.
} 
amai. Early and Middle Woodland sites were incrementally becoming more sedentary as horticultural activities increased fueling the creation of many of the complex earthworks of the Lower and Middle Ohio River. This pattern collapsed from 400 AD till 1000 AD, known as the Late Woodland. It was marked by weakened trade relationships outside the region. Regionally diverse, the small mampi tended to build much smaller burial mounds rather than the large complicated enclosures of the Adena-Hopewell cultures. From 900 AD, when maize was introduced to the Okahok amai, the occupants of the Monyton Onqyayun started to rely much more on agriculture. This required the mampi to become more organized and politically centralized. ${ }^{6}$ Maize, in particular, led to increased food production with minor additional labor, which increased the populations that could be supported within a region but also required social mechanisms for maintaining and distributing the surplus. Maslowski theorized that a pattern of large nucleated mampi on the high terraces and smaller hamlets on bottom lands and uplands developed to more effectively utilize natural resources. This developed by $1050 \mathrm{AD}$ into what has been identified as the Fort Ancient cultural period. ${ }^{7}$

Whend escribed by James Griffin in the late 1930s, the Fort Ancient cultural pattern was an Ohio Valley expression of the trends towards bows and arrows, maize-beans-squash agriculture, and dramatically increasing populations. The switch from grit to shell tempered pottery, along with the use of gilloche designs along the neck, were unique developments to the Fort Ancient pattern. Initailly, mampi looked very similar to the hamlets that had dotted the

\footnotetext{
${ }^{6}$ Supporting this nucleation process is M. F. Seeman and W.S. Dancey, "The Late Woodland Period in Southern Ohio: Basic Issues and Prospects" In Late Woodland Societies: Trade and Transformation Across the Midcontinent, edited by T.E. Emerson, D.L. McElrath, and A.C. Fortier (Lincoln: University of Nebraska Press, 2000), 583-611. In response to this R. Berle Clay and Steven D. Creasman, "Middle Ohio Valley Late Woodland Nucleated Settlements: "Where's the Beef?"' West Virginia Archeologist 51: 1\&2 (1999), 1-10. Recent work on the Childers site (46Ms0121) not only shows an intrusive dominant S-twist population but also dedicated household spaces within a larger enclosure which seems to support Seeman and Dancey.

${ }^{7}$ Two important discussions of the transition from Late Woodland to Fort Ancient cultural patterns are in Pullins et al, 2008, 73-77, 81-85; Robert F. Maslowski, "Woodland Settlement Patterns in the Mid and Upper Ohio Valley" West Virginia Archeologist 37: 2 (1985), 23-34.
} 
valley during the Woodland period with four or five single-family ati but were placed much closer together with a central plaza area. By the seventeenth-century, mampi had developed into very dense collections of 30-50 much larger extended family ati surrounded by defensive palisades and their mataque. The ati typically had rectangular or oval bases dug into clay floors for long-term occupation, though there seems to have a good deal of variation of house size and shape. Burials were placed within or close by the house, and secondary burial may have been practiced regularly. It is still unclear whether the houses were bent-pole bark-covered lodges or thatched-roofed mud-walled building.

Within the houses residents boiled and roasted a wide range of foods. The largest portion of their diet was grown in the mataque. Maize alone provided nearly $60-80 \%$ of their diet according to Carbon isotope analysis of teeth. Though local domesticated plants appear to have declined in importance within their diet, they still comprised a signioficant, $10-20 \%$ of the archaeological remains found at archaeological sites within the Okahok amai. Mast, hickory and chestnut nuts along with beans, chenopods, blackberries were collected from the tahkai inkte (Table 4.5). The largest scources of dietary protein came from deer and freshwater mussels, but Wahtakai also ate box turtles, fish, bears, and snakes of all kinds (Table 4.6). The increasing presence of storage pits inside mampi and sometimes inside ati has been connected to food surpluses but also to the appearance of palisades and evidence of warfare.

The Okahok amai was dotted with different types of occupations to effectively utilize the resources of the environment but from an archaeological perspective there are only two site types that have been identified: villages (mampi) and camps. Places like the salt brines at Rand unfortunately have limited indigenous materials due to constant occupation and excavation during the nineteenth century. The area Rand also contanined some possible flint quarries and 
opened up onto the large flood plains east of the mouth of the Elk River. This region was highly desirable for agriculture and has always been one of the most heavily occupied. On the ridges and the interior onqyayun were hundreds of camp sites identified by fire cracked rock and lithic scatters that marked the staging areas for hunting expeditions. Rock shelters, many quite large, provided fall and winter protection for families travelling between seasonal occupations. Though villlages were occupied all year, many families dispersed to remoter locations, especially in harsher winter seasons. This general pattern spread the influence of human occupation out over a wider area of the environment and increased the length of time a mampi could stay in one place.

The landscape usage above was a logical response to the mountainous terrain of the Okahok amai and the combination of cultural influences from Fort Ancient traditions in the west and the Siouan traditions east of the mountains. The Okahok amai is cultrally transitional in the same way that Fort Ancient and Oneota patterns were to the west. Oneota, a Mississippian influenced population in Illinois and Indiana, was contemporaneous to the Fort Ancient patterns in Ohio. Penelope Drooker describes the Oneota as "ethnically mixed" between Algonquian and Chiwere Sioux that dominated the region to the east and west respectively, as such they had cultural elements of both groups. Graybill and others make that case for the Okahok amai being the transitional expression of Fort Ancient and Eastern Siouan elements. As you travel east through the region sites shift from mostly rectangular Fort Ancient structures to more ovoid Siouan style ati. The layout of the village plaza becomes less structured and Mississippian-like as you move east. This could be explained by the constrants of the physical landscape. Even the burial features of the Monyton Onqyayun quickly abandon the Fort Ancient tradition of stonelined graves interred with platform pipes, and utilize a great deal more marine shell Citico gorgets from Tennessee, and deer bone tube beads in simpler extended burials. 
Dan and Haw River Siouan pottery styles, i.e. Radford pottery, are also much more prevalent in the Monyton Onqyayun than undecorated Fort Ancient style pottery. Throughout the Fort Ancient period, Ohio pottery became progressively less ornamental and more utilitarian in construction. Net impressions and simple roughing for firing purposes were the majority of the surface treatments in Madisonville sites along the Scioto River in Ohio. Pottery from sites like Buffalo (46Pu0031) and Burning Springs Branch (46Ka0142) continued to mark pots with complicated designs especially around the necks of the pots well into the seventeenth century. East of the Ohio River archaeological sites also contained pots with corncob impressed pottery that was identifiably Siouan. The transition from Fort Ancient, mainly Madisonville focus, towards Dan-Haw River Siouan cultural expressions suggests that the region was socially and cultrally dynamic through a great depth of history. ${ }^{8}$

The beginning of the Fort Ancient cultural period, of which the seventeenth-century Monyton Onqyayun residents were examples, marked reinvigorated inter-regional trade networks, intensive maize agriculture, and with it much more complex social structures. The development of the cultural pattern was influenced by Mississippian traditions to the south and west, especially in the adoption of shell-tempered pottery and the reinvigorated exotic goods trade. While Late Woodland sites had low archaeological visibility, Late Prehistoric sites tended to be occupied longer and therefore left significantly more material. The development of Late Prehistoric traditions was delayed within the Appalachian Highlands of the eastern Okahok amai, where shell-tempered pottery and large nucleated mampi do not appear until around 1200 AD.

\footnotetext{
${ }^{8}$ Siouan traits: Spencer 2009, Maslowski 1984, Ward and Davis 1993, Ward and Davis 1999. Fort Ancient traits: Graybill 1981, Griffin 1937, Griffin 1943, Drooker 1997: 43.
} 
This may coincide with the full-fledged adoption of intensive maize agriculture that is marked by the Middle Fort Ancient Roseberry phase 1250-1450. ${ }^{9}$

The Early Fort Ancient period (1050-1250) was marked by Late Woodland style open, dispersed mampi with somewhat larger populations consolidated into fewer mampi. As farming helped maintain increased populations, and increased populations required more agricultural effort, mampi became clustered closer together to maximized farming lands, epsically in the restricted bottomlands of the Kanawha-New River Valley. Dispersed individual plots of land surrounded the mampi, facilitating the centralizing, storing, and distribution of inevitable food surpluses. Middle Fort Ancient period (1250-1450) Wahtakai expanded their reliance on maize agriculture by settling on floodplains rather earlier terraced locations. This led to more clearly planned nucleated mampi, though no evidence of palisades have been found during the Middle Fort Ancient period.

After a millennium of increasing sedentarism and more systematic usage, the Okahok amai was dotted with remnants of occupation that influenced residents of the sixteenth- and seventeenth-centuries. Mounds, rock art, petroglyphs, quarries, trails, and selective maintenance of the mountain flora and fauna were prominent features of the protohistoric Okahok amai (Table 4.5, Table 4.6). So far the story of the populations of the Okahok amai is one of constant change, adaptation, and interaction. New populations met, new landscapes were utilized, things changed. At least in this way not much changed for Wahtakai of the Monyton Onqyayun during the sixteenth- and seventeenth-centuries, though, the consolidation of mampi reached new hieghts as suplusses grew, and borderland tensions over resources increased between neighboring peoples.

\footnotetext{
${ }^{9}$ Roseberry phase: Pullins et al. 2008: 81, 83, 101-2; Jeffrey R. Graybill, "Carbonized Corn from the Roseberry Farm Site" West Virginia Archeologist 28 (1979), 50-52.
} 


\section{Late Fort Ancient 1500-1640}

The beginning of the Late Fort Ancient period (1450-1690) was markedly different from the previous periods. Fifteenth-century mampi, such as Clover (46Cb0040), Orchard (46Ms0061), and Buffalo (46Pu0031), were large organized, nucleated, and highly fortified mampi (Map 1.2). Following the pattern of the Early and Middle periods, the number of Late Fort Ancient sites decreased but dramatically increased in size and population. The increase in population has been extrapolated from the Late Prehistoric increase in house sizes. The inclusion of larger extended families promoted further development of clan and kinship structures within mampi. There were also seasonal extractive camps placed along the more remote areas of the floodplain to facilitate both specialized and frequent access to materials like Kanawha Black flint, salt brines, and even hunting glens. Unlike Early and Middle period sites, the Late Fort Ancient pattern shows increasing cultural similarity across the region. Pottery manufacture became more standardized with fewer types of tempering, in some sites over $90 \%$ consisted of shell-tempering. This was also seen in external treatments and decorations. It is important note the asemblages were never homogenous. This has been interpreted as decreasing mampi autonomy but as suggested by a peer-polity model could also be evidence of increasing allianceconfederations found among historic Wahtakai. ${ }^{10}$

Local variations, or phases, became much less distinct during the Late Fort Ancient period suggesting greatly increased interactions between Clover, Orchard, Woodside, Bluestone, and Mount Carbon sites (Table 1.1). The somewhat vague distinctions between phases have been interpreted as functions of both temporal and cultural, but to varying degrees, they all shared Mississippian influences emanating from the South. In particular, these sites include shell trade beads of Conch columnella, marginella, and olivella along with many examples of shell gorgets

\footnotetext{
${ }^{10}$ Middle-Late FA: Pullins et al, 2008, 83-84.
} 
that were produced in the Gulf coast (Diagram 1.3a-c). The addition of hammered copper and extra-local cherts also indicate dramatically increased connections with Wahtakai throughout most of the eastern half of North America. The highly developed trade networks witnessed by the Spanish during the 1500s support this flourishing period, and it appears that even in the 1500 s, the Okahok amai was a crossroads of cultural trade encompassing materials from across the Mississippi, Great Lakes, Iroquoia, Atlantic Seaboard, and the Gulf Coast. ${ }^{11}$

The five archaeological phases that cover the sixteenth and early seventeenth centuries: Clover, Orchard, Woodside, Bluestone, and Mount Carbon. Since a phase is largely focused on cultural traditions, they often are difficult to pin down temporally. More frustratingly, they are ambiguous when it comes to defining the "ethnicity" of the residents of particular mampi. Clover phase sites were restricted to the western edge of the Okahok amai from 1450-1640. Due to the mixture of pottery and the large number of shell gorgets from eastern Tennessee, Maslowski suggests that these mampi were Siouan or Yuchi speaking occupations, but his claims need to be refined. Recent ethnohistorical work indicates that the Yuchi were already on the move by the end of the 1500s. Their likely location seems to have been in eastern Tennessee throughout the sixteenth century; therefore, the presence of shell gorgets and clay figurines from the region is evidence of the connection between the Siouan speakers at Clover sites and the Yuchi remnants in the Cumberland Valley. Graybill notes that the Clover phase was the last pre-contact Fort Ancient phase, or as he termed it, "pristine." There are some major cultural issues with a heterogeneous "pristine" culture. Maslowski recommends that, despite the lack of European

\footnotetext{
${ }^{11}$ Shell beads, Copper, Local cherts: Pullins et al. 2008, 20-1; Penelope B. Drooker, "Madisonville Metal and Glass Artifacts: Implications for Western Fort Ancient Chronology and Interaction" Midcontinental Journal of Archaeology, MCJA 21 (1996), 145-190; Drooker, 1997.
} 
materials, Clover was a protohistoric site. This seems more likely considering the pottery traditions and lack of mounds at Clover style sites (Diagram 4.1). ${ }^{12}$

The Orchard phase has been identified as the descendants of the Clover phase and as an Algonquian cultural intrusion into the Monyton Onqyayun. But the interpretive problems of the Orchard site may be due to limited excavations and analyses. Pottery again shows a mixed society that practiced a Madisonville style pottery tradition, but European trade beads found at the site show at least some occupation into the late seventeenth century. Graybill originally identified the phase from 1640-1690 and occupied by Shawnee, Maslowski has proposed that Orchard was the remnants of the Clover mampi. Considering the ethnic mixing already discussed, this could be evidence of the mixing of Algonquian speakers with Siouan speakers present at other more Southern mampi. ${ }^{13}$

On the eastern edge of the Okahok amai in the Bluestone River valley was the Bluestone Phase. This was one of the earliest phases ranging from 1200-1450 and coincided with the cultural consolidation in western Virginia at the Trigg site (44My0003). The archaeological literature is limited for pre-proto historic shifts yet the high degree of cultural similarity between Bluestone sites indicates that many of these people moved eastward bolstering populations at other Siouan sites. The presence of historic materials at Barkers Bottom (46Su0072-46Su0672), however, indicates that despite limited archaeological evidence the Bluestone was not emptied.

\footnotetext{
${ }^{12}$ Yuchi: Frank G. Speck, Ethnology of the Yuchi Indians (Originally published 1909; University of Nebraska Press, Lincoln: 2004); Maslowski,1984, 161. Clover Site: Jeffrey R. Graybill, "Graybill: Late Prehistoric Study Unit” (Unpublished manuscript on file at the West Virginia State Historic Preservation Office, Charleston, 1988); Maslowski 1984.

${ }^{13}$ Orchard phase in Graybill 1988. Burning springs focused in Pullins et al, 2008.
} 
There is little question that culturally the occupants of the Bluestone Valley were predominantly Siouan speaking peoples with close ties to groups like the Tutelo, Saponi, and Occaneechi. ${ }^{14}$

On the southern edge of the Okahok amai, along the Tug and Guyandotte, was the

Woodside phase. This was a more amorphous cultural zone of mampi along the most restricted rivers. The amount of arable land in this region was significantly lower than in more northern areas in the Okahok amai. Mampi show evidence of frequent flooding that both assisted and hindered occupation. While flooding frequently washed away permanent structures, such as ati, it also made the pockets of flat land highly productive. Likewise, the steep mountainsides, while restricting the farmable lands, also protected those pockets from the worst frosts and made locations relatively easy to defend from passing raiders. Woodside phase sites were relatively early ranging from 1030-1630. The notable exception to this is Logan (46Lo0004) with glass trade beads dated to around 1630, (Table 4.1a-b). This likely means that while other Woodside populations moved out of the region, the remnants of Man (46Lo0005) and other mampi consolidated into the very large mampi at Logan during the mid-seventeenth century. The presence of European materials at Logan was one reason why Briceland indicated it as the location for Gabriel Arthur's "Monyton." This seems unlikely and will be closely examined below. $^{15}$

The most important phase and region consists of the middle portion of the Monyton Onqyayun. The Mount Carbon phase probably dates around 1400-1660. This included a diverse collection of sites with both Fort Ancient and Virginia Siouan traits. Graybill identified this

\footnotetext{
${ }^{14}$ Trigg: Boyd 1993; William T. Buchanan, Jr., The Trigg Site, City of Radford, Virginia Special Publication No. 14. (Richmond: Archaeological Society of Virginia, 1986). Bluestone Phase: Pullins et al, 2008, 85; Fuerst 2007; Smithsonian Institute. River Basin Survey, Bluestone Reservoir, West Virginia. (Unpublished Manuscript, 2005).

${ }^{15}$ Woodside phase: Robert C. Dunnell, Lee H. Hanson and Donald L. Hardesty, "The Woodside Component of the Slone Site, Pike County, Kentucky" Southeastern Archaeological Conference, Bulletin n. 14. (Morgantown: WVGES, 1971); Alan Vance Briceland, Westward from Virginia: The Exploration of the Virginia-Carolina Frontier 1650-1710, (Charlottesville: University Press of Virginia, 1987), 147-170.
} 
phase as the balanced intermediary between the two cultural traditions. This, however, helps us little in identifying the Wahtakai living at these sites. Mount Carbon is a multi-component mampi with long term occupations dating back into the Woodland period, but the latest major occupations were abandoned by the late-fifteenth century. This explains the pottery similarities between West Virginia collections and Madisonville in Ohio. Yet similar sites, like Marmet mampi, produced European trade beads from the mid-seventeenth century. While sites in the Bluestone have high percentages of Z-twist pottery, and Clover sites tend to have much lower percentages, the Mount Carbon phase is relatively balanced, supporting Graybill's theory that the sites in this area were the most evenly mixed. This, of course, proves to be a major headache in identifying cultural affiliations. $^{16}$

Establishing the chronology of sites often focuses on the presence of European items. Of the nine sites with European materials, only a few are well excavated (Map 2.1, Table 2.1). Sites like Logan (46Lo0004) and Gue Farm (46Cb0004) are poorly understood due to the limited excavation. Orchard and Rolf Lee have large amounts of European materials, which is understandable due to their proximity to the Ohio River. The most common items found in these sites were small glass beads. Many of these beads were from the first half of the seventeenth century. While these trade materials may have been introduced during the first half of the century, it is probable that many of these beads trickled inward from the Atlantic coast at a much slower pace than previously assumed. Glass trade beads appear to have found their way to the Monyton Onqyayun from Virginia, New York, and the Gulf coast. Most of the beads as well as other European trade goods are found in the context of the burials, these highly mobile and valuable materials didn’t always find their way underground. This further complicates the

\footnotetext{
${ }^{16}$ Mount Carbon and the central Monyton Onqyayun, a good overview begins in Pullins et al, 2008, 85-86; John E. Guilday and Donald P. Tanner "Vertebrate remains from the Mount Carbon Site, (46-Fa-7), Fayette County, West Virginia" West Virginia Archaeologist 18 (July 1985): 1-14.
} 
analysis of the chronological position of each of these sites. There is a noticeable lack of later seventeenth-century English materials and few larger items from the Spanish or French. ${ }^{17}$ Indigenous trade items are also important for establishing the chronology of sites. These items are also difficult to date. The residents of the Monyton Onqyayun were quite literally at the crossroads of the most lucrative trade routes in all directions yet residents maintained their relatively egalitarian meritocracy. The trade routes differed in many ways to modern economic practice. Regardless of whether the materials were indigenous or European, the amount of material along the route decayed and slowed in progress. Four hundred beads given to Powhatan for furs would mostly be distributed amongst his people and then become political capital. From this dispersion, the beads would eventually be split farther. Of the original four hundred, only about four or five of those beads likely made it to the Monyton Onqyayun. The speed and range of this trade is constantly discussed by archaeologists, but the only certainty seems to be its irregular opportunism.

The strength of foreign trade understandably was dictated by proximity within the Okahok amai. Northern mampi tended to have stronger Monongahela and Iroquoian trade connections, Bluestone mampi with Piedmont Virginia. Woodside tended to exhibit stronger Mississippian trade connections, and western Clover phase had stronger Algonquian connections. The presence of non-local materials has been a defining influence in the

\footnotetext{
${ }^{17}$ Transmission of Euro trade goods, special focus on the speed of transmission, glass trade beads: Drooker 1995, 48-58; Karlis Karklins, "Seventeenth Century Dutch Beads" Historical Archaeology (1974), 64-82; Karlis Karklins and Roderick Sprague, "Glass Trade Beads in North America: An Annotated Bibliography" Historical Archaeology (1972), 87-101; Stanely W. Baker, "Early Seventeenth Century Trade Beads from the Upper Ohio Valley" Ohio Archaeologist 36:4 (1986), 21-24; Gary L. Fogelman, Glass Trade Beads in the Northeast and Including Aboriginal Beads Industries (The Pennsylvania Artifact Series, Booklet 70, 1991).
} 
determination of cultural affiliation. This assumption continues to be reexamined from the perspective of multi-ethnicity in the prehistoric and protohistoric periods. ${ }^{18}$

Recent surveys of shell gorgets, pottery and cordage twists have produced interesting results. Archaeologist Darla Spencer's work is particularly useful in examining the various supporting evidence of Siouan occupation within the Okahok amai. (Map 1.4a-b, Table 1.2) ${ }^{19}$ During the fifteenth-century, Okahok amai mampi acquired access to the shell gorget trade (Diagram 1.4a-c). Gwynn Henderson and Darla Spencer both suggest that eastern and western Fort Ancient mampi were in nearly constant contact due to cultural similarity. ${ }^{20}$ Gorgets were largely produced in Tennessee and the Carolina Mountains from materials obtained from the Gulf Coast. The concentration of so many Citico, Mask, and smaller maskette gorgets indicates at least some cultural influence from the Southeast. This has been interpreted as evidence of participation in the Southeast Ceremonial Complex as James Griffin described in 1952 but recently criticized by Vernon Knight and others. ${ }^{21}$ As these exotic materials became important to intertribal trade, the strength of political alliance seems to have increased as well. The Tomahitta, who will be discussed in greater detail below, were powerful Southern allies of the Monyton and may have been one of the groups responsible for distributing the gorgets throughout the Okahok amai. The gorgets appear to have been valuable enough to be occasionally divided into smaller

\footnotetext{
${ }^{18}$ Heather A. Lapham, "More Than "A Few Blew Beads": The Glass and Stone Beads from Jamestown Rediscovery's 1994-1997 Excavations” The Journal of the Jamestown Rediscovery Center 1 (Jan. 2001); Heather A. Lapham and William C. Johnson, "Protohistoric Monongahela Trade Relations: Evidence from the Foley Farm Phase Glass Beads" Archaeology of Eastern North America 30 (2002), 97-120.

${ }^{19}$ Darla Spencer, "An Analysis of Late Prehistoric Pottery from Native American Villages in Southern West Virginia" Final Narrative Report, Grant No. 9022 (Unpublished report, 2009).

${ }^{20}$ East-West FA connection: Darla I. Spencer, "Evidence of Siouan Occupation" West Virginia Archaeologist (2009); A. Gwynn Henderson, David Pollock, and Christopher A. Turnbow, "Chronology and Cultural Patterns" In Fort Ancient Cultural Dynamics in the Middle Ohio Valley, edited by A. Gwynn Henderson. Monographs in World Archaeology No 8 (Madison, Wisconsin: Prehistory Press, 1992), 253-280, 267; Drooker 1997, 73-76.

${ }^{21}$ SE Ceremonial complex: James B. Griffin, An Interpretation of the Place of Spiro in Southeastern Archaeology. In The Spiro Mound, by H. W. Hamilton. Missouri Archaeologist 14 (1952), 89-106. Critique in Adam King, ed., Southeastern Ceremonial Complex: Chronology, Content, Contest (Tuscaloosa: University of Alabama Press, 2007); Vernon James Knight, Jr., "Farewell To The Southeastern Ceremonial Complex" Southeastern Archaeology 25:1 (Summer 2006), 1-5.
} 
maskettes often found with children. As the Mississippian chiefdoms declined and the power of Eastern Algonquians wavered, Southern gorgets also seem to have waned, suggesting a dramatic change in the indigenous politico-economic networks of the sixteenth and early seventeenth centuries. $^{22}$

While portable exotic materials, like gorgets, copper, and chert, indicate political and trade connections, not to mention some degree of individual mobility, locally manufactured materials hold the best clues to the identity of the Monyton Onqyayun Wahtakai. Mampi across the sixteenth and seventeenth centuries exhibited pottery styles that were remarkably similar to Virginian and Carolinian Siouan traditions. Incised rims on shell tempered pots and corncob impressions were used to identify the percentage of Siouan-style pottery at each site. Small percentages of pottery from Buffalo, Burning Spring Branch, Marmet, and other western sites were identified as Siouan (Diagrams 1.2a-d). Each of these sites continued to exhibit strong Fort Ancient Madisonville pottery traditions but with a greater degree of temper, style, and decorative features than sites west of the Okahok amai. Interestingly, Siouan-pottery (Radford, etc.) becomes more frequent moving east up river towards the New River. Within the Bluestone sites Piedmont Siouan pottery are dominant. This also further supports the view of the Monyton Onqyayun as a transitional multi-ethnic area. ${ }^{23}$

In her focused studies of surface features on protohistoric pottery in the Monyton Onqyayun, Darla Spencer has discussed a corncob surface treatment that strongly indicates the

\footnotetext{
${ }^{22}$ Gorget trade: Maslowski 1984 suggested that the Clover site may have in fact been Yuchi due to the large number of shell maskettes found as grave goods. This coupled with the large number of clay human shaped figurines at the site match closely Yuchi sites in Alabama and Mississippi. Darla S. Hoffman, "From the Southeast to Fort Ancient: A Survey of Shell Gorgets in West Virginia" West Virginia Archeologist 49:1-2 (1997), 1-40; J. P. Brain and P. Phillips, Shell Gorgets of the Late Prehistoric and Protohistoric Southeast (Cambridge, Ma.: Peabody Museum Press, 1996); Janet G. Brashler and Ronald W. Moxley, "Late Prehistoric Engraved Shell Gorgets of West Virginia" West Virginia Archaeologist 42:1 (Spring 1990), 1-10; David J. Hally, "Mississippian Shell Gorgets in Regional Perspective" In Southeastern Ceremonial Complex: Chronology, Content, Contest edited by Adam King (Tuscaloosa: University of Alabama Press, 2007), 185-231.

${ }^{23}$ Pottery styles and multi-ethnicity: Pullins et al 2008, 91-94.
} 
presence of Siouan speaking peoples within the onqyayun. In this method, the corn kernels are removed from the cob and it is rolled or smacked onto the wet surface of the pot for decorative effect. Spencer noted some references by Lee Hanson and Graybill from the 1970s and 1980s but more recent work has misclassified corncob impressions as fabric impressions. Keith Egloff's work on Woodland and Late-Prehistoric sites in southwestern Virginia shows this feature to be highly indicative of the Siouan-speaking peoples that became the Tutelo and Saponi along with other Piedmont Siouans. At Virginia Siouan sites around 8-10\% of pottery have signs of corncob impressions, a figure generally matched at sites in the Monyton Onqyayun. Like sites within the Okahok amai, Virginia Siouan sites exhibit comparable evidence of multi-ethnicity. ${ }^{24}$

Much like the Siouan-styling of corncob impressions, fabric impression can tell researchers a great deal about the identity of the potter. Fabric and cord impressions in pots leave indications of the twisting methods used in the manufacture of the textiles. There are two methods for producing twine, $\mathrm{S}$ and $\mathrm{Z}$ twist, named for the direction of the fibers. Twine manufacture tends to maintain a high degree consistency as it is passed from generation to generation. Once learned it becomes engrained in muscle memory. Cordage twist direction used in conjunction with other traits within a site can be used to evaluate cultural identities. The theory that sites such as Burning Spring (46Ka0142), Marmet (46Ka0009), and even Snidow (46Mc0001) are within a contact zone between Fort Ancient and Siouan traditions is based on the dominance of Z-twist cordage, a Siouan trait (Maps 1.4a-b). During the Middle Woodland in

\footnotetext{
${ }^{24}$ Fabric and Corncob impressions: Darla Spencer, "The Significance of Corncob-Impressed Pottery at Late Prehistoric Sites in Southern West Virginia" (Paper presented at the 74th annual Society for American Archaeology meeting, Atlanta, Georgia, 2009); Lee H. Hanson, Jr., The Buffalo Site - A Late 17th Century Indian Village Site (46PU31) in Putnam County, West Virginia. Report of Archaeological Investigations 5, (West Virginia Geological and Economic Survey, Morgantown, 1975); Graybill 1981. Graybill, 1984, 40-50; Keith T. Egloff, Ceramic Study of Woodland Occupation along the Clinch and Powell Rivers in Southwest Virginia (Virginia Division of Historic Landmarks, Research Report Series 3, Richmond, 1987); Keith T. Egloff, "The Late Woodland Period in Southwestern Virginia" In Middle and Late Woodland Research in Virginia: A Synthesis, edited by Theodore R. Reinhart and Mary Ellen N. Hodges, 1992: 187-223.
} 
fact the appearance of intrusive S-twist sites along the western edge of the Okahok amai has been interpreted as the introduction of new cultural groups. Parkline sites have been interpreted as Siouan reoccupations of sites on the western edge of the Okahok amai that had been dominated by Algonquian speaking peoples. ${ }^{25}$

During the sixteenth-century, the Okahok amai witnessed a great deal of social and demographic change. During the Woodland period, new populations of Wahtakai settled west of the Okahok amai that were, at least initially, much more mobile and culturally different than the residents of mampi, like Childers (46Ms0121) on the Ohio River. Middle-Late Woodland period (100 BC-AD 1000) sites along and East of the Ohio River showed a great deal more variation than the Late Prehistoric occupations of the same region. Wahtakai at Childers mampi (100 BCAD 750) used dominantly S-twist cordage for surface treatments on their pottery. Roseberry phase (AD 1000-1450) sites, like nearby Rolf Lee (46Ms0123), impressed their pottery with dominantly Z-twist cordage (Map 1.4a-b). The diversity of the Late Woodland period has been explained as a period when Algonquian and Iroquoian Wahtakai began moving from their northern homelands southward to eventually become the Tuscarora, Cherokee and Shawnee. Siouan wahtakai pushed back against these encroachments strengthening their control east of the Ohio. The Scioto Valley continued to be a balanced mix of S and Z twist well into the Late Prehistoric and Protohistoric period. By the arrival of the Spanish in the sixteenth-century,

\footnotetext{
${ }^{25}$ Siouan Z-twist: Christopher Carr and Robert F. Maslowski, "Cordage and Fabrics: Relating Form, Technology, and Social Processes" In Style, Society, and Person: Archaeological and Ethnological Perspectives, edited by Christopher Carr and Jill E. Neitzel, (New York: Plenum Press, 1995), 297-343; Pullins et al 2008; Emory E. Jones, Jr., "Archaeological Investigations at the Snidow Site (46MC1), Mercer County, West Virginia" West Virginia Archaeologist 39:1 (Spring 1987), 1-20; Hillis J. Youse, "Marmet Village - Archaeological Site 46KA9" West Virginia Archaeologist 40:1 (Spring 1988), 47-49; Parkline Siouan in Algonquian territory in Pullins et al 2008: 75.
} 
Siouan wahtakai were the largest ethnic group but practioners of non-local cultures always comprised at least a quarter of the overall population. ${ }^{26}$

\section{Climatic Change and a Dynamic Landscape}

As evidence of Siouan occupation of the Monyton Onqyayun mounts with each excavation in the region, it also becomes apparent that the cultural and ethnic fluidity of the fifteenth and sixteenth centuries increased the diversity within the Okahok amai. This flexibility proved to be one of the most effective social mechanisms to cope with not only new Wahtakai, as it had been in the past, but also environmental changes as the Little Ice Age grew tumultuous.

Climate change, much in the news presently, has always been a major factor in the dialectic process of cultural change. The climate around 1250 began a steady decline in temperature from the Medieval Warm Period, which was much like the climate of North America during the twentieth century. By 1500, winters were growing much colder, snowier, and deadlier. This is only part of the complicated changes in weather. The Little Ice Age (1500-1900) gained a reputation, from European historical experiences, as a period of nearly perpetual winter. Brian Fagan has begun to deconstruct these misperceptions of the Little Ice Age in his discussion of the subject in 2000. "The five centuries of the Little Ice Age were defined by these shifts: short periods of relatively stable temperatures were regularly punctuated by markedly colder or wetter conditions that brought storms, killing frosts, greater storminess, and cycles of poor

\footnotetext{
${ }^{26}$ For further conversations about cordage twists, Penelope B. Drooker, "Approaching Fabrics Through Impressions On Pottery" (Unpublished manuscript. 2001). Childers twist data is from Nancy O'Malley, "Ceramics from the Childers and Woods Sites" In Childers and Woods: Two Late Woodland Sites in the Upper Ohio Valley, Mason County, West Virginia, by Michael J. Shott, (University of Kentucky, Program for Cultural Resource Assessment Archeological Report No. 200, 1990), 691- 815; R. F. Maslowski and D.L. Dawson, "Childers (46Ms121): A Terminal Late Woodland Village" West Virginia Archeologist 30 (1980), 4-32, 26. Discussions of Parkline from Charles M. Niquette and J.P. Kerr, "Late Woodland Archeology at the Parkline Site, Putnam County, West Virginia" West Virginia Archeologist 45: 1\&2 (1993), 43-49; and Charles M. Niquette and Myra A. Hughes, eds. Late Woodland Archeology at the Parkline Site (46PU99), Putnam County, West Virginia (Contract Publication Series 90-93. Cultural Resource Analysts, Lexington, Kentucky, 1990).
} 
harvests. ${ }^{27}$ This variability broke the most resilient of European subsistence farmers. Fagan continued that the exact climatic conditions that plagued Europe during the sixteenth and seventeenth centuries also affected North America. ${ }^{28}$

Tree ring data suggests this geographic assumption needs to be reevaluated. The ocean currents and Jet Stream, as discussed by Brian Fagan, were moving around and bringing much colder currents and air to Europe but did not impact North America as severely. Recently William Foster synthesized the current historical literature in Climate and Culture Change in North America AD 900 - 1600. Foster's analysis primarily focused on Spanish documents from the sixteenth century with limited reference to the tree ring analysis of Harold Fritts and others. De Soto and Coronado contain the best evidence of dramatically colder temperatures. In the 1540s, both conquistadores were traveling in the southern half of North America. Both unexpectedly dealt with deep snows in the Lower Mississippi and Great Plains. Despite the colder winter temperatures, and the likely decrease in frost free days, the most dramatic problem appears to have been droughts. ${ }^{29}$

Cypress populations along the Virginia coastline show evidence of severe droughts during the late sixteenth century affecting the region from 1560 to 1612. Santa Elena was so badly affected by drought that Fagan suggests this was a major reason the Spanish capital was moved to St. Augustine in 1589. Roanoke also may have been caught by this extreme drought in 1587. Fagan proposes, and Foster agrees, that when Jamestown was built in 1607, the English

\footnotetext{
${ }^{27}$ Fagan 2000: 102.

${ }^{28}$ Climate change, Medieval warm period, Little Ice Age: Fagan 2000, William C. Foster, Climate and Culture Change in North America AD 900 to 1600 (Austin: University of Texas Press, 2012); C. J. Sapart, et al. "Natural and anthropogenic variations in methane sources during the past two millennia" Nature 490 (4 Oct. 2012), 85-88.

${ }^{29}$ Foster 2012; Fritts 1991; David W. Stahle, et al., 1998, 564-567.
} 
were arriving in the final throws of a nearly fifty year drought. Recent work on upland Appalachian forest drought data indicates that this period saw similar droughts far inland. ${ }^{30}$

The period leading up to the 1640 s was one of great environmental potential and was a factor in the increasing populations of the Okahok amai. This is shown in the paleoclimatological data collected in Appendix 3. Compared to the baseline of 1901-1970 weather data, the tree-data set showed a period of above average rainfall peaking at 12" above baseline in 1638, which meant extremely good conditions for agriculture throughout the first half of the seventeenth century. This period coincides with the largest populations in the region during the late Prehistoric-Protohistoric period. These ecological-economic highs were directly correlated to population increases since it facilitated higher maize yields; thus, as the climate shifted, the Okahok amai Wahtakai responded in myriad ways to maintain their standard of living. ${ }^{31}$

The entire Okahok amai exhibited ecological resilience to cold climate that made it a rich resource. This meant furrier beavers well into the eighteenth century, even after over hunting. It also produced deer with thick and desirable skins. Natural selection, along with selective human intervention, created a population of animals and plants suited well to feeding robust populations of Siouan, Algonquian, and Iroquoian speaking peoples. The Little Ice Age during the first half of the seventeenth century allowed the Monyton to flourish and increase their control over the Okahok amai. But climatic conditions were worsening during the 1650 s as the precipitation

\footnotetext{
${ }^{30}$ Stahle et al 1998; Fagan 2000, 96; Foster 2012, 127-129.

${ }^{31}$ Panoply and Cultural ecology: Carole L. Crumley, "The Ecology of Conquest: Contrasting Agropastoral and Agricultural Societies' Adaptation to Climatic Change” in Historical Ecology: Cultural Knowledge and Changing Landscapes, edited by Carole L. Crumley (Santa Fe: School of American Research Press, 1994), 183-202; Delcourt Delcourt, 2004; Brian D. Smith, Introduction: Indigenous North American Societies and the Environment. In The Subsistence Economies of Indigenous North American Societies: A Handbook. Edited by Bruce D. Smith, Washington, DC: Smithsonian Institution Scholarly Press, 2011: 1-10; Mark Q. Sutton and E. N. Anderson, Introduction to Cultural Ecology (Walnut Creek, CA: AltaMira Press, 2004). The socio-cultural implications of this dialectic will be covered in greater detail in Chapter 2 and 4.
} 
began declining dramatically and would contribute to the demographic collapse witnessed later in the seventeenth century.

\section{An Old World stumbled upon...}

Far from a cultural backwater or depopulated terra nullius, the Okahok amai was a highly sophisticated cultural crossroads. The Monyton Onqyayun and surrounding Okahok amai was just beginning to flourish and deepen its connections to Mississippian chiefdoms to the South, Algonquian confederacies in the East, and Iroquoian confederacies to the North as the conditions that brought prosperity for a long century began to destabilize. New trade items, people, animals and plants began to travel along well-worn trade routes through the heart of the Okahok amai while the weather took a turn for the worse.

Wahtakai had become accustomed to greeting travelers, traders, diplomats, and warriors during the hieghts of the population increases of the sixteenth and early-seventeenth centuries. Their world had grown to include trade materials from thousands of miles distant and even become influenced by religious rituals from the Mississippians chiefdoms. Though most days were occupied with maize farming and hunting in the tahkai, the residents of the Monyton Onqyayun eagerly devoured the stories carried along the trade-paths of rapacious light-skinned people travelling in the south. 


\section{Chapter 2: \\ Europeans on the edge of the Monyton Onqyayun, 1500-1650}

"But for any salt water beyond the mountaines, the relations you haue had from my people are false."

While there is no evidence of Europeans visiting the Okahok amai during the sixteenth and early seventeenth century, their presence and actions were likely well known and reported. European actions had immediate diplomatic and economic effects within the trade networks across the entire eastern half of North America and beyond. From the introduction of European metals to the diseases that were beginning to take hold along the coast, the changes were subtle at first but accumulated quickly. The arrival of Spanish, French, and English settlers played a significant role in the changes witnessed within the Okahok amai. The presence of European trade items, especially Spanish metals and beads, in sixteenth-century archaeological sites within the Monyton Onqyayun were among the most visible changes. The influence of Spanish entradas in the Southeast has seen a rebirth in the historiography recently with the work of Charles Hudson, Robbie Ethridge, and Joseph Hall. These reevaluations place de Soto in the vibrant Wahtakai socioeconomic and cultural networks that fed into the Okahok amai and beyond. ${ }^{2}$

\section{Spanish Introductions, 1514}

The first introductions to the Spanish for mid-Atlantic Wahatakai begin in 1514 with the slave raids of Captain Pedro de Salazar along the modern day South Carolina coast. While these raids were admittedly minor in scope affecting only a few locations and totaling a few hundred people, the tales of these initial contacts were the first indirect contact interior Wahtakai had with the Spanish. It is also likely that these stories were received with little concern. Except for the

\footnotetext{
${ }^{1}$ Edward Arber, ed., Travels and Works of Captain John Smith (Edinburgh: John Grant, 1910), 1:121. Powhatan to Smith.

${ }^{2}$ Charles M. Hudson and Paul E. Hoffman, The Juan Pardo expeditions: explorations of the Carolinas and Tennessee, 1566-1568 (Tuscaloosa: University of Alabama Press, 2005); Ethridge 2010; Hall 2009.
} 
fact that the Spanish arrived in ships, the abduction of Wahtakai was well within the cultural expectation for warfare at the time. What was more frustrating, at least for affected coastal Wahtakai, was that reprisal was nearly impossible as the Spanish had no accessible settlements. This changed in the 1520s as slave raiding increased and the Spanish attempted permanent settlements. Pedro de Quejo and Francisco Gordillo repeatedly attacked and abducted Wahtakai from not only the Carolina coastline but all the way north to the Delaware River in 1521 . Some of these slaves became begrudging interpreters for Lucas Vázquez de Ayllón. In 1526, he attempted to settle 600 Spaniards at Winyaw Bay but they lasted only a few months after Ayllón grew sick and died. More importantly, the formerly enslaved Wahtakai interpreters abandoned the settlement within days of arrival. For nearby Chicora and other Wahtakai these former captives disseminated an understandably negative message about the Spanish: Beware! ${ }^{3}$

Pánfilo de Narváez’s 1527 exploration was closer to the Spanish entrada utilized in Central and South America. While limited trading had occurred within the Ayllón settlement, Narváez introduced some of the classic Spanish trade materials that came to dominate trade networks of the seventeenth century when they met a chief claiming to be an enemy of the Apalache: "We gave him beads and hawk-bells and other presents, and he gave the Governor the skin with which he was covered..." ${ }^{4}$ Though again unsuccessful by the goals of the expedition, the very brief visit along the Gulf coast introduced European materials, most notably glass beads, into one of the largest conduits of the indigenous trade network in North America (Map 2.2a).

While whispers of these newcomers certainly reached well into the interior of North America, it was the de Soto expedition that brought the Spanish presence into the Monyton

\footnotetext{
${ }^{3}$ Salazar, Quejo-Gordillo, and Ayllon: Charles Hudson, Knights of Spain, Warriors of the Sun; Hernando de Soto and the South's Ancient Chiefdoms (Athens: University of Georgia Press, 1997), 32-34.

${ }^{4}$ Alex D. Krieger and Margery H Krieger, "Appendix 2: Account of the Disasters (Relación de Los Naufragios) Alvar Núñez Cabeza de Vaca" We Came Naked and Barefoot: The Journey of Cabeza de Vaca Across North America. (Austin: University of Texas Press, 2002), 155-242: 164.
} 
Onqyayun. Hernando de Soto, fresh from the occupation of Tenochtitlan with Hernan Cortez, directed his efforts toward Florida. After such meager initial settlements, the Spanish now presented themselves to sixteenth-century Mississippians in extravagant style. Much like Hall's work in Zamumo's Gifts, it is important to view de Soto's interactions within the context of the social implications for the Wahtakai themselves. De Soto bisected the southern trade routes that connected the Okahok amai to some of the wealthiest and most active Southeastern mampi. His presence has been shown to have greatly disrupted local politics and economies; disruptions that altered indigenous trade in both beneficial and negative aspects. The introduction of large numbers of beads, axes, and copper pots increased the authority of the recipients within the trade networks (Map 2.2a).

De Soto's journey provides insight into not just indigenous politics but also the climatic issues affecting the entire region including the Okahok amai. The winters from 1539 to 1543 were very severe with debilitating snows in the Southeast; this matches the paleo-climatic models produced using carbon isotopes captured form ice cores. ${ }^{5}$ The expedition was forced to winter along the Gulf Coast of Florida in 1539, very early in the expedition, from the beginning of October till March of the next year. The implication here is two-fold. First, local Apalachee appear to have left them alone during this time. This could be due to the weather coupled with the general anxiety towards engaging Spanish horses, dogs, and guns. Secondly, the weather was moist and cold, much like it was later along the Mississippi, enough to make the Gulf Basin difficult to navigate. There was no mention of snow but the marshy landscape was not one the Spaniards were accustomed to navigating, especially on horseback. ${ }^{6}$

\footnotetext{
${ }_{6}^{5}$ Sapart et al, 2012.

${ }^{6}$ Lawrence Clayton, Vernon James Knight Jr., and Edward C. Moore, De Soto Chronicles: Hernando de Soto to North America in 1539-1543 (Tuscaloosa: University of Alabama Press, 1993), Rangel, 267.
} 
By December of the next year, de Soto and company were in Alabama at Chicaza and came upon another possible indication of the climatic shifts. The severe flooding Ranjel discusses on December 14, 1540 forced the party to create boats to float across. The winter months were difficult on not only the Spaniards, but also on occupants of the Southeast. A few days later, the floodwaters began to recede only to be replaced by deep snows. The Spaniards stayed at Chicaza till March of 1541, much to the concern of the local Wahtakai as food supplies were already stressed without the burdensome Spanish intrusion. ${ }^{7}$ The next winter appears to have been worse. In a description of the practice of snaring rabbits, the Elvas account alludes to the commonality of hard frosts and snow in the South. From November 1541 till March of 1542 the Spaniards wintered at Autiamque along the Mississippi River in modern-day Arkansas:

"Many [rabbits] were taken in the maize field, especially when it froze or snowed. The Christians were there a month amid snow during which they never left the town. When firewood was needed, the governor with those of horse going frequently to and from the woods." 8

Each winter of the campaign forced a halt from late November till mid-March. This is much longer than the current winter cycle in the Southeast, corroborating a severely shortened growing season during the early sixteenth century. This matches William Foster's theory that there was a cold snap during the 1500s heralding in the beginning of the Little Ice Age in North America.

The de Soto expedition entered the territories of many of the southern trading partners of Monyton Onqyayun mampi. The lasting effects of this contact could be seen by subsequent expeditions of Spaniards. While much has been made of the destructive effects of contact with Europeans, especially from disease, this seems hardly sufficient to explain the dramatic changes

\footnotetext{
${ }^{7}$ Clayton Knight Moore 2005: Rangel, 297.

${ }^{8}$ Ibid: Elvas, 129.
} 
in the Southeast from the 1540s till the 1560s. Pauketat, Hudson, and Hill interpret the demographic collapse witnessed during the sixteenth century as part of a cultural process stemming from the weaknesses inherent in the highly stratified Mississippian social structure and coupled with an increasingly unreliable climate. In particular, Hudson notes there is little evidence of disease among de Soto's Spanish cohort and thus foreign diseases probably had little to do with the collapse. The cultural landscape was already in great flux by the end of the sixteenth century. ${ }^{9}$

Twenty years later, Tristan de Luna re-entered the Southeast and despite his limited success provided some important anecdotes of the cultural landscape. From his accounts we can establish that the populations of the Southeast appeared to have decreased, violence was increasing, and food was scarce. This at least was true for the Coosa River valley, but recent archaeological and historical work suggests that this poorly planned and recorded trip may have missed the demographically stronger regions to the east and west. Luna's expedition, however, does show that the residents of mampi previously contacted by de Soto were weakened and suspicious of the renewed Spanish interest. In fact, Wahtakai uprisings were a constant worry. Luna's correspondence with one of his lieutenants stationed closer to the coastline at Nanipacana explained that he "feared that the natives may revolt when they collect their corn from fields," because he had to "take it [corn] from them as they will have to do so as to maintain themselves." Luna was well aware of the desperate hopes that "they [i.e. the Spaniards] are only passing through," which led the Wahtakai to "give them carriers and everything they ask merely

\footnotetext{
${ }^{9}$ Any conversation about demographic collapse of course has to start with Henry F. Dobyns, Their Number Become Thinned: Native American Population Dynamics in Eastern North America (Knoxville: University of Tennessee Press, 1983); more recent work has suggested that Dobyns may have grossly exaggerated the immediacy and primacy of disease in depopulation. The list of critics include: Marvin T. Smith, "Aboriginal Population Movements in the Early Historic Period Interior Southeast" In Powhatan's Mantle: Indians in Colonial Southeast edited by Peter H. Wood, Gregory A. Waselkov, and M. Thomas Hatley (Lincoln: University of Nebraska Press, 1989), 43-56; Timothy R. Pauketat, Chiefdoms and Other Archaeological Delusions (Lanham: AltaMira Press, 2007), 31-52; Hudson 1997, 179-180; Hall 2009, 20-1.
} 
to get them out of the country." ${ }^{10}$ While the uprising was scuttled, the constant fear of attack led Luna to return to the friendlier coastal mampi prematurely. The distinction between the coast and the interior Wahtakai remained a dichotomy of friend-foe well into the seventeenth century, as can be witnessed by the Tomahittan attacks on Gulf Coast Spanish towns in the 1670s (Map 2.2b).

Luna and Fray Domingo Salazar discussed another ethnographic detail while at Coosa that highlights the diversity and mobility of Southeastern Wahtakai. Salazar noted, "The language is another one, very different and more difficult, although they have some words from there [Nanipacana]." Luna uses information "according to what we have understood from the interpreters" repeatedly to describe the political connections and responsibilities between mampi. The use of the plural is intentional indicating a pre-existing diplomatic linguistic network similar to the one de Soto found. This multi-lingual system, while cumbersome and prone to mutual cross-cultural misunderstandings, also facilitated the transmission of stories about the behaviors of these new people to seemingly remote Wahtakai, such as the residents of the Monyton Onqyayun. $^{12}$

Luna also provided details about the changing climate. After Luna wrote of the scarcity of food on his way north to Coosa, Governor Velasco wrote from Mexico:

"Thy assert that in the more than five years during which Soto traversed it they never lacked food, and that in some of the towns where they wintered, staying four or five

\footnotetext{
${ }^{10}$ Luna Papers 1: 209, Luna to Sauz, Nanipacana; 1560 1: 234-244 See also 1:221, Luna [?] to Velasco (Xaramillo, memoir) Ochuse [?] August 1560, 1: 194-234.

${ }^{11}$ Luna Papers 1, 245: Fray Domingo Salazar to Navarro, Coosa, July 31 [?] 1560.

${ }^{12}$ Luna Papers 1, 223, Luna to Sauz, Nanipacana, 1560 234-244.
} 
months, they left food to spare when they went away. [Hence] I am surprised at the great scarcity of it which you encountered.",13

Luna discussed the source of this scarcity in a letter he wrote to Lieutenant Sauz earlier in 1560. He noted the weather is "unequal, with extremes of heat and cold" and went on to describe unreliable rainfall. In that same letter he describes Coosa, a major mampi, as having 40-50 houses, which was a great deal smaller than the hundreds witnessed by de Soto two decades earlier. This instability affected different parts of the Southeast differently and understandably altered the distribution of people across the Southeast as they sought more stable landscapes. ${ }^{14}$

After a brief and quickly scuttled French occupation, Charlesfort, along the Carolina coastline, the Spanish resumed attempts to explore the Southeast. If not for Charlesfort in 1562, though, Juan Pardo would have probably been equally as unsuccessful at Luna. One of the residents of Charlesfort, Guillaume Rouffi, had remained and learned the coastal Siouan languages. In his instructions for the expedition, Pardo was informed that Pedro Menédez de Avilés, adelantado to provinces from the king, was bringing "Guillermo Ruffín [Guillaume Rouffi], a Frenchman and interpreter for much [of the] land of Florida. ... being a person who is an interpreter of the said Indians and ordinarily understands them all." ${ }^{\prime 15}$ For the better part of two years, the Pardo expedition navigated the Carolinas and revisited the Northern and Eastern segments of de Soto's journey. These were the closest Wahtakai to the Monyton Onqyayun and therefore this account revealed much more of their cultural landscape.

Pardo, along with acquiring an interpreter, was also told to "Be very friendly with them [Wahtakai], trying to persuade them to the obedience of His Majesty..."16 Despite this, Pardo

\footnotetext{
${ }^{13}$ Luna papers 2, 149: Velasco to Luna, Mexico, September 13, 1560 (2:137-153).

${ }^{14}$ Fritts 1991: xviii-xix; see also Foster 2012: 120-168.

${ }^{15}$ Hudson Hoffman 2005: 258.

${ }^{16}$ Ibid.
} 
was severely distrusted by the mampi he visited. He was after all heavily armed in much the way de Soto had been before and was tasked with building permanent forts throughout the Southeast. That the occupations of Spanish garrisons lasted an entire year does suggest the tenacity of Pardo and his Spanish cohort. The journals of the multifaceted explorations of Pardo and Moyano showcased the continued diversity of the Carolina Piedmont and Mountains. Ruffin was able for the first six weeks to translate directly the dominant languages spoken in the mampi until their arrival at Tocae on October $1,1567 .{ }^{17}$ Afterwards most of the mampi required an ever greater number of interpreters, which always were readily available. The persistence of such a diverse linguistic and cultural population has been interpreted as evidence of the demographic collapse stemming from European contact. In light of the examples of diversity already discussed, this diversity was more of a product of the social continuity from "prehistoric" to "historic."

The Pardo documents highlight the trade materials distributed from 1566 to 1568 and compare favorably with some of the materials found in Monyton Onqyayun sites. The lists exhibit the discriminating trade desires and active selection of Wahtakai. At Otari on September 17, 1567 Bandera recorded a transaction replicated throughout the expedition, "to the cacicas, ... an axe .., to those understood to be principals, to each one an axe and to the others, subject to them, to some a chisel and to others enameled buttons and some red taffeta." ${ }^{18}$ In excavations at the Berry site (31Bk0022) in North Carolina, archaeologists have identified most of these materials. The hundreds of axes, chisels, knives, buttons, and copper snippets were broken into ever smaller pieces through the Wahtakai trade through the late sixteenth and seventeenth century. Of all the materials that the Spanish traded, beads seem to have preserved the best.

\footnotetext{
${ }^{17}$ Ibid, 266.

${ }^{18} \mathrm{Ibid}, 262-3$.
} 
Some of the beads found in sites like Logan, Marmet, and Rolf Lee could have come from this period (Map 3.8). ${ }^{19}$

Much as intergroup and interregional trade had been a constant and necessary social process, violence also fueled the social networks. It had changed the settlement patterns of Wahtakai starting in the 1300s. Intergroup violence was a major rationale for the change from open mampi to secured palisaded consolidated mampi. Pardo recorded one of the best explanations for the creation of palisades at Tanasqui in 1567:

"Cacique and Indians of the place had built a wall with three towers for its defense. ...

To which question [why built] the cacique replied that [he did it] for defense from his enemies, who, if they came to do him harm, had not place by which to enter his town (pueblo) except by that place."20

The protection afforded by the palisades hid another defensive measure that caught the Spanish off-guard in 1568. Pardo received word from an unnamed friendly Wahtakai in the summer that there was a plot in the works to destroy all the forts created the year before. Neighboring Wahtakai set the four forts at Chiaha (Fort San Pablo), Guatari (Fort Santiago), Canos [Cofitachequi] (Fort Santo Tomas), and Fort San Juan ablaze destroying the structures and scattering the Spaniards. Most astounding to Pardo was that "Indians of Chisca, Carrosa, Costehe, and Coza ... have an understanding (competiencia) between themselves and those Zacatecas." 21 The local caciques had had enough of the disruptive Spanish and had organized a large and collective effort to wipeout the occupation of their land. These developments are

\footnotetext{
${ }^{19}$ Spanish archaeological materials: Berry site: David G. Moore, “Appendix B: The Berry Site” In Catawba Valley Mississippian: Ceramics, Chronology and Catawba Indians by David G. Moore (Tusacloosa: University of Alabama Press, 2002), 213-256; Robin A. Beck, Jr., David G. Moore, and Christopher B. Rodning, "Identifying Fort San Juan: A Sixteenth-Century Spanish Occupation At The Berry Site, North Carolina" Southeastern Archaeology 25:1 (Summer 2006): 65-77.

${ }^{20}$ Hudson Hoffman 2005: 268.

${ }^{21}$ Ibid: 315 .
} 
instructive of the alliance system that existed between fiercely autonomous mampi but hidden from European view.

Despite the setback of the Pardo expedition, the Spanish attempted one more occupation of importance, this time in the Chesapeake Bay, known to its Algonquian residents at Tsenacomoco. ${ }^{22}$ The account of the Spanish mission at Ajacan (1570-1572) begins with a random Wahtakai man picked up by Spanish sailors around Santa Elena along the Carolina coast. It is from this individual, who later was baptized Luis de Velasco, from which the name Ajacan derives. This mission had a rough experience from its inception. The Powhatan Confederacy was not yet as powerful as it would be when the English arrived, but there were signs that the political landscape was altering dramatically. ${ }^{23}$ Father Rogel, the second leader of the mission, observed "that the population in the Chesapeake was greater than in any other region through which he had travelled, that the people were more sedentary than the Florida tribe." ${ }^{24}$ This differs greatly from the descriptions of Pardo and Luna in the decline of Southeastern Wahtakai.

Barely a year after arriving, the original leaders of the mission, Father Luis de Quirós and a Brother Solis, were murdered by Luis de Velasco. The details of this late winter attack were poorly recorded but seem to have related to trade goods the Father would not distribute. This would explain a great deal of Don Luis' behavior. The distribution of exotic trade goods was a major social binding agent and a requirement to maintain social order amongst most Wahtakai. Father Quirós attempted to restrict trading in 1570 even before establishing the mission. He

\footnotetext{
${ }^{22}$ Merrell 2012: 466 from Daniel K. Richter, Facing East from Indian Country: A Native History of Early America (Cambridge: Harvard University Press, 2001), 70 notes that literal translation of the term Tsenacomoco means "densely populated land."

${ }^{23}$ Clifford M. Lewis and Albert J. Loomie, The Spanish Jesuit Mission in Virginia, 1570-1572 (Chapel Hill: University of North Carolina Press, 1953), 44.

${ }^{24}$ Lewis Loomie 1953, 55.
} 
complained in a letter of the ship's crew engaging in trade "without permission." Lewis and Loomie propose that "Clearly, he wanted to teach the Indians their duty of supporting the missionaries and also keep the natives from contamination from white traders and their wares." This easily upset the well-established indigenous trade system of Tsenacomoco that even Basque fisherman had participated in during the previous fifty years. The disruption of trade by the overzealous Quirós also earned him the enmity of Don Luis and the Spanish sailors. The deaths of Quirós and two others precipitated the eventual demise of the mission as Don Luis left the mission and "went native" in 1571 . By the winter of 1572 , the mission had decreased to only a few Jesuits led by Father Rogel who was dispatched to lead the mission and investigate the murders. His interrogation of the local Paspahegh and Kecoughtan was followed by the execution of some captive Wahtakai. This symbolic punishment likely would have been followed by reprisals had the mission been abandoned a few months later. ${ }^{25}$

The record of Quirós and the Jesuits at Ajacan also contains relevant environmental information. In a letter to a friend in Cuba in September of 1570, Quirós no ed: "They [the Powhatan] are so famished, that all believe they will perish of hunger and cold this winter." The "great difficulty" by which they can find food "which they usually sustain themselves" was due to "great snows." 26 For the conditions to be so dire in the early fall when food should be at its most plentiful suggests that it had been a bad crop cycle. Quirós worried a few months later about the deep snows that the Paspahegh Wahtakai had warned him about. This coincides with Cypress tree ring data suggesting a series of summer-fall droughts and harsh winters in the last three decades of the sixteenth century. Those droughts, in fact, seem to have continued to plague

\footnotetext{
${ }^{25}$ Ibid: $43-48$

${ }^{26}$ Ibid: $36,89-90$
} 
the Mid-Atlantic well into the seventeenth century. The unreliability of the food supply likely exacerbated tensions with the Spanish. ${ }^{27}$

Beyond the obvious ill will towards Spaniards that would have rippled through the Tsenacomoco Algonquians, this environmental calamity may have been a leading influence in coalescing the Powhatan confederacy during the late sixteenth century. The Spanish noted some of the details of the cultural landscape a few years after the ordeal. Bartolomé Martínez in 1610 set down a memorial to the "martyrs" and Ajacan and noted the political organization of Tsenacomoco: "There is no king or prince who lords it over them, but only that chief is recognized wherever one tongue is spoken, and there are many in that region." On a more regional scale he suggested that "the Indians of the long wide valleys are the enemies of those in the mountains and in summer a savage war is waged." ${ }^{, 28}$ Considering the social structures of the Powhatan Confederacy of the seventeenth century, this more closely resembles the egalitarian mampi of the Monyton Onqyayun. The mountainous region to the west was of keen interest to the Spaniards. The gold lust historically attributed to the Spanish ran wild with their descriptions of Ajacan and the nearby mountains. Martínez suggested it was a "fertile land with, gold and silver and pearls," where the residents wore "golden circlets on their brows and bracelets on their wrists and ear rings." Neither the archaeological nor geological record corroborates this flight of fantasy. In 1588 while exploring the Patuxent River, Spanish Captain Vicente Gonzales "discovered a certain chief who went about with four or five gold rings in his ears, and on his head there was a band of span and half's length and six fingers wide." ${ }^{29}$ Gonzales' description of large amounts of highly prized copper are much more credible. This highly prized trade item

\footnotetext{
${ }^{27}$ Stahle et al, 1998.

${ }^{28}$ Lewis and Loomie 1953: 161

${ }^{29}$ Ibid: 195
} 
came to Tsenacomoco from copper seams in the Great Lakes and beyond the Mississippi. The same copper is found in Monyton Onqyayun mampi.

Father Quirós inquired about the mountainous regions to the west when he visited the falls of the James River, near Monacan territory. He met travelling Wahtakai and was informed through interpreters: “Three or four days' journey from there lie the mountains. For two of these days one travels on a river. After crossing the mountains by another day's journey or two, one can see another sea." ${ }^{30}$ The "sea" they were referring too could be an idiomatic expression or the effect of looking down onto the Ohio, but it would appear that the Wahtakai had a working knowledge of the region. This coupled with the likely Monacan identity of these Western informants provided yet another pathway for information about the Spanish to reach the Okahok amai.

\section{French Introductions: 1530}

To the north of the Chesapeake Bay and the Mid-Atlantic, in the St. Lawrence and the Great Lakes, the French were beginning to introduce themselves and their fur trade practices to Iroquoians and Algonquians. While the wide ranging Basque fishermen had come into the St. Lawrence, it was not until Jacque Cartier and Samuel Champlain that Europeans became a major factor in indigenous socio-cultural networks. Cartier traversed the northern St. Lawrence and encountered both Iroquoian and Algonquian Wahtakai during the 1530s and 1540s. Much like the Spanish in the South, Cartier frequently abducted Wahtakai to ensure safe passage and enlist guides. On his return to France in 1535, Cartier abducted chief Donnacona and nine other Stadaconans for exhibition to the King. Though abduction was common in Wahtakai warfare, the problem with the French, as with other Europeans, was that the revenge cycle was frustrated by

\footnotetext{
${ }^{30}$ Ibid: 91
} 
limited contact. This left a social tension that was difficult to release. By the time Cartier convinced the King to fund his return in 1541 all of the Stadaconans were dead from disease. ${ }^{31}$

The cultural landscape responded to the trade materials and implements of war that Cartier introduced but it was Samuel de Champlain in the beginning of the seventeenth century that wedged the French permanently between the Iroquois and Algonquian Wahtakai of the Laurentian Valley. After Cartier's 1542 expedition, the French became focused on easier and more lucrative ventures elsewhere, largely ignoring New France till Samuel de Champlain arrived in 1603. Champlain became intimately involved in the Algonquian-Iroquoian rivalries along the St. Lawrence River. The French desire for furs often forced them to receive Iroquoian traders despite French alliances with many of the Algonquian groups. As their Algonquian allies suffered attacks from Eastern Iroquoian speaking Wahtakai, such as the Seneca and Mohawk, the French waged small scale attacks in reprisal. These internecine conflicts led to short-lived periods of peace most notably during 1624. During these brief interludes the trade between the Iroquois and the French increased dramatically. The French, though, were hardly the only Europeans interested in trading with the Iroquois (Map 2.3). ${ }^{32}$

\section{Dutch Introductions: 1614}

By 1614, the Dutch strengthened their presence in the Hudson Valley with the building of Fort Nassau. Dutch traders sought furs and they had no compunction against selling guns or metal tools for pelts. The Algonquians and smaller Iroquoian groups in the St. Lawrence had gained small arsenals of guns through conversion to Christianity among the French Jesuits. This temporary military advantage over less connected Iroquoians to the east lasted barely a decade once the Dutch began freely selling arbusques to Mohawks and other nearby Wahtakai. French

\footnotetext{
${ }^{31}$ Cartier: Parmenter 2010: 10.

${ }^{32}$ Champlain: Parmenter 2010: 28-33, Brandão, José António. "Ye fyres shall burn no more: Iroquois Policy toward New France and Its Native Allies to 1701. Lincoln: University of Nebraska Press, 1997.
} 
Jesuits publicized their frustrations of Iroquois depredations among their Algonquian acolytes in 1656 by blaming Dutch influences. The Algonquians noted that the Dutch "conceived a fondness for the beavers of the natives," and provided guns, "with which it was easy for them to conquer their conquerors [the Iroquois]." This led to a military strength beyond defense as it "rendered them formidable everywhere, and victorious over all the Nations with whom they have been at war; it has also put into their heads that idea of sovereign[ty], ... mere barbarians although they are. ${ }^{33}$ This animosity towards the Iroquois-Dutch trade continued to be found in discussions of the depopulations of the Ohio and other southern areas.

The Dutch also had contact with the Susquehannock and other Chesapeake allied Algonquians. Of greater interest than guns to Wahtakai during the first half of the seventeenth century were more utilitarian trade goods such as beads, metal goods, and fabric. The presence of fabric can only be traced through European trade records, but it was highly prized. Few examples of archaeologically preserved European fabrics exist. More durable goods were more likely to travel along trade networks. Most beads found in Monyton Onqyayun sites appear to be Dutch and date from the first half of the seventeenth century. The economic influence of the Dutch can be witnessed in the diffusion of glass beads and metal fragments, copper especially, far inland from the Atlantic coast. ${ }^{34}$

\section{English Introductions: 1607}

While the French and Dutch were distantly affecting the cultural landscape, the seventeenth-century Monyton Onqyayun was most dramatically affected by the changes directly

\footnotetext{
${ }^{33}$ Rueben G. Thwaites, ed., The Jesuit Relations and Allied Documents: Travels and Explorations of the Jesuit Missionaries in New France, 1610-1791 (Cleveland: Burrows Brothers, 1896-1901), JR: 45: 201-205.

${ }^{34}$ Dutch-Susquehannock connections, beads: Drooker 1995, 48-58; Karklins 1974, 64-82; Karklins Sprague 1972 , 87-101; Baker 1986, 21-24; Fogelman, 1991; Robert Mazrim and Duane Esarey, "Rethinking the Dawn of History: The Schedule, Signature, and Agency of European Goods in Protohistoric Illinois" Midcontinental Journal of Archaeology 32:2 (Fall 2007): 145-200.
} 
east in Tsenacomoco-Chesapeake, where the English first established themselves in North America. From the accounts of John Smith and Henry Fleet we can begin to understand the influence of the English trade within the Mid-Atlantic. Smith travelled extensively within the Chesapeake and the Atlantic seaboard in 1607-1609 and 1614-1615. Henry Fleet covered similar territory twenty years later but he was more a trader than adventurer. Much like the French, English settlers entered a socio-political trade network that had already experienced Spanish fishermen, traders, priests, and soldiers. These contacts left a legacy that tainted English interactions from their inception.

With the creation of Jamestown, conflicts arose with the Powhatan confederacy. John Smith famously was thrown into the middle of this after his capture and release in the winter of 1607-1608. Most important for this work is Smith's examination of the Siouan speaking peoples directly west of Powhatan. Notably absent from the Ajacan relations of the 1560s, Smith mentions two groups of Siouan speaking Wahtakai: the Monacan and the Mannahoacs. It is difficult ascertain from historical sources whether these two groups existed before the seventeenth century or if they were products of the coalescence affected by the Spanish mission and the ascension of the Powhatan confederacy (Map 2.4). ${ }^{35}$

Smith's discussion of linguistic diversity hints that the Monacan might be somewhat more homogenous than the Mannahoac, a coalescent society:

Vpon the head of the river of Toppahanock is a people called Mannahoacks. To these are contributers the Tauxsnitanias, the Shackaconias, the Outponcas, the Tesoneaes, the Whonkentyaes, the Stegarakes, the Hassinnungas, and diuerse others; all confederats with

\footnotetext{
${ }^{35}$ Monacan and Mannahoac: Goddard 2005: 15-19.
} 
the Monacan, though many different in language, and be very barbarous, living for the most part of wild beasts and fruits. ${ }^{36}$

The English placed themselves at odds with these Western Wahtakai in an attempt to align with the powerful Powhatan. Smith in 1609, after relating the stories of salt water seas, silver, gold, and crystal mines across the mountains, offered to "conclude their revenge against the Monacan." Wahunsenacawh chastised Smith for his presumption. "As for the Monacan, I can revenge my owne iniuries.... But for any salt water beyond the mountaines, the relations you haue had from my people are false." ${ }^{37}$ English interest in the western mountains were received by the Monacan with the same irresistible fanciful stories that Plains Indians had used to whet Coronado's gold-lust. By telling stories of distant riches the unwanted intruders would hopefully leave their lands hastily. It is amusing to think Powhatan chastising Smith for believing such stories.

Smith mentions one other important group traveling through the Chesapeake region during the first half of the seventeenth century. The numerous Massawomecks were a likely Iroquoian-speaking Wahtakai that traveled down the Allegheny and Susquehanna Rivers to raid the Algonquian mampi of the Chesapeake Bay and surrounding territory. After his 1608 encounter with the Massawomeck towards the mouth of the Susquehanna River, John Smith was told about these distant enemies, the "Atquanahucke, Massawomecke, and other people; signifying they inhabit the river of Cannida, and from the French to haue their hatchets and such like tooles by trade." 38 The Massawomecks assisted both intentionally and accidentally in the spread of French trade items during the seventeenth century. Unlike many other groups the

\footnotetext{
${ }^{36}$ Arber I: 71.

${ }^{37}$ Ibid: 121 .

${ }^{38}$ Ibid: $118-119$.
} 
Massawomeck persisted in threatening the Chesapeake Wahtakai well into the 1630s as evidenced by Henry Fleet's record of a meeting in the summer of $1632 .{ }^{39}$

Henry Fleet's journal written on his journeys up the Chesapeake from 1631-1632 also recorded the types of trade items his Wahtakai clients desired and what he offered. From one of his trade posts on Kent Island, Fleet and rival traders distributed a mélange of European trade items from Dutch cloth to Spanish axes. When meeting new Wahtakai and their leaders Fleet would distribute presents to solidify the alliance and to show prospective clients his catalogue. Early in 1631 Fleet provided presents lavishly: "Unto these four kings, I sent four presents in beads, bells, hatchets, knives, and coats, to the value of $£ 8$ sterling. ${ }^{40}$ Later in 1632 , Fleet wrote to his financier complaining that he "had but little, not worth above one hundred pound sterling, and such as was not fit for these Indians to trade with, who delight in hatchets, and knives of large size, broad-cloth, and coats, shirts, and Scottish stockings. ${ }^{, 41}$ Fleet noted a gendered difference - "women desire bells, and some kind of beads" in trade desires that was absent in Smith's accounts. How much this gendering was influenced by English ideals of masculine and feminine goods is unclear. Both Fleet and Smith highlighted the control that Wahtakai could and did exert in the trade with Europeans by selectively valuing some items over others.

By 1650, the English, French, Spanish, and Dutch had become for better or worse major players in the ever-shifting intercultural networks of the eastern half of North America. But how far inland their influences traveled whether by direct contact, trade, or disease must be examined closer. As shown above, Wahtakai varied greatly in their reactions to outsiders and new trade

\footnotetext{
${ }^{39}$ Massawomeck: James F. Pendergast, "The Massawomeck: Raiders and Traders into the Chesapeake Bay in the Seventeenth Century" Transactions of the American Philosophical Society, New Series 81, No. 2 (1991): i-vii, 1101.

${ }^{40}$ Edward D. Neill, The Founders Of Maryland As Portrayed In Manuscripts, Provincial Records And Early Documents (Albany: Joel Munsell, Microform, 1876), 27.

${ }^{41}$ Neill 1876, 30.
} 
items. Beyond the concrete materials of trade, what kind of landscape were mid-seventeenthcentury were Wahtakai navigating? Looking from the Monyton Onqyayun outward, the world had monumentally changed in just fifty years.

\section{Vignette: 1650}

As shown above, the century and a half before 1650 was marked not by cultural and environmental stasis but rather a highly volatile world that required constant cultural adjustments. The Monyton Onqyayun had responded to dramatic changes in environment, new powerful coalescent and amalgamated societies, along with the evaporation of many of their closest allies. Robbie Ethridge proposes the presence of a Mississippian shatter zone from 1500 to 1715 . As the Mississippian chiefdoms collapsed, new diseases, changing economies, and new people arrived, Wahtakai societies flexibly used existing cultural traditions to cope with the shattering social landscape. As 1650 began, the Mississippian shatter zone had left indelible marks within the Monyton Onqyayun. ${ }^{42}$

The environment had somewhat rebounded within the Okahok amai, to the point that populations were much higher after the severe cold and dry snap of the late sixteenth century. The winters were frustratingly long, which had shortened the growing season slightly. Mountain farmers were assured two corn crops a year, while to the east along the Atlantic farmers suffered some of the worst droughts of the past hundred years. This may explain some of the statements that Smith and others made about Powhatan living:

"When all their fruits be gathered, little els they plant, and this is done by their women and children; neither doth this long suffice them: for neere 3 parts of the yeare, they only

\footnotetext{
${ }^{42}$ Ethridge, 2006, 207-218. The discussion has been greatly expanded in Ethridge Shuck-Hall 2009.
} 
obserue times and seasons, and liue of what the Coutry naturally affordeth from hand to mouth, \&c.",43

Climatologists in 1998 submitted a report about the effects of drought using bald cypress trees along the Meherrin and Nottoway rivers. Their study showed the period from 1606 to 1612 as one of the worst droughts in the data. ${ }^{44}$ Coastal Wahtakai exhibited increased intergroup violence that may have been exacerbated by climactic instability. The Okahok amai seemed to have shielded its residents from the worst effects of coastal droughts and as such their populations grew reliant on a flourishing and carefully manipulated environment. With high amounts of precipitation especially due to melting snows and spring rains, the narrow valley floodplain soils of the Monyton Onqyayun were replenished frequently boosting the productivity. This fluorescence would be short-lived.

Much like the pre-1650 cultural stability in the Monyton Onqyayun, some groups became much more powerful during the late sixteenth and early seventeenth century. The development of the Iroquois League was one of the most significant of these coalescent societies. A nascent League of the Iroquois between the Seneca, Cayuga, Onondaga, Oneida, and Mohawk appeared during the late sixteenth or early seventeenth centuries. The League officially coalesced around 1634 due to both internal Iroquois tensions and external pressures and opportunities. Iroquoian mampi were increasingly threatened by the better-armed Laurentian Iroquois and Algonquian Wahtakai during the sixteenth century even while they were experiencing increasing contact with French, Dutch, and English traders. The increasing volume and diversity of trade items, both indigenous (such as wampum), and European, was bound to cultural and anecdotal information disseminated simultaneously. These two external influences also coincided with a rising

\footnotetext{
${ }^{43}$ Arber I: 63

${ }^{44}$ Stahle et al, 1998, 564-567.
} 
"Iroquois" geographic identity and an increasingly sophisticated collaborative defensiveoffensive planning by Iroquois leaders. ${ }^{45}$

As part of the coalescence process, the Iroquois League adapted much older traditions into a single highly-symbolic diplomatic ritual. The condolence ceremony had analogs found across much of the eastern half of North America. These rituals played directly into the progressive ideology of Hiawatha and Deganawidah that promoted peace through an expansion of Iroquois control along the white roots of peace. The implications of this will be discussed in greater detail in subsequent chapters as it more directly affected the Monyton Onqyayun later in the seventeenth and eighteenth centuries. This Iroquois coalescence of course directly contributed to the creation of an equally destructive shatter zone along the St. Lawrence during the late sixteenth and early seventeenth century. As the Mohawk and other Iroquois Wahtakai acquired arbusques from the Dutch trade, they began to overpower their western competition. This has often been identified as the beginning of the Beaver Wars within the twentieth-century historiography. Parmenter and many others have criticized the underlying assumptions of this monocausal framework. ${ }^{46}$

\footnotetext{
${ }^{45}$ Iroquois League developing: Lewis Henry Morgan, League of the Iroquois (New York: Corinth Books, 1851, Reprint 1962); Parmenter 2010.

${ }^{46}$ Beaver War-Mourning war: Parmenter 2010: 30-38; Anthony P. Schiavo, Jr. and Claudio R. Salvucci, eds., Iroquois Wars I: Extracts form the Jesuit Relations and primary sources from 1535 to 1650 (Bristol, PA: Evolution Publishing, 2003), 1, 11-13; Brandão, 1997, 45, 84; William C. Johnson, "The Protohistoric Monongahela and the Case for an Iroquois Connection" in Societies in Eclipse: Archaeology of the Eastern Woodlands Indians, A. D. 1400-1700 eds. David S. Brose, C. Wesley Cowin and Robert Mainfort, Jr. (Washington, D. C.: Smithsonian Institution Press, 2001), 67-82; Drooker 1997, 64; Daniel K. Richter, "Ordeals of the Longhouse: The Five Nations in Early American History" in Beyond the Covenant Chain: The Iroquois and Their Neighbors in Indian North America, 1600-1800 eds. Daniel K. Richter and James H. Merrell (University Park, PA: The Pennsylvania State University Press, 1987), 11-27, 19-20; Neal Salisbury, "Toward the Covenant Chain: Iroquois and Southern New England Algonquians, 1637-1684" in Beyond the Covenant Chain: The Iroquois and Their Neighbors in Indian North America, 1600-1800, eds. Daniel K. Richter and James H. Merrell, (University Park, PA: The Pennsylvania State University Press, 1987), 61-73, on 61-65; Daniel K. Richter, The Ordeal of the Longhouse: The Peoples of the Iroquois League in the Era of European Colonization (Chapel Hill: University of North Carolina Press, 1992), 50$74,144-149$.
} 
Another oft repeated mantra of the shatter zone is the detrimental effects of foreign disease on Native American populations. The Spanish noted disease but, as Hudson points out, the didactic notaries surprisingly did not refer to it as small pox or any other specific epidemic. There is almost no evidence of disease among the Spaniards themselves, which therefore begs the question of the method of transmission. During the 1630s Jesuits recorded epidemics of smallpox raging among the Huron. This is much more likely as smallpox was on the rise abroad in Europe and throughout the Americas as higher numbers of Europeans arrived. While stories of the debilitating effects of these diseases certainly traveled with witnesses and survivors it remains unlikely that it was transmitted into the Monyton Onqyayun by the Iroquois or any other group. Epidemiologists and historians have noted that the spread of smallpox and other epidemic diseases was severely limited by each disease's gestation and contagion periods. Monyton mampi populations from the sixteenth century do not show demographic or biological evidence of massive epidemics. The few mass graves present are much later and correspond to evidence of violence (Table 4.2). ${ }^{47}$

In 1650 populations of Siouan-speaking Wahtakai occupied a swath from the Dan River in Virginia through the Appalachian Mountains and into what is now Tennessee. Though some Siouan-speaking peoples like the Yuchi, Mosopelea, and Ofo were slowly moving west and south, the cultural landscape within the Okahok amai appeared relatively stable. Mampi had begun consolidating into larger and fewer settlements always with palisades to protect them from other Wahtakai raiding their territory. Those mampi also focused on the secondary terraces to maximize access to flood plain fields and their gathering and hunting areas while others began, like the Monongahela, to occupy defensible ridge tops. Mirroring their defensive measures,

\footnotetext{
${ }^{47}$ Disease: Dobyns 1983; Paul Kelton, Epidemics and Enslavement: Biological Catastrophe in the Native Southeast 1492-1715 (Lincoln: University of Nebraska Press, 2007); Spanish notaries Hudson 1997: 179-180; Jesuits relations 1630 Huron, Schiavo Salvucci 2003: 7-11.
} 
Monyton Onqyayun residents watched as the areas around the Okahok amai were dramatically altered.

Northern trade partners, the Monongahela disappeared and left a cultural vacuum quickly filled by Seneca traders, hunters, and warriors. During the severe droughts of the 1580 s and then again between 1607 and 1612 the Monongahela Wahtakai suffered depopulation and receded into small protected onqyayun. Depredations of the increasingly powerful Iroquois prompted the remaining Monongahela peoples to become refugees among Iroquoian-speaking Wahtakai, mostly the Susquehannock. Some may have even traveled to the vicinity of Richmond and continued further southward during the later seventeenth century. This, of course, opened the Monyton Onqyayun to even easier access by raiding Seneca. By 1635, the Monongahela had been dispersed like the Huron and Eries. ${ }^{48}$

The weakening and fracturing of the Powhatan Confederacy, another group of Algonquian-speaking Wahtakai, affected the Monyton Onqyayun by opening up increasing European trade and interest in the mountains. The rising tensions between the Powhatan and the English provided a vivid lesson of the modus operandi of English trade and expansion. While skirmishes had occurred frequently between Tsenacomoco's residents and the English from 1607 to 1609 , the tide of English occupation became too unbearable leading to the first Anglo-

Powhatan War. The resolution of this conflict succeeded only in truncating Powhatan lands and a limited truce solidified by the marriage of Matoaka (Pocahontas), the Powhatan chief's daughter, to John Rolfe in 1614. Far from defeated, it was only eight years until Opechancanough (Wahunsenacawh's brother) again took the initiative to fight back against the encroachment of Powhatan lands. Despite a high body count, the conflict resulted in an increased presence of

\footnotetext{
48 James B. Richardson III, David A. Anderson and Edward R. Cook, "The Disappearance Of The Monongahela: Solved?" Archaeology of Eastern North America 30 (2002), 81-96.
} 
Englishman in Tsenacomoco. The death knell of the Powhatan confederacy seems to have rung during the final Anglo-Powhatan war starting in 1644. Disease had ravaged through

Tsenacomoco in 1639 as the constituent mampi of the confederacy made one last effort to resist English encroachment by force. The resulting Treaty of 1646 was a testament to the destruction of the Powhatan Confederacy when Chief "Necotowance do acknowledge to hold his Kingdome from the Kings Ma[jes]tie of England." It further established absolute English control over most of the James River up to modern day Richmond, meaning Wahtakai found within these borders could be killed if not on official business. This treaty also makes one of the earliest requirements that Wahtakai, particularly the Pamunkey, "redeliver upon demand such Indian Servants as have been taken prisoners \& shall hereafter run away." Unsurprisingly, as the Powhatan receded, many other Wahtakai took their place in the flourishing trade, and some quickly suffered a similar fate. ${ }^{49}$

When John Smith discussed the Monacan and Mannhoacs in 1607 he identified the tensions that existed between them and the Powhatan. He even provided limited evidence about their languages especially in the cause of the multi-lingual Mannahoac. As the English persisted to push inland along the James, the Monacan mampi inevitably had more frequent contact. The weakening of the Powhatan Confederacy provided an opportunity for the Monacan and their Western neighbors to flourish and take the place of the Powhatan as primary trade partners of the English. The Monacan-Mannahoac were not successful, in fact, by the 1660 s all that seems to remain of either group was the small Manakin Town across from Fort Henry on the James River.

\footnotetext{
${ }^{49}$ Powhatan decline, Wars 1610-14, 1622-24, 1644-46, Treaty of 1646: Helen C. Rountree, "The Powhatans and the English: A Case of Multiple Conflicting Agendas" in Powhatan Foreign Relations 1500-1722 ed. Helen C. Rountree, ed., (Charlottesville, VA: University Press of Virginia, 1993), 173-205, 183-6; Treaty of 1646. Acts of the General Assembly, October 1646, Thomas Jefferson Papers, Series 8, Volume 7, Library of Congress. Accessed online August 10, 2012: http://www.virginiamemory.com/online_classroom/shaping the_constitution/doc/treaty. Further discussion in Jack H. Wilson, Jr., "A Study of the Late Prehistoric, Protohistoric, and Historic Indians of the Carolina and Virginia Piedmont: Structure, Process, and Ecology” (Unpublished Dissertation: University of North Carolina at Chapel Hill, 1983), 65-67.
} 
From 1646 to 1670 , both the Monacan and Mannahoac appear to the have been replaced by new polities like the Occaneechi, Saponi, and Tutelo, though this may have more of a culturalpolitical fracturing. ${ }^{50}$ The alterations to Tsenacomoco and the Piedmont of Virginia mirrored the social change found in the North, leaving two of the primary connections to the Monyton Onqyayun nearly severed. Archaeological sites in the region show few trade materials from the 1630-1650 period. The lack of material is often used as a diagnostic trait for earlier occupation, but this assumption may need to be reevaluated since the major trade routes to French, Dutch, and English goods became impassable as the weather was starting to turn. Much of the trade with the Southeast remained relatively intact and stable. Monyton residents relied on their access to wampum, shell gorgets, and even pieces of metal from Catawba, Yuchi, Cherokee, Muskoge, and Hitchiti speakers. Though not yet fractured, the Monyton Onqyayun was starting to feel the effects of European-Wahtakai affairs in the surrounding regions. From the forested ridge tops residents of the Monyton Onqyayun could see storm clouds swirling around them.

\footnotetext{
${ }^{50}$ Monacans-Mannahoacs in Arber I: 52, 55, 71; Goddard 2005: 15-19. The development of these "new" identities will be examined in closer detail in Chapter 3.
} 


$$
\begin{gathered}
\text { II: } \\
\text { Tañyi (Autumn) } \\
\text { 1650-1700 }
\end{gathered}
$$




\section{Chapter 3: \\ Preparing the Monyton Onqyayun Shatter Zone 1650-1680}

"We have found Mohetan Indians who having intelligence of our coming were afraid it had been to fight them and had sent him to the Totera's to inquire. We gave him satisfaction to the contrary and that we came as friends, presented him with three or four shots of powder.",

The interest of the English in the distant mountains reached a milestone in the $1650 \mathrm{~s}$.

This was facilitated by the defeat of the Powhatan Confederacy in 1644. Pamunkey, severely weakened by nearly thirty years of conflict with the ever growing population of English Virginians, lost control of their satellite Wahtakai. The mid-seventeenth century can best be characterized as a shatter zone where fragmented mampi restructured and realigned often times seeking to maximize access to European trade. The English felt emboldened to begin circumventing mampi formerly controlled by the Powhatan Confederacy, and seeking trade partners farther west. Their efforts were aided by the forts, like Fort Henry, built by Governor Berkeley in the 1650s, (Map 3.1).

The research in Virginian history has focused on the authors of the travelogues and exploration reports form the seventeenth century, but the story of the supporting characters and the pivotal role of Wahtakai, remains largely ignored by current analysis of these documents. The primary focus here will shift to the Wahtakai actors in each document and what this can tell about the socio-political landscape of the Okahok amai and surrounding areas. Even in 1650, the mountains remained a mysteriously shut door to the western passage. Many Englishmen in Virginia, Abraham Wood and William Berkeley for example, believed that just across the mountains was Spanish territory and the Pacific Ocean. Connecting the Eastern seaboard with the Pacific Ocean would finally make the connection to Asian trade so desired in London.

\footnotetext{
${ }^{1}$ Clarence W. Alvord, Lee Bidgood, The First Explorations of the Trans-Allegheny Region by the Virginians, 16501674 (Cleveland: Arthur H. Clarke Co., 1912), 193.
} 
Wahunsenacawh had criticized John Smith in 1609 for the idea that the ocean was so near, but the hope persisted among eager Virginians.

When writing from the perspective of Virginia and its expansion historians have understated the complexity of the seventeenth-century Wahtakai Okahok amai. It is true that Edward Bland and Abraham Wood ventured hundreds of miles away from Fort Henry but the limited presence of Wahtakai in their accounts and the distances covered can be misleading. Land due west of Fort Henry remained under the watchful eye of a growing number of Wahtakai, especially during the 1680s and 1690s. English authors grossly overstated control over the region based on the imperial misconception that European exploration created legal ownership. In addition, after pushing through the densely populated coastal regions, Englishmen found the land sparsely populated. The increased interest in expanding trade networks and land ownership prompted the House of Burgesses in Virginia to shift payments for maintaining forts from tobacco and money to land titles in the West. This understandably increased Englishmen's interest in the West and South, especially in regards to Wahtakai trade.

The creation of Maryland in 1632 barred Virginia from Wahtakai trade north of the Potomac River. Afterwards the focus shifted westward and southward to the residences of many Siouan-speaking peoples related to the Monyton Onqyayun. Equally important was the knowledge base of the guides from various Wahtakai that assisted the Virginia Englishmen in their expeditions (Map 3.2). Without these connections and assistance of indigenous guides into Siouan, Algonquian, and Iroquoian territories, the Virginians would have gotten lost and probably killed in quick order. The identities and actions of these Wahtakai from the second half of the seventeenth century must be examined closer. Often hidden or minor characters in the recordings of these excursions, Wahtakai from many groups directed and even constrained the 
process of exploration in serious ways. At times, it even seems that Wahtakai guides were slowing or misguiding their unaware wards.

\section{Edward Bland}

While Edward Bland and company traveled southward in 1650 well away from the heart of Siouan amai, their guides provided important insight into the inherent social and climatic instabilities of the Carolina-Virginia Piedmont that seriously affected Monyton political and trade connections. Bland's "Discovery of New Brittaine" provided interesting details about the differences between Virginia and the lower latitudes of the Carolinas (Map 3.3). While Virginia has "but one" crop of corn, "They [Carolinas] have two Crops of Indian Corne yearely." This seems to contradict Smith and others that suggested there were actually two cycles of corn, but could be indicative of the dramatic decline in climate that was quickly becoming a crisis in Virginia but may not have affected the Carolinas. The Virginia Tidewater had been suffering a three-year cycle of medium drought in 1644-1646, while the Virginia Piedmont had received a few years of average rainfall. The drought of 1644-1646 was much less severe further south along the coastline. ${ }^{2}$ Bland likewise noted that the Carolina Piedmont was more hospitable than the southwestern portions of Virginia. Massive trees and "old Indian fields of exceeding rich Land" made the Carolina Piedmont "a place so easie to be settled in."”

Pyancha, an Appomatox (Algonquian) war captain, directed Bland and his party of Virginians southward along the major trade paths that were ingrained in his own mental map as well as well-trodden into the land. These paths while not immutable were highways of Wahtakai

\footnotetext{
${ }^{2}$ Drought docs for 1644-1646: Edward R. Cook, David M. Meko, David W. Stahle, and Malcolm K. Cleaveland. Drought Reconstructions for the Continental United States. Journal of Climate 12 (April 1999): 1145-1162; and E.R. Cook, et al. 2004. North American Summer PDSI Reconstructions. IGBP PAGES/World Data Center for Paleoclimatology Data Contribution Series \# 2004-045. NOAA/NGDC Paleoclimatology Program, Boulder CO, USA. At ftp://ftp.ncdc.noaa.gov/pub/data/paleo/drought/pdsi2004/readme-pdsi-na2004.txt accessed 01/10/2011 11:30am. Cook et al 1999 and Cook et al 2004 respectively.

${ }^{3}$ Alvord Bidgood 1911, 110-111, 120; Bland in Briceland 1987, 45-91.
} 
traffic dating back at least to the fourteenth century. It is significant in two ways that Pyancha was a war captain. First, this position gave him a marketable knowledge of the trails connecting both friendly and enemy mampi within hundreds of miles of his mampi. Second, his varied contacts and linguistic skills made him a valuable, though not unbiased, intermediary and translator for the English. Pyancha led the men to a Nottoway (Iroquoian) mampi in the South where they picked up another guide, Oyeocker, a Nottoway. As becomes apparent, Oyeocker resented the push of the English deep into his people's territory and even refused to guide them further across their land into the Okahok amai of other Wahtakai. ${ }^{4}$

The refusal to take Bland's party to the "Blandina" river showed a perception of control and limitation on the part of Oyeocker, a high ranking werrowance (chief). Two possible explanations for this have been posed. Either there was local animosity towards the English and Appomattox amongst the Occaneechi and Nessoneick (Saponi), as Alvord and Bidgood stated, or Oyeocker was unable to provide safe passage through enemy territory. Pyancha stepped up and offered to lead Bland through the territory and to the falls of the "Blandina." This makes a great deal of sense considering the trade networks and trail systems. The Appomatox were closely connected to the Occaneechi and others along the trail known as the Occaneechi Trail.

The long-term impact of this and the two following trips is debatable. Alvord and Bidgood interpreted the silence of the historical record from 1650 till 1669 as a period of traders regularly but quietly taking advantage of these new contacts. Alan Briceland conversely suggested that the period was much more cautious with few if any trade expeditions. In this instance, Briceland's caution understated the evidence of trade that Lederer, Fallam, and Arthur found in the Piedmont and mountains twenty years later. The presence of and desire for

\footnotetext{
${ }^{4}$ Refusal in Bland: Alvord Bidgood, 1911, 125; Wilson 1983: 68-73 despite a detailed and step-by -step discussion of Bland, Wilson mis-identifies some of the informants, namely Oyeocker as a town instead of a person.
} 
European trade items that the Occaneechi alone express to Lederer in 1670 were testament to at least a few contacts with English traders. Unfortunately, we do not have the records from Fort Henry and other major trade posts in the Virginia backcountry during this period, but considering the large volume of Wahtakai trade during this time, it is entirely possible that the Occaneechi and other lesser-known groups visited the Virginians to secure access to trade items. ${ }^{5}$

\section{John Lederer}

It was a German naturalist sent to survey natural resources, as well as the human landscape, that reopened active exploration of the Virginia and Carolina highlands. John Lederer in the spring of 1669 set out from the Chickahominy mampi and attempted to make his way past the falls of the James River. Lederer with his three Pamunkey guides, Magtakunh, Hopottoguoh, and Naunnugh, set out westward on March 9 and began crossing steeper ridges by March 17. On March 18, Lederer ditched his horse and took two of his guides up a very steep ascent and spent the night on the top of the ridge. Lederer wandered around on this snow-covered ridgetop till March 24 when he returned to his horse and other guide. The record of the expedition did not include any of the events of the return. ${ }^{6}$

This first short foray into the western mountains provided more detail than previous historians have discussed. First, Lederer noted the presence of snow and the deep cold on the ridgetop in late March of 1669 (Map 3.4). This may not seem wholly surprising but at the height of the Little Ice Age, it seems odd that there is not more snow. "Here I did wander in snow, for

\footnotetext{
${ }^{5}$ Silence of 1650-1670 period: Alvord Bidgood 1911, 49-53, Briceland 1987, 92-100, even Wilson 1983, 73 suggests that the Piedmont was terra incognita from 1650-1670.

${ }^{6} 1^{\text {st }}$ Lederer expedition: John Lederer, William P. Cumming, ed. The Discoveries of John Lederer, with Unpublished letters by and about Lederer to governor John Winthrop, $J r$ (Charlottesville: University of Virginia Press, 1958), 5-18; Alvord Bidgood 1911, 64-66 and 145-149; Wilson 1983: 78-86; Up-to-date conversation concerning first expedition in Richard Jason Burns, Creating Virginia: The Role of John Lederer in the Transition of Western Virginia from a Wilderness into a Colony (Unpublished Master's Thesis. Morgantown, West Virginia University, 2006), 25-32.
} 
the most part..." but noted that the snow was not very deep and had been melting a great deal. ${ }^{7}$ This matches Galinee experiences in Canada in 1669-1670 with one of the coldest and harshest winters for the region. ${ }^{8}$ This could likewise be indicative of the droughts that were affecting the entire region. The PDSI index for 1669 was 1.312 which slightly above normal, but 1670 was 2.265; meaning that the climate became much drier and possibly warmer (Appendix 3.8c). ${ }^{9}$

Lederer's company on the trip was quite astonishing. By selecting only three Pamunkey Wahtakai whom he names and no other European companions indicates Lederer's trust of these guides. It is unclear how Lederer got setup with his guides, but we are left wondering what Lederer promised these three or if they were bound by obligation from some debt to Abraham Wood. The latter seems likely as the Pamunkey were heavily indebted to English traders such as Wood. After reading some of Lederer's other records, it seems that these three were more porters than guides, as Lederer was shooting due west into rough terrain that does not conform to any of the major trails throughout the region. Unlike his mentions of paths and roads during his second expedition, this first seemed aimless, though Lederer seemed unaware of this. Either by design or lack of knowledge, Lederer was "led" to a ridgetop that had no path to the valley below. While his first expedition was of limited success, Lederer's observations of plentiful wildlife and mineral resources, like a cache of mica, did fuel interest in a second expedition. ${ }^{10}$

\footnotetext{
${ }_{8}^{7}$ Alvord Bidgood 1911, 148-149, quote.

${ }^{8}$ Louise Phelps Kellogg, Early Narratives of the Northwest, 1634-1699 (New York: Charles Scribner's Sons, 1917), 198.

${ }^{9}$ Droughts in Carolinas 1667 and 1671, Langdon Cheves, comp., The Shaftesbury Papers and other records relating to Carolina and the first settlement on the Ashley River prior to the year 1676 (Charleston, SC: South Carolina Historical Society [1897] 2010), 89, 333, 347, 349.

Palmer Drought Severity Index (PDSI): Cook et al 1999; Cook et al 2004; Foster 2012; Fritts 1991; Stahle, et al. 1998, 564-567; I. Nalbantis, "Evaluation of a Hydrological Drought Index" European Water 23/24(2008), 67-77; David W. Stahle, and Malcom K. Cleaveland, "Reconstruction and Analysis of Spring Rainfall over the Southeastern U.S. for the Past 1000 years" Bulletin of the American Meteorological Society 73:12 (Dec. 1992), 1947-1961, 1949-1953; David W. Stahle, Falko K. Fye, Edward R. Cook, and R. Daniel Griffin, "Tree-ring reconstructed megadroughts over North America since A.D. 1300" Climate Change 83(2007), 133-149, 134-136; Maxwell, et al., 2012, 1053.

${ }^{10}$ Lederer's first expedition: Briceland 1987, 96-97.
} 
The next summer in 1670 , Lederer set out with a great deal more provisions and a much larger company. The expedition, completely subsidized by Abraham Wood, one of the most powerful Virginia traders, and co-led by Lederer and Major William Harris, was accompanied by twenty additional English men on horses and five Wahtakai that were mostly Pamunkey. Oddly, these five were left unnamed after Lederer's care to name the three guides from his first expedition. The larger party and a new mission directive shifted Lederer's focus from gathering information from Wahtakai guides to more scientific observation. This left Harris and others in the expedition to manage the daily interactions with the Wahtakai guides. This journey was a great deal more successful and informative than Lederer's previous excursion.

Four days after setting out from the falls of the James, the party arrived at Monakin mampi. This was a ponderous pace that wore heavily on Lederer and his Wahtakai guides who had covered three times as much ground during his first expedition in the same time despite his aimlessness. After a standard greeting of "Volleys of Shot" the party entered the mampi to meet with the elders. "Here enquiring the way to the mountains, an ancient man described with a staffe two paths on the ground; one pointing to the Mahocks [Mohawk], and the other to the Nahyssans; ..." Further showing the disconnect between Lederer and the direction of the expedition, the Englishmen decided to ignore the guidance of the elder and strike off due west. In a rare moment of peevish indignation, Lederer referred to his fellow Europeans as "land-crabs" bent on blind observance of compass direction over wretched terrain devoid of trails. "In these mountains we wandered from the twenty-fifth of May till the third of June, finding little sustenance for manor horse; for these places are destitute both of grain and herbage."11

\footnotetext{
${ }^{11}$ Alvord Bidgood 1911, 149 and discussion of pathways in Briceland 1987, 99-123; Additional conversation on Siouan languages: Goddard 2005, 15-19, 28.
} 
The egotism of the English who had decided to strike off disregarding the road map laid before them by the Monakin elder was rewarded with disappointment and hunger that probably led to Lederer's decision to abandon the troupe and strike off with only a single Susquehannock guide. That moment on May 24, 1670, as the Monakin elder drew on the ground a forked map to the mountains, was monumental. This brief moment was the first glimpse into the Monyton Onqyayun. First, this elder had knowledge of the pathways indicating that the Monacan had a relationship with the Wahtakai within the Okahok amai, whether through alliance or warfare remained hidden. Second, and somewhat less unsurprisingly, the Monacan also had knowledge of and relationships with Iroquois groups in the North that had been attacking along the Great Warriors Path. By discussing the map of the Okahok amai, this elder permitted the English access beyond their mampi. No longer could the Monacan play gatekeepers to the west, especially as the Occaneechi were gaining in power, a fact that Lederer discovered later in the expedition. It is easy imagine the double-edged humor and horror of the Monacan as the English brazenly struck out due west after being given the geographic keys to the western trails. ${ }^{12}$

This humor and horror was certainly not lost on Lederer, the Wahtakai guides or their empty bellies twelve days later when the party finally stumbled back to the James River. Wearied and put out by the hunger and boredom of the expedition, the majority of the group planned to return to Fort Henry only to find Lederer crossing the James and heading southward. Here again is evidence of how the larger party slowed their progress westward. After Major Harris begrudgingly gave Lederer a rifle, the German and a Susquehannock guide, Jackzetavon, headed south. Presumably, he did so with as much of the trade materials that could be heaped upon the back of two horses, though on this particular point he remained quiet. Since Lederer

\footnotetext{
${ }^{12}$ Alvord Bidgood 1911, 150-152, Jonathan Allen Burns, "Prehistoric Rockshelters Of Pennsylvania: Revitalizing Behavioral Interpretation From Archaeological Spatial Data" (Unpublished Dissertation, Temple University, 2009), $32-35$.
} 
later ran out of trade items this probably was not much. Lederer's trailblazing was taken by the Virginia elite as evidence of his insanity and led many to question his diary's credibility on his return.

With Jackzetavon, Lederer proceeded to move into Siouan land far South of Virginian control and at the border of what would become North Carolina. For three days they travelled through rugged locations, presumably without the aid of well-worn trails, until they reached Sapon, a Nahyssan mampi:

“... though I had just cause to fear these Indians, because they had been in continual Hostility with the Christians for ten years before; yet presuming that the Truck which I carried with me would procure my welcome, I adventured to put my self into their power...,13

This little detail has a great deal of weight when examining the perspective of Monyton on the English, as close relatives and possible allies of the Saponi. Saponi enmity for the English had led them to attack in alliance with the Richahecrians, a group of Iroquoian migrants later known as the Westo, from 1654 to $1669 .^{14}$

Despite these previous tensions, Lederer and Jackzetavon were received at Sapon by the Nahyssan king with great celebration on June 9, 1670. On the surface, Lederer's account of the meeting exhibited a nonchalance towards the Saponi that bordered on dangerous. He presumed to be offered "marriage" to one of the mampi's daughters but "with much a-do, waved their courtesie, and got my Passport, having given my word to return to them within six months."15 Political and economic alliances were solidified with such marriages, much like European

\footnotetext{
${ }^{13}$ Lederer Cumming 1956, 22-23.

${ }^{14}$ Saponi and Richahecrians attacked in 1654-1669, The defense of Edward Hill: VMHB 3:3 (Jan. 1896), 239-252, synthesis of these interactions in Ethridge 2010, 97-98.

${ }^{15}$ Lederer Cumming 1956, 23
} 
custom; for Lederer to ignore a power play from this satellite mampi was a big deal. Notably, Lederer bypassed the Saponi king's main mampi, possibly avoiding a reprise of his tense meeting, and headed towards the Akenatzy (Occaneechi) further down the Roanoke River.

By June 12, after ambling leisurely southward, Lederer entered the stronghold of the Occaneechi gatekeepers of the Wahtakai trade. These people had moved further down river during the 1620 s to Occaneechi Island presumably to gain closer access to English trade goods. While the Occaneechi had maintained their position as middlemen since the 1650 s, their power seems to have dwindled by 1670 . It would have been unheard of for an English trader to go further inland only a few years prior, but Lederer successfully snuck out of the mampi with Jackzetavon. During their two days on Occaneechi Island, Lederer and Jackzetavon witnessed two very important transactions. ${ }^{16}$

On arrival, Lederer noted the presence of "four stranger-Indians, whose Bodies were painted in various colours with figures of Animals whose likeness I had never seen.” After conversing through "signes" and probably interpreters, he suggested a backstory for these refugees. They were the last of a party of fifty Wahtakai from the Northwest. "They crossed a great Water, in which most of their party perished by tempest, the rest dying in the Marishes and Mountaines by famine and hard weather, after a two-months travel by Land and Water in quest of this Island of Akenatzy." The likelihood that these people spoke a Siouan language is very high considering their Siouan hosts, and considering that Siouan languages only seemed to extend to the Ohio River by this point; this could be one of the first recorded examples of

\footnotetext{
${ }^{16}$ Arrival at Occaneechi: Alvord Bidgood 1911, 153-154; Briceland 1987, 115-117; Occaneechi: Ethridge 2010, 97 103.
} 
refugees from the Monyton Onqyayun. The arrival of a delegation of "Rickohokans" Richahecrians on the next day implies that these unnamed refugees were unrelated. ${ }^{17}$

The treatment of the delegation of Rickohokans is another telling sign of the political instabilities in the mountains. The southward movement of these aggressive Iroquoian speaking people divided the Siouan speaking peoples. The Saponi had fought alongside the newcomers in 1656 attacks against the remnant Powhatan and emboldened English. The ambassador was initially offered standard hospitality but during the feast later that night the party of Rickohokans were murdered. This show of force may have served two functions. First, as it was done quite theatrically in front of Lederer, it could be considered an exhibition of their strength or even an offering to the English who were known to have continued hostilities with the Rickohokans. Lederer's presence, while clandestine, might have been no coincidence. Second, and probably more importantly, the Occaneechi were already beset by emboldened Wahtakai and traders that were disregarding their position as middlemen in the fledgling Indian-English trade network. Killing a diplomatic party so publicly was certainly a warning to other Wahtakai to not cross the Occaneechi. $^{18}$

The fear that it struck in Lederer and his Susquehannock guide prompted them to not wait around and ask a lot of dangerous questions. Breaking with protocol, Lederer and Jackzetavon left without a word early in the morning on June 14. This is yet another sign of the weakness of the Occaneechi even before the calamity of 1676. These two aimless explorers found a way past the most powerful and aggressive Wahtakai traders of Virginia. This provided Lederer access to a series of Siouan mampi in what would become North Carolina. Their first stop was Oenock, a

\footnotetext{
${ }^{17}$ Lederer Cummings 1956, 13-14; Alvord Bidgood 1911, 154-156; Goddard 2005, 16; Wilson 1983, 80.

${ }^{18}$ Rickohecrians: Ethridge 2010, 98; Burns 2006, 39-40 suggested that the Rickohockans were Cherokees, though they were possible Iroquoian speakers most suggest that they were northern Iroquoians. Briceland oddly leaves them completely out of his account of Lederer.
} 
small mampi near modern-day Rougemont, North Carolina. Lederer noticed dramatically different house structures here: "These and the Mountain-Indians build not their houses of Bark, but of Wattling and Plaister.” These were round houses, unlike those within the Monyton Onqyayun, the construction is indicative of permanent year-round mampi with a strong reliance on corn agriculture. "They plant abundance of Grain, reap three Crops in a Summer, and out of their Granary supply all adjacent parts." It was unlikely that there were three crops of corn, it does point to the productivity of the Piedmont. This agricultural security was a draw for mountain peoples to move eastward during the $1670 \mathrm{~s}$ and $1680 \mathrm{~s} .{ }^{19}$

From here Lederer and Jackzetavon passed quickly through Shakori. This has been placed at the Jenrette site (31Or0231a) in Orange County, North Carolina. The pair circumnavigated the powerful mampi spending the night in the woods and opted to move on to the West. The reason for this is unclear, but they seem to pick up their pace covering almost 60 miles over the next three days to arrive deep in the mountains at Watary, possibly the Madison Cemetery site (31Rk0006). After only one night, they moved on to Sara, about 10 miles Southwest. Lederer's journal becomes much sparser offering limited details compared to earlier slower-paced periods. Lederer and Jackzetavon travelled through Wisacky and on to Ushery. Both were occupied by mountain Siouan decedents of Jaora and Yssa mampi that had been visited by the Spanish in the previous century. The arrival of Lederer while interesting does not seem to have caused any concern within the mampi. The Ushery informed him that they had a very active trade alliance with both the Sara and the Spanish that were two and a half days to the

\footnotetext{
${ }^{19}$ Locations of Mampi: H. Trawick Ward and R. P. Stephen Davis, Jr., Indian Communities on the North Carolina Piedmont: A.D. 1000 to 1700, Monongraph No. 2, (Research Laboratories of Anthropology, the University of North Carolina, Chapel Hill, 1993), 10, 14; Helen C. Rountree, "Trouble Coming Southward: Emanations through and from Virginia, 1607-1675" in The Transformation of the Southeastern Indians, 1540-1760, ed. Robbie Ethridge and Charles Hudson, (Jackson, MS: University Press of Mississippi, 2002), 65-78, 74; Lederer Cumming 1956, 27.
} 
Southwest. But even these far interior Siouan peoples had tense relations with the Rickohokans who had mampi across the mountains and to the north. ${ }^{20}$

Having run out of trade goods, Lederer decided to return by a different route. Archaeological study of sites like Forbush (31Yd0001), Saratown (31Sk0001a), and Jenrette (31Or0231a) supports the theory that after contact the mampi began consolidating and moving. Lederer established trade contact for future English traders, his presence was only briefly a destabilizing force. The collapse of Wahtakai trade after Bacon's Rebellion hobbled Virginians' Western trade interests. The two explorations immediately following Lederer's travels made a more dramatic impact in the Okahok amai of Western Virginia Wahtakai. Another factor that limited the role Lederer played stems from the overly academic recording of the expedition. As it was written in Latin, the account was poorly disseminated. The only extant copies we have unfortunately are reprints of somewhat poor translations by William Talbot in 1671. The stories Lederer was telling were widely discredited well into the twentieth century. ${ }^{21}$

\section{Thomas Batts and Robert Fallam}

Abraham Wood was one of the wealthy Virginians whose appetite for accessing the Wahtakai trade was fueled by John Lederer's account. He convinced two of his more active agents, Thomas Batts and Robert Fallam, to head westward. Fallam's journal is the only extant first-hand account of exploration of the Monyton Onqyayun from the seventeenth century. Their course has been examined by many authors over the years but two main versions of the trip were created by Clarence Alvord and Lee Bidgood in 1911 and by Alan Briceland in 1987, Map 3.5 shows the two proposed pathways. Using GIS technology, archaeological surveys, and a closer examination of Fallam's diary I developed a more feasible real-world reconstruction of the

\footnotetext{
${ }^{20}$ Alvord Bidgood 1911, 157-161.

${ }^{21}$ Translation by Talbot: Alvord Bidgood 1911, 69; Briceland 1987, 101; Burns 2006, 6 ftn 1.
} 
expedition (Map 3.6a, Table 3.1). The proposed path places the terminus of the expedition at Sandstone, West Virginia along the Monyton River (New River). Included in this is a reconstruction of not just the English participants but a variety of Wahtakai (Tutelo, Saponi, and Monyton) and their travels within the story. ${ }^{22}$

Briceland correctly noted in 1987 that "Historians have long underestimated Batts and Fallam's accomplishment." He proceeded then to lay out a very ambitious passage deep into the Appalachian Mountains into a region that was depopulated long before the 1671 expedition. After extensive examination, Isaac Emrick developed a more reasonable and archaeologically validated pathway (Maps 3.6a-g) that also represents and reconstructs the Native American involvement in the story. What follows focuses on the notable moments of that expedition for the Monyton and their allies, the Piedmont Virginian Siouans. ${ }^{23}$

Fallam's journal provides a detailed account of the party involved in the expedition consisting of a multi-ethnic and multi-polity mélange of English, Portuguese, Appomatuck, Saponi, and Tutelo. Penecute, is the only named Wahtakai, but the number and described actions of the Wahtakai provide interesting insight to the ways they directed the journey. Most notable is the lack of any contact with the Occaneechi near the beginning of the expedition. Only a year after Lederer's visit, the power of the formerly powerful mampi seems to have waned even

\footnotetext{
${ }^{22}$ Briceland without support suggests that the N\&S railroad has similar pathway to Batts and Fallam because "railroads, like Indians, prefer the level route and the gentle grade" Briceland 1987, 144.

Ethridge 2010, 151; Batts and Fallam to Ohio, Drooker 1997, 64; to Kanawha-New Alvord Bidgood 1911, Edward Gordon Simpson, Jr., Pioneer Trails through Southeast Virginia (Unpublished Masters thesis for Virginia Polytechnic Institute and State University, Blacksburg, 1971), 20-23 also James B. Griffin, "The Fort Ancient Aspect: Its cultural and Chronological position in Mississippi Valley Archaeology" University of Michigan, Museum of Anthropology, Anthropological Papers. n. 28 (Ann Arbor, 1943), 31; Sigfus Olafson "Gabriel Arthur and the Fort Ancient People" West Virginia Archaeologist 12(1960), 32-41, 32-33.

${ }^{23}$ Batts and Fallam: Mentioned in Robert Beverly The History and Present State of Virginia (Richmond: J.W. Randolph, 1705), 64-65, but his account fabricated many details according to Briceland 1987, 128. Alvord Bidgood 1911, 70-77, 183-204; Briceland 1987, 124-146; Alan V. Briceland, "Batts and Fallam Explore the Backbone of the Continent" in Appalachian Frontiers: Settlement, Society, and Development in the Preindustrial Era ed. Robert Mitchell, (Lexington, KY: University Press of Kentucky, 1991), 23-36; a slightly dated conversation from roughly the same time as Briceland but more anthropological-archaeological sound is Wilson 1983: 86-92, mostly agrees with Alvord and Bidgood suggested path.
} 
further. The act of circumventing the Occaneechi would have been unthinkable only a few years before, but in 1671 the mampi only twenty miles away from Sapon didn't even warrant a mention.

The main party passed a lesser Saponi town on the Roanoke to arrive at the Sapon main mampi, most likely the one Lederer named Pintahae. Contact with these Siouan-speaking Wahtakai had expanded even further since Bland and Lederer warranting a permanent representative of Abraham Wood at the mampi. Woods interest in this expedition was evidently piqued when he had not heard from them so he sent out seven kinsmen of Perecute as reinforcements. They arrived at Saponi mampi on September $5^{\text {th }}$, the day after the main party's arrival and just as they were getting ready to depart. This band stuck with the expedition through the entirety of the trip. The arrival of seven Appomatox in Saponi mampi did not warrant much discussion or produce any notable unrest among the residents suggesting that this was a relatively common occurrence. A Portuguese trader, stationed in the mampi by Woods, dutifully left to report the arrival of the main expedition party and the Appomattox emissaries. ${ }^{24}$

The party, guided by a "hired" Saponi Wahtakai, followed a more northern route than Lederer, striking due west through Sapon land stopping among a small mampi of Hanathaskies who were "satellites" of the Saponi. The full implications of this are not clear from the account but considering the unstable cultural landscape it is unlikely that they were a Wahtakai defeated by the Saponi. The more likely scenario is that they were a related Wahtakai, possibly refugees that were joining the Saponi for protection and trade connections. From Hanathaskie's Long

\footnotetext{
${ }^{24}$ Alvord Bidgood 1911, 185.
} 
Island mampi in the Roanoke River, the party continued without entering another mampi until well into the Shenandoah Valley. ${ }^{25}$

This short-cut was suggested when Batts and Fallam "here hired a Sepiny Indian to be our guide towards the Teteras, a nearer way than usual.” My reconstruction of Batts and Fallam's expedition indicates that this may have been less of short-cut than Fallam assumed. The details that Fallam provides in the journal pose a directly western route till at least September 7 and then adjusting circuitously through the mountains roughly west-northwest. Considering the presence of a major path just north of the Roanoke River and nearly connecting with Totera, most likely the Trigg site (44My0003) near Blacksburg, Virginia, this doesn't seem to be the "nearer" way. But more important in this statement are the last two words "than usual." A fledgling WahtakaiEnglish trade connection already existed by 1671 . This is further supported by the record of their stay at Totero. ${ }^{26}$

Fallam did not mention the firing of guns as they entered Totero on September 9. Since he did mention the ritual at Sapon, the omission implies one of two things. Either these people did not possess guns, which is highly improbable, or firearms were such a recent addition and the mampi's remoteness made them too precious to use in this manner. The use of firearms by various guides and other Wahtakai in the party might have been so common that Fallam neglected to mention it. At arrival, the party was "exceedingly civilly entertain'd" by the Tutelo with whom the party stayed for three days, the longest stay of any location during the trip. The alliance between the Tutelo and the English was strong enough that the party decided to leave

\footnotetext{
${ }^{25}$ Discussion of Saponi and Tutelo combined into a larger discussion of the Monacans and Mannahoacs in Goddard 2005, 16-19; For Hanathaskies see Goddard 2005, 18, 44 ftn. 2; and Wilson 1983: 88, 91.

${ }^{26}$ Totero and Trigg site: Buchanan 1986; Howard MacCord Sr. and William T. Buchanan, Jr., The Crab Orchard Site, Tazewell County, Virginia, (Richmond: Archaeological Society of Virginia Special Publication No. 8, 1980), 149; Boyd 1993; MacCord 1984, 178-179; Howard MacCord and William Buchanan, "Trade Goods form the Trigg Site, Radford, Virginia” (Unpublished report at VDHR, 1974).
} 
their horses at the mampi. Also supporting a previous relationship is the ease with which they hired a Tutelo man to guide them further west. ${ }^{27}$

Now on foot, the party had to rely much more on the direction of their Tutelo and Saponi guides. From the New River the party picked its way over rough terrain in the Southeastern Okahok amai. Archaeologists have suggested that this region had been depopulated during the late 1500 s or early $1600 \mathrm{~s}$, but limited archaeological data has made a good chronology difficult to develop. There have been a few seventeenth-century glass beads found at Barkers Bottom (46Su0003) and 46Su0672 (Map 1.3). Using the description of the river crossings and the archaeological materials from the Summers county section of the New River, I propose that the September 13 description of "Indian old fields" was in the vicinity of the French Farm site (46Su0009). While no European materials were recovered from the site, flooding of the site has eroded evidence of later occupations. There were no remains of a mampi mentioned because the site had been abandoned for quite some time. ${ }^{28}$

It is important to note that the Tutelo and Saponi guides had knowledge of the Okahok amai and mampi locations but their guides were understandably tight-lipped in relaying sensitive information to Batts and Fallam. It is also possible that they never asked. Food was growing scarcer as they arrived at French Farm leaving the party a bit stressed. More importantly, the Wahtakai were solely responsible for feeding the party of twelve with little help from the Englishmen. On September $15^{\text {th }}$ Fallam notes "Our Indians having done their best could not kill us no meat." At the end of the next day, the two Siouan guides abandoned the main party and oddly Fallam merely notes that it happened and they were not seen until the return to Totera. ${ }^{29}$

\footnotetext{
${ }^{27}$ Alvord Bidgood 1911, 187.

${ }^{28}$ Bluestone: Pullins et al, 2008: 85; Fuerst 2007; Smithsonian Institute 2005. Woodside phase: Dunnell et al 1971; Briceland 1987, 147-170.

${ }^{29}$ Alvord Bidgood 1911, 190.
} 
The reason for the abandonment became apparent from two seemingly disconnected events in Fallam's log. On September 16 Appomatox men told him they had heard a drum and gunshot to the northwards while out gathering and hunting. This odd event suggests a meeting of two Wahtakai parties nearby. The presence of concerned Monyton at Totero when the party returned can best be explained by a clandestine meeting between the Saponi and Tutelo guides and a small party of Monyton along the path westward to Marmet. Concerned about the intentions of the Englishmen of the party, the Monyton convinced their already disenchanted allies to return to Totero to await a conversation with the English. ${ }^{30}$

The Appomatox and English of the main party meanwhile continued along from Camp 9 along the Greenbrier River to its mouth on the New River, the current location of Hinton, West Virginia. Fallam notes, "We understand the Mohecan [Monyton] Indians did here formely live. It cannot be long since for we found corn stalks in the ground." Unfortunately, the presence of modern Hinton makes corroborating this story archaeologically very difficult. According to SHPO site files, Summers County has 13 identified villages, 26 Mounds, 28 Rockshelters and over 400 generic “camps." The area around Hinton has 533 acres of arable land making it the only riverside location within the surrounding mountains capable of sustaining large "old fields." (Map 3.6e) Most importantly, the account could indicate that a mampi, probably a small one consisting about 50 people, had recently evacuated the area in the last year or so. Fallam did not mention any ati (houses) but this is not surprising as he was most likely standing on the northerneastern banks of the New River and the fields were on the western and southern banks. If the mampi had been burned or destroyed in some way, the remains probably were not visible. ${ }^{31}$

\footnotetext{
${ }^{30}$ Ibid, 190-191; Briceland 1987, 143, The abandoning of the Tutelo and Saponi guides is not examined or explained in detail in the Alvord and Bidgood nor the Briceland analyses as both are more concerned with the English explorers.

${ }^{31}$ Alvord Bidgood 1911, 191-192.
} 
The party made its way further north along the New River walking on the flatter ridgetops to the location of Sandstone Falls. They arrived late on September 17 and began cutting their way through a field covered in the secondary growth evidence of former Monyton occupation. The brambles made picking their way down to Sandstone Falls tedious but once there, Fallam noted his infamous "tides." He found further evidence of the tidal quality of his measurements while looking west from Chestnut Mountain, southeast of the falls. "Over a certain delightful hill a fog arise and a glimmering light as from water. We supposed there to be a great Bay. ${ }^{32}$ But due to poor provisions, threatening weather, and no small pressure from their Appomatox guides, Batts and Fallam decided to head back East. The Appomatox wearied by hunger and dangerously aimless meandering in increasingly rugged terrain wisely pressured their English wards to return. It is likely that they were uncomfortable skulking through other Wahtakai's Okahok amai, namely the Monyton, without permission. This could explain what Briceland interpreted as fear when he noted that the party "came in the end to an abandoned native village site, a place where their Indian guides were afraid to remain long." 33

The tensions the English had caused became immediately apparent after arriving in Totero on September 24, 1671. William Byrd had been sighted three miles east of the mampi possibly exploring the Roanoke for mineral deposits, wildlife, and plant materials he hoped to procure. ${ }^{34}$ Considering Byrd's involvement in the Indian slave trade, his presence was certainly a bad sign. In addition, waiting for Batts and Fallam was an armed and jittery Monyton Wahtakai sent to ascertain the meaning of the incursion into their territory, "having intelligence of our

\footnotetext{
${ }^{32}$ Ibid, 192

${ }^{33}$ Ibid, 192; Briceland 1987, 128.

${ }^{34}$ Alvord Bidgood 1911, 77, 192-193; Merrell 1989, 39; Briceland 1987, 126-127; Rice 2012, 26.
} 
coming were afraid it had been to fight them." The Englishman protested that they "came as friends, presented him with three or four shots of powder."35

The English foreigners tried to allay the quite reasonable fear that the English were coming to attack the Monyton's Okahok amai. Due to the constant threat of Wahtakai attacks throughout the Appalachian Mountains, the Monyton had increasingly consolidated into defensible palisaded mampi throughout the seventeenth century. Therefore the Monyton were sensibly expressing concern that these newcomers were just another threat to mampi life. Stories of the English (as most Europeans) were certainly frightening coming from their Tutelo and Saponi allies in the East. The Monyton Onqyayun was a dangerous place, yet the Monyton Wahtakai felt secure enough in his affiliation with the Tutelo to travel to meet with these intruders. The security of the Monyton emissary, however, was not strong enough to have confronted the English and Appomattox on the open path. Here we see "edge of the woods" diplomatic protocols being observed by the Monyton emissary even if the English did not recognize it at the time. As was the custom, the two Englishmen distributed "three or four shots of powder" to the Monyton. This act alone carried much cultural and geopolitical weight. ${ }^{36}$

Fallam did not say he gave a gun to the man, which would have been illegal in Virginia at the time, but rather gave him additional supplies for a weapon he presumably already possessed. How the man acquired the gun is unknown but this will be considered when discussing Gabriel Arthur and his contact in 1674. One thing, again, is certain: if the Monyton had guns, even a small number, they had to have close Wahtakai allies that worked as intermediaries. Tutelo, Saponi, the Yuchi or the waning Occaneechi were all likely candidates for this trade connection.

\footnotetext{
${ }^{35}$ Byrd in the slave trade: C. S. Everett, ““'They shalbe slaves for their lives” Indian Slavery in Colonial Virginia”, In Indian Slavery in Colonial America, edited by Alan Gallay (Lincoln: University of Nebraska Press, 2009), 67 108, 80; Alvord and Bidgood 1911, 193.

${ }^{36}$ Alvord Bidgood 1911, 193.
} 
The act of giving shot more directly connected the Monyton emissary to the English and somewhat diminished the fear of an attack (i.e. enemies do not give each other ammunition). Another important detail here is the presence of an interpreter among the Tutelo through which the Monyton was able to speak to the English. This further supports a close linguistic and sociopolitical connection with the Tutelo.

The unnamed Monyton then described the Okahok amai the English had just intruded upon. If the party had gotten "half way to the place they now live" and they already possessed guns, then the mampi site should have European materials. This narrows down the selection of possible archaeological sites a great deal. The best fit, and one that best fits the description Gabriel Arthur gave three years later, is Marmet mampi (46Ka0009) on the southern shore of the Kanawha River. This mampi was seventy-one miles from Camp 10 where the Tutelo and Saponi guides left the main party. At the time the party was roughly seventy-four miles from Totero. Hillard Youse discussed yet more evidence linking Marmet to the Monyton emissary present at Totero in 1671. Youse interpreted three skeletons buried together on their sides with traumatic injuries as evidence of a violent attack towards the end of the mampi's occupation. All three, a male, female, and young child, were clubbed to death. This violent attack was certainly on the mind of the emissary as he tried to identify the intruding Englishmen. ${ }^{37}$

The second half of the emissary's comment laid out the demographic landscape of the Monyton Onqyayun. First, he noted that Marmet was the "place they now live" suggesting that while mampi were relatively stationary, Monyton occasionally moved mampi locations. This fits well with the archaeological record, which indicates that mampi were occupied for 10-20 years

\footnotetext{
${ }^{37}$ Alvord Bidgood 1911, 193; Youse 1988, 47-49; Cyrus Thomas, Catalogue of Prehistoric Works East of the Rocky Mountains (Smithsonian Institution, Wash. DC 1985-1891), 221; Pullins et al, 2008, 97, 111, 822; Roland E. Barnett and C. L. Paxton, "Notes of Glass and Shell beads from 46-KA-9 (Marmet)" West Virginia Archaeologist 7 (July 1955), 31-33; Darla Spencer, "Evidence For Siouan-Speaking Groups In Southern West Virginia" West Virginia Archaeologist (2009), 5.
} 
and then abandoned due to depletion of local resources or attacks from outsiders. Beyond Marmet, along the Ohio River salt brines were plentiful and other mampi were present. The Ohio he noted has a "great number" of Wahtakai, presumably many more than the waning Monyton Onqyayun during the 1670s. Alvord and Bidgood referred to a letter written 80 years later by John Mitchell, a naturalist in 1755, to support their claim that the Monyton emissary was noting enemy mampi. ${ }^{38}$ This seems unlikely as the emissary noted that they obtained salt, a vital resource for preserving food, from these mampi. The meeting with the Monyton emissary concluded as the Monyton refused to discuss anything beyond the Ohio. Batts and Fallam responded by reiterating their peaceful intentions before concluding the meeting. The Englishmen stayed at the mampi for two more days. ${ }^{39}$

There were certainly many other meetings and transactions that transpired during their visit that would be enlightening but sadly are lost to the historic record, but the length of their stay and the peaceful meeting with the Monyton representative opened wider the Wahtakai trade within the mountains. As the party continued west, now reunited with their horses, they made quick time to the Hanathaskies and Saponi land. They carried with them furs and other trade items for Abraham Wood to peruse, along with stories of finding the headwaters of a vast tidal sea. More importantly for the Siouan-speaking Wahtakai of the mountains, the proposition of closer trade with the English was increasingly a part of their political and economic consideration. The Tutelo by having increasing direct English contact also had to balance the threat of encroachment with the potential benefit of a trade alliance. The Monyton emissary returned to Marmet mampi and certainly recounted a very bizarre encounter with their Tutelo-

\footnotetext{
${ }^{38}$ Mitchell Letter: Alvord Bidgood 1911, 196-205.

${ }^{39}$ End of expedition: Ibid, 193.
} 
Saponi allies and the English party in the western reaches of the Okahok amai. Their peripheral access to the English trade would become more direct in just three short years.

\section{James Needham and Gabriel Arthur}

Nearly every discussion of James Needham and Gabriel Arthur's expedition begins by connecting Abraham Wood's increased western interest to the success of Thomas Batts and Robert Fallam (Map 3.7a-b, Table 3.2). While true, 1672 and 1673 were very busy for Wood, William Byrd and other Virginian traders began tapping into the networks fostered by the expedition among the Tutelo, Saponi, and Monyton. The first failed attempt of Needham and Arthur in March of 1673 was not sent to strengthen the Siouan trade along the Roanoke and New Rivers but rather to explore new trading partners in the Southwest. This is another difference between the Batts and Fallam expedition, tasked more with geographic and territorial exploration, and Needham and Arthur's primarily trade-focused trip. Woods initially sent the party out with three months of provisions, but they floundered "by misfortune and unwillingness of ye Indians before the mountaines." 40

James Needham was a rising acolyte of Abraham Wood having only arrived in Virginia in 1670 from the Bahamas by way of Port Royal. Gabriel Arthur was an illiterate servant to Wood but little else is known about his origins. ${ }^{41}$ Needham was the leader of the expedition with Arthur along as his assistant. On May 17, 1673, Needham, Arthur, eight Wahtakai probably Appomatox, and four horses left Fort Henry heading to the south-southwest (Map 3.7c). The

\footnotetext{
${ }^{40}$ Needham and Arthur primarily comes from Abraham Wood's Letter to John Richards written two months after Arthur's return to Fort Henry in 1674, Alvord Bidgood 1911, 210-226. Though reprinted in a few different formats and locations (Shaftesbury Papers [1897] 2010: 452-3), there are no noticeable errors that make using Alvord and Bidgood's problematic. Briceland 1987, 147-170, discusses Needham and Arthur again with a focus on the geography and largely ignores the geopolitical and ethnographic information contained in the secondhand account. Based his positioning of Monyton town on the Big Sandy, that leg has been adjusted, but the rest of the expedition agrees well with the current geospatial and archaeological anaylsis. Alvord and Bidgood's geographic rendering is very generic and thus has been disregarded.

${ }^{41}$ Shaftesbury Papers [1897] 2010: 271, 411.
} 
party was on foot leaving the horses to carry a month and a half supply of food and parcels of "truck" including hatchets, knives, beads, and duffels (blankets) to whet the Wahtakai trade appetite. $^{42}$

The party had to overcome an initial obstacle to even begin their westward endeavor in the form of the Occaneechi. Though numerically weaker, the Occaneechi were positioned along the major trading path into the interior and were attempting to maintain their middleman position in the Wahtakai trade. As Needham and Arthur arrived, they were sought out by a party of Tomahittans that had recently arrived at Occaneechi mampi. The presence of these far interior Wahtakai suggests that they were already participating in the English trade through the Occaneechi as their intermediaries. Their eagerness to conference with Needham was an attempt to circumvent the Occaneechi and seek a more direct contact with the Virginians. This particular detail was overlooked in interpretations by Alvord and Bidgood and later with Briceland. The fate of both Needham and Arthur during the winter of 1673-1674 was connected to the Tomahittan attempts to break with their former allies and trade partners. ${ }^{43}$

The party of Tomahittan Wahtakai offered to quietly travel to Abraham Wood and deliver a message of the expedition's progress in exchange for the two Englishmen traveling to the Tomahittan mampi to start a trading partnership. While those eleven Tomahittan Wahtakai travelled, the rest of the party stayed with the Virginians so as to not arouse the suspicion of the Occaneechi. Rainy weather delayed the emmissaries' return and the Occaneechi were growing suspicious of the Virginians and Tomahittan's collaboration, so the forty Tomahittan Wahtakai decided to return home before the arrival of the emissaries, taking Needham and Arthur with

\footnotetext{
${ }^{42}$ Alvord Bidgood 1911, 210-211.

${ }^{43}$ Occaneechi: Goddard 2005, 7-8; Ward Davis 1993, 1, 214, 383, 416, 428-430; Rice 2012, 42-48; H. Trawick Ward and R. P. Stephen Davis, Jr., Time Before History: The Archaeology of North Carolina (Chapel Hill: The University of North Carolina Press, 1999), 99, 242-257.
} 
them. Just before reaching the mountains, around July 14, 1673, the emissaries caught up with them. A few days later, the party passed Sitteree, which is remarked as the last place of inhabitance till Tomahitta mampi.

Around August 10, the entire party arrived at Tomahitta in the vicinity of modern-day Rome, Georgia. While among the eager Tomahittans Needham and Arthur both began observing the culture of their new hosts. Despite the extensive discussion about the identity of these Wahtakai, Robert Rankin notes there is precious little to go on either linguistically or culturally. The most likely scenario considering the cultural movements of the 1670 s in the Southeast seems to point to them being Yuchi. While none of the well-documented Rome sites exhibit overt Yuchi cultural markers, flooding has destroyed at least two known seventeenth-century sites. The migrant Tomahitta were well protected from other polities in the region and were in the process of allying with other migrant groups to form the Creek nation. This particular mampi remained in contact with many groups from its original location in the Middle Ohio River Valley. Arthur's account also noted the presence of Spanish materials, "ye Tomahitans have a bout sixty gunnes, not such locks as oures bee" and "have a mongest them many brass potts and kettles from three gallons to thirty." ${ }^{44}$ It is easy to account for the pots as acquired by raiding, but the use of and maintenance of guns necessitated a complicated relationship with the Spanish. These cultural complications could be part of the reason for the Tomahittans trying to secure a permanent trade relationship with the English who were known for handing out gunshot liberally to their allies. ${ }^{45}$

\footnotetext{
${ }^{44}$ Alvord Bidgood 1911, 214.

${ }^{45}$ Location of Tomahittan town: Alvord Bidgood 1911, 82; French Broad and Little Tennessee; Briceland 1987, 156-157; Ethridge 2010, 86-87 falls in line with Briceland. Gregory A. Waselkov, "Seventeenth-Century Trade In The Colonial Southeast" Southeastern Archaeology, 8:2 (Winter 1989), 117-133, 118; Goddard 2005, 36. Ethic identity: Yuchi: John R. Swanton, Early History of the Creek Indians and Their Neighbors Originally published in 1922 by the Smithsonian Institution, Bureau of American Ethnology, Bulletin 73, (Gainesville University Press of Florida, 1998), 184-191; further support Speck 1909, 30-31, clay figures corroborated by Maslowski in Pullins et al 2008, 84; Goddard 2005, 11; Robert F. Maslowski, "Cultural Affiliation Statement: New River Gorge National River and Gauley River National Recreation Area” Northeast Region NAGPRA Program,
} 
It would seem that the Tomahittans had only arrived at their 1673 mampi about a decade earlier. This is supported by the accounting of their early trade encounters with the Spanish to the South. One of the survivors of this ill-fated expedition was one of the emissaries who visited Abraham Wood. The fact that the expedition carried beaver skins to the Spanish suggests that these were more Northern people attempting to establish a new trade relationship using items more common to the Northern trade networks. Arthur's account did provide a strange bit of information about the Tomahittan mampi. Arthur described the palisade as a rectangle but the description more closely matches the semi-circular palisades of earlier Ohio mampi. Much like Buffalo mampi (46Pu0031) along the Kanawha River, the Tomahitta's mampi defenses used the river escarpment and a palisade to restrict access. ${ }^{46}$ Arthur also noted that there were people at the mampi other than Tomahittans, such as the mullato women who appear to have been taken from the Spanish. But Arthur noted that "all ye white and black people they take they put to death since theire twenty men were barbarously handled." It is very likely that there were a few wives and children within the mampi from allied Wahtakai such as the Occaneechi, Siteree, and even Monyton. ${ }^{47}$

Needham immediately turned around with a small party of Tomahittans and his Appomatox guides and returned to Fort Henry on August 12, 1673. Gabriel Arthur was left among the Tomahittans to learn the language. There is little information about what transpired on the journey back Northeast. The trip back to Tomahitta raised the stakes in the tensions brewing with the Occaneechi. After a short rest at Fort Henry, Needham and the party of twelve Tomahittans started back towards Occaneechi Island. The account of what happened was pieced

NPS (Boston, MA, June 2011), 51; Hall 2009, 146. Cherokee: Alvord Bidgood 1911, 78-89; Caruso 2003, 18; Russell Thornton, The Cherokees: A Population History (Lincoln: University of Nebraska, 1990), 19.

${ }^{46}$ Waselkov 1989, 117-133, 118.

${ }^{47}$ Alvord Bidgood 1911, 214. 
together from the testimony of a trader from Occaneechi mampi and an unnamed investigator sent out by Wood. They made it past the Occaneechi by about two days and a conflict broke out between Needham and one of the Tomahittans. The story was that the unnamed Wahtakai dropped one of the packs into a river they were crossing. An Occaneechi, named Hasecoll also referred to as Indian John, took offense to Needham's chastisement of the Tomahittan porter and began threatening Needham. After passing Yattken mampi, the confrontation reached a boiling point when Needham "tooke up a hatchet which lay by him, haveing his sword by him threw ye hatchet on ye ground by Indian John and said what John are you minded to kill me." Hasecoll promptly shot Needham in the temple despite the protestations of the worried Tomahittans. ${ }^{48}$ The brazen behavior of Needham in such a tenuous position was not evidence of a "heroyick English man" but rather someone wholly out of touch with Wahtakai etiquette. Considering the alliance between the Occaneechi and the Tomahittans, as well as the cultural confusion of the account, Hasecoll's relationship to the party was more than opportunistic; in fact kinship rules dictated that he respond to the attack on his kin. That Needham survived long at all after the initial berating of the Tomahittan porter may have only been a product of his status as an English trader. From a Wahtakai perspective, Needham's death could have brought the wrath of the English upon the Tomahittans. Hasecoll and the Occaneechi would have been wise to listen to Tomahittan concerns, because this was a major factor in Bacon's Rebellion a few years later. Despite their worries, a portion of the party was convinced by Hasecoll to race back to Tomahittan mampi and rid themselves of Gabriel Arthur. The political, ethnic, and economic

\footnotetext{
${ }^{48}$ Alvord Bidgood 1911, 214-218.
} 
divisions within the Tomahittans were on display on October 5, 1673 as the returning party of Tomahittans convinced their kin to tie Arthur to a stake for burning. ${ }^{49}$

The king of the Tomahittans was not present at the beginning of the exchange, but was quickly made aware and ran home from hunting to intervene. As he walked in, he found Arthur bound to a post as Indian John and others gathered kindling. Notably, Arthur described one of his assailants as a "Weesock," or Siouan-speaking Waxhaw, who was lighting a torch to set him ablaze. As proposed before, ethnic refugees and exogamous marriage made the mampi population very diverse. He also noted "ye uprore for some was with it and some a gainst it." The king shot the Weesock after the Wahtakai proudly announced that he was going to set Arthur on fire. This sequence is striking in many ways, as it assumes that after approximately two months Arthur was conversant enough in Tomahittan (Yuchi) to understand the basics of the exchange. It also alludes to the fact that the king felt that the repercussions of killing one of his residents was outweighed by protecting Arthur. The protection afforded by the king, however, came with a price. ${ }^{50}$

Arthur was required to accompany the king on a series of raids far from the Tomahitta, "for that is ye course of theire liveing to forage robb and spoyle other nations." The distances travelled by the Tomahittans shows the security they felt at home. The first raid went south along the Chattahoochee River to a Spanish presidio just south of the mouth of the Flint River. The raiding party was out from October 8 till November 5. Their return was short-lived as "another party was commanded out a gaine ... to Porte Royall.” Arthur exerted some control over this expedition as he pressured the king to promise not to attack the English at the relatively new settlement, stating that "he would not fight against his own nation, he had rather be killd." The

\footnotetext{
${ }^{49}$ Rice 2012, 25 suggests that Wood close to Occaneechi even after they killed Needham. Arthur being threatened: Alvord Bidgood 1911, 218.

${ }^{50}$ Alvord Bidgood 1911, 218.
} 
mission was to "cut off a town of Indians which lived near ye English." The identity of these people remains unclear but most likely these were remnant Cusabo Wahtakai. The raiding party tested this when they ransacked an Englishman's house for beads, knives, and other trade goods. They had allowed Arthur to run ahead and warn the English residents to get out of the house to safety. Afterward, they attacked the nearby Cusabo mampi and headed on foot back to Tomahitta, arriving around January $8,1673 / 1674 .^{51}$

The most significant segment of Arthur's adventures happened during the late winter and spring of 1674. The Tomahittan king made another trip to visit allied Wahtakai in the North. The Monyton that they visited lived on a great river and were former neighbors when the YuchiTomahitta lived along the Ohio River. The nature of their alliance, although vague from Arthur's perspective, was based on historical, linguistic, and cultural similarities. On March 8 the Tomahittan king took Gabriel Arthur and sixty other Wahtakai and headed north to "give ye monetons a visit which were his friends." The trip took 10 days along the major warpath along the western side of the Appalachian Mountains. There have been lengthy discussions concerning the location of the Monyton mampi. Alvord and Bidgood noted that the mampi was about a day's journey or roughly 30 miles upstream from the mouth of the Kanawha River, placing it near Winfield in Putnam County. Briceland proposed that the Monyton mampi was near Louisa at the confluence of the Tug and Levisa fork of the Big Sandy River, in line with his reconstruction of the Batts and Fallam expedition. Previously, Buffalo mampi, 46Pu0031, was the location of Monyton based on glass beads found at the site, but more recent analysis has shown that the

\footnotetext{
${ }^{51}$ Alvord Bidgood 1911, 218-221; Briceland 1987, 162-165.
} 
beads at Buffalo are from the late 1590s-1620s. Buffalo mampi had been abandoned for at least forty years in $1674 .^{52}$

The description provided by Arthur supports Marmet site (46Ka0009) as the Monyton mampi. One day's journey below Marmet is the mouth of the Coal River and an area of significant archaeological activity at St. Albans. The river runs "north west and out of the westerly side of it goeth another great river" and it seems very likely that there is an undetected (or destroyed) mampi at St. Albans. Arthur's suggestion that "the inhabitance are an inumarable company of Indians" implies that the mampi got much bigger along this westerly path. The Monyton informed Arthur that the "inumarable company of Indians" is "twenty dayes journey from one end to ye other of ye inhabitance, and all of these are at war with the Tomahittans." There are two important comments in this statement. First, Monyton language was sufficiently similar to Tomahittan that he does not appear to have needed a translator. This further supports the Tomahittan being Yuchi. Secondly, this alludes to ethnic and political differences between each of these Western mampi, yet they were allied against a common enemy, the Tomahittans. When the Tomahittans left, notably, the Monyton did not join them on their campaign west.

Despite the meager information about the Monyton mampi from Arthur's account, it is important to note some of the things that were not mentioned. Arthur spent three or four days with the Monyton but never once mentioned whether they had guns or trade items. Considering he mentioned it later in the campaign against the Western Indians, the omission was not accidental. The present of shot from Fallam at Totero in 1671 and this omission points to the Monyton' access to guns and other European trade items. The evidence from Marmet indicates

\footnotetext{
${ }^{52}$ Alvord Bidgood 1911, 221-222; Briceland 1987, 165-166. Buffalo mampi: Pullins et al 2008, 93-94; Hanson, 1975.
} 
continued European trade connections that likely strengthened, albeit briefly, after their encounter in 1671 at the Tutelo mampi with Batts and Fallam.

The Tomahittans and Arthur travelled three days westward to attack "some of that great nation" of "inumarable" enemy Wahtakai. The identity of this group is even murkier than that of the Monyton, but the language was different enough that Arthur had to use sign language to communicate with them. Arthur's arrival was a shocking surprise when sorting through the captives and bodies. His long hair brought attention to the fact that he was not a Tomahittan. Their reaction to this provides insight into the issues of captives in Wahtakai warfare. The presence of a non-Tomahittan in the war party was neither a surprise nor cause for alarm, but being English probably saved Arthur's life. These Ohio Wahtakai certainly knew of the Eastern settlements of the English much as they had heard of the Spanish to the south. They had probably even heard of the Frenchman la Salle's expedition in 1670. The location of this mampi was in the vicinity of Ironton, Ohio, too far upriver from the Mississippi to have had frequent contact with any Europeans in the spring of $1674 .^{53}$

"They not knowing ye use of guns" and "had not any manner of iron instrument that hee saw amongst them," Arthur took this opportunity to start a trade conversation. A fresh beaver pelt caught Arthur's eye and he tried to show that he would give the people a knife for a number of those skins. He arranged that if they let him go back to "the white people toward the sun riseing" that he would "bring many things amongst them." Despite all the talk of hatchets and knives, Arthur was adamant that the Tomahittan gun must return with him. The hopes for future trade connections with the English were enticing for these far Western Wahtakai, but after they

\footnotetext{
${ }^{53}$ Alvord Bidgood 1911, 222-223.
} 
left Gabriel Arthur along the Great Warriors path tensions on the eastern side of the Appalachian Mountains would scuttle any attempts to return in time to honor his promises. ${ }^{54}$

Arthur made it back to Tomahitta around April 9, 1674 and almost immediately headed out for a canoe excursion on the Coosa River to the Atlantic Ocean around Mobile, Alabama. The goal of the expedition was primarily for food gathering and the account did not mention meeting any other Wahtakai along the way. They returned upstream in the canoes and finally began preparing to return Arthur to Fort Henry. By May 10, 1674 the Tomahittan King, Arthur and eighteen additional Tomahittan porters "laden with goods" left Tomahitta and headed northeast to Saratown. Unbeknownst to the party, a group of four angry Occaneechi waited there to kill Arthur like they had Needham. On June 5, 1674, the party learned of the trap camped in the woods outside of Saratown. From their hiding spot they saw Hasecoll in town. By nightfall, the Occaneechi raised an alarm that the town was being attacked by "strange Indians" which prompted the Tomahittan king to flee with all of his men leaving behind all of the furs, Arthur and a "Spanish Indian boy." The Occaneechi searched for Arthur but could not find his hiding spot. The pair waited in the bushes till morning when the Occaneechi left the mampi. Arthur and the slave carried six of the packs of furs into Saratown and hired four Sara residents to carry the packs to Aeno but none of the porters could be convinced to carry the packs past the Occaneechi and on to Fort Henry. So Arthur and the Spanish Indian boy left their truck at Aeno presumably under the care of the sick trader Woods had sent in search of information back in November 1673. The pair continued on and snuck past the Occaneechi and arrived at Fort Henry on June 18, 1674. Woods informed John Richards that Gabriel Arthur spoke at length providing a great

${ }^{54} \mathrm{Ibid}, 222$. 
deal more information "which were here too tedious to relate. Thus endes ye tragedy I hope yet to live to write cominically of ye business."

The promises of protection and the allure of a trade alliance between the Tomahittans and the English were not forgotten by the Tomahittan king after he left Saratown. He returned to Tomahitta and within a few days left with his two sons and another man all carrying packs of furs. Instead of travelling in proximity to the dangers posed by the Occaneechi, the four Tomahittans went up the Great Warriors path past the Cumberland Gap and to Totero. From here they made their way northeast to the James River and canoed down to Manikin mampi and arrived in Fort Henry on July 20. This path shows a kinship among Siouan-speaking Wahtakai that provided a stable social-mechanism for maintaining economic connections with Europeans across the Piedmont. The king stayed at Fort Henry for a few days and on leaving promised to return in the fall "with a party that would not be frited by ye way and doubt not but hee will come if hee bee not intercepted by selfe ended traders." This thinly veiled criticism of the Occaneechi speaks volumes to the shatter-zone politics gripping Wahtakai from Tsenacomoco to the Okahok amai. ${ }^{56}$

\section{The Nathaniel Bacon Effect}

The world of Wahtakai-Virginia trade was catastrophically upended a few months later with the beginning of Bacon's Rebellion. The Tomahittan king, Monyton, and Ohio Wahtakai eagerly awaited the removal of Occaneechi-control of the English trade but the consequences of the coming "rebellion" would weaken all Wahtakai trade and push many interior Wahtakai towards establishing connections with the Carolinas, the Spanish, and the French. As the summer closed and the leaves began to fall, the tensions in the Siouan Piedmont were reaching a fevered

\footnotetext{
${ }^{55}$ Ibid, 223-225.

${ }^{56}$ Ibid, 224; Briceland 1987, 168-170.
} 
pitch. English farmers complained of increasing Wahtakai attacks and wanted the Virginia legislature to protect them. Woods verbalized this criticism concerning the Occaneechi's "strongly fortified by nature and that makes them soe insolent for they are but a handful of people, besides what vagabonds repaire to them it beeing a receptackle for rogues." ${ }^{.57}$

The Occaneechi dealt with their demographic instability and waning economic power the way many groups had, like the Iroquois, by adopting refugees and war captives. These orphaned Wahtakai, the "rogues" Woods referred to in 1674, initially benefitted from the protection of adoption. No amount of social engineering, though, could prepare the Occaneechi for the fight brought to their doorstep by Nathaniel Bacon. Stephen Saunders Webb and many others have stressed the meanings and effects of Bacon's Rebellion for English citizens but have given little attention to the chilling effects on Wahtakai communities. James Rice balances this in Tales from a Revolution by discussing in great detail the effects of Bacon's attacks on Occaneechi mampi in 1676. In a last ditch effort to maintain control over their land and restrict trade access of Western Wahtakai, Posseclay, the chief of the Occaneechi, convinced Bacon and his followers to allow the Occaneechi to attack the Susquehannock forts to the West. On their successful return, Posseclay displayed the scalp of the Susquehannock King and the plunder of both forts. To solidify the alliance between the two men, Posseclay offered Bacon the seven Susquehannock captives. Bacon accepted the prisoners, which his men immediately executed; but he went further by asking for enough food to return home. Bacon brazenly breached indigenous protocol

\footnotetext{
${ }^{57}$ Quote from Needham Arthur account in Alvord Bidgood 1911, 224-225. Stephen Saunders Webb, 1676: The End of American Independence (Syracuse: Syracuse University Press, 1984), 3-4, 16, 21-25, discusses Bacon's Rebellion but there is no mention of the incident at Occaneechi Island nor Posseclay and Bacon's conference in June of 1676. Instead, Webb discusses the Susquehannock and their tensions with the Iroquois. While focusing on tensions between Berkeley and Bacon's movement, he was focused on rationalizing the volatility of Bacon's interventions in Indian affairs. "No bullets can pierce beaver pelts" and the failure of Berkeley's Indian policies and inability to protect fringe poorer settlers from generic Indian attacks, Webb 1984, 38, 21-25. James Rice's 2012 work on Bacon's Rebellion goes into greater details of the interactions between Indians and Virginians.
} 
further by insisting that Posseclay hand over the large stash of beaver pelts gathered from the Susquehannock. ${ }^{58}$

Insulted but chastened by the militia of angry Virginians in and around his town, Posseclay unsuccessfully offered to split the pelts with Bacon. The argument descended into a melee and then outright war that left Occaneechi mampi and many of the nearby mampi abandoned and burning. Many Occaneechi were sold into slavery and the mampi were plundered by rampaging Baconites. The valiant fight of the Occaneechi exacted a high price; Governor Berkeley accused Bacon of losing more Virginians at Occaneechi Island in one day than in the Anglo-Powhatan wars from 1644 till 1646. The losses were even more devastating to the Occaneechi forcing them to relocate in 1677 to the Frederick site (31Or0231) in North Carolina. A single day had reconfigured the Siouan Piedmont cultural landscape dramatically, almost completely severing the Monyton from the East. The ripples of this event would continue to be evident well into the eighteenth century. ${ }^{59}$

In summarizing the pervasive and lasting effects of Bacon's Rebellion, as the culmination of seventy years of English occupation of Virginia, Rice posed that the followers of Bacon had "won the battle over how best to deal with Native Americans." The perceived success of Baconites in removing the "Indian problem" stemmed from the shift from Wahtakai controlling all but the narrow swath of English settlement along the Atlantic coast to perceived English dominance. This perception was largely overstated and self-serving for the Virginians, but it was becoming increasingly evident to Wahtakai that "early eighteenth century colonists had gained

\footnotetext{
${ }^{58}$ On Bacon's dealings on the Carolina-Virginia Piedmont: Webb 1984 as mentioned briefly, Rice 2012, 42-48; Wilson 1983, 100-106.

${ }^{59}$ Occaneechi relocation: Ward and Davis synthesized the whole discussion of Bacon's effects on the Occaneechi in Time Before History 1999, 257, leading to their removal to the Frederick site. John Lawson, A New Voyage to Carolina, Edited by Hugh T. Lefler (Chapel Hill: University of North Carolina Press, 1967), 50-53, 232, discussed the Occaneechi removal to the Eno River region in 1701.
} 
the upper hand." ${ }^{60}$ From the Wahtakai perspective, the "strategy" was yet another contributing element in the shatter zone politics of the Southeast. How the Monyton reacted to this shattering socio-economic and political landscape was as fractured and shifting as the world to which they were responding. One thing was certain by 1680 , Virginians were not to be trusted and their allies were diminishing. ${ }^{61}$

\footnotetext{
${ }^{60}$ Rice 2012, 214.

${ }^{61}$ H. Trawick Ward and R. P. Stephen Davis Jr., "Tribes and Traders on the North Carolina Piedmont, A.D. 10001710" in Societies in Eclipse: Archaeology of the Eastern Woodlands Indians, A. D. 1400-1700 eds. David S. Brose, C. Wesley Cowin and Robert Mainfort, Jr. (Washington, D. C.: Smithsonian Institution Press, 2001), 125-141, 139.
} 


\section{Chapter 4: \\ Monyton Diaspora: Refugees, Captives, and Slaves, 1670-1700}

"There are among our settlements several small tribes of Indians consisting of some few families each: but those Tribes of Indians which we, on account of their being numerous and having lands of their own, call Nations, are all of them situated on the Western Side of this Province and at various distances as I have already mentioned."

As the days shortened in the late autumn of 1680 , only six years after Gabriel Arthur had visited the Monyton mampi, the remaining residents of the mampi were facing a series of major decisions. The harvests had been weak during the previous decade and this year's crop was barely enough to survive. There were constant threats from Seneca war parties from the North and Westo and Shawnee slave raiders from the South. The Tutelo and Saponi had switched from trading with volatile Virginians to trading with Carolinians. The onqyayun that had been home for many generations and the Okahok amai they had known for millennia no longer provided safety or sustenance. Like so many before and after, the Monyton uprooted their mampi and took them to new locations in the territory of other Wahtakai. This diaspora of the last remaining Siouan speakers from the region, that would come to be known as the Ohio, was a story of refugees, captives, and slaves. ${ }^{2}$

As the world was catching fire during the 1670s, Monyton were hardly isolated from the social turmoil surrounding them. Tensions between the English traders and neighboring Wahtakai were only a minor problem for residents of the Monyton Onqyayun. The alliances and wars between nations of Wahtakai continued much as it had since the advent of agriculture and bows and arrows, though during the late seventeenth century the stakes were much higher for Wahtakai. The socio-economic and cultural landscape began shifting wildly after the removal of

\footnotetext{
${ }^{1}$ James Glen (1761) in B. R. Carroll, comp., Historical Collections of South Carolina: Embracing many rare and Valuable Pamphlets and other Documents Relating to the history of that State... to... 1776, 2 vols. (New York, 1836), 2: 242.

${ }^{2}$ This chapter is an update and summary of my Master's thesis, Emrick The Monyton Diaspora: A history of the Middle Ohio River Valley, 1640-1700 from 2005.
} 
many of the Monyton's closest allies, like the Monongahela, during the mid-seventeenth century. Their list of allies grew thin as they were beset by attacks from warriors seeking scalps or captives, an unstable environment, and even from unforeseen cultural changes within their palisades. Past traditions were reinvigorated and altered in an attempt to cope, but Monyton individuals and families still became refugees among far flung mampi.

Recent work by Stephen Warren, while focused on the Shawnee, discusses the removal of people from the Ohio and generally suggests that the region had been cleared of inhabitants by 1650. He argues that French Sulpician Priest René de Bréhant de Galinée’s 1669 account of “a Southern informant" and former slave that described the Ohio as densely populated, in reality returned home to find the region completely depopulated. The archaeological record of the Ohio and Okahok amai contradicts this assumption since there is evidence of continued significant occupations throughout the mid-seventeenth century. Stories about French efforts in the Great Lakes and on the Mississippi were certainly making their way along trade routes into the Okahok amai by 1670. La Salle's expedition to the Ohio was unsuccessful, yet Nitarikyk's slave was still a harbinger of changes to come for all Wahtakai. French emissaries, like Andre Penicault, traveling along the late seventeenth-century Mississippi also heard Southern Wahtakai descriptions of a complicated cultural landscape of warfare and settlement along the Ohio. The perspectives of the French from Iroquoia, Illinois, and along the Mississippi provide insight into how early evacuations began and some of the claimed reasons for relocation. ${ }^{3}$

By 1680 the Okahok amai was becoming unsustainably depopulated and mampi citizens had to make a tough choice whether to remain in their long-time ati or abandon their amai (land) in hopes of finding refuge among former allies or even with powerful enemies. Old alliances were tenuous and Wahtakai who chose to not sell slaves were under constant threat of slave raids

\footnotetext{
${ }^{3}$ Warren 2014, 13.
} 
themselves. Despite high mortality from new virulent diseases transmitted through IndianEuropean trade in the Tidewater, the mountains of the Okahok amai created epidemiological and geographical constraints that buffered the Okahok amai from some of the epidemics' worst consequences. The ravages of disease were carried in whispered stories along the trade-war paths from every direction but did little to halt the exodus from the Okahok amai.

The story of the demographic collapse of the Okahok amai and the ensuing Monyton Diaspora highlights the sophisticated cultural and land-based identities of the late seventeenthcentury Southeastern shatter-zone. Unlike the responses of the Shawnee or other larger Wahtakai groups, the Monyton were subsumed into the cultural matrix, first into the Siouan Tutelo, Saponi, and Occaneechi mampi in the Piedmont, then into the Catawba. Some appear to have joined their former Yuchi allies and possibly the Lower Creeks. Many were adopted into their captive nations like the Westo, Shawnee, Cayuga, and Seneca. The building of Fort Christanna in 1714 briefly housed the last "farr Indians" in Virginia before they removed to Pennsylvania and later joined the Iroquois like many of their brethren.

\section{French Incursions and Interests}

During the late seventeenth century, there was a growing interest in the territory between the French and the English, including the Okahok amai. French Jesuits noted the presence of "southerners" and ontouagannah, "those who cannot speak" throughout the 1640s and 1650s, yet it was not until the 1660s that a clearer picture of the cultural landscape to the south began to emerge in the Jesuit records (Map 4.1). ${ }^{4}$ Sulpician Priests, François Dollier de Casson and René de Bréhant de Galinée, spent the winter of 1669 far to the north of the Okahok amai among the Algonquian speaking Nippissings. The account of their contact with the slave of the Nippissing

\footnotetext{
${ }^{4}$ Spero 2010,38 .
} 
chief, Nitarikyk, has been interpreted as a first contact with a Shawnee individual. ${ }^{5}$ While this could be true, it is far from certain. Any Wahtakai living along the western edge of the Okahok amai were familiar with Algonquian languages enough to learn Nippissing. Europeans often noted the shocking linguistic abilities of captives, some of even greater cultural distance. More significantly, the slave's description of the southern region provides some interesting context clues. The slave described the "Ohio," using the Iroquois name for the river, on which "are settled a multitude of tribes, from which as yet no one has been seen here, but so numerous are they that ... a single nation will include fifteen or twenty villages." ${ }^{\prime 6}$ Galinee reported that the Algonquian speaking Ottawa had presented the slave to Nitarikyk in 1668 "from a very remote tribe in the Southwest." Even though he specifically mentioned the "Honniasontkeronons and Chiouanons," the slave was not identified as either of these groups, in fact he remained anonymous. Later while among the Seneca, and after Galinee had learned some of the slave's language, he could still not understand the "Touguenhas" Shawnee captive despite also knowing Ottawa and Algonquin. This validates the slave's story and hints that he was from a Siouanspeaking mampi $^{7}$

After being rebuffed by the Seneca, who warned of the dangerous presence of "Antastoez" (Delaware), the French headed to Lake Ontario where a mampi possessed "a number of slaves there from the nations to which we desired to go." The party found it relatively easy to acquire a "Shawanons" and Ottawa slave. It is important to note the linguistic diversity in this passage. Galinee switched from Iroquoian to Algonquian words casually. Despite a deep desire to convert Wahtakai, Galinee and Dollier never made it near the Ohio or Okahok amai. No

\footnotetext{
${ }^{5}$ Warren 2014, 57.

${ }^{6}$ Kellogg 1917, 168.

${ }^{7}$ Parmenter 2010, 54-7; Allen W. Trelease, Indian Affairs in Colonial New York: The Seventeenth Century (Lincoln: University of Nebraska Press, 1960), 95-6; Richard White, Middle Ground: Indians, Empires, and Republics in the Great Lakes Region, 1650-1815 (New York: Cambridge University Press, 1991), 1-24.
} 
matter where Nitarikyk's slave ended up, he exhibited sophisticated diplomatic and social manipulation to successfully escape captivity and return home. ${ }^{8}$

The cultural information offered to Galinee and the French throughout the entire passage alluded to some careful embellishments and omissions. It remains unclear what ethnicity Nitarikyk's slave was nor what language he taught Galinee, but it is unlikely that it was identifiably Algonquian or Iroquoian. The presence of mampi southeast of the Ohio within Virginia documents and the archaeological record points to a deliberate omission of the Okahok amai, not that it was unoccupied. It seems unlikely that the slave was steering Galinee towards his mampi since he abandoned the French at the first opportunity. Instead, he used his geographic knowledge to whet his French employer's appetite for the benefit of his freedom but left out significant details about his origins to protect his Okahok amai. The same protectionist attitude was exhibited by the Monyton emissary that met Batts and Fallam in 1671.

On the very same day (May 17, 1673) that James Needham and Gabriel Arthur began their journey through the Piedmont into Occaneechi land, Louis Jolliet and Father Jacque Marquette set out for the Mississippi River from Michilimakinac. Around June 14, the party reached the mouth of the Oubaoukigou, or Wabash River. During the seventeenth-century the French adopted this Illini name for the lower half of the Pelawathepiki but switched to the Iroquois Ohio and La Belle Riviere a century later. This was the river "where dwell the people called Chaouanons in so great a numbers." Marquette reiterated the description from Nitarikyk's slave but hypothesized that the residents of the Ohio were "not at all warlike," and that they "allow themselves to be captured and taken like flocks of sheep." " A few days later, Joliet and Marquette and their small entourage of canoes encountered some skittish Wahtakai along the

\footnotetext{
${ }^{8}$ Warren 2014, 57-58; Kellogg 1917, 165-170.

${ }^{9}$ Kellogg 1917, 250-251; JR 59:145.
} 
banks of the Mississippi. When Marquette attempted to converse in Huron with the unidentified Wahtakai they responded "by a word which seemed to me a declaration of war against us." Kellogg proposes in her translation, that these were either Iroquoian speaking Tuscarora or Cherokee. Either would have been far from their home territories but were ranging widely into enemy Chickasaw territory raiding for slaves and deerskins. The Cherokee and Tuscarora both had direct knowledge of the entire Ohio. ${ }^{10}$

Marquette described their arrival, around June 18, at an Akamsea mampi on the west bank of the Mississippi. The Akamsea have been identified as the Quapaw, a group that had moved to the Mississippi from the Ohio. While it is difficult to precisely date the arrival of the Quapaw along the Mississippi, some archaeologists suggest the late-sixteenth or earlyseventeenth century. The migration of the Quapaw was used by Marvin Jeter to solve a lack of archaeological continuity between early Arkansas sites and later occupations. He proposes that their constrained settlement and limited numbers at initial contact with the French in 1673 meant a more recent arrival than AD 1200. If they left the Ohio from 1570-1620, this corresponds with the removal of the Woodside phase on the south side of the Ohio River in what is now Kentucky. This territory was being pressured by not only Iroquoian war-parties but also increasingly mobile Shawnees from the Cumberland Valley. ${ }^{11}$ Marquette's Akamsea match descriptions of many Siouan-speaking Wahtakai in the East. The men's hair was cut short and they adorned their noses and ears with heavy spools and beads, as was the Southeastern custom and matched the archaeological signature from mampi in the Okahok amai. ${ }^{12}$

\footnotetext{
${ }^{10}$ Kellogg 1917, 251-252.

${ }^{11}$ Marvin D. Jeter, "From Prehistory through Protohistory to Ethnohistory in and near the Northern Lower Mississippi Valley" in The Transformation of the Southeastern Indians, 1540-1760 eds. Robbie Ethridge and Charles Hudson, (Jackson, MS: University Press of Mississippi, 2002), 177-223, 188; George Sabo, III, "The Quapaw Indians of Arkansas, 1673-1803" In Indians of the Greater Southeast: Historical Archaeology and Ethnohistory ed. Bonnie G. McEwan, (Gainesville: University Press of Florida, 2000), 178-203.

${ }^{12}$ Kellogg 1917, 254-255; Woodside phase and adornment: Dunnell et al 1971; Graybill 1981, 116-7.
} 
The removal of the Quapaw was slower and much more deliberate than the Monyton who later evacuated the Okahok amai. The presence of the intrusive Quapaw mampi along the Mississippi River during the 1670 s and 1680s was due to their integration into the Chiwere Sioux-Algonquian socio-political framework of the region. Their removal from the Ohio was not hasty or urgent, and their mampi relocated en masse not piecemeal. Rather than refugees, the Quapaw maintained a distinct cultural identity, even into the modern era. On arriving, they developed violent animosities with many of the previous inhabitants as witnessed by Joliet and Marquette as well as subsequent French visitors. The Quapaw experience was an example of how regional intergroup networks accommodated the wholesale migration of mampi. The arrival of Monyton refugees in the Southeast a century later stressed these social mechanisms to the breaking point (Map 4.2). ${ }^{13}$

By 1698, when Andre Penicault wrote of his explorations at the mouth of the Ouabache (Ohio), the cultural landscape appeared to have changed greatly. The scope of Penicault's knowledge of the middle reaches of the Ohio River remained blurred by the informants but this time it was due to the depopulation of the region rather than active obfuscation. The unnamed Wahtakai guides informed the Frenchmen that the "Kasquinampos" river, or "Riviere des Cheraquis," was 10 leagues up from the mouth. Beyond these geographic details, the guides provided limited ethnographic information about the large populations upriver. ${ }^{14}$

Beyond their glimpses into the Mississippi and Great Lakes, the strongest French contribution to the discussion of the Okahok amai was their recording of Iroquois war parties and captives. French-Iroquois relations were tempestuous and the French tended to represent the

\footnotetext{
${ }^{13}$ Shatter zone: Ethridge 2006, 207-218; Ethridge in Ethridge Shuck-Hall 2009, 1-62. Joliet, Marquette with Quapaw: Kellogg 1917, 254-6.

${ }^{14}$ André Pénicault and Richebourg Gaillard McWilliams, ed. Fleur de Lys and Calumet: being the Pénicault narrative of French adventure in Louisiana (Baton Rouge: Louisiana State University Press, 1953), 35-36.
} 
Iroquois as villains attacking remote peaceful Wahtakai for no discernable reason. Iroquois war parties traveled frequently along the Ohio. Tonti met four bristling unhappy Iroquois scouts in 1680 along the Mississippi by the mouth of the Ohio. They warned him of the one hundred additional kinsmen that were travelling behind them. Iroquois raiding parties, like this one, were a common sight in the Okahok amai by the 1630 s, and after nearly fifty years had whittled down most of the local opposition. ${ }^{15}$

\section{Iroquoia Invades}

The beginning of Iroquois intervention within the region discussed in chapter 3 focused on the impetus and methods of the practice. Nearly five decades of Iroquois war parties produced a complex series of social calculations within the Okahok amai that directly led to their decision to leave their mampi. First as captives, then as refugees, the Monyton often became members of Iroquoian kanstaks (towns). The threat of such violence, the burning of crops, raiding, and concomitant demographic stress, pushed people out of the Okahok amai. ${ }^{16}$

The increase of violence during the late sixteenth and seventeenth century has been the subject of recent work by Matt Jennings, Joseph Hall, and Robbie Ethridge. Yet archaeological materials indicate only a moderate increase in violence during this period within the Okahok amai (Table 4.2). The development and proliferation of food storage pits is partially connected to this increase in violent attacks. Food storage pits are an insurance plan in the eventuality of war parties attacking, protecting a portion of the year's supply of food from destruction. The food pits are only partially explained by warfare as many other Wahtakai experienced the same

\footnotetext{
${ }^{15}$ Kellogg 1917, 297-304; Effects of Iro. Raids 1630-1680: Parmenter 2010, 78-80; Daniel K. Richter, "War and Culture: The Iroquois Experience" William and Mary Quarterly, 3d ser., 40 (1983), 529-537, 529; Brandao1997, 33 34.

${ }^{16}$ Captivity: George Sioui and Sheila Fischman, trans., For an Amerindian Autohistory: An Essay on the Foundations of a Social Ethic (Montreal: McGill Queen's University Press, 1992), 230; Carocci Pratt 2012, 1-22; Paul Kelton, Epidemics and Enslavement: Biological Catastrophe in the Native Southeast 1492-1715 (Lincoln: University of Nebraska Press, 2007), xviii-xx.
} 
increased use of food storage pits, in fact sixteenth- and seventeenth-century Monongahela houses incorporated a storage alcove within the structure. ${ }^{17}$ Warriors from other groups could have easily identified and destroyed food pits. Environmental stress also contributed to their use. Considering the examples of warfare and the mortality of Wahtakai in surrounding regions, the infrequent examples of mass graves, signs of fatal violence, or even healed wounds incurred in warfare would seem to suggest the Okahok amai was idyllic. ${ }^{18}$

Examining the social mechanisms and consequences of captive warfare gets us closer to making sense of the archaeological record in Okahok amai mampi. Warfare could benefit opportunistic warriors in many ways. The number of deer bones in Monyton mampi indicates a wealth of deer hides, frequently in conjunction with glass beads, metals, and cloth gained through trade with Europeans. If Dr. Daniel Coxe's account is to be believed there were quite a few English traders on western expeditions that have escaped our historical view. He wrote of a party of ten to twelve English traders in 1680 that had traveled across the mountains to the Ohio and on to Mississippi. They were treated well and traded for furs among forty or more nations around 1680. While stolen trade goods did bring prestige, it paled in comparison to the martial, biological, social, and spiritual power of taking live captives. Richard White and Richard Aquila, when discussing Iroquois mourning war practices, identify revenge and male martial validation as the primary cultural rationalizations. The same was true for most Eastern Woodland groups

\footnotetext{
${ }^{17}$ This has been correlated with the beginning of the Little Ice Age during the 1400s.

${ }^{18}$ Evidence of violent attacks: Drooker 1997, 55, 206 (little evidence of); David Pollack and A. Gwynn Henderson "Toward a model of Fort Ancient Society" in Fort Ancient cultural dynamics in the Middle Ohio Valley eds. A. Gwynn Henderson and Emanuel Breitburg, (Madison: Prehistory Press, 1992), 281-294, 287; Hudson, Charles. "Introduction." in The Transformation of the Southeastern Indians, 1540-1760, eds. Robbie Ethridge and Charles Hudson, (Jackson, MS: University Press of Mississippi, 2002), xi-xxxix, xxii, (Europeans caused increase); R. Barry Lewis, Kentucky Archaeology (Lexington: University Press of Kentucky, 1996), 177 (Slone stockade rebuilt 3 times), 180 (warfare already common, scalped skeletons at Fox farm and Larkin); Marvin T. Smith, Archaeology of Aboriginal Culture Change in the Interior Southeast: Depopulation during the Early Historic Period (Gainesville: University of Florida Press, 1987), 13, 20, 132-140. Monongahela food storage houses: Bernard K. Means, Circular Villages of the Monongahela Tradition (Tuscaloosa: University of Alabama Press, 2007); John P. Hart, "Storage and Monongahela Subsistence-Settlement Change" Archaeology of Eastern North America, Papers of the 1992 Monongahela Symposium. 23 (1995), 41-56.
} 
throughout the seventeenth- and eighteenth-centuries. ${ }^{19}$

Much of the historiographical focus has been on the role of the captives in the development of Iroquoian adaptive processes but has not dealt with the social effects on the mampi and individuals abducted. The threat of attack and capture was powerful enough that during the late sixteenth century mampi began consolidating populations in larger towns and building palisades as defensive measures. This was not sufficient to halt the onslaught of Iroquoian raiding parties. Monongahelans abandoned their homes in the Upper Ohio Valley early in the seventeenth century just as their pottery styles became more common in the Southern Seneca kanstaks (towns). It cleared a major obstacle to the Okahok amai and led to increased attacks deep into the Monyton Onqyayun (Table 4.3). The limited evidence of violent deaths in mampi along the onqyayun alludes to the fact that while attacks were common, captives and trade items not casualties were the primary desires. ${ }^{20}$

As Parmenter discussed in Forests Edge, the demographic instability of Seneca and other Iroquoian towns further bolstered a cultural impetus to capture large numbers of foreign Wahtakai for incorporation (Table 4.3). The mourning war complex of the first half of the seventeenth century was feared but also produced a paradox for many Monyton. As other factors like increasing environmental instabilities and more frequent slave raiding from Southern Wahtakai made life in the onqyayun frustratingly difficult, many Monyton left the Okahok amai and sought refuge among the Iroquois captors of their family members. Evidence of such movements was apparent in French accounts of Iroquois raids and the large number of foreign

\footnotetext{
${ }^{19}$ Richter 1983, 529-537; Aquila 1997; Jon Parmenter, “After the Mourning Wars: The Iroquois as Allies in Colonial North American Campaigns, 1676-1760" The William and Mary Quarterly 64:1, Free to Enslave: Politics and the Escalation of Britain's Transatlantic (Jan. 2006), 39-76; Parmenter 2010; Dr. Coxe: Alvord Bidgood 1911, 53; Deputy-Governor Keith to Mr. Popple, Feb 16, 1719, The National Archives Catalogue Reference: CO 5/1265, Nos. 124, 124 i.|CO 5/1293, pp. 181-203. Calendar Reference: Item 61, Vol 31 (1719-1720), 31-41.

${ }^{20}$ Monongahela villages abandoned and pottery issues: Richardson et al, 2002, 81-96.
} 
Wahtakai among the kanstaks (towns) of Iroquoia. ${ }^{21}$

The raids of the Okahok amai reached their peak in the 1660s and 1670s, but during the 1680 s the focus of Iroquois attacks shifted further west to the Great Lakes. Much of the recent scholarship on the Shawnee by Stephen Warren and Laura Spero assumes the usage of

Ontouagannha, "those who cannot speak," as synonymous with the Shawnee. This term could easily be applied to numerous people under threat by Iroquois attacks. Father Julien Garnier in 1672, for example, noted an old captive man "from the Ontouagannha, or Chaouanong," which has been used as evidence of such an assumption. Closer examination of the French text shows that Garnier was identifying the captive as one of the many peoples identified by the Iroquois as Ontouagannah, possibly the Shawnee, not that the terms were the same. While the Shawnee were more numerous, there many peoples within the Iroquois sphere of interaction. One of these, the Tutelo, were distinctly identifiable among the Iroquois later during the eighteenth century. Any analysis of the term Outouagannha has to consider that during the 1680s French observers were as yet unfamiliar with Eastern Siouan Wahtakai, so an Iroquois reference would most likely be explained by their unfamiliar Siouan language. ${ }^{22}$

The presence of Siouan style pottery among the Seneca further supports the increasing incorporation of Monyton, Tutelo, and Saponi during the late seventeenth century. While more archaeological work to fine tune the pottery chronology of Seneca kanstaks (towns) and

\footnotetext{
${ }^{21}$ White 1991, 18-20; JR 62: 208-9 [Letter of Father Thierry Beschefer, Superior of the missions of the Society of Jesus in Canada, Written to the Reverend Father Provincial of the province of france. Quebec, this 21st of October, 1683. among Miamis of Illinois: "Many Chaouanons whom he found among the Miamis (these are tribes who live much Farther away Toward the South, whom the Iroquois war has compelled to abandon their own country)" ${ }^{22}$ JR 56:61; Warren 2014; Spero comes to same conclusion in her dissertation, 2010, 38. Tutelo: E.B. O'Callaghan, M.D., ed., Documents Relative to the Colonial History of the State of New York (Albany: Weed, Parsons and Company, Printers. Assorted Vol, 1855) NYCD 6: 611; Jay Hansford C. Vest, "An Odyssey among the Iroquois: A History of Tutelo Relations in New York" American Indian Quarterly, 29:1-2 (Winter \& Spring 2005): 124-15, 130; and Frank G. Speck, "Siouan Tribes of the Carolinas as Known from Catawba, Tutelo, and Documentary Sources." American Anthropologist, New Series 37:2, Part 1 (Apr. - Jun., 1935), 201-225, 207-208. To be discussed in further detail below.
} 
onqyayun mampi must be completed to clarify the process, it is clear that Iroquoia's increasingly diverse residents created complicated connections with the Okahok amai (Table 4.3). Not only were its residents being taken but many decided to join relatives living in the North during the last decades of the seventeenth century. The maintenance of family ties and cultural identity is well established in the accounts of Iroquois "slaves" informing former family members of impending attacks. The social pressures building within the Okahok amai led many residents to utilize these remaining kinship connections as a cultural opportunity to join adopted captives among their new families. The Iroquois welcomed such refugees during the early eighteenthcentury. Historian Jay Vest notes that, "The political agenda of the Iroquois tolerated, even fostered, the retention of tribal institutions among those minority bodies of natives who voluntarily migrated." For the Iroquois, these refugees provided an opportunity to maintain the long-house political metaphor. ${ }^{23}$

\section{Disease and Depopulation}

Once incorporated as members of the Iroquois or as satellite communities, as additional props of the longhouse, the relatively small number of Monyton blended into their new mampi. By 1687, as a major outbreak of smallpox spread among the Iroquois and many Eastern mampi, the populations of the Monyton Onqyayun were noticeably diminished, but this did little to insulate them from the effects of epidemic disease. ${ }^{24}$

The detailed work on the role of disease in depopulating North America during the seventeenth and eighteenth centuries has broadened from Alfred Crosby's discussion of virgin soil epidemics to Paul Kelton's recent look at epidemiological and environmental factors. Kelton

\footnotetext{
${ }^{23}$ Siouan Pottery in Seneca Sites: Penelope B. Drooker, "The Ohio Valley, 1550-1750: Patterns of Sociopolitical Coalescence and Dispersal" in The Transformation of the Southeastern Indians, 1540-1760, eds. Robbie Ethridge and Charles Hudson, (Jackson, MS: University Press of Mississippi, 2002), 115-134, 124. Refugees: Vest 2005, 131.

${ }^{24}$ Dobyns 1983, 15, 17, 19, 23.
} 
deconstructs some of the biological assumptions of Henry Dobyns' statement that over ninety percent of the population of North America was decimated by small pox and other European diseases. While small pox was a major killer among the Iroquois, even during the worst epidemics of the late seventeenth century, the disease exhibited mortality rates closer to fifty or sixty percent (Table 2.2). When the mortality was significantly higher this was often due to dehydration and starvation rather than the disease itself. This stemmed from family members abandoning the sick or becoming sick themselves and therefore not providing the basic care for those who would have otherwise survived. ${ }^{25}$

A few myths about Wahtakai health persist in the historiography. Dobyns voiced one of the most prevalent myths; that Wahtakai were "nearly disease free" before European contact and became sickly through increased contact with Europeans and the many things, seen and unseen, they brought with them. As mentioned in Chapter 3, dental carries, malnutrition, arthritis and even chronic tuberculosis and syphilis were common in archaeological populations throughout the continent (Table 4.2). The mid-to-late seventeenth century burials found at the Orchard site, 46Ms0061, along the Ohio included a mass grave of forty individuals. Since mass graves were extremely rare in the Okahok amai, this may indicate a case of epidemic disease. ${ }^{26}$ The main culprit for this incident is smallpox, but this is difficult to verify since it rarely leaves clues on

\footnotetext{
${ }^{25}$ Alfred W. Crosby, "Virgin Soil Epidemics as a Factor in the Aboriginal Depopulation in America" The William and Mary Quarterly, 3rd Ser, 33:2. (Apr., 1976), 289-299; Dobyns 1983, 10; Marvin T. Smith, "Aboriginal Depopulation in the Postcontact Southeast" In The Forgotten Centuries: Indians and Europeans in the American South, 1521-1704, edited by Charles Hudson and Carmen Chaves Tesser (Athens: University of Georgia Press, 1994), 257-275; Kelton 2007; Sciulli 2002, 39-57; Smith, 1994, 257-275; Hudson 2002, xi-xxxix; Marvin T. Smith, Aboriginal Population Movements in the Postcontact Southeast, in The Transformation of the Southeastern Indians, 1540-1760, eds. Robbie Ethridge and Charles Hudson, (Jackson, MS: University Press of Mississippi, 2002), 3-20; Dobyns 1983; Richter 2001, 60; Milner, George R.; David G. Anderson; and Marvin T. Smith. "The Distribution of Eastern Woodlands Peoples at the Prehistoric and Historic Interface." in Societies in Eclipse: Archaeology of the Eastern Woodlands Indians, A. D. 1400-1700, eds. David S. Brose, C. Wesley Cowin and Robert Mainfort, Jr. (Washington, D. C.: Smithsonian Institution Press, 2001), 9-18; Ward Davis 2001, 125-141; Drooker 1997, 74, 209; Hudson 2002, xxiii; Ann F. Ramenofsky, Vectors of Death: The Archaeology of European Contact (Albuquerque: University of New Mexico Press, 1987).

${ }^{26}$ Though other interpretations conclude this was due to warfare. The residents of Orchard were probably Algonquian speaking people and culturally distinct from the Monytons.
} 
the bones of its victims unless they survive. Therefore, it is little surprise that none were persevered in the mass grave at Orchard mampi. The arrival of an unknown epidemic in Orchard was definitely cause for alarm and further fueled the growing stream of people leaving the Monyton Onqyayun. ${ }^{27}$

Smallpox was especially virulent due to the twelve to fourteen day incubation period before symptoms became present, allowing highly contagious carriers to travel long distances unknowingly spreading the virus. The disease, in ideal conditions, could even be transmitted by scabs and fluids on fabrics long after the epidemic receded. The presence of a possible smallpox incident on the western boundary of the Okahok amai could be linked to two possible outbreaks emanating from Iroquoia, one in 1678 and the other from 1687 to 1691. Due to the geographic breadth and severity of the 1687-1691 outbreak, it is likely that Orchard residents became infected by one of the numerous Iroquois raiding parties travelling on the Ohio after 1687 . The extent of the outbreak remains hidden due to poor preservation and limited excavation of Okahok amai archaeological sites. Kelton poses that "remote and difficult to access Appalachian highlands" were "most protected" and in fact "there were no serious germs to be protected from in the first place." By the time of the mega-epidemic of 1696, the protection Kelton describes was due more to the extremely low populations in the Okahok amai rather than any geographic buffering. Unfortunately, hidden forces not only threatened their bodies but also threatened their livelihoods in the Okahok amai. ${ }^{28}$

\section{Climatic Chaos, Environmental-Economic systems and Demographic Responses}

Monyton onqyayun mampi populations had grown during the first half of the seventeenth

\footnotetext{
${ }^{27}$ Dobyns 1983, 34; Andrew T. Chamberlain, Demography in archaeology, Cambridge manuals in archaeology (New York: Cambridge University Press, 2006), 151-159. Orchard: Pullins et al, 2008, 84, 99.

${ }^{28}$ Kelton 2007: 36-38, quotes 95. Dobyns 1983, 18-20, concerning the 1687-1691 epidemic; Parmenter 2010: 219; corroborating smallpox evidence collection issues: Chamberlain 2006, 151-159.
} 
century, in large part due to optimal weather patterns providing plentiful and reliable

precipitation, but beginning in the 1660s a more chaotic pattern began to emerge. The mampi had relied on relatively long warm growing seasons that produced at least two cycles of mataque. Frequent flooding from spring and fall rains replenished soils depleted through the summer. A dramatic four year drop in precipitation beginning in 1661 affected most of the Mid-Atlantic region (Appendix 3.8c). There is also paleoclimatological evidence of significantly shorter growing seasons, which limited the production of maize, sometimes by as much as fifty percent. The mampi were able to survive the occasional year of drought or colder temperatures by rationing and storing food surpluses, but the periods of drought and cold were becoming more frequent and severe. After the droughts of 1661-1665, weakened mampi suffered deep droughts again in 1670 and 1676 . These droughts in the Mid-Atlantic were severe enough to warrant a letter from a Carolina farmer to Lord Ashley on July 30, 1671. He noted that even though all crops "were destroyed by the drought and the seed lost ... the Indians say such droughts are [not] usuall., ${ }^{29}$

Paleoclimatological data indicates that the 1670 s also witnessed a major series of cold snaps that could have shortened the growing seasons from 120-160 days down to $80-90$ days or less. The colder conditions caused frosts to form earlier and stay longer, killing secondary crops, leaving mampi to subsist on a single cycle of fresh maize and whatever had been stored from the previous year. Two or three years of cold weather could destroy the reserves of a mampi. Droughts further weakened crops, making the late-seventeenth century one of the worst periods

\footnotetext{
${ }^{29}$ Quote: Shaftesbury 2010, 349. Climate matters: Henry F. Diaz and David W. Stahle, "Climate and cultural history in the Americas: An overview" Climatic Change 83 (2007): 1-8; Bradley et al, "Climate of the last millennium" In Paleoclimate, Global Change and the future, eds. Keith D. Alverson, et al, (Springer 2003), 105141, 113 from Briffa et al 2001. Raymond S. Bradley, Paleoclimatology: Reconstructing Climates of the Quaternary, $2^{\text {nd }}$ ed. (San Diego: Harcourt Academic Press, 1999), 425, Fig. 10.22; Stahle Cleaveland 1992: fig 1, p. 1950; fig. 3, p. 1954. David W. Stahle, et al, "Tree-ring reconstructed megadroughts over North America since A.D. 1300" Climatic Change 83 (2007):133-149; excellent explanation of PDSI and the examples of error-consistency. Cook 2004, for PDSI 237, 247. Maxwell et al 2011 and 2012 reconstructions.
} 
for agriculture. The winter of 1670, according to another letter to Lord Ashley, had been significantly colder than previously:

"Especially when the wind is att North or North west the wind is very sharpe when itt frezes I have seen Ice about an inch thick of one nights freezing butt not Snow the wind is very Sharpe in my Apprehens'on Colder than in England butt very Clear days \& little or No Rayne all winter." ${ }^{30}$

This was witnessed at Port Royal in the Carolinas, an area generally known during the time for its pleasant and warm climate. 1676 was a year without agriculture within the Okahok amai as a severe drought and cold snap took hold simultaneously. The climate momentarily rebounded in 1677 , yet the shock to the economy, biology, and population of the Okahok amai were extreme and repeated two or three more times before the climate began to stabilize in $1690 .{ }^{31}$

The climatic instabilities coincided with dramatic changes within the economic behavior of the Monyton and many other Virginia Wahtakai. Mampi residents had to find ways to cope with the limited supplies of corn and other crops after 1670 and this meant reallocating their energy into hunting and gathering activities to supplement their diet. Mampi benefited from this change in a variety of ways. The takhai's fruits, nuts, berries, and seed plants diversified their diet and the limiting of corn starch helped prevent malnutrition and iron deficiencies. Unlike maize, which was susceptible to being stolen or burnt by raiding parties, forest resources were dispersed and often fire resistant. ${ }^{32}$ This had a dramatic effect on the women of the mampi as

\footnotetext{
${ }^{30}$ Shaftesbury 2010: 275, along with 272.

${ }^{31}$ Agricultural stress of the Little Ice Age: David G. Anderson, "Climate And Culture Change In Prehistoric And Early Historic Eastern North America" Archaeology of Eastern North America 29 (2001): 143-186, 166.

${ }^{32}$ Some forms of Mixed Mesophytic forest flora actually benefited from firing the takhai. William M. Jurgelski, "Burning Seasons, Burning Bans: Fire in the Southern Mountains, 1750-2000" Appalachian Journal 35:3 (Spring 2008): 170-217; Paul A. Delcourt, Hazel R. Delcourt, Cecil R. Ison, William E. Sharp, and Kirsten J. Gremillion, "Prehistoric Human use of fire, the Eastern Agricultural Complex, and Appalachian Oak-Chestnut Forests:

Paleoecology of Cliff Palace Pond, Kentucky" American Antiquity 63:2 (Apr. 1998): 263-278; Amy E. Hessl, Tom
} 
their time became spread thinly across a variety of tasks each imperative for survival. Based on interviews with contemporaneous Piedmont Siouans and the archaeological record, planting and maintaining mataque was a woman's task and connected them to amai (land) and political decisions. As the crop cycles became disturbed, time had to be spent gathering along the takhai inkte, preparing meals and curing the surplus for storage. These two chores occupied a great deal of time, but the woman's role as hide producers was by far more influential. ${ }^{33}$

Hunting, even on the scale found in many late seventeenth-century sites, was not unique or uncommon but it indicated that the social context of deer and beaver hides had changed dramatically by the 1670 s and 1680 s. Heather Lapham discussed the intensification of deer hide production during the seventeenth-century by connecting it to the acquisition of exotic trade goods and elevation of social status for young hunters. These individuals seized an opportunity to become lucrative traders but also altered the standard course for young men in mampi social hierarchies. While social status remained a major part of the process for young men, this revitalized behavior was also a sophisticated response to the climatic instabilities of the period. Far from being just a process for acquiring wealth, hunting served a multitude of utilities for hunters, their families, and the mampi. The hunting glens were quick and reliable sources of protein as maize-beans-squash agriculture became unreliable. Lapham implies that the number of deer found in archaeological sites was disproportionately large compared to the needs of agricultural societies (Table 4.5). Taken in the context of the established environmental instabilities, this makes a great deal more sense. It is notable that deer remains were found in

Saladyga, Thomas Schuler, Peter Clark, and Joshua Wixom, "Fire history from three species on a central Appalachian ridgetop" Canadian Journal of Forest Resources 41 (2011): 2031-2039.

${ }^{33}$ Women's role in Agriculture: C. Margaret Scarry and John F. Scarry, "Native American 'Garden Agriculture' in Southeastern North America. World Archaeology" 37:2 Garden Agriculture (June 2005): 259-274. Gathering and deerksins: Gabriel Judkins, Marissa Smith And Eric Keys, "Determinism within human-environment research and the rediscovery of environmental causation" The Geographical Journal 174:1 (March 2008): 17-29. 
refuse pits within Monyton Onqyayun mampi in similar proportion to Lapham's Tutelo and Monacan mampi in southwestern Virginia. Cooler climatic conditions produced deerskins that would have been thicker thus more desirable for sale to Europeans. ${ }^{34}$ This likewise made beaver from the Okahok amai much more valuable, despite the fact that beavers comprise a much smaller percentage compared to deer within the archaeological assemblage. ${ }^{35}$

The adaptation of the subsistence economy to the late seventeenth-century environmental shifts provided increased opportunities for trade with the English living in Virginia and in fact created conditions that necessitated these connections. There were social consequences to these new trade arrangements. The egalitarian social structure exhibited in the burials of the onqyayun throughout the early seventeenth century remained intact as Wahtakai incorporated more exotic trade goods, especially European beads and metal pendants. Instead of social hierarchies developing to maintain control and distribution of exotic trade goods, the exact opposite occurred within Monyton mampi. Lapham noted that the deer skin trade provided young Wahtakai easy and frequent opportunities to access European trade, often through Wahtakai middlemen, thus circumventing mampi leaders and the established social hierarchy. While the leaders were hardly as strong politically as Mississippian chiefs, they were socio-political gate keepers that moderated interactions of their residents. Young Wahtakai no longer had an impetus to work within the established social mechanisms and status. These nouveau riche Wahtakai also

\footnotetext{
${ }^{34}$ Per conversation Joe Candillo, 9/1/2014: The best times to hunt for hides were the late Fall and early Winter as the fur was thickest and the hide had the healthiest fat stores. The fat made tanning slightly more difficult but would have made the skins most desirable for trade. Most hide dressing left the fur on to remain water repellent and warm. ${ }^{35}$ Heather A. Lapham, Hunting for Hides: Deerskins, Status, and Cultural Change in the Protohistoric Appalachians (Tuscaloosa, AL: University of Alabama Press, 2005); Richard Michael Gramly, "Deerskins and Hunting Territories: Competition for a Scarce Resource of the Northeastern Woodlands" American Antiquity 42: 4 (Oct. 1977): 601-605; Jeanne Kay, "Native Americans in the Fur Trade and Wildlife Depletion" Environmental Review: ER 9:2, Special Issue: American Indian Environmental History (Summer, 1985): 118-130; Kristen J. Gremillion, "Human Ecology at the Edge of History" In Between contacts and colonies: archaeological perspectives on the protohistoric Southeast, edited by Cameron B. Wesson, and Mark A. Rees. Tuscaloosa: University of Alabama Press, 2002: 12-31; Calvin Martin, Keepers of the Game: Indian/Animal Relationship and the Fur trade (Berkeley: University of California Press, 1978). Totero-Tutelo-Trigg connection: MacCord 1984, 178-179; Buchanan 1986.
} 
unwittingly unbalanced the gender-based political power by becoming the de facto diplomatic faces of the mampi with European traders. As young Wahtakai with limited or no social authority entered into trade relationships, they not only brought back valuable trade goods but also indebtedness, recreational tobacco smoking, and an unfettered desire for increased status. ${ }^{36}$

The full social ramifications of such interactions, though clear now, were rationalized and legitimized through cultural norms and traditions of reciprocity, meritocracy and spiritual power. Due to external and internal social pressures, similar to the ones that developed in mourning warfare, the deerskin trade mutated into a dangerous and nearly boundless system of revenge killings and theft. The deerskin trade opportunistically developed to stabilize mampi social structures while opening up the Monyton onqyayun led to more direct interdependency on the English trade. Symptomatic of this interdependency was the growing threat of Southern Wahtakai slave raids. $^{37}$

\section{Indian Slavery}

The storm swirling around the Okahok amai during the 1670 s was most virulent in the South (Table 4.7). The rise of the Indian slave trade was yet another example of adaptive social behaviors that metastasized into a major problem for all Wahtakai and Europeans whether they actively participated or not. The Mississippian chiefdoms during the fourteenth- and fifteenthcenturies practiced many forms of slavery that involved periods of warfare followed by diplomacy that inevitably concluded periods of violence. Slaves were taken in battle or could be offered as part of a diplomatic settlement solidifying the ties between each group. Despite the socio-economic power inherent in Mississippian slavery, there were elements of the Indian slave

\footnotetext{
${ }^{36}$ Lapham 2005, 138-150; Hall 2009, 66-67. Smoking Culture: Sean M. Rafferty and Rob Mann, "The Culture of Smoking: The Archaeology of Tobacco Pipes in Eastern North America (Knoxville: University of Tennessee Press, 2005). Trade deficits: Gallay 2002; Gallay 2009, 1-32; Everett 2009, 67-108.

${ }^{37}$ Mourning War complex development: Richter 1983, 529-537; Aquila 1997; Parmenter 2010, xliv-xlvi.
} 
trade that were unique to indigenous-European relations. The first instances of the slave trade were modest and not too far removed from the Mississippian practices of slaves as diplomatic pawns.

By the 1640 s the practice had become commodified in the Virginia tidewater as slaves were sold to settle estate debts, traded for horses, and even exchanged in the growing intercolonial slave trade. The Monyton, Tutelo, and Saponi were not tributary nations of Virginia and so were not protected by any of the legal restrictions on slavery in the Treaty of Necotowance that concluded the second Powhatan-Anglo War in 1646. The Saponi-Nahyssan and their WestoRichahecrian allies learned this a decade later when a Virginia militia expedition attacked, captured, and sold many of their members into slavery on Virginian tobacco plantations. Expeditions like these eventually forced the Saponi, Westo, and Occaneechi south into the Carolina Piedmont during the 1670s. The Tutelo remained in the Virginia Mountains for a decade longer before moving southward. The Monyton tense reception of Batts and Fallam at Totero seems increasingly reasonable in the context of Virginia's war with the Saponi and Westo and their promotion of the Indian slave trade. After Bacon's rebellion, the growing trade power of the Carolinas easily broke Virginia's tenuous control of the Indian trade. ${ }^{38}$

The Westo became Carolina's main Indian trade partner in the 1670 s after they moved from the Virginia Piedmont to the Savannah River. Their mid-seventeenth-century travels south from Lake Erie had taken them through the Okahok amai and across the Appalachian Mountains along some of the most heavily traveled paths in the Monyton Onqyayun. The Westo maintained a close connection with the Saponi and many remained along the Dan River even after the

\footnotetext{
${ }^{38}$ Everett 2009, 67-108.Virginia control of Indian trade: Kristalyn Shefveland "Sic jurat transcendere montes ("Thus he swears to cross the mountains"): Alexander Spotswood, Virginian Exploration, and Native Diplomacy" (Paper presented at American Society of Ethnohistory 59th Annual Meeting, 2012 New Orleans, La.); Hatfield 2004, 3436; Hahn 2004: 35; Switch from Westo to Savannah in SC, 1677: see FTN 63: in Salley, Alexander S. Journals of the Grand Council of South Carolina, July 14, 1677, April 12, 1680, June 4 and 24, 1680, 82-85.
} 
majority had moved to the Savannah River in 1674 . Their prowess as slavers was feared by coastal Siouans long before Henry Woodward's clandestine meeting with the Westos. This meeting began the process that led to their establishment as Carolina's primary Indian slavers. ${ }^{39}$ Monyton were likely members of the Westo Woodward visited in October of 1674. Whether as slavers or diplomats, the Westo would have sought a way to secure safe passage through the Monyton Onqyayun during their original exodus in the 1650s. Standard protocol varied depending on whether they were aggressively or peacefully traveling, but the effect demographically was the same. Mampi residents were abducted, married, and sometimes ritually adopted to ensure passage. Due to their close peaceful ties and possible defensive assistance to the Saponi, it seems more likely that the Westo created political alliances with the Monyton. In addition to their alliance with the Westo, Monyton maintained connections to the Virginia Piedmont, especially their brothers the Tutelo and Saponi. These were their longest, strongest, and most stable alliances through the last thirty years of the seventeenth century. Many Wahtakai in the Monyton onqyayun - fearful of Iroquois depredations - viewed an alliance with the Westo as protection from such attacks. Despite these protective measures, the Monyton remained under constant threat of slave raid parties. ${ }^{40}$

If mampi had remained intact after 1695, slave raiding would have been a continued

\footnotetext{
${ }^{39}$ Saponi and Piedmont Siouans: Heriberto Dixon, “A Saponi by Any Other Name Is Still a Siouan” American Indian Culture And Research Journal 26:3 (2002) 65-84; Daniel L. Simpkins, "Final Report, First Phase Investigations Of Late Aboriginal Settlement Systems In The Eno, Haw, And Dan River Drainages, North Carolina" (Research Laboratories of Anthropology, University of North Carolina at Chapel Hill, October, 1985), 49-65; Daniel L. Simpkins and Gary L. Petherick, "Final Report, Second Phase Investigations Of Late Aboriginal Settlement Systems In The Eno, Haw, And Dan River Drainages, North Carolina" (Research Laboratories of Anthropology, University of North Carolina at Chapel Hill, October, 1986).

Woodward: Alexander S. Salley, Jr., Narratives of Early Carolina, 1650-1708 (New York: Charles Scribner's Sons, 1911), 127-128; Introduction to Woodward journal; 130-134.

40 "Indian Slaves" The William and Mary Quarterly, 6:4 (Apr., 1898): 214-215; "Indian Slaves" The William and Mary Quarterly 8:3 (Jan., 1900): 165. Christina Snyder, Slavery in Indian Country: The Changing Face of Captivity in Early America (Cambridge, Harvard University Press, 2010); Almon Wheeler Lauber, Indian Slavery in Colonial Times within the Present Limits of the United States, 54: 3 (Longmans, Green \& Co., Agents, New York Columbia Uni. 1913).
} 
vector for smallpox to decimate their numbers. Paul Kelton proposed that the devastating smallpox epidemic of 1696 was made possible by the wide geographic distribution of slave raiding parties that had consistent contact with Charles Town (later Charleston). Any protection afforded them by alliance with the Westo was short-lived as the Shawnee vied for preeminence in the Carolina trade. The Shawnee were long-time Monyton enemies and were recent refugees from rivers flowing into the Ohio. Monyton were at a gross disadvantage numerically compared to the Shawnee, further forcing refugee Monyton to join with Westo, Tutelo, and any other allied peoples for protection. After only five years, the Westo relationship with Carolina had soured and the English enlisted a group of Shawnee (Savannah) to unseat their former allies. The Westo were defeated in 1680 and the Shawnee immediately took their place as the primary Indian traders and slavers. ${ }^{41}$

By 1700, the Shawnee had also been displaced by other groups willing to sell neighboring Wahtakai into slavery. The social volatility and cycles of indebtedness inherent in the slave trade were major factors in the development of a region-wide Southeastern shatter zone during the late seventeenth and early eighteenth century. Though not specifically mentioned within the slave trade accounts, Monyton were certainly caught up in the social, economic, and geographic changes it wrought. The sale of Wahtakai into European slave markets fueled the Monyton diaspora, binding them to tobacco fields in Virginia, Spanish missions in Florida, and most irretrievably, on sugar plantations in the West Indies (Map 4.3a). Once sold into English slavery any prospect of tracking individual or ethnic identities was destroyed. In 1695, over thirty years of periodic slave raiding and mourning warfare had wracked the Monyton Onqyayun, on top of the environmental and socio-political instabilities already mentioned. Captive

\footnotetext{
${ }^{41}$ Small pox connection 1696-1700: Kelton 2007: 143-159. Shawnee exodus: Warren 2014: 83-104, Spero 2010: 86, Lakomäki 2014: 24-34.
} 
migrations often prompted voluntary ones as Monyton sought better lives among friends and allies abroad. $^{42}$

\section{Siouan Refugees Abroad}

The Okahok amai became fully engulfed in the Southeastern shatter zone by 1680 and by 1695 the region was largely cleared of Wahtakai. The Monyton became refugees among a sea of dispossessed and fractured families and mampi, yet the full costs of their refugee status depended on their destinations. The refugee process began as the social support structure provided by the Okahok amai was weakened or destroyed and families were forced to choose new homes. They often followed kinship ties with neighboring groups. If direct kinship ties did not exist, then linguistic and cultural similarity played a role in the selection of new homes. In a larger exodus, the migrants sent emissaries for permission to settle, but in the case of the Monyton of the 1680s and 1690s there were too few Wahtakai left to warrant such efforts. This small scale removal meant that the political-ethnic identity eroded and was subsumed within a generation or two into the host identity. Ethnic identities sometimes persisted, as in the case of the Tutelo among the Iroquois, maintained by the persistence of their original language and cultural traditions. In the Southeast, expectations and receptions of refugees varied from group to group and town to town. $^{43}$

\footnotetext{
${ }^{42}$ End effects of Slavery: I covered this more specifically in Emrick 2005, Chapter 5. The general effects of slavery on the Southeastern Indians overall were covered in Gallay 2002 and his edited volume in 2009. Slavery was a major part of the "shatter zone" as in each article in Ethridge Shuck-Hall 2009. Theda A. Perdue, Slavery and the evolution of Cherokee society, 1540-1866 (Knoxville: University of Tennessee Press, 1979) discussed the institution as it internally affected the Cherokee but not how it connected them to the larger social network. Kelton 2007 and Snyder 2010 focused in on the connections across the region and the issues of epidemic disease and economic factors.

${ }^{43}$ Refugees: Carocci Pratt 2012, 1-22; Kelton 2007; Ethridge 2010, 94-6; Matthew Jennings, New Worlds of Violence: Cultures and Conquests in the Early American Southeast (Knoxville: University of Tennessee Press, 2011), 132-3; White 1991, 149; Spero 2012, 86, 112-3; Warren 2014, 13; Maureen Meyers, "From Refugees to Slave Traders: The Transformation of the Westo Indians" In Mapping the Mississippian Shatter Zone: The Colonial Indian Slave Trade and Regional Instability in the American South edited by Robbie Ethridge and Sheri Shuck-Hall (Lincoln: University of Nebraska Press, 2009), 81-103; Kathryn E. Holland Braund, Deerskins and Duffels: Creek Indian Trade with Anglo-America, 1685-1815 (Lincoln: University of Nebraska Press, 1993), 4-5.
} 
The process of leaving the Monyton Onqyayun may have begun after Iroquois attacks in the 1660s and 1670s, but it was the collapse of Virginia trade networks during the 1680s that instigated the largest segment of the Monyton diaspora. The indiscriminate violence of Bacon's Rebellion soured the fledgling trade relationship with Piedmont Siouans and forced the Occaneechi west and south away from Virginian traders. By 1680, they had largely coalesced with other Siouans into the mampi of the Catawba. Cultural and economic ties to the Tutelo drew the largest number of Monyton refugees southeast into the Staunton river basin. Historian Jay Vest includes the Monyton among the former Monacan Confederate peoples that joined the Tutelo in their migrations on the late seventeenth- and eighteenth-centuries. ${ }^{44}$

Siouan sites like Frederick in North Carolina were ethnically diverse and exhibited a wide variety of pottery and house styles. When the Occaneechi moved into the area during the late 1670 s, they brought with them slaves acquired from trade and warfare, along with allied peoples like the Saponi and some Tutelo. The bonds between these three worked like a magnet for other "naked" and "foreign" Wahtakai. These three groups successfully gathered together the remnants of the Siouan speakers from Virginia through the first decade of the eighteenth century. It was among this large collection of former mampi that William Byrd noted in 1733, "It must have been a great misfortune to them to be obliged to abandon so beautiful a dwelling, where the air is wholesome, and the soil equal in fertility to any in the world." ${ }^{45}$

When Governor Spotswood opened up Fort Christanna along the Meherrin River in 1714 it was meant to protect the newly chartered Virginia Indian Company's monopoly in the trade. In

\footnotetext{
${ }^{44}$ Vest 2005, 124.

${ }^{45}$ Frederick et al: Ward Davis 1993, 415-7, 425. William Byrd, The Westover Manuscripts: containing The History of the Dividing Line Betwixt Virginia and North Carolina (Petersburg: Edmund and Julian C. Ruffin, 1841), 112113. Mooney $1^{\text {st }}$ to track Siouan movement, 1894, 37; David I. Bushnell, Jr., Native Villages and Village Sites East of the Mississippi (Smithsonian Institution, Bureau of American Ethnology Bulletin 69. Government Printing Office, Washington, 1919), 13, 17; Speck 1935, 205-206.
} 
addition the Occaneechi, Tutelo, Saponi, and their allied Wahtakai agreed to become tributaries of Virginia in exchange for protection from the well garrisoned fort. William Byrd II noted this continued cultural alliance in the remnants of Fort Christanna on Nov. 18, 1728:

This people is now made up of remnants of several other nations, of which the most considerable are the Sapponies, the Occaneches, and Stoukenhocks, who not finding themselves separately numerous enough for their defence, have agreed to unite into one body, and all of them go under the name of the Sapponies. ${ }^{46}$

The facility was extremely expensive and cut into profits for wealthy traders not affiliated with the Virginia Indian Company; therefore the General Assembly did not agree to maintain it after 1717. Without the protection of the fort, the Tutelo moved to Pennsylvania near Shamokin and established their own mampi named Oskohary. Francis Jennings described central Pennsylvania as "a veritable united nations of Indians speaking Iroquoian, Algonquian, and Siouan languages." ${ }^{47}$ Following the Tutelo northward were enough Occaneechi and Saponi to each have their own mampi nearby. The former residents of the Monyton Onqyayun, as adopted members of each of these groups, became another nation represented in Pennsylvania. ${ }^{48}$

Throughout the 1700s, the Tutelo strengthened their relationships with the Iroquois in an attempt to protect themselves from raiding parties still heading southward against the Catawba (Map 4.3c). This was finalized in 1753 when the Tutelo were adopted as little brothers of the Cayuga. Many of the Tutelo moved up to Cayuga territory by the 1770 s and eventually joined disaffected Iroquois on the Grand River in Canada during the 1790s. This was the location of

\footnotetext{
${ }^{46}$ Byrd 1841, 88-89.

${ }^{47}$ Francis Jennings, William Fenton, and Mary Druke, David Miller, eds., The History and Culture Iroquois Diplomacy: An Interdisciplinary Guide to the Treaties of the Six Nations and Their League (Syracuse: Syracuse University Press, 1985), 41.

${ }^{48}$ Edward P. Alexander, "An Indian Vocabulary from Fort Christanna, 1716" Virginia Magazine of History and Biography, 79: 3 (Jul., 1971): 303-313, 304-5; Jennings et al, 1985, 41; Vest 2005, 124-155.
} 
Horatio Hale's interviews with the last speaker of Tutelo, Nikonha (Map 4.3d). The northern branch of the Tutelo was unknown to Byrd in 1733 when he relayed a story from the Saponi about the daughter of the last Tutelo king. She joined the Saponi as they were leaving their home on the Meherrin "and removed in a body to the Catawbas." Her father had recently passed away but Byrd praised him as "the most intrepid Indian we have been acquainted with." Byrds's compliment seems to hint at the Tutelo's role in the Indian slave trade, since "He made himself terrible to all other Indians by his exploits." As the Saponi told it, the daughter killed herself rather "she should not be treated according to her rank." It is unclear the real reason for her death but she was certainly not the last of her people in the Southeast. ${ }^{49}$

As the majority of Tutelo, Saponi, and Occaneechi moved north out of the Carolinas during the eighteenth century, they left behind many family members within the nearby coalescent Catawba nation. As Merrell established in The Indians New World, the Siouan speaking peoples sought "the path of least resistance" in reforming mampi. Byrd and Banister had knowledge of this coalescence, presumably from their indigenous guides when they described another group, the Sara along the Haw River on October 1, 1733. The Sara "who had been a considerable nation... retired more southerly, as far as Pee Dee River, and incorporated with the Kewawees, where a remnant of them is still surviving." ${ }^{50}$ The Keyawees became one of the dominant groups in the Catawba confederation. Thus the Monyton, with large numbers of Tutelo and Occaneechi, joined the Northern Catawba mampi during the first few years of the eighteenth century. As the Catawba consolidated from 1700 to 1720, they were formidable slave raiders thus bringing the Monyton and other Siouans into the slave trade in a slightly more advantageous position. Byrd discussed the movement of the Tutelo, Saponi, and Monyton, but

\footnotetext{
${ }^{49}$ Vest 2005, 124-155; Byrd 1841, 89-90; Speck 1935, 206 on Tutelo adoption and last King story.

${ }^{50}$ Byrd 1841, 112.
} 
also noted that they did not maintain a distinct identity within the Catawba. This suggests that the refugee Monyton, in order to enter into already functioning town and political structures as individuals and families, would have to go through social-identity rituals. The relatively warm reception, as Siouan brothers, that the Catawba offered was not found in mampi further away from the Okahok amai. ${ }^{51}$

In addition, there are accounts of "foreign" Wahtakai allied with the Yuchi that arrived in Lower Creek talwa and okli (Muskogean and Hitchiti towns) along the Coosa and Alabama Rivers. The Tomahittans, close allies of the Monyton, were a segment of the Yuchi and as such joined the residents of Yuchi Town (1Ru63) along the Savannah River as they headed west during the 1680s and 1690s (Map 4.3b). As they descended the Coosa and into the Alabama River, the Yuchi sought refuge among the powerful Hitichi-speaking Lower Creeks. By the 1680s, the Yuchi and Shawnee were loosely allied and became members of the northern-most talwa of the Lower Creeks. The inclusion of Monyton among these refugees is indicated by the presence of small amounts of Siouan style pottery in greater numbers during the late-seventeenth and early-eighteenth centuries. ${ }^{52}$

The Monyton had a great deal of contact with the Shawnee throughout the seventeenth and eighteenth centuries especially considering the dispersal of the Algonquian people throughout the eastern half of North America. (Map 7.1) It is likely that the large body of Shawnee travelling to Maryland and Pennsylvania in 1694 was at least partially made up of voluntary and enslaved Monyton. Martin Chartier and his band of Shawnee left the Illini in 1688

\footnotetext{
${ }^{51}$ Catawba: Merrell 1989, 25-27; Byrd and Monacan allies in Catawba territory, Byrd 1841, 85-87.

${ }^{52}$ Warren 2014, 192; Steven C. Hahn, "'They Look upon the Yuchis as Their Vassals': An Early History of YuchiCreek Political Relations" In Yuchi Indian Historian Before the Removal Era ed. Jason Baird Jackson, (Lincoln: University of Nebraska Press, 2012), 123-154; John E. Worth, "The Lower Creeks: Origins and Early History" in Indians of the Greater Southeast: Historical Archaeology and Ethnohistory, ed. Bonnie G. McEwan (Gainesville: University Press of Florida, 2000), 265-298: 277-285; Ethridge 2010, 239.
} 
after their alliance collapsed. The Wabash-Miami also joined Chartier and the Shawnee in 1689 much to the concern of Henri Tonti who warned that "All the Indians that you take along to the Ssouwenas [Shawnees] will be killed, and yourself also."53 The dispersed band wound their way to the Ohio and into the Okahok amai, probably through Sonontio, Lower Shawnee town, which was in its infancy. This was another vector for the Monyton to leave their home and the accounts of Maryland officials might provide several hints of their presence. A Maryland official admitted "the English cannot easily distinguish one Indian from another," they recognized the Shawnee and Martin Chartier. Maryland officials remained worried that he was also accompanied by unknown "farr" and "foreign" Wahtakai. This body of refugees joined the Minisink and Delaware on the Susquehanna River by $1696 .^{54}$

Many bands of Shawnee showed up from the West unannounced, there was at least one that arrived after being requested by the New York Governor Benjamin Fletcher. Seeking to circumvent the authority of the Iroquois and strengthen their Southern trade, the Governor sent Arent Viele, a Dutch trader and interpreter, to the Ohio to bring the Shawnee and others in the region back to Albany. After two years crossing through the Okahok amai, Viele returned in February 1694 with 700 Wahtakai, mostly Shawnee but also some unidentified stragglers. Their arrival frightened and angered the Iroquois and aggravated an already tense standoff between the Iroquois and New York. The refugee Monyton had no choice but to ally, and in most cases, identify almost entirely as members of their host whether Minisink, Cayuga, Seneca, Catawba, or Creek. $^{55}$

\footnotetext{
${ }^{53}$ NYCD XIII: 551.

${ }^{54}$ Emrick 2005, 57-59; Trelease 1960, 324-325; Charles A. Hanna, The Wilderness Trail Vol. 1 -2 (New York: G.P. Putnam's Sons, 1911), 2: 124; Francis Jennings, The Ambiguous Iroquois Empire (New York: W.W. Norton \& Company, 1984), 197-198; Warren 2014, 138-147; Spero 2010, 124.

${ }^{55}$ Warren 2014, 135-146; Archives of Maryland (AoM), Proceedings of the Council of Maryland (Baltimore: Maryland Historical Society, 1883), 2: 196, 5: 245, 8: 534.
} 
As Monyton and many other Wahtakai became refugees, residents and kin across the eastern half of North America, there is one last group of Monyton that must be discussed. There were families that could not bring themselves to leave the Okahok amai and thus remained. Although they occasionally stayed in their former mampi, most of the time was spent in mobile hunting camps not unlike ones from the Woodland period over a thousand years before. They were relatively isolated and did not participate in the Indian trade with Europeans. The huntergatherer lifestyle that had led many Monyton Wahtakai into the deerskin trade during the 1670s necessarily displaced full-scale agriculture during the early eighteenth century. Archaeologists have noted an increased use of rock shelters during the late-seventeenth and early-eighteenth centuries even in places away from major trails and mampi locations. Despite the small-scale presence of a handful of families, the Okahok amai would appear unoccupied for the next thirty years. $^{56}$

\section{Wāneni comes to the Okahok amai}

As the first Wāneni (Winter) snows fell late in 1699, the Okahok amai began to fade into oral tradition and historical memory. The few families unable, or unwilling, to leave the Okahok amai roamed through it leaving only small campsites and lithic scatters along trails and former mampi sites. A millennia of Siouan control ended with quiet footsteps and a last glance backward before crossing a mountain ridge for a new distant locations. Ati collapsed, mataque fields became overgrown and soon the tahkai pushed against the clearings maintained by Wahtakai for decades at a time. The onqyayun grew quieter under deep snows. The Okahok amai became a memory buried deep and spread wide during the Monyton Diaspora of the late seventeenth and eighteenth centuries. The Okahok amai was left to natural ecological processes, yet the efforts of

\footnotetext{
${ }^{56}$ Increasing rockshelter use: Michael B. Barber, "Prehistoric Rockshelter Use On Virginia's Appalachian Plateaus: Settlement Patterns, Looting, And Survivability" Archaeology of Eastern North America 33 (2005): 31-49.
} 
centuries of Siouan environmental management were not completely washed away. In fact, the remnants of the long dialectic relationship between Wahtakai and their Okahok amai produced a landscape so desirable that it would become the flashpoint for a world-wide conflict. Winter would not last long. 


$$
\begin{gathered}
\text { III: } \\
\text { Wāneni (Winter) } \\
\text { 1700-1730 }
\end{gathered}
$$




\section{Chapter 5: \\ Monyton Onqyayun Untended, 1700-1730}

"When the Plants, who were friendly to Man, heard what had been done by the animals, they determined to defeat the latter's evil designs. Each Tree, Shrub, and Herb, down even to the Grassess and Mosses, agreed to furnish a cure for some one of the diseases named, and each said: 'I shall appear to help Man when he calls upon me in his need.' Even weeds were made for some good purpose, which we must find out for ourselves."

Looking down from the ridgetop above the remnants of Marmet mampi, collapsed ati were barely visible under thick snow and the only signs of mataque were a few broken stalks poking above the white. The leaves had long since fallen, yet the once clear line between fields and trees was being crossed by saplings and young trees. The early winter deer, still plump from fall mast, stood out against the snow brazenly wandering through the mampi. The only sign of human activity was the rising wispy smoke from a campfire over the ridge to the north. While this scene would suggest a dormant abandoned landscape, the reality of the early eighteenth century was that the former Monyton Onqyayun was still very dynamic ecologically and socially. An explosion of growth was just beginning that would make this seemingly formidable region of steep river valleys one of the most desirable locations in North America. The lack of constant human maintenance, intermittent hunting, and Iroquois landscape ideologies all influenced the rising interest in the region.

\section{Hiatus: What do you call an abandoned landscape?}

Much of the ethnohistorical research concerning human ecology in North America has focused on the times when Wahtakai were active and how they interacted with the environment. This chapter, conversely, examines the tahkai without Wahtakai. The history, natural and human, did not end with the exodus of the Monyton. The landscape of the former Monyton onqyayun was highly managed, producing identifiable patterns in the region's ecosystem composition and

\footnotetext{
${ }^{1}$ James Mooney, Myths of the Cherokees (Dover 1995 [1900]), 252.
} 
mechanisms. Yet during the late eighteenth and early nineteenth century, as Europeans began to occupy the region, they described the former Monyton onqyayun and entire Okahok amai as an untamed and dangerous wilderness. While it is true that that the former Okahok amai had been abandoned; even in 1770 it was far from a pristine wilderness. William Denevan appropriately labeled the idea of a pristine wilderness, an area untouched by human disturbance, a myth during the period of Wahtakai contact with Europeans. He proposed in his critique of the myth, rather counter-intuitively, that "the Indian landscape of 1492 had largely vanished by the mideighteenth century, ... [and] was more 'pristine' (less humanized)." ${ }^{2}$ Denevan also outlined some of the effects of human interactions for flora and fauna especially as the land began the process of regeneration. But due to the broad hemispheric focus, his analysis did not define the socioecological process that left the landscape clear of human interference.

There are three possible descriptions in the literature for the ecological process produced by the Monyton diaspora. Most commonly, historians have described it as fallowing. In a farming context, fallowing involves plowing but not seeding land in order for nutrients to naturally replenish. After a few years, the farmer resumes seeding the field. The farmer continues to live nearby during the fallowing process and human intervention remains an active part of the entire ecosystem of the farm and surrounding region. What happened in the former Okahok amai involved the removal of nearly all systematic human interaction with the environment. The connection between the occupants and the ecosystem was severed. Francis Jennings referred to this as "widowed land" in 1976. He was more right than he knew as “... significant regions with dense sedentary population, with productive technologies, and cultural landscapes shaped by centuries of adaptation to changing environmental conditions..." effectively disappeared. He recognized that "not only was nature not a stable structure, but non-Europeans had their own

\footnotetext{
${ }^{2}$ Denevan 1992, 370 .
} 
history of life on the land."3 Despite this, Jennings' analysis was a bit too apocryphal, stating that epidemics and warfare cleared the land of Wahtakai. Disease and warfare certainly factored in the removal process, but the landscape was not wholesale widowed; rather it was abandoned. Landscapes were abandoned unevenly both spatially and temporally for complex reasons, therefore the legacy of such removal processes were quite different than the immediate demographic effects of epidemics and warfare, or the continuity of fallowing. ${ }^{4}$

Though the landscape was abandoned, I refer to $1690-1740$ as the Hiatus period to recognize the continued Siouan cultural memories that were placed upon the land by its former residents and their descendants. First, it is very likely, although unprovable, that refugees from the region found ways to return periodically thus maintaining their connections to the former Okahok amai. Participating in hunting parties to the region also allowed them to perpetuate their cultural understandings of the landscape in visceral ways. Second, even long after peoples left a "homeland," the cultural meanings of the landscape remained ingrained in stories and ceremonies. This manifested particularly through the processes of historicizing and myth creation. Diaspora studies have struggled with the psychological and cultural baggage carried by individuals and communities concerning their homelands. The focus here is on the legacies of those now distant communities and individuals within their homelands long after removal. Within diaspora studies, the homeland can maintain an increasingly mythological and ethnic potency, even the landscape remembers, much like the plants of Cherokee myths. Unlike cultural memory, as the landscape spends longer without systemic human interaction, the ecological

\footnotetext{
${ }^{3}$ John Brooke, "Ecology" in A Companion to Colonial America edited by Daniel Vickers (Oxford: Blackwell Publishing, 2006), 44-75, 47. In reference to Francis Jennings, The Invasion of America: Indians, Colonialism, and the Cant of Conquest (Chapel Hill: University of North Carolina Press, 1975).

${ }^{4}$ Abandoned landscape: Cohen 2007; John Solomon Otto, "Forest Fallowing among the Appalachian Mountain Folk: An Ethnohistorical Study” Anthropologica 30: 1 (1988): 3-22; Laetitia M. Navarro and Henrique M. Pereira, "Rewilding Abandoned Landscapes in Europe" Ecosystems 15 (2012): 900-912.
} 
needs, and personalities of flora and fauna began to dramatically alter even wipe away the layers of human influence. The exact nature and lasting legacies of this abandonment and subsequent successional ecosystems are discussed below. ${ }^{5}$

Although humans played a limited role in the immediate daily workings of the early eighteenth-century patchwork of ecosystems of the former Okahok amai, the lasting effects of nearly a millennia of human intervention and interaction remained deeply ingrained within the composition and interrelationships between flora, fauna, and scattered intermittent humans (Diagram 5.1). As the natural ecology exerted greater influence on forest composition, a succession of non-local ethnogeographies were also laid upon the former Okahok amai. In the absence of active Monyton control, Shawnee, Iroquois, English, and French peoples began to place their own concepts of ownership and cultural meaning on the landscape, even in absentia. Most prevalent of these was the Iroquois political language of the expanding white roots of peace and single spoon and dish. This expansionist language laid the groundwork for the expansion of physical settlements into the former Okahok amai during the mid-eighteenth century.

The lasting effects of Monyton occupation have been obscured within the historical record due to two major issues. First, European occupation and examination of the Kanawha River did not happen until the late eighteenth and early nineteenth centuries. Of the few eighteenth century accounts of the region, the journals of Dr. Thomas Walker (1750) and William Preston (1756) provided only limited environmental data. Christopher Gist's journals, from 1751 and 1752, were the only accounts to provide systematic and detailed accounts of the environment, flora and fauna witnessed while travelling through what are now Pennsylvania,

\footnotetext{
${ }^{5}$ Diaspora studies "homeland": Cohen 2007; James Clifford, "Diasporas" Cultural Anthropology, Further Inflections: Toward Ethnographies of the Future 9:3 (Aug., 1994): 302-338; Minkah Makalani, "Introduction: Diaspora and the Localities of Race" Social Text 98, Diaspora and the Localities of Race (Spring, 2009): 1-9; Gal Leoussi Smith 2010; Jaroslav Vojta and Lucie Drhovska "Are abandoned wooded pastures suitable refugia for forest species?” Journal of Vegetation Science 23 (2012), 880-891.
} 
Ohio Kentucky and West Virginia (Table 4.5, Table 4.6). This was due entirely to his explicit instructions to observe "the Produce, the several Kinds of Timber and Trees, observing where there is Plenty and where the Timber is scarce." The Ohio Company, seeking as much profit from these lands as possible, cautioned Gist "not to omit proper Observations on the mountainous, barren, or broken Land, that We may on your Return judge what Quantity of good Land is contained within the Compass of your Journey..."6 There are a few instances of Europeans captured and brought through the Kanawha valley but their accounts were often recorded much later second-hand and focused on the human actors rather than landscape descriptions. Close examination of the region's environmental situation does not begin in earnest until the 1780s after nearly fifty years of Shawnee and European hunting alongside continued regeneration. The effects of sporadic hunting and gathering were minimal compared to the systematic agriculture-horticulture combination practiced during previous Wahtakai occupations. Nearly a century of forest regrowth obscured the most obvious signs of Monyton occupation. ${ }^{7}$

The second more frustrating issue with historical documentation of the former Monyton onqyayun has to do with the expectations of the authors. Europeans often ignored or misunderstood the nature of the forest and pathways they were witnessing. Trails that had been maintained for centuries within the mountains were nearly invisible to the authors except to remark on their narrowness impeding all but foot traffic. As mampi began decaying, whatever human interventions Europeans would have been able to decipher were rendered nearly invisible. Therefore this environmental reconstruction of the former Okahok amai relies on support from

\footnotetext{
${ }^{6}$ W. M. Darlington, ed., Christopher Gist's Journals, with Historical, Geographical and Ethnological Notes (Pittsburgh,1893), Darlington Gist 1893, 67.

${ }^{7}$ Gist: Darlington Gist 1893. Dr. Thomas Walker: J. Stoddard Johnston, ed., First Explorations of Kentucky: Journals of Dr. Thomas Walker, 1750, and Christopher Gist, 1751, No. 13 (Louisville, KY: Filson Club Publications, 1898). "Preston's Journal of the Sandy Creek Expedition" in The Thirty-Fifth State: A Documentary History of West Virginia eds. Elizabeth Comfetti and Festus P. Summers (Morgantown, WV: West Virginia University Library, 1966), 41-47.
} 
archaeological and ecological research as well as historical detail. With this in mind, the most ubiquitous element of this discussion begins with the climatic conditions within the former Okahok amai. ${ }^{8}$

\section{Climatic Reprieve}

After global temperatures bottomed out for second time around 1675-1680, there was a period of steady increase until the nineteenth century. By 1750 , the global average temperature had increased from $-0.6^{\circ} \mathrm{C}$ below normal $\left(-1.08^{\circ} \mathrm{F}\right)$ in 1678 to $-0.3^{\circ} \mathrm{C}$ below normal $\left(-0.54^{\circ} \mathrm{F}\right) .^{9}$

On a global scale this meant the temperatures were becoming much closer to that of the twentieth century, but local temperature trends in the former Okahok amai remain difficult to pinpoint with available proxy data, i.e. tree rings. ${ }^{10}$ Topography, ecological, and climatic conditions may have tempered such temperature increases within the mountains of the Southeast. ${ }^{11}$ As noted before, while temperature was important, variation in precipitation was the more problematic issue

\footnotetext{
${ }^{8}$ Environmental blindness of Euros: Strother E. Roberts, "Changes in the Genre: A Brief Survey of Early MidAtlantic Environmental Histories" Pennsylvania History: A Journal of Mid-Atlantic Studies 79:4 (2012): 345-356. These authors make the connection between this historical blindness and the "Cronon-lite: a list of now-familiar ecological transformations characterized by the dispossession of native peoples and the depletion of natural resources occasioned by what Stradling calls "the profit motive" and what Cronon referred to as "the market" or "capitalism." Such a move is frustratingly familiar throughout early American historiography and implicitly represents (or at least perpetuates) a mistaken belief that real environmental change, and thus environmental history, did not begin in the territory that today makes up the United States until the first stirrings of industrialization around the turn of the nineteenth century." Patricia Seed, Ceremonies of Possession in Europe's Conquest of the New World, 1492-1640 (New York: Cambridge University Press, 1995). Likewise noted this but suggested that they were blind to preexisting ethnogeographies due to their cultural expectations from England, France and Spain.

${ }^{9}$ Normal in Paleoclimatology typically refers to the aggregation and averaging of data during the period from 19011970. The data from this time period is well documented and consists of extremely precise measurements across fine-grained spatial distributions.

${ }^{10}$ There are no naturally occurring lakes in West Virginia that could be used for analysis. River and stream sediments are too disturbed to provide an accurate picture of the pollen profile of the local hillsides.

${ }^{11}$ National Climate Assessment and Development Advisory Committee Report January 2013 Draft for Public Comment. Melillo, Jerry M., Terese (T.C.) Richmond, and Gary W. Yohe, Eds., 2014: Climate Change Impacts in the United States: The Third National Climate Assessment. U.S. Global Change Research Program, 841 pp. doi:10.7930/J0Z31WJ2: 29. The recent NCDC report on climate change shows that, while drought and flooding may have been exaggerated in the Southeast, according to temperature records from 1990-2010, appears to have limited increases and in some areas there was actually a moderate decrease in temperature. The reasons for this are still being examined, while factors like less-pervasive industry and lower population densities are important, topography and environmental composition may also contribute in ways that could highlight those same effects during the Little Ice Age. If the Southeast is resistant to warming, the region may have continued its LIA pattern as other regions warmed during the eighteenth century.
} 
within the former Okahok amai. Tree ring data indicates that the regional climate remained unstable as it became slightly more temperate.

The eighteenth century began following a series of extreme droughts within the Appalachian Mountains from 1696 to 1700. At the same time, global temperatures dropped slightly due to a series of volcano eruptions exacerbating the Little Ice Age by spewing ash into the upper atmosphere blocking solar radiation (Appendix 3.12). ${ }^{12}$ A major drought struck much of the eastern half of North America in $1708 .{ }^{13}$ Mount Fuji's category 5 eruption, late in 1707, may be linked to the droughts a few months later across most of North America. The severe drought only appeared to last a summer since various examinations of tree ring data noted that the annual precipitation fluctuated predictably and much more moderately during the subsequent twenty years (Map 5.1). Maxwell et al recorded a major flooding event in the mid-Atlantic during 1717, but the Cook and Central USA data sets show either minor flooding or no potential for flooding. The yearly fluctuations in precipitation appeared much milder during the first half of the eighteenth century. The first half of the eighteenth century witnessed only three other category 5 eruptions (1721 Iceland, 1739 Japan, 1755 Iceland) and no category 6 events. Japan's Shikotsu was equally as destructive as Fuji's eruption in 1707, but it did not appear to affect the climate of eastern North America. This may be due its location over 500 miles to the north where upper atmosphere winds carried the ash to Canada instead. Likewise, Iceland's sporadic eruptions were carried by winds to Europe and did not affect the climate of the former Okahok

\footnotetext{
${ }^{12}$ SI Volcano: Cereme, Indonesia (3) and Cotopaxi, Ecuador (3) add more the volcano data from SI and USGS charts. http://www.volcano.si.edu/search_eruption_results.cfm, Accessed March 1, 2015.

${ }^{13}$ Maxwell et al 2012; Pederson, N., A.R. Bell, T.A.A. Knight, C. Leland, N. Malcomb, K.J. Anchukaitis, K. Tackett, J. Scheff, A. Brice, B. Catron, W. Blozan, and J. Riddle. 2012. "A long-term perspective on a modern drought in the American Southeast" Environmental Research Letters 7:1 (January-March 2012), 14-34; Cook et al 1999 and Cook et al 2004.
} 
amai. Despite this, it is apparent that there was only moderate volcanic activity during the first half of the eighteenth century. ${ }^{14}$

During the 1720s and 1730s, when the first Lenape and Shawnee settlers began moving west into the Juniata and Allegheny valleys, far to the north, there were a few minor floods $(1726,1729,1739)$, but the climatic conditions of the former Okahok amai were ideal for the development of the mixed mesophytic forests found during the late eighteenth century. Where humans had a more direct influence on the composition of the forest, warming temperatures along with mildly fluctuating spring and fall precipitation allowed more diverse populations of plants to flourish than had during Monyton control. ${ }^{15}$ The influence of the climate was much slower and more nuanced than human interaction, even intermittent hunting parties. While I have noted that animal populations, especially deer and beaver, would have become more robust, increasing temperatures did cause one negative result, at least from an economic perspective.

The market value of eighteenth-century beaver and deerskins from the former Okahok amai was slightly lower due to the warmer seasons. ${ }^{16}$

Shifts toward more moderate climatic conditions coincided with the Monyton diaspora during the late seventeenth century. While abandonment alone would have produced many of the ecological changes seen during the early eighteenth century, increased temperatures and predictable rainfall provided the stable environmental foundation for such changes to flourish.

\footnotetext{
${ }^{14}$ Fagan 2002: 105, and SI Volcano database, USGS volcano volume calculations, http://www.volcano.si.edu/search eruption results.cfm, Accessed march 1, 2015.

${ }^{15}$ Rise of mixed mesophytic slopes: Donald Edward Davis, Where There Are Mountains: An environmental history of the Southern Appalachians (Athens, GA: University of Georgia Press, 2000), 16-17; Cynthia D. Huebner, et al., "Short-Term Dynamics of Second-Growth Mixed Mesophytic Forest Strata in West Virginia" Castanea 72: 2 (June 2007), 65-81; Jesse Bellemare, Glenn Motzkin, and David R. Foster, "Legacies of the Agricultural past in the forested present: an assessment of historical land-use effects on rich mesic forests" Journal of Biogeography, 29 (2002): 1401-1420.

${ }^{16}$ Deer skin values: White, "Liquor and Deerskins: Consequences of the Market Economy" 1983, 69-96; Andrea L. Smalley, “"The Liberty of Killing a Deer”: Histories of Wildlife Use and Political Ecology in Early America” (Dekalb, IL: Northern Illinois University, unpublished Dissertation, 2005).
} 
As the Little Ice Age temporarily lifted, the conditions that had restricted species diversity and successional expansion of the Appalachian forests were removed.

\section{Deconstructing the Mampi ecosystem}

A rough outline of the human ecosystem was discussed earlier, the focus was on the humans themselves, but the effects of such interactions with the environment must be examined closer to establish ecology during human residency and the effects of the vacancy within the human niche. The cultural ecology of the Okahok amai, a human ecosystem, is here examined using panarchy theory as an evolving hierarchical system with multiple interrelated elements. This theory describes "human ecosystems as holistic, self-organizing, complex, and adaptive" that are produced by complex interactions with the environment. Far from the environmental determinism of E. C. Semple or Jared Diamond, Delcourt and Delcourt pose the process as a series of increasingly complex conversations between humans and nature. There are four phases in each panarchical level. The $\mathbf{r}$ phase is the initial opportunistic utilization of natural resources and the development of a knowledge base. $\mathbf{K}$ phase is the institution of rigid cultural rules for utilizing the landscape that nature responds to through negative effects, declining animal and plant populations, and humans are forced to respond. Where $\mathbf{r}$ phase was in the ancient past, $\mathbf{K}$ phase for the purposes of this analysis was the $1640 \mathrm{~s}-1670 \mathrm{~s} .^{17}$

This chapter is concerned with the second half of the process. Beginning in the $1680 \mathrm{~s}$, a critical threshold was reached where Wahtakai were unable to continue within the Okahok amai. The $\boldsymbol{\Omega}$ phase was characterized by demographic crisis. In larger populations this phase would have initiated the $\boldsymbol{\alpha}$ phase, a period of social reorganization and technological innovation developed to better exploit and manage their ecosystem. This was what had happened during the

\footnotetext{
${ }^{17}$ Delcourt Delcourt 2004, 11-17; panarchy definition in Lance Gunderson and C. S. Holling, Panarchy: Understanding Transformations in Systems of Humans and Nature (Island Press, 2001), 1-5.
} 
1500s as the Little Ice Age reached its coldest and most unstable period. By planting new cold resistant corn types and reorganizing into consolidated large mampi, the Fort Ancient cultures survived new environmental and ecological conditions. The $\mathbf{\Omega}$ phase of the 1690 s severed the environmental ties to the Okahok amai leaving the ecosystem to reorganize around natural internal processes during the $\boldsymbol{\alpha}$ phase, 1700-1730. The cycle returned to $\mathbf{r}$ phase exploitation in the 1740 s as new peoples began opportunistically settling within the former Okahok amai. ${ }^{18}$

Let us back up a bit to establish the ecological situation during the end of Monyton occupation (Map 5.2a-b, Diagram 1.1). One of the most important resources a mampi required was firewood. A mampi needed a great deal of firewood throughout the year, this alone left the forest irrevocably altered keeping the tahkai floor cleared of most combustible materials especially within a single day's hike. Within only a few years the firewood needs would have pushed the forest edge back to the least arable slopes. The continuous need for building materials further compounded the wood needs of the Wahtakai. Wood scaffolds and posts were the beginning of almost all structures within Monyton mampi. The straightest and tallest tree trunks were required for palisade posts and probably accounted for a majority of the timbering within the nearby tahkai. The initial timbering required for building mampi structures and main palisade cleared the majority of floodplain and well up the nearby slopes. Selective timbering expanded into the local hillside seeking trees large and tall enough for palisade posts. This opened and widened patchy proto-glades that became thriving marginal ecotones with successional plants that were not only useful for Wahtakai but also attracted wildlife. The steep hillsides restricted the development of glades for hunting to ridgetops and unused floodplains. After a decade the forests within 10 miles of a mampi had been pruned and culled of the medium sized oaks and

\footnotetext{
${ }^{18}$ Delcourt Delcourt 2004, 11-17. Environmental possibilism: Sutton Anderson 2004, 19; Smith in Smith 2011, 2-3.
} 
pines used for building and the lowest stories of the branches would have been cleared for firewood. $^{19}$

Constant utilization and monitoring kept the floor cleared of most second generation growth forcing hunters to progressively go further in search of good hunting locations. The most visible evidence of management was apparent along the river. Just downriver from Marmet on the north bank was a 3.75 mile long floodplain that was prime for agriculture and secondary growth hunting glens due to the abandoning of Burning Springs branch mampi (46Ka0142) in the early 1600s. The northern bank also protected a major salt brine, one of the most important resources found within the Monyton Onqyayun (Map 5.3). Salt brines were found throughout the western portion of the onqyayun, yet the salt at modern-day Malden remains the most desirable for food and curing purposes. The utilization of this salt brine was a major operation requiring a constant supply of clay evaporation basins that have been found in many onqyayun sites.

Christopher Gist noted this practice and the environmental conditions surrounding salt brines along the Conhaway (former Monyton Onqyayun) in 1751 and 1752. In fact, the naming of the Bluestone River may be due the effects of such brines in major watersheds. Gist wrote that “several Salt Licks, or Ponds, formed by little Streams of Dreins of Water, clear but of a blueish Colour, \& salt Taste the Traders and Indians boil their Meat in this Water,..." Gist noted the presence of salt licks and brines throughout the former Monyton Onqyayun during his 1752. The

\footnotetext{
${ }^{19}$ Wood selection in sites, floodplain cover, firewood needs and effects: Silver 1990, 59-62; Hu Maxwell, "The Use and Abuse of Forests by the Virginia Indians" The William and Mary Quarterly 19:2 (Oct. 1910): 73-103; Gordon M. Day, "The Indian as an Ecological Factor in the Northeastern Forest" Ecology 34 (1953) 329-46; Richard P. Guyette, Daniel C. Dey, and Michael C. Stambaugh, "Fire and Human History of a Barren-Forest Mosaic in Southern Indiana” American Midland Naturalist 149:1 (Jan. 2003): 21-34.
} 
continued visibility of these resources suggests that even in 1751, the areas around salt resources had significant disturbance from frequent human extraction. ${ }^{20}$

The systemic opening of the forest floor also increased soil erosion, as heavy rains carried sediments into the major watersheds of the Kanawha and New Rivers. The soil and its nutrients were eventually deposited along the banks of the Kanawha and Ohio rivers. While this promoted growth along the river bottoms, the constant clearing and erosion negatively impacted the nutrients in the soils on the slopes and restricted the composition of the forest even further during the late seventeenth century. Even as the canopy was opened for edge development, understory growth remained inhibited by soil erosion as it washed away the seeds of edge plants like Milkweed and Grey Birch. Other species, pokeweed, Pin Cherry, raspberries, and sumac all could quickly reintroduce themselves into these disturbed zones and were probably assisted by Wahtakai who used the edge species for a wide variety of food and medicinal purposes. (Table 5.1, Diagram 5.3a-b) This counteracted the soil disturbances of wood collection, yet the process of regeneration was complicated by the occurrence of fires, whether accidental or intentional. ${ }^{21}$

Much of the twentieth-century research on the environmental impacts of Native Americans centered on their use of fire. Unfortunately, direct evidence of widespread fire management during the seventeenth and early eighteenth centuries is limited and inconclusive, at least in the former Okahok amai. Some researchers, citing evidence that lightning-strike forest fires happened with roughly the same frequency throughout the seventeenth and eighteenth centuries as it does today, note that elevated populations of fire-resistant and fire-friendly trees

\footnotetext{
${ }^{20}$ Salt uses in the valley: Ian W. Brown, "The Role of Salt in Eastern North America Prehistory” Dept. of Culture, Recreation and Tourism, Louisiana Archaeological Survey and Antiquities Commission Anthropological Study No. 3 (May 1981); Darlington Gist 1893, 42.

${ }^{21}$ Soil erosion in mature human ecology, restrictions on forest composition: Silver 1990, 61; Kelly Y. Hopkins, “A New Landscape: Changing Iroquois Settlement Patterns, Subsistence Strategies, and Environmental Use, 16301783" (PhD Uni. Of California, Davis, 2010), 140-142; P. L. Marks, "On the Origin of the Field Plants of the Northeastern United States” The American Naturalist 122: 2 (Aug., 1983): 210-228.
} 
indicated the widespread use of fire during these earlier periods. Historical forest fire evidence in central Appalachia is hampered by the history of deforestation and forest fires from the early twentieth century that left so much of the region burnt to the bedrock. Ethnological accounts from the surrounding region during the seventeenth century suggest that while fire was sometimes used in mass deer hunts, it was not common or effective in conjunction with the forest management practiced in the Monyton Onqyayun. ${ }^{22}$ Especially towards the late stages of Monyton occupation, fire would have been hard to instigate and manage and would have been potentially damaging to the economic value of the hides. Witness trees from the 1750 s and 1760 s indicate that fire-friendly species were more prevalent throughout the Appalachians but were not the only or dominant trees. The tahkai closest to mampi consisted of mostly fire-friendly trees. This pattern has even been found in modern forests around known archaeological sites, supporting the theory that human caused fires, whether intentional or accidental, were common and influential in the composition of the forest. ${ }^{23}$

The fauna of the onqyayun were also connected into this web. As Wahtakai cleared the tahkai they fostered a delicate balance of drawbacks and benefits for grazing animals like deer. The pruning of branches certainly limited that source of the food supply but the promotion of open spaces promoted edge species for the deer to consume in glens and open areas along small

\footnotetext{
${ }^{22}$ Ethnology of fire use in surrounding regions: White 1983, 10-11; Silver 1990, 59-64, lighting strikes 10-11; Serena R. Aldrich, et al. "Three centuries of fire in montane pine-oak stands on a temperate forest landscape" Applied Vegetation Science 13 (2010): 36-46; Paul A. Delcourt and Hazel R. Delcourt, "The Influence of Prehistoric Human-Set Fires on Oak-Chestnut Forests in the Southern Appalachians" Castanea 63:3 (Sep. 1998): 337-345; Delcourt et al. 1998, 263-278; Hessl et al. 2011, 2031-2039.

${ }^{23} \mathrm{WV}$ state forest fires and effects, Ronald L. Lewis, Transforming the Appalachian Countryside: Railroads, Deforestation, and Social Change in West Virginia, 1880-1920 (Chapel Hill: University of North Carolina Press, 1998), 265-8. Witness trees: H. Thomas Foster II, Bryan Black, Marc D. Abrams, "A Witness Tree Analysis of the Effects of Native American Indians on the Pre-European Settlement Forests in East-Central Alabama" Human Ecology 32:1 (Feb., 2004): 27-47; Bryan A. Black and Marc D. Abrams, "Influences of Native Americans and Surveyor Biases on Metes and Bounds Witness-Tree Distribution" Ecology 82:9 (Sep., 2001): 2574-2586; Bryan A. Black, Charles M. Ruffner, and Marc D. Abrams, "Native American influences on the forest composition of the Allegheny Plateau, northwest Pennsylvania" Canadian Journal of Forest Resources 36 (2006): 1266-1275; James M. Dyer, "Using witness trees to assess forest change in southeastern Ohio" Canadian Journal of Forest Resources 31 (2001): 1708-1718. Fire-resistant tree patterns around arch sites: Delcourt et al. 1998, 337-345.
} 
waterways. (Table 5.1) Populations of deer before the development of the skin trade were managed and appeared relatively robust and stable due to seasonal restrictions. This process was destabilized within the onqyayun during the late seventeenth century with advent of the Eastern deerskin trade. Three decades of less discriminate hunting, though far from indiscriminate poaching, produced herds of deer that were significantly smaller biologically and demographically at the turn of the eighteenth century. Beaver populations also dramatically declined during the seventeenth century and are rarely found in later onqyayun sites. Whatever role the beaver played in maintaining the ecology of the former Okahok amai, their niche was minimal. ${ }^{24}$

We finally come to the enigmatic effect of bison. They were hunted during the late seventeenth century, but they are not well represented in the archaeological record within the onqyayun. There are two interpretations of this. Either they were avoided or ignored unless absolutely necessary, which seems unlikely in the highly constrained ecosystems of the Monyton Onqyayun, or the bison were relatively new and only increasing in number towards the very end of the seventeenth century. This smaller species of bison was not known for the large herds like its plains relatives but rather smaller bands. They could still do a great deal of damage to crops along the floodplain. Gist and Preston both witnessed buffalo in the former Okahok amai during the 1750s and noted the presence of a "Great Buffalo Road." These deeply compacted and disturbed soils most often coincided with the largest paths used by Wahtakai. The ecological niche that bison carved for themselves would last until the early nineteenth century when the last of these animals were hunted by American settlers. ${ }^{25}$

\footnotetext{
${ }^{24}$ Archaeology of deer and beaver populations: Gramly 1977, 601-605; Smalley 2005.

${ }^{25}$ John A. Jakle, "Salt on the Ohio Valley Frontier, 1770-1820" Annals of the Association of American Geographers 59:4 (Dec. 1969), 687-709; Preston in Comfetti Summers 1966, 44-45, Darlington Gist 1893, 72-73.
} 
The overall effect of nearly thirty years of combined mature mampi-forest management and hide-trade hunting decreased the medium and large size faunal biomass significantly and weakened the ecological framework that had sustained the mampi for many decades. The scale of the human-influenced ecological instability was combined with the increased drought and decrease in temperatures of the late seventeenth century. The former Monyton Onqyayun of the turn of the eighteenth century was dominated by steep mountainside open floor mature forest with pockets of fire-resistant and fire-friendly tree species crisscrossed by well-trod paths connecting not only permanent mampi on the floodplain and higher terraces but also rock shelters and salt-brine extraction sites. Outside the main onqyayun, the tahkai became increasingly occupied by more diverse tree and shrub species surrounded by second generation growth making passage off the main paths difficult. Deer and beaver were relatively rare in the onqyayun but much more frequently seen in the surrounding tahkai. Deer herds had become noticeably smaller and younger. Abandoned mampi and mataque fields dotted the entire onqyayun; this was the managed landscape left behind.

\section{Hiatus: Ecological $\alpha$ phase}

Floodplains, as the zones of the most pervasive and systematic manipulation, exhibited the most immediate and dramatic ecological changes. It took a few seasons for soils on the floodplains to replenish and the tahkai inkte with valuable secondary growth plants quickly outgrew the sunny edges and begun spreading across former mataque fields and mampi sites. Ecologists have noted that mature forest can inhibit secondary growth plants due to the poor dispersal of seeds the plants exhibit, but the conditions of the former Monyton Onqyayun were an ideal "early-successional, anthropogenically managed mosaic of forests and old-fields" that 
provided nearly continuous corridors for expansion. ${ }^{26}$ Even on floodplains heavily utilized for agriculture and thus nutrient depleted by over farming, the yearly flood deposits would have further facilitated the spread of plants like raspberries, pokeweek, and sumac. Ground cover and herbaceous plants were quickly followed by successional trees like Pin Cherry, Red Cedar, and Gray Birch. Within five to ten years the distinct treeline and edge habitats broadened from tens to hundreds of feet. After two decades, medium-sized successional and young mesic trees began to fill in the canopy and shrink the open areas along the floodplains. The floodplains quickly became choked off by river cane as noted by Gist, Walker, and Preston in later expeditions. The areas of longest occupation along the Kanawha, from Marmet to St. Albans, could have taken nearly three decades to become choked with successional species and was only beginning to see the dissolution of a clear tree-line by the time Algonquian-speaking peoples began to settle in the region (Diagram 5.4). ${ }^{27}$

This process of expanding the tahkai inkte, edge ecotone, also provided a more robust supply of food for all sizes of fauna. Deer especially benefitted from infrequent culling and increased food supplies and became physically larger. In fact, after nearly thirty years of unbridled growth, the deer population became a burden on the mountain ecosystems. By the late eighteenth-century, carnivorous species also benefited from such faunal growth. Wolves and coyotes became too numerous for the deer population and turned to easier livestock species introduced by Europeans. ${ }^{28}$

\footnotetext{
${ }^{26}$ Delcourt Delcourt 2004, 132; Marks 1983, 223.

${ }^{27}$ Marks1983; DelcourtDelcourt2004: Soil and seed bed issues with secondary growth Marks 1983 most of his marker species were already in exsistence as part of the standard pharmacopeia and food materials of Indians. Davis 2000: 16-17: mixed mesophytic composition; Steven G. Platt, Christopher G. Brantley, and Thomas R. Rainwater, "Native American Ethnobotany of Cane (Arundinaria spp.) in the Southeastern United States: A Review" Castanea 74: 3 (2009):271-285; Preston in Comfetti Summers 1966, 44; Johnston 1898, 62; Darlington Gist 1893, 36, 65.

${ }^{28}$ Davis 2000: 16-17: wolves and carnivorous species. Deer: Smalley 2005.
} 
Farther from the heavily occupied areas along the river, along the steeper slopes, a slightly different dynamic was apparent. The fragmented canopies and secondary growth became less common. Fire-resistant species of pines dominated and kept the floor relatively clear of growth. Oases of marginal forest openings, often caused by tree-falls or fires, were bustling centers of faunal and floral diversity within a sea of a few tree species. Walker's expedition in 1750 stumbled into this kind of old growth ecosystem where "the Timber being so blown down that we could not get through. ${ }^{29}$ Along the main slopes, mesophytic deciduous and coniferous species dominated, while the higher ridges were occupied by the largest and oldest fire-resistant species of hickory and chestnuts. Christopher Gist provides the most detailed account of the mixed mesophytic composition of the former Okahok amai. He hiked "to the Top of a high Ridge" over the "Conhaway" but noted that the forest was "mixed with Pine and not very good." As he moved down the slopes and onto the flat river bottoms, Gist was much more pleased with "the Land to the NW which I found to be rich \& well timbered with lofty Walnuts, Ash, Sugar Trees \&c but hilly in most Places." The "lofty" and widely spaced timber made for easy passage throughout the former homes of the Monyton. In another location, Gist recorded the presence of walnut, locust, cherry, and sugar trees occupying the flat lands of the Elk River that flowed into the Kanawha. The patchwork of edge ecosystems bounded by mature old-growth mixedmesophytic and pine pockets described by Gist in 1751 match the ecological descriptions of "managed forest" that had been abandoned for over fifty years. ${ }^{30}$

After only five years, the former Monyton Onqyayun was overgrown with second generation plants that had once been staples of the Wahtakai diet. Yet without daily human

\footnotetext{
${ }^{29}$ Johnston 1898, 60.

${ }^{30}$ Karl B. Raitz, Richard Ulack, and Thomas Leinbach, Appalachia: A Regional Geography: Land, People and Development (Boulder: West View Press, 1984) 68. Mixed Mesophytic forest, climax of number of species share dominance beech, tuliptree, basswood, sugar maple, sweet buckeye, chestnut (before C. blight), red \& white oaks, hemlock, Darlington Gist 1893, 64-65, 70-77.
} 
intervention, competition for sunlight and nutrients bounded the growth and expansion of the secondary growth. Ecologists have found that ecosystems are characterized by the greatest degree of biodiversity during the $\boldsymbol{\alpha}$ phase, but this was catalyzed by the types of disturbance residents had left behind. While Monyton occupation certainly altered the amai (land), their moderate populations and forest management techniques proved the ideal amount of disturbance for the development of a mixed mesophytic forest with extremely high biodiversity and productivity. Like a weeded garden, there was an explosion of flora and fauna after abandonment.

Before the story again leaves the former Okahok amai and it's shifting ecological mechanisms, it is important to deal with the role of the few remaining bands of Monyton and other Wahtakai in the region. Mampi sites were abandoned and corn agriculture ceased along the river bottoms but people continued to influence and be influenced by the Okahok amai. The effects of human occupation can be found in the continued use of rock shelters and campsites along ridgetops. Numerous published rock shelter excavations exhibit evidence of protohistoric and colonial period occupations. Although exploration and excavation of mountaintop sites remains limited for numerous logistical and historical reasons, a handful of upland camp locations have been excavated. They have provided insight into the resources that prompted people to occupy such marginal sites. Sullivan and Prezzano note that mountain ridges, though ecologically marginal, provided certain benefits especially for those escaping centralized authority structures in this case the Iroquois, English, and French. ${ }^{31}$

\footnotetext{
${ }^{31}$ Lynne P. Sullivan and Susan C. Prezzano, “A Conscious Appalachian Archaeology” in Archaeology of Appalachian Highlands eds. Lynn P. Sullivan and Susan C. Prezzano, (Knoxville: University of Tennessee Press, 2001), 323-331, 329-330; Carole Nash, "Gaps in Our Knowledge: Hunter-Gatherers and High Elevation Blue Ridge Settlement" Uplands Archaeology in the East, Symposia VII \& IX, Archaeology Society of Virginia Special Pub. 2005: 89-102.
} 
Rock shelters throughout the former Monyton Onqyayun were often big enough to protect large families and serve as staging areas for hunting and gathering activities for most of the year, especially during the winter months. These could become long-term homes, but more frequently these were temporary arrangements as families followed game. Constricted rockshelters did not provide room for food storage pits but their location did make them advantageous for the highly mobile hunting and gathering lifestyle. Surrounded by steep hillsides, rock shelters often provided good visibility for spotting game and for defense, but as part of stone escarpment they also provided edge and disturbed forest openings that could be exploited for berries and other successional plant resources. The point here is that remaining Monyton lived quietly and successfully without corn agriculture by focusing on hunting and gathering traditions. These opportunistic foraging behaviors were helped by the selective management that had been developed in the tahkai for a thousand years. As successional plant species began filling in forest edges and trees began to colonize clearings, the diversity of both the flora and fauna was mutually beneficial to the ecosystem and the diet of itinerant Monyton. The successional growth also had the effect of attracting and sustaining game. For those choosing to occupy rock shelters one last benefit remained: their position in the middle elevations provided easy access to a much wider range of ecotones that the floodplains below provided, especially by way of trails that often connected rock shelters, floodplains, and ridgetops. ${ }^{32}$

To a modern observer, ridgetop sites might seem like poor locations on which to camp or settle. During the Woodland and Late Prehistoric period the presence of small agricultural

\footnotetext{
${ }^{32}$ Burns 2006; Prudence M. Rice, E. Pendleton Banks, and Robert E. Pace, "Contact Zones and Eastern United States Prehistory: Evidence from a Piedmont Rock Shelter" Southern Indian Studies 24 (Oct. 1972): 42-53; Marcy Rockman and James Steele, eds. Colonization of Unfamiliar Landscapes: The Archaeology of Adaptation (London: Routledge, 2003); Nash 2005: 89-102; J. P. Nass, Jr., "Subsistence-Settlement Change and Continuity in Western Pennsylvania" in Archaeology of Appalachian Highland eds. Lynn P. Sullivan and Susan C. Prezzano, (Knoxville: University of Tennessee Press, 2001), 177-197.
} 
hamlets on ridgetops has been recorded in the Upper Ohio River valley especially along the Monongahela River. These locations often are protected from frosts that descend into the valley bottoms. ${ }^{33}$ The gaps in high ridges not only provided access to both sides of the ridges and their resources, but collection points for control of those pathways. The depth of cultural materials at Dennison (46Lg0016) and James Creek (46Bo0025) indicates that sites were repeatedly visited through 10,000 years. Ridges provided limited access to the mesophytic forest slopes below but were used as pathways to nearby valleys. Marmet mampi was linked by a local Southern trail to James Creek site. While these sites were the primary settlements for Wahtakai during most of their occupation of the Appalachian Mountains, during the rise of agriculture around AD 1000 the uplands became secondary to the floodplains and lower terraces. From the eleventh to seventeenth centuries the ridges were mainly used as staging sites for hunting. ${ }^{34}$

In an analysis of the evidence of "mountaintop" occupations in southern West Virginia, archaeologist Gary Wilkins noted the "lack of evidence of extensive exploitation of mountaintop sites" during the Late Prehistoric. Wilkins cautioned against jumping to conclusions from such a small sample size and, since his article, many have begun excavating at higher elevations. Late prehistoric assemblages consist mostly of diagnostic flint points and fire cracked rock with a few charred animal bones. Both Dennison and James River contained pottery from late Fort Ancient cultural expressions. These sherds indicate that activities during the sixteenth- and seventeenthcenturies included more than just male-centric hunting. Even beyond the limitations of collected materials, the identification of late seventeenth and early eighteenth-century campsites poses challenges akin to a needle in a haystack. Durable European metal implements, adopted over

\footnotetext{
${ }^{33}$ Ronald W. Moxley, "The Dennison Site (46LG16): A Mountaintop site in Logan County" West Virginia Archaeologist 34 (Fall 1982): 34-42; Gary R. Wilkins, "Prehistoric Mountaintop Occupations of Southern West Virginia" Archaeology of Eastern North America 6 (1978): 13-40.

${ }^{34}$ Nash though sites mostly archaic to late woodland, gaps very important to mobile groups for access to resources, Nash 2005, 89-102.
} 
flint tools during the previous thirty years, were less likely to be left behind in a campsite. Even if flint knapping occurred in these sites, it would be impossible to distinguish whether a flint point was from 1680 or 1720 . Carbon dating of fire cracked rock has produced some dates but these have a wide margin of error. ${ }^{35}$

The presence of Monyton refugees, whether living in rock shelters or in ridgetop camps, and their return to subsistence hunting and gathering had little effect on the ecological processes underway in the absence of systematic management. In fact, displaced Monyton interactions with their environment closely approximated the behaviors of Shawnee, Delaware, and Iroquois hunting-war parties that began arriving in the 1740s and 1750s. While individual families attempted to maintain cultural and ethnic identities by remaining within the Okahok amai, the visible vestiges of political and cultural control of the amai (land) disappeared with the Monyton refuges scattered across the eastern half of North America. As the ecological impressions of Wahtakai management became blurred into natural processes of forest succession and maturation, new peoples were beginning to place their own cultural and ethnic identities upon the former Okahok amai.

\footnotetext{
${ }^{35}$ Wilkins 1978, 34-35.
} 


\section{Chapter 6: \\ New Ethnogeographies in the Okahok amai: \\ Reimagining the Hunting Ground, 1700-1730}

"And therefore have them their advice to use the Woods with the same freedom as they would a Kettle with Victuals when invited to a feast and with one Spoon \& Knife to eat all together sociably \& without begrudging those that had a better appetite \& eat more than others."1

As the natural ecology exerted greater influence on forest composition, a succession of

new layers of cultural meaning from people living outside the region, non-local

ethnogeographies, were laid upon the former Okahok amai. In the absence of active Monyton

control, Shawnee, Iroquois, English, and French peoples began to place their own concepts of

ownership and cultural meaning on the landscape, even in absentia. Most prevalent of these was

the Iroquois political language of the expanding white roots of peace and the "dish with a single

spoon." This expansionist language laid the groundwork for increasing settlements and land

claims in the former Okahok amai during the mid-eighteenth century. These new indigenous

concepts of landscape were grossly misunderstood by contemporary Europeans and have

continued uncritically in the historiography as support for the "common hunting ground" myth of

the Ohio region. Not only were the content and meaning of indigenous ethnogeographic

information misunderstood, but since these types of land-use were the first that Europeans

encountered in the Ohio, they also assumed it was a deeply rooted historical artefact. It was not.

The legal construction of ownership, whether indigenous or European, must be examined within

the context of the real-world interactions of their citizens and the environment of the former

Okahok amai. ${ }^{2}$

\footnotetext{
${ }^{1}$ Milton W. Hamilton, ed., The papers of William Johnson (Albany: The University of the State of New York, 1962), WJ XIII: 432, October 4, 1767, Kahnawake-Kanesatake Mohawk to the British Governor of Quebec.

${ }^{2}$ HG myth: Merritt, 2003, 10; Hinderaker, 1997, xi; Anderson, 2001, 13, 18; Withers, 1895, 44; McConnell, 1992 , 9, 19; Williams, 2001, 7.

Dish and Spoon: Robert A. Williams, Linking Arms Together: American Indian Treaty Visions of Law and Peace, 1600-1800 (New York: Routledge, 1999), 126-131, discusses one bowl one spoon as confederacy iconography
} 
The social complexity of intra and intergroup dynamics among Native Americans has been overgeneralized in ways that have facilitated pushing them to the edge of the historical narrative of the former Okahok amai and Ohio region. With more indigenous-centric and robust examination of the seventeenth and eighteenth centuries, the myth of the common hunting ground should be buried next to the hatchet once a for all. The story of the common hunting ground in the Ohio, while not a lie, is grossly incomplete and misrepresents the complexity of the meaning of landscapes in indigenous societies. The Kahnawake Mohawk, in the quote above, mirrors both the intent and complications that were inherent in the single dish and spoon metaphor. The principle promoted free access and proper distribution of resources but the metaphor of hospitality acknowledges that those with "better appetite" often strained the agreement. This truth was played out during the early-eighteenth century at many cultural and political scales within the former Okahok amai.

Whereas the last chapter discussed the developments within a physical and objective reality within the former Okahok amai, here I examine the ephemeral cultural elements laid upon the landscape especially in regards to the issues of access and ownership. Admittedly, both terms are complicated and heavily laden Western concepts. Understanding the differences in the cultural application of access and ownership, known as usufruct structures, within each culture further illuminates their competing interests within the former Okahok amai. The rationales, goals and language of landscape expansion were carried into the region and directed human interactions long before systematic and permanent occupation resumed. In the terms of Pierre Bourdieu, the ecological shifts already discussed were the "field," a discrete reality outside human control. The cultural layers placed upon the former Okahok amai were an ever changing 
"habitus" of human perception and meaning manifested in human actions. Both Wahtakai and Europeans intellectually and physically colonized the former Okahok amai during the beginning of the eighteenth century. The contemporary observers of this habitus struggled and often failed to understand and explain the depth of cultural baggage that structured their actions. Even though the cultural meanings of the landscape were often invisible their effects on real-world behavior were not imaginary. ${ }^{3}$

\section{A Dish and a Single Ladle: A Better Model of Indigenous Landscapes}

It is hard to overstate the role that metaphors played in the indigenous landscape, and the ownership of land is no different. Many Iroquois leaders, and a few Algonquians, conceptualized the Ohio and the surrounding region using the metaphor of the dish and single spoon. Much like the White Roots of Peace, this metaphor carries a lot of cultural baggage in the eighteenthcentury Ohio. The metaphor is derived from the stories of Deganawidah and the development of the Iroquois League of Peace but appears, much like the condolence and calumet ceremonies, to have had cognates among many in the Eastern Woodland nations. The Haudenosaunee began as a peaceful way to allocate resources required to maintain kanstaks (Iroquois towns) but became, by the eighteenth-century, an integral component of Iroquoian attempts at imperial hegemony in the Ohio and abroad. This language was even used between the Nishnaabeg and the Iroquois for sharing the western Great Lakes. Robert Williams poses the metaphor as a corporate process with "different peoples acting to mutualize and converge their interests." not one of land ownership but rather access and intra-intergroup interactions and negotiations. It

\footnotetext{
${ }^{3}$ Carson 2002, 779-780, introduces this concept from Pierre Bourdieu, "Structures, habitus, practice" in The logic of practice edited by Pierre Bourdieu (Stanford, CA: Stanford University Press, 1990), 52-79, 54. The habitus is the dialectic combination of subjective and objective reality. This is in support of his use of "ethnogeographies" that could be multi-layered and contradictory placed on the landscape simultaneously.

${ }^{4}$ Williams, 1999, 126.
} 
is a social process rather than a concrete geographic space with assumptions of explicit occupation or avoidance. ${ }^{5}$

The problem with the mythology of the hunting ground it is an incomplete picture of the interactions among the Wahtakai and between the Wahtakai and the environment. The single dish and spoon framework, especially as voiced by Deganawidah and the Kahnawake Mohawk. The metaphor was based on a very common indigenous understanding of hospitality and diplomacy, though complicated, individuals and kanstaks (towns) were supposed to provide food and lodging for peaceful individuals. The act of eating together was a sacred honour second only to the condolence ceremonies that greeted individuals. Peace and war were intertwined in the narrative of League stability. For the original members of the League, peace could only be maintained by expanding their influence beyond Iroquoia. The constitution of the League explicitly dictated the terms for this expansion. The roots of the White Pine, the tree of peace, spread outwards in all four directions "signified the extension of the Law, the Peace, to embrace all mankind." As the roots inevitably spread into new territory. Deganawidah declared, if "other nations, not yet members of the League" possessed "goodwill," they "would desire to follow [the roots] to their source and take shelter with others under the Tree. ${ }^{, 6}$ Conversely, if people of illwill happened upon the roots and attempted "hack them down" the Eagle sentinel at the top of the Tree would alarm all member nations. Then the use of violence was permitted. The method of this expansion, however altruistically stated to their own members, was one of the major causes for the diaspora of Siouan peoples from the former Okahok amai. The irony of this expansion into former Siouan territory is that so many former residents eventually joined Iroquois kanstako (towns) as momentary sources of stability but this did not last long.

\footnotetext{
${ }^{5}$ Leanne Simpson, "Looking after Gdoo-naaganinaa: Precolonial Nishnaabeg Diplomatic and Treaty Relationships" Wicazo Sa Review 23:2 (Fall 2008): 29-42; and Blair, 1955.

${ }^{6}$ Paul Wallace, The Iroquois Book of Life: White Roots of Peace (Sante Fe, NM: Clear Light Publishers, 1994), 28.
} 
The metaphor also maintained the cohesion of mampi and clans throughout the former Okahok amai, whether Shawnee, Delaware or Iroquois. Their hunting grounds held value for the entire mampi and had to be properly maintained and distributed to be utilized most effectively and in a culturally appropriate manner. The metaphor of the dish and single spoon was a major foundation of the social rules of the condolence ceremonies and to Deganawidah's guidelines for a proper and peaceful society. From an anthropological perspective, the single dish and spoon framework was the development of culturally unique usufruct rights, each group, settlement and nation implemented different versions of the basic principle as circumstances, language, and cultural requirements dictated. Among the Iroquois, this cultural tool was motivated by two of the freedoms presented by Deganawidah through Hiawatha: the freedom of trade and the freedom from want. To maintain the freedom from want, Deganawidah proclaimed, "We shall have one dish in which shall be placed one beaver's tail, and we shall all have a co-equal right to it, and there shall be no knife in it, for if there a knife in it there will be danger that it might cut someone and blood would thereby be shed." ${ }^{7}$ The peaceful intentions of this metaphor were dropped entirely when props of the longhouse, such as the fractious Shawnee and Delaware, would ignore their Iroquois leaders. Algonquian resistance to Iroquois control in the Ohio provided the Iroquois a scapegoat to deflect British political pressure during the 1740s and 1750s. It was easier to agree to the terms of treaties giving away the Ohio dish, than to sacrifice their lands in Iroquoia.

The Iroquois claimed many lands as part of the extended roots of peace, and these were held so that all members could "eat out of one dish, and one spoon, and so be one." 8 The language of universal access is misleadingly complex when examined in actual practice within

\footnotetext{
${ }^{7}$ Wallace $1994,71-72$.

${ }^{8}$ NYCD 4: 694.
} 
many indigenous land systems. The implementation of usufruct structures, often hidden from European knowledge, divided commons into smaller parcels attributed for the use by particular subsets of the group. While ethnohistorians have only recently begun to examine the specific manifestations of these practices among the eighteenth-century Iroquois, there are early indications of the geographic division of tribal hunting rights. French and English documents noted the dominant presence of the Seneca within the upper Ohio during the first half of the eighteenth century. Usufruct divisions provided a meaningful way to expand the knowledge of a landscape for more effective utilization. Families returned to hunting lands repeatedly, and possibly cyclically, incorporating the features of their territories into cultural memory. ${ }^{9}$

This metaphor may have tapped into the communal language of Wahtakai diplomacy, but was not a simple statement of a "common hunting ground." Rather, the landscape was intimately tied to maintaining society at all levels, physically, economically, emotionally, politically, and religiously. The agreements, like all alliances in intergroup politics had to be continually maintained and renewed periodically. The placement of the dish and a single spoon provides one last and very important metaphorical structure connecting the landscape to its people.

Condolence rituals connected the various parties for the duration of a meeting but always the dish and single spoon sat between them. The hunting grounds, even when shared were a product of boundaries or demarcations between two groups. Historian Theophilus Amenius noted that the lands along the Ohio River were called "middle ground" by eighteenth-century Indians. Amenius interpreted this as evidence that the land "was never settled by them [Indians]" and thus lacking any title. When reinterpreted through lens of a single dish and spoon, this "middle ground" was an active and fully integrated part of the economic and political lives of Shawnee, Delaware and Iroquois. Again the customs, rules, and protocols of diplomatic rituals dictated behaviors not

\footnotetext{
${ }^{9}$ Usufruct structures: Cronon 1983, 62-67.
} 
only in ceremonies but also within the hunting grounds. Whereas common hunting grounds would be vague spaces within open access to all resources at all times, the dish and a single spoon metaphor was a highly ordered and managed landscape with rules and socio-economic value that had to be protected. Similar to the misunderstandings of other elements of indigenous culture, eighteenth century Wahtakai land policies were way more sophisticated and controlled than previously thought. ${ }^{10}$

As the Shawnee and others moved into the watersheds feeding the Ohio River, they were coming into contact with ecologies both familiar and unfamiliar. They were essentially colonizing the ecosystems of the Ohio, since they had to explore the resources, infrastructure and topographies of their new homes. Admittely this process was not performed in an ethnogeographic vacuum in the way that Europeans colonized the Atlantic coastline. Both the Algonquians and Iroquoians had been travelling through and progressively familiarized with the resources and pathways of the Okahok amai, but the initial hunting parties branched out from the known trails and into harder to reach areas. The scouting involved in this type of colonization was documented in the nineteenth century in the western Great Lakes among the Northern Ojibwa. In that case study scarcity and topography played a role in determining what areas would be selected for hunting grounds. The territories the developed fluctuated over time and overlapped among the various settlements, though boundaries were observed especially during the harsh winters. Much like among the Ojibwa, mutually agree hunting patterns divided up the former Okahok amai among families so as to better utilize the resources. Families from Iroquois

\footnotetext{
${ }^{10}$ Laurier Turgeon, "The Tale of the Kettle: Odyssey of an Intercultural Object" Ethnohistory 44:1 (Winter, 1997): 1-29; Victor Plytwyn, "A Dish with one spoon: the shared hunting grounds agreement in the Great Lakes and St. Lawrence Valley Region" in Papers of the Twenty-eighth Algonquian Conference ed. David H. Pentland, (Winnipeg: University of Manitoba, 1997), 210-11; Parmenter 2010, 17, 261-2; John Arthur Gibson, "Concerning the League: The Iroquois League Tradition as Dictated in Onondaga" in Algonquian and Iroquoian Linguistics Memoir No. 9, ed. and trans. Hanni M. Woodbury, in collaboration with Reg Henry and Harry M. Webster (Winnipeg: University of Manitoba, 1992), 459-60; NYCD 4: 476, 655, 690-95, 742, 895, 9: 715-17; Warren 2014, 235 ftn 41; Simpson 2008, 29-42.
} 
kanstaks would disappear for most of the year on hunting expeditions leaving behind some women to plant and only returning for the harvest. These prolonged stays within the former Okahok amai, while mobile and temporary, were systematic and began integrating geospatial and environmental information into the conceptualization of the region including resource identification and feature naming. ${ }^{11}$

Accessing these Southern hunting lands, claimed by the Iroquois, was an involved process requiring families to move to hunting lands for most of the year. Hunting parties often included groups of ten to twenty family members each with specific tasks in the processing of the bodies of animals obtained. Hunters' camps, like the one Dr. Thomas Walker visited on the Holston River in 1749, were identifiable through the scattered debris of skin scrappers, tanning frames, and deep fire pits among "four Indian Houses built with loggs and covered with Bark, and there were abundance of Bones, some whole Pots and Pans, some broken, and many pieces of mats and Cloth." ${ }^{12}$ Women and children provided much needed labor in the camps as the men were out. The camps had to be mobile to follow the herd movements and to gather traps dispersed throughout the narrow valleys. Post-contact eighteenth-century camps were smaller and with the increased availability of metal, no longer included flint debitage used to identify earlier sites. While these hunting camps were far from permanent, they were the beginning of colonizing and exploring a new landscape during the $\mathbf{r}$ phase (Diagram 5.2). Hunting parties travelled southward from Iroquoia during the early eighteenth century often following the

\footnotetext{
${ }^{11}$ Bishop, Charles A. The Emergence of Hunting Territories among the Northern Ojibwa. Ethnology 9:1 (Jan., 1970): 1-15.

${ }^{12}$ Johnston 1898, 43-44.
} 
environmental observations of war parties traveling through the former Okahok amai towards the Catawba and Cherokee. ${ }^{13}$

\section{Reinterpreting the Hunting Ground as a Paradigm}

The hunting ground is one of the most persistent descriptions of Native American land use during the contact and colonial periods and it continues to be a major trope in the American historiography with little critical examination. First we have to identify the standard elements of a theoretical hunting ground. This was a large tract of "pristine" wilderness bound by major rivers or mountain ridges claimed by a specific tribe for the purpose of hunting. Historians, like Theophilus Armenius in 1820, were quick to note that the Ohio "was never settled by them [Indians]' and Dr. Hildreth corroborated their nomadic tendancies since 'Indians had no fixed residence." Clandestine and erractic male hunting parties arrived seasonally depending on where the best hunting was that year, though it remains unclear in the myth how this information was acquired. In this model, access to these hunting lands was closely controlled by a group of tribal leaders. Europeans based this perception on a legacy of Eurocentric geographic and political assumptions that more easily describe English land-ownership rather than an indigenous landscape. Europeans perceived land ownership as antithetical to "pristine" wilderness, or the lack of human intervention. Ownership required discrete territorial boundaries with the goal of individual occupation and improvements, like houses and fences. The language of the common hunting ground, as was defined through English land-ownership, over-generalized and obscured Native American conceptions of land and land-use. ${ }^{14}$

\footnotetext{
${ }^{13}$ Discussion of the composition of hunting parties in Hopkins 2010; Snow 1968; 1143-1151; Speck 1923, 452-471; Charles A. Bishop, "The Emergence of Hunting Territories among the Northern Ojibwa” Ethnology 9:1 (Jan., 1970): 1-15.

${ }^{14}$ Definition of "hunting ground" from Krech 1999; Dean R. Snow, "Wabanaki "Family Hunting Territories."” American Anthropologist, New Series, 70:6 (Dec., 1968): 1143-1151; Frank G. Speck, "Mistassini Hunting Territories in the Labrador Peninsula" American Anthropologist, New Series, 25:4 (Oct. - Dec., 1923 ): $452-471$.
} 
The traditional historiographical construction of the "hunting ground" framework is completely inadequate to describe the former Okahok amai at any period. The frequent petitions to protect and preserve hunting territories in treaties between the Indians and English became necessary as English populations grew dramatically during the seventeenth century, especially in Virginia. After the second Anglo-Powhatan War during the 1640s, a treaty was signed that recognized the right of Necotowance, the chief of the weakened Powhatan Confederacy, and the remnants of the Pamunkey "to Inhabit \& hunt on the Northside of Yorke River without any interruption" unless the Governor and Council decided to permit Englishmen to live in the region. The English dictated a precise eastern boundary with "paine \& penaltie" of death for those who dared cross into English lands. This codified an inherent double standard as English traders (and settlers) were free to cross over into other nations' Okahok amai. After the third Anglo-Powhatan war in 1677 , the Pamunkey agreed to the terms of the Treaty of Middle Plantation that indicated their defeat and subjugation. But in a dramatic tonal shift, the treaty made no mention of hunting or hunting grounds instead offering only a provision to ensure that if the Wahtakai "have not Land sufficient to Plant upon, be (upon Information) forthwith provided for." ${ }^{15}$ Not all treaties (Table 7.1) were nearly as harsh as the one at Middle Plantation. A year later, the Treaty of Casco ended King Philip's (Metacom's) war and provided for a concrete demarcation of lands specifically for hunting. The treaty also required English traders to pay rent to Indian nations for access to their lands. ${ }^{16}$

By the beginning of the eighteenth-century, the diplomatic language of hunting lands encompassed much more than just concerns for subsistence. Beyond concern for maintaining the buffer between Wahtakai and European settlements, the participants in treaty negotiations voiced

\footnotetext{
${ }^{15}$ Treaty of Middle Plantation 1677, Article 3.

${ }^{16}$ Mary Lou Lustig, The Imperial Executive in America: Sir Edmund Andros 1637-1714 (Cranury, NJ: Associated University Presses, 2002), 82.
} 
concerns about maintaining their position in the fur trade. The incorporation of the fur trade into the political language of hunting began overtake references to subsistence. The Treaty of Lancaster in 1722 provided an example of the complaints that Iroquois and allied Wahtakai had been shot or abducted while hunting in lands protected by previous treaties. The Governor of Pennsylvania, William Keith, eager to steer more fur trade to his colony, offered "five pieces of Strouds for clothing, five Casks of Powder \& 500 wgt of Lead, to encourage your hunting that you may grow rich \& strong." ${ }^{17}$ While representatives at the 1722 conference did not refer directly to hunting grounds, Ampamit, a Mohegan leader, spoke to the pressures for land and the methods the English used to defraud the Indians. First, "the Christians when they buy a small spot of Land of us ... take in a greater Bounds than was intended to be sold them." Ampamit continued that the defrauding was made worse because "the Indians not understanding what is writ in the Deed or Bill of Sale sign it and are so deprived of Part of their Lands."18

This complaint against the English contradicts the assumption that Indians had no concept of land ownership. While his own society was different, Ampamit was well aware that deeds were meant to outline explicit boundaries for territory, but since he was unable to read the English cursive on the paper, he had to rely on the explanations provided by the English. This extremely common complaint, though, was about much more than just hunting lands or even subsistence. Ampamit and many others recognized the uneven application of the very laws that their "friends" expected Indians to follow but could not be trusted to follow themselves. By the beginning of the eighteenth-century, the Ohio was starting to be recast by opportunistic Wahtakai and Europeans as a valuable commodity, a hunting ground, yet the full repercussions of such intellectual alterations would not become clear until the nineteenth-century.

\footnotetext{
${ }^{17}$ Keith Quote NYCD 5: 679.

${ }^{18}$ Treaty of Lancaster 1722: NYCD 5: 657-681.
} 
The first historiographic discussions of the "hunting grounds" west of the Virginia Mountains did not develop until the nineteenth-century with historians like Samuel Kercheval (1833), Wills De Hass (1851), and Alexander Withers (1895). ${ }^{19}$ The hunting ground myth and its more pejorative "common hunting ground" corollary were developed during the national conversation about the place of Indians in the application of the Indian Removal Act. There no forced or active removals from the former Okahok amai during the 1830s, yet contemporaneous historians of the Ohio often seemed motivated to rationalize the removal process. While Withers and de Hass briefly mentioned the presence of Massawomecks within the seventeenth-century Upper Ohio, the middle portion of the valley was described as a perpetually sparsely populated "hunting ground." While hunting grounds did exist, they have been misrepresented as unoccupied zones that had remained unchanged through time immemorial. Ohio valley historians and geographers, like Walter Meinig, have continued to recite this myth, "in the long section between the Iroquois and the Cherokee ... such lands had for many decades been disputed ground between these two Indian nations, and had lain unoccupied by any other." Meinig reiterated a dichotomous view of trans-Appalachian Indian politics, that the Cherokee and Iroquois were only two powerful nations in the region. This could not be farther from the reality during the early-eighteenth century. By focusing such distant Iroquoian-speaking polities, he ignored the active role of Shawnee, Delaware, and numerous other polities and their ethnogeographies. He continued by claiming that the Ohio was "such an expanse where Indians appeared only as occasional hunting or raiding parties..."20 When the English began to settle the trans-Appalachian borderlands during the second half of the eighteenth century, the most

\footnotetext{
${ }^{19}$ Samuel Kercheval, A History of the Valley of Virginia (Winchester: Samuel H. Davis, 1833); de Hass 1851; and Withers 1895. The legacy of this broad generalization is apparent in the reactions I get when I say that I study West Virginian Native American History. "Funny, I didn't think there were any Native Americans in West Virginia. It was just a common hunting ground."

${ }^{20}$ Meinig 1986, 286.
} 
powerful indigenous partners and threats were the Iroquois and the Cherokee. European diplomats tended to view the indigenous world through the lens of these two cultural groups. Hence European observers assumed that since the Iroquois and Cherokee had been present at contact, they had always been present and in charge. This view relies on another myth of Native American history: that Native Americans did not change themselves or their world until Europeans wrecked their "pure and natural harmony." Twenty-first century ethnohistorians have discredited this myth but it remains an underlying rationale within the colonial period Ohio historiography.

Wahtakai involvement in the former Okahok amai during the early eighteenth century shows just how wrong this perception is. According to the historiography, not only was the region a common hunting ground during the eighteenth century but it had been one in perpetuity. While the English assumed the Iroquois and Cherokee had always been in the Ohio, diplomats from the two did not dispossess the English of this politically advantageous assumption. Based on this historical reality, the hunting ground framework also assumes that the people that hunted in the Ohio when Europeans arrived had been doing so for thousands of years, despite the fact that many had only settled near the region around 1730. Much like their temporal vagueness, "common hunting grounds" were described with fuzzy geographic boundaries that were wholly uncharacteristic of the specific boundaries within Indian-English treaty negotiations. $^{21}$

Historical documents are notoriously fuzzy in their geographic references, leading to much debate, but the issue here is more one of misquoting. Samuel Kercheval only referenced the Shenandoah Valley, not the Ohio Valley, as a common hunting ground. Kercheval continued to claim that the Ohio was "not claimed by any particular nation who had authority to sell." This

\footnotetext{
21 This reminiscent of the critique posed by Eric R. Wolf, Europe and the People Without History (Berkeley: University of California Press, 1982).
} 
is understandable since most of Kercheval's stories were gathered through interviews with the children and grand-children of the earliest European settlers in the Shenandoah Valley and beneficiaries of such legal ambiguity. ${ }^{22}$ Alexander Withers described the Upper Ohio River Valley using the same broad terms. James Hall in 1834 provided an even more revealing description of eastern Kentucky, "It is not known that any tribe was ever settled permanently in Kentucky; no ownership was exercised in that region, and no exclusive title asserted to it, by any nation of Indians, when it was first visited by the whites." This, of course, goes even further to rationalize the dispossession of the eighteenth and early-nineteenth centuries. Hall did not see the contradiction of his following claims that the Ohio "was a common hunting ground for many tribes, who visited it from a great distance, roaming over its rich pastures during the season for taking game, and making temporary residence during part of every year, for that purpose.” 23 Due to the work of Kercheval, de Hass, Withers, and Hall, it would seem that an extensive common hunting territory stretched from southwestern Pennsylvania, western Virginia, eastern Kentucky, and eastern Tennessee, encompassing millions of acres. The description has little temporal reference other than "when first visited by whites." Many of the details of Hall's quote directly refute his conclusions. First, he focuses on "title," a purely European legal construct that is difficult to correlate with indigenous land concepts. Hall based the lack of title on his definition of Wahtakai seasonal hunting patterns as "temporary residence," as interpreted through his own cultural understanding of land ownership. Ironically, he noted the presence of "rich pastures," which were in reality evidence of abandoned cornfields likely surrounding the remnants of a mampi. Hall mistook the $\boldsymbol{\alpha}$ phase of ecosystem reorganization for "pristine

\footnotetext{
${ }^{22}$ Kercheval 1833, 60-63.

${ }^{23}$ James Hall, Sketches of History, Life, Manners in the West (Philadelphia: Harrison Hall, 1834): 80-81.
} 
wilderness. ${ }^{24}$ English perspectives, especially the ones examined by Hall, were a product of the ethnogeographic and legal legacies carried over from England.

In seventeenth- and eighteenth-century England, the few places left to hunt were mostly owned by the Crown for the sole privilege of the nobility. The game preserves were highly controlled discrete geographic areas monitored by prestigious legally mandated gamekeepers. During the 1500 s and 1600 s, the laws identifying and prohibiting poaching were strengthened to draconian levels. English immigrants to North America, especially the upper classes, viewed Wahtakai land use through the lens of English game law. The English naturally translated the Native American concepts of land use through their own cultural expectations and biases when they recorded references to hunting grounds. From the English perspective, if no one developed the land for agriculture and private use then any claims were nullified according to domicilium vacuum, thus "reverting" to Crown control. While this legal language and its socio-cultural geospatial blinders influenced the views of the English and how they described North American land use, this alone does not explain the pervasive use of "common hunting ground" in the nineteenth-century historiography. ${ }^{25}$

Oldest of all the terms, hunting ground is the most generic and refers to the real-world needs of mampi as well as non-Indian families on the western edge of English settlement. But understandably the term held very different meanings for Wahtakai and Europeans. Wahtakai mampi and large extended families required not just the meat from hunting, but the bone, sinew, entrails, and a variety of other parts for maintaining clothing and gear on a daily basis. Hunting

\footnotetext{
${ }^{24}$ Ibid $80-81$.

${ }^{25}$ For discussions of English "Game" laws see Chester Kirby "The English Game Law System” The American Historical Review 38:2 (Jan 1933): 240-262; Chester Kirby and Ethyn Kirby, "The Stuart Game Prerogative" The English Historical Review 46:182 (Apr. 1931): 239-254. It may important to note that many non-aristocrat settlers in North America responded to English game laws and history in their conceptualization land ownership. They sought to break with English legal convention by squatting and claim land rights by occupation and "improvement." The increasing distance between English land laws and settler squatting not only frustrated the Wahtakai but was increasing tensions with English nobles amd their military forces.
} 
grounds must be well-stocked enough to feed the population during summer but also big enough to provide ample room for family hunting parties to disperse. Traditional seasonal mampi dynamics served the eighteenth-century residents well as it increased their ability to participate in the deerskin trade. Developing hunting territories specific to families and clans was an important part of the colonization process that had been progressing during the early and middle eighteenth century. $^{26}$

All people in the seventeenth- and eighteenth-century North America recognized the need to supplement their diets with meat and even for Europeans much of this came from hunting in the lands surrounding their settlements. There were mentions of hunting grounds dating back to the earliest occupation of Virginia and Massachusetts. As histories of the colonies were written, the language of "hunting grounds" began to crystalize. The phrase "hunting ground" was often focused on Indians because of their lack of domesticated animals like cows and pigs (Diagram 6.2a-b). ${ }^{27}$ In 1767, Thomas Hutchinson distinguished this difference by referring to a fortified settlement of the Wampanoag in the "middle of the Indian's hunting ground." That same year, $A$ new collection of voyages, discoveries and travels further explained the difference that "Indian

\footnotetext{
${ }^{26}$ Hunting ground anthropology: Adrian Tanner, "The New Hunting Territory Debate: An Introduction to Some Unresolved Issues" Anthropologica, New Series, 28: 1/2, À qui appartient le castor? Les régimes fonciers algonquins du nord remis en cause / Who Owns the Beaver? Northern Algonquian Land Tenure Reconsidered (1986), 19-36; Gregory A. Waselkov, "Evolution Of Deer Hunting In The Eastern Woodlands" Midcontinental Journal of Archaeology, 3:1 (Spring 1978), 15-34; Snow 1968, 1143-1151; Speck, 1923, 452-471; Michael F. Johnson, "The evolution of the bifurcate hunting system in the interior Piedmont of Fairfax County, Virginia" in Piedmont archaeology: recent research and results: proceedings from a Conference on Piedmont Archaeology, May 20-21, 1983 eds. J. Mark Wittkofski, Lyle E. Browning, et al. (Richmond: Archeological Society of Virginia, 1983), 55-73; Nash 2005: 89-102.

${ }^{27} \mathrm{http} / / /$ ngrams.googlelabs.com/. A new tool in the research of historiographies has been developed by Google labs called the Ngram Viewer. This tool searches the vast digital library acquired by Google Books for specific words and phrases. I queried the Ngram for references to "hunting grounds," "common hunting grounds" and "Indian hunting grounds" from 1600 till the present. The results forced me to reevaluate some of my initial thoughts about the beginnings of this phrase. English "game" laws from the fifteenth and sixteenth century seemed like a logical place to start. The Ngram viewer also shows the specific references in the documents that it used to produce the graphs. The use of the term appears as a rationalization for the fevered discussion of Indian removal during the $1820 \mathrm{~s}$ and $1830 \mathrm{~s}$. This only further strengthens my belief that this is a myth with the underlying motivation of rationalizing indigenous people out of the history of the Ohio and by extension the eastern US.
} 
lands are of two kinds-Their dwelling-land, where their castles are; and their hunting-ground." This distinction had become a source of great concern for British settlers throughout North America after the Proclamation of 1763 that attempted to create a discrete protected region of "Indian lands." Even though the Crown's proclamation did very little to stem the flood of new European settlers acorss the Appalchian Mountains, it did create a legal framework of racially specific land ownership. The counter-intuitive result eventually led to the creation of "Indian hunting grounds" as a distinct area around Indian settlements in 1790 with the Indian Intercourse Act. The United States found that these exterior areas could be redistributed at the will of the government to open up further American settlement. ${ }^{28}$

By 1788, the use of the phrase "Indian hunting grounds" indicated two very important changes in the perception of Indian land claims. This label further codified a distinct racial category for indigenous land use that proved detrimental since it was easy to override and later redistribute the land to non-Indians. The second more problematic issue was the use of the generic racial term Indian. The identification of a pan-Indian race had begun to develop by the eighteenth-century as shown by Pennsylvania Governor William Keith's concern over the Iroquois' attacks on Southern Wahtakai during the 1721 treaty negotiation at Conestoga: "We therefore cannot but wonder, how you, that are a wise People, should take Delight in putting a bind to your Race." ${ }^{29}$ Wahtakai visiting Conestoga in 1721 did not perceive a universal imperative to protect members of other tribes due to racial similarity. ${ }^{30}$

\footnotetext{
${ }^{28}$ Thomas Hutchinson. A History of the Province of Massachusetts Bay ... Unitil the Year 1750. Boston, Thomas and John Fleet, 1767, 73; A new collection of voyages, discoveries and travels... Vol. II London: J. Knox, 1767, 280; Annual Register or a View of the History, Politicks, and Literature, for the Year 1763. London: 1764, 20. Proclamation of 1763 .

${ }^{29}$ Pennsylvania. The Particulars of an Indian Treaty at Conestogoe. Philadephia, 1721, HEH Copy. Conestogoe: July $9^{\text {th }}, 1721$ : Gov. William Keith.

${ }^{30} 1788$ North Carolina House of Commons for Indian Hunting grounds. For European determinations of Indian race: Nancy Shoemaker, "How Indians Got to be Red" AHR (June 1997): 625-644.
} 
It was not until the 1820 s that "common hunting ground" began to enter the historiographical discussion (Diagram 6.2c). The issue of commonality or communal ownership was directly at odds with European concepts of individual ownership. Historians began framing the Ohio River Valley increasingly as a "common hunting ground from1830 till 1880. Dr. Hildreth in 1820 noted that the eighteenth-century Ohio "was used as the common hunting ground of several different tribes, more particularly the Shawnees, the Delawares, and the Wyandotts." As noted already, this was only part of the story. Theophilus Armenius, with a more critical tone, explained that the eastern portion of Kentucky "was held by none of the tribes exclusively, was never settled by them, but held as a common hunting ground." He goes on to argue that since "this region was formerly claimed by various tribes of Indians, whose title, if they had any, originated in suc a manner as to render it doubtful which ought to possess it." $\mathrm{He}$ concluded, correctly, that eastern Kentucky "became an object of contention, a theatre of war." The power of this rationalization for English occupation found its way into the public consciousness in North America and even abroad in France and England as can be seen in Mrs. Trollope's Domestic Manners of the Americans from 1832. She repeated almost verbatim Armenius' account of the American settlement of Kentucky. The legal definition of "common hunting grounds" even reached the United States Supreme Court in 1829 with Paterson vs. Jenks et. al. This case relied on the Constitution and the 1790 Indian Intercourse Act. Afterwards, there were a few references to the "common hunting grounds" within late nineteenth-century US treaties with Western Indians like the Pawnee. These references account for less than 5\% of all the references to "common hunting ground," the rest were focused on the Ohio valley. ${ }^{31}$

\footnotetext{
${ }^{31}$ Dr. Hildreth, "Notes on Ohio," American Journal of Science and Arts Vol. X (Feb. 1820): 152-162, 160; Theophilus Armenius, "The First Discovery of Kentucky, Feb. 10, 1820," Methodist Magazine Vol. 3 (1820): 384 389; Mrs. Trollope, Domestic Manners of the Americans $4^{\text {th }}$ ed. London: Whittakerm Trecaher and Co., 1832: 48; Paterson-Jenks, Supreme Court 1829.
} 
The historiography of the Seven Years War and southwestern Pennsylvania highlights yet another problem with the "common hunting ground" myth. Delaware and Shawnee groups, some recently arriving north from the Carolinas, began moving westward to escape growing land pressures. For the Delaware, the gradual move through the mountains did not arise from any ancient legacies of ancestral homelands, but the story for the Shawnee was quite different. Michael McConnell wrote of their journey, "Shawnee people [were] reunited in their old Ohio Valley homeland for the first time in a century. This westward trek was made still easier ... by strong ties to the Ohio Valley and knowledge of its land and resources." ${ }^{32}$ Their connection to the western Ohio valley is well documented but has recently been examined much closer. Penelope Drooker noted a few significant details of the Shawnee while in the Southeast. First, the five bands of the Shawnee were distinctly identifiable during the seventeenth century and travelled as separate entities, despite identification as Shawnee. Second, three of the bands moved south into the Carolinas from the Kentucky-Ohio section of the Ohio River. The other two bands of the Shawnee in the central interior of Ohio along the Scioto River were invited by representatives of New York to move east to the Susquehanna River around 1694. ${ }^{33}$

The nineteenth-century switch to describing Indian hunting grounds as "common" certainly approximated the indigenous communal ideology but twisted it into a rationale for stripping these "unused" lands from Indians and redistributing them to whites that would use them more effectively. Hunting grounds were not visibly improved or bounded according to English guidelines thus voiding Indian claims at the most basic level. When the term became common in the 1830s, it coincided with the rationales for Indian removal from the East.

\section{New Wahtakai in the former Okahok amai, 1700-1730}

\footnotetext{
${ }^{32}$ McConnell 1992, 15.

${ }^{33}$ Drooker, 2002, 123-127; Spero 2010; Warren 2014; Lakomäki 2014.
} 
The mid-eighteenth-century former Okahok amai seemed like an isolated backwater after the demographic collapse of the late seventeenth century compared to the bustling Upper Ohio Valley, but Wahtakai regularly traveled through the region. From Iroquoia, it took five days by canoe or an eight day journey by land. ${ }^{34}$ War-hunting parties, traders, refugees, explorers, and many other people found their way through the former Okahok amai. The onqyayun was relatively unoccupied from 1700 till 1730, yet the Iroquois traveled frequently through the former Okahok amai as they were perpetually engaged in war with Southern Wahtakai, especially the Catawba. Southern Wahtakai, of course, responded in kind with raids to the North. Many war parties followed the Great War Path that followed the Blue Ridge Mountains and the fringe of English settlement, but a new Great War Path was simultaneously being worn in directly through West Virginia away from English and French scrutiny. This would become the Great War Path of the second half of the eighteenth century. ${ }^{35}$

Even as small families of Monyton quietly continued hunting and gathering through their lands, the Ohio continued to bustle with the activities of Algonquian and Iroquoian speaking peoples. While there were a few settlements within the former Okahok amai during the first thirty years of the eighteenth century, the polities that had maintained control during the seventeenth century no-longer existed in the former Okahok amai. The Shawnee town of Sonontio (Lower Shawnee Town) may have continued with small occupations. While Jerry Clark suggested that the Lower Shawnee town (Sonontio) was occupied as early as 1707, the account of Peter Chartier from 1745 has a great deal more credibility. ${ }^{36}$ Chartier reported that he had stayed with the fully functional and large population at the Kentucky town across from the

\footnotetext{
${ }^{34}$ This would equate to 240 miles by river ( 6 days), and 190 miles by land ( 7.6 days).

${ }^{35}$ Great War Path: Hanna 1911, 121; Warren 2014, 168.

${ }^{36}$ Though Clark refers to the town as Eskippikithiki which does not match Shawnee nouns since it starts with a vowel, Lakomäki 2014 refers to the town as Sonontio.
} 
mouth of the Scioto River. In order to have the hundreds of residents and palisades, houses, and fields by Chartier's arrival the community probably was reoccupied in the 1730 s. This border region to the Okahok amai experienced a much shorter hiatus than the mountains to the East. By the 1730s Miamis, Ottawas, and other Algonquians joined the Shawnee at the extremely diverse diplomatic mecca of Sonontio. The Shawnee presence to the West provided a home base for increased hunting expeditions in the contested territory that was the former Okahok amai. The linguistic legacy of this can be seen in Christopher Gist's 1751-1752 journals when he identified the rivers and streams using Shawnee names. The river that had been called the Monyton during the seventeenth century, then briefly Wood's River, switched for the last time to be called the Conhaway (Kanawha). The role of the Shawnee within the former Okahok amai remained sporadic and limited until after the migrations West during the $1730 \mathrm{~s}$ and $1740 \mathrm{~s}^{37}$

Hunting and fur-trapping were more economic concerns not a purely territorial issue since for many access not ownership ensured continued success. During the Great Treaty of 1722, the Iroquois mentioned "that some of our people that have been out a hunting to ye Eastward," but the presence of Englishmen in this same area was only a problem because they had captured the Iroquois hunters and held them hostage. ${ }^{38}$ During the Lancaster Treaty of 1744, the Iroquois representatives reported that one of their satellite Wahtakai groups, the Conoys, had moved west to find better deer hunting, which had been over hunted by Europeans in the East [last part awkward]. Here again hunting is a process rather than a discrete territory. The Iroquois

\footnotetext{
${ }^{37}$ For a closer examination of the Shawnee ethnogeography in Gist's account see Chapter 7.

${ }^{38}$ Conference between Governor Burnet and the Indians. [New-York Papers, Cc., 97-101.] The Great Treaty of 1722 Between the Five Nations, the Mahicans, and the Colonies of New York, Virginia, and Pennsylvania, NYCD 5: $657-681$.
} 
did warn Pennsylvania, Virginia, and Maryland representatives, "the Lands to[o] belong[ed] to us long before you knew any thing of them." 39

Another group to begin laying claim to the former Okahok amai was the Iroquois but the foundation of the claim was fundamentally different than the Shawnee. The limited Iroquois presence within the Ohio region began during the seventeenth century as they escalated the attacks on the Outnnaghana. As discussed earlier, these attacks stemmed from the complex needs of the Iroquois including captives for adoption, lands for deerskins and beavers, as well ancestral animosities. Though the wars against Southerners, like the Monyton, Tomahittans, Cherokee, and Catawba, had been ongoing for centuries, national boundaries were observed by Wahtakai warriors. Access to warpaths through a territory, though, did not indicate its subjugation or ownership by the warriors' home nations. Iroquois traditions, combined with pressure from both the English and the French, began to change the nature of warpaths during the seventeenth century. By the beginning of the eighteenth century the Iroquois claimed lands far removed from their council fires, including the former Okahok amai. This shift also begins to make more sense viewed within the context of the religious and political-diplomatic language of kaswentha, the white roots of peace, and the dish and single spoon. Despite historian Francis Jennings accurate critique of the extent of authority of the Iroquois in their "empire," the imagined hegemony they claimed in the early eighteenth century did have real world effects. The Iroquois ethnogeography of the former Okahok amai was expressed as rehearsed political metaphors. Iroquois perceptions influenced the actions of many people. Some groups, like the

\footnotetext{
39 “'A Treaty Held at the Town of Lancaster, By the Honourable the Lieutenant Governor of the Province, and the Honourable the Commissioners for the Province of Virginia and Maryland, with the Indians of the Six Nations in June, 1744" in Indian Treaties Printed by Benjamin Franklin, 1736-1762, eds. C.Van Doren, and Boyd, J. P. (Philadelphia, PA: The Historical Society of Pennsylvania, 1938, 41-79.
} 
Shawnee and Lenape actively worked to subvert or ignore Iroquois claims, while the English and French attempted to coopt them for their own imperial ventures. ${ }^{40}$

Iroquois warrior-trader-diplomats had been traveling the paths through the Okahok amai for centuries in their campaigns into the South. This certainly provided them with at least a moderate level of geographic knowledge that was incorporated into their understanding of the land and its Iroquois cultural meanings. How systematic this knowledge was during the seventeenth century is difficult to examine, but they proclaimed a deep geospatial knowledge during the entire eighteenth century beginning in 1701 . These proclamations could certainly be exaggerated considering the distance from Iroquoia. Haudenosaunee diplomats also had a vested interest in maintaining the appearance of control over their land claims and the satellite nations dispersed throughout them. The collapse and failures of the 1690 s after half a century of epidemic disease and endemic warfare was solidified in Iroquois consciousness (Table 6.1).

King Williams War, especially the treaty negotiations during 1698, precipitated a new era in Iroquois-European relations. The demographic pressures facing the Iroquois could not be solved simply through mourning war, trade alliances, or any other traditional social mechanism. Allying with the English against the French had cost them thousands of men while their allies had been barely affected. The Iroquois had been powerful because of their geographic and diplomatic ability to play the French and English off each other, but by the turn of the eighteenth century, the game had turned on them. The Treaty of Ryswick in 1698 glossed over the issues of how the English and French would divide the Indian trade leading to a series of negotiations between the two nations in London the next year. In Europe colonial administrators could easily

\footnotetext{
${ }^{40}$ Iroquois claims of conquest in Ohio: McConnell in Richter Merrell 1987: 93; Dale Miquelon, "Ambiguous Concession: What Diplomatic Archives Reveal about Article 15 of the Treaty of Utrecht and France's North American Policy" WMQ 3rd series 67:3 (July 2010): 459-486, 466; Jennings 1984, 200; C. C. Baldwin, The Iroquois in Ohio, Tract No. 40 (Western Reserve and Ohio Historical Society, 1858), 8.
} 
ignore Wahtakai, and since the power of the weakened Iroquois was in doubt, the French and English agreed to an "interim arrangement" of Iroquois neutrality and equal access to trade with both nations. This alleviated some of the pressure on the Iroquois. They signed the Great Peace of 1701 with the French, meanwhile strengthening the Covenant Chain with England. Neutrality did not last long as Queen Anne's war broke out in 1702. ${ }^{41}$

Throughout most of the war, campaigns remained limited and internecine, in other words, business as usual in the Great Lakes region. To the South, the former Okahok amai remained quiet except for the increasing number of hunting parties. Territorial claims to the former Okahok amai were solidified through both warfare and land use (hunting) according to the Iroquois during the early eighteenth century. In a deed written in 1701, the Iroquois claimed this territory by right of military conquest as they had "four score years agoe totally conquer and subdue and drove them [Wendat and others] out of the country." hundreds of thousands of square miles of territory "conteigning in lengthy about eight hundred miles and in bredth four hundred miles," including the former Okahok amai in the southeastern corner. This fit the main motives and structure of the League in regards to the expansion of the white roots of peace.

The Iroquois continued to claim the rights of conquest in the Ohio Valley and use throughout most of the eighteenth century until the Treaty of Fort Stanwix in 1784. The doubleedged politics of neutrality and diplomatic recognition inherent in the period after King William's War were codified by the Great Peace of 1701. While the Iroquois maintained their tenuous position between the French and the English; simultaneously, and surreptitiously, the

\footnotetext{
${ }^{41}$ Miquleon 2010; Douglas Edward Leach, The Northern Colonial Frontier: 1607-1763 (New York: Holt, Rinehart and Winston, 1966), 117-118; J. A. Brandão and William A. Starna, "The Treaties of 1701: A Triumph of Iroquois Diplomacy" Ethnohistory 43:2 (Spring, 1996), 209-244.

${ }^{42}$ NYCD 4: 908.
} 
Iroquois attempted to ensure their political hegemony and physical land claims within the Ohio River valley and westward. Partially this was to protect themselves from the English as they were pushing interminably west into Iroquois lands. The former Okahok amai already existed as part of the territory under the shade of the Tree's Law, and since the region was unencumbered by permanent large scale occupations it was quickly incorporated into the metaphor of the "dish and single spoon."43

The Iroquois certainly played a primary role in perpetuating the myth of the common hunting grounds during the mid-eighteenth century. The Iroquois were struggling to maintain an appearance of strength among its European allies not to mention its satellite Wahtakai. The Haudenosaunee, when negotiating with the English, often acquiesced to English demands for more land cessions by selling lands that they claimed through their hegemony over groups like the Shawnee and Delaware to protect more sacred Iroquoian lands. Underlying these calculating land cessions was the powerful metaphor of the dish and single spoon. Since lands were held in trust for the entire Confederacy, the elders were culturally authorized to sell off lands considered less important for the survival of the Confederacy.

\section{English and French ethnogeography}

Far from the council fires of the Iroquois, Shawnee, and Delaware, and certainly distant from the former Okahok amai, were English and French colonial administrators plotting with increasing vigor ways to control the interior of North America. Whether for trade, territory claims, or even settlement, the trans-Appalachian landscape became an important topic in international diplomacy. The diplomatic conversations and treaty articles were nascent examples of English and French ethnogeographies being placed on the former Okahok amai. Debate over

\footnotetext{
${ }^{43}$ White 1991, 143-149; Parmenter 2010, 271-3; Ian Steele, Warpaths: Invasions of North America (New York: Oxford University Press, 1994), 140-146.
} 
the European ownership of the Ohio region came in two varieties. These foreign nations disputed each other's claims of discovery and with equal vigor quibbled over the claims of each Wahtakai nation as subjects of their own crown. Subjugation of the Iroquois, as one of the most powerful and well-positioned nations, was of particular concern for both the English and the French. Both foreign powers hoped to ensure access to trade with not only the Five Nations but also their satellite nations as well. The Virginians had attempted and failed to control the Occaneechi for similar reasons half a century earlier.

Despite the focus on maintaining Indian alliances and subjects, European land claims continued to be framed within their own concepts of property and landscape that were understandably quite different from the Iroquois and other Wahtakai. There were even major differences between French and English land claim philosophies and priorities that significantly impacted their perceptions of the Ohio and former Okahok amai. Patricia Seed outlined their differences in Ceremonies of Possession. English ownership required specific improvements, such as hedge-fences, gardens, and clearing. Early visitors to the Appalachian Mountains did not notice any evidence of attempts to subdue the "wilderness;" therefore Wahtakai residents lacked a rightful claim to the land. The purely English concept of domocilium vacuum was easy to apply to the former Okahok amai since old fields were no longer occupied and well-trod paths could be explained away as buffalo traces. In addition to the standard settler "improvements," the English adapted Spanish discovery rights to legitimize their claims to lands extending west beyond the Appalachian Mountains. While their populations were growing rapidly, much to the concern of interior Wahtakai, the English were forced to recognize the necessity of Indian diplomacy and appeasement, even when their land claims failed to meet English standards. ${ }^{44}$

\footnotetext{
${ }^{44}$ Seed 1995; Patricia Seed, "Taking Possession and Reading Texts: Establishing the Authority of Overseas Empires” The William and Mary Quarterly, $3^{\text {rd }}$ ser., 49: 2 (Apr., 1992): 183-209.
} 
The French, on the other hand, used ceremony and present distribution to acquire lands from Wahtakai. Patricia Seed remarked on the elaborate and sophisticated ritual performed in an effort to not only inform of the colonial intent and establish the social hierarchy, but also to gain consent. Without the inherent violence of the Spanish requirimiento, the French similarly sought to coopt the indigenous social hierarchy and utilize it to maintain their access to the lands and tribal alliances. The French were especially adept at solidifying their indigenous alliances through diplomatic gift exchanges and marriages. By the turn of the eighteenth century, FrenchIndian relationships were becoming strained due to European economic hardships that made blankets, shot/powder, and even beads harder to obtain. During the 1700 s to 1730 s, the French were much more concerned about stemming the tide of English settlers west and maintaining access to the trade with resident tribes, like the Miami, than directly accessing the Ohio valley. ${ }^{45}$ The guidelines for right by discovery had become well established even though the outcomes were constantly disputed between France, and England. By the eighteenth century each had explored the Appalachian Mountains and maintained claims of discovery. While the 1671 Batts and Fallam expedition had been a watershed moment for the Monyton, it also provided the English one of the primary rationales for claiming the Ohio River valley. Abraham Woods had ordered the two men to measure the rise and fall of the river in hopes of finding tides indicating the elusive western sea, which they identified on the New River, over two thousand miles away from the Pacific Ocean. ${ }^{46}$ Woods determination did provide England with one of the stronger claims to all lands downstream from the headwaters of "Wood's River." Needham and Arthur did the same by exploring the deep interior of the Carolina Mountains and pushed English claims far across the Appalachians. The French had their own potential claims to discovery with the

\footnotetext{
${ }^{45}$ Late $17^{\text {th }}$ French intentions: Seed $1995,41-68$.

${ }^{46}$ Even though Wahsecanough had warned John Smith of the folly of this search in 1607.
} 
various explorations of the Lower and Upper Ohio also in the 1670s. In particular, the claims rested in Marquette and Joliet's 1673 travels to the headwaters of the Allegheny. While they purported La Salle's dubious travels down the Ohio as far as the falls at Louisville, Kentucky. Both nations felt secure in their cases but further rationalized their claims through the alliance, conquest and subjugation of Wahtakai.

Primary among the valuable Wahtakai nations, the Iroquois were situated between the English and French, which frequently proved both beneficial and dangerous. The nations of the confederacy often benefited by playing each imperial power off the other, but far from the fires of indigenous politics, colonial administrators used the Iroquois and other tribes as pawns in the international treaty negotiations. After King William's War, both the French and English attended the 1697 treaty negotiations in the Dutch city of Ryswick carrying explicit notes about territorial claims but little concern for the indigenous inhabitants. The Treaty of Ryswick did not settle the status of the Indian allies that had done most of the fighting and lost so many of their brethren and property in the process. Even as the representatives were arguing the minutiae of the truce, the Iroquois continued to fight the French detrimentally sapping their strength till they were forced to accept the Great Neutrality of 1701. The neutrality was far from peaceful, and by 1702 many Iroquois were fighting against the French again. This led to further bloodshed in Queen Anne's War which lasted till 1713 when European ambassadors gathered in Utrecht, Netherlands to sign a peace treaty. The Ohio and the former Okahok amai, were quietly left out of these conflicts, but the tensions they created among Wahtakai led many to the relative seclusion the Ohio River provided. This would not last long.

In 1701 the Iroquois signed a deed that notified King William of England of the wide territory they "had peaceable and quite possession of the same to hunt beavers ... wee had been 
sixty years sole masters and owners of the said land." This "deed" was drawn up by New York's Indian Affairs secretary Robert Livingston, at the behest of a Mohawk leader, to legitimize Iroquois land claims but also to establish the Crown's duty to "protect and defend" the people and use of the vast tract. From the Iroquois perspective this was an attempt to protect themselves from French and French allied Wahtakai, while also ensuring their own position, as the English certainly used this as the basis of their claims of the Iroquois as English subjects. After King William died the next year, the administrations of Anne and her successor George I both continued to identify the Iroquois, along with their many satellite tribes, as subjects and therefore all their lands as belonging to the English Crown. ${ }^{47}$

The French signatures on the Treaty of Utrecht begrudgingly recognized the legitimacy of English claims to the Iroquois as subjects, but this quite clearly remained contentious until the conclusion of the Seven Years War half a century later. Beyond some minor territorial adjustments, the most significant provision came in Article 15: "Let the subjects of France ... afflict with no impediment or molestation in future the five Nations or Cantons of Indians subject to the power of Great Britain as well as the remaining natives of America joined to them in friendship. ${ }^{, 48}$ Following this recognition, though, there were two provisions that effectively undercut Great Britain's authority concerning the Iroquois. Understandably, if naively, the article requests that English settlers and allied Indians likewise "will behave peacefully" in return. Despite economic and military threats, neither Great Britain nor France could effectively hinder the Iroquois and other Wahtakai groups from engaging in warfare abroad. In fact, they often goaded them to fight other tribes frequently. The last stipulation required a commission that would "determine exactly and clearly those who will be or ought to be considered subjects and

\footnotetext{
${ }^{47}$ NYCD 4: 908-911; Parmenter 2010, 268-269; Miquelon 2010, 467.

${ }^{48}$ Miquelon 2010, 486.
} 
friends" of each nation proved a major frustration for both France and Great Britain. ${ }^{49}$ While French had recognized that the Iroquois were under the power of Great Britain, the treaty did not specifically legitimize or delineate the territory of the League and thus left unresolved the northern boundary between the two powers. The treaty negotiations ended French claims to the western half of the Carolinas. As Miquelon notes, they later regretted the restrictions this placed on their access to the Mississippi River and Indian trade, but "in 1712 it constituted no major reversal of a French bid to dominate the trans-Appalachian interior, for none had existed."50 Among the scattered coeur du bois and French leaders in Montreal, the Treaty of Utrecht embodied the paradox of their relationship with the Iroquois and their claims to the Ohio. In 1697, Louis XIV recognized the necessity of sharing access to the fur trade with the Iroquois obut concluded that this scenario was "the inevitable occasion for new wars."51

The rationales for claiming Indians as subjects, along with the perceived heroism of European explorers certainly trickled down into the perceptions of colonists concerning the western lands. While many feared Indian attacks so far from the protection of colonial cities, this was attributed more to the waywardness of the Indians rather than any infringement of natural right to the lands. Most colonial settlers were not as informed or concerned as Thomas Chalkley's 1751 chastisement of fellow Quaker settlers: “Virginians have made an Agreement with the Natives, to go as far as the Mountains, therefore [you are] out of that Agreement; by which you lie open to the Insults and Incursions of the Southern Indians." ${ }^{, 52}$ Even the fear of Indian attacks did not stop many German and Irish families as they had become accustomed to

\footnotetext{
49 Treaty of Utrecht: Miquelon 2010, 466, 486.

${ }^{50}$ Miquelon 2010, 479-480.

${ }^{51}$ Treaty of Utrecht and Queen Anne's war: Miquelon 2010; Aquila 1997, 85, 91, 158; Leach 1966, 118-124; Steele 1994, 151-159.

52 Thomas Chalkley, A Journal or Historical Account of the Life, Travels, and Christian Experiences, of that Antient, Faithful Servant of Jesus Christ, Thomas Chalkley, 3rd ed. (London: Luke Hinde, 1751), 310.
} 
frequent ethnic wars back in Europe. As the Cumberland and many smaller mountain gaps were more frequently crossed and more information gathered about the western mountains, successional human outposts began to intrude back into the former Okahok amai.

\section{Signs of Wehahempēi (Spring)}

Winter, much like the unpredictability of the Little Ice Age, changed to spring at different times in different locations. Understandably, occupation began along the Ohio much sooner than up in the steeper river valleys. As hunting parties found their way through the Okahok amai they established patterns of hunting and gathering that was integrated into their cultural landscape. The single dish and spoon manifested within the cultural imaginations of the Shawnee, Iroquois, English, and French, predicated on the history of Siouan removal, environmental regeneration, and perceived ethnic efforts, began to become a reality by 1730 and would flourish in all its complexities by the beginning of the 1750s. The patches of snow covering barely recognizable mampi plazas had small patches of early spring trillium and grass popping through. Buffalo and elk, lured by the rampant grasses around salt licks, joined robust deer in the former mataque fields and mampi. The allure of the onqyayun wildlife drew Shawnee hunters and their families with increased frequency as spring opened the mountain passes for travel. Within a few short years the quiet of the hiatus would yield the clatter of quivers, clinking of guns, and the rattle of surveyors chains. By the 1730s, the cultural imaginations of many peoples that had focused on the former Monyton Onqyayun began to manifest into a physical reality that was constrained by environmental possibilities of the former Okahok amai. The spring of reoccupation began in earnest in 1740 as Shawnee and Delaware mampi moved west and then south along the edges of their ancestral home in the Ohio. 


$$
\begin{gathered}
\text { IV: } \\
\text { Wehahempei (Spring) } \\
1730-1755
\end{gathered}
$$




\section{Chapter 7}

\section{Foreigners in an Untidy Garden, 1730-1755}

"Father, it appears that you wish all the Indians who are on Beautiful river to withdraw; you know that is a Republic composed of all sorts of Nations, and even many of those who lived near you have settled there. It is a country abounding in game, and this it is that attracts them thither."1

There was a growing noise of people within the former Monyton Onqyayun as spring flowers poked through the ground cover. Buffalo and deer gave birth and shed their winter coats. New mampi were built, hunting camps cleared of brush, and old "Indian Roads" became major highways for Wahtakai and Europeans in war and trade. Much as before, the landscape responded to the increased traffic building second growth edges along old pathways. The theoretical land claims that had existed in the cultural ether in the East were materialized within the former Okahok amai as Miami, Shawnee, Delaware, Iroquois, French, and English peoples settled nearby and began utilizing the onqyayuns. These new occupants proved greatly different than the Monyton in their interactions with the environment on nearly every level.

While the variety of people provided a sense continuity, the cast of characters was wholly new; yet the competition for resources, access to trade, cultural autonomy, and seemingly inevitable colonial wars encroached on the former Okahok amai once again. The Kanawha-New River was desired for its ecological potential, yet this region also promised other benefits to those seeking refuge from colonial pressures. Sadly, no amount of distance could shield these new occupants from the changing winds. In many ways, their migrations reconnected the region to the international tempests they were trying to leave behind.

This landscape has been portrayed in the historiography as full of Indians and Europeans vying for supremacy and control that led to the outbreak of the Seven Years' War in 1754. Many scholars have placed ground zero for this conflict in the Ohio. Despite the losses Wahtakai in the

\footnotetext{
${ }^{1}$ NYCD 10:206 Cayuga to Joncaire, May 15, 1750.
} 
West suffered during the war, the Seven Years' War continues to focus on the Europeans and their imperial conflict. The motivations for Iroquois, Miami, Shawnee, and Delaware actions remain largely hidden behind the land grabs of the Europeans. As already shown in previous chapters, the Ohio Valley has been inaccurately described as a hunting ground where diverse Wahtakai groups practiced communal resource extraction that dated back into the early sixteenth century. The four main Wahtakai nations dealt with in this chapter were relatively recent permanent residents during the eighteenth century. This complicates the narrative of ancestral control and requires close examination of the actual distributions of people across the Middle Ohio River Valley through the first half of the eighteenth century, especially in the former Okahok amai. $^{2}$

It is important to revisit the differences between the former territory of the Monyton and the surrounding areas. On the western side of the Ohio, the land quickly turned into rolling hills, and the necessity for trails and regimented pathways diminished. The percentage of arable land increased dramatically only a few miles away from the Ohio. South of the Ohio and Big Sandy Rivers the land was steeper and narrower, similar to the New River Gorge. By the 1730s, the region directly east of the former Okahok amai was becoming heavily occupied by English farmers. (Map 6.1, Map 6.2) The landscape around the confluence of the Monongahela and Allegheny rivers was rugged, but harbored many wide flat bottom lands that had sheltered the agriculture of the Monongahela mampi during the seventeenth century. Even by 1730 , the region was being occupied by small Wahtakai hamlets as stepping stones for the waves of Algonquian and Iroquoian peoples that would come in the subsequent thirty years. It was also the favorite trade route for English men seeking to access the Ohio and Mississippi Valleys.

\footnotetext{
${ }^{2}$ Landscapes of Indians and Europeans: Carson 2002, 769-788.
} 
So we return now to the former Okahok amai, and as established in the last chapter, the valleys housed families throughout the fall, winter and early spring as they systematically followed deer, elk, and bison herds. Their occupations left few remains other than some clearings, fire cracked rocks, and a few bones of the quarry. They built houses for the coldest months but these sites were also visited frequently by war parties. The use of the landscape, while systematic, was also opportunistic. By 1730, English traders had established regular expeditions through the former Monyton Onqyayun. Unlike the Iroquois and Catawba warriors, these men hunted extensively for fur along their way to trade with Wahtakai on the north side of the Ohio. Their ponderous movements through the rough terrain were slowed even further when they returned with numerous horses and hundreds of packs of furs. These packtrains became targets to Wahtakai war parties. The Kanawha-New River corridor was heavily travelled by Virginia traders transferring materials across the mountains, second only to the AlleghenyPotomac corridor. While not nearly as prosperous as the Monongahela Valley to the North, the Kanawha-New region became an important staging ground for many peoples seeking renewed fur-trade profits. Much like the upper Ohio, the former Okahok amai had become a refuge away from the pressures of Iroquois claims of hegemony and of English settlement. Within the former Okahok amai, the fallowing process had produced an untidy garden of overgrown weeds and fat deer but also a social and economic refuge for Wahtakai (both Algonquian and Iroquoian) pushed westward by other Indian and European powers. By the 1750s, the buffer between the region's new occupants was beginning to dwindle, despite the incorporation of former Okahok amai into the subsistence and trade economies of mampi like Sonontio. The brief process of Shawnee colonization, coupled with ancestral rights, led to claims of ownership and a desire to protect their new home. In 1755, the landscape would have been nearly unrecognizable to its 
seventeenth-century residents as buffalo and elk had taken over only to be hunted by Shawnee,

Delaware and Iroquois men living in mampi at the edge of the former Okahok amai.

\section{Twightwees and Wyandots in the Ohio}

The story of the repopulation of the Middle Ohio River began far to the northwest in French-controlled territory of the late seventeenth century. The Algonquian-speaking Miami would become one of the first Indian nations to fill the vacancies left by the collapse of Fort Ancient influenced mampi. By the 1730s, the Miami had increasing tensions with the French and began channel their fur trade efforts towards British traders canvassing the Ohio River. English traders had begun traveling and living in the region and their supplies and prices were much better. But far from a purely economic calculation, they had begun to move onto the Wabash River to separate themselves from constant French political and religious manipulations.

Likewise, divisions within the Miami divided the nation into factions spreading them across most of the Great lakes region. Charles de la Boische, the Marquis de Beauharnois, the Governor of New France, had become frustrated with the inability of the French to control their Indian allies and his increasingly dictatorial approach from 1730 to 1734 caused the Miami to relocate from Fort St. Louis and other French strongholds. ${ }^{3}$

Along with the Miami, Wea, Piankashaws, Kickapoos, and Mascoutens joined to form the Twightwees, a collection of Algonquian-speaking peoples that settled along the Wabash and Miami Rivers. Richard White described the migration of the Twightwees as occurring through the relocation of whole mampi with social structures intact in contrast to the later movements of the Wyandots, Shawnee, Delaware, and even Mingo. These later groups fractured before leaving their original homes and reformed multi-ethnic mampi that were wholly new in the Ohio Valley. This gave the Twightwees a distinct advantage throughout the 1730s, but by the 1740 s their

\footnotetext{
${ }^{3}$ Miami movement: White 1991, 166, 175.
} 
culturally dynamic brethren to the East had been better situated to adapt to the increasing pressure from the French and the English as well as the diverse pressures from other Indian nations. The development of these "little republics," as Richard White referred to them, were nearly identical to the multi-ethnic mampi of the seventeenth century. Even in 1744 Vaudreuil noted "each village has its own chief who, with his warriors, follows the course that seems good to him, so that they are so many small republics." ${ }^{, 4}$ The diverse members provided access to their kinship connections through marriage and clans thus broadening political and economic power of places like Sonontio far beyond the Ohio into the Lower Mississippi and up into the Great Lakes. $^{5}$

The Miami, in particular, had taken over the Ohio hunting lands from the Scioto River to the White River, once frequented by Shawnees during previous centuries. As the Shawnee began to resettle their old lands along the south side of the Ohio around 1730, the Miami worried about Shawnee and other Wahtakai encroaching on their lands claims. The land north and west of the Ohio were still occupied by the Miami in 1752 when visited by Christopher Gist. The Twightwee Confederacy, though, sought to maintain peaceful relations with the notorious and numerous Shawnee by adopting them as brothers in 1732 and invited them the next year to share the land north and west of the Ohio River. An important component of the Shawnee adoption in 1732 was the formal recognition of their land claims to all territory south and east of the Ohio, including the former Okahok amai. The Miami played a major role in the "well-planned Shawnee strategy for reclaiming their old homelands." ${ }^{6}$ This also seems to have provided the Miami with a much

\footnotetext{
${ }^{4}$ Patricia Galloway, ed. Mississippi Provincial Archives, 1729-1748, French Dominion (Baton Rouge: Louisiana State University Press, 1984), 4:216; in Warren 2014, 214.

"Village "republics": White 1991, 188-189; Spero 2010, 101; Warren 2014, 212.

${ }^{6}$ Lakomäki 2014, 49.
} 
needed ally within the Ohio at a time when the Huron-Petun and other French Indians were threatening their mampi. ${ }^{7}$

Another unlikely addition to the cultural mix within the Ohio region was a nation of Wahtakai that had broken off from the Petun-Huron living in the western Great lakes. Ironically, the rift that led to the creation of the Wyandots stemmed from the peace the Huron-Petun had made in the 1730s with the Catawba. One chief in particular, Orontony (Nicholas) had disagreed and in order to maintain their war, moved down to the Sandusky River. Throughout the 1740s and 1750s the Wyandots joined Shawnee and Delaware mampi along the Ohio. Despite their arrival after the Shawnee, Gist reported in 1751 that the Wyandot laid claim the lands west of the Ohio. $^{8}$

These two groups did not profess or actively engage in hunting within the former Okahok amai, but their alliance with the Shawnee, especially those that would come to live at Sonontio, provided the local protection and land claim support that made the Shawnee so powerful in the mid-eighteenth-century Ohio. An alliance with the Shawnee not only provided access to English traders and goods but also provided access to diplomatic kinship ties with the Iroquois and Delaware as well.

\section{Greatest Travellers, Shawnee Return to the Ohio aka Pelawathepiki}

Before returning to the Ohio Valley, the Shawnee travelled extensively throughout the eastern half of North America. Three historians, Laura Keenan Spero, Stephen Warren, and Sami Lakomäki, have revitalized the significance of these journeys especially by examining their

\footnotetext{
${ }^{7}$ Arrival of Miami-Twightwees 1720-63; Miami River locations, OH; Francis Jennings, “'Pennsylvania Indians' and the Iroquois" in Beyond the Covenant Chain: The Iroquois and Their Neighbors in Indian North America, 16001800 eds. Daniel K. Richter and James H. Merrell, (University Park, PA: The Pennsylvania State University Press, 1987), 75-91; Parmenter2012, 236, 240; Warren2014, 191-200; White 1991, 145-147, 167-176, 186-190; Lakomäki 2014, 28, 47-49.

${ }^{8}$ Wyandots: White 1991, 147, 188-193; McConnell 1992, 30; Lakomäki 2014, 45-46.
} 
seventeenth-century origins and their role in the first half of the eighteenth century. For their travels back to the Ohio valley, we must begin with their movements out of the Southeast from 1715-1730. The end of the Yamasee war shattered the last remaining Indian slave trading markets, along with much of the power coastal Wahtakai had in the Carolinas. The Shawnee had fought in the war alongside the Yamasee against the South Carolinians and lost, forcing most to move west to join Lower Creek talwa on the Chattahoochee River. The few remaining Shawnee in Georgia and the Carolinas fled northward to join family living in the Susquehanna River Valley. Some Shawnee seem to have begun living west of the Appalachian Mountains during the late 1710 s and 1720 s, but the largest populations consolidated among the mampi of the Delaware who would become their closest allies during the mid-eighteenth century. ${ }^{9}$ (Map 7.1)

The tensions among the Shawnee and Iroquois led to the first major Shawnee cheelakawtha (village), Opessa town, relocating from the Susquehanna to the Potomac River near modern day Cumberland, Maryland. ${ }^{10}$ The unified numbers and power of the Shawnee was a major factor in their inclusion as a "prop' of the Iroquois political longhouse, but as groups began to fracture off from their Susquehanna-allied cheelakawtha, they found themselves along the Juniata and then Allegheny Rivers. The Iroquois, often at the behest of Virginia and Pennsylvania, continued to try to coax the divisive Shawnee back East. But no amount of Iroquois pressure could persuade the Algonquians to return after the Iroquois had given away

\footnotetext{
${ }^{9}$ Shawnee in the Yamasee War: Lakomäki 2014, 56-57; John E. Worth, "The Lower Creeks: Origins and Early History" in Indians of the Greater Southeast: Historical Archaeology and Ethnohistory ed. Bonnie G. McEwan, ed. (Gainesville: University Press of Florida, 2000), 265-298, 285. Conoys were also a minor part of the collection of peoples at Sonontio: Warren 2014, 162-179; Stephen R. Potter, Commoners, Tribute, and Chiefs: The Development of Algonquian Culture in the Potomac Valley (Charlottesville, VA: University Press of Virginia, 1993), 19-24, 188198; Lakomäki 2014, 30-1, 40, 43-44.

${ }^{10}$ Tuscarora territory 1719-1722, after leaving the South because of the Tuscarora War, left after 1722 as Sixth Nation of Iroquois: Jennings in Richter Merrell 1987, 83-84; R. P. Stephen Davis, Jr., “The Tuscarora Migration and Evidence for the Tuscarora Near Martinsburg, Berkeley County, West Virginia” West Virginia Archaeologist 27 (1978): 1-15; Wayne E. Lee, "Fortify, Fight, or Flee: Tuscarora and Cherokee Defensive Warfare and Military Culture Adaptation” The Journal of Military History 68:3 (Jul. 2004): 713-770.
} 
large swaths of Shawnee and Delaware lands in an effort to maintain their control of lands to the North. $^{11}$

By the late 1720s thriving Delaware and Shawnee towns emerged on the Allegheny River; this opened up easier access for Shawnee interests within the former Okahok amai and ushered even more active control. The ancestral Shawnee claims to the lands south of the Ohio during the 1720 s and 1730 s were unequivocally accepted by the Miami. The Twightwee confederacy members assisted the Shawnee during the 1730s and 1740s as Catawba and Cherokee hunters began intruding into the Cumberland, Big Sandy, and Kanawha rivers. They were even attacking the Shawnee on the Allegheny. The redevelopment of dual cheelakawtha (villages) at the mouth of the Scioto River prior to 1739, called Sonontio, began as an attempt to get further away from English and Iroquoian control. The cheelakawtha were at another crossroads between the Kanawha-New River trade path and the various North-South war paths providing access to ample hunting lands and numerous trading opportunities. By the end of the 1730s, many English traders had relocated to the growing town. ${ }^{12}$

Nucheconner, Coyacolinne, and Laypareawah, Shawnee leaders of the most numerous towns along the Allegheny, consolidated at Sonontio and began inviting every ally they could find to the town. Pennsylvania, Virginia, and the Iroquois continued their attempts to coax the fractured "props" back to their lands in the East. Nucheconner and the others found this

\footnotetext{
${ }^{11} 18^{\text {th }}$ century deerskin trade: Hinderaker 1997, 19-22; Smalley 2005; Braund1993; Lapham 2005; Allen DieterichWard, "The Changing Nature of Environmental History: An Interview Joel A. Tarr" Pennsylvania History: A Journal of Mid-Atlantic Studies 79:4 (2012): 331-344; Verner W. Crane, The Southern Frontier: 1670-1732 (Ann Arbor: Ann Arbor Paperbacks, 1964): 109. Opessa Town, Warren 2014, 150, 172; Lakomäki 2014, 36-38; Hinderacker 1997, 27-29.

${ }^{12}$ Develop of Sonontio, Lakomäki 2014, 54-55; Warren 2014, 188-193; Clark 1993, 23, though refers to it as Eskippakithiki. Attacks of the Catawba-Cherokee: Salley, Journal of the Commons House Assembly Feb 12, 1707/8, 62, 38; MPCP July 22, 1707, 2:389-90; MPCP 3:97, 169, 66 [Hazard Min. Prov. Council of PA.]; James H. Merrell, “Their Very Bones Shall Fight': The Catawba-Iroquois Wars" In Beyond the Covenant Chain: The Iroquois and Their Neighbors in Indian North America, 1600-1800, eds. Daniel K. Richter and James H. Merrell, (University Park, PA: The Pennsylvania State University Press, 1987), 115-133.
} 
particularly offensive and ridiculous after a series of Iroquois-authorized Pennsylvanian land grabs in the Susquehanna Valley, most notably the Walking Purchase of 1737. Beyond the insult of corrupt land transfers, Shawnee were also unable to feed or fund themselves through hunting within their newly constricted lands. The competition between Indians and the English in hunting areas along the Susquehanna River left Indians emptyhanded, leading to flashpoints ending in bloodshed. These Shawnee explained their reasoning for heading west:

“The Trackt of Land you have Resarved for us does nott sute us at Present, and we would not have you take itt amiss that we don't come and settle upon... We don't Desire two goe any Further Distance from our Brethren than we are, butt Gether two Gather and make a strong Towne, and keep our Young men at home from goeing to Worse [War], for a whole Year... and that we would Live in Peese and Quiettness and become another People. "13

Not only were the Shawnee and their Delaware allies keeping their towns along the Allegheny, they were creating their own "Council" fires along the middle Ohio River far from any of the imperial efforts of the French and English but most especially the Iroquois. The arrival of Iroquois representatives, known as half kings, in the upper Ohio during the 1730 s and 1740s was a last ditch effort to control. Shawnee understood "leadership as persuasion, not as coercion" and despite attempts to quietly coerce Ohio Indian towns, the Iroquois were never able to keep their Ohio props under control to their own, or English, satisfaction. ${ }^{14}$

\footnotetext{
${ }^{13}$ PA 1:551 Allegheny March 20, 1737/8 Loyparcowah, Newcheconer, Coycacolenne (Shawnee) to Thomas Penn and James Logan.

${ }^{14}$ Half Kings: Randolph C. Downes, Council Fires on the Upper Ohio: A Narrative of Indian Affairs in the Upper Ohio Valley until 1795 (Pittsburgh: University of Pittsburgh Press, 1940), 43-45; Anthony F. C. Wallace, The Death and Rebirth of the Seneca (New York: Vintage Books, 1969), 111-114; McConnell 1992, 58-59. Delaware/Shawnee Council Fires: Lakomäki 2014, 80-81; Downes 1940, 20-32. Walking Purchase, 1737: Merritt 2003, 46-49; Leach 1966, 141-143; Merritt 2003: 21-23.
} 
Half kings like Tanachrisson, a Catawba captive-adoptee who had become a prominent Seneca leader, was appointed to keep an eye at Logstown in the late 1730s. By 1747, Tanachrisson was hosting Conrad Weiser at Logstown and proclaiming himself the representative of a new group on the Ohio, the Mingo. This term has produced a great deal of controversy in the historiography, but it appeared to be a dissent group of mainly Seneca residents within the Ohio. Richard White poses that it was the distance from Iroquoia that stripped them of a voice in the Iroquois Council. Rather, the Ohio Iroquois, by selecting to be called Mingo and move far from Iroquoia, were attempting secure their own social and political identities. Michael McConnell places this factionalism within the context of Western Senecas' particular concerns that were not shared by Onondaga over an increased French presence and the desirable resources of the Ohio. "There began to emerge a growing collective identity with the upper Ohio Valley, at once rooted in localized dynamics of Wahtakai societies, the natives' locale, and the challenges they ultimately faced from ambitious outsiders." ${ }^{15}$ Much like Twightwees and Wyandot who moved southeast away from French ambitions, the Shawnee and Delaware sought the autonomy of distance.

Tanachrisson's emplacement among the Delaware at Logstown inevitably created some tensions with residents, especially since he was there to ensure that the upper Ohio "props" were not engaging in their own independent diplomatic ventures. He was ultimately unsuccessful in

\footnotetext{
${ }^{15}$ McConnell 1992, 20. Mingo Controversy: Wallace 1969, 113, "Iroquois hunters domiciled there, known locally as Mingoes;" Michael N. McConnell, "Peoples 'In Between': The Iroquois and the Ohio Indians, 1720-1768" in Beyond the Covenant Chain: The Iroquois and Their Neighbors in Indian North America, 1600-1800 eds. Daniel K. Richter and James H. Merrell, (University Park, PA: The Pennsylvania State University Press, 1987) 93-112, 100, suggested that "Mingo" was a British term of ethnically diverse people I the Ohio. White 1991, xi, Mingos connected to Huron Petun, then (189 ftn 4) "distance from their native villages had deprived them of an equal voice in the councils." Steele 1994, 179, "becoming know as Mingo" dissidents. Anderson 2001 did not even use the word or recognize much of a distinction between Ohio Iroquois villages. McConnell 1992, 15-20, referred to them as Ohio Indians or Ohio Iroquois, Mingo was used in historical documents but mostly by British when dealing with Iroquois in conferences to reference Ohio Iroquois who were dissidents. Merritt 2003, 76-79, also refers to them loosely but only as Ohio Indians.
} 
the eyes of the Iroquois, but the savvy diplomat was able to gain respect among the Mingo and other Ohio Wahtakai by placing himself as the intermediary between the Western Indians and troublesome Pennsylvanian and Virginia traders. His position was contingent upon English munificence and therefore he became "in effect, their Indian on the Ohio" in 1748. His position began to decline nearly as quickly as it rose in 1749 as traders established direct contacts within Ohio Indian cheelakawtha, thereby negating the need for Tanachrisson's intervention. ${ }^{16}$

Just as the "Half-King" was distinguishing himself from the main body of Iroquoia, Shawnee embitterment with the French prompted them to thaw relations with the Iroquois. Both French and English forces and allied Indians wreaked havoc throughout the Great lakes and Ohio region as King George's War raged in 1747. Progressively the buffer between the Shawnee settlements, like Sonnotio, and the Europeans grew weaker. Allied Ottawa and Miami emissaries delivered a series of French warnings to stop trading with the English, and Shawnee warriors opportunistically retaliated by capturing, killing, and scalping some Canadian fur traders. This graphic declaration of war on France brought the Shawnee back to their numerous former allies, the Iroquois. Nucheconner and Kakewatchily renewed older alliances with the Seneca, Onondaga and Cayuga in 1747 to strengthen their support against the Europeans. This led to a gathering of the Ohio Wahtakai at Logstown later that year to plan for dealing with both English and French encroachment. ${ }^{17}$

The détente between Sonontio and the Iroquois proved mutually beneficial in the short term. The Iroquois again claimed them as props, thus bolstering their perceived authority with the Pennsylvanians and Virginians. Iroquois representatives interceded with the Pennsylvanians

\footnotetext{
${ }^{16}$ McConnell 1992, 101-103. Tanachrisson 1747-1749: Journal of Gaspard-Joseph Chaussegros de Léry, Northwestern Pennsylvania Historical Series, edited by Sylvester K. Stevens and Donald H. Hunt, 1940: 19; McConnell, 1987, 101-106; Anderson 2001, 18, 20-21; White 1991, 225-226; McConnell, 1992, 68-69, 75-76.

${ }^{17}$ King George's War: Steele 1994, 170-174; White 1991, 198-203. French Friction: Lakomäki 2014, 61-67.
} 
to accept Shawnee apologies for a supposed attack by Peter Chartier's band of Shawnee that had relocated near the French controlled Alabama Fort in 1748. This benefited the Iroquois because the delegations from Philadelphia and Williamsburg both preferred dealing with Ohio Indian concerns through Iroquois intermediaries. The Iroquois succeeded in 1748 in arranging the release of Shawnee captives from the Wea, members of the Twightwee confederacy. ${ }^{18}$

By 1748 , the upper and middle Ohio Valley was thriving with thousands of people living in cheelakawtha, hamlets and small hunting camps throughout the region. The former Okahok amai was surrounded on the eastern side by growing numbers of English settlers, on the north by strings of Delaware utèney, Shawnee cheelakawtha, and Ohio Iroquois/Mingo kanstaks, and on the West by Wyandot and Shawnee cheelakawtha and many small hunting camps. The number of furs being extracted from the former Okahok amai was increasing dramatically in the 1730s and 1740s, fueling the highest exportation of furs in nearly fifty years. (Diagram 7.1) Though no historical details of large Shawnee cheelakawtha are specifically mentioned, the hunting grounds in the former Okahok amai were being systematically hunted again. In fact, the efficiency of Shawnee fur hunting already had major ecological consequences, as shown by the expeditions of Dr. Thomas Walker, Christopher Gist and many others. ${ }^{19}$

\section{Salley, Walker, Bienville, and Gist: Intruders Claiming the Garden Again}

Virginians residing on the western edge of English settlement (Map 7.2) along the Blue Ridge Mountains wrote to the King of Great Britain in 1739 that they were increasingly concerned about the threat posed by Indian raiding parties. John Howard complained that "in the most western part of Virginia, where we were continually exposed to the fury of the unknown savages, who more than a hundred times and in different places have murdered the subjects of

\footnotetext{
${ }^{18}$ Peter Chartier and Iroquois interventions for apologies; Lakomäki 2014, 64-65; Warren 2014, 177-180; McConnell 1992, 53-54; White 1991:, 189-194.

${ }^{19}$ Deer hides 1740s: Braund 1993, 61-80; Smalley 2005, 74-77.
} 
your Majesty." ${ }^{20}$ Howard, a resident of Augusta County, Virginia, sought to rekindle alliances with the growing number of Wahtakai in the Ohio, "Deeming for this reason that the best way of remedying this our condition was to go to visit these natives and to make a treaty with them." In 1737, Howard received a commission from Governor Gooch of Virginia to carry out such an expedition. The legislature even provided supplies and presents for the diplomatic effort, but Indian attacks along the Shenandoah River in 1738-1740 forced Howard to ask for permission to find and punish "the savages continuing their inhuman murders and having killed six of my neighbors in one day in a meeting house. ${ }^{21}$ Howard easily received the new commission to go "after the murderers in the direction of the highest branches of the river Mississippy." Howard did not record his exact path in 1737 , but we can reconstruct the likely route he took.

Considering his location in the lower portion of the Shenandoah Valley, the trade path across the Greenbrier and Kanawha Rivers was the most likely route for him to take to the Upper Ohio Indians. The only record of Howard's first expedition to the Ohio is his brief note that he had "found several indian nations by whom I was informed that those who had struck the blow were of their people." Seeing the supposed scalps, Howard demanded that the Upper Ohio Wahtakai to give up the perpetrators of the attack but was informed that they "fearing we would take vengeance, had fled toward the lakes."22 (Map 7.3a-b) Howard, loathe to leave empty handed, took and "punished" some unrelated villagers." It is assumed that he killed the men in retaliation. It is unclear how far up the Ohio Howard travelled to find this location, but it further enflamed

\footnotetext{
${ }^{20}$ Fairfax Harrison, "The Virginians on the Ohio and the Mississippi in 1742" Virginia Magazine of History and Biography 30:2 (April 1922), 203-222, 208-9.

${ }^{21}$ Harrison 1922, 209.

22 Ibid.
} 
an already fraught relationship between Shenandoah English settlers and the residents of the Ohio. ${ }^{23}$

After Howard returned to his home on the Shenandoah, his hopes for diplomacy and trade with Western Indians were rekindled. Since his original commission remained in effect through 1742, he reorganized the diplomatic expedition, which included his son, Josiah Howard, John Peter Salley, Charles Sinclair, and John Poteat. They left from Salley's home on the Shenandoah River on March 16, 1742 and arrived at the New River two days later. Salley's journal, the only surviving account of the expedition, referred to the New "as Mondongachate, now called Woods River, which is eighty-five Miles, where we killed five Buffoloes, and with their hides covered the Frame of a Boat." ${ }^{24}$ The party of five Virginians floated down the rocky New River with a few unlisted portages until April 3 when they reached Sandstone Falls, seventy years after Batts and Fallam had visited the location. They left the river after the falls and headed into the mountains towards the headwaters of the Big Coal River. Following the river, they joined the Kanawha River on May 1 and quickly proceeded down the Ohio nine days later. From here they proceed down the Ohio to the great falls by modern-day Louisville, Kentucky. Notable in this entire passage, up till they reached the Mississippi River, was the absence of any Indian contacts or even sightings. Considering Howard's stated mission of diplomacy and trade, the absence of Indians from the record could mean that the party passed undetected through the region. This means that they passed Sonontio, the major Shawnee cheelakawtha on the Ohio, which had been gaining strength since their beginnings sometime in the 1730s. As they were

\footnotetext{
${ }^{23}$ Alvord Bidgood 1911, 205; Kercheval, 1925, 51.

${ }^{24}$ Harrison 1922, 213, Mondongachate appears to be an Algonquian word of unknown origin and only seen in this one document.
} 
travelling on the Ohio during the late spring and early summer, when traffic was the heaviest, it is hard to believe that they did not pass a few canoes on the way. ${ }^{25}$

Salley's journal, as copied by Joshua Frye, gave useful topographical information by describing the ease or difficulty of the terrain they were passing through but provided very few ethnographic details like the ones found in the accounts of more literate and educated individuals like Christopher Gist or Robert Fallam. One reason for the limited contact with Ohio Indians may have been that Howard's return had been noticed and cheelakawtha cleared in case he had arrived with a larger contingent of armed men. The party, unconcerned with attempting to contact known "enemies" on the Ohio, sped past and ignored Sonnotio and other Shawnee cheelakawtha in hopes of contacting French Indians further down river. The choice of paths through the Kanawha-New river watershed indicates a sophisticated knowledge of the landscape acquired through previous travel. Unlike Salley, who comes across as wide-eyed about the sights, Howard appeared to have traveled through the region numerous times with Indian guides. The passage from Hinton to the head of the Big Coal River was a major shortcut off the windy path from New to the Kanawha River and avoided major obstacles like Kanawha Falls. (Map 7.3b) This further supports the increasing presence of English traders passing through the convoluted valleys of the former Okahok amai during the eighteenth century. Howard's group travelled from the falls to the Mississippi only to get arrested by the French for trespassing on July 2, 1742 and were imprisoned until Salley's escape in 1744. His return through the Southeast brought him into much closer contact with French, English and Spanish allied Indians, which he

\footnotetext{
${ }^{25}$ Origin of Salley Journal: Harrison 1922, 205, I have a suspicion that this was active omission of Indians for the purpose of promoting the settlement.
} 
described in great detail. Though his adventures of returning to Virginia after May 1742 were certainly interesting, they shed no light into the former Okahok amai. ${ }^{26}$

The English assured of their land claims in western Virginia, began dividing up the transAppalachian region into three new land companies, the first of these was the Ohio Land Company created in 1747 . Two years later the Loyal and Greenbrier land companies were organized to parcel up the West. (Map 7.4) The Loyal Land Company was required to settle their lands in what is now southwestern Virginia within seven years. They were the first to organize a major expedition, led by Dr. Thomas Walker into the West. He had been influenced by the backcountry explorations of William Byrd and William Banister during the 1730s, and had led a surveying campaign into Cherokee lands within the Appalachian Mountains in 1748. This led the Loyal Land Company to give him a commission on his return "in order to discover a proper Place for a Settlement. ${ }^{, 27}$ He quickly organized an expedition in the winter of 1748 and gathered around him settlers from the Shenandoah Valley to accompany him. ${ }^{28}$

On March 6, 1749, Walker met Ambrose Powell, William Tomlison, Colby Chew, Henry Lawless, and John Hughes at his house just south of modern-day Charlottesville, Virginia. From here they set off southwest staying among friends and relatives living on the western fringe of English settlement. (Map 7.5) Walker was very well aware of the threats of Indian attacks throughout this part of the trek but did not mention coming into contact or seeing any Indians. They reached William Ingles settlement at Draper's Meadows near modern day Blacksburg on March 16 then crossed the New River the next day. After a short stay among "Duncards," German Baptist settlers who moved southward from Pennsylvania during the 1730s, they

\footnotetext{
${ }^{26}$ Salley's journal and expedition end: Harrison 1922, 218-222.

${ }^{27}$ Johnston 1898, 33.

${ }^{28}$ Loyal Co.: Johnston 1898, 5-7. Ohio Co.: McConnell 1992, 89-93; Lakomäki 2014, 66-68; Lois Mulkearn, ed. George Mercer Papers Relating to the Ohio Company of Virginia (Pittsburgh, 1954): 99-114; de Hass 1851, 43-45.
} 
continued west along the Holston River. They had been traveling parallel with and twenty miles outside the eastern boundary of the former Okahok amai. ${ }^{29}$

Walker had arranged prior to the trip for Samuel Stalnaker, a Pennsylvanian-born trader among the Cherokee who was living at the intersection of the Holston trail and Catawba Warpath, to "pilate me as far as he knew." When they arrived at his camp on March 24 they found that Stalnaker's "affairs would not permit him to go with me." Despite this set back, the party continued past the Holston River and beyond the edge of the English "inhabitans" on March 25. This is a telling departure from the expeditions of the seventeenth century, as Walker's willingness to go alone into new territory without local Indians or traders as guides suggests that he did not feel threatened by local Indians. This may be because he was aware that a serious change had occurred within the cultural landscape over the last century. Walker's few references to Indians were mostly to recent attacks by war parties within the Shenandoah Valley, but this changed immediately after leaving the perceived English sphere of influence. ${ }^{30}$

Four days later, on March 29, while resting after a hard trek along the increasingly rocky Holston River, Walker noted that "Our Dogs were very uneasie most of this Night." As they discovered the next morning, this was due to the passage of a party of twenty or so Indians during the night heading eastward. The unknown individuals notably did not attack, nor did they introduce themselves to this invading party of Englishmen. Walker's entry is devoid of details, but these kinds of events were probably commonplace while traveling so far from English towns, and it did not deter them. Two days later, on March 31, at a fork of the Holston River, the party came across a collection of empty Indian Houses "built with loggs and covered with Bark, and there were abundance of Bones, some whole Pots and Pans, some broken, and many pieces of

\footnotetext{
${ }^{29}$ Johnston 1898, 33-40.

${ }^{30} \mathrm{Ibid}, 40-42$.
} 
mats and Cloth." Across the river were another four houses in a similar state. Just beyond this was a palisaded "Indian Fort." The evidence of recent occupation was direct evidence that the Indians that had been living there had left in a hurry very recently. This site was only thirty miles to the southwest from the edge of the former Okahok amai but well into Cherokee territory. ${ }^{31}$

From the beginning of April till May, the party skirted old Indian towns and collections of houses within the Cumberland valley, the home of the Shawnee. The party noted each time that "Indians have lived about this Ford Some years ago." While Walker did not record what specific materials caused him to report this hamlet, there were no contacts with the local Indians, even when Walker having struck out ahead on his own in late April followed a "fresh Track of 7 or 8 Indians, but could not overtake them." This did lead to another collection of "several Indian Cabin's" but again no people living in the area. Then again on May 3, Walker and the party used a freshly occupied Indian camp along a major trail leading to the Ohio. Evidence of Indian occupation of the Cumberland watershed was everywhere as they turned back east towards the Okahok amai. The woods west of the Red River had "been burnt some years past, and are now very thick, the Timber being almost all Kill'd." 32 It is likely that this was the result of fires started to hunt deer. They found more recently burned woods on May 30 with numerous buffalo trails winding in and out of the area. ${ }^{33}$

Walker's party entered the former Okahok amai on June 5 heading to Paint creek and the Big Sandy River, which he identified as the Totteroi. Throughout June, they were within the former Okahok amai, the only obvious signs of native peoples were witnessed along Paint creek on the western edge of the region. On June 8, while hunting about a mile from camp, Walker

\footnotetext{
${ }^{31}$ Ibid, 43-44.

32 Ibid, 61 .

33 Ibid, 61-65; Beisaw 2012, 369; Braund 1993, 65; Capt. Thomas Nairne, Alexander Moore, ed., Nairne's Muskhogean Journals: The 1708 Expedition to the Mississippi River (Jackson: University of Mississippi Press, 1988), 52.
} 
heard a gunshot from across the river. He made a point in his journal to remind readers that none of his party had yet forded the waters since flooding had halted them, and therefore likely made by Indians. The pathway through the steep mountainsides that Walker described took them through remote and difficult terrain that could have been avoided had they stuck to the major trails. While Walker may have possessed detailed knowledge of the Holston, his rambling path through the former Okahok amai indicated the limit of his western database. At one point, the party became ensnared in mountain laurel and was forced to cut their way through a steep ravine as their horses and baggage slowed their progress even further. Notably, during this mid-summer stretch, Walker remarks on the scarcity of game, which would seem understandable considering the din they were causing beating aimlessly through the area. But afterwards, while staying at a camp from June 15 to 18 , Walker and his crew observed the game returning, "turkey are plenty and some Elks." They shot three turkeys and three bears, and left camp with "a good stock of Meat." He would brag later they could have killed three times as much on their journey. The increasing presence of large ungulates, like Buffalo and Elk, in the southeastern corner of the former Okahok amai was due to the open expanses left by empty mataque and mampi and the limited threat from hunting. That all began to change in the mid-eighteenth century with the arrival of Englishmen like Walker. ${ }^{34}$

For the rest of the expedition, after his June 6 arrival at Paint Creek, Walker did not mention Indians again. The party reached the Bluestone River on June 27 and immediately followed it downriver to camp at the mouth of the Greenbrier. At this point, Walker had entered into the land claims of the Ohio and Greenbrier Land Companies. He had spent most of his trek outside the boundaries of the original Loyal land grant but this fact did not seem to concern him much. Circa 1740, English settlers began quietly making their way to the headwaters of the

\footnotetext{
${ }^{34}$ Johnston 1898, 67-69.
} 
Greenbrier River. Walker expected to find some settlers at the mouth of Anthony Creek but the party skirted past them without any contact. Not long after, on July 7, five Englishmen from across the ridge to the East found them and directed them towards the Jackson River settlement. By July 13, all of the party was back home in the Shenandoah Valley. ${ }^{35}$

Dr. Thomas Walker and his small group, without guidance, wandered through treacherous terrain, especially the passage from Paint Creek to the Bluestone River. The absence of Indians was most notable during this mid-summer segment, especially after the frequent signs of Indian activity from the Holston through the Cumberland valleys in late spring. While Walker showed a general understanding of the Appalachian Mountains and its geography, the path picked through the former Okahok amai, with occasional trail-blazing through difficult mountain laurel thickets, was poorly developed. The trek steered far from the major trails and zones of previous occupation. But even when the party returned to major pathways, like the Bluestone River, the region was now settled by English families, thus obscuring evidence of Indian occupation.

At the same time as Walker began his journey westward other European interests were focused on the Ohio. Foremost on the mind of the Governor of New France, Roland-Michel Barrin de La Galissonière, was the continuing unrest within the Ohio River valley. He sought to solidify the weak position France had been in after King George's War and the tepid peace of the Treaty of Aix-la-Chappelle in 1748. The resolutions left unresolved the imperial claims to the Ohio country and thus stoked further competition between the French and the English in the region. The expedition of Dr. Walker was predicated on the legitimacy of the land grant from the Crown and Virginia and therefore did not appear concerned with trying to create evidence to

\footnotetext{
${ }^{35}$ Ibid, 69-75.
} 
support their right to be surveying the trans-Appalachian watersheds for settlement. Galissoniere and his military commander had other plans for the Ohio in the $1740 \mathrm{~s}^{36}$

While Dr. Walker was cutting through the mountain laurel thickets of the Big Sandy river valley on June 15, 1749, another crew of foreigners gathered in New France to travel into the Ohio River valley to solidify French land claims. Pierre Joseph Céleron de Bienville was commanded by Governor Galissoniere to travel to the Allegheny River and down to the Ohio to strategically bury lead plates claiming the land for the French. He was also tasked with the diplomatic mission to reincorporate the Ohio Wahtakai into the French trading network. Bienville's failure in diplomacy was matched only by the failure of the lead plates to solve European land claims in the Ohio. (Map 7.6a) Bienville's canoe expedition sheds light on the tense situation throughout the backcountry. ${ }^{37}$

Bienville left Fort Frontenac along Lake Ontario on June 30 as Walker was travelling up the Greenbrier. His force consisted of thirty-five French military, one hundred eighty Canadian militiamen, a chaplain, supplemented by fifteen Iroquois and fifteen Abenaki warriors. He entered Lake Erie on July 14 and arrived at the Portage Chatakuin and the long overland trek to the Allegheny River later the next day. They continued carrying their canoes and materials a little over thirty miles to Conewago Creek and launched downriver. Bienville ran into immediate difficulties in fulfilling his mission of allaying Indian fears of attacks, and bringing them back to French patronage through trade presents. During a meeting with the Iroquois residents of Kachinodiagon [Cut Straw], Bienville stated: "You will see suitable marks which I have fixed along the Beautiful River, which will prove to the English that this land belongs to me, and that

\footnotetext{
${ }^{36}$ King George's War and Treaty of Aix-La-Chapelle: Steele, 1994, 170-174; Lakomäki 2014, 65; McConnell 1992, 82-83.

${ }^{37}$ White 1991, 203-208; McConnell 1992, 83-90.
} 
they cannot come into it without exposing themselves to be expelled from it." ${ }^{38}$ The conciliatory response from the residents of this small Seneca village, so close to Lake Erie, was not surprising especially with such a large contingent of armed Frenchmen and allied Indians in front of them. Two days later on August 1, Bienville ushered his two hundred plus men into their canoes and headed downriver. Word of this conference and the rigid demeanor of Bienville rippled out in front of him, warning settlements downriver long before he had arrived. ${ }^{39}$

Bienville arrived at the first abandoned town on August 3. He assumed the residents had left for the safety of Chinique (Logstown) a few days travel downriver. The only remaining residents were five or six Iroquois men who kept a close watch on Bienville's movements. Even when there were no Indians visible, the party never went out of the careful watch of scouts and sentinels from the local cheelakawtha (towns). Bienville sped past all but the largest utèney and cheelakawtha, stopping only briefly at Attique with its twenty-two houses that had also been abandoned for Chinique. Bienville's second in command Joncaire had been sent ahead to Attique and had been interrogated by the only remaining chief, presumably a war chief, and two young men. They had "demanded of him the motives of his voyage" to which Joncaire had assured that he "had only come to speak to the nations of the Beautiful River, to animate the children of the (French) government which inhabited it." ${ }^{40}$ The chief accepted strands of wampum to support this message to be carried southward so that they would "remain quiet upon their mats" to hear Bienville's “advantageous" suggestions. ${ }^{41}$

Frustratingly for the French, the message seemed to have little effect as the party travelled through mostly empty utèney and cheelakawtha until they reached Chinique on August

\footnotetext{
${ }^{38}$ C. B. Galbreath, ed., Expedition of Celoron to the Ohio Country in 1749 (Republished for Ohio Archaeological and Historical Quarterly. Columbus, OH: F. J. Heer Printing Co. 1921), 21-22.

${ }^{39}$ Beginning till Visit to Kachinodiagon: Galbreath 1921, 12-23.

${ }^{40}$ Ibid, 26-27.

${ }^{41}$ Ibid, 23-27.
} 
8. The only Wahtakai bold enough to remain were scouts and English traders undeterred by the threat of French canoes. Just after leaving Attique on August 6, the campaign surrounded six English traders transporting 150 bales of fur eastward towards Philadelphia. Bienville handed them a letter declaring that they were trespassing on French land and ordering that they never return. This, of course, did nothing to stop these men and others like them from returning yearly in the lucrative fur trade beyond the Ohio. Bienville came upon more English traders only few days after leaving Chinique this time paddling upriver in four boats with "packages," presumably furs, returning from Sonontio. The constant travel of English traders along the Ohio and into the Allegheny-Monongahela watersheds was a product of major trade network established with Pennsylvanians. (Map 7.6a) $)^{42}$

Despite Bienville and Joncaire's suggestion to the contrary, the events at Chinique's conference on August 8-9 were indicative of a dramatic, and certainly destructive, change in French policy towards Ohio Indian diplomacy. The distrust between the Wahtakai and these invaders was immediately apparent as Bienville's canoes floated to the shore by the utèney. Bienville had checked and distributed arms to his men "in case of need" before heading out the morning before they reached the utèney that consisted of fifty houses of Iroquois, Shawnee, and Delaware. The settlement was also surrounded by refugees from upriver. When sighted, the Indians on the shore fired powder-only shots in customary greeting and then directed the canoes to the fast channel to shore. As the French canoes began making landfall, Chinique residents began threateningly firing live ammunition directly over the heads of the Frenchmen. Bienville understandably became concerned about these intentional "accidents" and ordered the Wahtakai to stop firing or he "would open fire on them." The tensions increased after the French commander finally made landfall when he ordered his hosts to take down an English flag and

\footnotetext{
${ }^{42}$ Ibid, 27.
} 
tent erected beside the French flag and tents. As the residents took care of these surreptitious orders, Bienville struck a defensive camp by the canoes. The initial French insults toward Chinique's leaders and residents plagued Bienville's later attempts at diplomacy. ${ }^{43}$

After a brief introductory meeting with utèney leaders "accompanied by thirty or forty braves" the Frenchmen and Indians separated to allow a feast and dance to continue in Chinique. Bienville's men went on alert when some of the Iroquois scouts reported that the utèney had met and determined to attack the French camp. When the presumed attack did not occur, Bienville sent Joncaire to "tell them that I knew the resolution they had taken, and awaited them with impatience; and if they did not make haste and put in execution what they had planned, I would go and attack them.. ${ }^{, 4}$ The utèney leaders arrived two hours later with calumets. Bienville between customary condolence ceremony rituals upbraided them for their "manner of acting." The Frenchman's abrasive and uncustomary behavior continued throughout the next day. This further convinced the leaders of Chinique that the French could not be reasoned with and must be removed from the utèney one way or another. ${ }^{45}$

Bienville, breaking with convention, became impatient to get back on the Ohio and ordered the chiefs and warriors to his camp the next morning to read Galissoniere's letter to all people on the Ohio. The letter assumed that "undoubtedly you [Indians] are not aware" of English plans for settlement which would surely "tend to nothing short of your total ruin." The French Governor's fatherly love prompted him to "appraise them of the danger" of English attempts to "render themselves masters of that territory, and drive you away, if I should let them do so." While exhorting the residents to neutrality and discrediting English land claims, Galissoniere repeatedly referred to the "Beautiful River, which belongs to me." The letter

\footnotetext{
${ }^{43}$ Chinique (Loggs Town) visit: Ibid, 29-36.

${ }^{44}$ Ibid, 31 .

${ }^{45}$ Attack plan at Chinique: Ibid, 29-30.
} 
included Iroquois "ownership" concerns as Bienville read further, "Chiefs of the Five Nations have told them [the English] not to pass over the mountains which form their boundaries." It is hard to understate how badly Bienville and Galissoniere misunderstood the indigenous political landscape of the Ohio during the mid-eighteenth century. While factually accurate, Bienville's analysis of his exchange at Chinique that "we can never regain the nations, except by furnishing them merchandise at the same price as the English" ignored the social context of that trade not to mention their desire to protect their land rights, which would maintain their ability to participate in that trade. ${ }^{46}$

On the morning of August 11, the residents returned and responded not only to the French claims of ownership of the Ohio, but also to the brusque treatment from Bienville. They promised to go to Montreal in the spring to renew their friendship. Even though the Shawnee leaders of Chinique expressed pleasure that the French had "expelled" the English, the leaders requested that the French bring traders to replace the vacancies or at least allow the English to stay till spring to get essential goods for the Indian trade. The chiefs pleaded, "You see in what an unfortunate plight we shall be, if you do not show us this kindness," but followed it with a bold warning that if the French ignored them, then "Do not be surprised at not finding answers to your belts." Bienville's non-committal response was only covered over by digging into the store of political presents he had brought. Both residents and the French were relieved when Bienville cast off his canoes and headed downriver that same day. ${ }^{47}$

Bienville's expedition traveled from August 14 till 18 with no contact with Indians or evidence of occupation along the river (Map 7.6b). They were travelling along the border of the former Okahok amai after placing a lead plate at the mouth of the Jenuanguekouan [Muskingum]

\footnotetext{
${ }^{46}$ Ibid, 33-34.

${ }^{47}$ Ibid, 35-36.
} 
river. Bienville did not mention a recently occupied (1740) Shawnee cheelakawtha across the Ohio from the Chinodaista [Kanawha] river. ${ }^{48}$ It would have been relatively small still and may have been evacuated till the Frenchmen had passed. Bienville placed his fifth lead plate at the mouth of the Kanawha on August 18, 1749, further attempting to undercut English land claims. In fact, he noted that, "The English of that government come that way to ply their trade on the Beautiful River." The party was forced to stay in camp at the mouth of the Kanawha River an extra day when heavy rains made the rivers impassable and threatened to fill up their canoes. Their camp by the shore of the Ohio had to be moved inland about a quarter mile for fear of being washed away. ${ }^{49}$

Half a day's journey downriver on August 20 brought them to the old riverbed of the Teay's river where they met a Delaware man returning from a war party in the South among the "Chien Nation." 50 The presence of a lone man returning from the South without ammunition or food indicates that this was an unsuccessful attack, but Bienville took pity on him and gave him enough food and ammunition to reach his destination at Chinique. But before releasing him to return home, Bienville interrogated him for details about Sonontio, their next destination on the Ohio. ${ }^{51}$ The Delaware man estimated the number of cabins at eighty to one hundred. This meant that Sonontio was the largest cheelakawtha along the Ohio housing at least eight hundred people. Gists' estimates put the population at roughly 1,500 in 1751 . Bienville's persistence in questioning this bedraggled warrior indicated the extremely limited knowledge the French possessed about this major cheelakawtha, and testified to how far outside French control the

\footnotetext{
48 Ibid, 40.

49 Ibid.

${ }^{50}$ Chien meaning "Dog" possibly Catawba: Ibid, 42.

${ }^{51}$ French wrote it, St. Yotoc [Sonontio].
} 
cheelakawtha remained. The appearance of a fleet of French canoes proved an unwelcome reminder of threats that had prompted them to buffer themselves in the mountains. ${ }^{52}$

Before arriving at Sonontio, the Caughnawaga Iroquois and Abenaki accompanying Bienville approached him concerned about making an unannounced visit to such a large cheelakawtha. Bienville offered that they were "afraid" but admitted:

“...there was reason to fear that these Indians were apprised of my voyage and would be restless from the fact that those who had brought them the news of my arrival might, as in the case of the villages by which I had passed, have carried them false reports, which would lead them to lay ambushes for us." 53

The dual concern for decorum and weaker military position led Bienville to send Joncaire, two of the Caughnawaga Iroquois, Ceganeis-Kassin and Saetaguinrale and three unnamed Abenaki to announce their arrival. The men traveled nearly sixty miles downriver to Sonontio on August 21 to find the residents "frightened out of their wits." More boldly than even the Chinique residents before, Sonontio's residents fired gunshots directly at the canoe. The security of nearly a thousand residents was obvious in such a defensive measure.

Joncaire, after finally being released from his canoe, held a tense council meeting where residents vocalized the Indian anxieties the expedition was creating along the river. One man interrupted Joncaire's explanation of the "commission" and suggested instead that "the French deceived them, and that they came only to destroy them and their families" and deserved to be killed. But this was avoided when a resident Iroquois chief "pacified them and volunteered to come to me [Bienville]." Joncaire left his Indian allies at Sonnotio and accompanied a mixed Shawnee-Iroquois canoe to catch Bienville the next morning. Bienville again had distributed

\footnotetext{
${ }^{52}$ Sonontio populations: 80-100 houses with correlates to 800 residents, Galbreath 1921, 42; 1200-1500 residents, Lakomäki 2014, 55; 1500 residents, Darlington Gist 1893, 16.

${ }^{53}$ Galbreath 1921, 42.
} 
ammunition to his men and headed downriver, but he didn't travel far before he sighted Joncaire in a canoe travelling upriver waving a tattered white flag. Bienville spoke briefly with the Iroquois chief, to whom Joncaire owed his life, and asked him to return and ensure that the Wahtakai not fire on the canoes when he arrived. ${ }^{54}$

Nearly seventy of Bienville's canoes arrived August 23 to a cacophony of gun salutes, despite the Frenchman's protestations. The expedition camped on the south shore of the Ohio across from the largest collection of houses they had yet encountered. The efforts to bring Upper Ohio and Eastern Indians to Sonnotio were apparently a major success. The numbers and armament were on display as Bienville arranged an initial meeting and watched as eighty warriors crossed the river and took positions "lined a hedge about twenty paces from us, and leaned on their guns." Bienville alarmed, ordered his men to arms and chastised the elders sitting before them. Even though the elders assured Bienville that "they did not come with any bad intention, but merely to salute us again, and that they should retire since it displeased me," the French were well aware of the veiled threat of defensive firepower that could be mobilized at a moment's notice. The diverse cheelakawtha consisted of a large body of Shawnee, a variety of Iroquois, Miami, Delaware, and Wyandots all presumed by Bienville to be "entirely devoted to the English.” The French commander's Eurocentric assumptions about the allegiances of Sonontio generalized the opportunistic reality of autonomous multi-ethnic cheelakawtha in the Ohio. $^{55}$

The next morning, Bienville held council and chastised the residents for their behavior but forgave them providing they "be wiser for the future" and "reject all the deceitful talk." Bienville's speech at Sonnotio, unlike Chinique, only made a single subtle reference to French

\footnotetext{
${ }^{54}$ Role of Iroquois at Sonontio: White 1991, 206-209; McConnell 1992, 102-103; Lakomäki 2014, $65-66$.

${ }^{55}$ Efforts to draw Indians to Sonontio, Lakomäki 2014, 54-55; Quote: Galbreath 1921, 44-45.
} 
ownership of the Ohio. Instead, the speech focused on the relationships between the cheelakawtha leadership and the European settlements and their traders to the East and North. The Shawnee response was notably short and devoid of the customary language for a proper condolence ceremony. Just as asked, the speaker thanked the French "father" and agreed to "no more play an evil part and will no longer listen to bad talk." The Shawnee speaker came to the main point of his speech to "encourage you to continue your route...so that the land may be at peace for us Chananaous." After the heavy-handed approach of Bienville, the Shawnee and others wanted the violent and disrespectful intruders out of their town. They got their wish on August $26^{\text {th }}$ after three days of increasing tensions. ${ }^{56}$

After leaving Sonnotio, Bienville moved into Twightwee territory along the Miami River and then returned north towards Lake Erie and back to Fort Frontenac. By the beginning of November, the expedition had disbanded and Bienville was reporting to Galissoniere in Montreal. Despite his orders to establish strong ties with the Indians along the Ohio and to forcibly kick the English out of the region, Bienville returned with unfulfilled promises to visit Montreal in the spring, glib agreements to be friendly and not listen to "bad words" from the English. Wahtakai along the Ohio had chosen to hide from the large military force, and the few cheelakawtha strong enough to deflect their attacks attempted to conclude their requisite conferences as quickly as possible to send the Frenchmen further downriver. The lingering burn of Bienville's brazen declarations of French ownership of the Ohio, especially the burying of lead plates, was a direct threat to Indian sovereignty not soon forgotten nor forgiven. ${ }^{57}$

\footnotetext{
${ }^{56}$ Galbreath 1921, 45-49.

${ }^{57}$ Effects of Bienville: Aquila 1997, 102-103; McConnell 1992, 24, 88; Downes 1940, 53-54; George A. Wood, "Celoron de Blainville and French Expansion in the Ohio Valley" The Mississippi Valley Historical Review 9:4 (Mar., 1923): 302-319.
} 
Establishing which settlements were active during 1749 and which had been permanently unoccupied is frustrated by the wave of Indian evacuations inland away from riverside homes as Bienville's expedition passed. A few things can be gleaned from these events concerning the distribution of cheelakawtha within the Ohio valley. The upper Ohio was much more evenly settled by four to eight house hamlets along the major creeks off the Monongahela, Allegheny, and down the Ohio within a roughly fifty mile radius from their confluence. There were five or six large cheelakawtha in this region as well with highly mobile populations of English, French, and Indian traders along with frequent stays by war parties heading to or returning from the Catawba wars. Within the middle Ohio River valley (from the Little Kanawha to the Scioto Rivers), especially within the former Okahok amai, there were fewer but bigger cheelakawtha that were significantly more diverse than in the surrounding regions. In the wide distances between major cheelakawtha like Sonnotio and Muskingum were no hamlets with permanent residents. Instead, the region was crisscrossed by trails and hunting shacks used by extended family groups as they hunted especially during the fall and winter. ${ }^{58}$

The highly consolidated palisaded towns along the Ohio were evidence of continued warfare much as they had been in the previous century. Indians had alliance networks throughout the Ohio, and though the arrival of a large detachment of French military was disturbing, residents were able to protect themselves by hiding in the forests or running to larger cheelakawtha where they could withstand an attack. Occasionally, the Wahtakai met with the French intruders in order to get them to leave quickly and then went about business as usual. As the first European military campaign in the region, Bienville initiated a nearly perpetual military presence that continued until the wars of the early American republic. While the armaments of

\footnotetext{
${ }^{58}$ Catawba Wars in upper Ohio: Lakomäki 2014, 66-68; White 1991, 231-232; James H. Merrell, Into the American Woods: Negotiators on the Pennsylvania Frontier (New York: W.W. Norton \& Company, 1999), 44, 213.
} 
Bienville's forces posed an immediate threat in 1749, it was the English that unleashed a much more quietly insidious force within the Ohio: the surveyor. The commodification of the lands across the Appalachian Mountains had already begun with the development of the land companies in Virginia but was furthered by the account of an extremely observant Indian trader in 1751 .

As an agent of the Ohio Land Company, the North Carolinian Indian Trader Christopher Gist was tasked to examine the entire Ohio River valley down to the Great Falls at modern day Louisville, Kentucky. The Ohio Company specifically wanted information about the "Ways \& Passes thro all the Mountains you cross" followed with a nearly scientific account of soil quality and timber within each of the valleys. Last on their list was an instruction to "observe what nations of Indians inhabit there, their Strength \& Numbers, who they trade with, \& in what Comodities they deal." The purpose of collecting all this information was so the Ohio Company could determine locations to accommodate the one hundred settlers the company was required to locate within the 200,000 acre initial patent within seven years. Gist's initial journal and report to the Committee of the Ohio Company were successful enough that he was commissioned for two subsequent expeditions before the Seven Years' War broke out. The first of these expeditions, in 1750 and 1751, went around the northern and western edges of the former Okahok amai before entering the region in the spring of 1751 (Map 7.7a). ${ }^{59}$

Gist's account of his first expedition described the Ohio country as a hive of activity for Indians and Europeans alike. He began his journey in October 30, 1750 at Thomas Cresap's house along the Potomac River and headed north with his "servant" and a few horses into the well-established network of Shawnee, Delaware, and Iroquois settlements along the Allegheny

\footnotetext{
${ }^{59}$ Darlington Gist 1893, 32-66. Ohio Co. docs: Mulkearn 1954; Kate Mason Rowland, "The Ohio Company" WMQ 1: 4 (Apr., 1893): 197-203; McConnell 1992, 90-93.
} 
River. He reached Shannopin town, a Delaware stronghold, on November 19 and then headed to Logstown on the Ohio on November 25. At this point he discovered that he was following two traders, young George Croghan and the seasoned Andrew Montour, as they headed to Muskingum. Two weeks later, Gist and his servant found Croghan and Montour living at Muskingum. Gist stayed with the Delaware and Mingo residents for a month during which time One Teafe, an Indian man who traded frequently near Lake Erie, returned and relayed a message from the Wyandots. After warning the trader to avoid the French-allied Ottawa, the Wyandots stated that "the Branches of the Lakes are claimed by the French; but that all the Branches of the Ohio belonged to Them [Wyandots], and their Brothers the English.” This proclamation of possession did not appear to upset the Delaware at Muskingum nor was it codified in treaties of the mid-eighteenth century, but seemed to be more of an opportunistic declaration of support for the English. ${ }^{60}$

By December 12, Montour and Croghan had stayed and traded with the Delaware and setup a meeting with their "king" to solidify the alliance between the Wahtakai and the English. They had a failed attempt at having a council meeting that was "a little disordered with Liquor." On December 14 they tried again and found diplomacy being carefully managed by the shrewd leaders of the Delaware. When Croghan invited the leaders to meet with the Governor of Virginia and "partake of their Father's Charity to all his children on the Branches of Ohio," one of the chiefs corrected an important error in Croghan's presentation. The chief thanked "their Brother the Governor" and declined to respond the Frenchman's claims until they "had a full or general Council of several Nations of Indians which coud not be till next Spring." After the diplomatic defeat, Montour and Croghan joined Gist as he journeyed southward to Sonontio. The Delaware dominated the Muskingum and Upper Scioto Rivers though their settlements were

\footnotetext{
${ }^{60}$ Darlington Gist 1893, 40; Wyandot claims: Lakomäki 2014, 48-49; MCPC 4: 234.
} 
relatively small, ranging from four or five families to twenty families. Gist noted that the westernmost Delaware town was just north of Sonontio. ${ }^{61}$

The party arrived in Sonnotio on January 29, 1751 to a much friendlier reception than Bienville had received two years earlier. This can be attributed to their differences from Bienville's military campaign. The trading party consisted of three men carrying trade items instead of tens of well armed and anxious soldiers. After a short stay, Gist continued with Croghan and Montour deep into Miami territory. The alliance between the Miami and Shawnee had become tense since Bienville's visit in 1749. Gist came upon nine Shawnee men on the path coming back to Sonnotio on February 15. They had been at Pickiwillany arranging the release of some kinsmen who had been mistakenly held captive by Miami. Gist did not travel as far as Pickiwillany but the word of the arrangements proved beneficial for the Englishman. A woman, who had been held in the incident, explained that she had been taken "last Fall, by some of the Wawaughtanney Warriors thro a Mistake.” The Shawnee men explained that they were returning to Sonnotio but had left fifteen of their brothers at the Miami town to ensure that their family was released. The complex alliances among the cheelakawtha in the Ohio required constant maintenance, and incidents like this one, whether secretly exacerbated by French prodding or not, strained relations. ${ }^{62}$

A few days later, the party arrived at the Miami (Twightee) town and found that an English trader, Robert Smith, was already living nearby. This town was another bustling hub of Miami, Delaware, Shawnee, and other unidentified Indians from "foreign" and distant nations. Little was said or recorded concerning the Ohio or the Shawnee at the council meetings held during their eleven day stay, and Gist and his companions did not proffer information about the

\footnotetext{
${ }^{61}$ Darlington Gist 1893, 41-42.

${ }^{62} \mathrm{Miami} /$ Shawnee tensions 1750-1751: Ibid, 52.
} 
real reason for his visit. If the true nature of Gist's employers' goal of settlement in the region had become public knowledge Gist probably would have not made it back to Virginia. By the beginning of March, Gist had decided to return to Sonontio separating from his travelling companions who were heading back towards Hockhockin town just south of Muskingum. Gist and his servant returned to Sonnotio determined to continue southward across the Ohio and pick their way through the mountains back East. ${ }^{63}$

Outside Sonnotio, on March 9 the two men were received by nearly everyone from the town. The residents, tense about the captivity incident, were "very glad that all Things were rightly settled in the Miamee Country." Gist was befuddled by the Shawnee excitement. At first, he assumed that it was due to the expedition's trading successes but it became clear that they were more concerned about the impending return of their brethren from accidental capture by the Miami and their continued "Peace with the western Indians." Miami Indians were not the only western concern discussed while at Sonnotio. A group of Mingo arrived the next day and warned Gist about a large party of French Indians at the falls of the Ohio and "if I went there they would certainly kill Me or carry Me away Prisoner to the French." Gist was undeterred by this danger and set out the next day south across the Ohio in hopes of fulfilling the full breadth of his Ohio Company commission. Even when two of Robert Smith's men, coming back from trading and hunting in the rugged mountains to the south of Sonnotio, corroborated the Mingo story of the sixty plus French Indians at the falls, Gist continued westward. ${ }^{64}$

He never did reach the falls; instead he turned southward on March 14 and then back East on March 21. The linguistic and geographic knowledge exhibited through the last three months of the expedition, as Gist and his servant travelled quickly through the steepest and most

\footnotetext{
${ }^{63}$ Ibid, 49-55.

${ }^{64}$ Ibid: 56.
} 
convoluted sections of the Appalachian Mountains, points to the fact that his servant was a former Indian resident of the Ohio, probably Shawnee. He stumbled into the headwaters of the Kentucky River that had been visited two years previously by Dr. Thomas Walker. On March 18, he heard several gunshots and then found freshly laid fur traps. At this point, he assumed he was close to the falls on the Ohio River and desired to travel briefly to them but could not bring himself to leave his "boy" companion. He was a little over one hundred and forty miles east of the falls and would have run out of food and probably been captured by French Indians had he continued. Instead he turned southwest till he reached the Kentucky River on March 13, 1751. These traps and scattered signs of Indians matched the string of sites mentioned by Walker in 1749 in roughly the same area. ${ }^{65}$

Gist and his servant continued through rough terrain and reached the edge of the former Okahok amai on April 1 and immediately began following the first distinguishable Indian path down to the Levisa Fork. Much like Walker's previous Paint Creek discovery, Gist found strong evidence of Indian use of the landscape along the western edge of the region. He found a "Warrior's Camp" capable of housing seventy or eighty men and appeared to have been used relatively recently by a crew who had painted a crane on a tree nearby to mark their stay. The location was secure and they needed rest, so Gist and his servant stayed there for two more days. On May 7, Gist found a "Warriors Road" that turned east and crossed the upper reaches of the Levisa. The path was well-trod but they quickly discovered that they needed to head east more than south and were forced to strike off across mountain laurel thickets and into "the worst travelling I ever saw." ${ }^{\prime 66}$ Their travel was so rough that they lost one of the horses to a bad fall.

\footnotetext{
${ }^{65}$ Ibid, 58-59.

${ }^{66} \mathrm{Ibid}, 62$.
} 
This was the same area that Walker had referred to as "Clifty Creek" and "Dismal Creek" while worrying about the scarcity of game. ${ }^{67}$

Things got much better as Gist headed up the Bluestone River at the beginning of May and back onto familiar paths. The Bluestone and New Rivers, while slightly easier to navigate, had few signs of Indian use. Gist's journal becomes less descriptive as he neared the New River but he noted that he utilized an "Indian Warrior's Camp" on May 10 that was located along the very same path travelled by Batts and Fallam along the New River in 1671. Back in familiar territory, Gist pushed his horses to get home along the Yadkin River in only eight days but found that due to Indian attacks flaring up along the western edges of Virginia's settlements his family had fled to Roanoke. He joined them there the next day. Soon after, in 1751, Gist reported his findings to the Ohio Company and was awarded with a similar commission to return to the Upper Ohio for further data collection. ${ }^{68}$

While Christopher Gist was out West, the Ohio Company had established a storehouse on the Potomac River and this was where he began his second journey on November 4, 1751. (Map 7.7b) His new commission was focused on the region from the Monongahela down the south side of the Ohio to the Kanawha River. This area had not yet been closely examined by the English for suitable settlement locations. Oddly, the company left out any references or instructions concerning Indians that may have been occupying the region. Whether by former knowledge or assumption, they seemed convinced Indian residents would not be a problem. Though it was not written in his instructions, he had also been tasked by Colonel Patton to invite every Indian he met to the planned treaty conference at Logstown the next May. Gist, accompanied by his son, left the Potomac heading north to the Youghiogheny River and stopped

\footnotetext{
${ }^{67}$ Ibid, 61-63.

${ }^{68}$ Ibid, 63-66.
} 
frequently to explore up creeks and runs. Notably, while Gist had previously discussed Indian settlements in the area, he appeared to avoid most of the utèney on the Youghiogheny River. His avoidance could have been due to Indian concerns after Gist's previous visit, but trade relationships between the English and Ohio Indians had also worsened in the year since his last visit. $^{69}$

Barely a month into the expedition, Gist encountered a Delaware hunting town along the Youghiogheny River. The chillier reception was indicative of the treatment of Gist along the Ohio in 1751-1752, especially among the Delaware. Gist bought some corn for his horses and brought up the coming meeting at Logstown. Though the Delaware "treated Me very civilly," his servant informed him that the Delaware had "threatened to take away our Guns and not let Us travel., ${ }^{, 70}$ The fear and anxiety exhibited by the Delaware in the upper Ohio was part of the growing realization that Christopher Gist represented the inevitablity of contact. Despite attempts to remove themselves from the pressures of English settlements, the new waves of Englishmen were not satisfied with trading and returning home. He was, by order of the Ohio Company, parceling up the territories claimed by Indians without their consent or acknowledgement. ${ }^{71}$ Indian residents of the Ohio had figured out his role in the desire for western lands after his previous visit. But not all the settlements he reached were openly hostile towards Gist since he had established friendships with a few of the regions' Delaware leaders. Oppaymolleah, an "Indian Captain," had camped a few miles from the hunting town and "seemed very glad to see Me, and wondered much where I was going so far in those Woods." Gist offered that he was out

\footnotetext{
${ }^{69}$ Col. Patton's directives: Ibid, 69.

70 Ibid, 69.

${ }^{71}$ Lancaster Treaty of 1748: A Treaty held by commissioners, members of the Council of the province of Pennsylvania, at the town of Lancaster, with some of the chiefs of the Six Nations at Ohio, and others, for the admission of the Twightwee Nation into the alliance of His Majesty, \&c. in the month of July, 1748. Philadelphia: B. Franklin, 1748. ECCO: W029578.
} 
inviting leaders to the Logstown conference in May but omitted his commission surveying the Ohio. While he sent his son to inform a nearby chief named Beaver about the Logstown Conference, at the behest of Oppaymolleah, Gist remained in the camp for another day. ${ }^{72}$

Gist began heading southeast towards the Kanawha River only to have his son develop frostbite, which forced them to camp until late January 1752. After the young man had recuperated and could walk again, they continued heading south and crossed into the northern edge of the former Okahok amai on February 17. The landscape he described was snowy and full of muddy areas on the river bottoms, but there were no major signs of Indians within the landscape. Just before entering the Okahok amai, Gist came across a series of landslides that had exposed an entire cliff face. Landslides are common in the Appalachian Mountains, especially during the late winter and spring. Other than describing the good timber of the region, the travel from the Little Kanawha to the Kanawha watershed was uneventful. They reached the edge of the Kanawha River on February 21. At this point, Gist began identifying Indian names, most likely in Shawnee, of the navigable branches of the "Conhaway" River. ${ }^{73}$

The linguistic layers Gist describes within the former Okahok amai had become a mix of Seneca, Shawnee, Delaware and Miami names. The Ohio was named by the Seneca and had become the convention through treaty negotiations among the English and French. The Shawnee had referred to the same river as the Pelawathepiki, but even this term had seemed to fade away by the 1750s. Along the Ohio entering from the Southeast, Gist described a creek called Beyanoss, but he gives no translation. ${ }^{74}$ Gist and his son returned to the Ohio, after camping at the headwaters of Beyanoss, at the mouth of the Lawwellaconin. ${ }^{75}$ Both of these words match

\footnotetext{
${ }^{72}$ Quote "seemed": Darlington Gist 1893: 71-72.

73 Ibid, $72-74$.

${ }_{75}^{74}$ Beyanoss is now called Sandy Creek, the camp was near Sandyville, West Virginia.

75 The mouth of the Lawwellaconin is now called the Little Sandy Creek near Ravenswood, WestVirginia.
} 
closely with Algonquian names and were probably of Shawnee origins. Gist continued naming the creeks up the Ohio till he reached the modern day location of Wheeling, where he left the Ohio and returned quickly to the Company store he had departed from, arriving on March $29 .^{76}$

This trip was significantly less successful for Gist as he wandered through territory that would be difficult to settle. In fact, the English would not be able to maintain permanent settlements in the Little Kanawha watershed until the beginning of the nineteenth century. The overall effect of Gist's forays into the former Okahok amai was to begin the process of systematically encoding geographic information into the nascent cultural landscape of the British. The efforts of Gist, Walker and Bienville fostered further European interest in the region and fueled the westward push of British settlers, but it simultaneously fomented the fires of animosity among Shawnee, Delaware, Mingo, and other Ohio Indians that would soon threaten to catch the world on fire. ${ }^{77}$

\section{Shawnee-Iroquois divisions 1752-55}

The détente established after 1748 between the Shawnee and the Iroquois crumbled almost as soon as it had been forged. Christopher Gist had invited the residents of the Ohio valley to Logstown for a May conference to discuss the tensions that had driven a wedge between the English and the Western Indians. This was the very reason the Shawnee had courted Tanachrisson and other Ohio Iroquois to assist them. It stemmed from a meeting eight years earlier between the Iroquois and English at Lancaster, Pennsylvania in which a broad treaty had been agreed upon protecting English settlements east of the Allegheny Mountains. Since the agreement, the Governors of Virginia and Pennsylvania had interpreted the document based on

\footnotetext{
${ }^{76}$ Darlington Gist 1893, 74-79.

77 This region, due to its rugged late stage dendritic river systems and limited bottom lands, is still much less populated than the bordering Monongahela or Kanawha watersheds.
} 
the original charters of the colonies to include all lands west to the Ohio River. The conference transcript recorded that:

"The Sachims or Chiefs on behalf of the said Six Nations Do here-by renounce and disclaim not only all the Right of the said Six Nations but also recognize and acknowledge the Right and Title of our Sovereign the King of Great Britain to all the Land within the said Colony as it is now or hereafter may be peopled and bounded by his said Majesty our Sovereign Lord the King his Heirs and Successors." 78

The treaty did not specify what the specific western border was, but there were two main problems for the document for those living within the Ohio Valley. First and foremost, the residents did not recognize the authority of the Iroquois chiefs present at the meeting in 1744 to give away the lands. There were no Ohio Indians present at the conference, otherwise they certainly would have argued bitterly at the broad terms of the land transfer. Second, neither the Indian attendees nor the residents of the Ohio recognized the "Land in the said Colony of Virginia" as extending all the way to the Ohio. ${ }^{79}$

The proceedings of the June 1752 Logstown conference, dominated by Tanachrisson, did little to solve the discrepancy. George Croghan opened on June 4 with the bold suggestion that "you [Iroquois] made a Deed recognizing the King's Right to all the Lands in Virginia, as far as it was then peopled, or hereafter should be peopled, or bounded by the King, our Father." While the "deed" was real, Croghan misunderstood the role Ohio Indians in its creation. He assumed that Tanachrisson and all Ohio Indians were willing and contributing parties to the transactions of the previous treaty. He continued to exhort the attendees to "confirm" the legitimacy of the

\footnotetext{
${ }^{78}$ Treaty of Lancaster 1744: Warren 2014, 159, 178, 198, 199, 220.

${ }^{79}$ The First Charter of Virginia, April 10, 1606, Hening's Statutes of Virginia, I, 57-66; The Second Charter of Virginia; May 23, 1609, Hening's Statutes of Virginia, I. 80-98; The Third Charter of Virginia; March 12, 1611, Hening's Statutes of Virginia, I. 98-110; and Treaty of Lancaster 1748.
} 
Treaty of Lancaster as the English understood it because the King desired "to make a Settlement of British Subjects on the South East Side of Ohio, that we may be united as one People." This unsurprisingly confirmed the worst fears of the residents of the middle Ohio. The Shawnee had removed to Sonontio and their small hunting camps in the former Okahok amai because of the distance from English settlers; it had provided a protective buffer. But Croghan did not stop there, instead he brazenly "reminded" the Ohio Indians that the English King "is not like the French King, who calls himself your Father, \& endeavoured about three Years ago with an armed Force to take Possession of your Country, by setting up Inscriptions on Trees, and at the Mouths of Creeks on this River, by which he claims the Lands." The hypocrisy of Croghan's speech was not lost on Tanachrisson or the Ohio Indians in attendance. ${ }^{80}$

To his credit, Tanachrisson rebuked Croghan on June 11 for his disingenuous speech and reiterated the oft spoken criticism of his broad interpretation of the Treaty of Lancaster. He mirrored the criticism Gist had heard at Oppaymolleah's camp near the Monongahela River on December 17, 1751 in which he wondered where exactly Indian lands were if the French and English claimed their respective side of the Ohio. Tanachrisson added to the list of culprits chipping away at the rights of the Ohio Indians. He noted that Croghan had "produced a Copy of the Deed, made by the Onondago Council at the Treaty of Lancaster," and pointedly rebuked the Pennsylvanian for asking the Ohio Indians to "confirm" it. He further attacked the terms wondering about the "King's Right" to extend his claims "whenever he shall think fit to extend his Settlements." He closed his initial response to Croghan by offering that they were "willing to confirm any Thing our Council has done in Regard to the Land," with the caveat that "we never

${ }^{80}$ Loggstown 1752: McConnell 1992, 95-96, 98, 111; Lakomäki 2014, 66-67. 
understood, before you told us Yesterday, that the Lands then sold were to extend further ... than the Hill on the other Side of the Allegany Hill." After this, he declined to say more. ${ }^{81}$

Tanachrisson returned to speak with Croghan and the commissioners on June 13 only to affirm that "we assure you of our Willingness to agree to what our Council does or has done, but we have not the full Power in our Hands here on Ohio" and sought leave to discuss the matter further with the Council at Onondaga. Later that day Tanachrisson met with Croghan and others in a private meeting that was not recorded. "They retir'd for half an Hour, \& then return'd, \& Mr. Montour said they were satisfied in the Matter \& were willing to sign \& seal the Writing," thereby confirming the rights of the English to settle east and south of the Ohio. Whatever was said there, Tanachrisson returned to the larger conference and signed the confirmation much to the surprise and anger of attending Shawnee, Delaware and probably a few Mingo. His language was entirely more pleasant as he addressed the gathering. He formally acknowledged their:

"Consent \& Confirmation of said Deed in as full \& ample a Manner as if the same was here recited. And whereas his Majesty has a present Design of making a Settlement or Settlements of British Subjects on the southern or eastern Parts of the River Ohio, called otherwise the Allagany. We ... do further promise that the said Settlement or Settlements shall be unmolested by us, and that we will, as far as in our power, assist and Protect the British Subjects there inhabiting." 82

Whatever Tanachrisson was thinking at the Logstown conference, the supposed "agreement" would not assuage the troubles in the Ohio. Even the English, who manufactured the deal, would remain unsatisfied till Ohio Indians stopped crossing the Appalachian Mountains.

\footnotetext{
${ }^{81}$ Croghan and 1752 Loggstown treaty: McConnell 1992, 92-99; White 1991, 236-237; Hinderaker 1997, 132-134; Downes 1940, 59.

82 Treaty of Loggstown 1752: MPCP 5:533-536.
} 
These words, yet again spoken by an outsider, would plague the Shawnee living in the Ohio for the next eighty years. Tanachrisson, and the other five signers of the Treaty of Logstown, quickly became estranged from their neighbors and found themselves weakened significantly in 1753 and 1754. The Shawnee and Delaware both continued to protest the illegitimacy of the treaty and the threats to their lands in the former Okahok amai. Their relationship with English traders became further weakened in 1753 when Lawachkamicky, a very powerful Shawnee chief, was wrongfully imprisoned for killing a South Carolinian trader. He died in the jail and the power vacuum left behind only further enflamed the Shawnee's desire to protect their hunting territories east of the Ohio along the Kanawha and New Rivers. The brazen development of Draper's Meadows, near Blacksburg, Virginia, and other settlements within the Greenbrier valley became targets for Shawnee men out hunting and in war parties still attacking Catawba mampi. The Shenandoah, Greenbrier, and New valleys became a constant reminder for the Shawnee of the threats they had experienced in the 1710s and 1720s back East. By the fall of 1755 much of those river valleys were under constant attack. The 1755 attack at Draper Meadows, and abduction of the Draper sisters, prompted Virginia to send out Col. Andrew Lewis in 1756 to attack the Shawnee and any other Indians they could find. ${ }^{83}$

Any shred of Shawnee and Delaware autonomy in the Ohio was further undercut in 1754 by the Iroquois, mainly Onondaga led, [awkward]agreement to the Albany Purchase which included all lands up to the Ohio. ${ }^{84}$ The Shawnee maintained even after the Seven Years' War that "You must know that God Who made all things gave us this Country \& brought us through

\footnotetext{
${ }^{83}$ Lawachkamicky: Lakomäki 2014, 67; Ian Steele, "Shawnee Origins of Their Seven Years' War" Ethnohistory 53:4 (Fall 2006): 657-687; Lewis Expedition 1756: David E. Johnston, "Chapter II. 1753 - 1766 (Part 2)" A History of the Middle New River Settlements and Contiguous Territory (Huntington, WV: Standard Printing \& Publishing Co., 1908).

${ }^{84}$ Merritt 2003, 173. Albany Purchase 1754: WJ 1: 495.
} 
this Ground, he gave you a Country beyond the Great Water." ${ }^{, 85}$ Even the failures of Pontiac's Rebellion did not deter the Shawnee from pressing their continued claims to all lands from the Allegheny Mountains west. Nymwha, a younger chief in 1768 chastised the British, explaining that Ohio Indians were "uneasy to see that you think yourselves masters of this Country, because you have taken it from the French, who you know had no Right to it, as it is the Property of us Indians." 86

\section{The Uncertain end of Spring}

Springs in the Little Ice Age were notoriously tempestuous in the Okahok amai, producing floods, droughts, snow, and high winds. In 1730, the ecology of the Kanawha-New valley had been revitalized significantly increasing the appetites of many peoples previously barred from utilizing its resources. By 1750, increased access by Shawnee hunters, along with near constant traffic of traders and warriors, was beginning to weaken the stability of the landscape. Soils and tree cover were no longer part of the management plans of the residents, but extraction of salt and larger fauna had altered the ecology yet again.

Mirroring this lopsided and opportunistic ecological shift, the human landscape had become a hodgepodge of overlapping land claims and competition. The Shawnee cheelakawtha primarily along the Ohio were nodes for systematic utilization of the former Okahok amai. But even these cheelakawtha that had relocated piece-meal to the Ohio to consolidate and preserve their security away from the pressures of Iroquois, French, and English control were again hemmed in by 1755 . Shawnee land claims, at least east of the Ohio, were founded on more recent occupation, but even ancestral occupations were not enough to maintain control of the region. Shawnee sovereignty was undercut by the needs for alliances with the Iroquois, who

\footnotetext{
${ }^{85}$ WJ 3: 211 Missiweakiwa, Shawnee April 7, 1760 Fort Pitt.

${ }^{86}$ MPCP 9: 528 Nymwha, Shawnee, May 3, 1768.
} 
protected their own self-interest in the face of similar threats from both the French and English. This unfortunate setup would eventually lead to further Shawnee dispossession and the supplanting of Indian control of the former Okahok amai during the slow take over by British and then American settlers.

The changing face of Indian control of the land was finalized in 1744 and confirmed in 1752 and 1754, despite Ohio Indian protestations. The borderlands between Indian lands that had moved east after the removal of the Tutelo and Monyton, was pushed back west encroaching again on the Kanawha-New hunting lands of the Shawnee, leaving an uncertain threat to Wahtakai settlements in the region. The garden was set to change hands and be reorganized yet again by the dawn on 1754. Despite a century of contacts with Indians in the middle Ohio, the shifting political fortunes of Indian residents in the region and their slowly diminishing presence permitted Alexander Withers to broadly proclaim in 1895 that:

"When improvements were begun to be made in the wilderness of North Western Virginia, it had been almost entirely deserted by the natives; and excepting a few straggling hunters and warriors, who occasionally traversed it in quest of game, or of human beings on whom to wreak their vengeance, almost its only tenants were beasts of the forest." 87

The land changed hands, the untidy garden abandoned by seventeenth-century Siouan occupants had already begun to show signs of overhunting by both Shawnee and English traders in 1755 . Meanwhile, international and intertribal conflicts turned what had been a desirable cornucopia for thousands of people into a bloodstained battlefield.

\footnotetext{
${ }^{87}$ Withers $1895,45$.
} 


\title{
Epilogue: \\ Tanachrisson, and Jumonville, 1754-1755 \\ The Final Arbiters of the Okahok amai
}

\author{
"Tu n'es pas encore mort, mon père," \\ "Thou art not dead yet, my father." 1
}

As Shawnee hunters hiked down the path from the ridge top above the location of Marmet mampi, they had to pick their way through scrubby secondary growth and medium sized chestnut trees. The paths had been maintained, for the most part, but new paths had been beaten into the land by buffalo and elk. Any evidence of the former mampi was now covered over with at least a foot of soil and blanketed in grasses and reeds. The river had a new Algonquian name after a small branch of the Piscataways, the Conoy, that had joined with the Shawnee at Sonontio. The Conhaway, later rendered Kanawha, ran into the Ohio, whose name had also been changed from its unknown Siouan name. The Yesanechi names that had been etched into the Okahok amai were buried and hidden from the new residents of the region. ${ }^{2}$

The mataque and ati that had lasted many Monyton generations were unknown to the Algonquian and Iroquoian speaking peoples and all but the oldest of stories began with the region belonging to the speaker's people, whether Shawnee, Delaware, Mingo, or Seneca. Though the onqyayun had been managed for agriculture and hunting preserves during the seventeenth century, its fallowing period had produced an over-grown garden and wildlife refuge that obscured much of this past. The Shawnee, Delaware, and Mingo began widespread and yearly systemic hunting that thinned the mid-range grazers, namely deer, and thinned the population of smaller fur animals, like mink and beaver. This unbalanced the ecosystem leading aggressive predator competition, namely wolves, to attack the few herds of cows and sheep

\footnotetext{
${ }^{1}$ Journal of Chaussegros de Léry, 1940, 27-28.

${ }^{2}$ Conoy: early developments of Conoy in Maryland in Potter 1993, 19-24; Conoy in the Ohio: Warren 2014, 159164, 202; Lakomäki 2014, 43-47.
} 
brought by English settlers. Meanwhile, the general decrease in systemic fire-use may have also contributed to the perception of the former Okahok amai as an impenetrable tangle of mountain laurel as it had certainly become by the 1750 s. $^{3}$

The height of Shawnee occupation, the Algonquian summer, began in 1740 and lasted till the late 1770s. More research is required before the exact dynamics of their mature landscape usage are established, yet one thing is certain: through Shawnee hunters the former Okahok amai had become integrally incorporated into the deerskin trade that was fueling the Shawnee economy of the eighteenth century.

Although much had changed since the demographic collapse of the seventeenth century, by the mid-eighteenth century the former Okahok amai had regained a robust if mobile human population. Much like the multi-ethnic mampi of the seventeenth century, the village "republics" along the Ohio were diverse and growing polities connected through marriage and adoption to the network of nations in the Southeast and Northeast. The social complexity of this region, including the changes and continuity with the seventeenth century, was violently played out on the morning of May 27, 1754 beside a small secluded rock shelter in the Monongahela watershed.

Much like this story began, the ending occurred outside the borders of the Okahok amai. The bloody morning of May 27, 1754 at Jumonville Glen in Pennsylvania began the final decline of Indian control of the former Monyton Onqyayun. This moment also brought the story of the former Okahok amai back to its Siouan roots in the form of Tanachrisson, the Flat-Head "HalfKing." The actions and legacy of Tanachrisson link the multi-ethnic world of the seventeenthcentury Monyton to the rebirth of the multi-ethnic cheelakawtha of the mid-eighteenth century.

\footnotetext{
${ }^{3}$ Unbalanced ecosystem overhunted: T.P. Rooney, "Deer impacts on forest ecosystems: a North American perspective" Forestry 74: 3 (2001), 201-208.
} 
The landscape was again vibrant with settlements, agriculture, hunting, and warfare, much like it had been under Siouan control. The world seemed so different, yet hidden in the events of 1754 was the legacy of the Okahok amai.

According to the backstory he provided to the French in the 1740s, Tanachrisson had been abducted from Catawba parents by a Seneca war party, probably around 1690-1700. He was adopted into his new Seneca family and as a Seneca man rose to prominence during the 1720s. This led to him being sent as a representative of the Seneca at Logstown. This may not have gone as the Iroquois had hoped, as Tanachrisson had earned clout among dissident Seneca, Cayuga, and a few Onondaga living in the Ohio Valley. He also was able to court the Shawnee and Delaware by promising to negotiate on their behalf with Virginia and Pennsylvanian officials. As discussed earlier this did not turn out so well when Tanachrisson shocked the Shawnee and Delaware at Logstown in 1752 by confirming the 1744 Treaty of Lancaster, thereby giving the English all lands up to the south and east of the Ohio River. ${ }^{4}$

This put Tanachrisson, along with all the other half-kings, in a precarious political position in the Ohio Valley. He had undercut his position among the majority of residents of the region; but he also had a longstanding and mutual distrust of the Iroquois at Onondaga. His position with the Ohio Indians could be fixed through distribution of English trade goods, but his access to those trade goods was predicated on his clout with the very Wahtakai he alienated in 1752. Tanachrisson was pulled into open war with the French when George Washington was sent in 1753 to build a fort at the fork of the Ohio (Map E.2). Tanachrisson had been promising this to his Ohio Indian supporters and Washington's appearance seemed to be the perfect opportunity to begin rebuilding his reputation. Unfortunately for him, a detachment of French

\footnotetext{
${ }^{4}$ Tanachrisson's Catawban history: Journal of Chaussegros de Léry 1940, 19; McConnell 1987, 101-106; Anderson 2001, 18, 20-21; White 1991, 225-226; McConnell 1992, 68-69, 75-76.
} 
troops arrived to kick out the English and build Fort Duquesne instead. After Washington retreated, Tanachrisson attempted to engage the French troops but his Delaware and Shawnee allies abandoned him in the face of stiff French resistance. So when Christopher Gist returned to the Allegheny River with George Washington in the spring of 1754 in order to remove the French at the forks of the Ohio, modern day Pittsburgh, Pennsylvania, Tanachrisson saw an opportunity to shore up his authority and make the most of the English visit. ${ }^{5}$

On the surface, the events surrounding the beginning of the Seven Years' War were centered on the upper Ohio, but the former Okahok amai was connected to every aspect of the nascent conflict. Ensign Joseph Coulon de Villiers, Sieur de Jumonville was dispatched by Claude-Pierre Pécaudy de Contrecœur, commander of Fort Duquesne, southward from the fort to catch Washington's forces before they could reach the forks. On May 24, Washington received a letter from Tanachrisson warning him that a French detachment had been sent out to intercept the English. The Ohio Iroquois were attempting to play the two European powers off one another in hopes that they would leave the Indians largely out of the conflict and clear the land of most of the immediate European threats. Tanachrisson's letter, and subsequent intervention at Jumonville Glen, instead brought the entire region and all its residents into the conflict forcing individuals to choose sides. ${ }^{6}$

As Jumonville settled in for the night in a little secluded glen off the main Catawba warpath on a stormy night on May 27, 1754, Tanachrisson informed Washington of the French force heading to cut off the English. That night, rather than be attacked early in the morning themselves, Tanachrisson led Washington and forty soldiers twenty miles northward. At sunrise, they finally came upon the party. There was a great deal of confusion in the brief fifteen minute

\footnotetext{
${ }^{5}$ Fort Duquesne 1753: Journal of Chaussegros de Léry 1940,19; Anderson 2001, 42-49; White 1991, 232-240; McConnell 1992, 107-108. Arrival of Gist and Washington in 1754: Anderson 2001, 52.

${ }^{6}$ French arrival in May 1754: Journal of Chaussegros de Léry 1940, 19.
} 
skirmish. One French account claimed the English fired without announcing their presence and that Tanachrisson scalped a conscious Jumonville. English accounts tended to focus on the fact the French had responded to Washington's announcement of their arrival by immediately firing back. Fred Anderson claims in his retelling of the Jumonville incident that a second-hand account of Private Shaw best captured the events. In this account, Tanachrisson split Jumonville's skull and grabbed his brains and "washed his Hands with them."7 The fact remains that at the end of the skirmish, Ensign Jumonville was dead along with eleven French men. Yet the gruesome story remained an important reason for the French declarations of war.

Washington, knowing the emotional power of this incident, and seeking to protect his "fragile reputation for military competence," carefully constructed his diary to downplay the role of Tanachrisson and his Mingo warriors and not mention the brutal scalping. ${ }^{8}$

One of the French survivors of Jumonville's campaign reported that Tanachrisson had come to Fort au Boeuf in 1754 and "talked there very boldly, and the report spread that he had killed M. de Jumonville, who was wounded, saying, 'You are not yet dead, my father,' and striking him several times with his tomahawk.” This corroborated much of Private Shaw's account. For the French, this was an affront to military honor in so many ways. Beyond the obvious claims of trespassing, the attack was considered cowardly since Jumonville and others claimed the party was an emissary to discuss the presence of the English. If true, Washington's attack would have been doubly offensive since it was carried out on the sly while the party was waking up and wholly unprepared for the engagement. The last and most significant problem was the context of the killing of Jumonville, the commanding officer. Whether or not Tanachrisson actually scalped and killed the officer, he and other Indian supporters did spread

\footnotetext{
7 “Affidavit of John Shaw," in William L. McDowell Jr., ed., Colonial Records of South Carolina: Documents Relating to Indian Affairs, 1754-1765 (Columbia, SC: 1970): 4-5.

${ }^{8}$ Tanachrisson's visit with Washington: Anderson 2001, 52-59; McConnell 1992, 107-112.
} 
the story. Tanachrisson, though, did not live long enough to benefit. Since the officer's death happened on Washington's watch, the French considered this an act of war by the British military. Tanachrisson, after many years of dealing with both the French and British, certainly considered the weight of such a symbolic move. Any hopes of utilizing this were scuttled when the Half King accompanied George Washington and George Croghan to Christopher Gist's Red Stone Fort to meet with Shawnee, Delaware, and Mingo leaders a few days later in June 1754. The Ohio residents, some coming from as far as Sonontio, declined to join their former spokesman or the English at Fort Necessity to defend against the French forces. This sealed Tanachrisson's fate among the Ohio Indians so he returned to Great Meadows and gathered his family and headed east to Croghan's trading outpost at Aughwick. He died there in October of a mysterious disease (Table 6.1). ${ }^{9}$

Tanachrisson's gruesome and pivotal act carried a meaning hidden even from the adopted Seneca. As an adopted "Teste Plate," "Flat head," better known as the Catawba, Siouan ancestors were able to wring one last act of defiance and revenge upon the forces that had destabilized the former Okahok amai. Many of the Catawba men and women that Tanachrisson had been stolen from, his kin, were related by blood and marriage to the Monyton and Tutelo who had once resided within the Okahok amai. Whether accidently or intentionally, Tanachrisson's actions unleashed an escalated level of war upon the French, the English and even his adoptive family, the Seneca. Tanachrisson provided the lit match that ignited the Seven Years' War. ${ }^{10}$

The violence started by Tanachrisson in Pennsylvania, was simultaneously catching in the south along the Shenandoah and Greenbrier Valleys, on the western edge of Virginia (Map

\footnotetext{
${ }^{9}$ Attack on Jumonville, Anderson 2001, 53-55; White 1991, 240-241. Scalping quote Journal of Chaussegros de Léry 1940, 19; Lakomäki 2014, 68-69; Merritt 2003, 169-174.

${ }^{10}$ Siouan Flatheads: Richter 1983, 537; Goddard 2005, 28, 47, for Waxhaw and Catawba; Aquila 1997, 205-206. Peter Wraxall, An Abridgement of Indian Affairs: Contained in four folio volumes, transacted in the colony of New York, from the year 1678 to the year 1751 (Cambridge: Harvard University Press, 1915), 50-52.
} 
E.1). Shawnee warriors increased their attacks on settlements from the Potomac River mouth of the Shenandoah to the Carolinas. This was reminiscent of the Richecrians in the early seventeenth century, though the stakes were a great deal higher. The homeland of the Siouan languages, the Okahok amai, had been buried, and by 1755 the Shawnee, Delaware, Conoy, Mingo, and others felt their new home was threatened by a tsunami of outsiders yet again. The first permanent British settlements along the Greenbrier River were also established in 1755. The Ohio Indian struggle to maintain their autonomy and distance from intruding European settlers reached a fevered pitch during the Seven Years War and would continue well into the nineteenth century. Tanachrrisson's self-purported act of violence against Ensign Jumonville was the perfect symbol for the complexities of the Ohio valley within inter-tribal and inter-racial relationships. ${ }^{11}$

The Indian story within the region was hardly over. Indians continued to maintain control of the former Okahok amai until the 1770s and would remain in the region up till the present. The metal hatchet Tanachrisson wielded against his fictive French "father" in 1754 connected in swift act all the themes of inter-tribal and inter-racial conflict and collaboration with his Siouan ancestors, longstanding Iroquois attempts to control the Ohio, and faux-European authority. His hatchet had yet again altered the social, political, economic, and environmental composition of the Ohio and in particular the former Okahok amai for the next century. From flint and stone axes to metal hatchets and guns, the world of Indians in the Appalachian Mountains continued to change.

\footnotetext{
${ }^{11}$ Shenandoah -Greenbrier attacks in 1755: de Hass 1851, 41-45; Charles H. Ambler, A History of Western Virginia, to 1861 (West Virginia Collection, Wise library, Morgantown, WV, Manuscript 1931), 19-20, 32-35; William Franklin Horn, "Jacob Horn's Diary 1735-1777" The Horn papers; early westward movement on the Monongahela and upper Ohio, 1765-1795, by W. F. Horn (Waynesburg, Pa., Pub. for a committee of the Greene County Historical Society, by The Herald Press, Scottsdale, Pa., 1945), 2-31, 31-32; Withers 1895, 60-61.
} 


\section{Future Research and Modern Implications of the Monyton Diaspora}

This body of work began as a challenge to the commonly held belief that West Virginia was just a "common hunting ground." I hope to have started a conversation here that will continue with the very real fact that Native Americans, Wahtakai have lived within the boundaries of this state for thousands of years and continue to in the twenty-first century. The indigenous history of the Ohio region has proven to be a microcosm of the complex and seemingly contradictory nature of Indians across the entire continent. Each chapter held promising questions for further examination, especially regarding the role of human-environment interactions in steering history. The work of archaeologists, climatologists, and ecologists all will become increasingly useful for future research within the former Okahok amai.

There are important real-world twenty-first century applications of the connections discussed above that honor the Wahtakai that used to live here. The difficulty of establishing specific cultural affiliations for the archaeological materials in West Virginia has been a stumbling block in the application of the Native American Graves Protection and Repatriation Act (NAGPRA) of $1990 .{ }^{1}$ This law was intended to provide a legal mechanism for returning remains to the appropriate tribal group to be handled per that group's cultural tradition. Nonnative academics must find ways to show respect to the individuals found buried within West Virginia, but the question is how to do this with no federally recognized tribes currently residing in the state. In 2013 a rule change opened up increased potential through a "proxy" federally Recognized Tribe. Basically, if a known tribe adopted or incorporated some or all of the residents in their own nation, then the historical connection could be used to facilitate the

\footnotetext{
${ }^{1}$ NAGPRA, 1990: http://www.nps.gov/archeology/tools/Laws/nagpra.htm, accessed on Feb. 13, 2015.
} 
protection of the remains. ${ }^{2}$ This dissertation establishes the strong connections between the multi-ethnic mampi within the seventeenth-century Okahok amai and their later homes among the Catawba, Seneca, Cayuga, Monacan, Creeks, Cherokee, and Shawnee. This dissertation hopefully, with the help of these nations, will begin a stronger role for the tribes in the state of West Virginia.

While the active participation of federally recognized tribes in protecting and managing West Virginia's cultural heritage is an important goal, so much more research remains to continue the Indian history began above. This dissertation captures a time period previously ignored, but the aftermath of Siouan control was not characterized by the immediate European take-over but rather a gradual shift away from Shawnee and other Indian control. Future research should continue the discussion of Indians in the former Okahok amai past the Seven Year's War and into the revolutionary period. Even the period of Indian Removal, the Civil War and the long twentieth century have hidden stories of Indians that remain important for the social and political well-being of West Virginia's growing Indian communities.

\footnotetext{
${ }^{2}$ Nagpra Proxy ruling 2013: http://www.gpo.gov/fdsys/pkg/FR-2013-05-09/html/2013-10966.htm, accessed on Feb. 13, 2015.
} 
Maps 


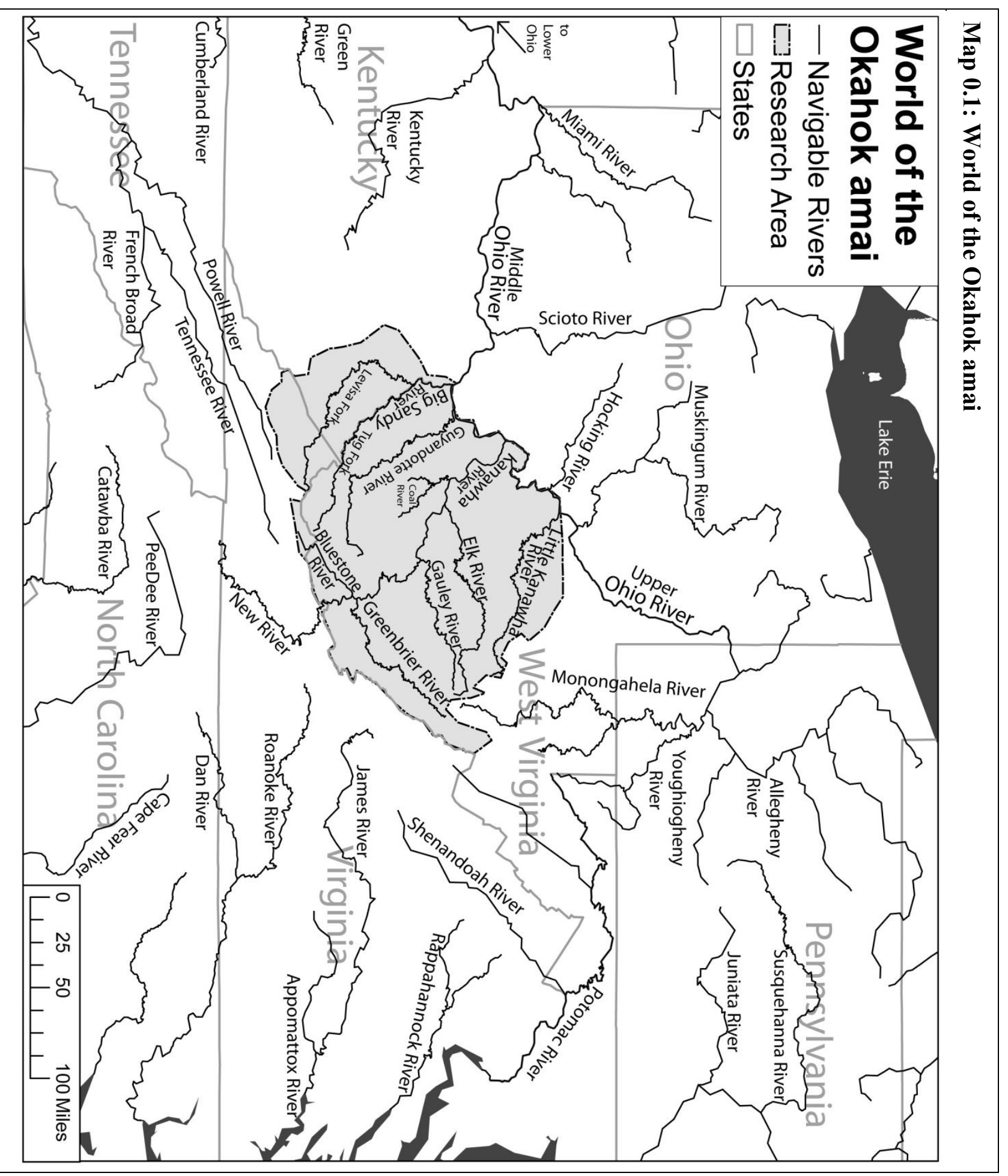




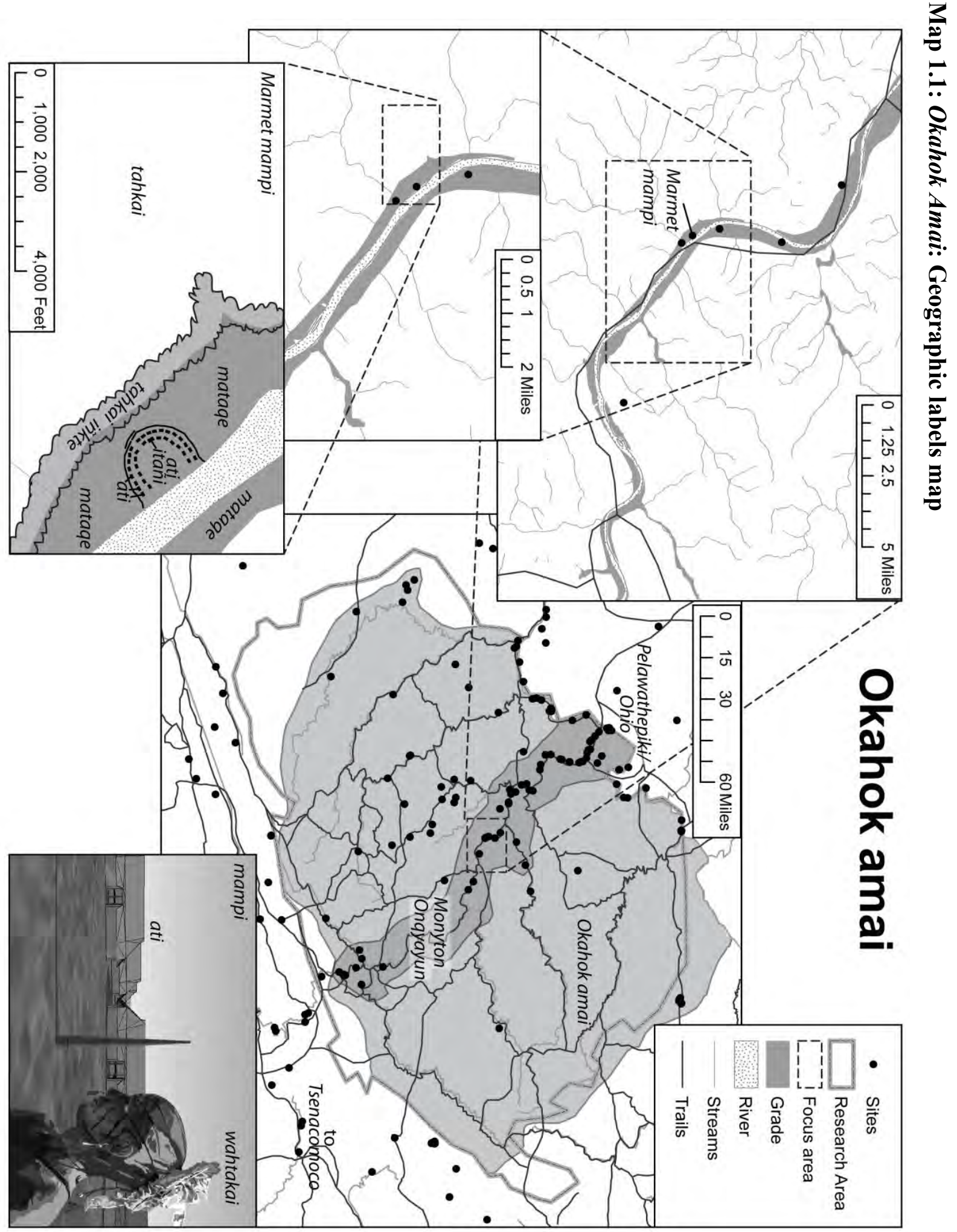




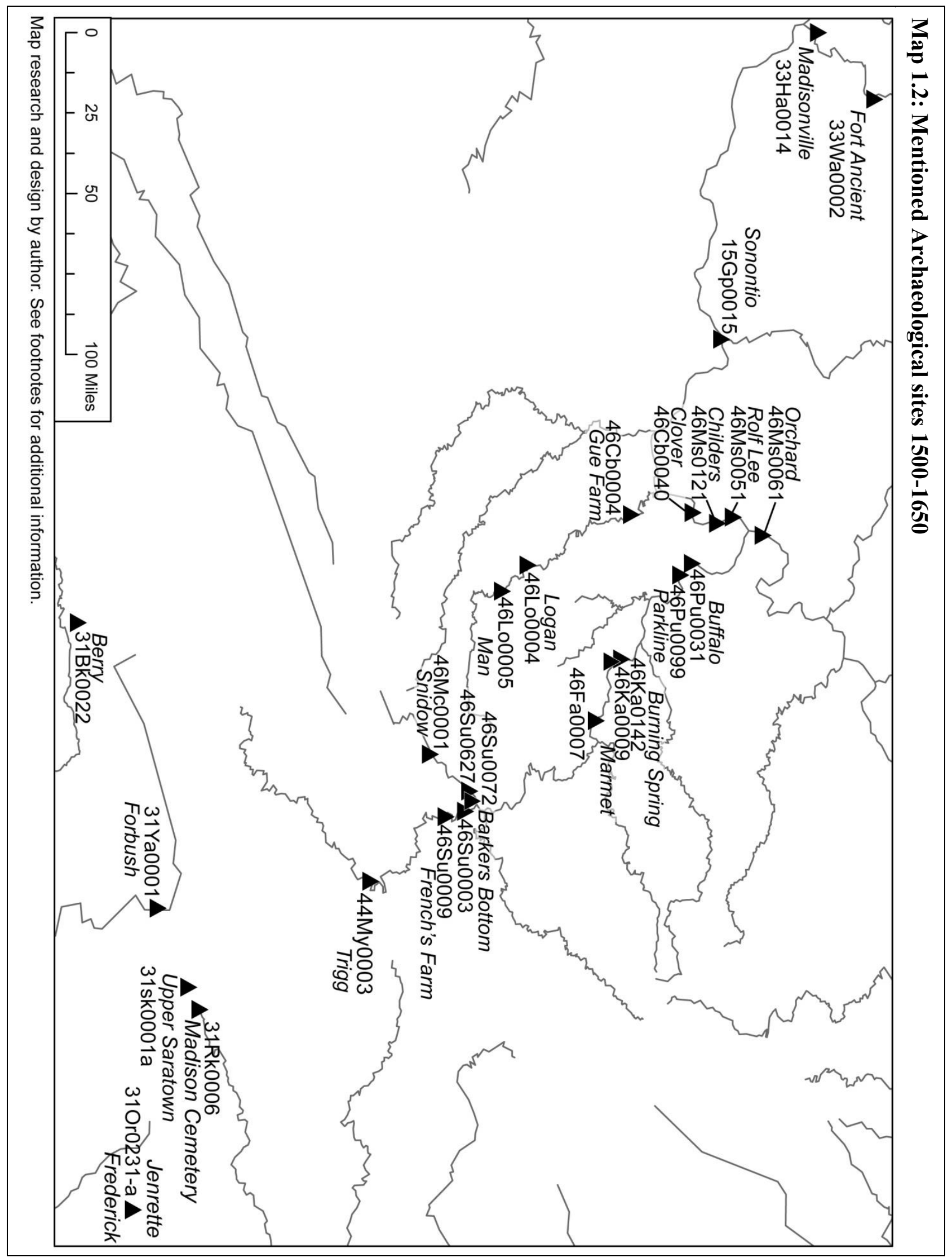




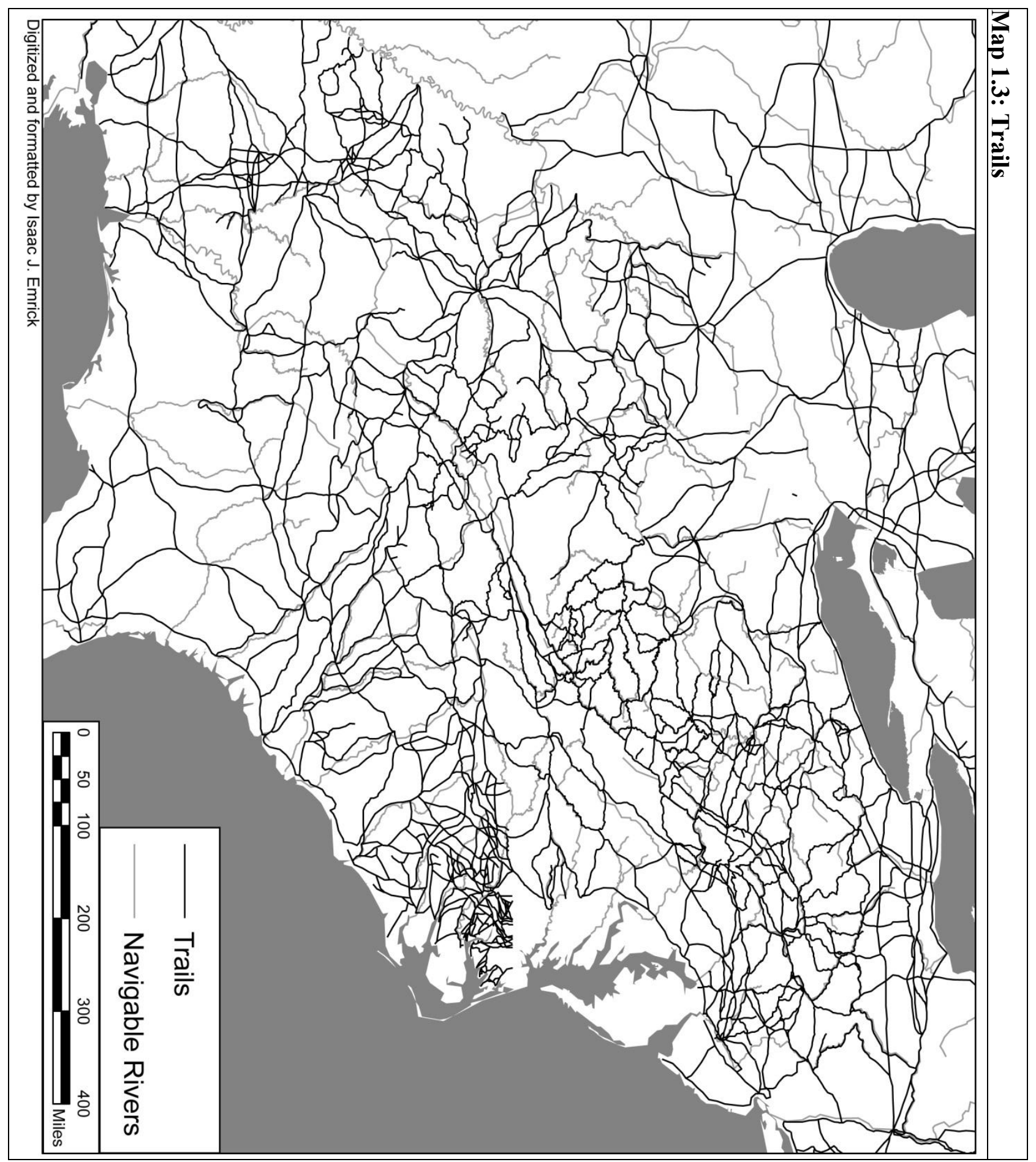


Map 1.4a: Z-Twist Percentages at Middle-Late Woodland Sites

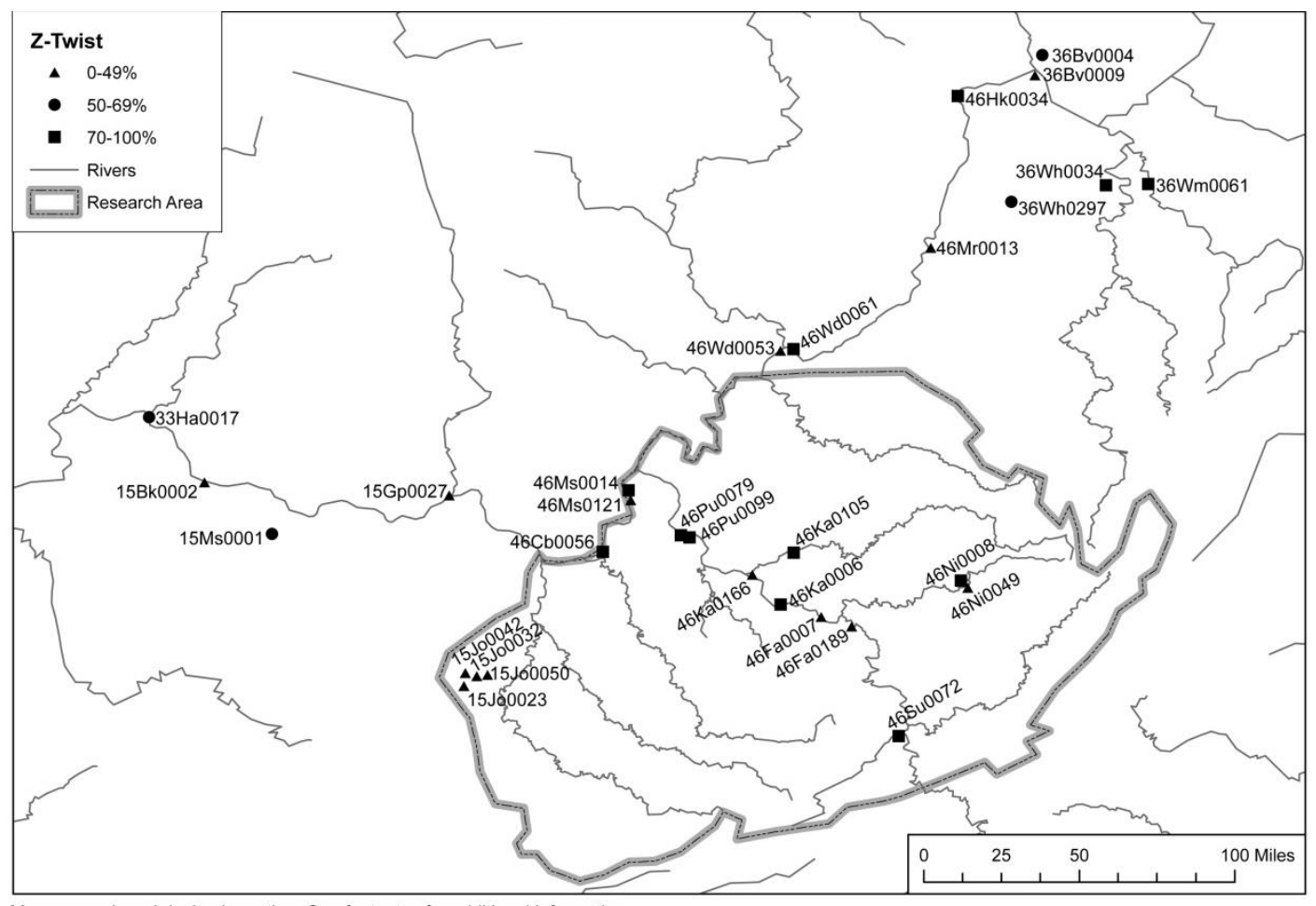

Map research and design by author. See footnotes for additional information.

\section{Map 1.4b: Z-Twist Percentages at Late Protohistoric Sites}

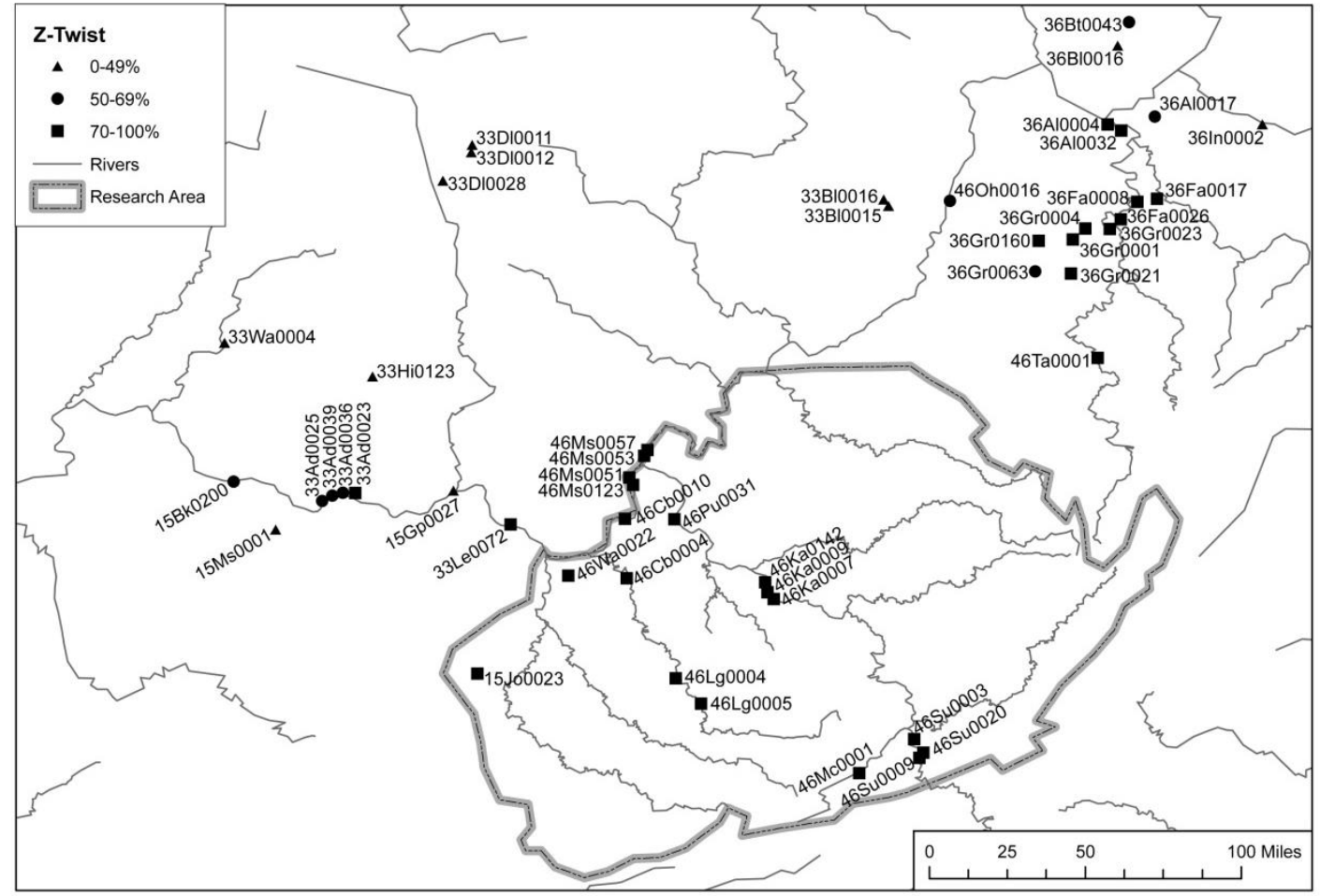

Map research and design by author. See footnotes for additional information. 


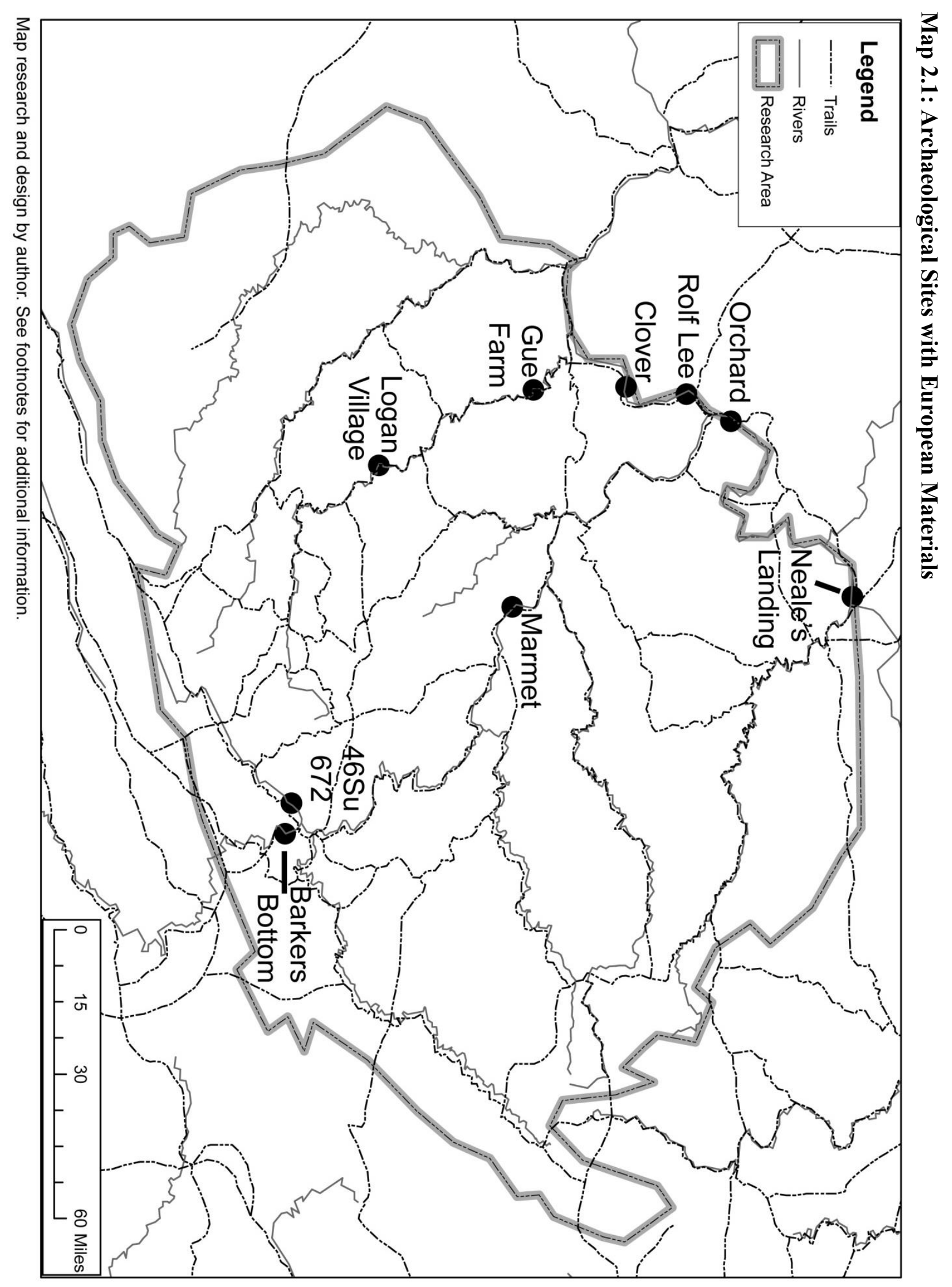


Map 2.2a: Spanish exploration 1526-1543

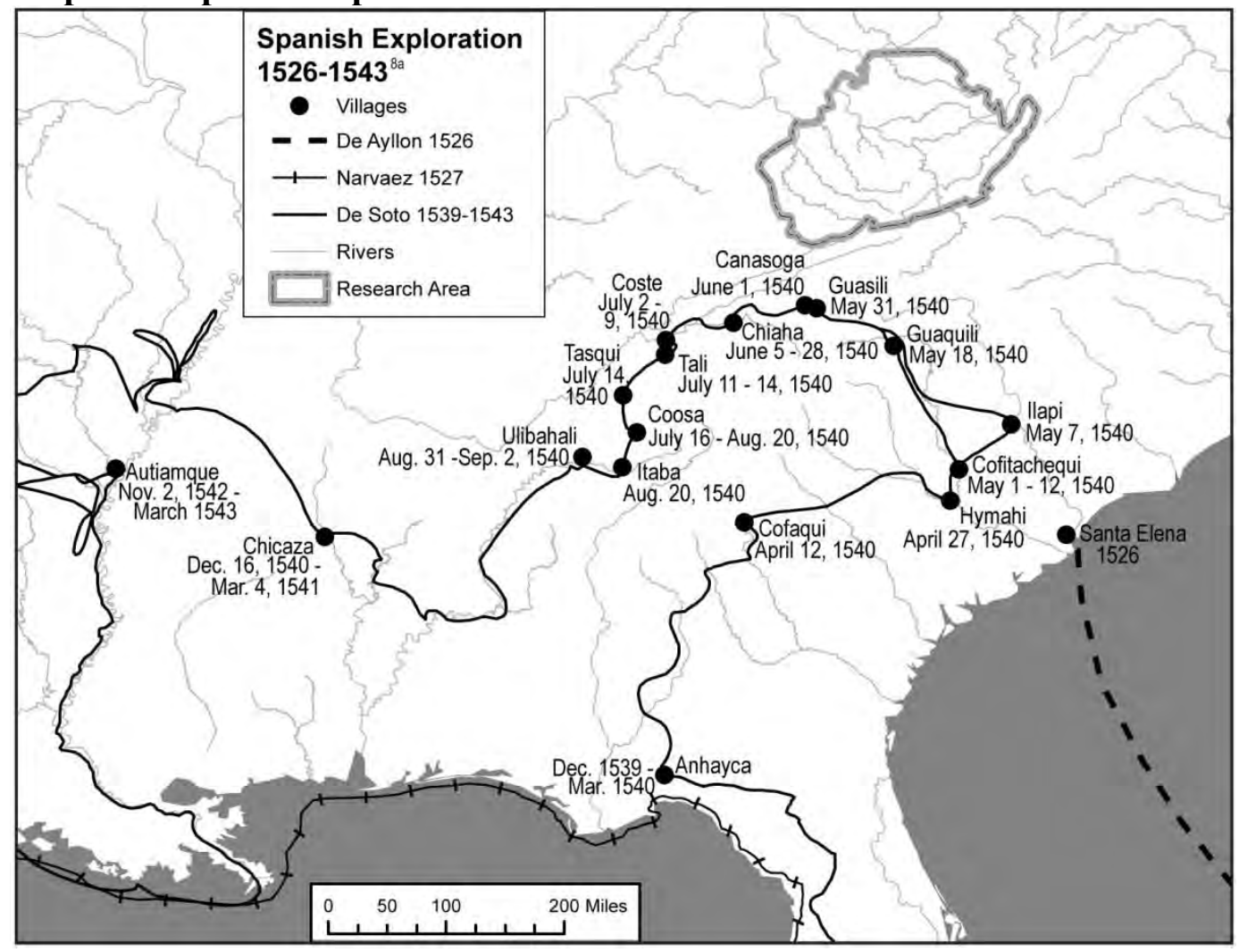

\section{Map 2.2b: Spanish exploration 1543-1600}

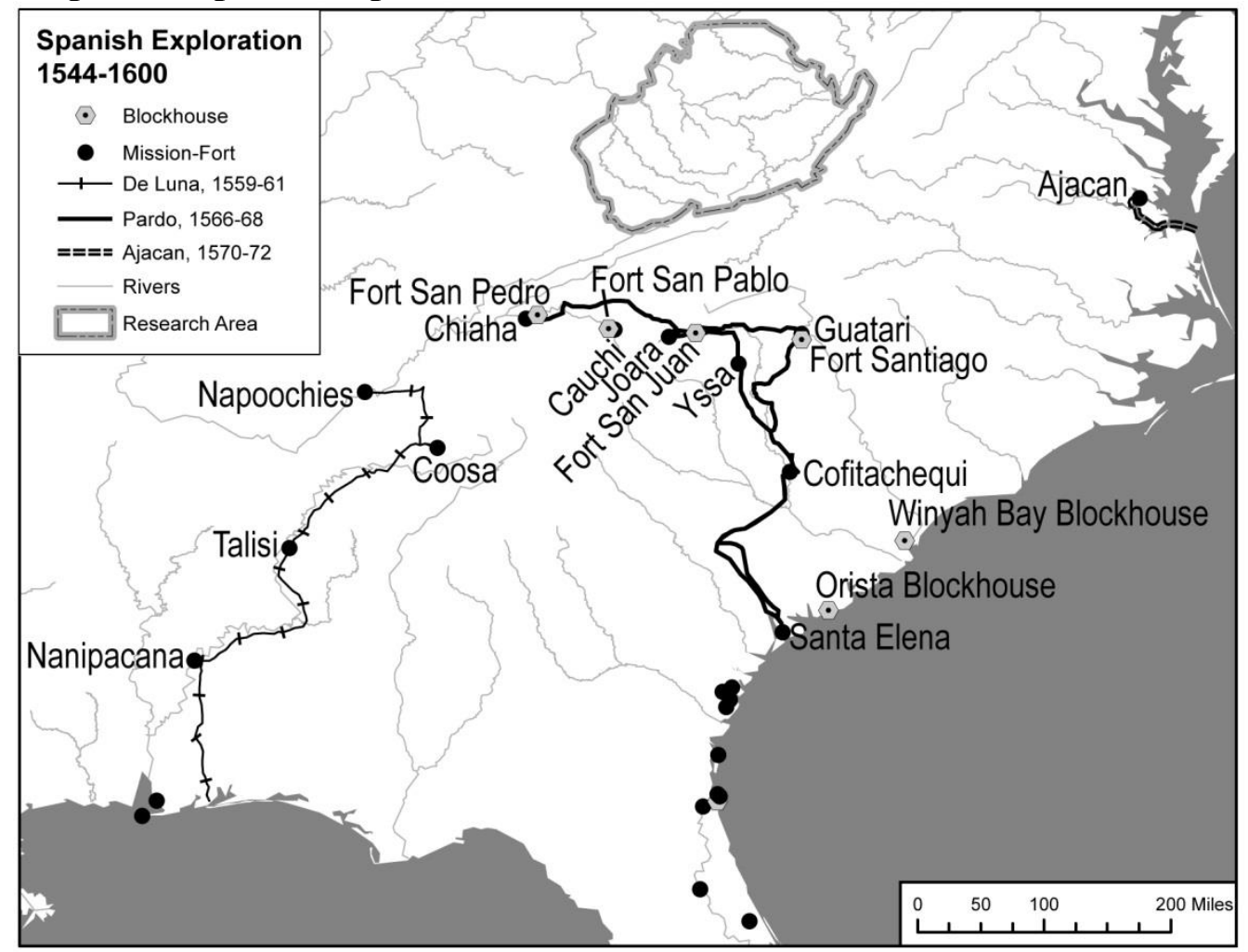


Map 2.3: French Dutch exploration 1530-1650

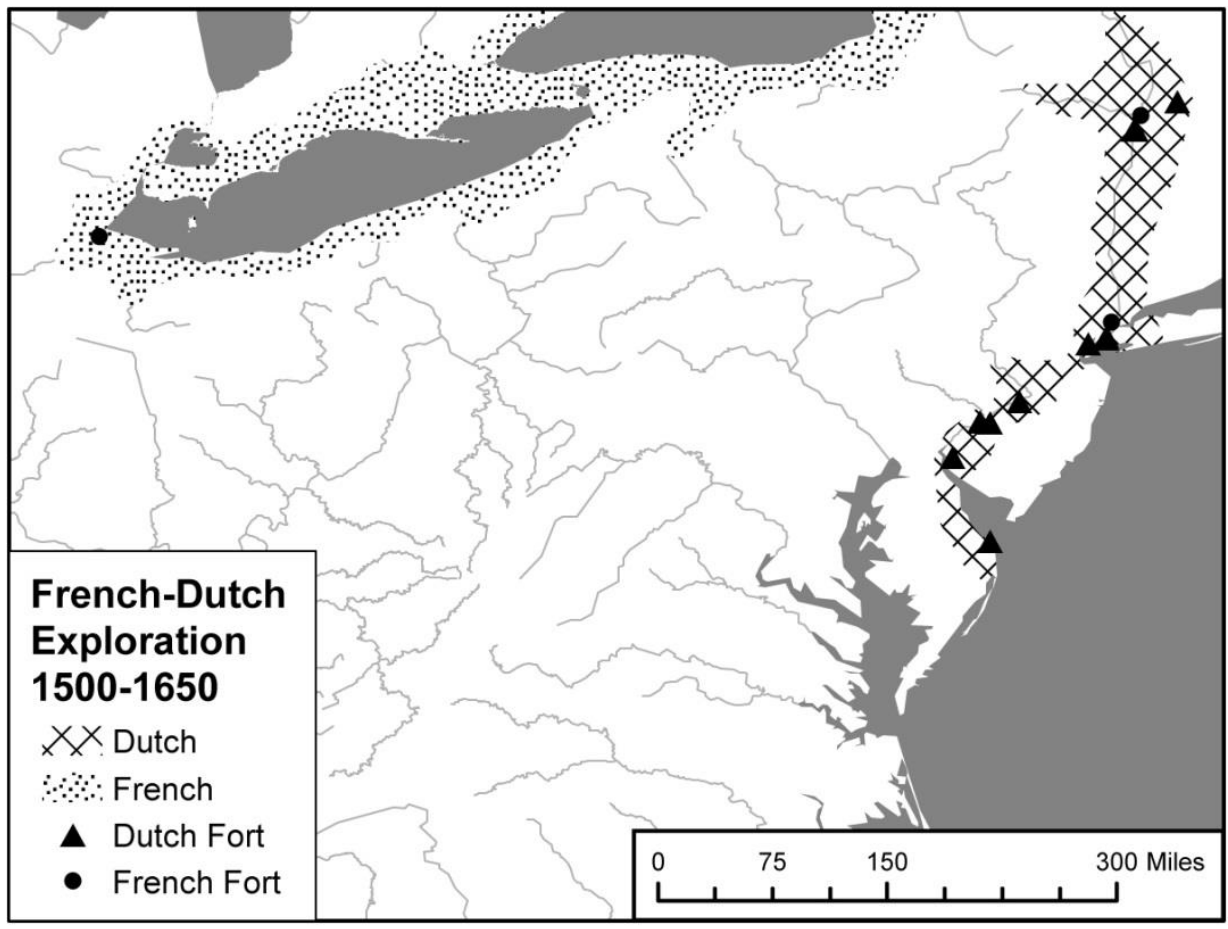

Map 2.4: Tsenacomoco exploration 1607-1650

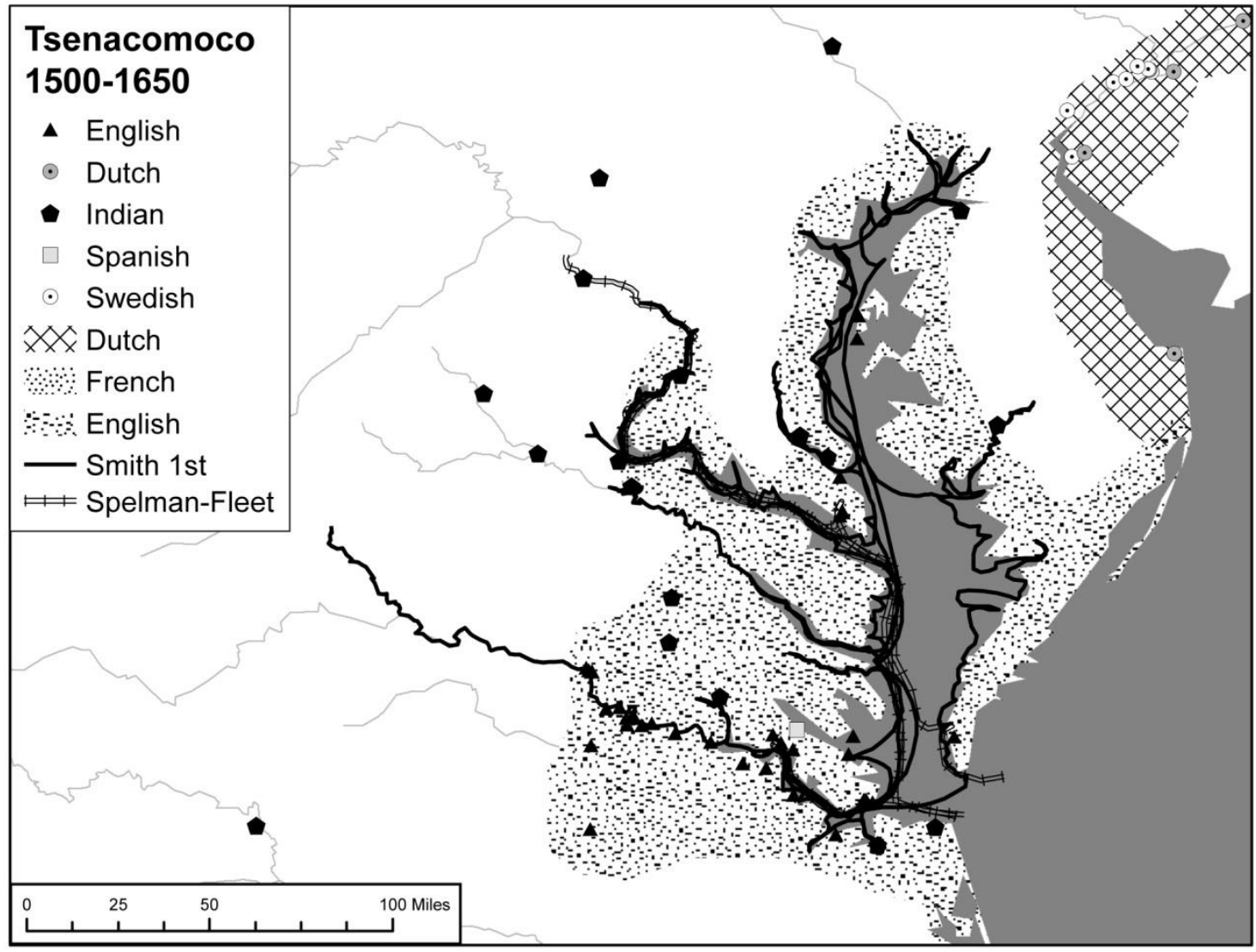




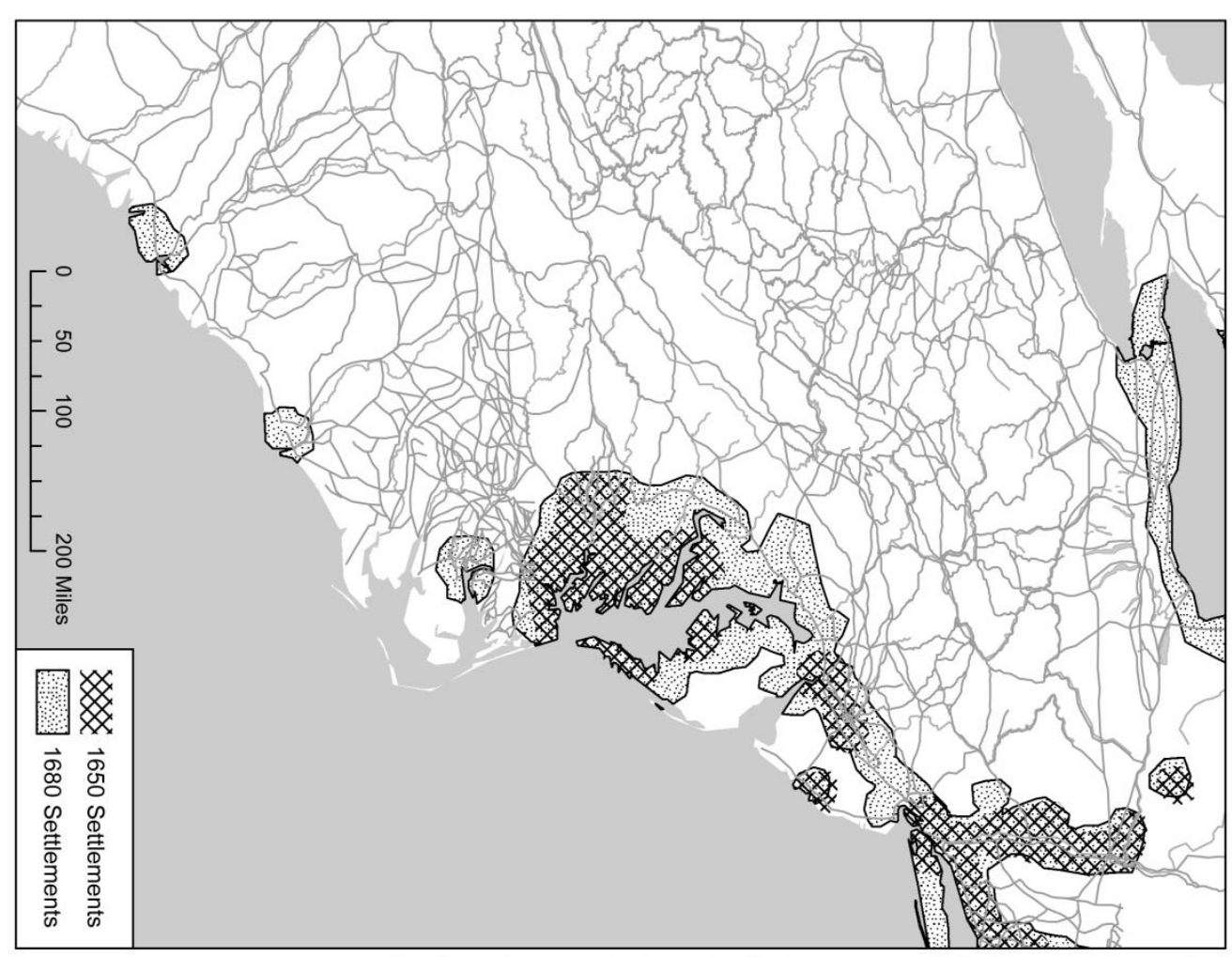

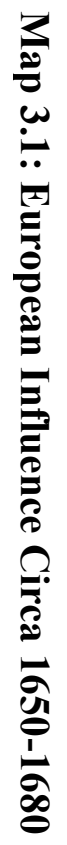

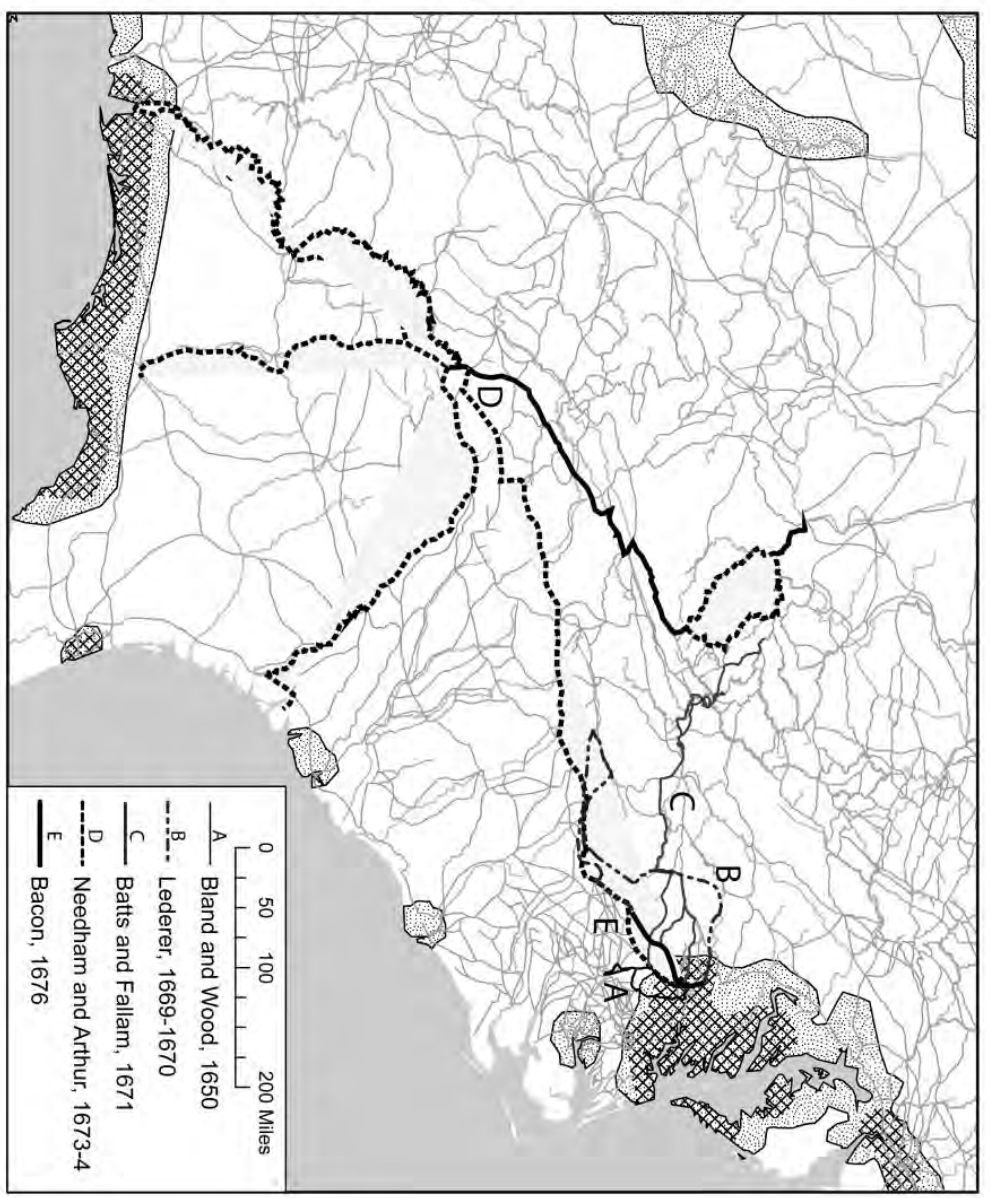

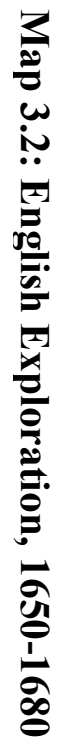



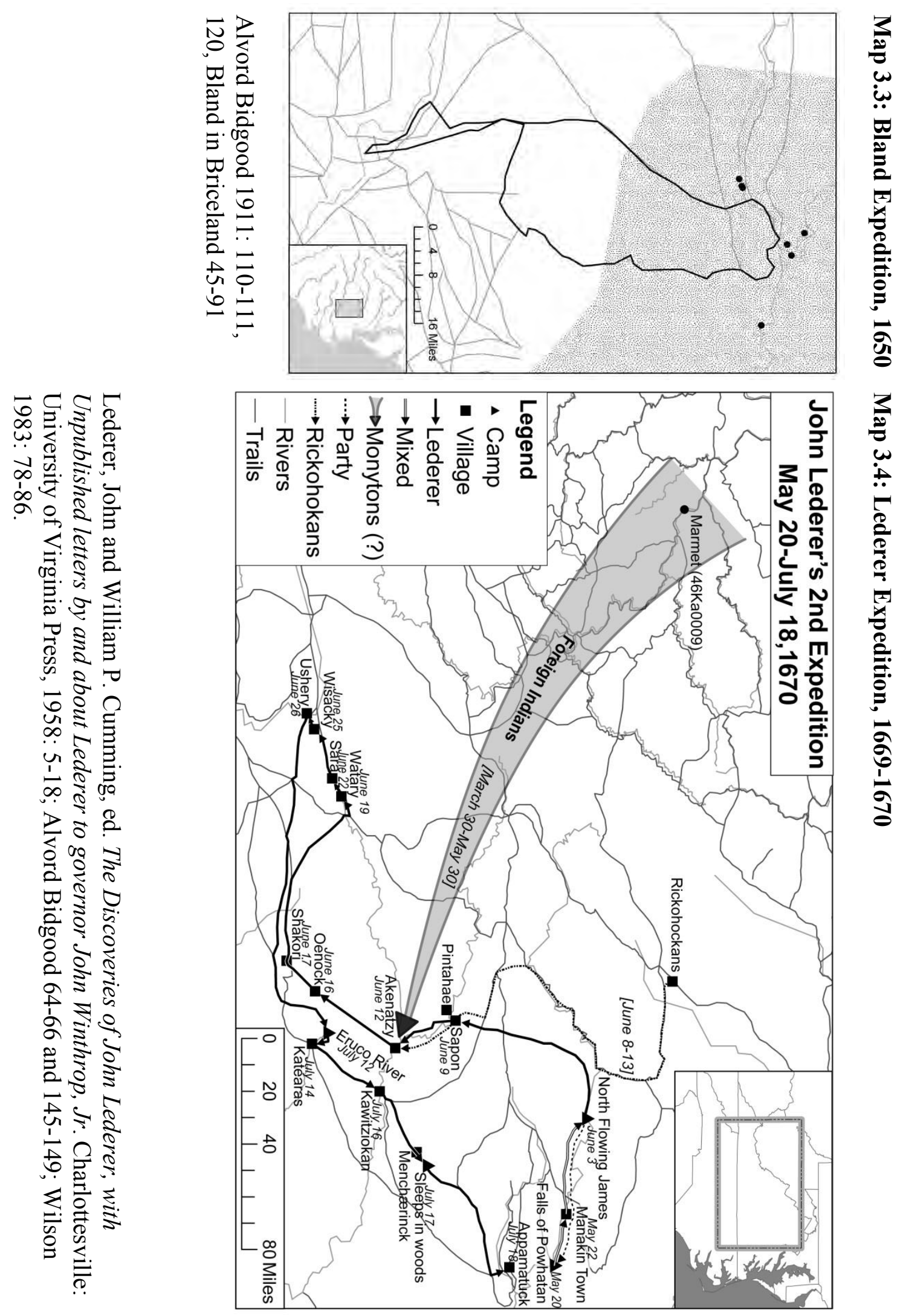
Map 3.5: Batts and Fallam Reconstructions from 1911 and 1987

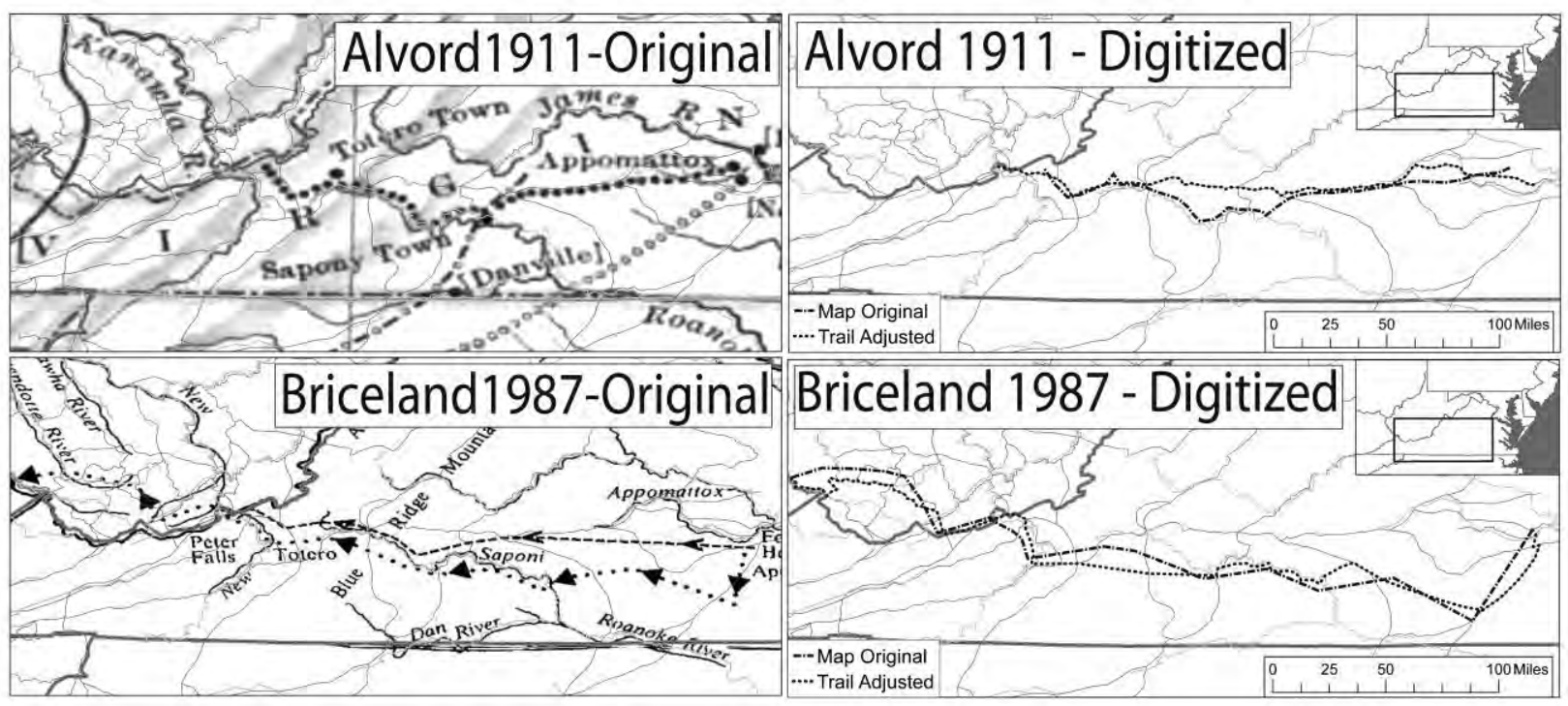

Alvord Bidgood 70-77, 183-204; Briceland 124-146.

Map 3.6a: Batts and Fallam Adjusted Reconstruction

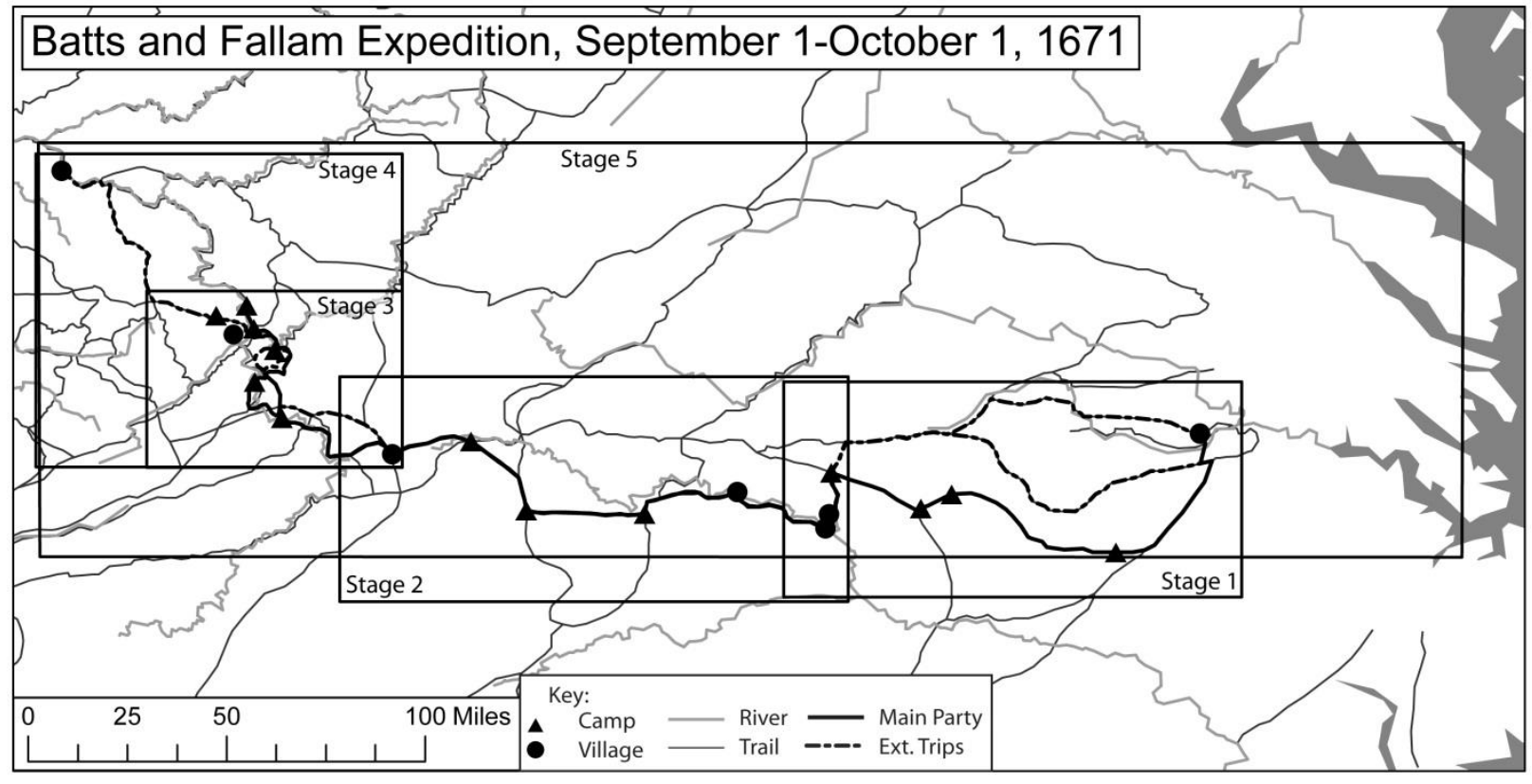


Map 3.6b-c: Batts and Fallam Reconstruction: Stage 1-2
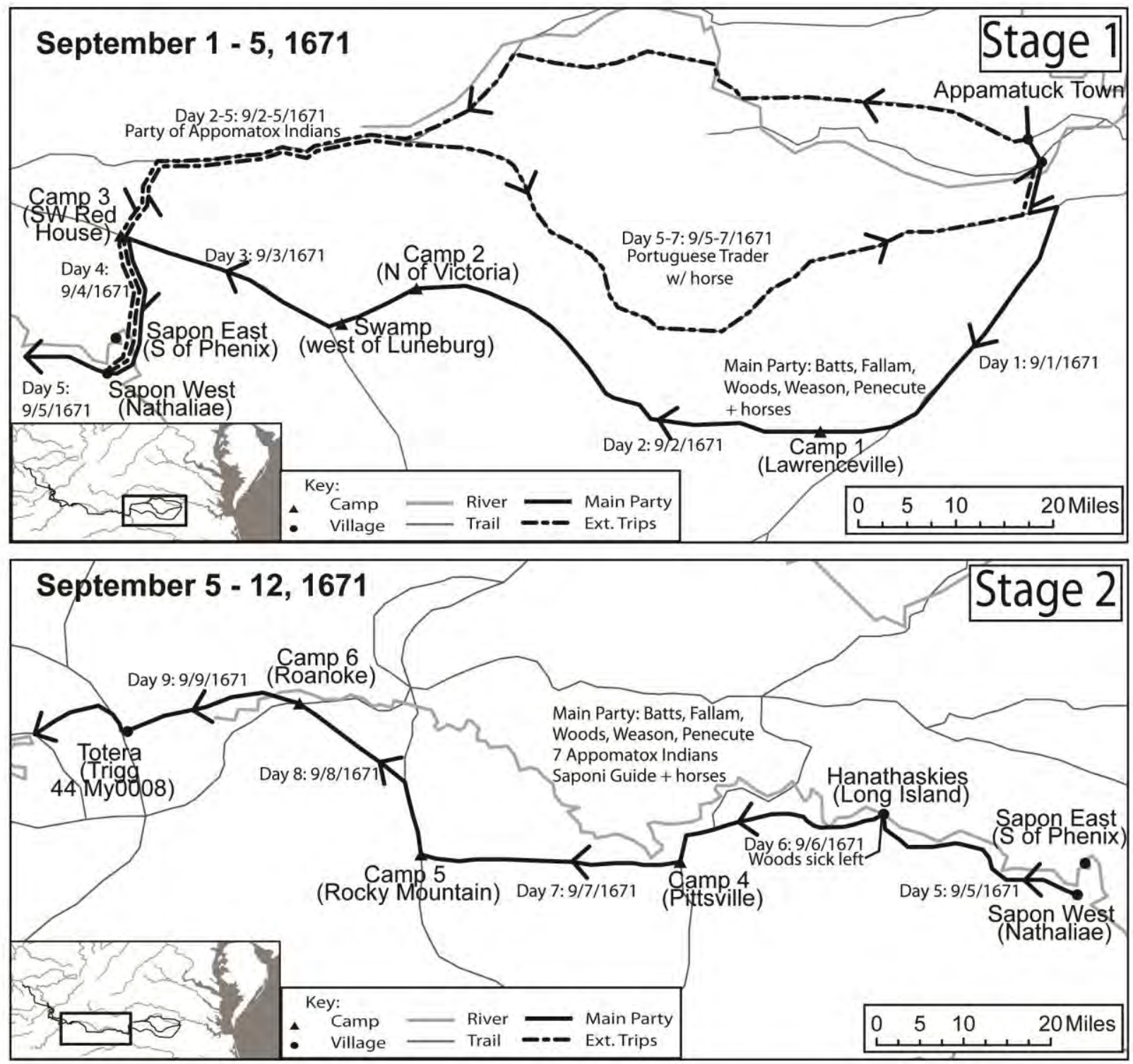

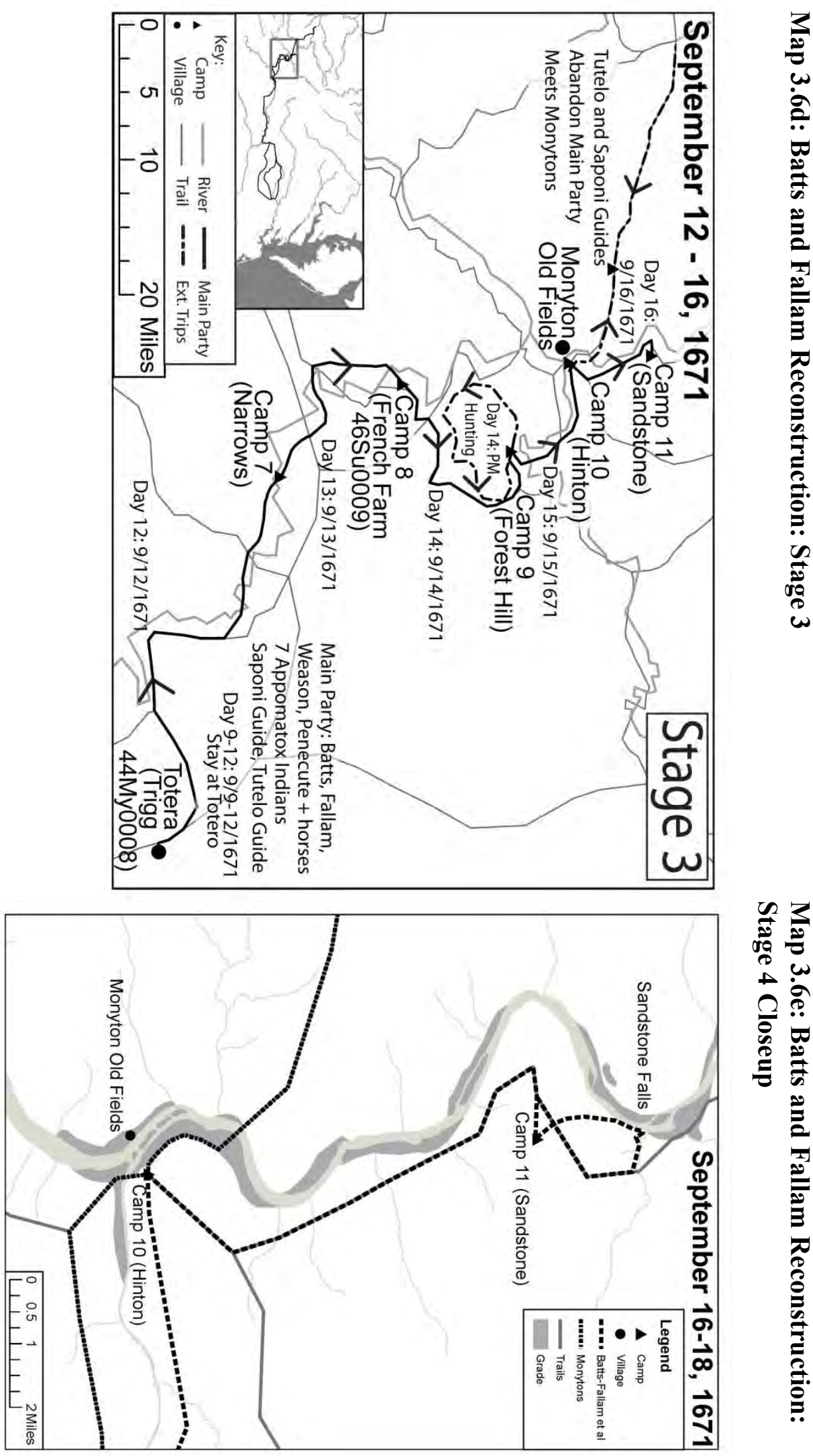
Map 3.6f: Batts and Fallam Reconstruction: Stage 4

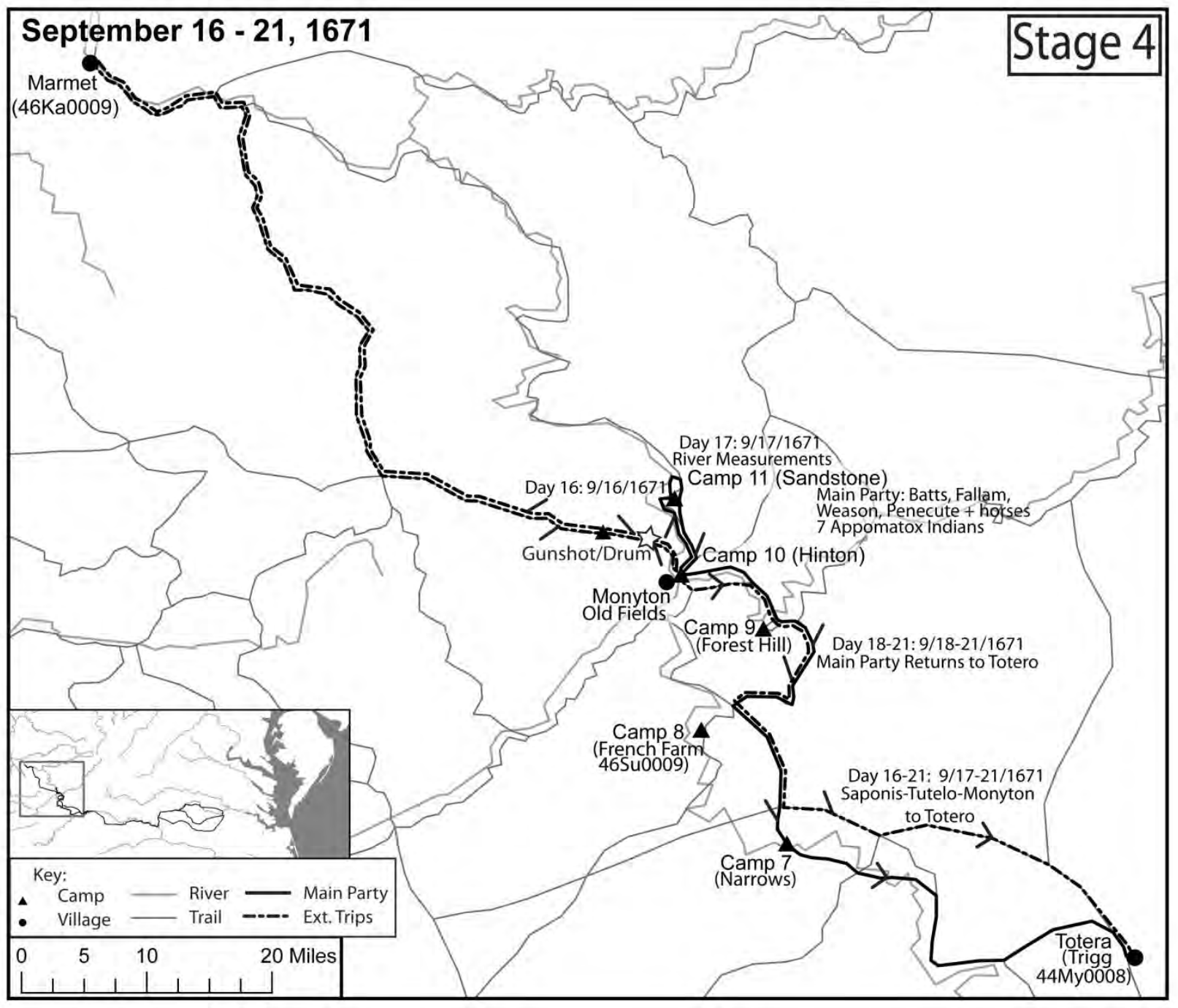

Map 3.6g: Batts and Fallam Reconstruction: Stage 5

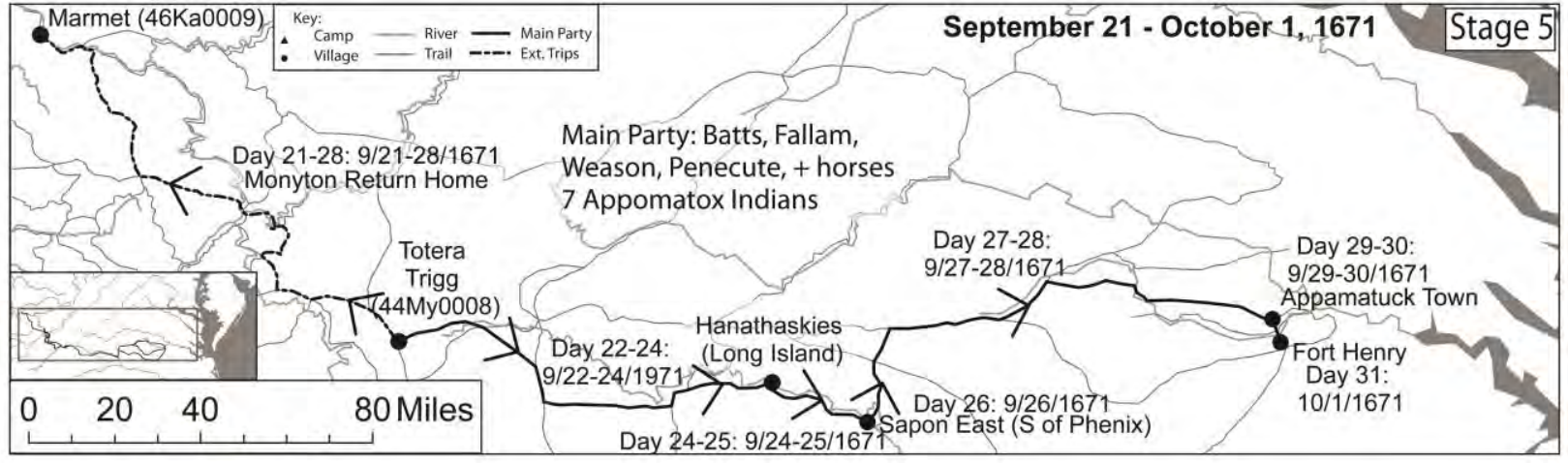


Map 3.7a: Needham-Arthur, 1911

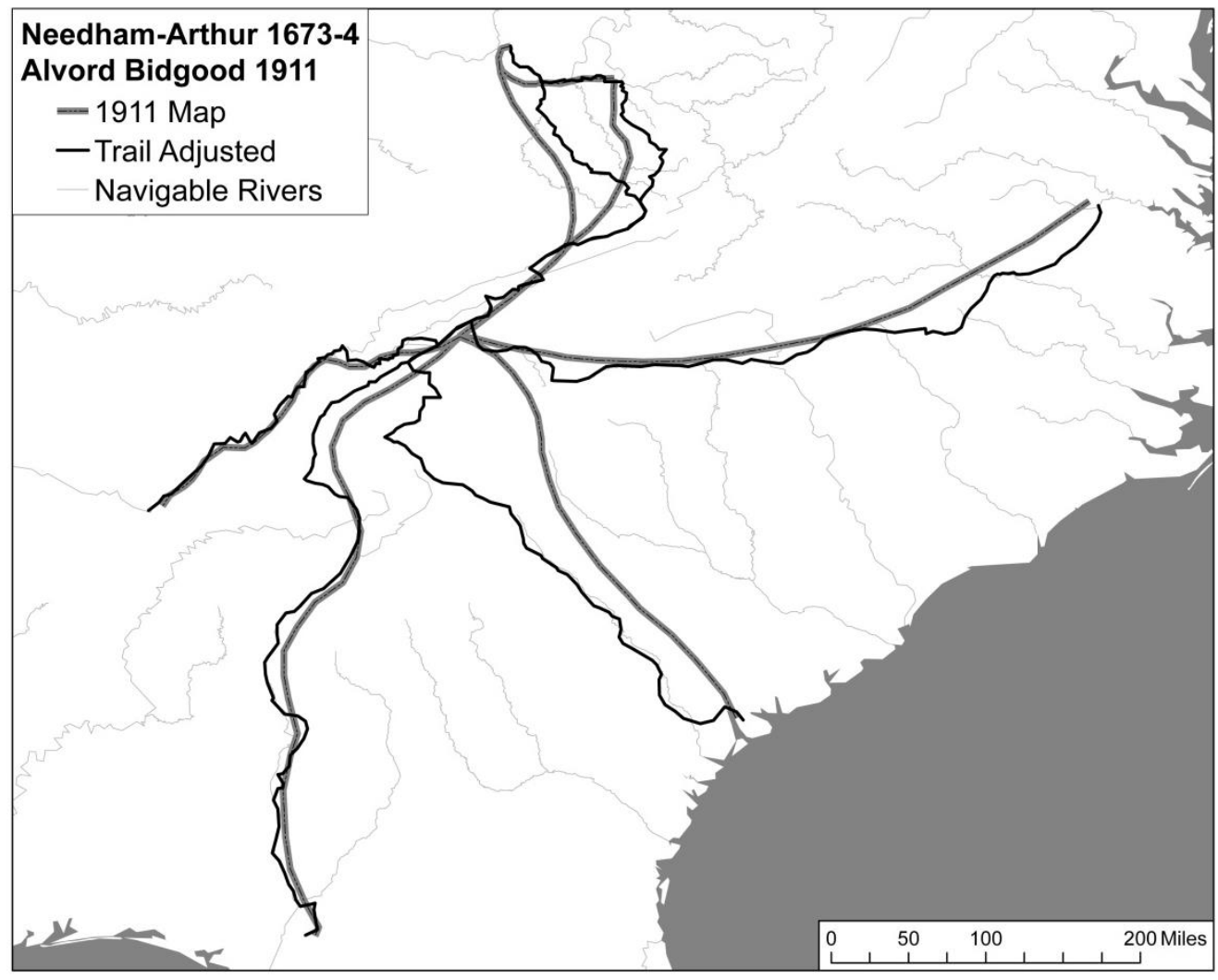

Map 3.7b: Needham-Arthur, 1987

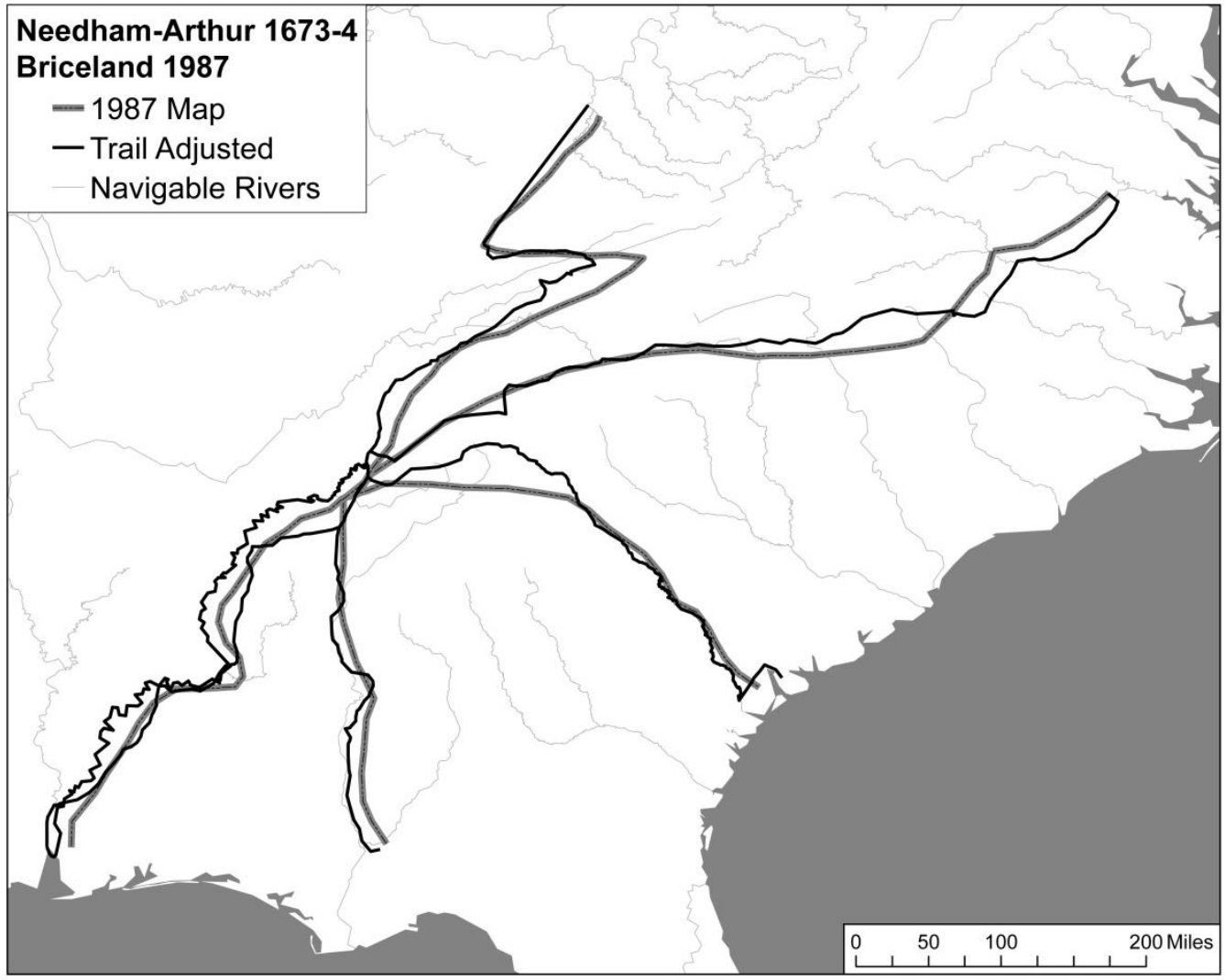




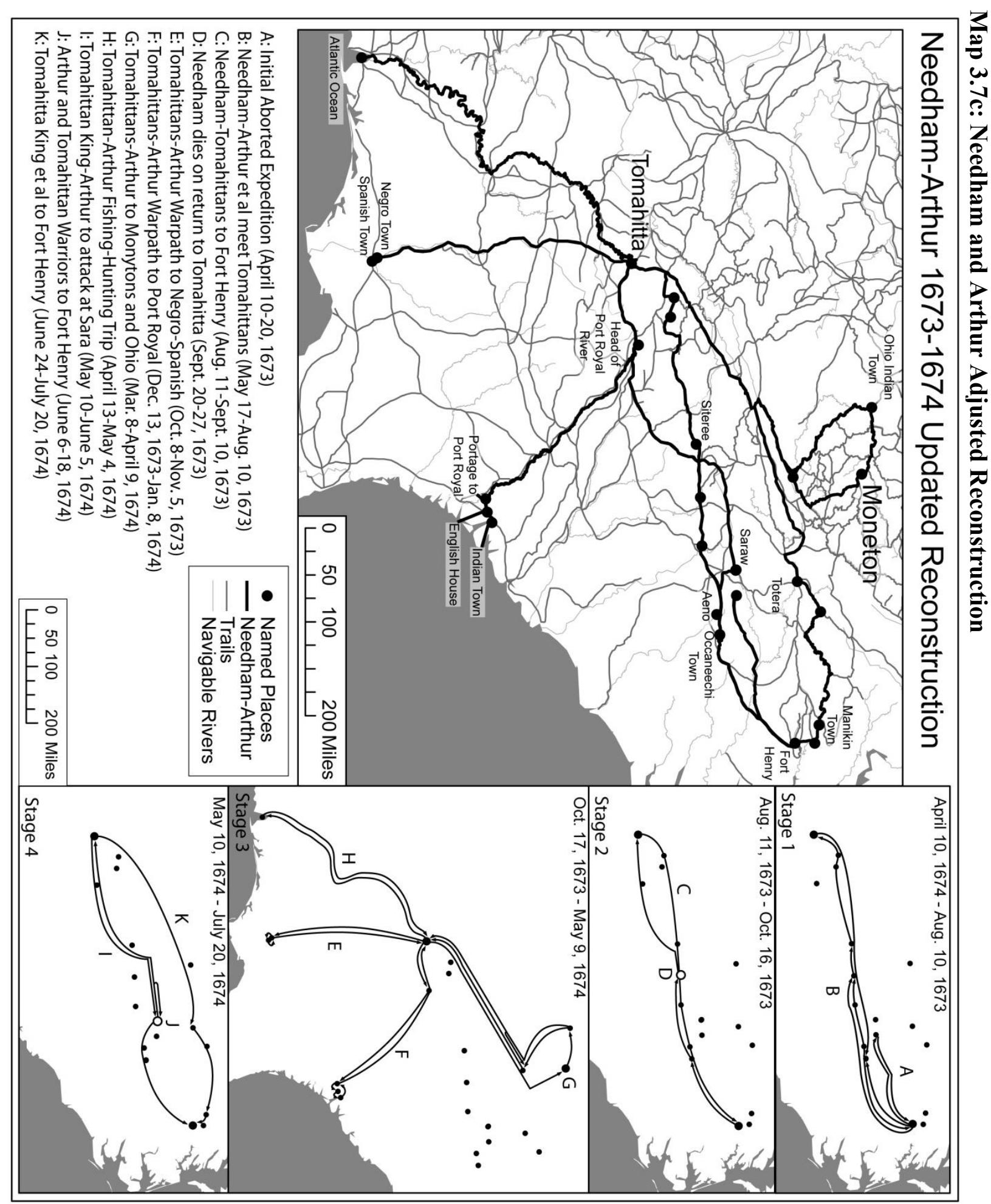


Map 3.8: Reconstructed FA Movements 1600-1700

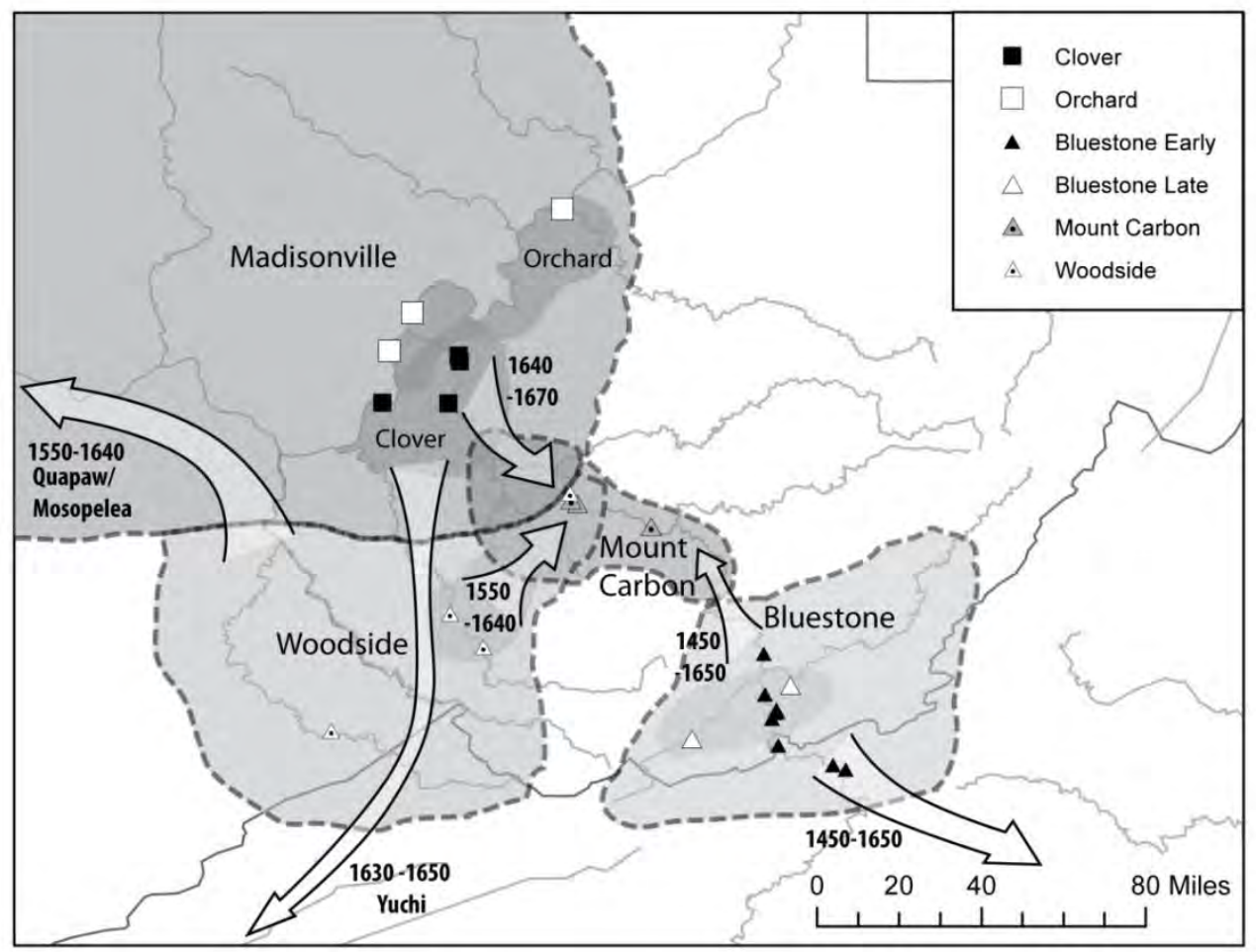

Overall outline of culture phases comes from Pullins et al 2008: 84-86.

\section{Map 4.1: French Exploration 1650-1700}

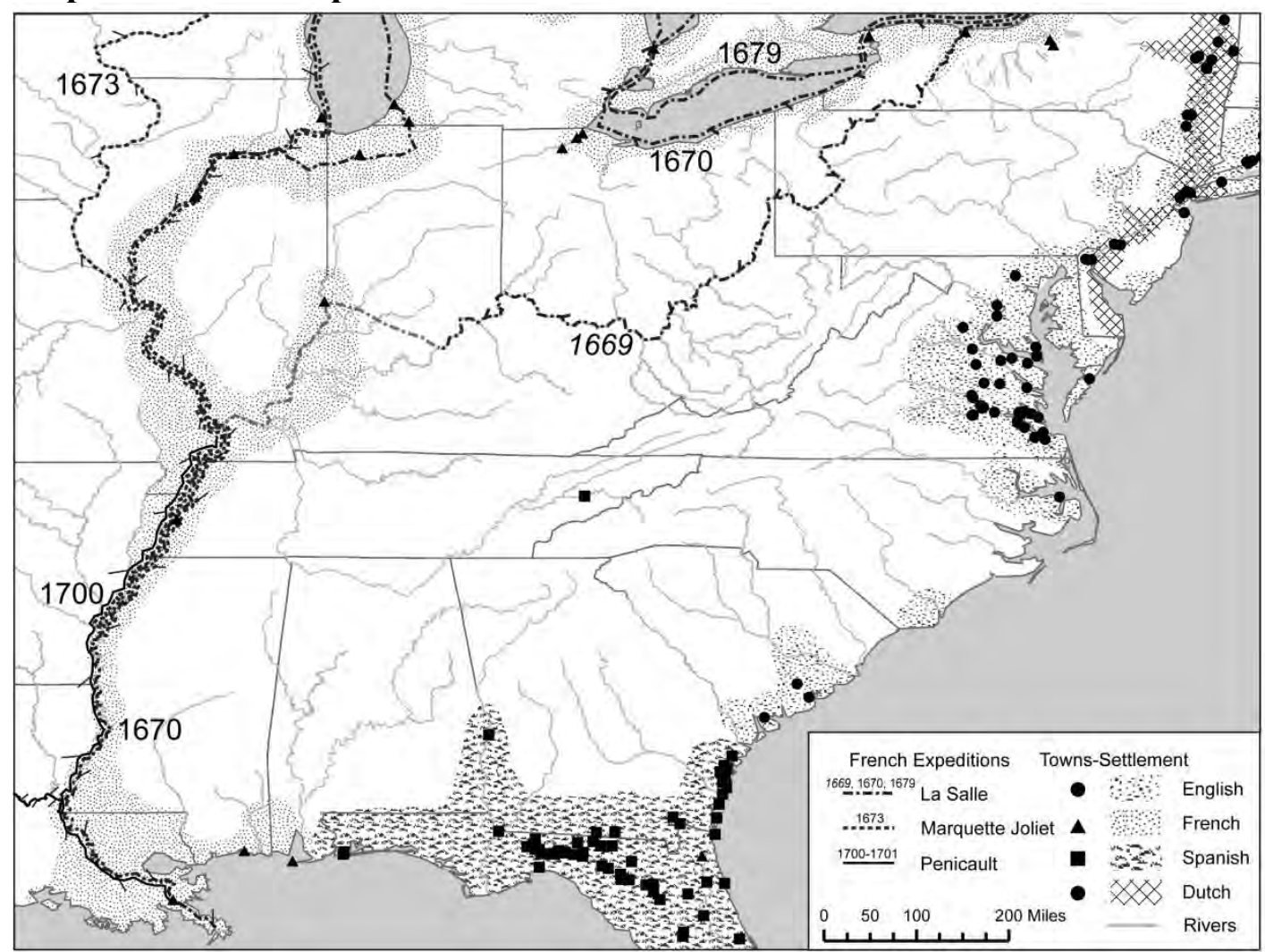



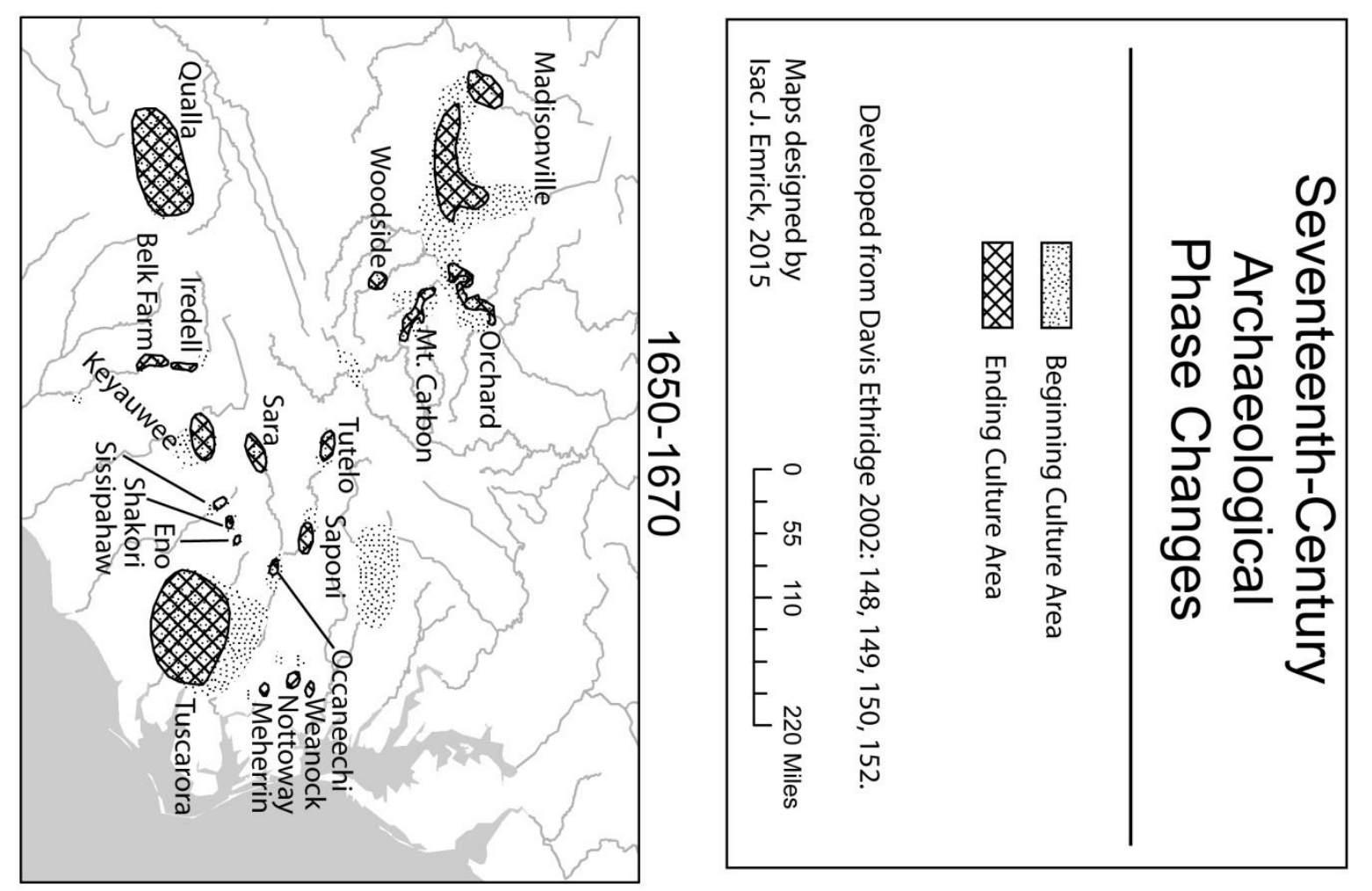

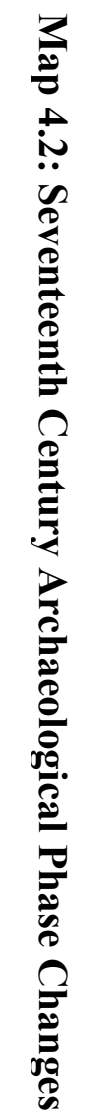
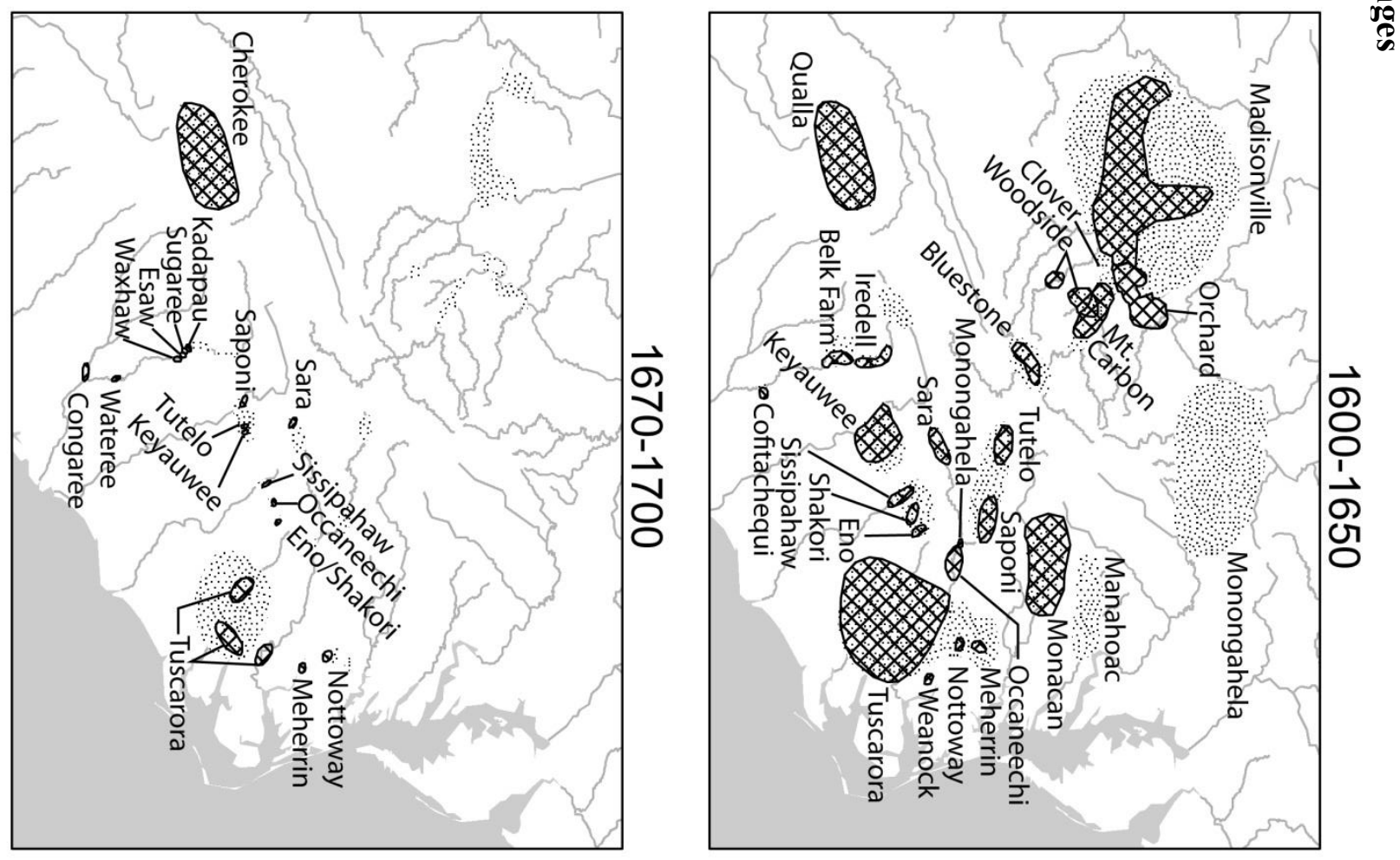


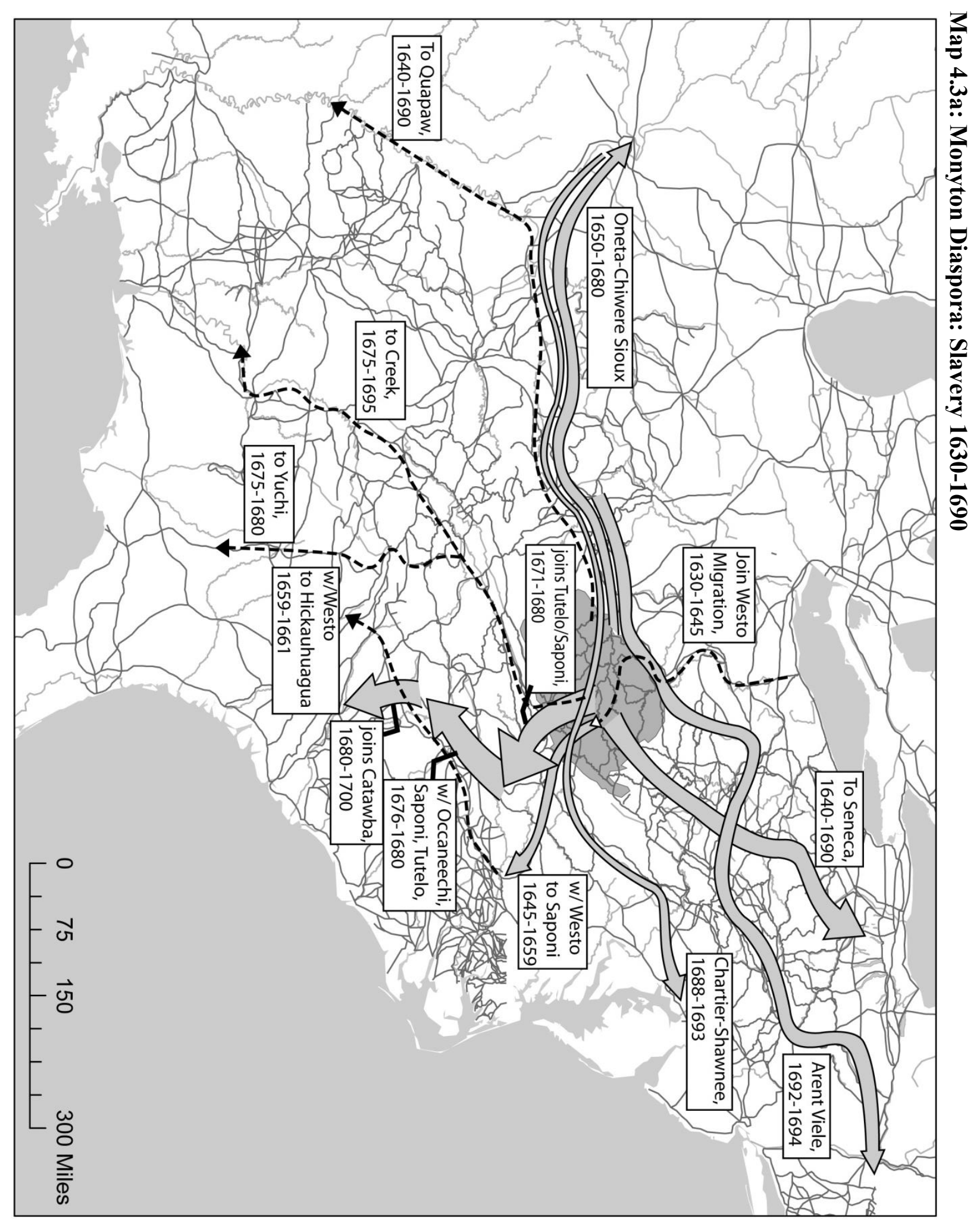




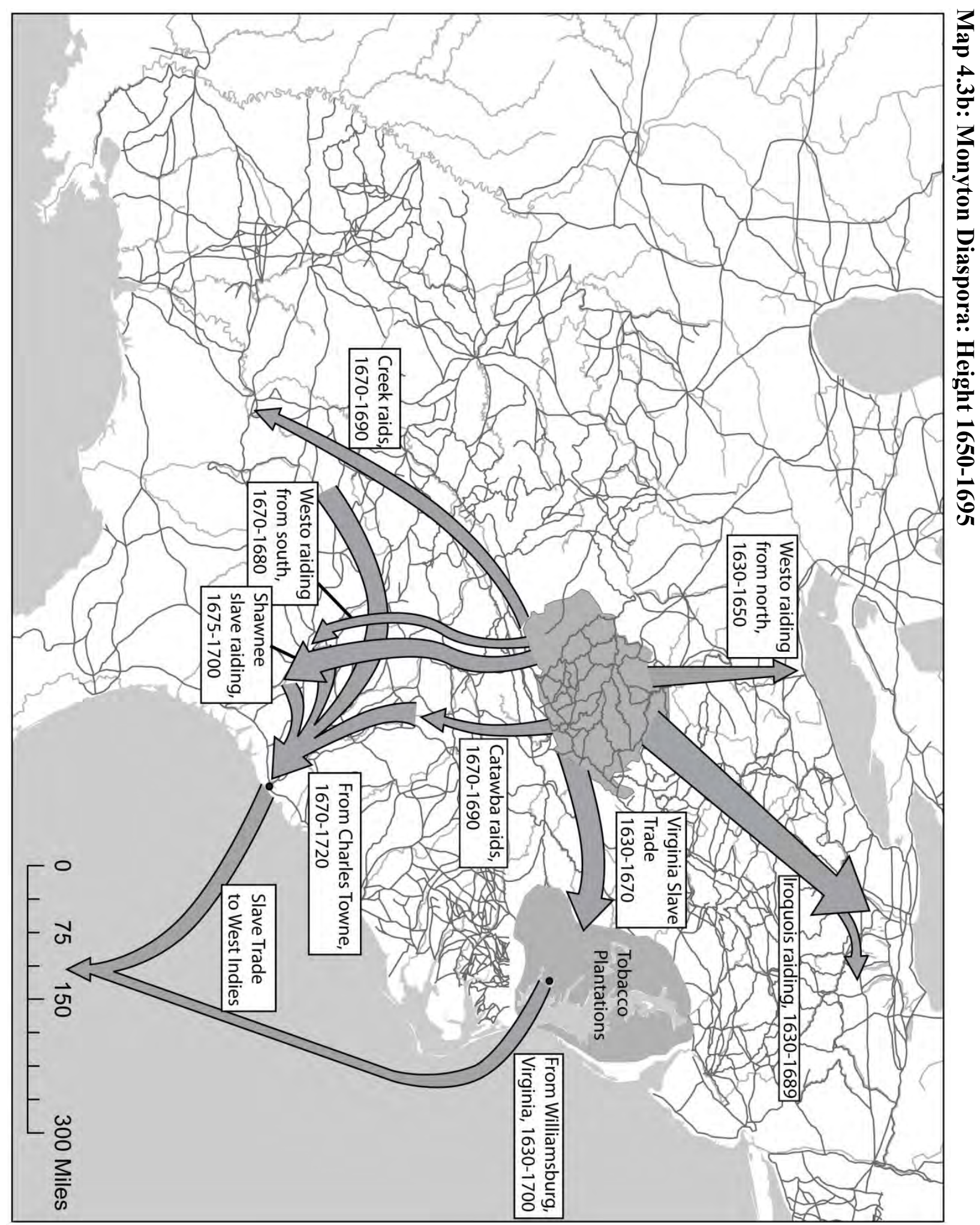




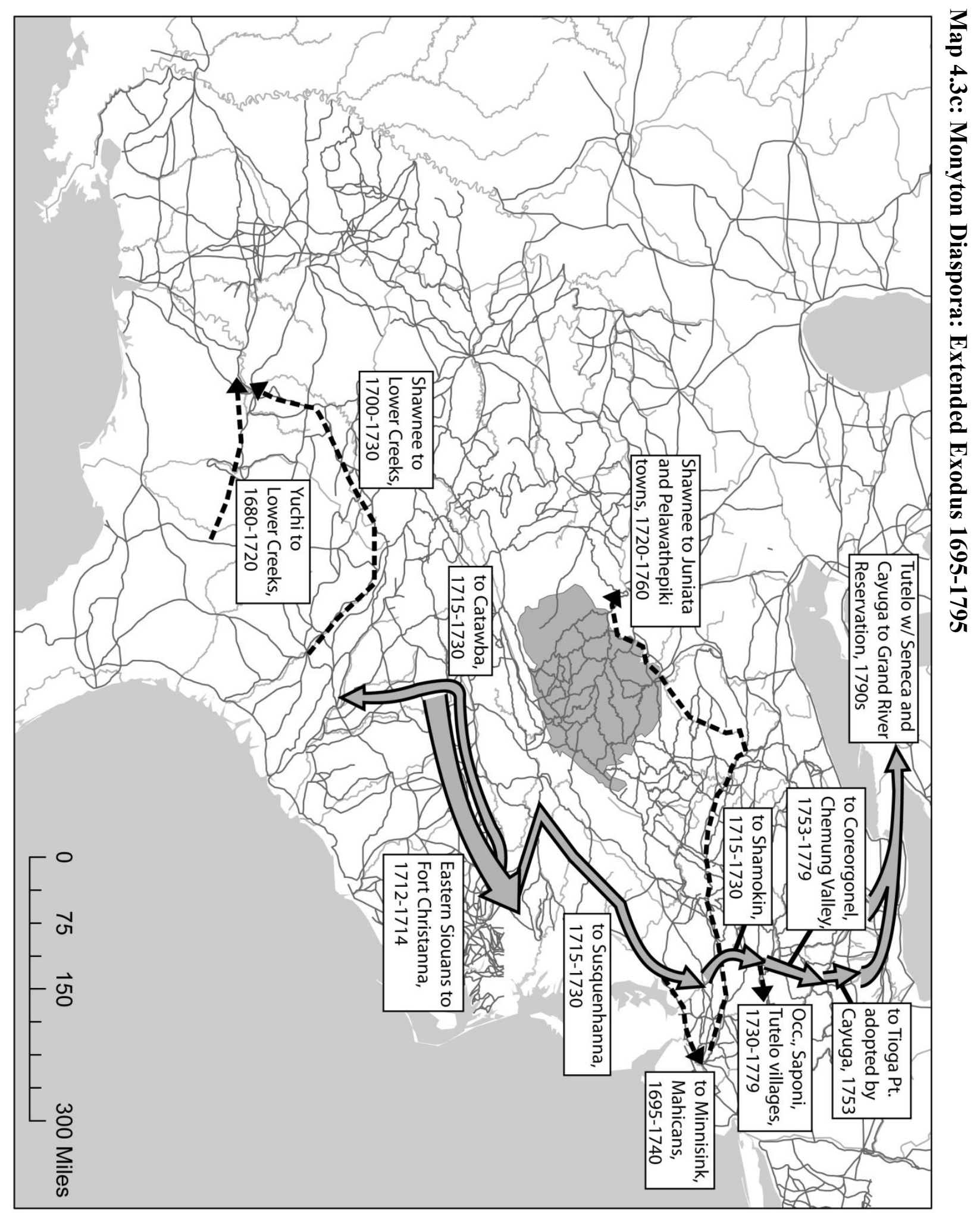


Map 4.3d: Monyton Diaspora: Remnant Eastern Siouan Communities

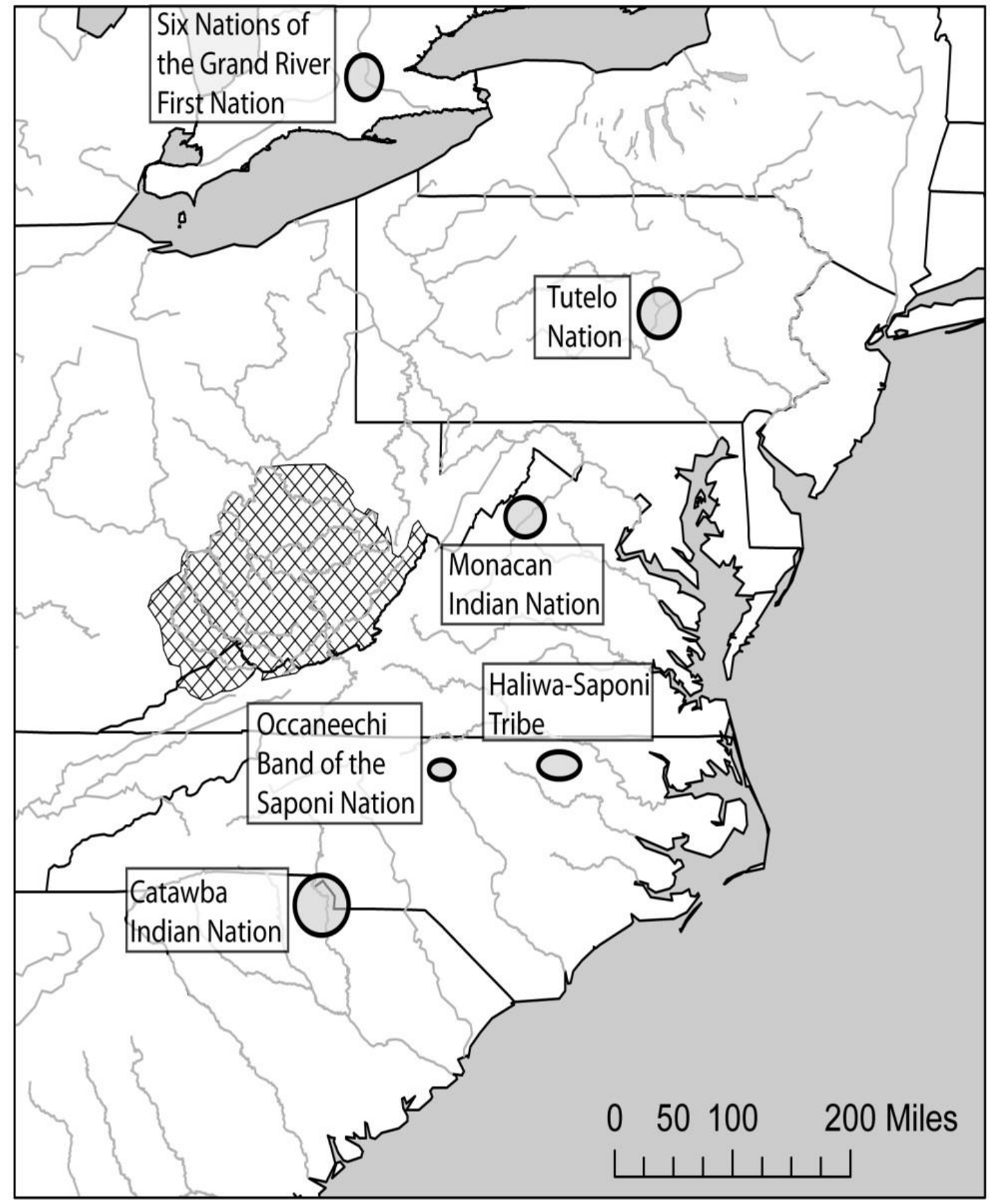




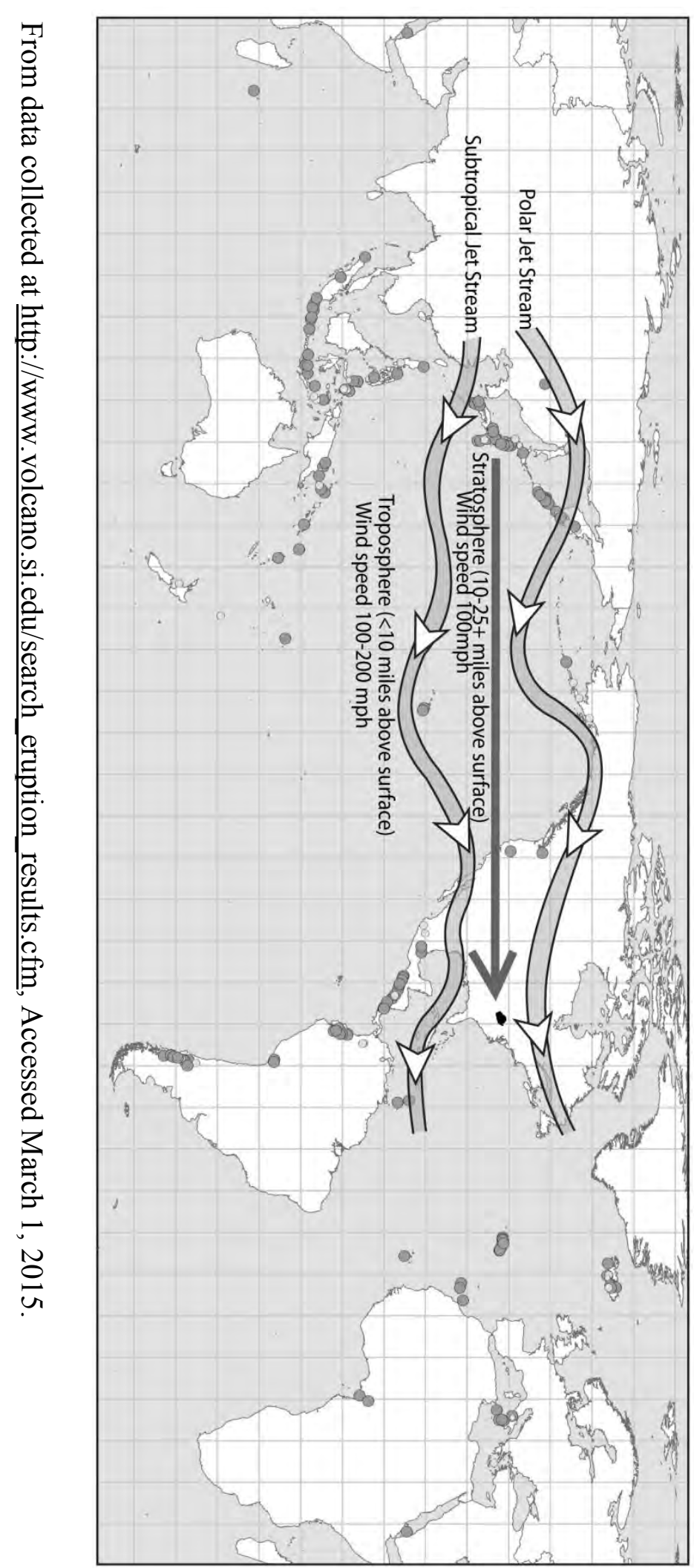

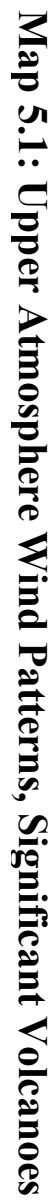


Map 5.2a: Marmet Catchment

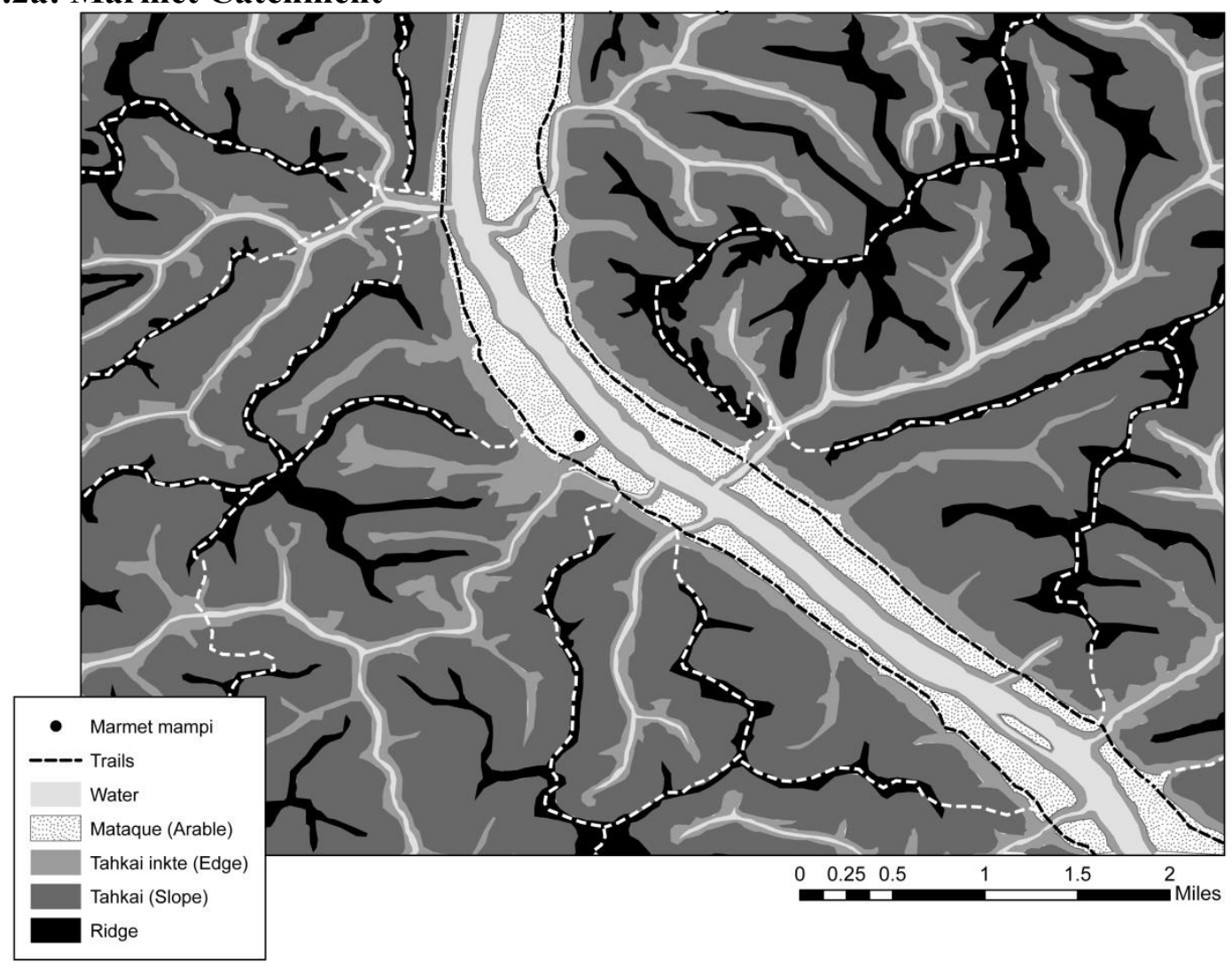

Map 5.2b: Man Catchment Map

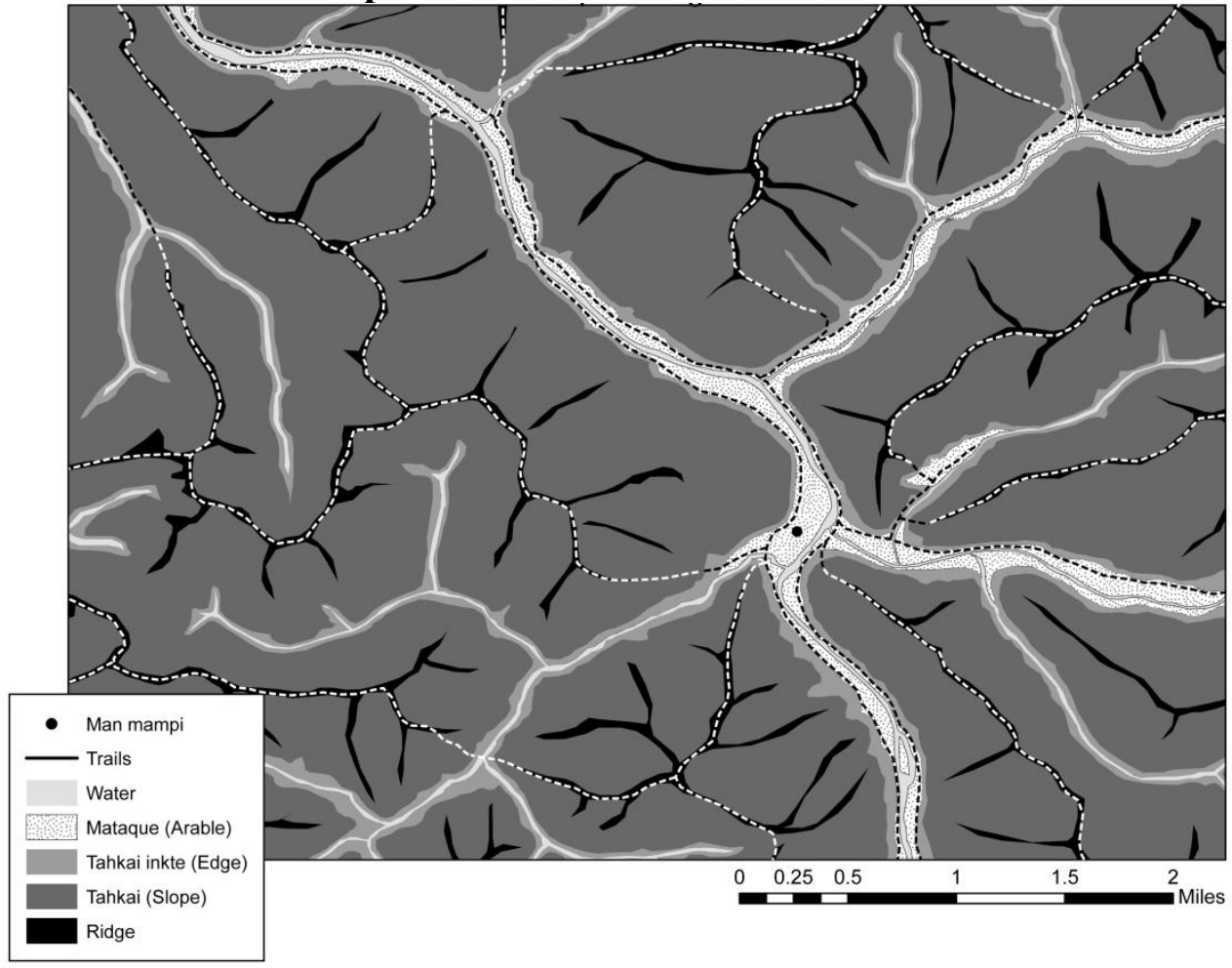




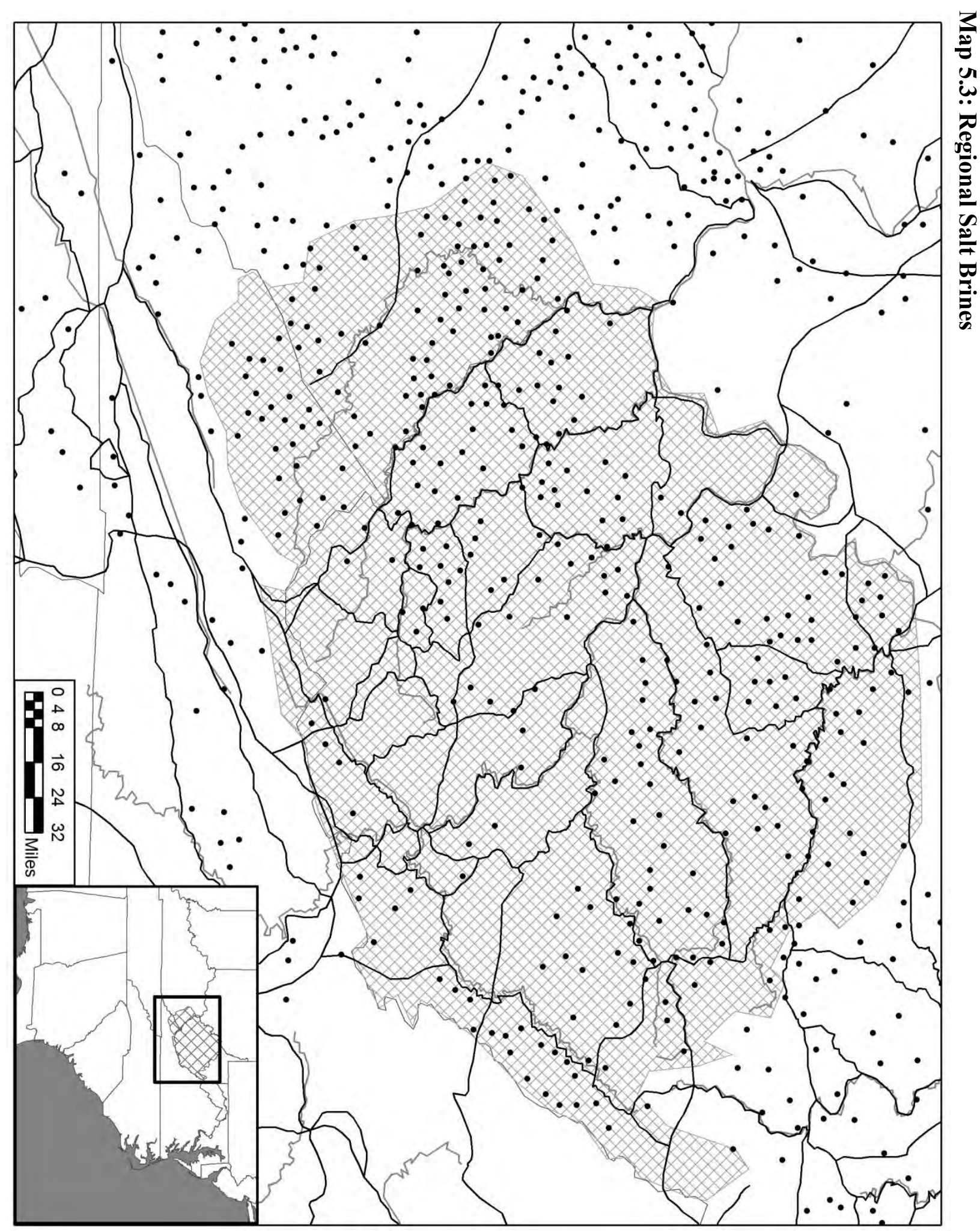




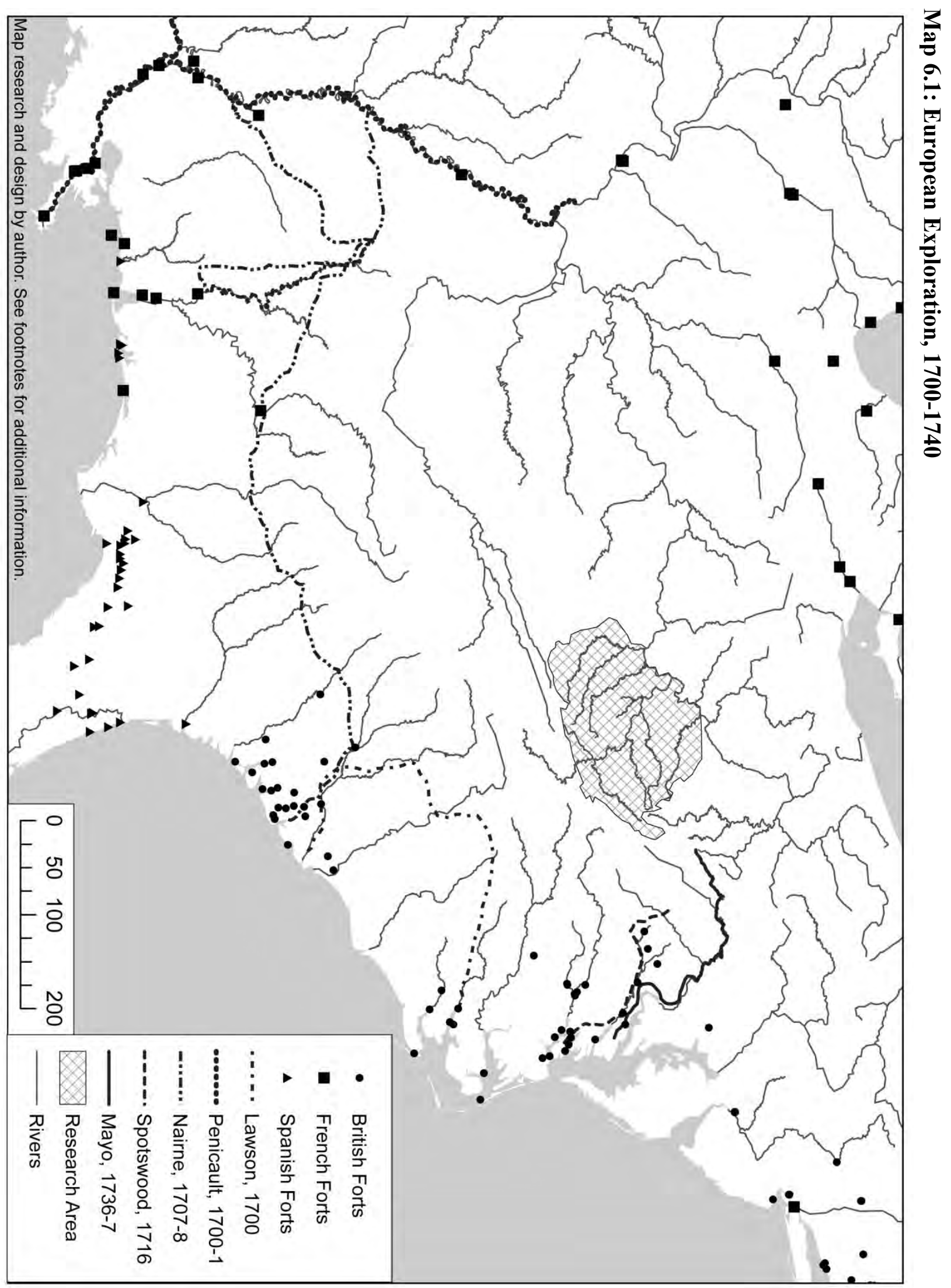


Map 6.2: European Settlement, 1700-1720

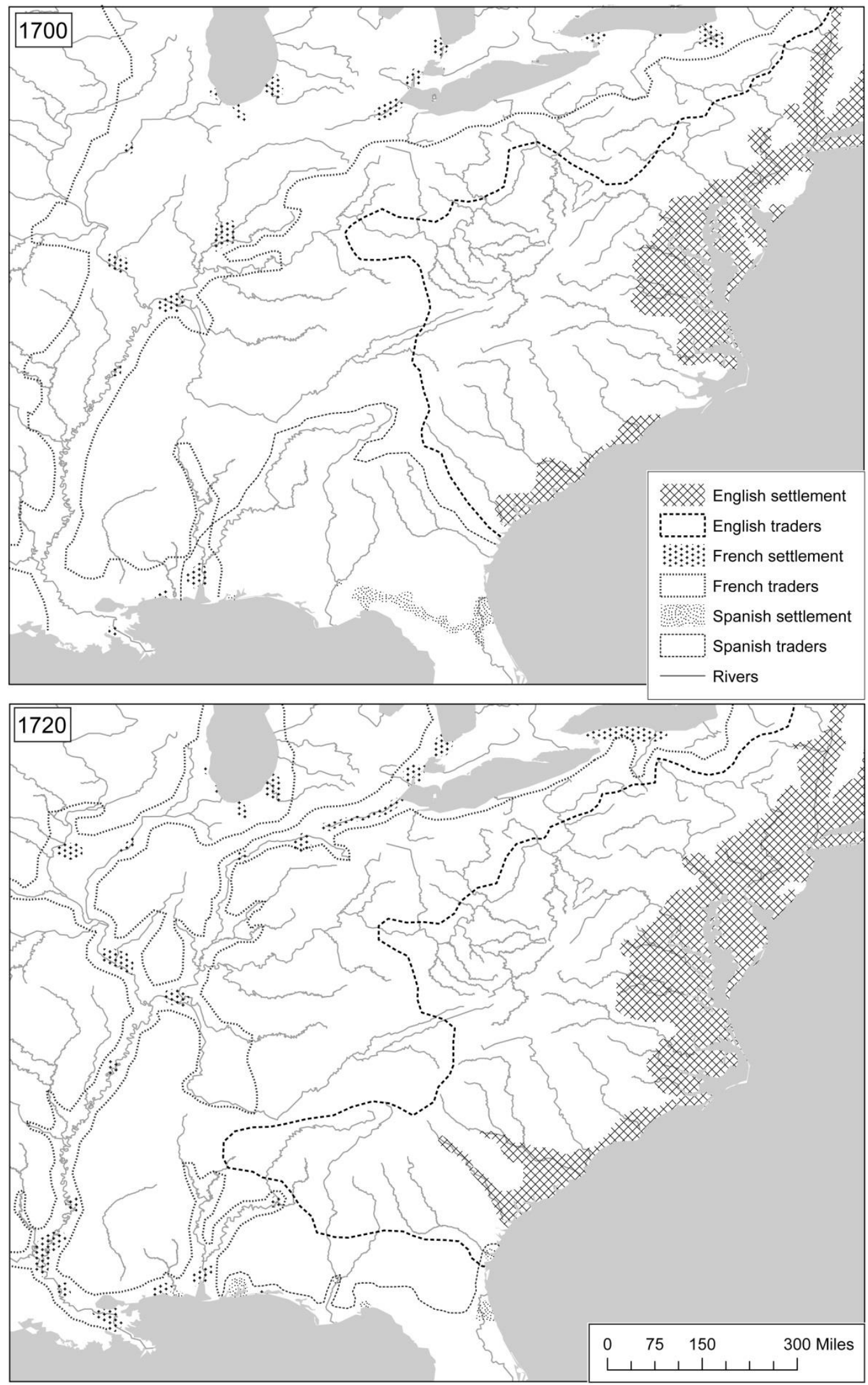




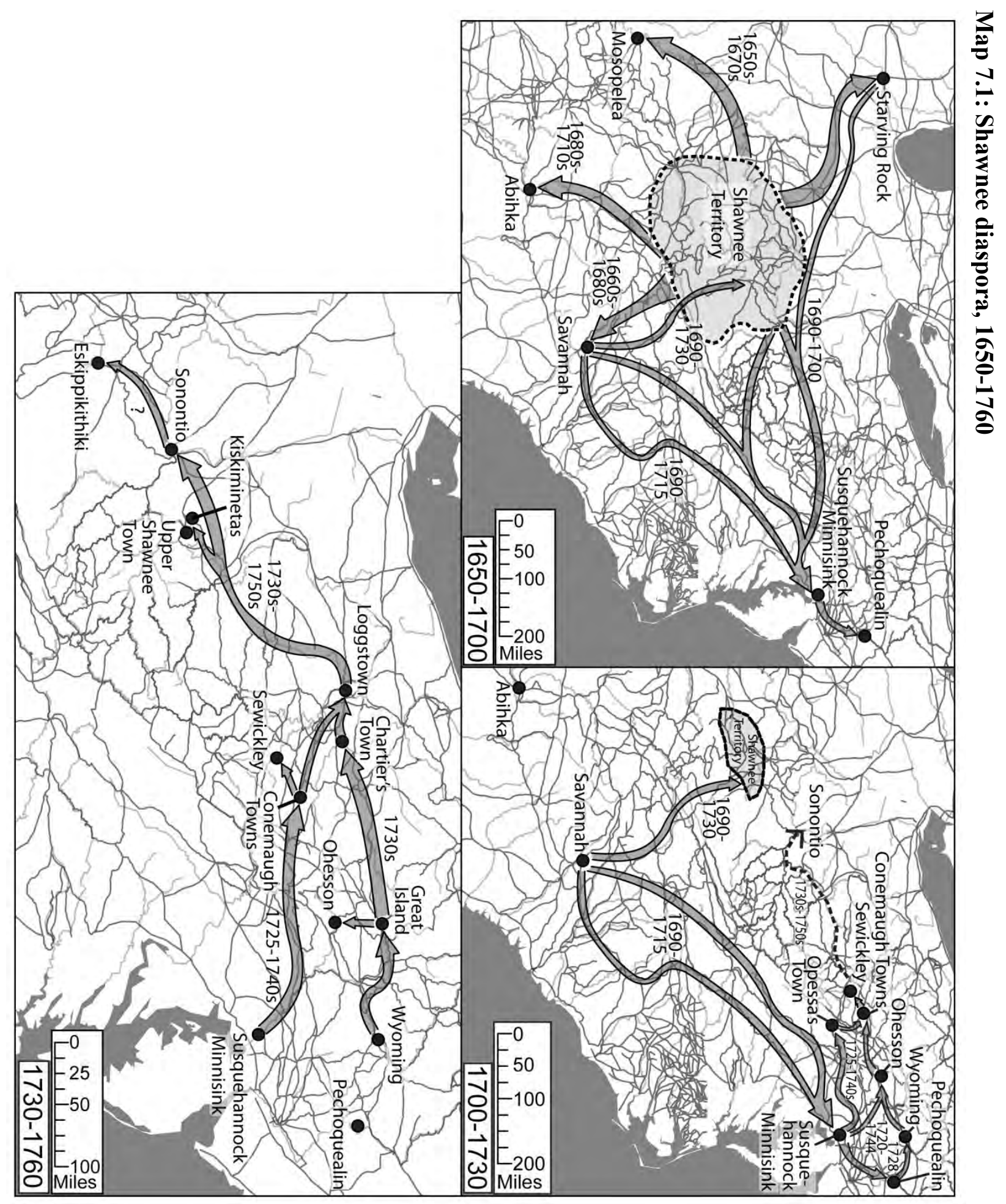




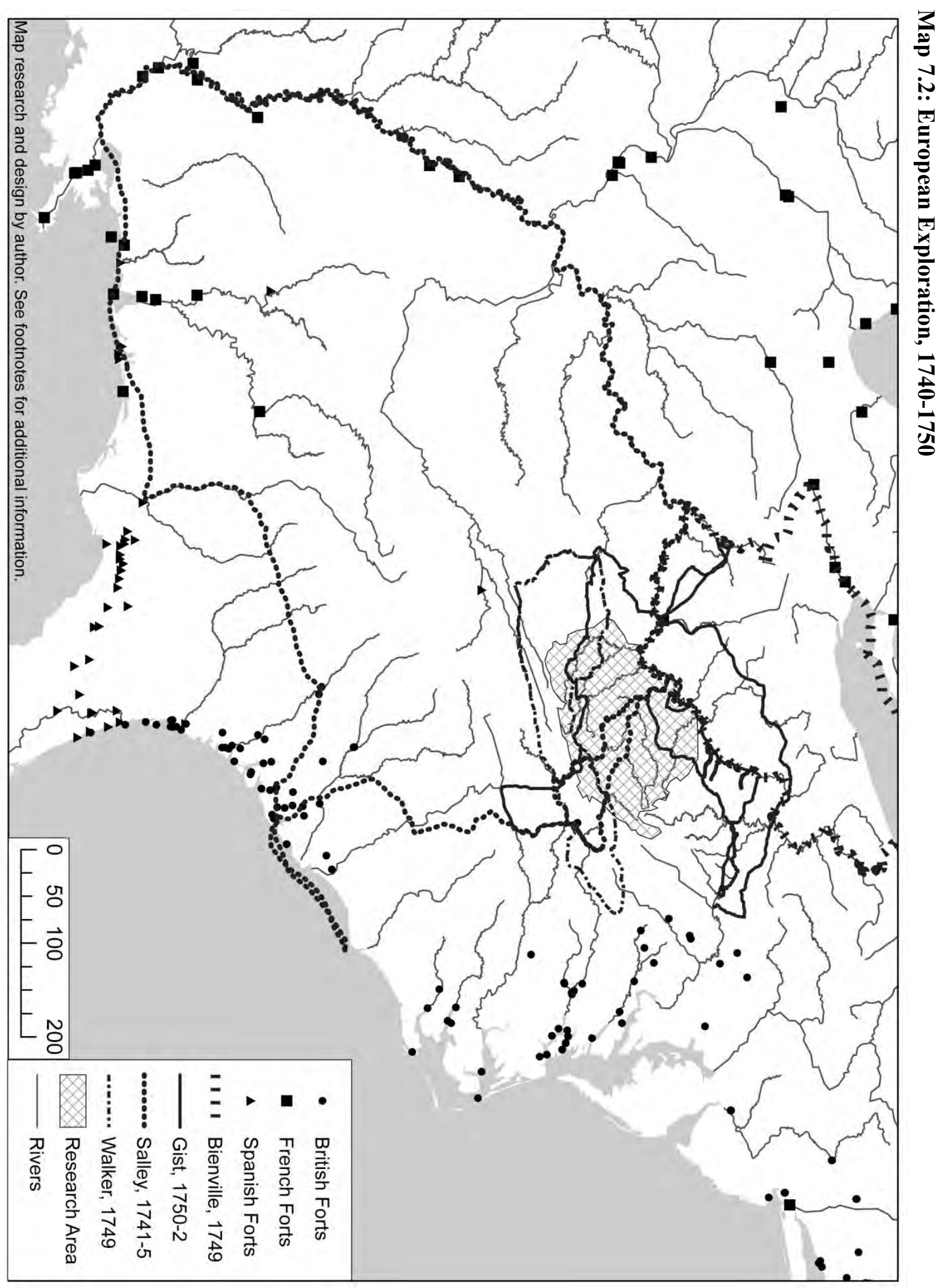




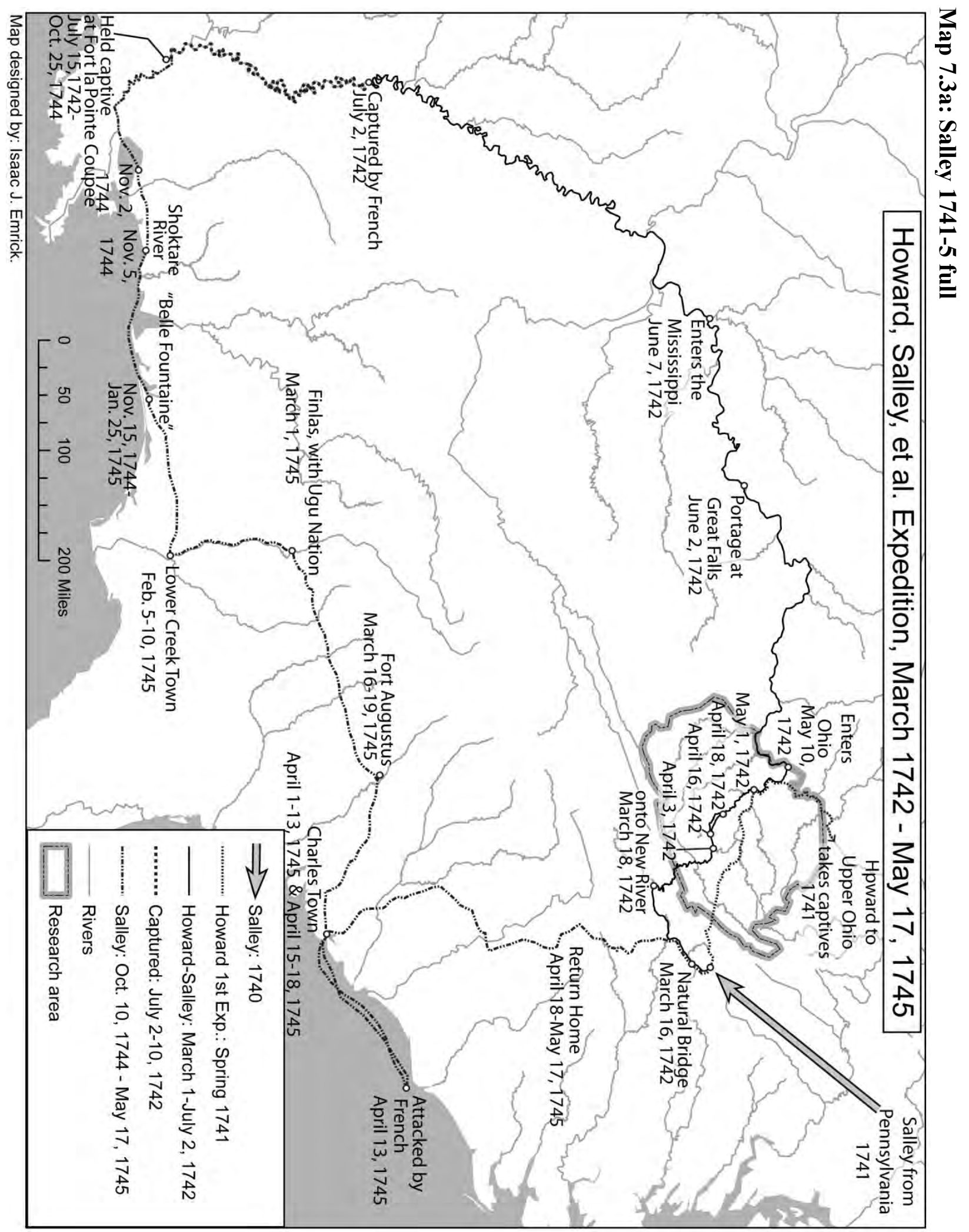


Map 7.3b: Salley 1741-2 region

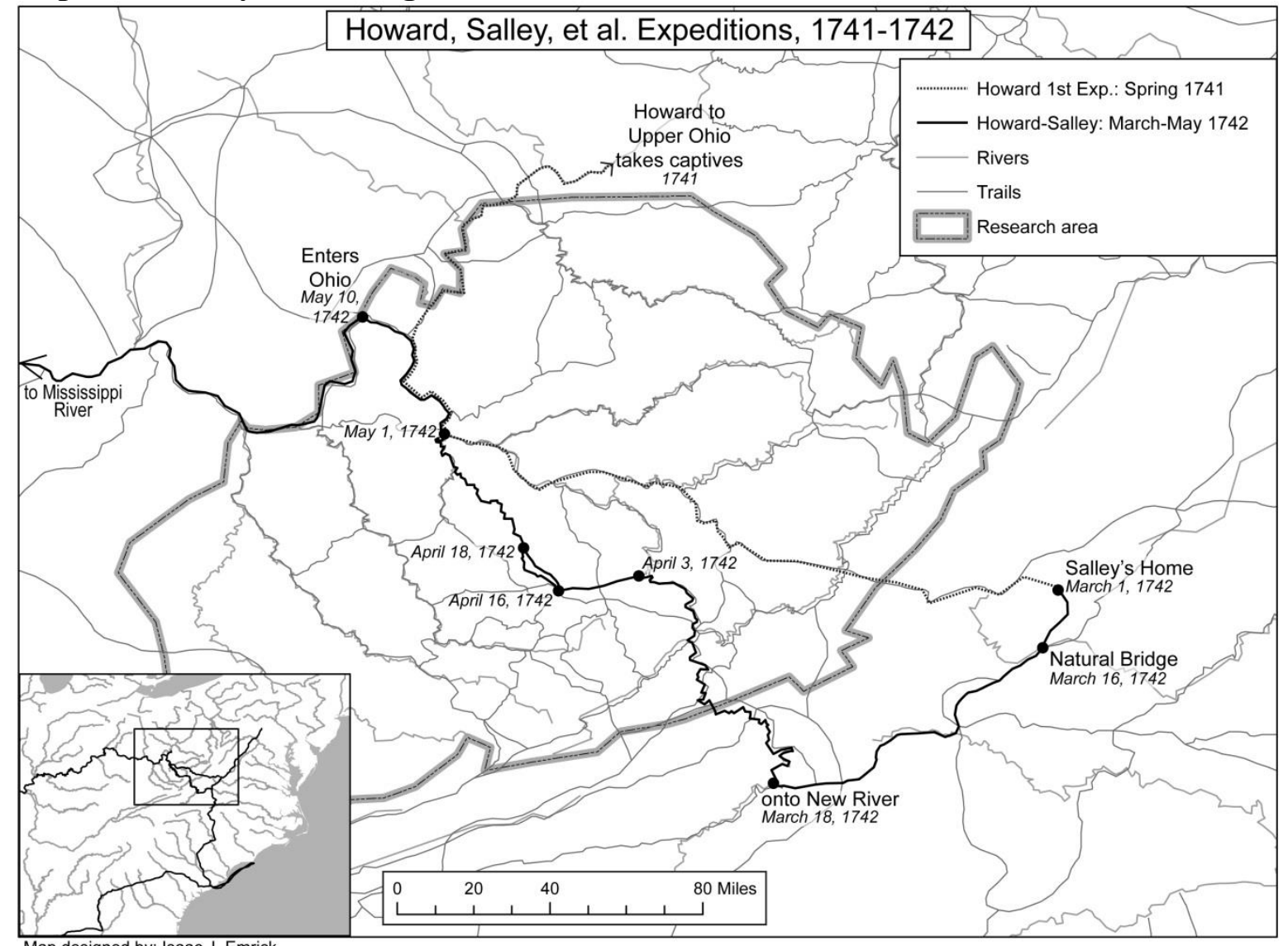

Map 7.4: Land Titles Ohio-Loyal-Greenbrier

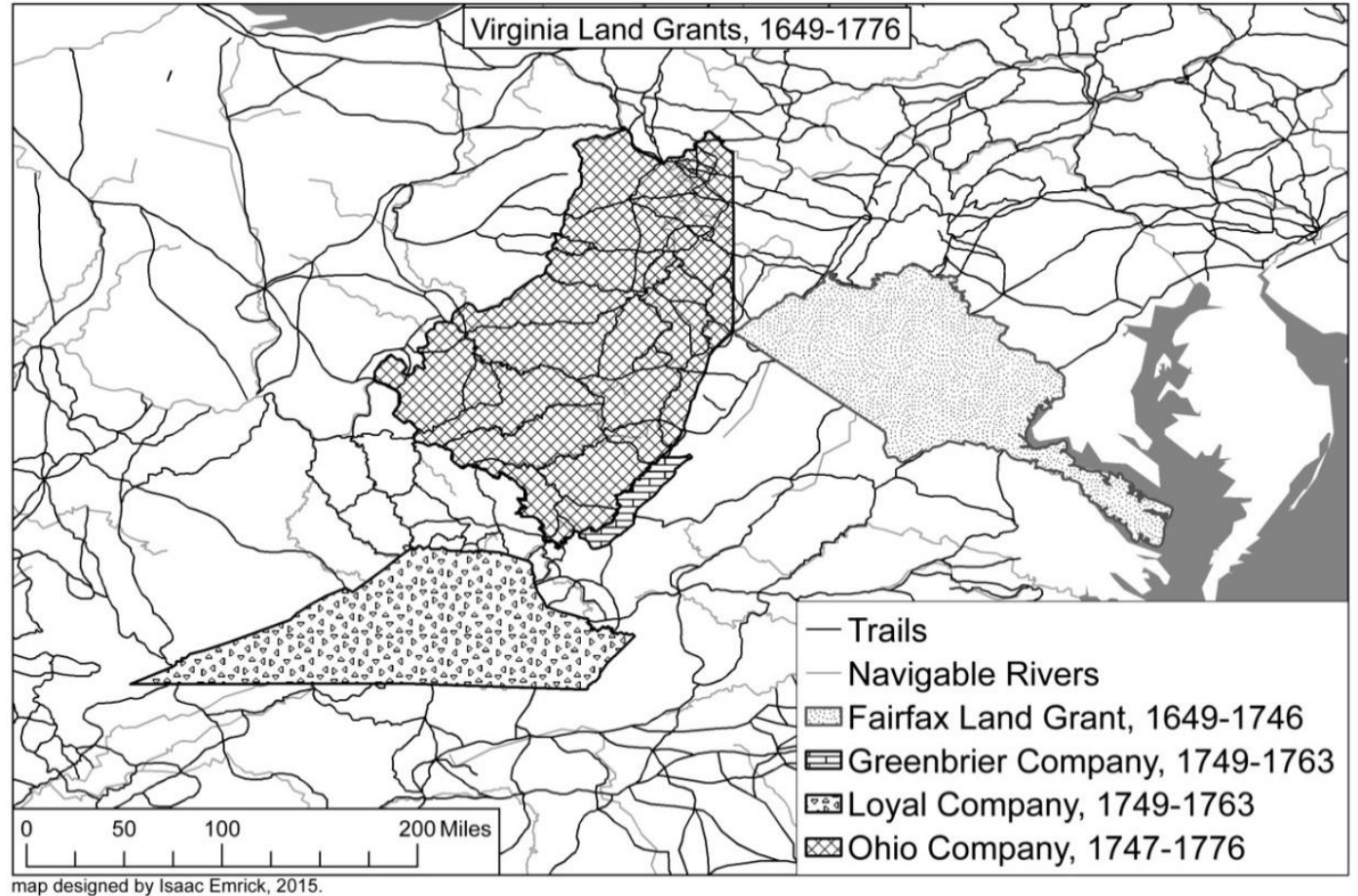

map designed by Isaac Emrick, 2015 


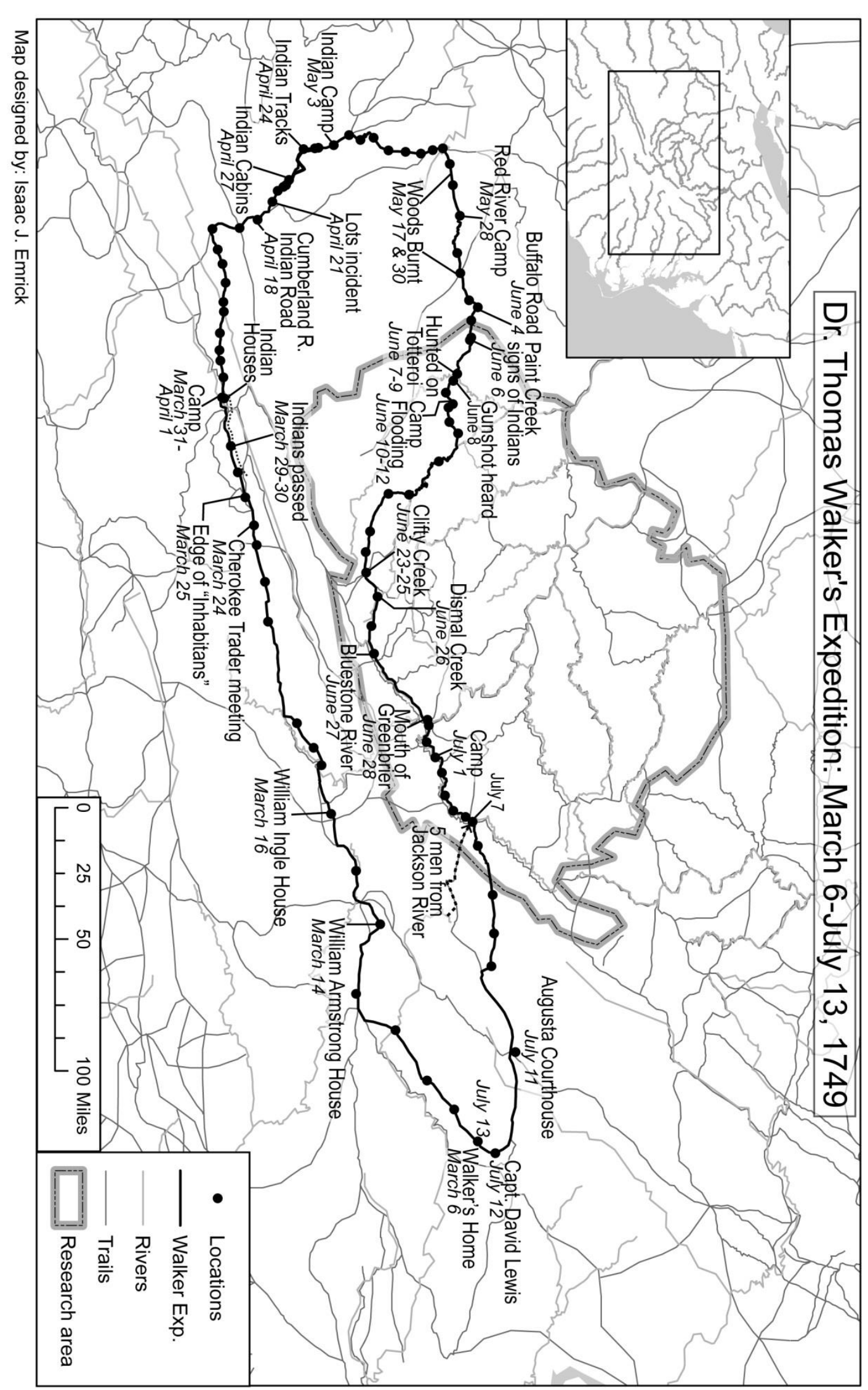




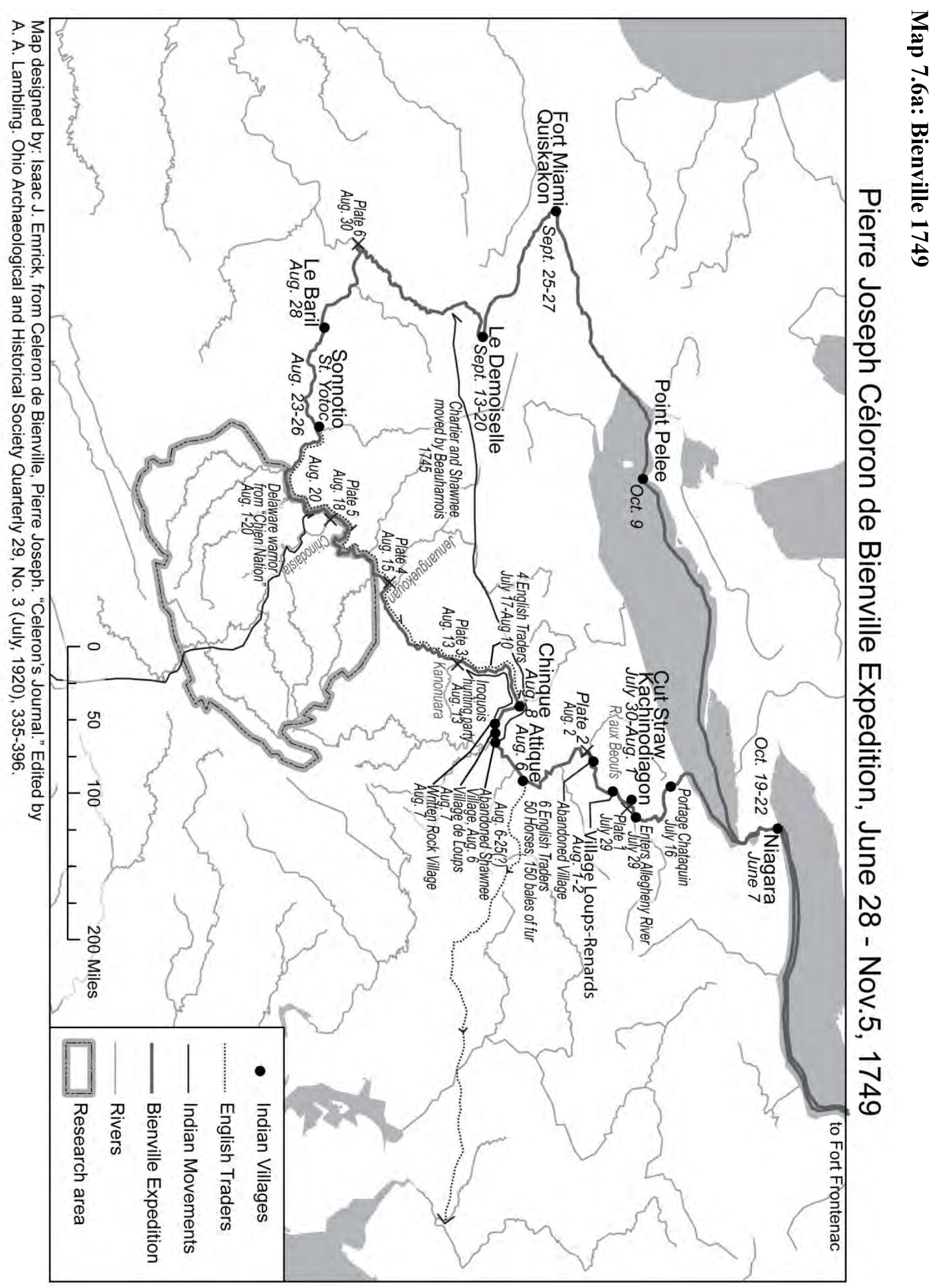




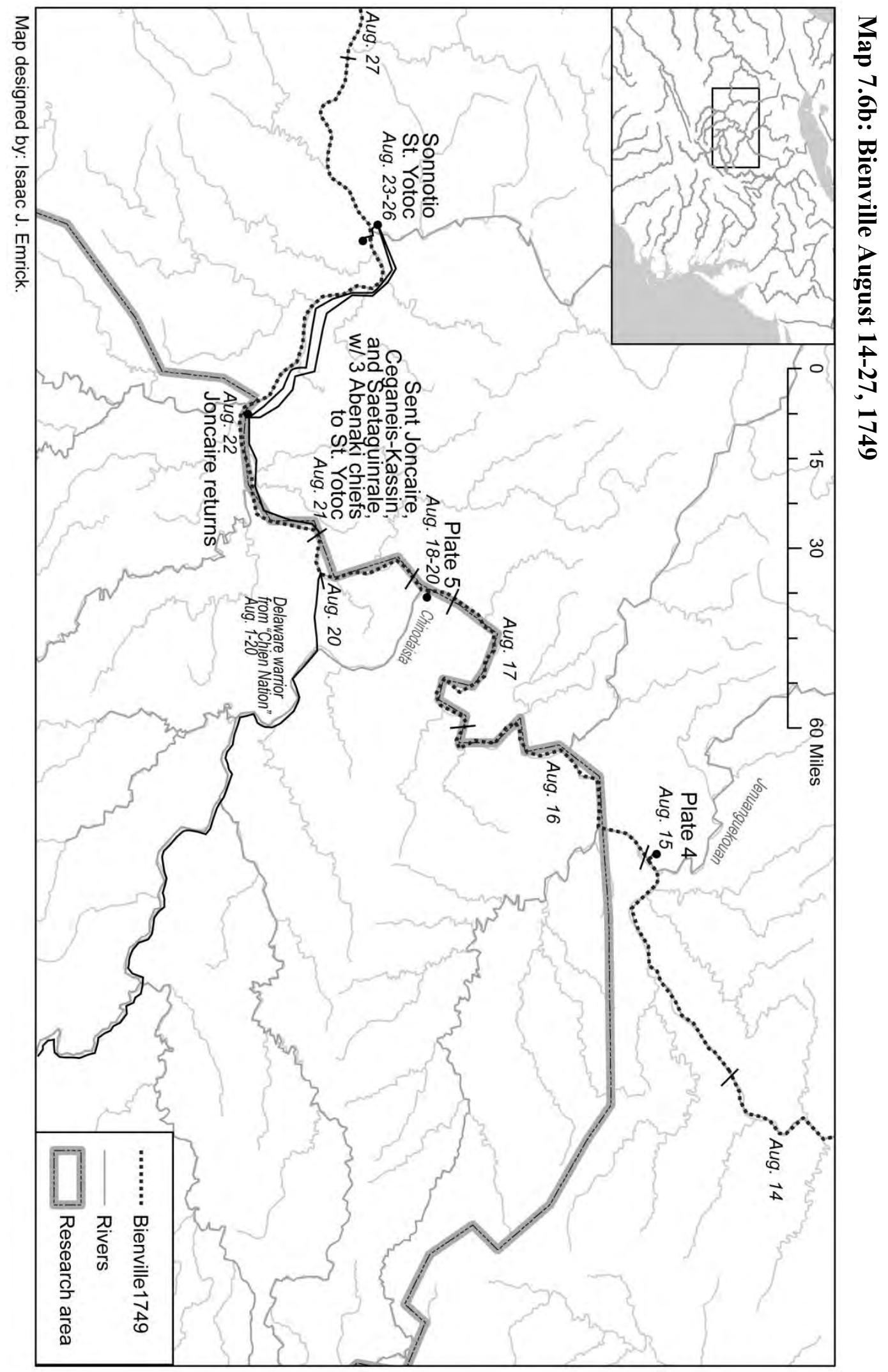




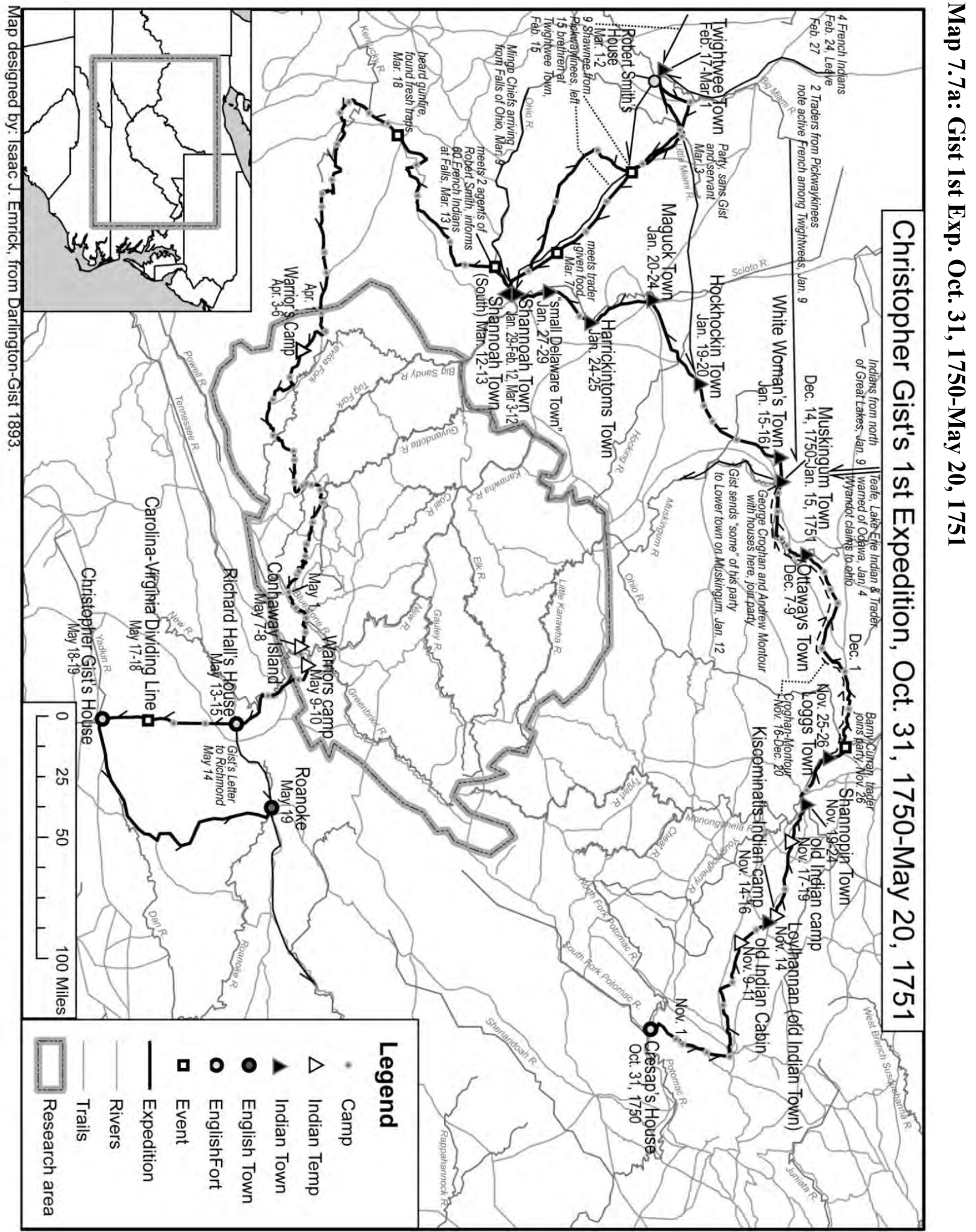




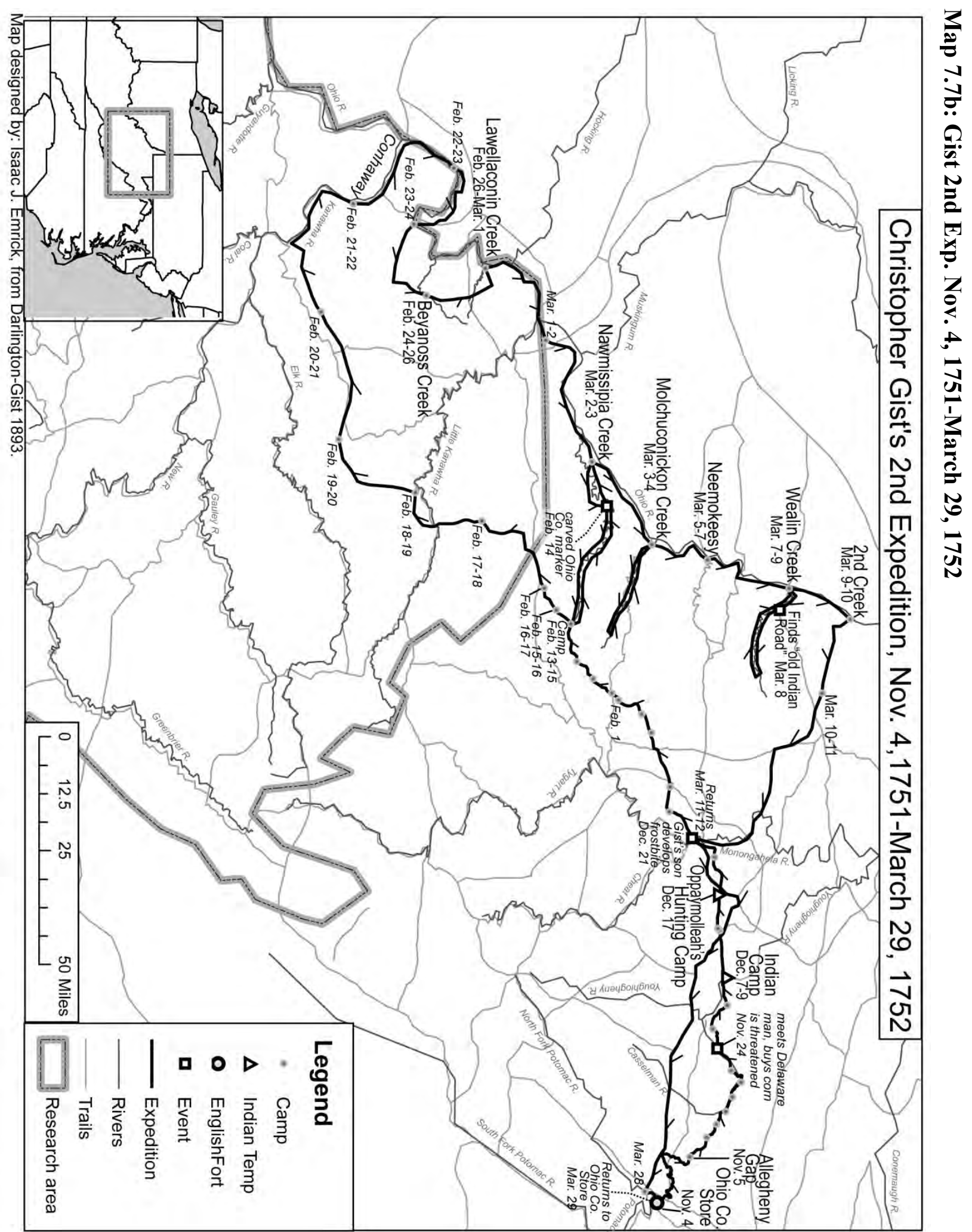


Map E.1: European Settlement, 1740-1760
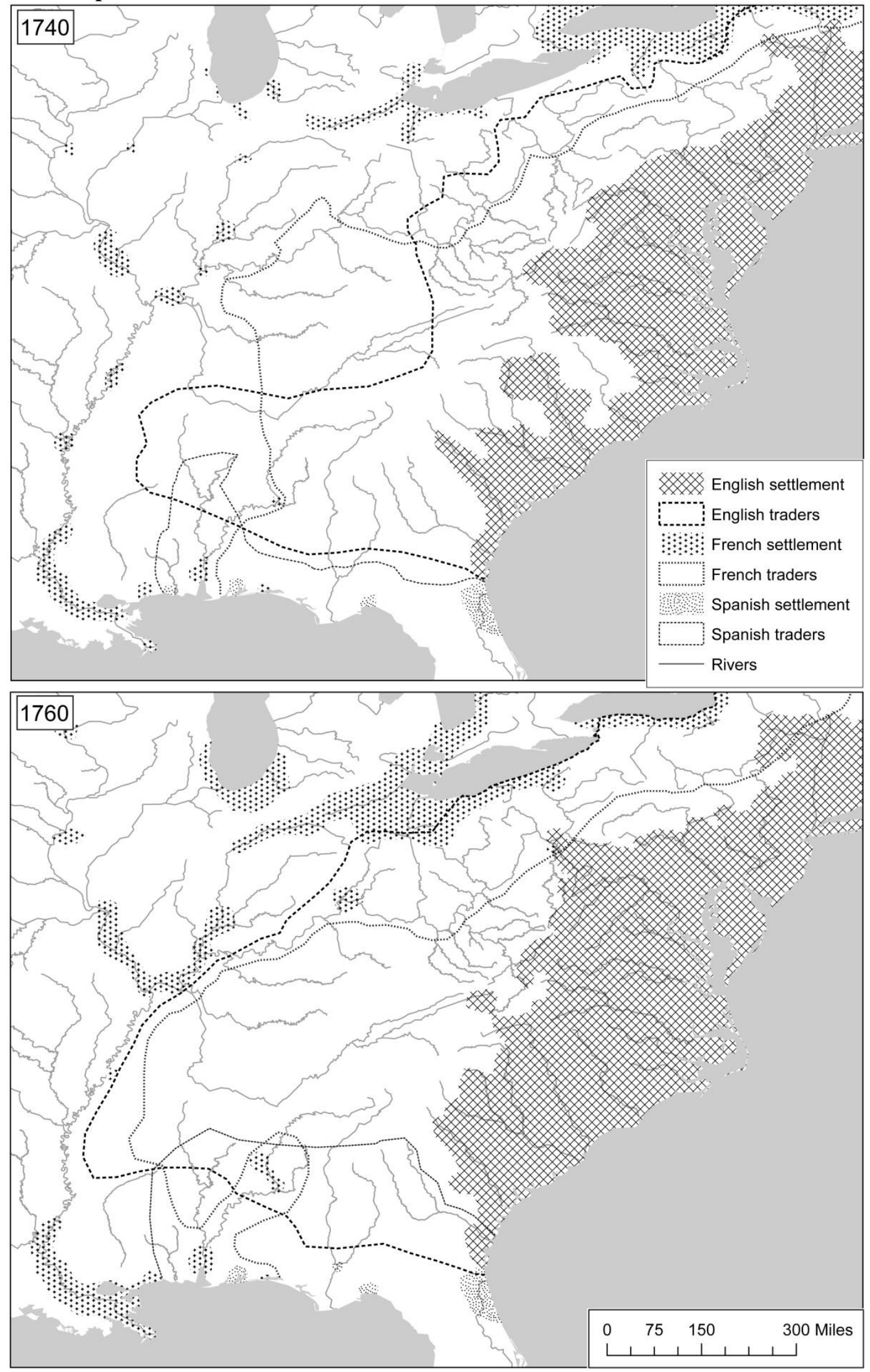
Map E.2: Locations mentioned, 1750-1755

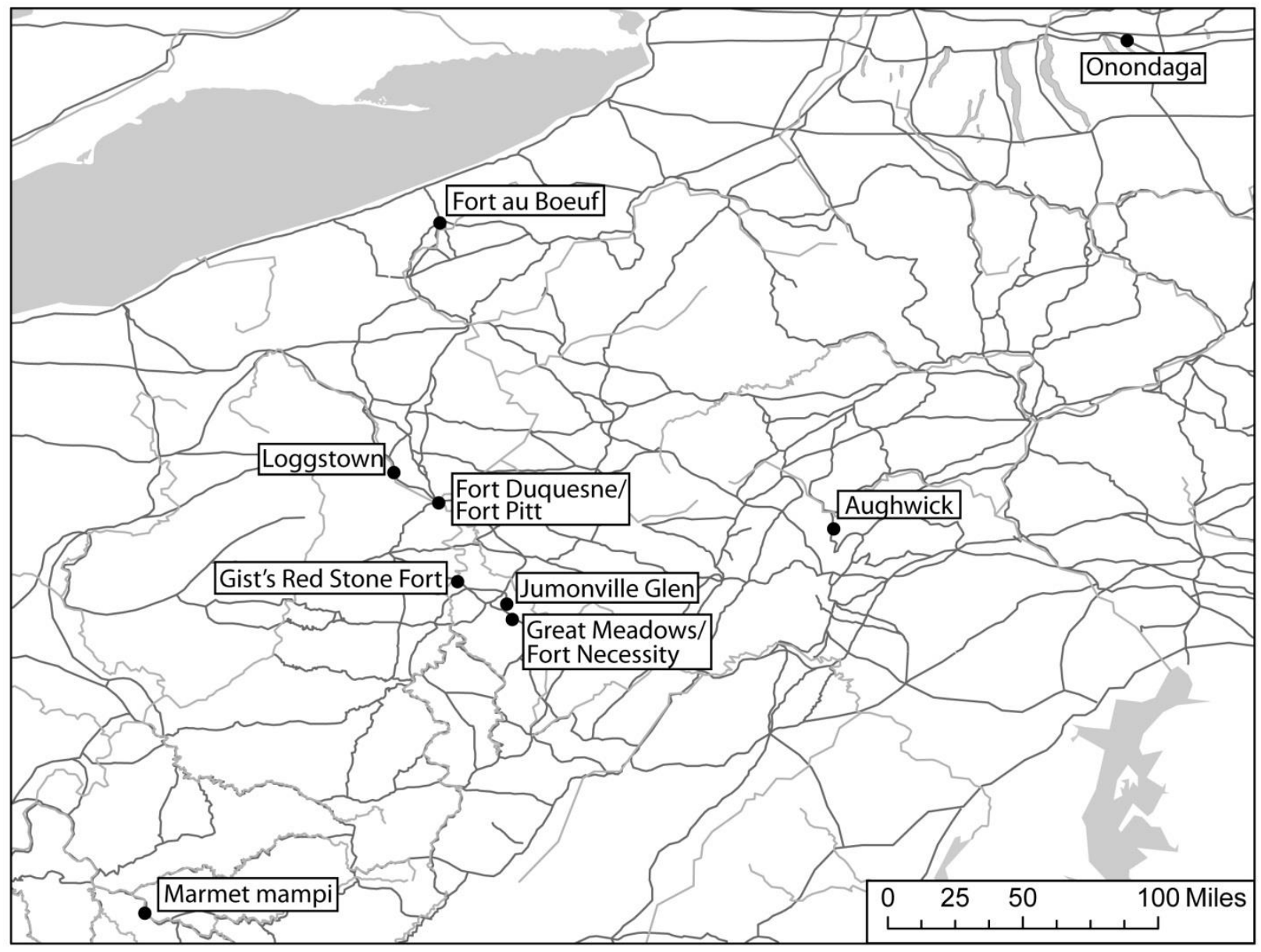


Tables 


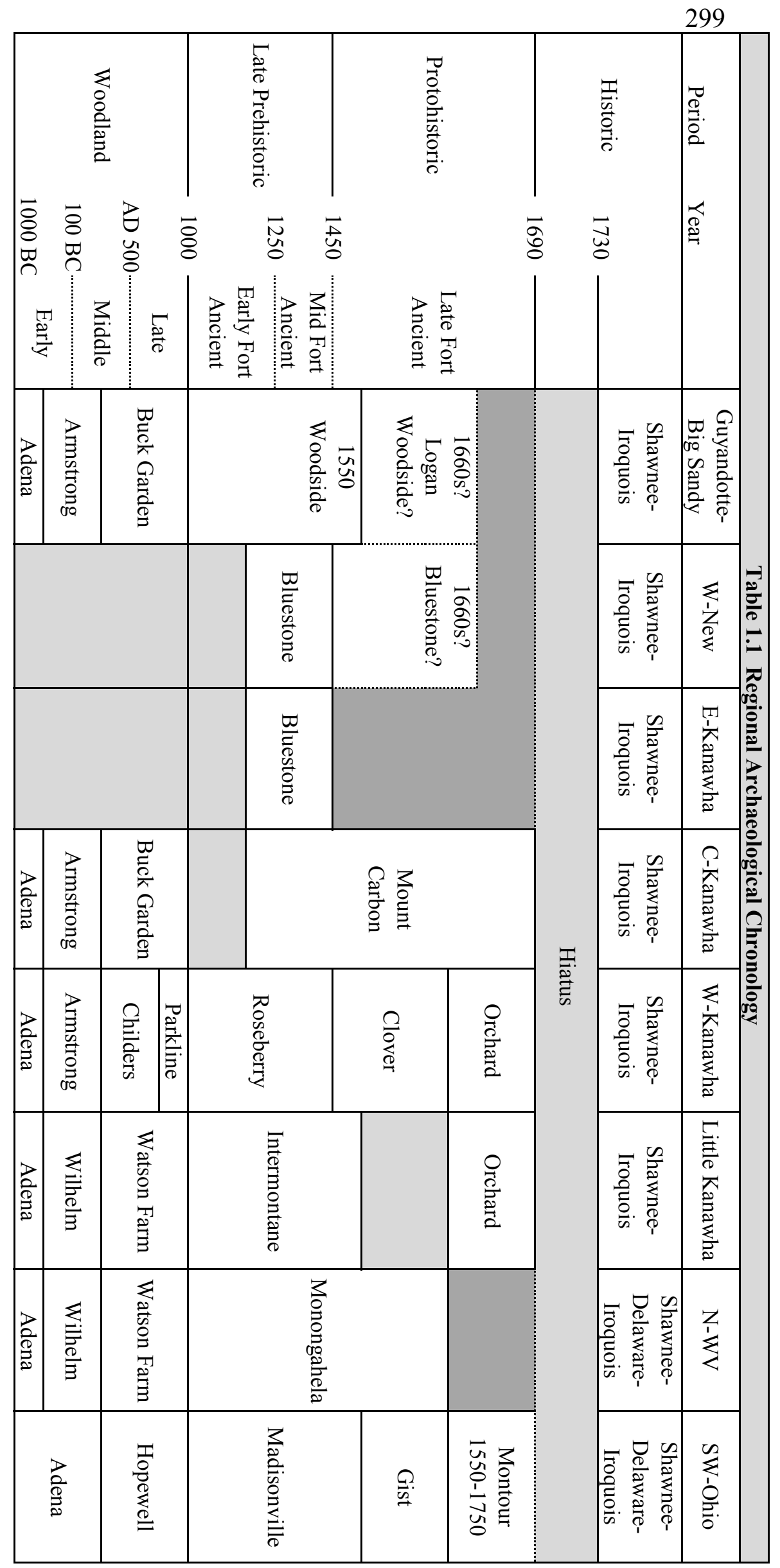




\begin{tabular}{|l|l|l|}
\hline Table 1.2 & Materials & Citation \\
\hline Name & $\begin{array}{l}\text { marginella and olivella, 1 large marine } \\
\text { shell gorget }\end{array}$ & $\begin{array}{l}\text { Maslowski 1985b, } \\
\text { USACE 1983 }\end{array}$ \\
\hline Island Creek 46Su0009 & $\begin{array}{l}\text { 13+ marine shell gorgets: Brakebill } \\
\text { rattlesnake w/child burial, 2 large shell } \\
\text { masks (one of these weeping eye), at } \\
\text { least 6 small maskettes }\end{array}$ & Hoffman 1997 \\
\hline Buffalo 46Pu0031 & $\begin{array}{l}\text { fresh and marine shell masks, 1 citico } \\
\text { rattlesnake, 2 small maskettes w/ } \\
\text { weeping eyes }\end{array}$ & $\begin{array}{l}\text { Hoffman 1997, } \\
\text { Brashler Moxley 1990 }\end{array}$ \\
\hline Clover 46Cb0010 & $\begin{array}{l}\text { 7 marine gorgets: 2 large Buffalo } \\
\text { weeping eye, some maskettes }\end{array}$ & Hoffman 1997 \\
\hline Marmet Village 46Ka0009 & $\begin{array}{l}\text { grave gogets, most of any WV site, } \\
\text { weeping eye, rattlesnake, maskettes }\end{array}$ & Pullins et al, 2008 \\
\hline Rolf Lee 46Ms0051 & several marine shell gorgets & Hoffman 2001 \\
\hline Orchard 46Ms0061 & cruciform marine shell mask & Hoffman 1997 \\
\hline Somers Farm 46Ms0038 &
\end{tabular}

\begin{tabular}{|l|l|l|}
\hline Table 2.1 & Materials & Citation \\
\hline Name & 1 blue glass trade bead & Solecki 1949 \\
\hline Barkers Bottom 46Su0003 & $\begin{array}{l}\text { 2 glass beads: 1 green 1600-25, 1 dark } \\
\text { blue-black nd }\end{array}$ & Trader 2003 \\
\hline 46Su0672 & Copper, Brass, Glass beads & $\begin{array}{l}\text { Hoffman 1997, } \\
\text { Brashler Moxley 1990 }\end{array}$ \\
\hline Clover 46Cb0010 & 1 glass bead & Maslowski et al 1985 \\
\hline Gue Farm 46Cb0004 & trade beads & $\begin{array}{l}\text { Maslowski 1984, } \\
\text { Maslowski et al 1995 }\end{array}$ \\
\hline Logan 46Lg0004 & European trade goods & Youse 1988 \\
\hline Marmet Village 46Ka0009 & $\begin{array}{l}\text { glass trade beads (1550-1650) Euro } \\
\text { copper, 1 iron ax }\end{array}$ & Hemming 1997 \\
\hline $\begin{array}{l}\text { 46Wle's Landing } \\
\text { Rolf Lee 46Ms0051 }\end{array}$ & $\begin{array}{l}\text { iron ax in child burial mound, early 17 } \\
\text { cent. glass beads } \\
\text { glass beads in burial context } \\
\text { 100s of beads with shell beads, copper } \\
\text { and brass bits 1575-1640 } \\
\text { 40 round blue glass beads }\end{array}$ & $\begin{array}{l}\text { Baker 1986 Ohio } \\
\text { Archaeologist, Youse } \\
1965: \text { per Graybill } \\
1981\end{array}$ \\
\hline Orchard 46Ms0061 & $\begin{array}{l}\text { brass and copper rolled beads, yes and } \\
\text { maybe of euro origin 1 white glass seed } \\
\text { bead, and an amber bead }\end{array}$ & Pullins et al, 2008 \\
\hline Buffalo 46Pu0031 & & \\
\hline
\end{tabular}




\begin{tabular}{|c|c|c|}
\hline \multicolumn{2}{|l|}{ Table 2.2} & \multirow{2}{*}{$\begin{array}{l}\text { Probable Epidemic Episodes to } \mathbf{1 6 9 9}^{\top} \\
\text { Reoion-Peonle Affected }\end{array}$} \\
\hline Date & Disease & \\
\hline $1520-1524$ & Smallpox & $\begin{array}{l}\text { Total geographic extent unknown; at least from Chile across } \\
\text { present United States, causing greater mortality than any later } \\
\text { episode }\end{array}$ \\
\hline 1528 & Typhoid & Gulf coast barrier islanders \\
\hline $1531-1533$ & Measles & $\begin{array}{l}\text { New Spain and probably far beyond the colony northward, } \\
\text { including Pueblos and more }\end{array}$ \\
\hline 1535 & Unknown & St. Lawrence River valley, southern Plains, Southeast \\
\hline 1559 & Influenza & Southeastern tribes; Gulf Coast to central New Spain \\
\hline $1564-1570$ & Unknown & Florida to Virginia and New England tribes \\
\hline $1592-1593$ & Measles & Sinaloa \\
\hline $1592-1593$ & Smallpox & $\begin{array}{l}\text { Central Mexico to Sinaloa; southern New England; eastern Great } \\
\text { Lakes }\end{array}$ \\
\hline 1602 & Measles & Sinaloa \\
\hline 1602 & Smallpox & Sinaloa and northward \\
\hline $1633-1634$ & Measles & $\begin{array}{l}\text { New England, New France, and Great Lakes groups; Native } \\
\text { Americans near Boston and Plymouth, to Mohawks, Oneidas, } \\
\text { Hurons, Montagnais, Narragansetts, Delawares }\end{array}$ \\
\hline 1639 & Smallpox & French and British Northeastern North America \\
\hline $1646-1648$ & Smallpox & $\begin{array}{l}\text { New Spain north to Nuevo León tribes and western Sierra Madre } \\
\text { to Florida }\end{array}$ \\
\hline 1647 & Influenza & New England tribes \\
\hline $1649-1650$ & Smallpox & $\begin{array}{l}\text { Northeastern tribes; Montagnais-Naskapi to Quebec, Huron, and } \\
\text { Iroquois; Florida }\end{array}$ \\
\hline 1655 & Smallpox & Florida chiefdoms \\
\hline $1658-1659$ & Measles & Canadian tribes; Florida to Mexico City with diphtheria \\
\hline $1662-1663$ & Smallpox & Iroquois, Delaware, Canadian tribes, and Central Mexico \\
\hline $1665-1667$ & Smallpox & Florida chiefdoms to Virginia tribes \\
\hline $1669-1670$ & Smallpox & French and British northeastern people \\
\hline $1674-1675$ & Smallpox & Coahuiltecan tribes of Texas, northeastern New Spain \\
\hline 1675 & Influenza & Iroquois and New England tribes \\
\hline $1677-1679$ & Smallpox & Northeastern tribes in New France and British territory \\
\hline $1687-1691$ & Smallpox & Northeastern tribes French-British frontiers, Texas tribes \\
\hline $1692-1693$ & Measles & Illinois peoples, Oneidas \\
\hline $1696-1698$ & Influenza & $\begin{array}{l}\text { Possible component with smallpox epidemic among Gulf Coast } \\
\text { and Southeastern peoples }\end{array}$ \\
\hline $1696-1699$ & Smallpox & Southeastern and Gulf Coast chiefdoms decimated \\
\hline
\end{tabular}

\footnotetext{
${ }^{1}$ Collated from Henry Dobyns, Their Number Became Thinned: Native American Population Dynamics in Eastern North America. Published by the University of Tennessee Press in cooperation with the Newberry Library Center for the History of the American Indian, 1983: 15, 17, 19, 23.
} 


\subsection{Batts and Fallam Calculations}

\begin{tabular}{|c|c|c|c|c|c|}
\hline Name & Mileage & Per day & Days & Est. $^{2}$ & $\begin{array}{l}\text { (H) Horses } \\
\text { (F) On Foot }\end{array}$ \\
\hline $9 / 1 / 1671$ & 43.21 & 43.21 & 1 & 40 & $\mathrm{H}$ \\
\hline 9/2/1671 & 39.67 & 39.67 & 1 & 45 & $\mathrm{H}$ \\
\hline 9/2-5/1671 Appomatox guides To Sapon & 59.94 & 14.99 & 4 & & $\mathrm{~F}$ \\
\hline 9/3/1671 & 27.8 & 27.80 & 1 & 40 & $\mathrm{H}$ \\
\hline $9 / 4 / 1671$ & 15.15 & 15.15 & 1 & & $\mathrm{H}$ \\
\hline $9 / 5 / 1671$ & 23.27 & 23.27 & 1 & 25 & $\mathrm{H}$ \\
\hline $\begin{array}{l}\text { 9/5/1671 Portuguese and horse to Ft. } \\
\text { Henry }\end{array}$ & 114.58 & 38.19 & 3 & & $\mathrm{H}$ \\
\hline $9 / 6 / 1671$ & 22.67 & 22.67 & 1 & 20 & $\mathrm{H}$ \\
\hline 9/7/1671 & 24.12 & 24.12 & 1 & 25 & $\mathrm{H}$ \\
\hline $9 / 8 / 1671$ & 21.95 & 21.95 & 1 & 30 & $\mathrm{H}$ \\
\hline 9/9/1671 & 17.08 & 17.08 & 1 & 25 & $\mathrm{H}$ \\
\hline $9 / 12 / 1671$ & 31.64 & 31.64 & 1 & 25 & $\mathrm{~F}$ \\
\hline 9/13/1671 & 15.67 & 15.67 & 1 & 22 & $\mathrm{~F}$ \\
\hline $9 / 14 / 1671$ & 16.75 & 16.75 & 1 & 20 & $\mathrm{~F}$ \\
\hline $9 / 15 / 1671$ & 9.3 & 9.30 & 1 & 15 & $\mathrm{~F}$ \\
\hline 9/15/1671 Indian Hunt ${ }^{3}$ & 20.06 & 20.06 & 1 & & $\mathrm{~F}$ \\
\hline 9/15-16/1671 Tutelo to Monyton & 71.91 & 35.96 & 2 & & $\mathrm{~F}$ \\
\hline $9 / 16 / 1671$ & 9.0 & 9.0 & 1 & 10 & $\mathrm{~F}$ \\
\hline 9/16-21/1671 Monyton-Tut-to Totera & 128.78 & 25.76 & 5 & & $\mathrm{~F}$ \\
\hline $9 / 18-21 / 1671$ & 74.12 & 18.53 & 4 & & $\mathrm{~F}$ \\
\hline $9 / 22-24 / 1671$ & 85.24 & 28.41 & 3 & & $\mathrm{H}$ \\
\hline $9 / 24-25 / 1671$ & 22.76 & 11.38 & 2 & & $\mathrm{H}$ \\
\hline $9 / 27-28 / 1671$ & 102.66 & 51.33 & 2 & & $\mathrm{H}$ \\
\hline $10 / 1 / 1671$ & 2.85 & 2.85 & 1 & & $\mathrm{H}$ \\
\hline \multicolumn{2}{|l|}{ Average Daily Miles } & & & & \\
\hline Main Party on Horseback & 26.22 & & & & \\
\hline Main Party on Foot & 14.41 & & & & \\
\hline Indians on Foot & 25.57 & & & & \\
\hline
\end{tabular}

\footnotetext{
${ }^{2}$ Estimated in Fallam's journal as printed in Alvord Bidgood

${ }^{3}$ Estimated based on location
} 


\subsection{Needham and Arthur Calculation}

\begin{tabular}{|l|r|r|r|l|}
\hline & & & & $\begin{array}{l}\text { (H) Horses } \\
\text { Name }\end{array}$ \\
& Mileage & Per day & Days & [R] On River \\
\hline $4 / 10-15 / 1673$ & 192.8 & 38.56 & 5 & $\mathrm{H}$ \\
\hline $4 / 15-20 / 1673$ & 193.16 & 38.63 & 5 & $\mathrm{H}$ \\
\hline $5 / 17-21 / 1673$ & 162.97 & 32.59 & 3 & $\mathrm{H}$ \\
\hline $7 / 10-14 / 1673$ & 316.8 & 79.2 & 4 & $\mathrm{H}$ \\
\hline $7 / 11-14 / 1673$ & 154.99 & 51.66 & 3 & $\mathrm{H}$ \\
\hline $7 / 14-20 / 1673$ & 58.89 & 9.82 & 6 & $\mathrm{H}$ \\
\hline $7 / 20-25 / 1673$ & 162.57 & 40.64 & 4 & $\mathrm{H}$ \\
\hline $7 / 25 / 1673$ & 21.09 & 42.18 & 0.5 & $\mathrm{H}$ \\
\hline $7 / 25-8 / 10 / 1673$ & 77.08 & 5.14 & 15 & $\mathrm{H}$ \\
\hline $8 / 11-9 / 10 / 1673$ & 634.88 & 20.48 & 30 & $\mathrm{H}$ \\
\hline $9 / 20-26 / 1673$ & 162.79 & 40.7 & 5 & $\mathrm{H}$ \\
\hline $9 / 26-27 / 1673$ & 101.45 & 50.73 & 1 & $\mathrm{H}$ \\
\hline $9 / 27 / 1673$ & 53.02 & 53.02 & 0.5 & $\mathrm{H}$ \\
\hline $9 / 27-29 / 1673$ & 101.45 & 50.73 & 2 & $\mathrm{H}$ \\
\hline $9 / 27-10 / 5 / 1673$ & 301.49 & 33.5 & 9 & $\mathrm{~F}$ \\
\hline $10 / 8-17 / 1673$ & 296.67 & 37.09 & 8 & $\mathrm{~F}$ \\
\hline $10 / 17-18 / 1673$ & 6.51 & 6.51 & 1 & $\mathrm{~F}$ \\
\hline $10 / 18-19 / 1673$ & 6.51 & 6.51 & 1 & $\mathrm{~F}$ \\
\hline $10 / 26-11 / 5 / 1673$ & 296.67 & 32.96 & 9 & $\mathrm{~F}$ \\
\hline $12 / 13-20 / 1673$ & 99.26 & 16.54 & 6 & $\mathrm{~F}$ \\
\hline $12 / 20-23 / 1673$ & 309.23 & 154.62 & 3 & $\mathrm{R}$ \\
\hline $12 / 23-25 / 1673$ & 14.16 & 14.16 & 2 & $\mathrm{~F}$ \\
\hline $12 / 25 / 1673$ & 14.24 & 14.24 & 1 & $\mathrm{~F}$ \\
\hline $12 / 25 / 1673-1 / 8 / 1674$ & 432.64 & 30.90 & 14 & $\mathrm{~F}$ \\
\hline $3 / 8-13 / 1674$ & 450.09 & 45.01 & 10 & $\mathrm{~F}$ \\
\hline $3 / 21-24 / 1674$ & 89.78 & 29.93 & 3 & $\mathrm{~F}$ \\
\hline $3 / 25-4 / 7 / 1674$ & 461.55 & 46.12 & 10 & $\mathrm{~F}$ \\
\hline $3 / 27-29 / 1674$ & 13.97 & 6.99 & 2 & $\mathrm{~F}$ \\
\hline $3 / 29-4 / 9 / 1674$ & 330.26 & 30.0 & 11 & $\mathrm{~F}$ \\
\hline $4 / 13-19 / 1674$ & 739.7 & 147.94 & 5 & $\mathrm{R}$ \\
\hline $4 / 19-5 / 4 / 1674$ & 734.95 & 49.0 & 15 & $\mathrm{~F}$ \\
\hline $5 / 10-6 / 5 / 1674$ & 399.87 & 14.81 & 27 & $\mathrm{~F}$ \\
\hline $6 / 5-6 / 1674$ & 0.47 & 0.47 & 0.5 & $\mathrm{~F}$ \\
\hline $6 / 5-7 / 1674$ & 27.57 & 27.57 & 0.5 & $\mathrm{~F}$ \\
\hline $6 / 5-20 / 1674$ & 399.87 & 26.66 & 15 & $\mathrm{~F}$ \\
\hline $6 / 6-7 / 1674$ & 0.47 & 0.47 & 1 & $\mathrm{~F}$ \\
\hline $6 / 7-9 / 1674$ & 62.13 & 31.07 & 2 & $\mathrm{~F}$ \\
\hline & & & & \\
\hline & & & \\
\hline & & &
\end{tabular}




\begin{tabular}{|l|r|r|r|l|}
\hline $6 / 9-11 / 1674$ & 24.74 & 24.74 & 2 & $\mathrm{~F}$ \\
\hline $6 / 11-18 / 1674$ & 162.73 & 27.12 & 6 & $\mathrm{~F}$ \\
\hline $6 / 11 / 1674$ & 0.23 & 0.23 & 0.5 & $\mathrm{~F}$ \\
\hline $6 / 24-7 / 15 / 1674$ & 445.26 & 22.26 & 20 & $\mathrm{~F}$ \\
\hline $7 / 15-16 / 1674$ & 45.72 & 45.72 & 1 & $\mathrm{~F}$ \\
\hline $7 / 16-18 / 1674$ & 182.08 & 60.69 & 2 & $\mathrm{~F}$ \\
\hline $7 / 18-18 / 1674$ & 20.46 & 20.46 & 1 & $\mathrm{~F}$ \\
\hline $7 / 19-20 / 1674$ & 23.33 & 23.33 & 1 & $\mathrm{~F}$ \\
\hline
\end{tabular}

Average Daily Miles

Horseback

39.58

River 151.28

Foot 25.00 
Table 4.1a: C14 database d $^{4}$

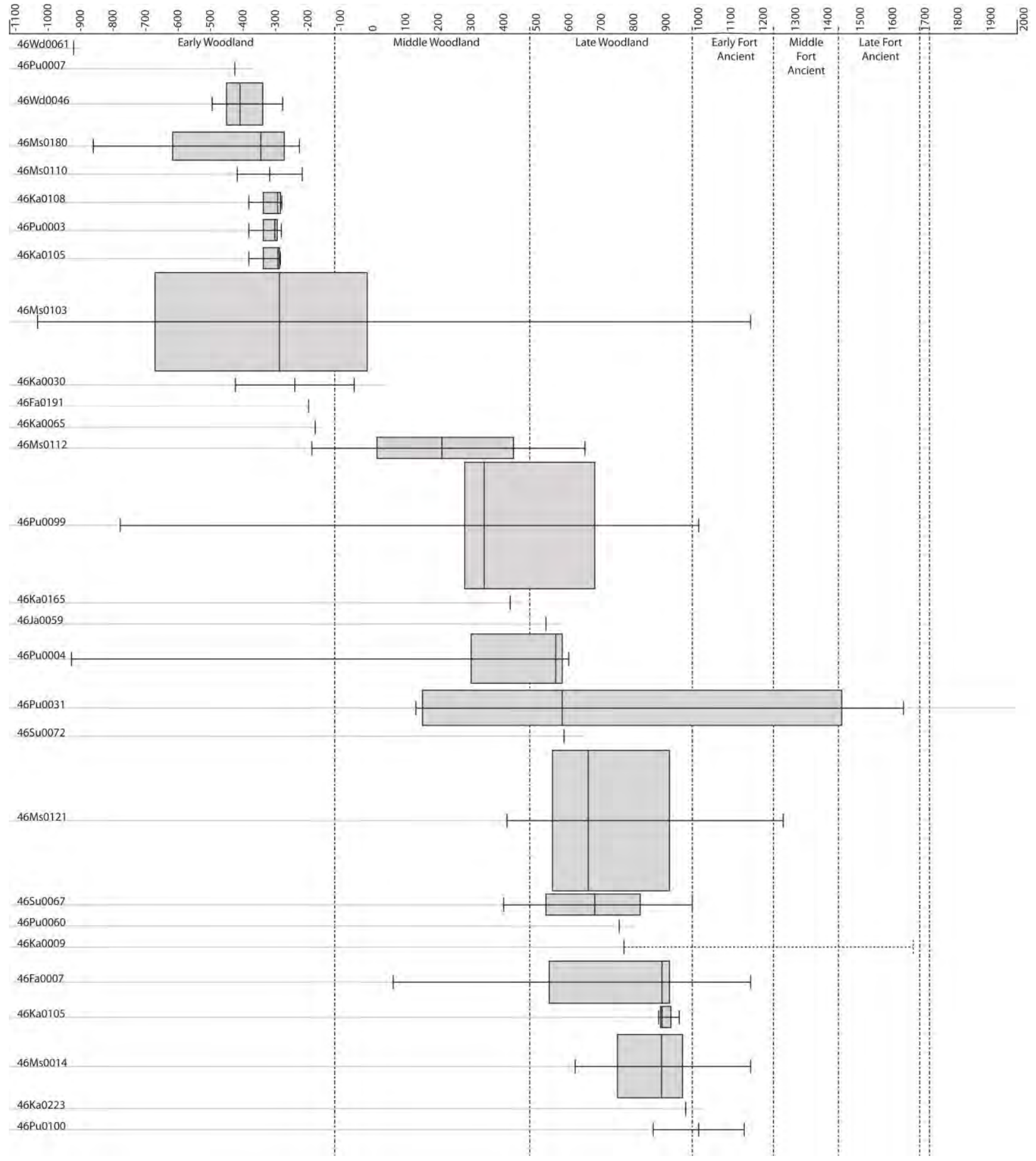

${ }^{4}$ Pullins et al 2008: Table 3.4 and Table 3.6. 
Table 4.1b: C14 database

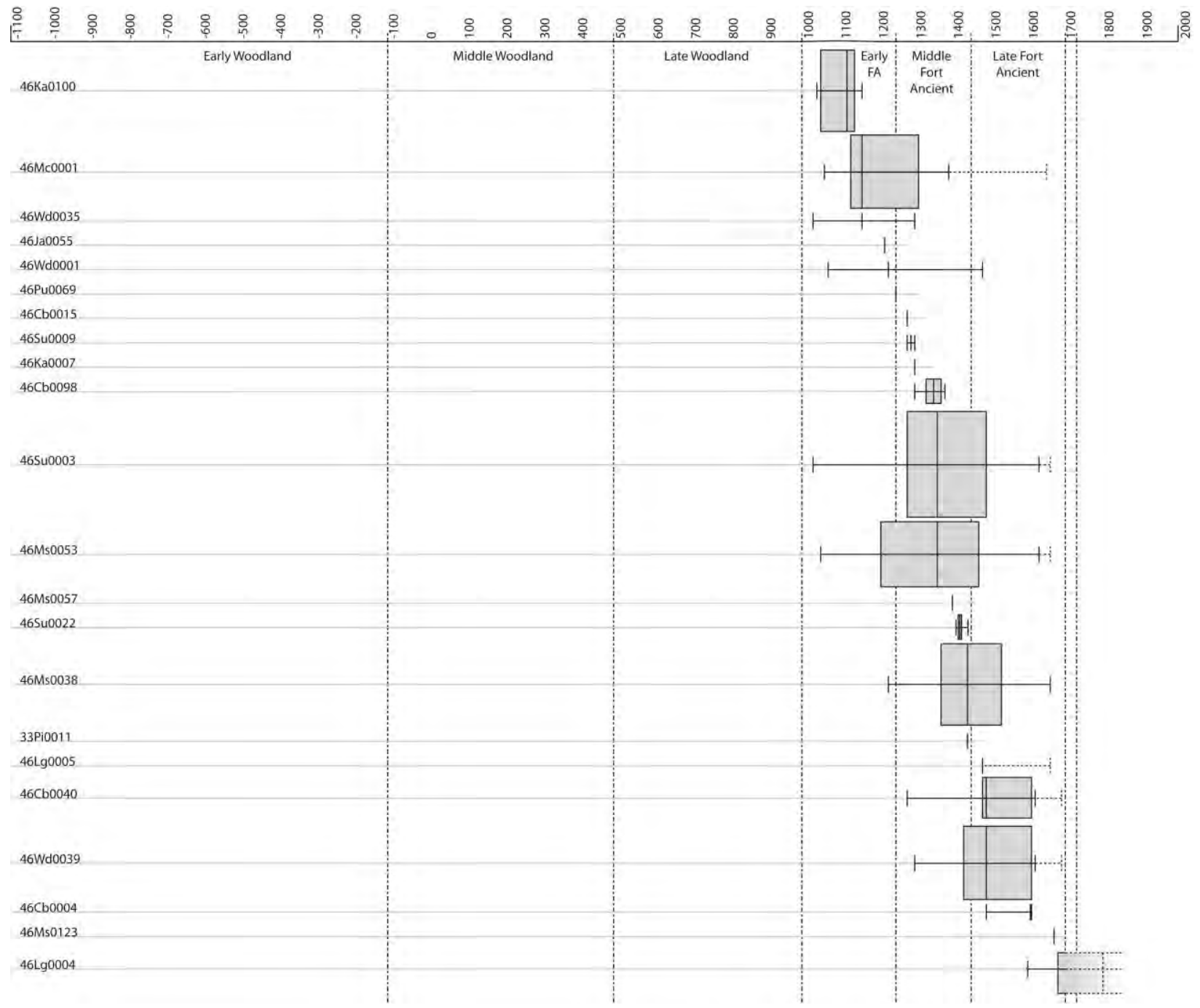


Table 4.2: Archaeological Grave data ${ }^{5}$

\begin{tabular}{|c|c|c|c|c|c|c|}
\hline Site & Site \# & State & Total & Multiple & Grave goods & Trauma \\
\hline Augusta & $15 \mathrm{Bk} 0200$ & KY & & 0 & $40 \%+$ & $10 \%$ \\
\hline Hardin & $15 \mathrm{Gp} 0022$ & KY & & & $47 \%$ & $1 \%$ \\
\hline Fox farm & $15 \mathrm{Ms} 0001$ & KY & & Common & nearly always & $1.7 \%+$ \\
\hline Slone & 16Pi0011 & KY & 53 & & $44.20 \%$ & \\
\hline Campbell Island & $33 \mathrm{Bu} 0002$ & $\mathrm{OH}$ & 21 & & $38-43 \%$ & 0 \\
\hline Taylor & 33Er0003 & $\mathrm{OH}$ & 17 & $?$ & $6 \%$ & \\
\hline Turpin 1 & $33 \mathrm{Ha} 0028$ & $\mathrm{OH}$ & 26 & & $8 \%$ & 7 \\
\hline Turpin 2 & $33 \mathrm{Ha} 0028$ & $\mathrm{OH}$ & 223 & & $24 \%$ & $4 \%$ \\
\hline Turpin 3 & $33 \mathrm{Ha} 0028$ & $\mathrm{OH}$ & 28 & & $14 \%$ & $5 \%$ \\
\hline Incinerator & 33Мy0057 & $\mathrm{OH}$ & 145 & $?$ & $30 \%$ & \\
\hline Fuert & $33 \mathrm{Sc} 0006$ & $\mathrm{OH}$ & & $1(4)$ & $8 \%$ & $0.7 \%+$ \\
\hline Anderson & $33 \mathrm{Wa} 0004$ & $\mathrm{OH}$ & 93 & $?$ & $28 \%$ & $6 \%$ \\
\hline Sand Ridge & $33 \mathrm{Wa} 0100$ & $\mathrm{OH}$ & 23 & $?$ & $?$ & \\
\hline Trigg & $44 \mathrm{My} 0003$ & $\mathrm{VA}$ & 313 & & $48 \%$ & \\
\hline Crab Orchard & $44 \mathrm{Tz} 0001$ & $\mathrm{VA}$ & & & $32 \%$ & \\
\hline Clover & $46 \mathrm{Cb} 0010$ & WV & 6 & & $33-50 \%$ & 0 \\
\hline Marmet & $46 \mathrm{Ka} 0009$ & WV & 60 & & $100 \%$ & $75 \%$ \\
\hline Burning Spring & $46 \mathrm{Ka} 0142$ & WV & 30 & & & \\
\hline Man & $46 \operatorname{Lg} 0005$ & WV & $37(80-120)$ & & $50 \%$ & \\
\hline Snidow & $46 \mathrm{Mc} 0001$ & WV & 26 & & & \\
\hline Shadle Farm & $46 \mathrm{Ms} 0004$ & WV & many & $1(13+)$ & $50 \%$ & \\
\hline Rolf Lee & $46 \mathrm{Ms} 0051$ & WV & $19(82)$ & $1(3)$ & $32-57 \%$ & $5.3 \%+$ \\
\hline Roseberry Farm & $46 \mathrm{Ms} 0053$ & WV & 26 & & & \\
\hline Orchard & $46 \mathrm{Ms} 0061$ & WV & $300(150)$ & $1(40+)$ & $25-30 \%$ & 1 \\
\hline Buffalo & $46 \mathrm{Pu} 0031$ & WV & 562 & & $22 \%$ & $2.3 \%+$ \\
\hline Island Creek & $46 \mathrm{Su} 0009$ & WV & 100 & & $33.33 \%$ & \\
\hline Neales Landing & 46Wd0039 & WV & & $1(3)$ & $53 \%$ & $9 \%$ \\
\hline
\end{tabular}

\footnotetext{
${ }^{5}$ Compiled from various site reports, especially Pullins et al 2008; Graybill 1981; Buchanan 1986, 264 and 266-7; Hanson1975; MacCord Buchanan 1980, Drooker 1999 and 1997.
} 


\begin{tabular}{|c|c|c|}
\hline \multicolumn{3}{|c|}{ Table 4.3: Iroquois War Raids ${ }^{6}$} \\
\hline Date & Groups & Note \\
\hline Winter 1661-1662 & Onondaga vs. Shawnee & $\begin{array}{l}\text { some Females and Children killed in Upper } \\
\text { Ohio Valley, "This was a reprisal for Onon } \\
\text { deaths incurred 8-9 years past when Onon had } \\
\text { attacked Shawnee." JR: 47:145-147. }\end{array}$ \\
\hline April 1663 & $\begin{array}{l}\text { Iroquois (Seneca, Cayuga, } \\
\text { Onon.) vs. } \\
\text { Susquehannock village }\end{array}$ & $\begin{array}{l}\text { 25+ Iroquois killed, } 10 \text { captured, unknown } \\
\text { number captured, Ohio River, JR: 48:7-79, } \\
\text { NYCD 12:431. }\end{array}$ \\
\hline $\begin{array}{l}\text { Mid to Late } \\
\text { August } 1669\end{array}$ & Seneca vs. Shawnee & $\begin{array}{l}\text { 1 Shawnee male captured, and tortured to } \\
\text { death, war party arrived this date, Galinee, } \\
\text { "Voyage de Dollier et Galinee" } 32,34\end{array}$ \\
\hline 26 August 1669 & $\begin{array}{l}\text { Iroquois (4 Onon and } 1 \\
\text { Seneca) vs. Shawnee }\end{array}$ & $\begin{array}{l}2 \text { Shawnee captured, don't know when } \\
\text { occurred, returned this day. JR: 53:245, } \\
54: 113,115\end{array}$ \\
\hline $\begin{array}{l}\text { Fall to Winter } \\
1669\end{array}$ & $\begin{array}{l}500 \text { Seneca } \& \text { additional } \\
\text { Cayuga vs. Shawnee }\end{array}$ & JR: 53: 47-49, 54:117 \\
\hline 17 June 1676 & Onon vs.? & $\begin{array}{l}50 \text { captured from } 2 \text { different tribes of whom } 6 \\
\text { female, } 5 \text { male, } 1 \text { male child and } 1 \text { child killed, } \\
\text { went } 200 \text { leagues SW, might have been } \\
\text { Shawnee? JR: } 60: 185 \text {, NYCD: } 3: 252\end{array}$ \\
\hline 6 Feb 1682 & Seneca vs? & $\begin{array}{l}35 \text { captured, at one location, } 4-5 \text { at another, } \\
\text { "New reported this day. Writing from Mt. } \\
\text { Paradise, Virginia, C. Jones notes } 35 \text { capt. in } \\
\text { an attack } 300 \text { miles SSW from his location, } \\
\text { and } 4-5 \text { capt. from some villages "under the } \\
\text { mountains" } 500 \text { miles away. Not clear if in } \\
\text { same direction." CSP 11:193 Calendar of State } \\
\text { Papers, Colonial series America and the West } \\
\text { Indies, ed. W. Sainsbury et al. }\end{array}$ \\
\hline Spring 1685 & Iroq. vs, Saponi & $\begin{array}{l}\text { some Saponi wounded, } 1 \text { captured, below the } \\
\text { mountains, LIR } 85\end{array}$ \\
\hline
\end{tabular}

\footnotetext{
${ }^{6}$ Table D.1: from José António Brandão, “Ye fyres shall burn no more: Iroquois Policy toward New France and Its Native Allies to 1701, (Lincoln: University of Nebraska Press, 1997), Table D.1.
} 
Table 4.4: Epidemiology $\mathrm{Chart}^{7}$

\begin{tabular}{|c|c|c|c|c|c|}
\hline Name & Incubation & Transmission & $\begin{array}{l}\text { Transm. } \\
\text { Rates }\end{array}$ & Mortality & Comm. \\
\hline Small pox & 7-17 days & $\begin{array}{l}\text { close airborne } \\
\text { droplets, lasts on } \\
\text { clothing and fabrics, } \\
\text { contact with pustules }\end{array}$ & $80 \%$ & $60-80 \%$ & $\begin{array}{l}\text { lasts till } \\
\text { scabbed } \\
\text { and fall off }\end{array}$ \\
\hline Measles & 7-18 days & $\begin{array}{l}\text { close airborne } \\
\text { droplets, mucus- } \\
\text { saliva contact, can } \\
\text { stay in atmosphere } \\
\text { (room) for } 2 \text { hours }\end{array}$ & $90 \%$ & $10 \%$ & $\begin{array}{l}5 \text { days } \\
\text { before } \\
\text { rash, } 4 \\
\text { days after } \\
\text { rash }\end{array}$ \\
\hline Influenza & 1-4 days & $\begin{array}{l}\text { close airborne } \\
\text { droplets, mucus- } \\
\text { saliva contact, can } \\
\text { stay on surface for } 2- \\
8 \text { hours }\end{array}$ & $50-70 \%$ & $30-35 \%$ & $\begin{array}{l}4-5 \text { days } \\
\text { after fever }\end{array}$ \\
\hline Chicken pox & 14-16 days & $\begin{array}{l}\text { close airborne } \\
\text { droplets, mucus- } \\
\text { saliva contact, } \\
\text { vesicule fluid }\end{array}$ & $80 \%$ & $1-10 \%$ & $\begin{array}{l}1-5 \text { day } \\
\text { before } \\
\text { rash-1 } \\
\text { week after } \\
\text { crusted } \\
\text { lesions }\end{array}$ \\
\hline Diptheria & 2-5 days & $\begin{array}{l}\text { close airborne } \\
\text { droplets, mucus- } \\
\text { saliva contact, lesion } \\
\text { fluids can stay on } \\
\text { materials for 2-4 } \\
\text { weeks }\end{array}$ & $30 \%$ & $\begin{array}{r}20 \% \\
\text { (children } \\
80-90 \% \text { ) }\end{array}$ & $\begin{array}{l}10-15 \text { days } \\
\text { coughing }\end{array}$ \\
\hline Scarlet fever & 1-3 days & $\begin{array}{l}\text { respiratory droplets or } \\
\text { direct contact }\end{array}$ & $50-70 \%$ & $15-20 \%$ & $\begin{array}{l}\text { 10-21 days } \\
\text { coughing }\end{array}$ \\
\hline Tuberculosis & 2-12 weeks & $\begin{array}{l}\text { cough, sneeze, or } \\
\text { otherwise transmit } \\
\text { respiratory fluids } \\
\text { through the air }\end{array}$ & $22 \%$ & $50 \%$ & $\begin{array}{l}10-15 \text { days } \\
\text { coughing }\end{array}$ \\
\hline $\begin{array}{l}\text { Whooping } \\
\text { cough }\end{array}$ & 6-20 days & $\begin{array}{l}\text { large respiratory } \\
\text { droplets or direct } \\
\text { contact }\end{array}$ & $70-100 \%$ & $10 \%$ & $\begin{array}{l}\text { before } \\
\text { cough- } \\
\text { 3weeks }\end{array}$ \\
\hline $\begin{array}{l}\text { Bubonic } \\
\text { plaugue }\end{array}$ & 2-6 days & $\begin{array}{l}\text { fleas, ticks, from } \\
\text { rodents, close } \\
\text { airborne droplets }\end{array}$ & $100 \%$ & $50-75 \%$ & $\begin{array}{l}\text { fleas for } \\
\text { months }\end{array}$ \\
\hline Typhoid & 10-14 days & flea, mite, tick & $100 \%$ & $10-50 \%$ & louse \\
\hline Cholera & $\begin{array}{l}3 \text { hours-5 } \\
\text { days }\end{array}$ & $\begin{array}{l}\text { contaminated water } \\
\text { and food }\end{array}$ & $100 \%$ & $50-90 \%$ & $\mathrm{~N} / \mathrm{A}$ \\
\hline
\end{tabular}

\footnotetext{
${ }^{7}$ http://ideas.health.vic.gov.au/bluebook.asp, Accessed March 1, 2015.
} 
Table 4.5: Flora in the Okahok amai: ranked by percentage of material in sites ${ }^{8}$

Trees

$\begin{aligned} \text { \# } & \text { Scientific name } \\ 1 & \text { Carya ovata } \\ 2 & \text { Juglans cinera } \\ 3 & \text { Pinus virginiana } \\ 4 & \text { Robinia pseudocacia } \\ 5 & \text { Fraxinus americana } \\ 6 & \text { Quercus alba } \\ 7 & \text { Acer saccharum } \\ 8 & \text { Quercus velutina } \\ 9 & \text { Platanus occidentalis } \\ 10 & \text { Liriodendron tulipifera } \\ 11 & \text { Ulmaceae } \\ 12 & \text { Fagus spp. } \\ 13 & \text { Betula lutea } \\ 14 & \text { Quercus rubra } \\ 15 & \text { Acer rubrum } \\ 16 & \text { Aesculus spp. } \\ 17 & \text { Alnus spp. } \\ 18 & \text { Juniperus virginiana } \\ 19 & \text { Magnolia acuminata } \\ 20 & \text { Pinus strobus } \\ 21 & \text { Tsuga canadensis }\end{aligned}$

Generic name
shagbark hickory
butternut
virginia pine
black locust
white ash
white oak
sugar maple
black oak
sycamore
tulip poplar
elm hackberry
beech
yellow birch
red oak
red maple
buckeye
alder
red cedar
cucumber tree
eastern white pine
eastern hemlock

Plants

$\begin{array}{rll}\text { \# } & \text { Scientific name } & \text { Generic name } \\ 1 & \text { Poaceae sp. } & \text { grass } \\ 2 & \text { Phaseolus vulgaris } & \text { bean } \\ 3 & \text { Rhus spp. } & \text { sumac } \\ 4 & \text { Scirpus sp. } & \text { rush } \\ 5 & \text { Vitis spp. } & \text { wild grape } \\ 6 & \text { Chenopodium sp. } & \text { chenopodium } \\ 7 & \text { Smilacina racemosa } & \text { false Solomon's seal } \\ 8 & \text { Iva annua } & \text { sumpweed } \\ 9 & \text { galium sp. } & \text { bedstraw } \\ 10 & \text { Rubus spp. } & \text { wild blackberry } \\ 11 & \text { Festuca sp. } & \text { fescue } \\ 12 & \text { Phalaris caroliniana } & \text { maygrass } \\ 13 & \text { Helianthus annuus } & \text { sunflower } \\ 14 & \text { Asimina triloba } & \text { pawpaw } \\ 15 & \text { Cornus spp. } & \text { dogwood } \\ 16 & \text { Diospyros virginiana } & \text { persimmon } \\ 17 & \text { Vaccinium spp. } & \text { blueberry } \\ 18 & \text { Viburnum sp. } & \text { viburnum } \\ 19 & \text { Agrimonia spp. } & \text { agrimony } \\ 20 & \text { Rosa carolina } & \text { wild rose } \\ 21 & \text { Sassafras varifolium } & \text { sassafras }\end{array}$

Table 4.6: Flora in the Okahok amai: ranked by percentage of material in sites ${ }^{9}$

\begin{tabular}{|c|c|c|c|c|c|}
\hline \# & Species name & Generic name & \# & Species name & Generic name \\
\hline 1 & Odocoileus virginianus & deer & 17 & Trachemys sp. & turtle \\
\hline 2 & Unionidae & freshwater mussells & 18 & Procyon lotor & raccoon \\
\hline 3 & Terrapene carolina & box turtle & 19 & Terrapene sp. & turtle \\
\hline 4 & Percidae & perch & 20 & Sciurus carolinensis & grey squirrel \\
\hline 5 & Lepisosteus osseus & longnose gar & 21 & Ictalurus punctatus & channel catfish \\
\hline 6 & Gastropodea & snails & 22 & Tamias striatus & eastern chipmunk \\
\hline 7 & Chrysemys picta & painted turtle & 23 & Sylvilagus floridanus & eastern cottontail \\
\hline 8 & Cricetidae & muskrat & 24 & Natrix sipedon & northern water snake \\
\hline 9 & Aplodinotus grunniens & freshwater drum & 25 & Castor canadensis & beaver \\
\hline 10 & Lamprogeltis getula & kingsnake & 26 & Trachemys scripta & pond slider \\
\hline 11 & Agkistrodon contortrix & copperhead & 27 & Micropterus sp. & sunfish-bass \\
\hline 12 & Colubridae & snakes & 28 & Agkistrodon piscivorus & cottonmouth \\
\hline 13 & Apalone spiniferus & spiny softshell turtle & 29 & Coluber constrictor & northern black snake \\
\hline 14 & Catostomidae & sucker fish & 30 & Ursus americanus & black bear \\
\hline 15 & Apalone sp. & softshell turtle & 31 & Didelphis virginiana & virginia opossum \\
\hline 16 & Ictaluridae & catfish & 32 & Leporidae & rabbits \\
\hline
\end{tabular}

\footnotetext{
${ }^{8}$ Based on Applegarth 1978, 11, and Pullins et al 2008, Appendix I: 23, 25.

${ }^{9}$ Based on Applegarth 1978 12, Pullins et al 2008, Appendix H: 3-7; Barfield and Barber, nd, 203-4, and Graybill 1981, 56.
} 
Table 4.7: Southern Native Americans sold in the British slave trade, 1670-1715 ${ }^{10}$

\begin{tabular}{|l|l|l|}
\hline Place-Peoples & Low Range & High Range \\
\hline Florida & $15000-20000$ & 30000 \\
\hline Arkansas, Taensa, Tunica & 1000 & 2000 \\
\hline Petite nations (Lower MS) & 1000 & $2000-3000$ \\
\hline Choctaw & $1500-2000$ & 2500 \\
\hline Tuscarora and allies & $1000-1200$ & $1800-2000$ \\
\hline Westo & 500 & 1500 \\
\hline Subtotal & $20000-28200$ & 41000 \\
\hline $\begin{array}{l}\text { Piedmont, Creek, } \\
\text { Savannah, Chickasaw, } \\
\text { Cherokee, Mocama, Guale, } \\
\text { and others }\end{array}$ & 4000 & 10000 \\
\hline Total & $24000-32200$ & 51000 \\
\hline
\end{tabular}

Table 5.1: Seed Dispersal Characteristics of Thirteen Field Plants ${ }^{11}$

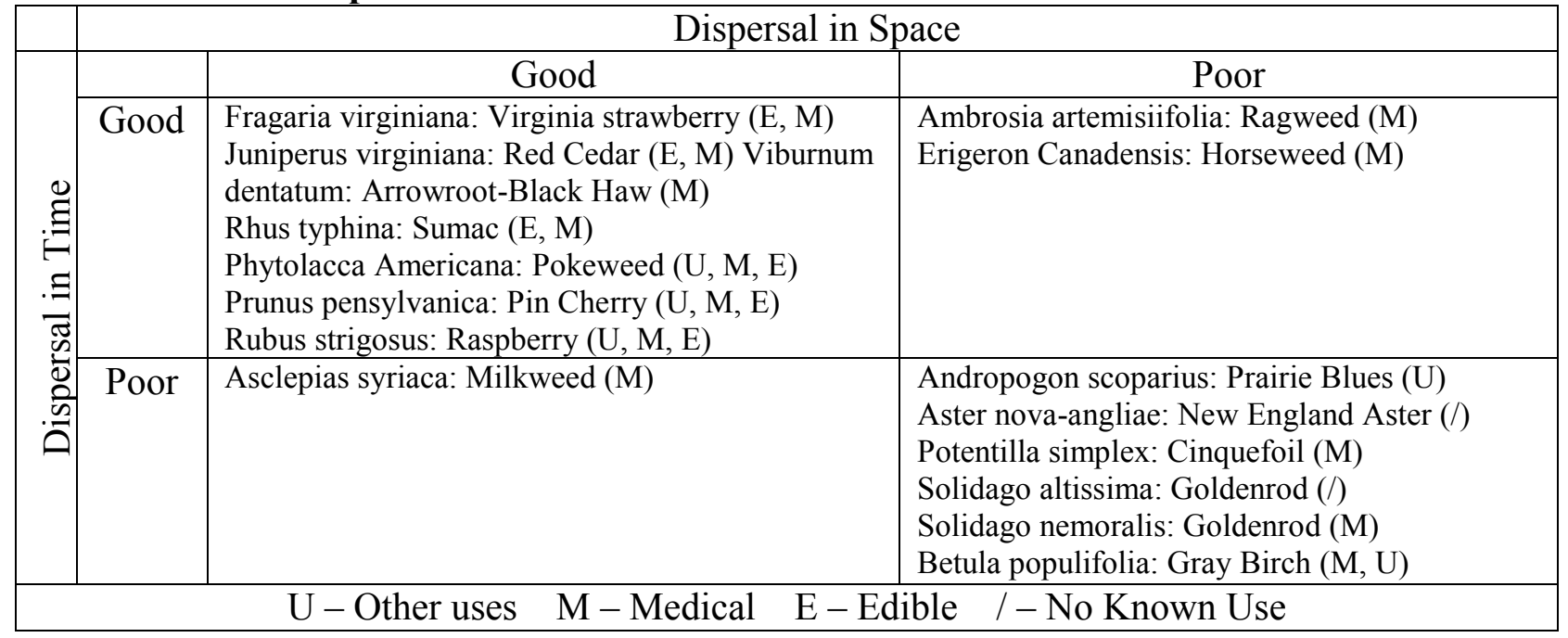

${ }^{10}$ Gallay 2007: 299

${ }^{11}$ Marks 1983: 222 
Table 6.1: Probable Epidemic Episodes: 1700-1760

\begin{tabular}{|c|c|c|}
\hline Year & Place & Disease \\
\hline 1702 & NY & Yellow fever \\
\hline $1702-03$ & Boston & Smallpox, and scarlet fever \\
\hline 1703 & FL & Unknown \\
\hline 1704 July-September & Mobile & Typhus, influenza, or measles \\
\hline 1706 & Charleston, SC; LA & Yellow fever \\
\hline 1708 September & VA & Multiple and unknown \\
\hline 1708 summer & Pensacola & Unknown \\
\hline 1709 February & $\mathrm{SC}$ & Unknown \\
\hline 1709 April & VA & Unknown \\
\hline 1709-1710 winter & VA & Unknown \\
\hline 1711 January & VA & Unknown \\
\hline 1711 winter & $\mathrm{SC}$ & Unknown \\
\hline 1711 May-1712 March & $\mathrm{SC}$ & Small pox \\
\hline 1711 summer & $\mathrm{NC}$ & Yellow fever (conjectural) \\
\hline 1711 December & $\mathrm{NC}$ & Typhus (conjectural) \\
\hline 1711 fall-1712 winter & $\mathrm{SC}$ & $\begin{array}{l}\text { Yellow fever, influenza, measles- } \\
\text { typhus (conjectural) }\end{array}$ \\
\hline 1713 & Boston & Measles \\
\hline $1715-1725$ & Most Colonies & Smallpox \\
\hline $1721-1730$ & Boston & Smallpox \\
\hline $1723-1730$ & NY, Philadelphia & Smallpox \\
\hline $1728-32$ & Charleston SC & Yellow fever \\
\hline 1729 & Boston & Measles \\
\hline $1732-33$ & Worldwide & Influenza \\
\hline 1734 & VA & Yellow Fever \\
\hline $1735-40$ & New England & diphtheria and scarlet fever \\
\hline 1738 & $\mathrm{SC}$ & Smallpox \\
\hline $1739-40$ & Boston & Measles \\
\hline 1741 & VA & Yellow Fever \\
\hline $1743-45$ & NY & Yellow fever \\
\hline 1747 & CT, NY, PA, SC & Measles \\
\hline 1752 & Boston, MA & Smallpox \\
\hline 1759 & North America & Measles \\
\hline $1760-1761$ & CT, RI, MA, Charleston & Smallpox \\
\hline $1761-62$ & North America \& West Indies & Influenza \\
\hline 1762 & Philadelphia & Yellow Fever \\
\hline $1763-64$ & Boston & Smallpox \\
\hline
\end{tabular}


Table 7.1: Treaties mentioned

\begin{tabular}{|l|l|l|}
\hline Date & Treaty & Parties \\
\hline 1646 & Treaty of Necotowance & Powhatan, Virginia \\
\hline 1677 & Treaty of Middle Plantation & Pamunkey, Virginia Indians, Virginia \\
\hline 1678 & Treaty of Casco & $\begin{array}{l}\text { Eastern Algonquian Indians, } \\
\text { Massachusetts }\end{array}$ \\
\hline 1698 & Treaty of Ryswick & $\begin{array}{l}\text { King Williams War, } \\
\text { European Nations }\end{array}$ \\
\hline 1701 & Great Peace of Montreal & Iroquois, French \\
\hline 1713 & Treaty of Utrecht & $\begin{array}{l}\text { Queen Annes War, } \\
\text { European Nations }\end{array}$ \\
\hline 1722 & Albany treaty & $\begin{array}{l}\text { Iroquois, British, New York, } \\
\text { Pennsylvania }\end{array}$ \\
\hline 1726 & Deed in Trust & Iroquois, British \\
\hline 1748 & Treaty of Aix-la-Chappelle & $\begin{array}{l}\text { Delaware, Mahicans, Susquehanna } \\
\text { River Indians, Pennsylvania }\end{array}$ \\
\hline 1744 & Treaty of Lancaster & European Nations \\
\hline 1748 & Treaty of Logstown & $\begin{array}{l}\text { Shawnee, Delaware, Ohio Indians, } \\
\text { Virginia }\end{array}$ \\
\hline 1752 & $2^{\text {nd }}$ Treaty of Logstown & Ohio Indians, Virginia \\
\hline 1763 & Treaty of Paris & Seven Years' War, European Nations \\
\hline
\end{tabular}




\section{Diagrams}



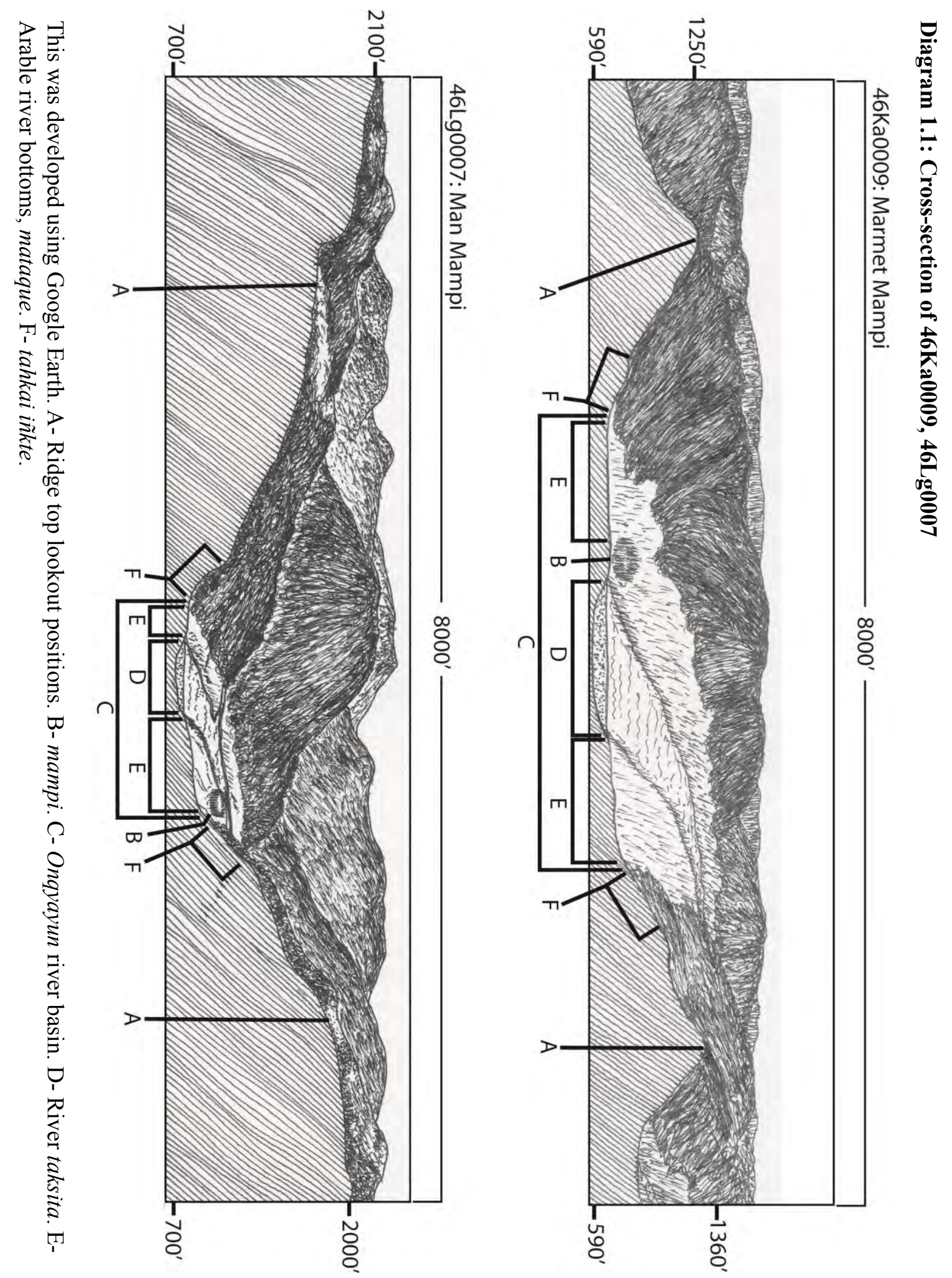


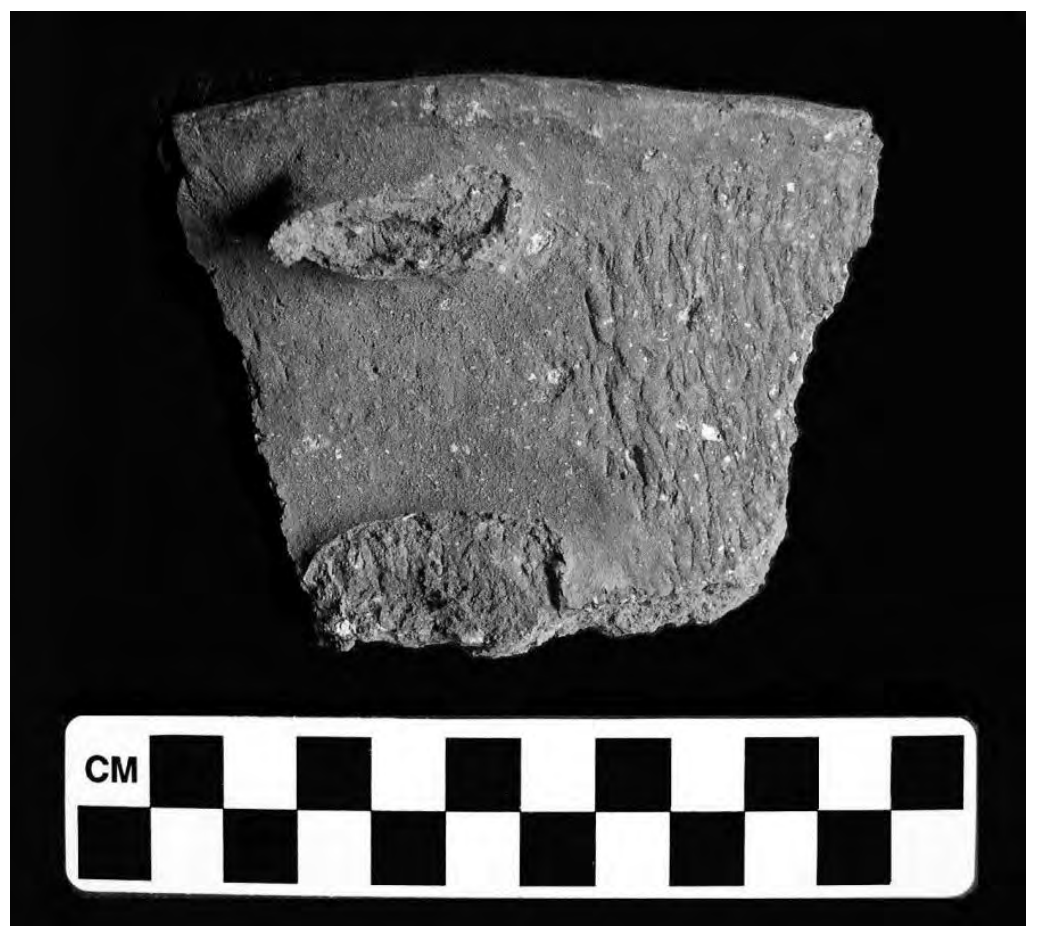

Diagram 1.2a Corncob impressions on rim of Buffalo mampi sherd (46Pu0031) (photo courtesy of Darla Spencer)

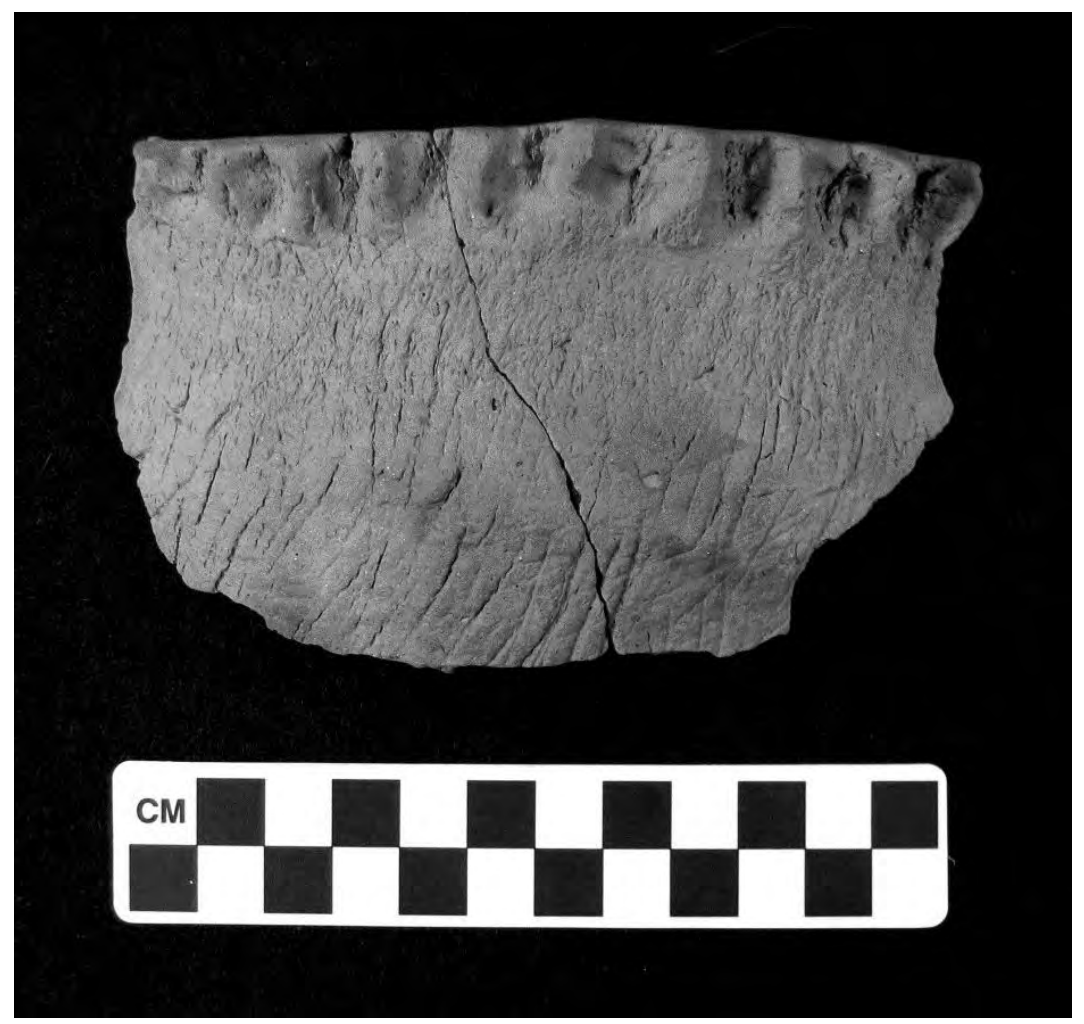

Diagram 1.2b Corncob impressions on rim of Burning Spring Branch mampi sherd (46Ka0142) (photo courtesy of Darla Spencer) 


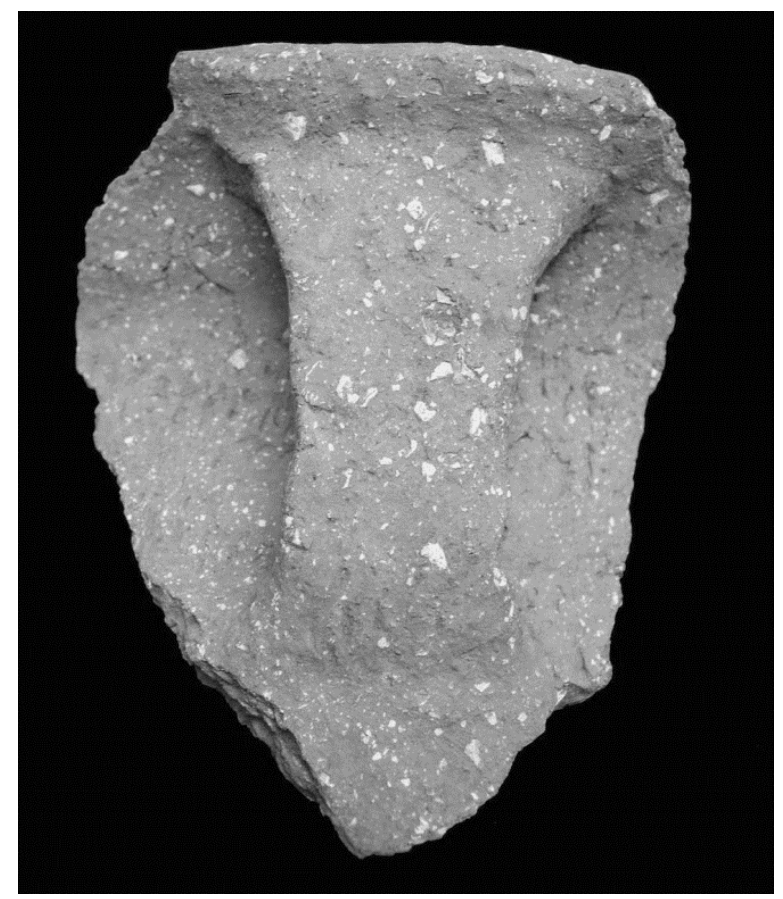

Diagram 1.2c Corncob impressions on rim and around strap of Marmet mampi sherd (46Ka0009) (photo courtesy of Darla Spencer)
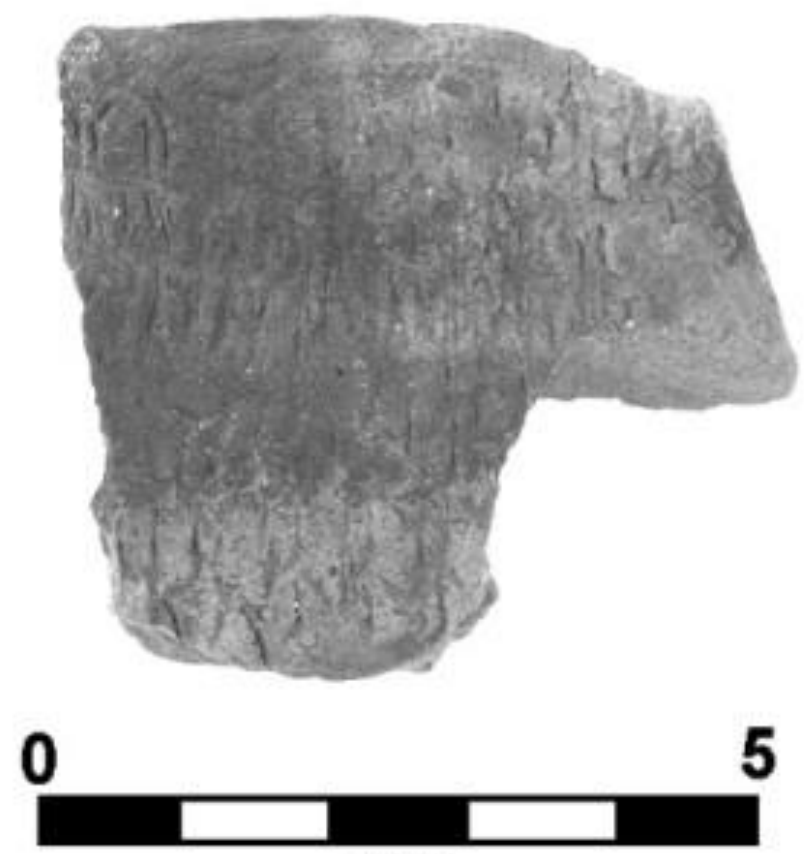

$\mathbf{c m}$

Diagram 1.2d Corncob impression on rim of Wells site (44Hr0009) Dan River sherd (Photo Davis, R. P. Stephen, Jr., Jane Eastman, Thomas O. Maher and Richard P. Gravely, Jr. Archaeological Investigations at the Wells Site, Henry County, Virginia. Research Report 16 (Research Laboratories of Archaeology, The University of North Carolina at Chapel Hill, 1997): 19. 


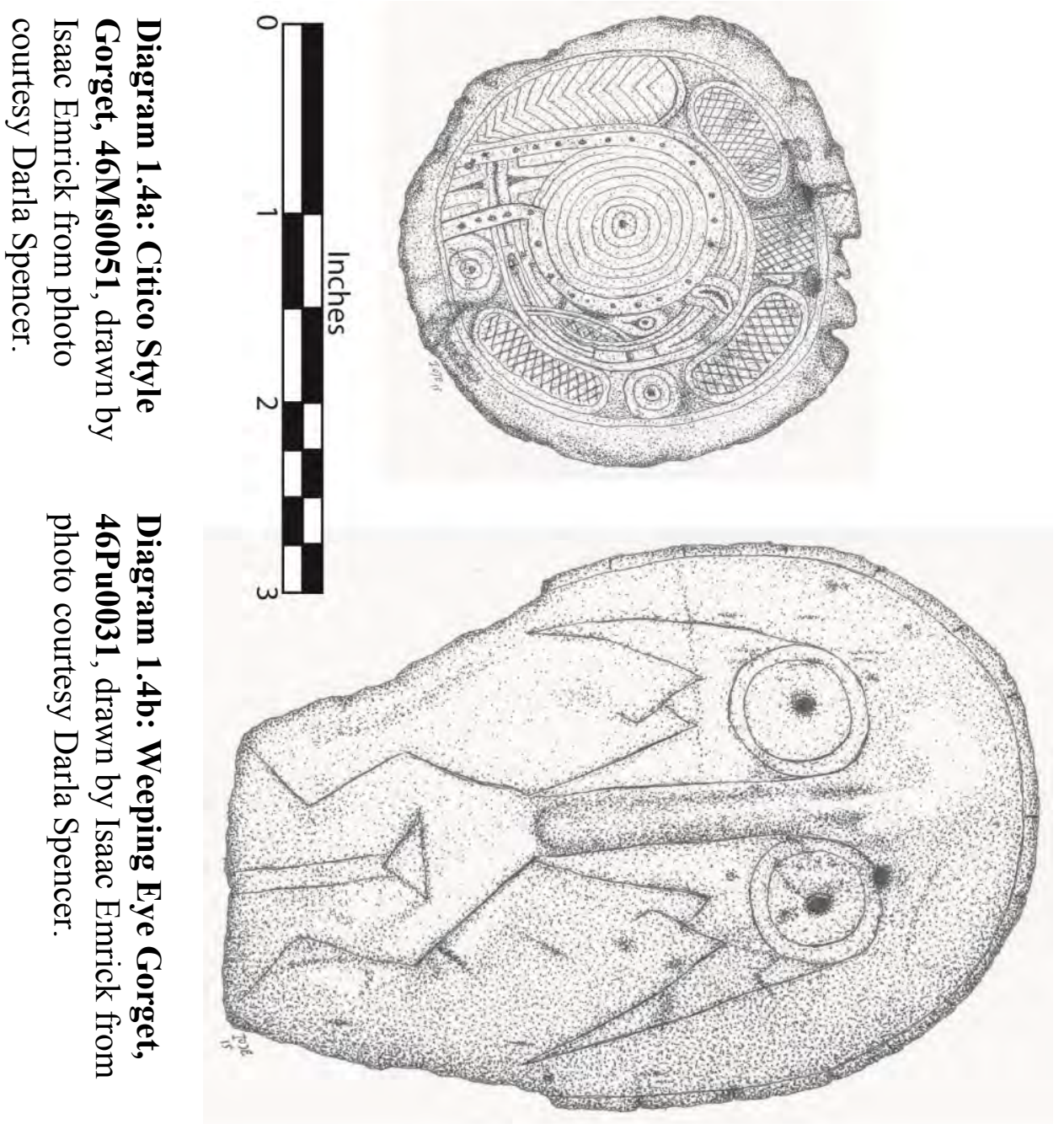

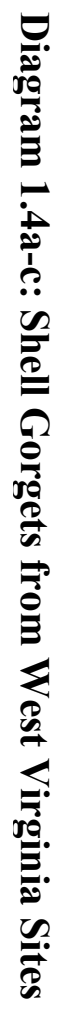
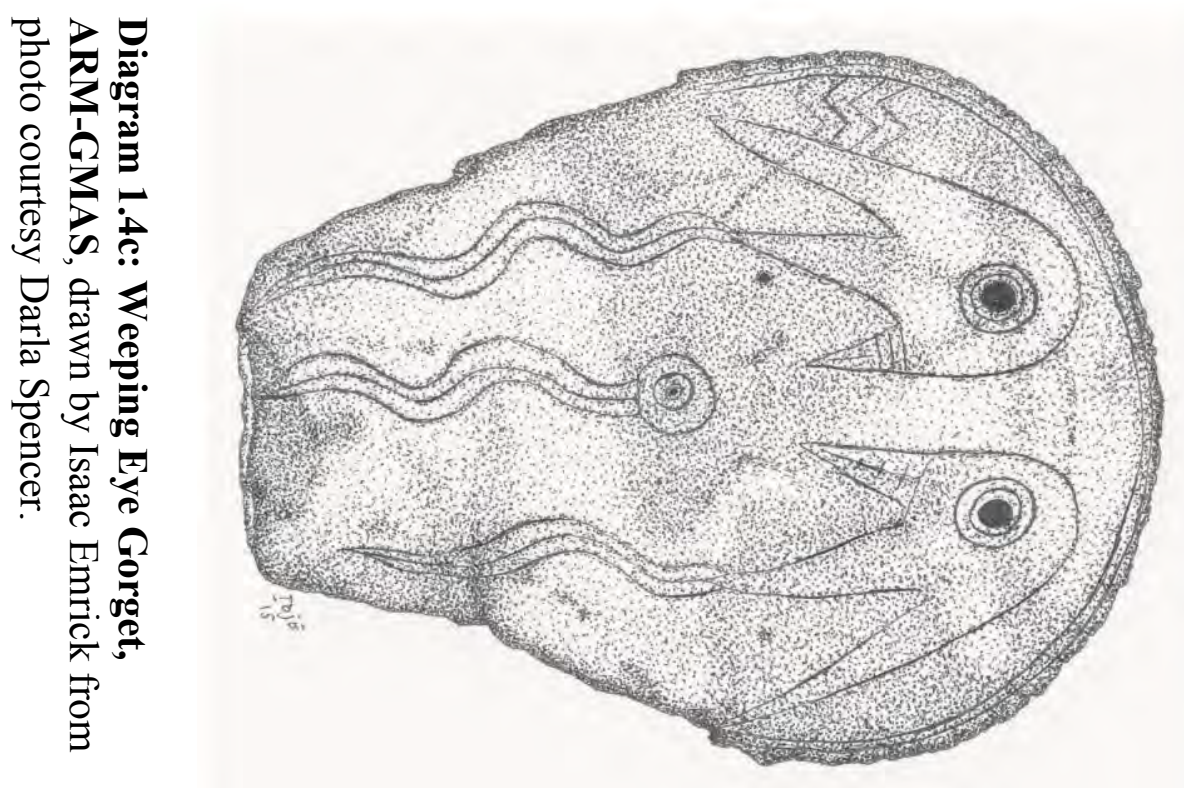

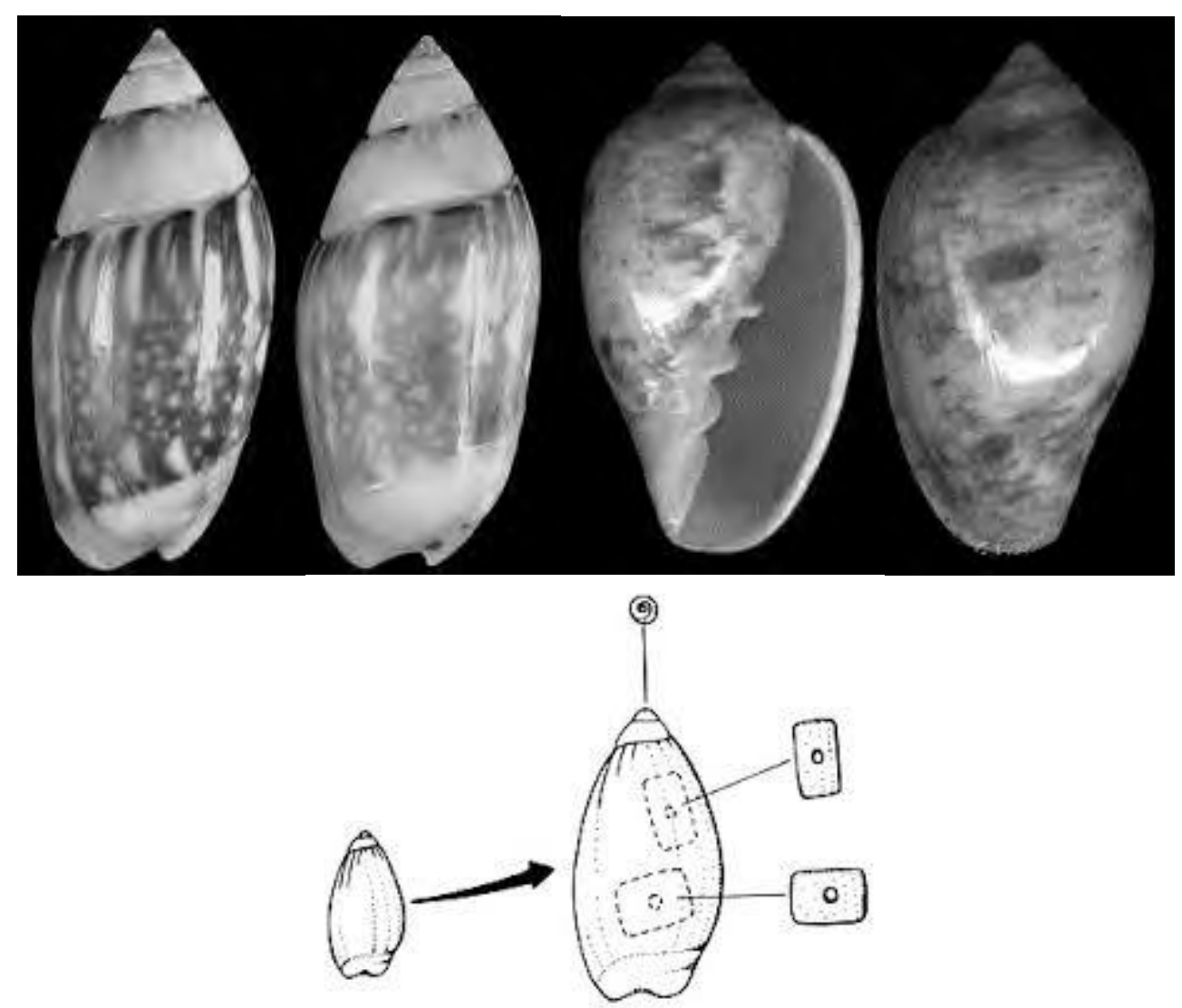

Diagram 1.3: From left to right, Marginella, Olivella, shells bead extraction method.

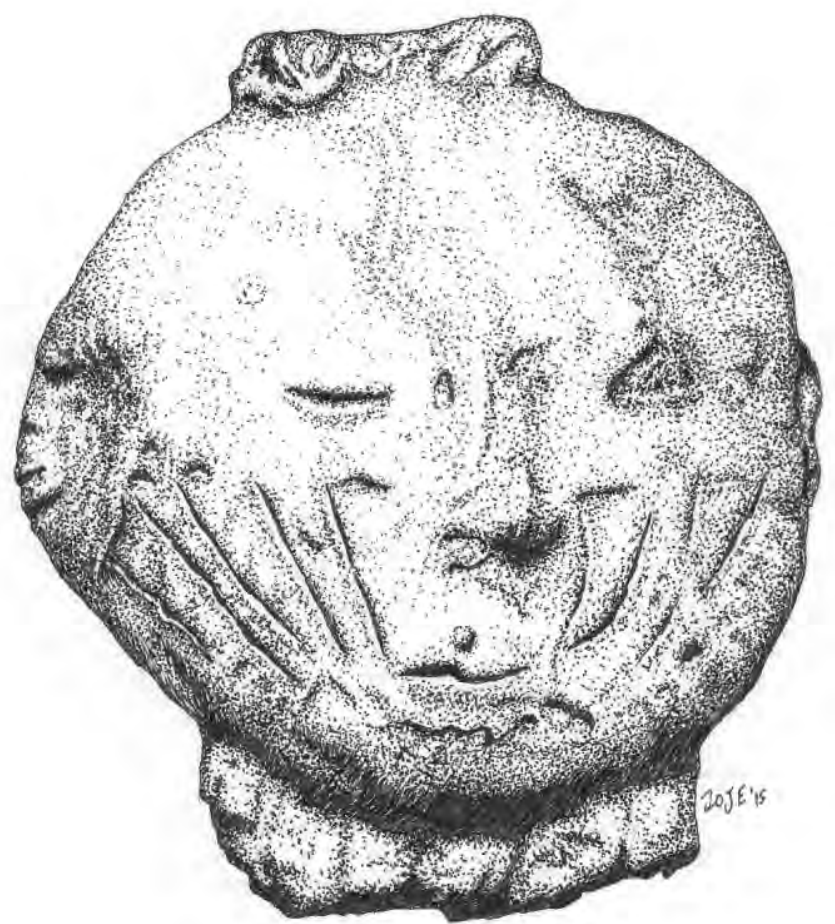

Diagram 4.1 Clay Head from Clover (46Cb0010), drawn by Isaac Emrick from photo courtesy Darla Spencer. 


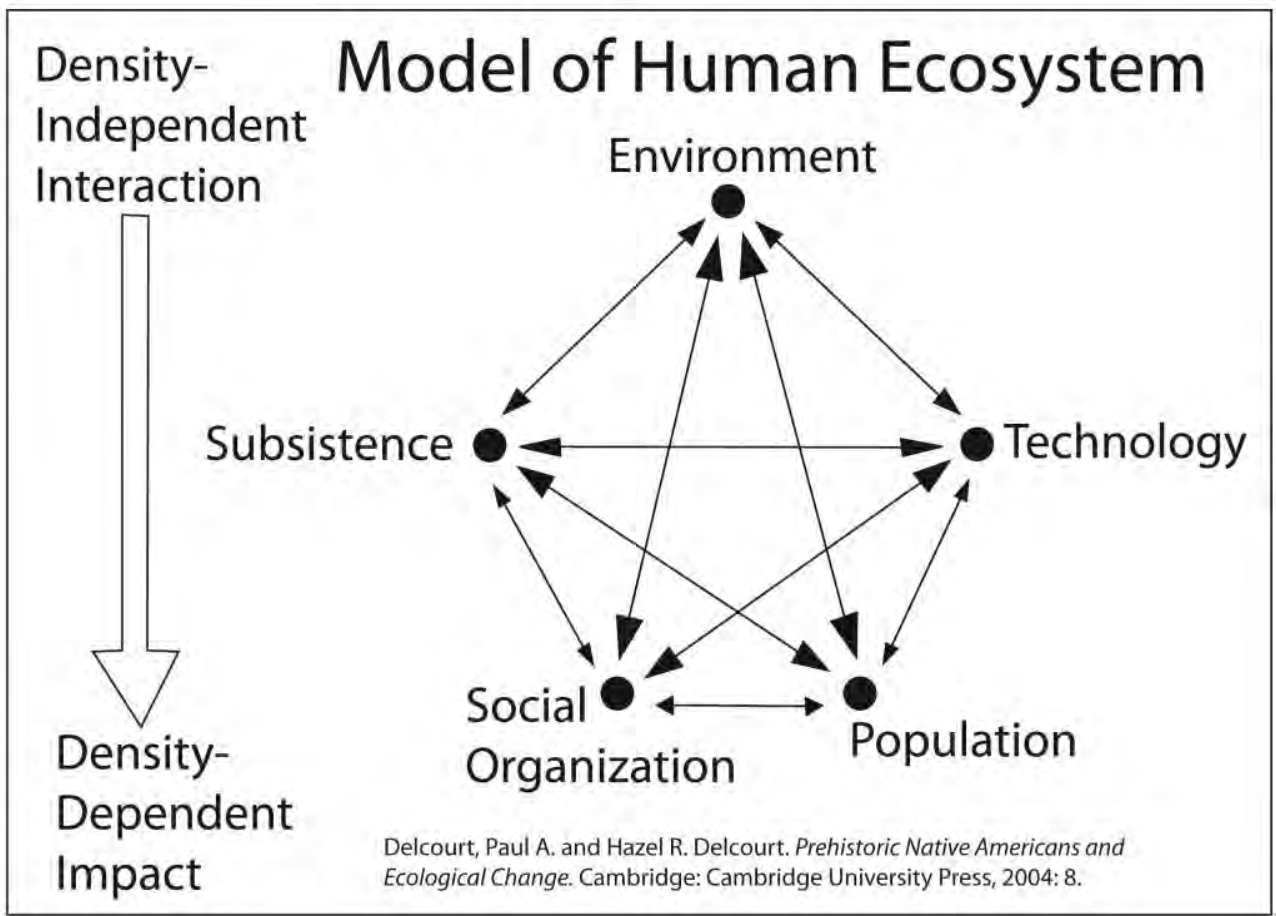

Diagram 5.1: Model of Human Ecosystem, Delcourt Delcourt 2004: 8 .

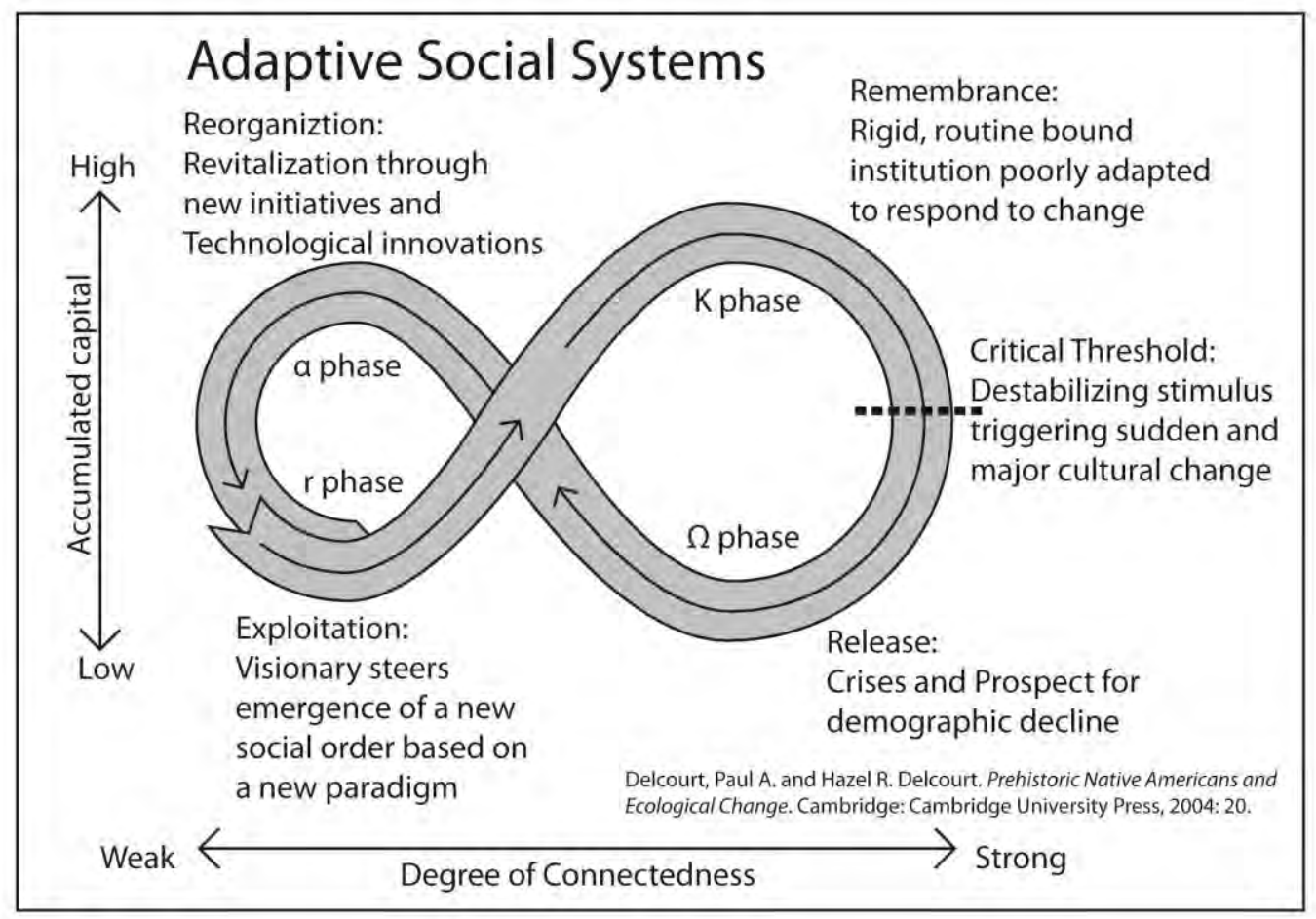

Diagram 5.2: Adaptive Social Systems, Delcourt Delcourt 2004: 20. 


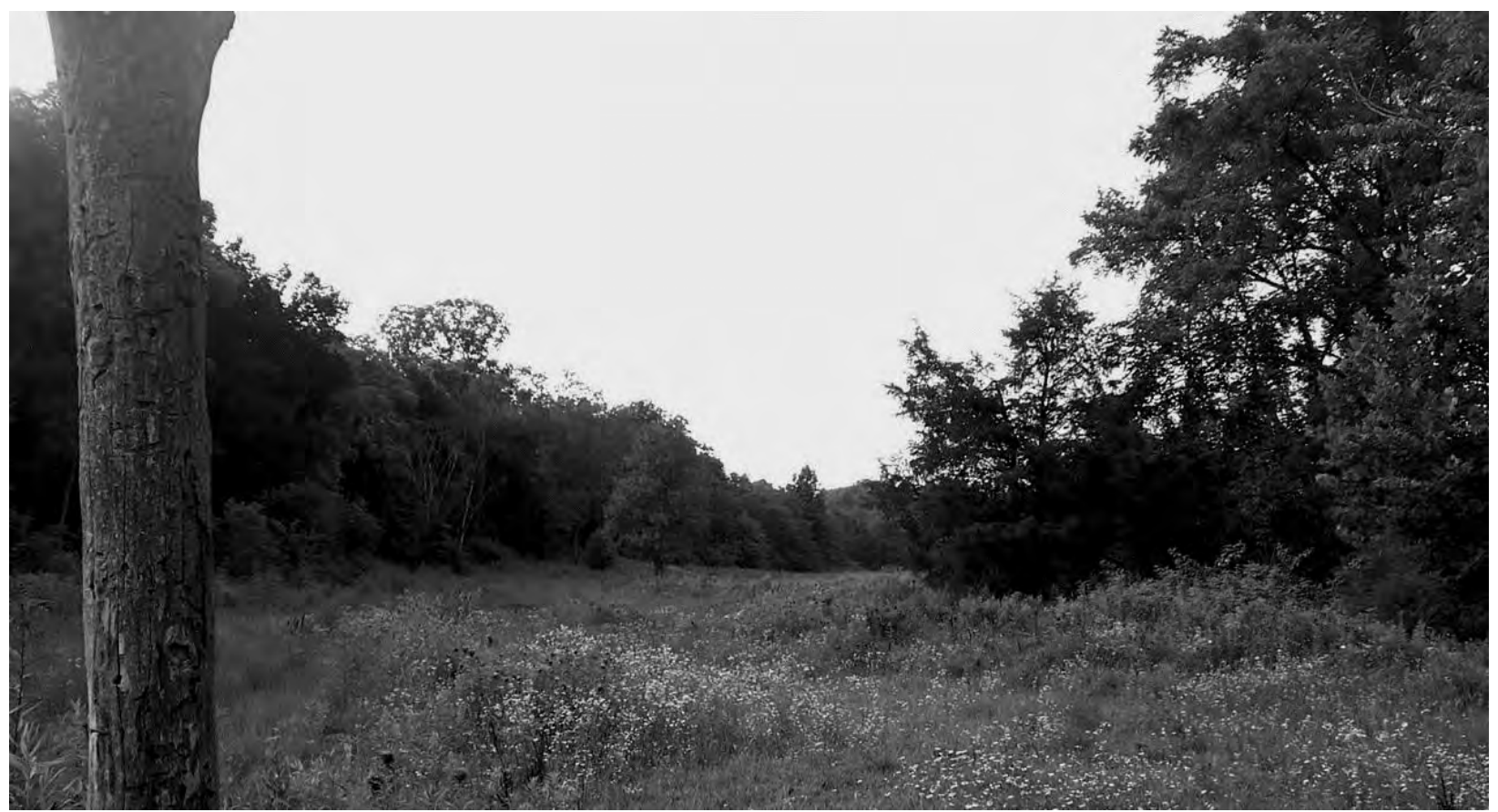

Diagram 5.3a: Forest-edge spread

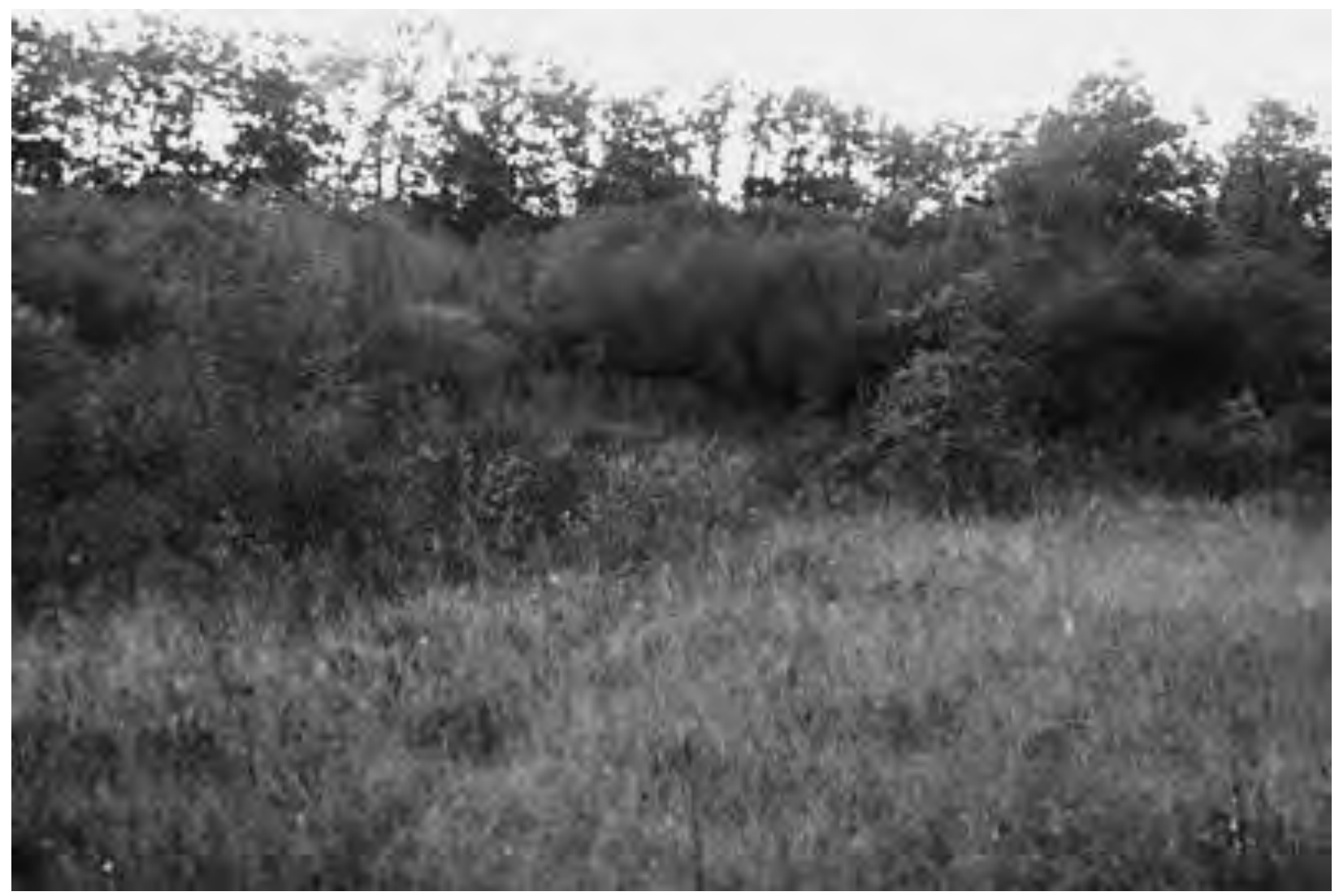

Diagram 5.3a: Forest-edge spread 


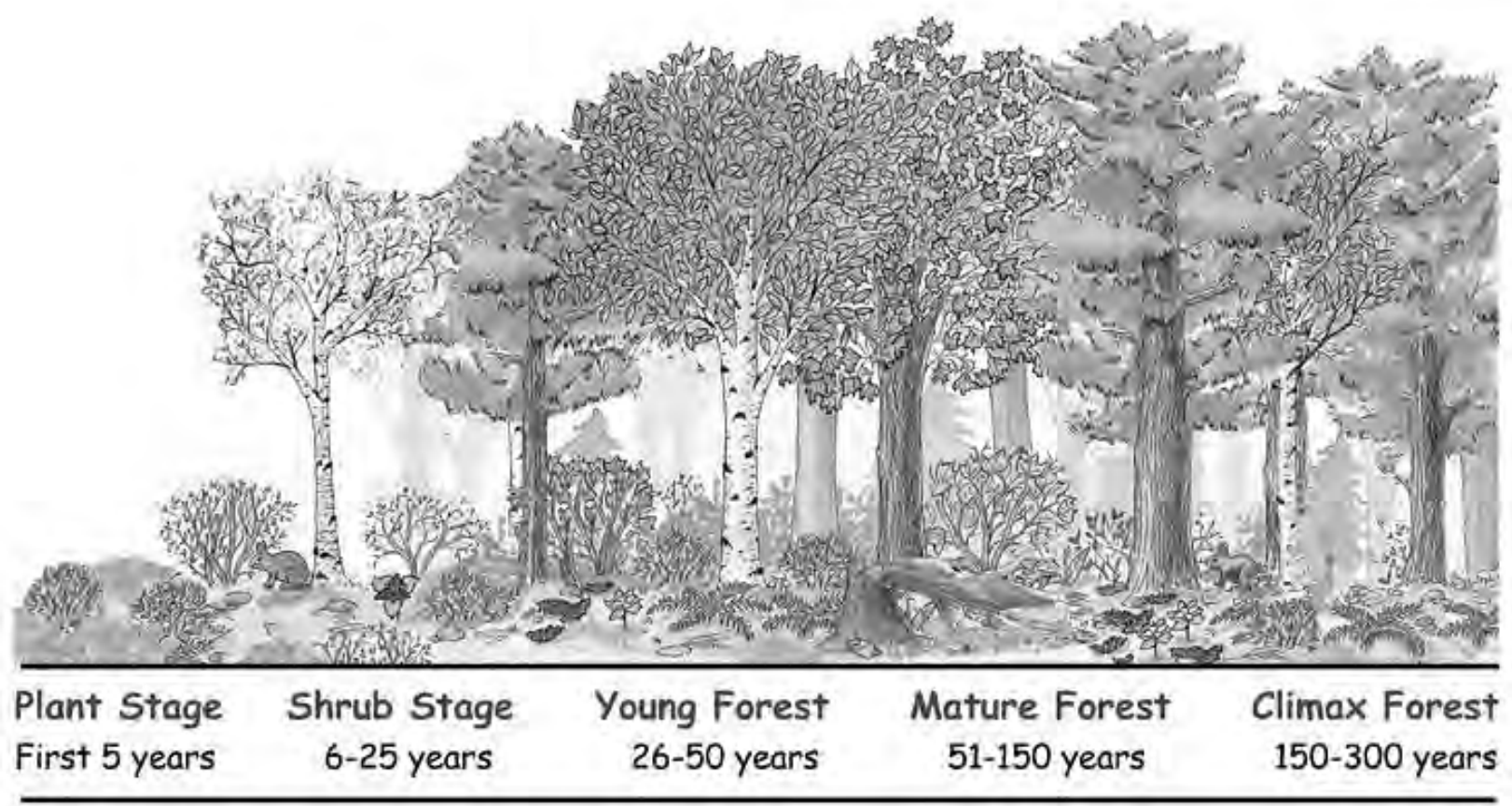

Diagram 5.4: Forest Succession: Imaged sued with permission of artist. Amsel, Sheri.

"Ecology." Forest Succession. Exploring Nature Educational Resource. 2005-2015. April 23, 2015. <http://exploringnature.org/db/detail.php?dbID=27\&detID=1207>

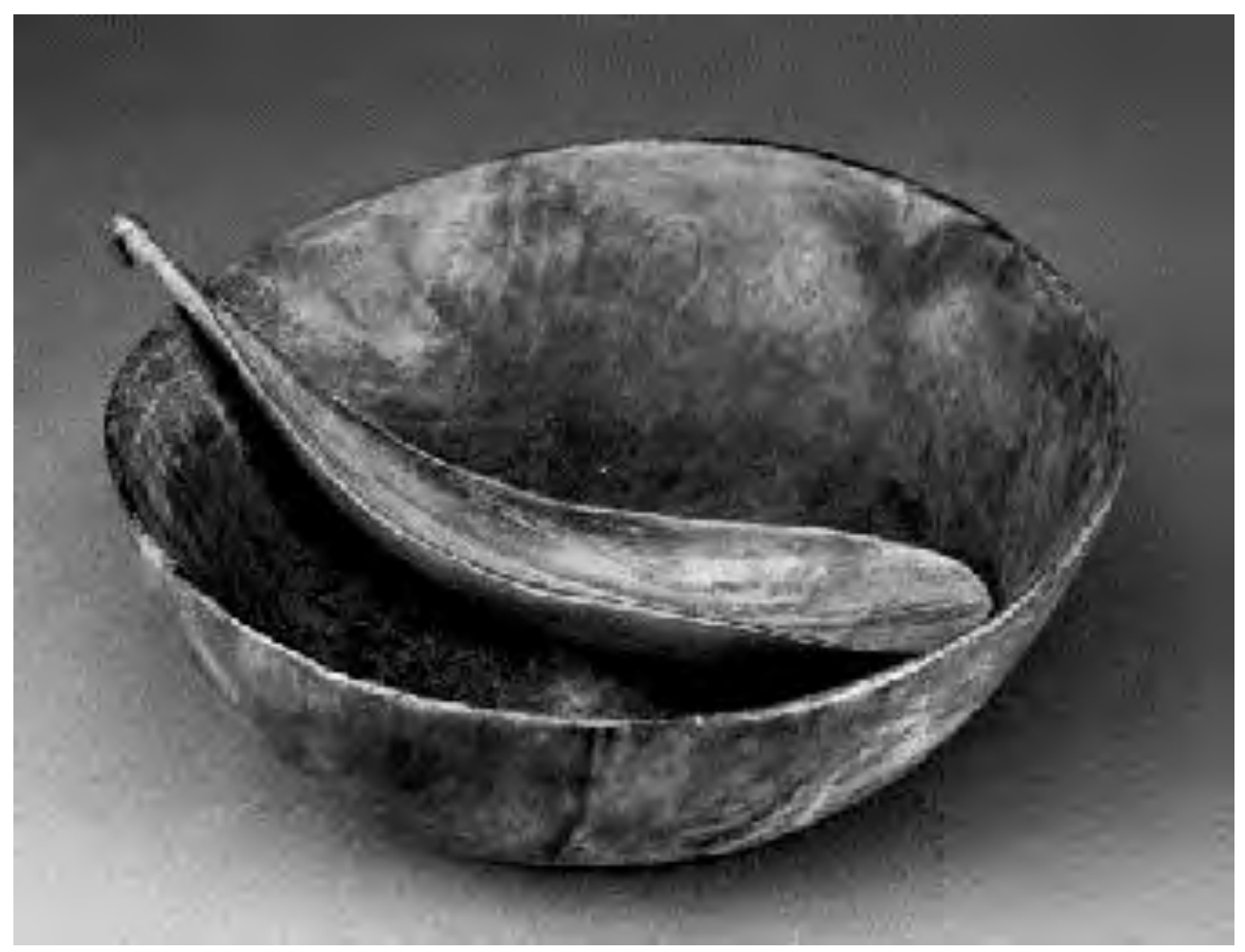

Diagram 6.1: "A single dish and spoon" 


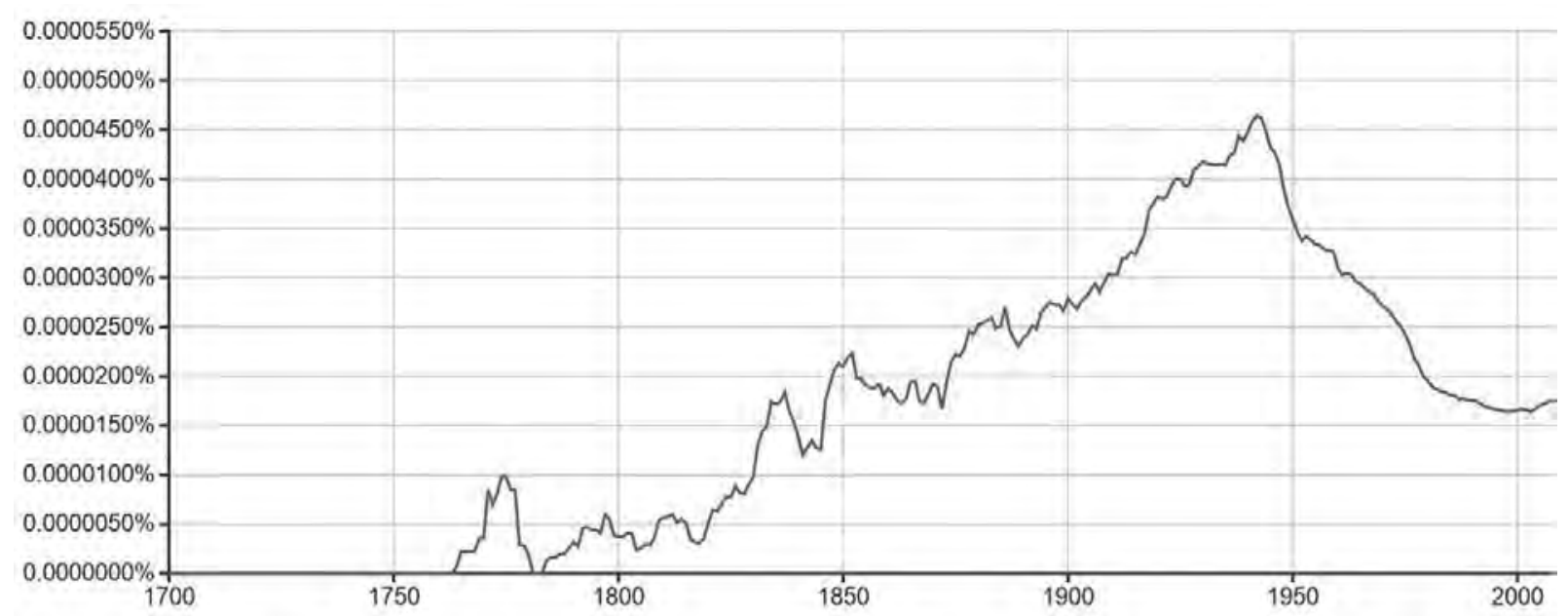

Diagram 6.2a: Ngram: "hunting ground"

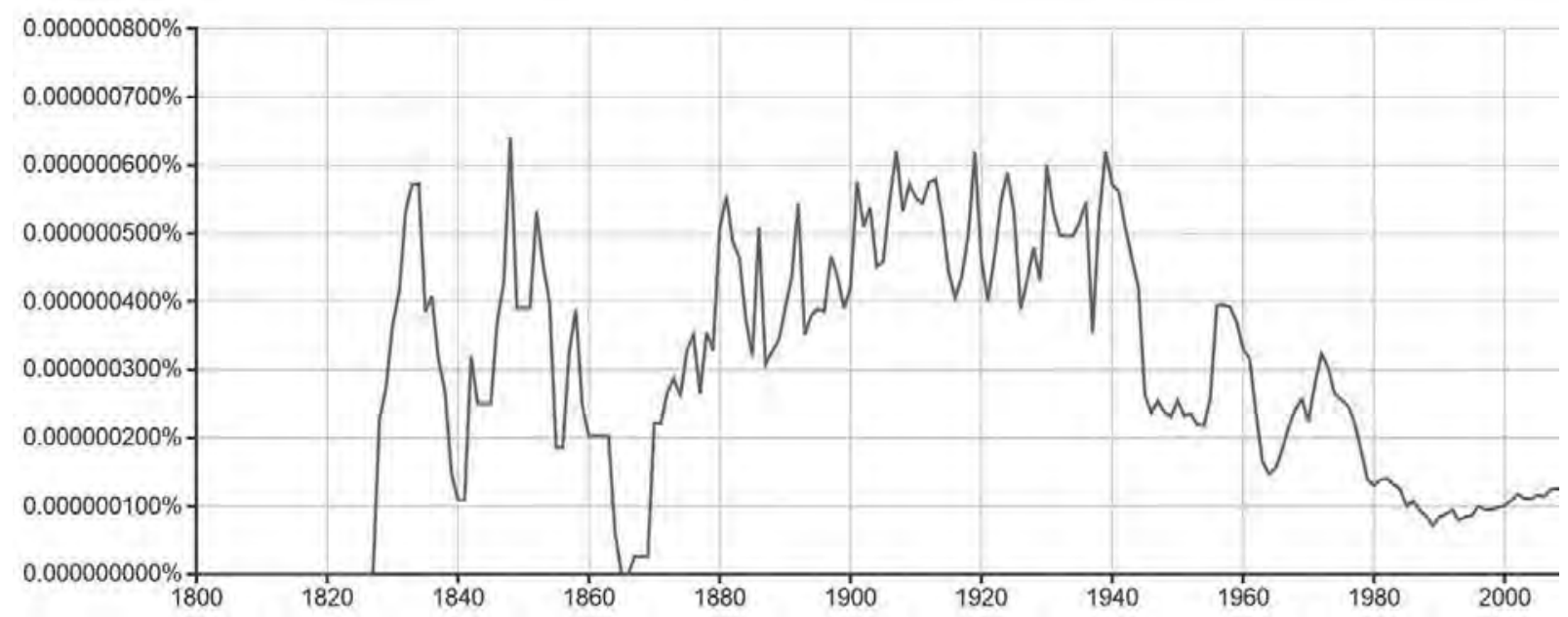

Diagram 6.2b: Ngram: "common hunting ground"

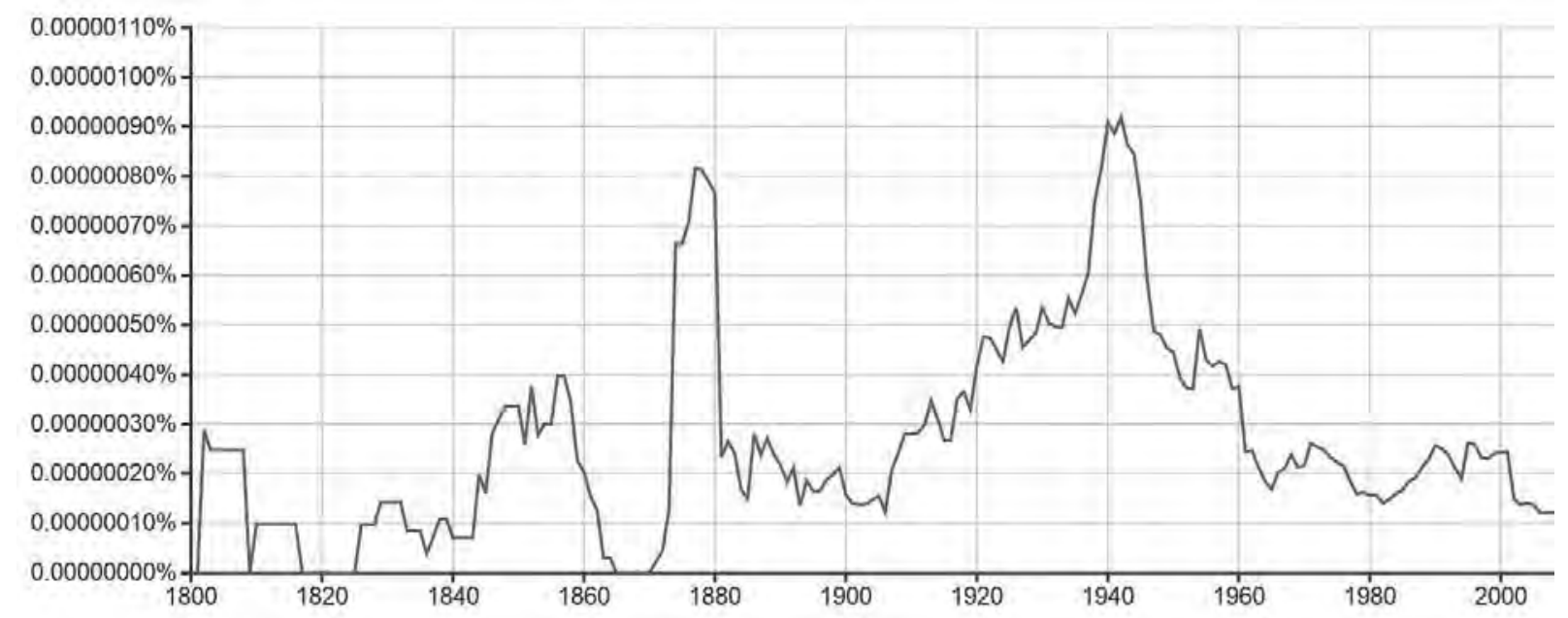

Diagram 6.2c: Ngram: "Indian hunting ground"

These were all created using https://books.google.com/ngrams. 


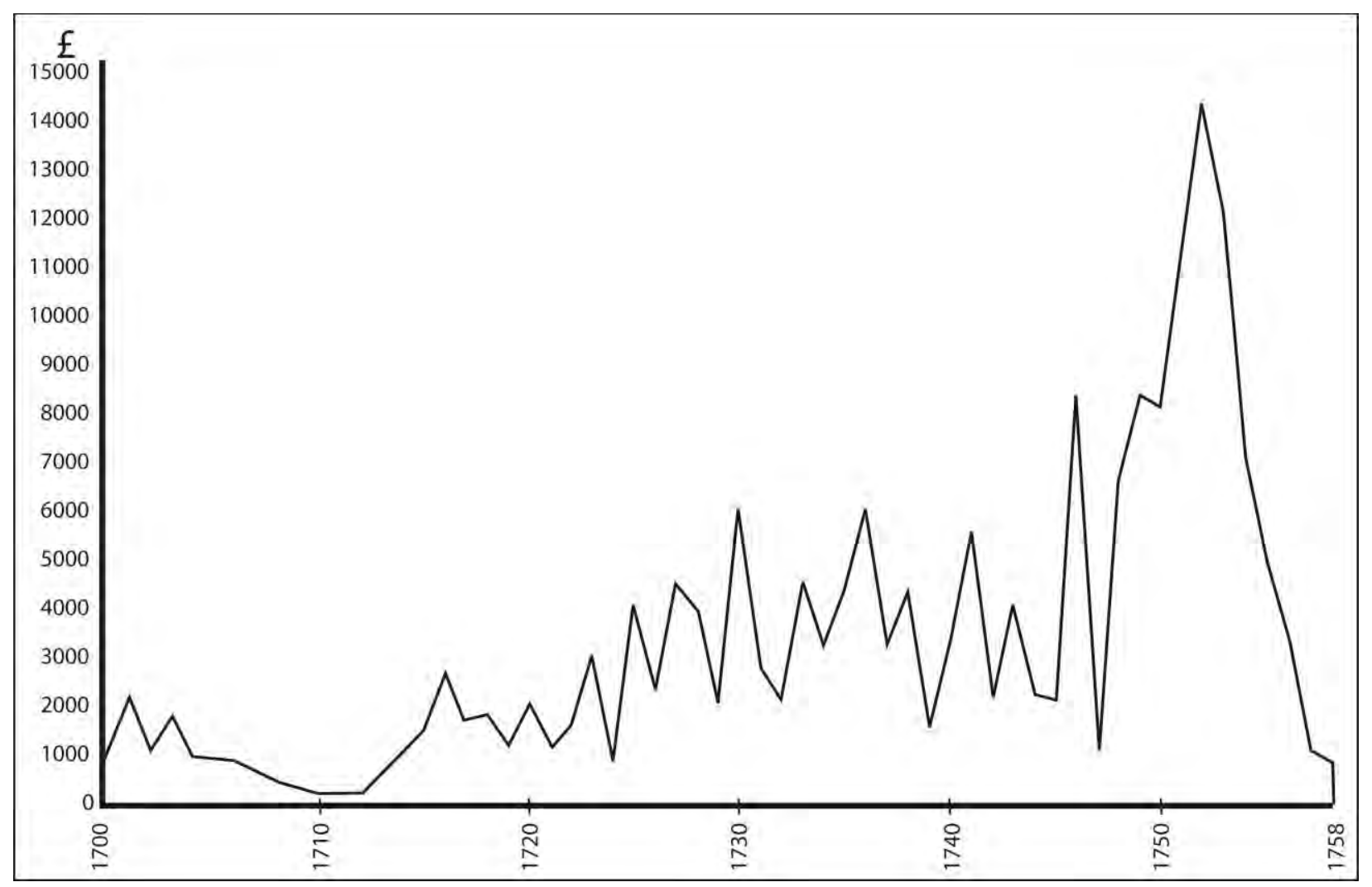

Diagram 7.1: Deer skin trade 1700-1758: Hinderaker 1997: 24. 


\section{Appendix 1: \\ Language Data}

Provided is not only a key to the Yesanechi words used within the above text, but also a comparative table of other important languages from the surrounding region. This list is hardly comprehensive but focuses on the landscape and social lexicons used by peoples mentioned throughout the entire text. 

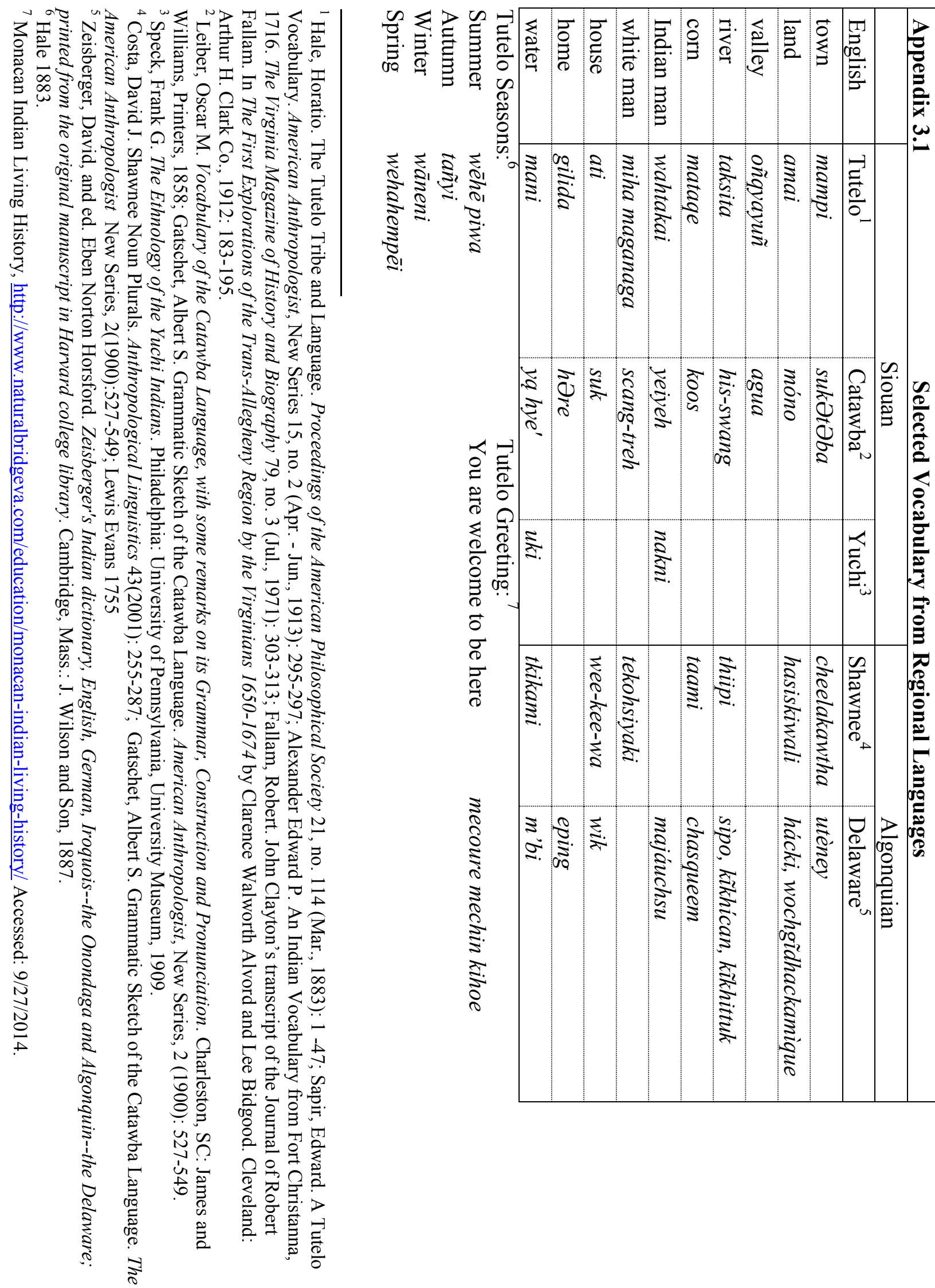

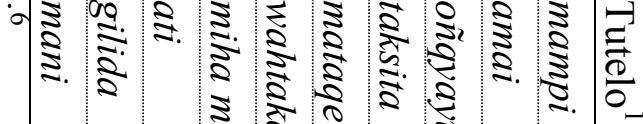

i.

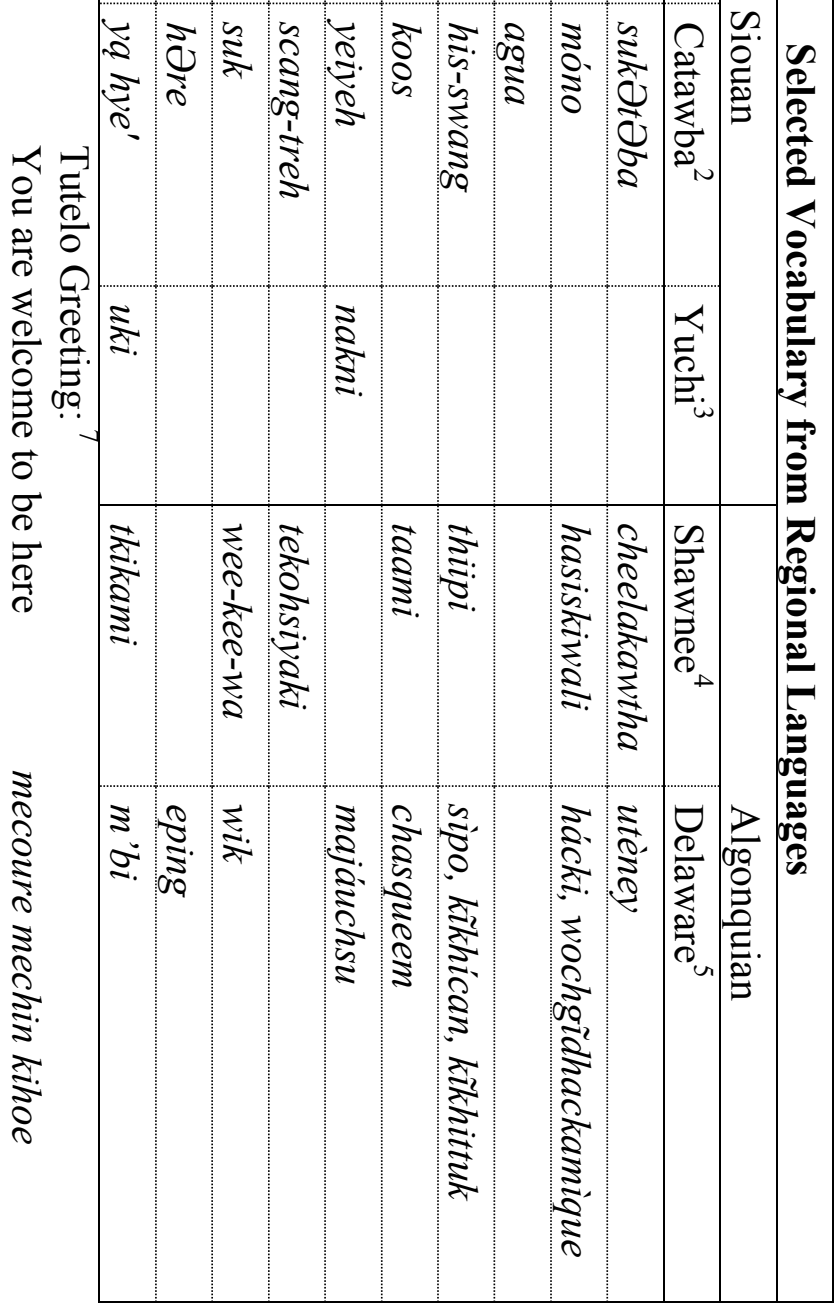




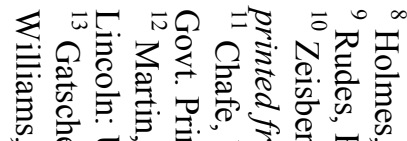

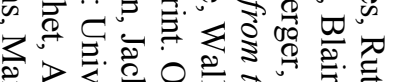

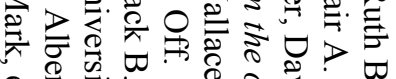

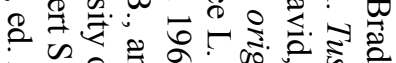

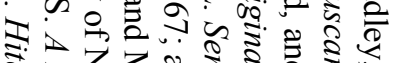

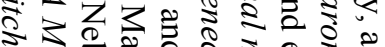
专 䛲 -

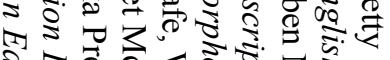

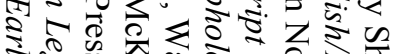

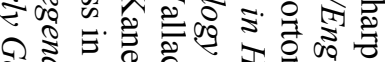

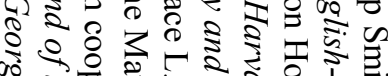
व.

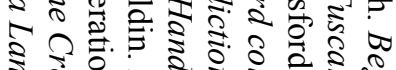

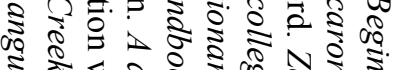

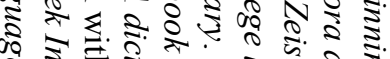

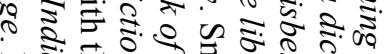

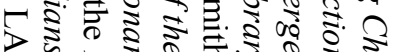

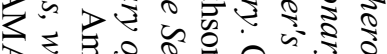

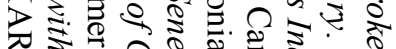

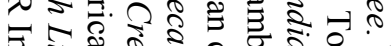
से

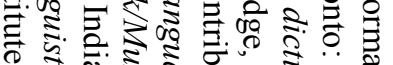
ช

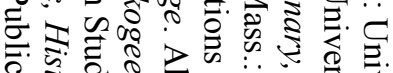
ॠ.

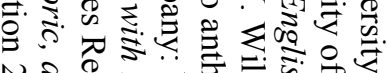

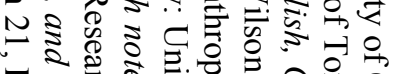

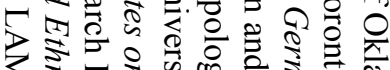

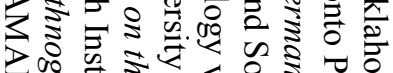

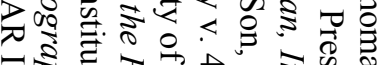

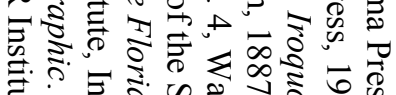
言.

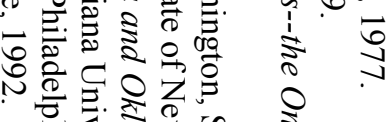

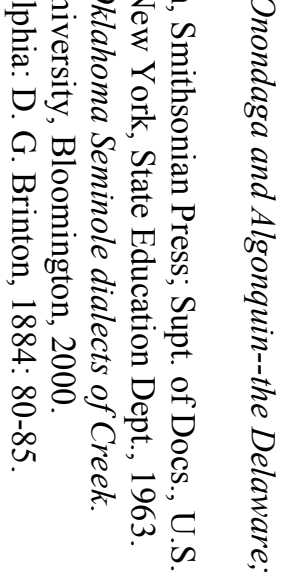

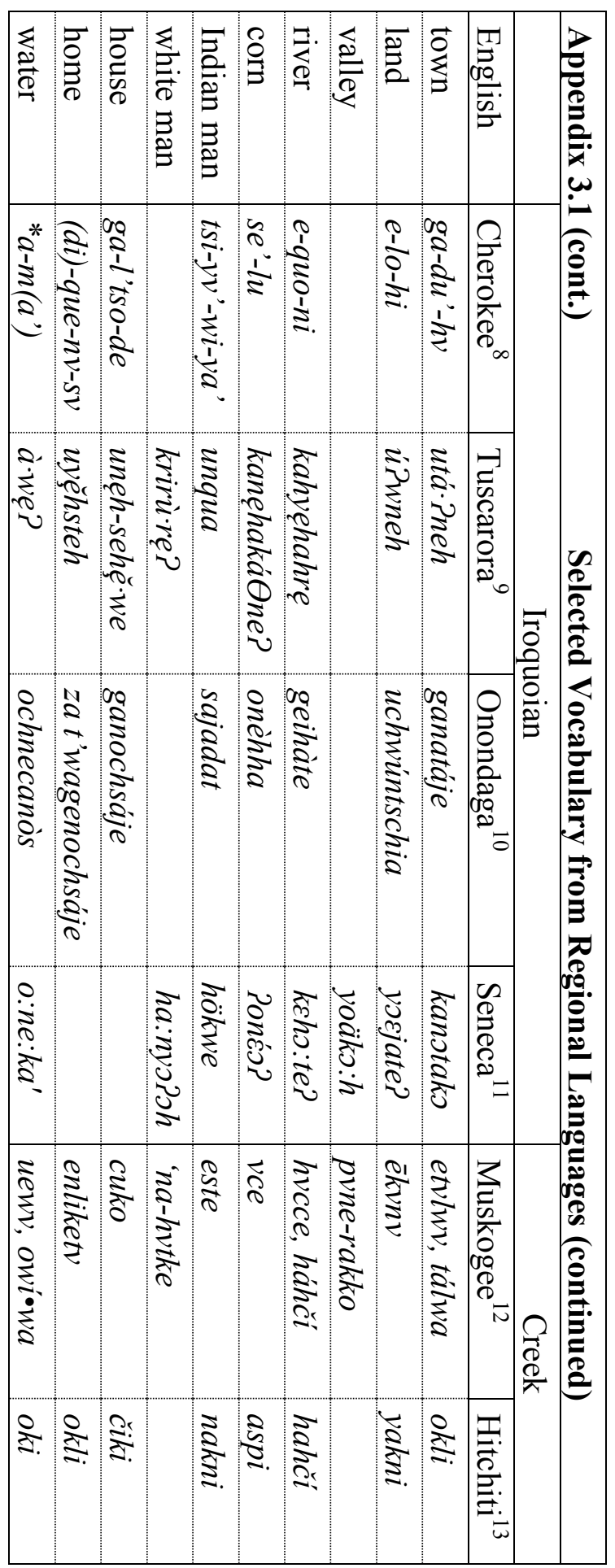




\section{Appendix 2: \\ Physical Landscape Data}

This follwing maps were created using ArcGIS 9.3 along with datasets provided through the West Virginia GIS Techincal Center at West Vigrinia Univeristy. The physical constraints of the Okahok amai are just as important to point out in identifying the locations for permanent settlements and the areas most likley to utilized regularly by wahtakai. These are the product of my earliest exlporation of those constraints. What I found profoundly enlightening was not how the landscape constrained residents, but how those residents overcame topographical diffuclties and adapted them into social and economic benefits,. i.e. seasonal flooding in the narrow onqyayun. 


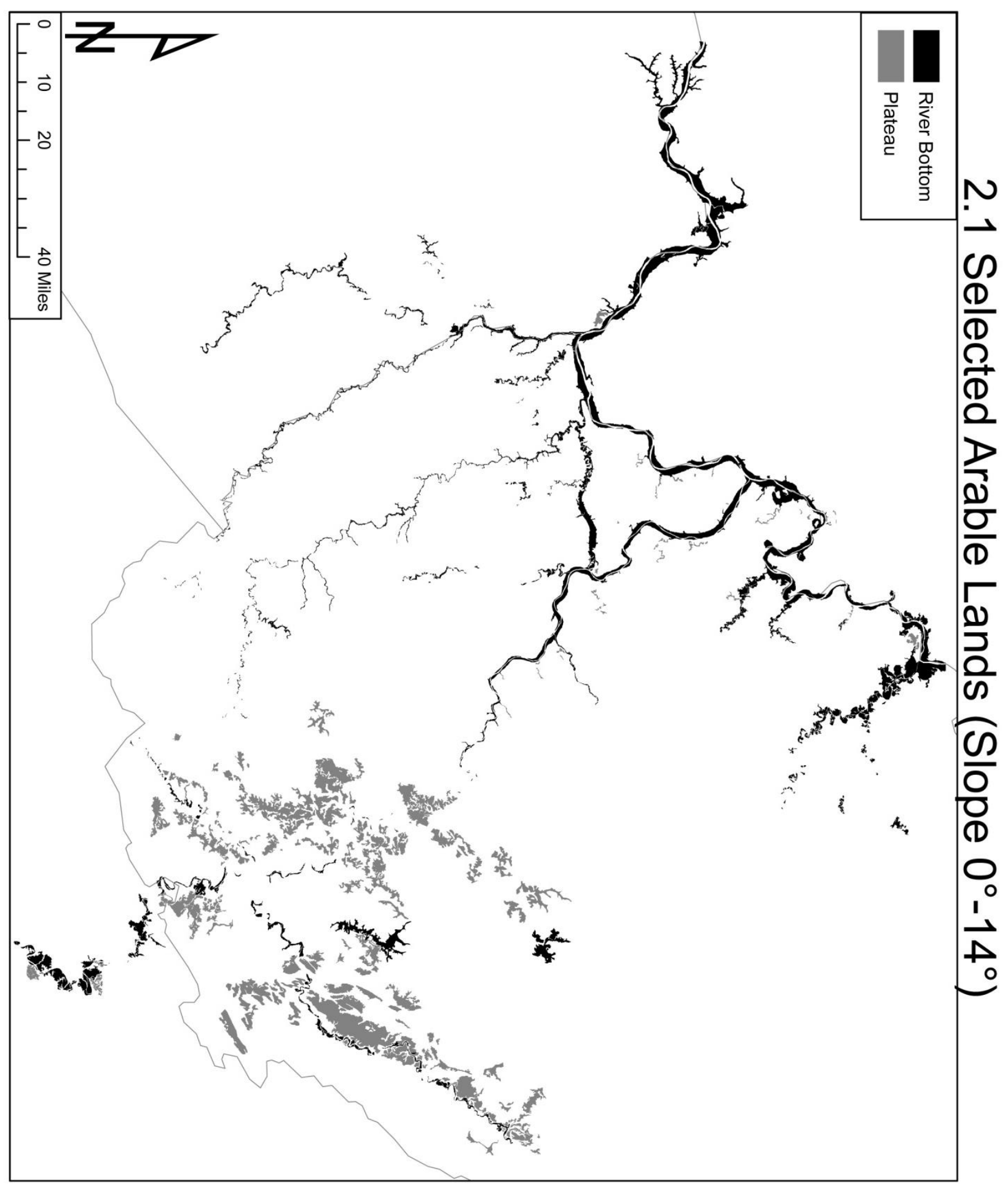




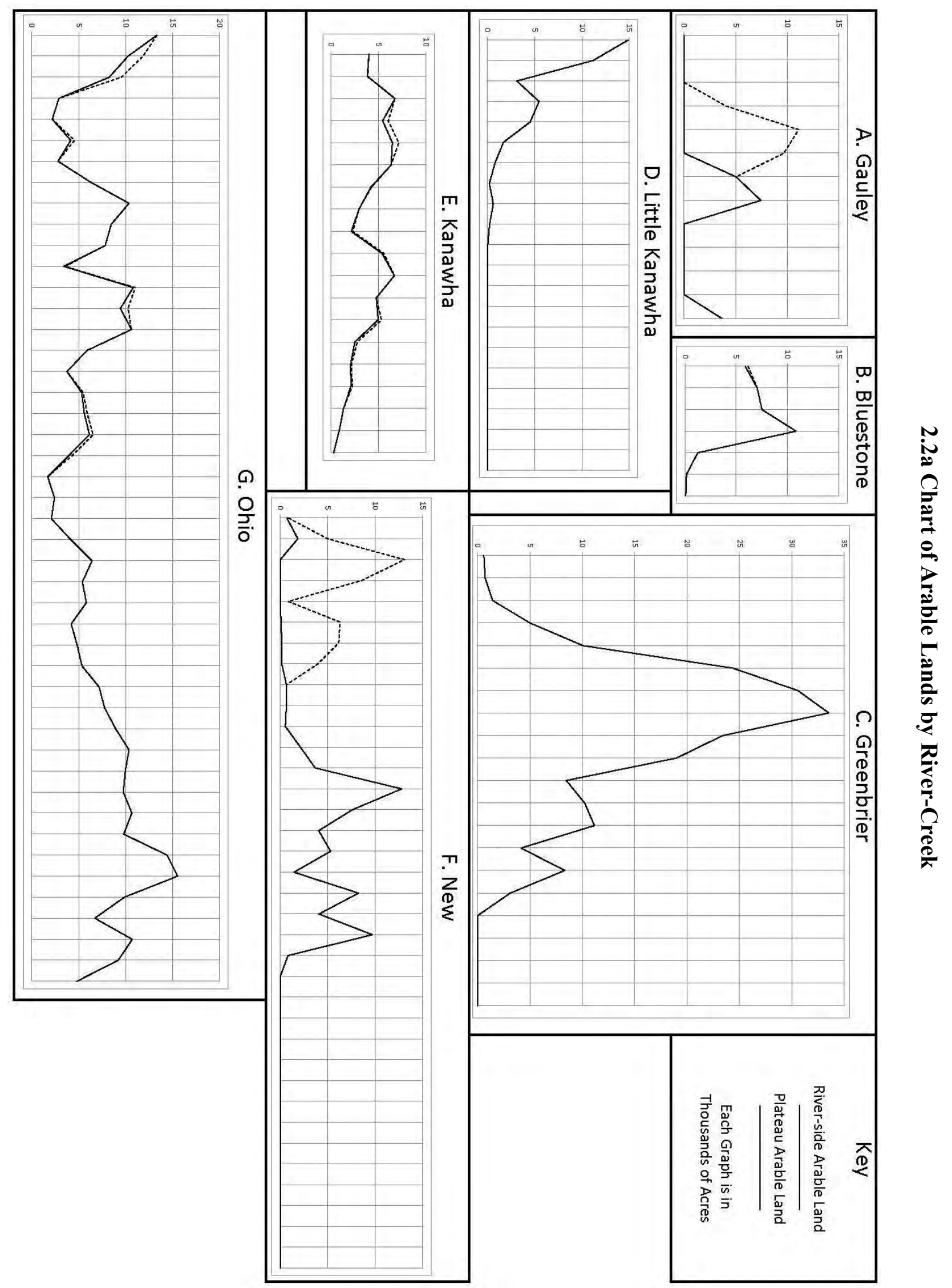




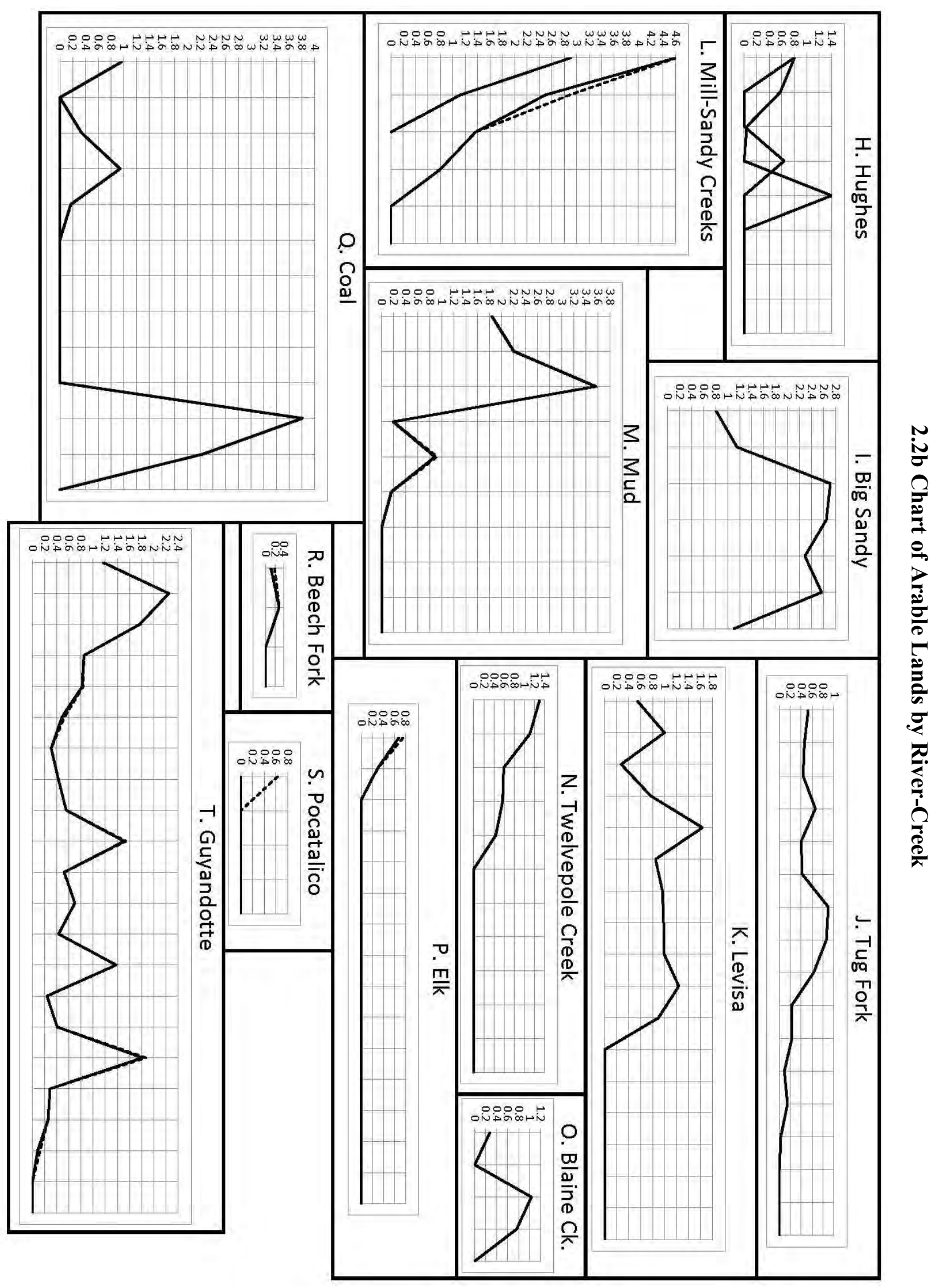




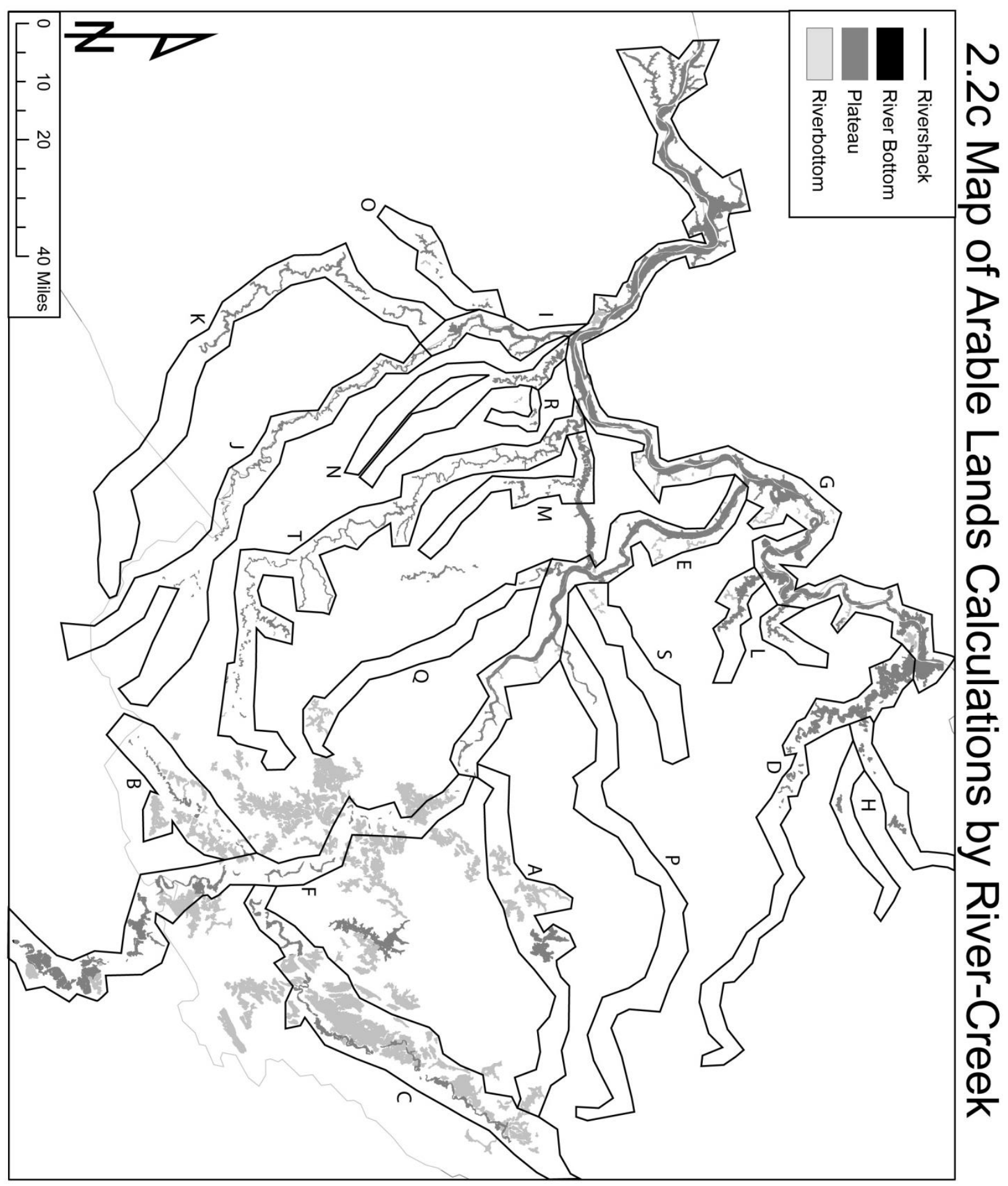




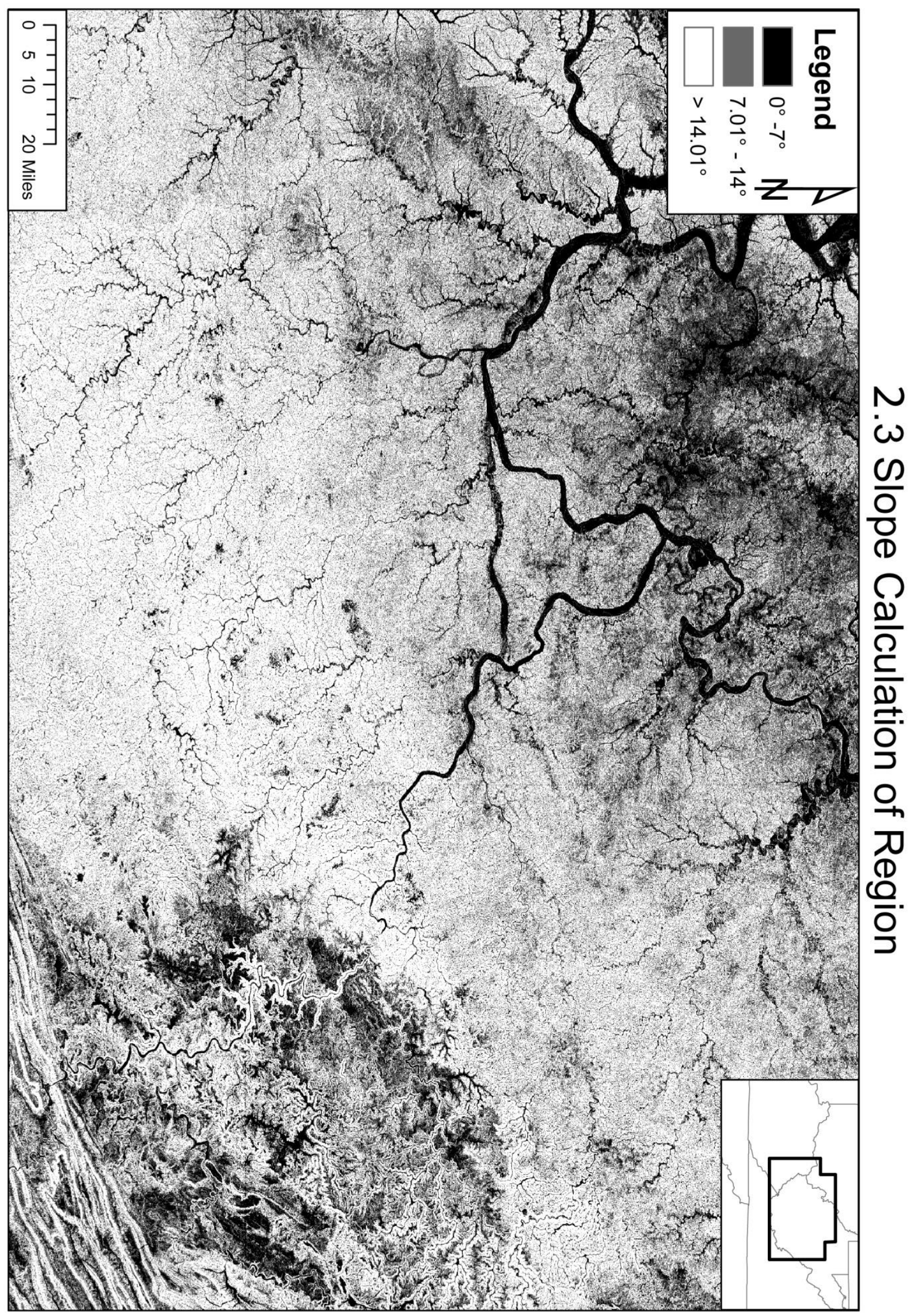




\section{Appendix 3: Paleo-Climatology Data}

In search of the role that the environment played in the decisions of the residents of the Okahok amai, I began gathering paleoclimatic research. This is a collection of that data, albeit limited in its scope and full analytic potential, but it highlights the difficulties that beset the region during the middle of the Little Ice Age. This series of graphs and maps is a very early attempt to process what is a growing and complex field working on reconstructing the physical climatic reality often before accurate human monitoring was developed. 
3.1 Selected Sites for Climate Data

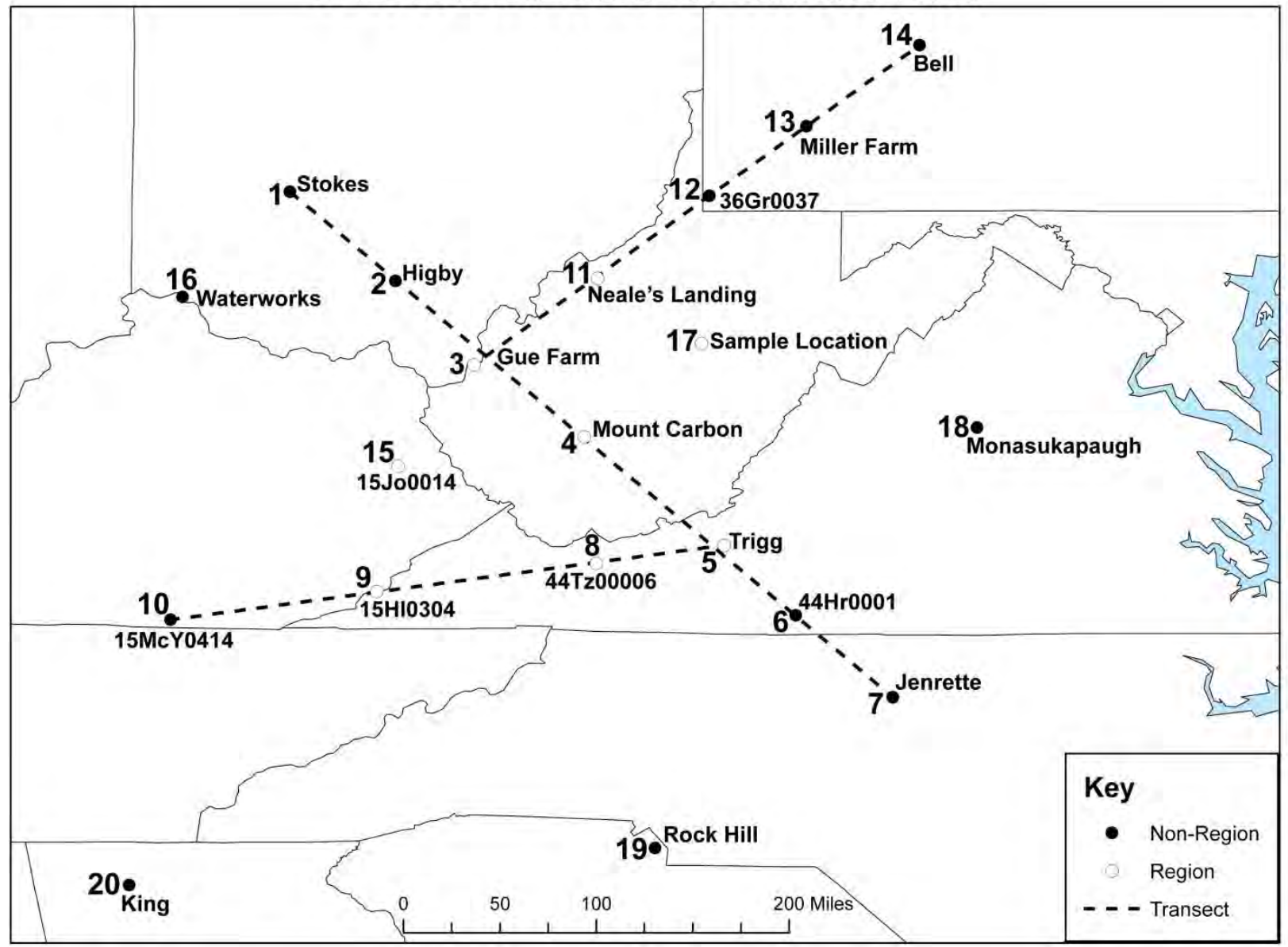

Notes: These locations were selected for their archaeological value. Then, using this grid, I recorded the values from maps that used to be posted on NCDC's website. The original tree-ring dataset analysis not only included precipitation anomalies but also estimated temperature anomalies. The temperature anomalies could not be scientifically evaluated, so I have not included them here. The calculations Fritts used in 1991 to develop the precipitation anomalies is more reliable, but I have here adjusted the values to match real-world calculations. These graphs are for comparative purposes with the other paleoclimatic datasets. 


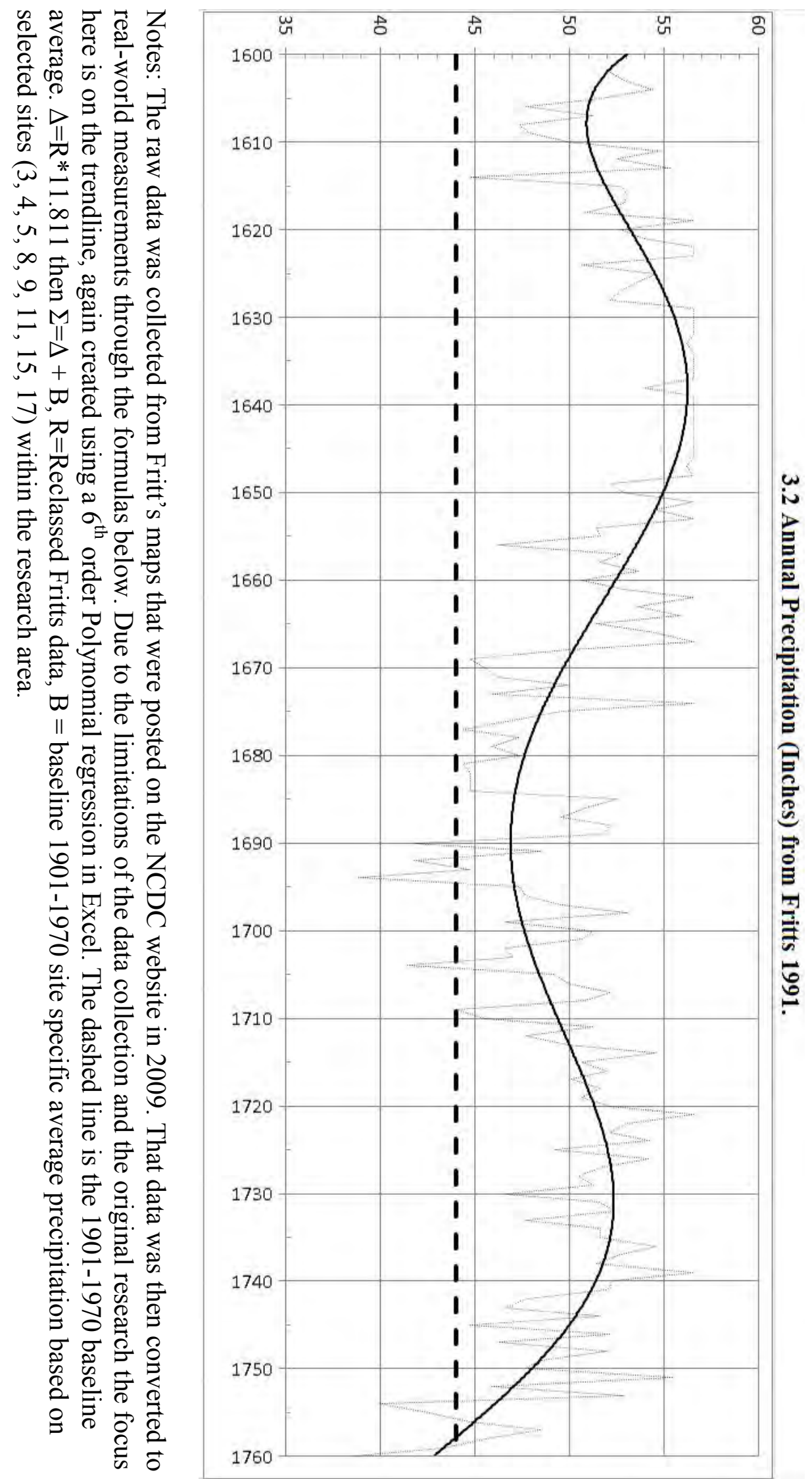


3.3 Spring Precipitation (Inches) from Fritts 1991.

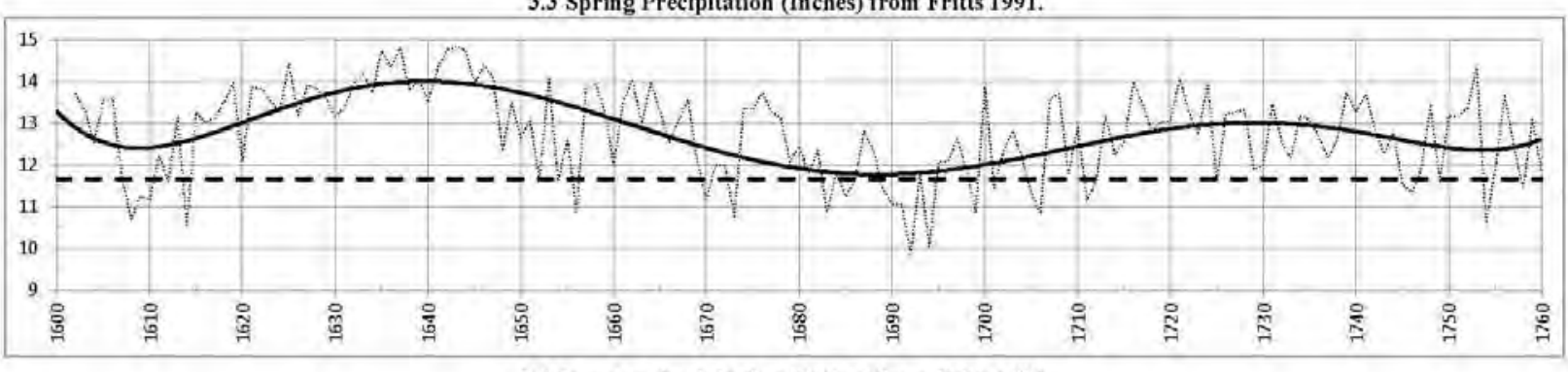

3.4 Summer Precipitation (Inches) from Fritts 1991.

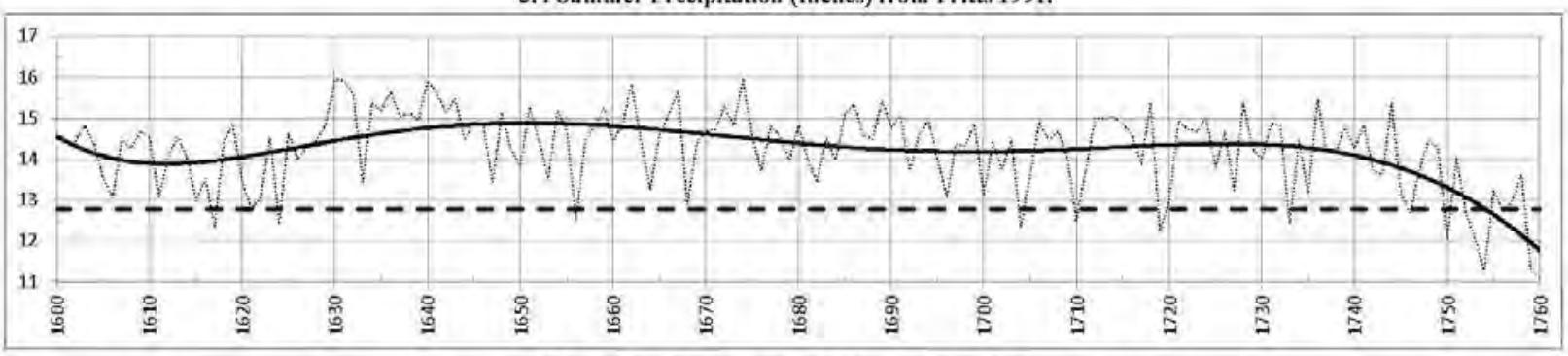

3.5 Fall Precipitation (Inches) from Fritts 1991.

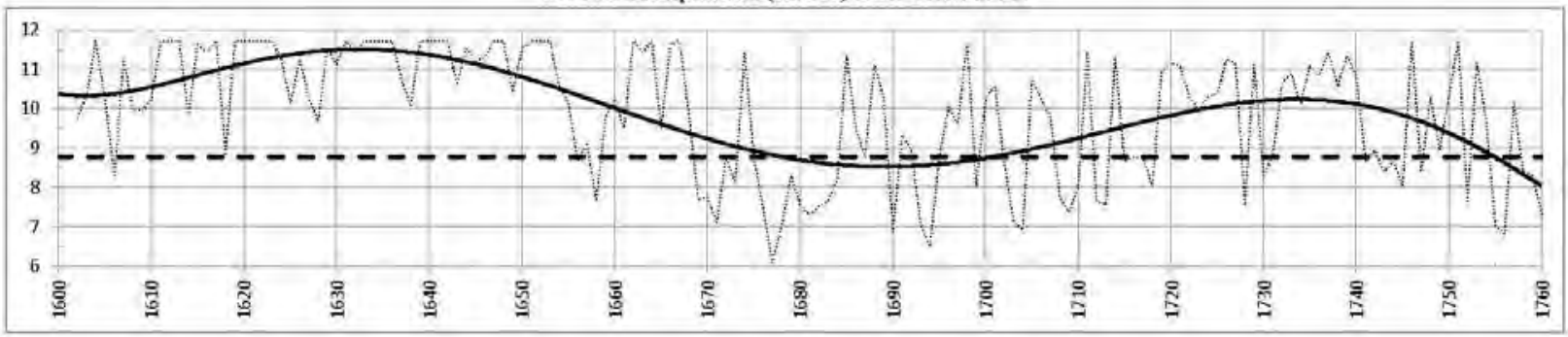

3.6 Winter Precipitation (Inches) from Fritts 1991.

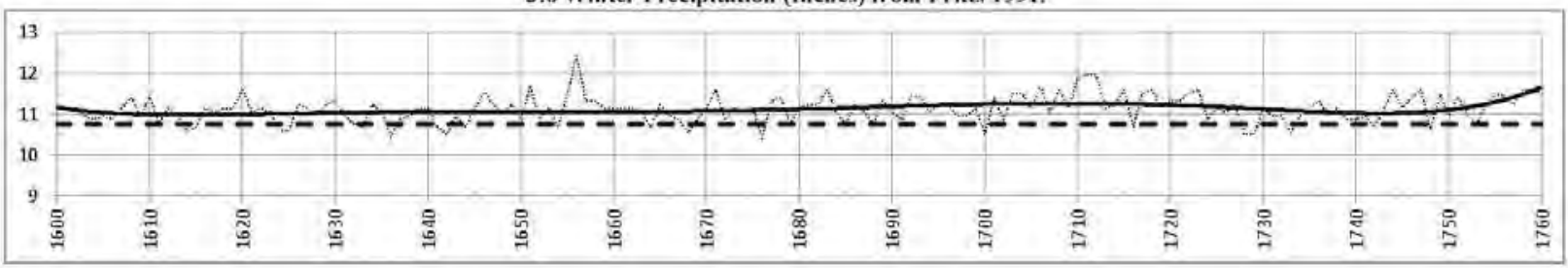

Notes: The changes in seasonal precipitation are particularly interesting in comparison to Maxwell and others who focus on a particular season, namely summer. The trendlines, data, and baselines were created in exactly the same manner as 3.2. 


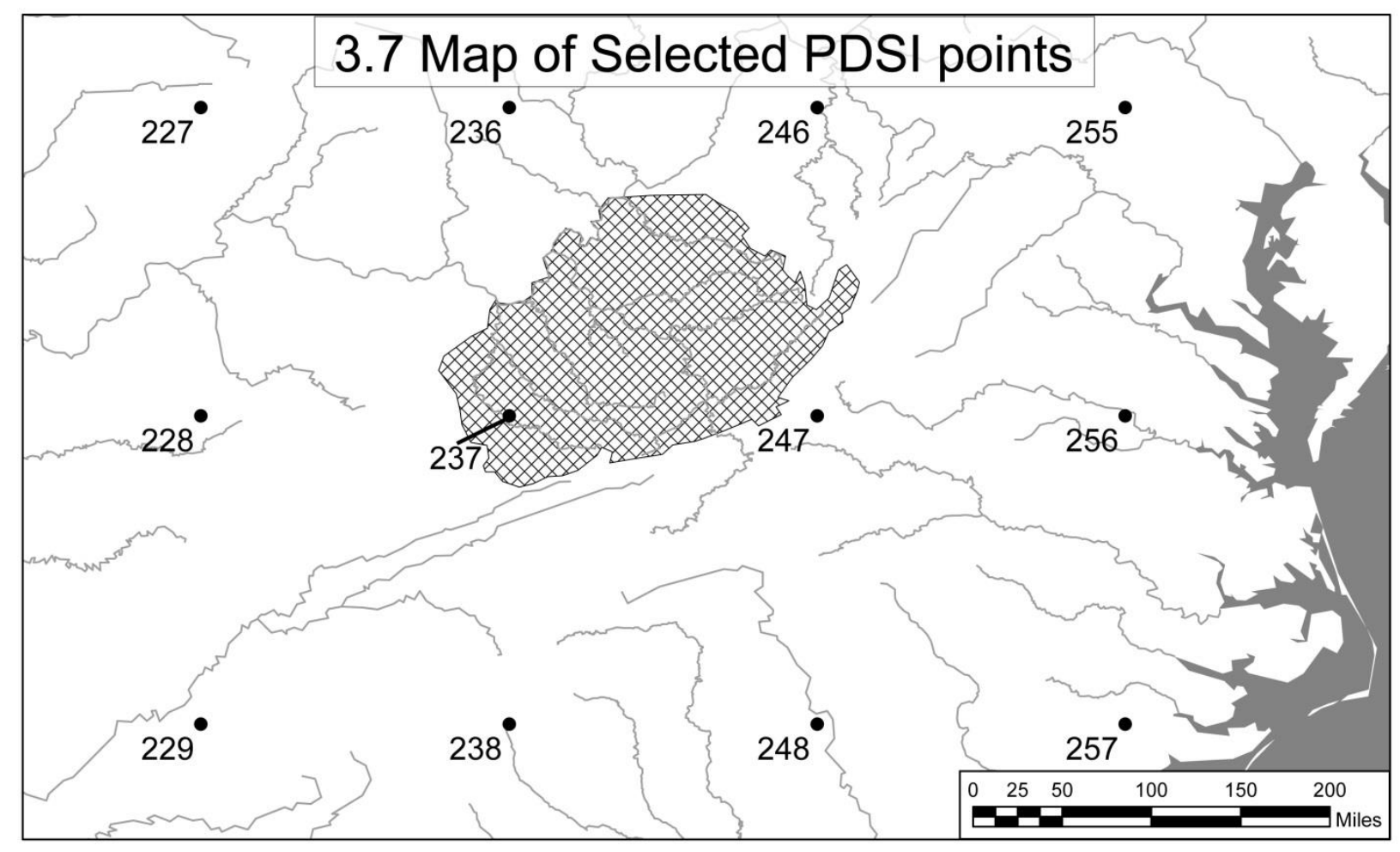

Notes: This was gathered in 2010 from http://www.ncdc.noaa.gov/paleo/newpdsi.html. The proximity of 247 and 237 were selected for this project. This data set was much more reliable than the Fritts data. The following data sets (3.8a-d) were based off the raw data posted at NOAA's http://www.ncdc.noaa.gov/paleo/pdsidata.html. The trendlines were created with Excel using a $6^{\text {th }}$ order polynomial regression. The dotted lines mark the level of the most severe droughts. 

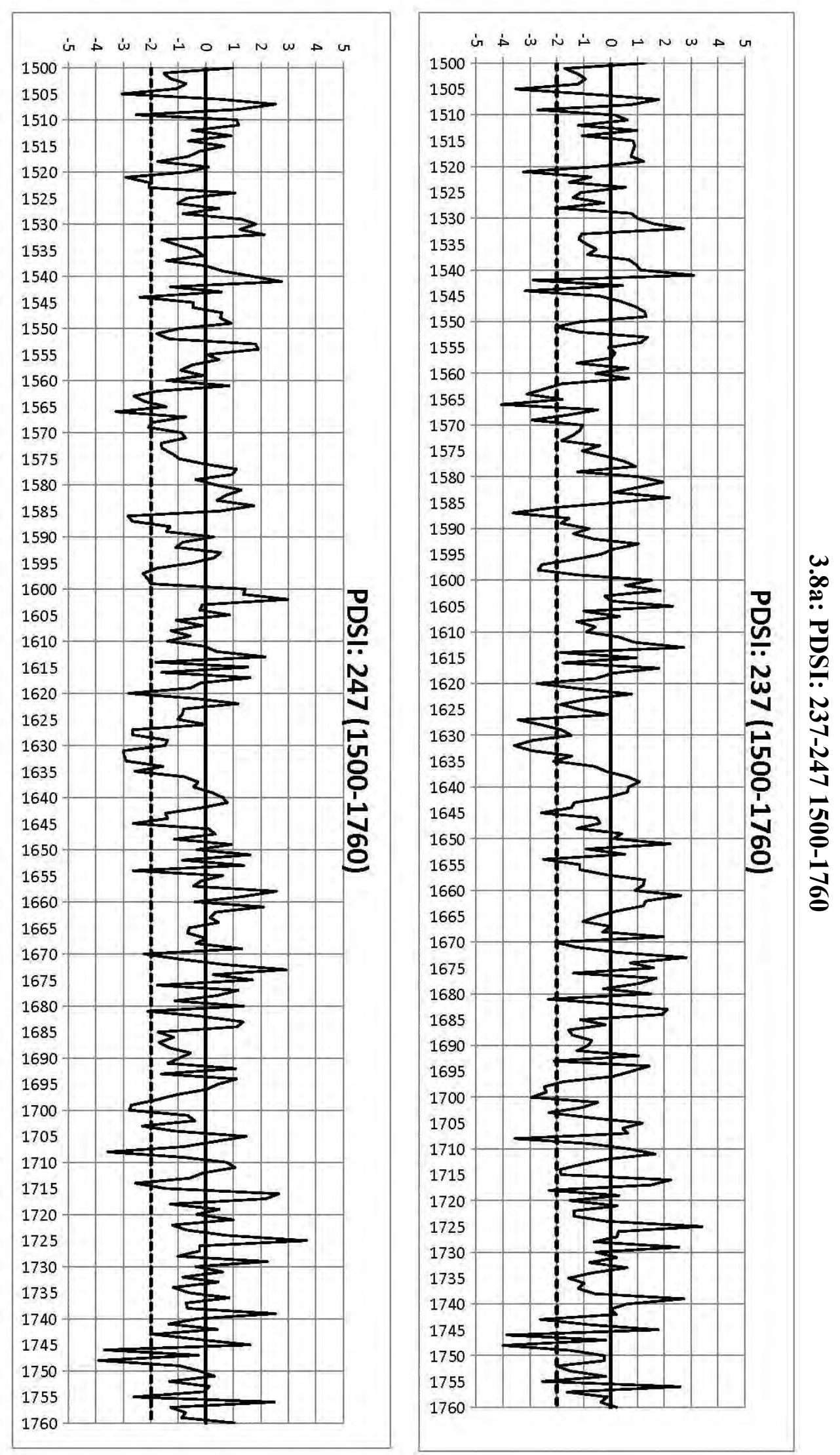

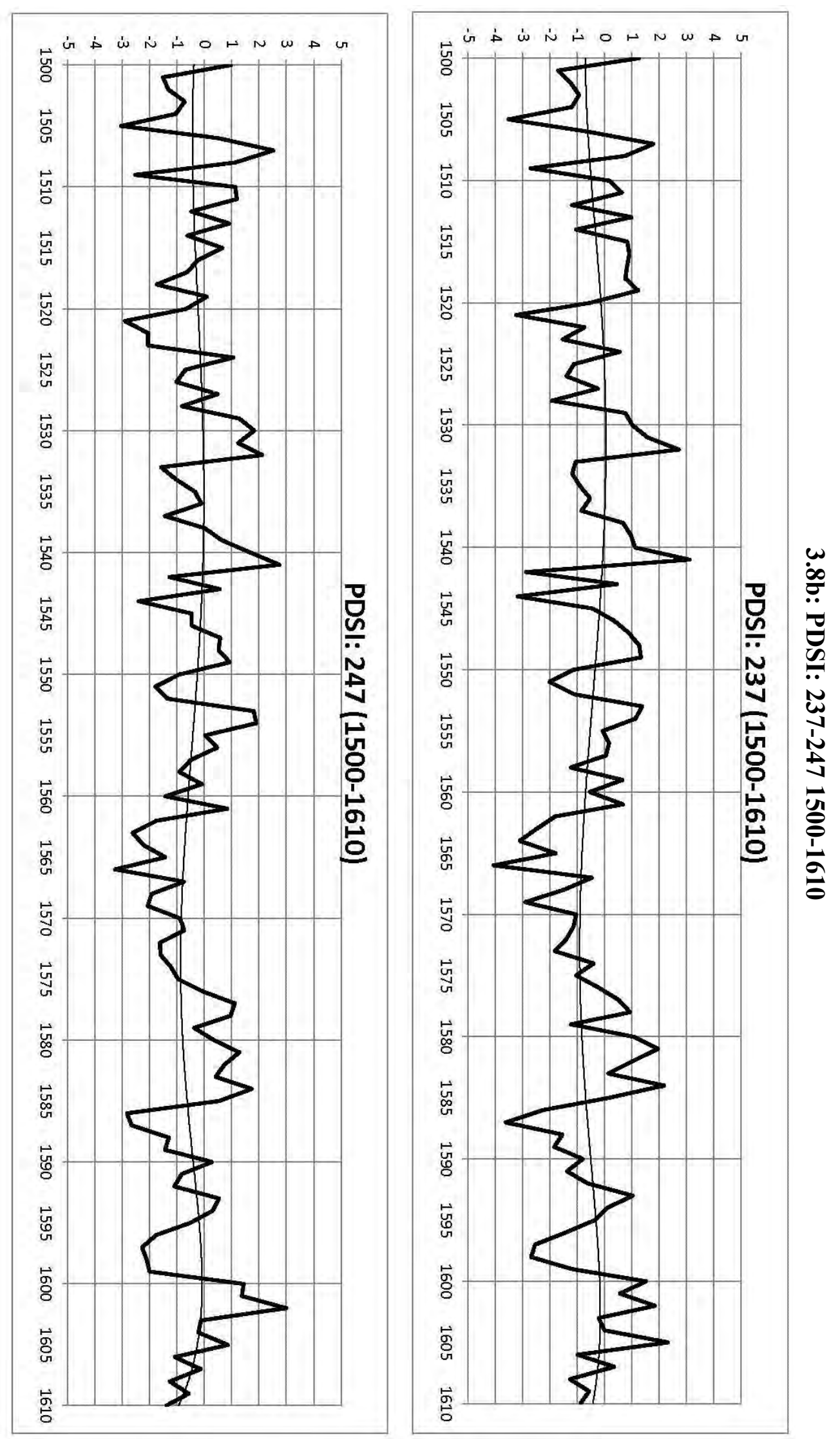

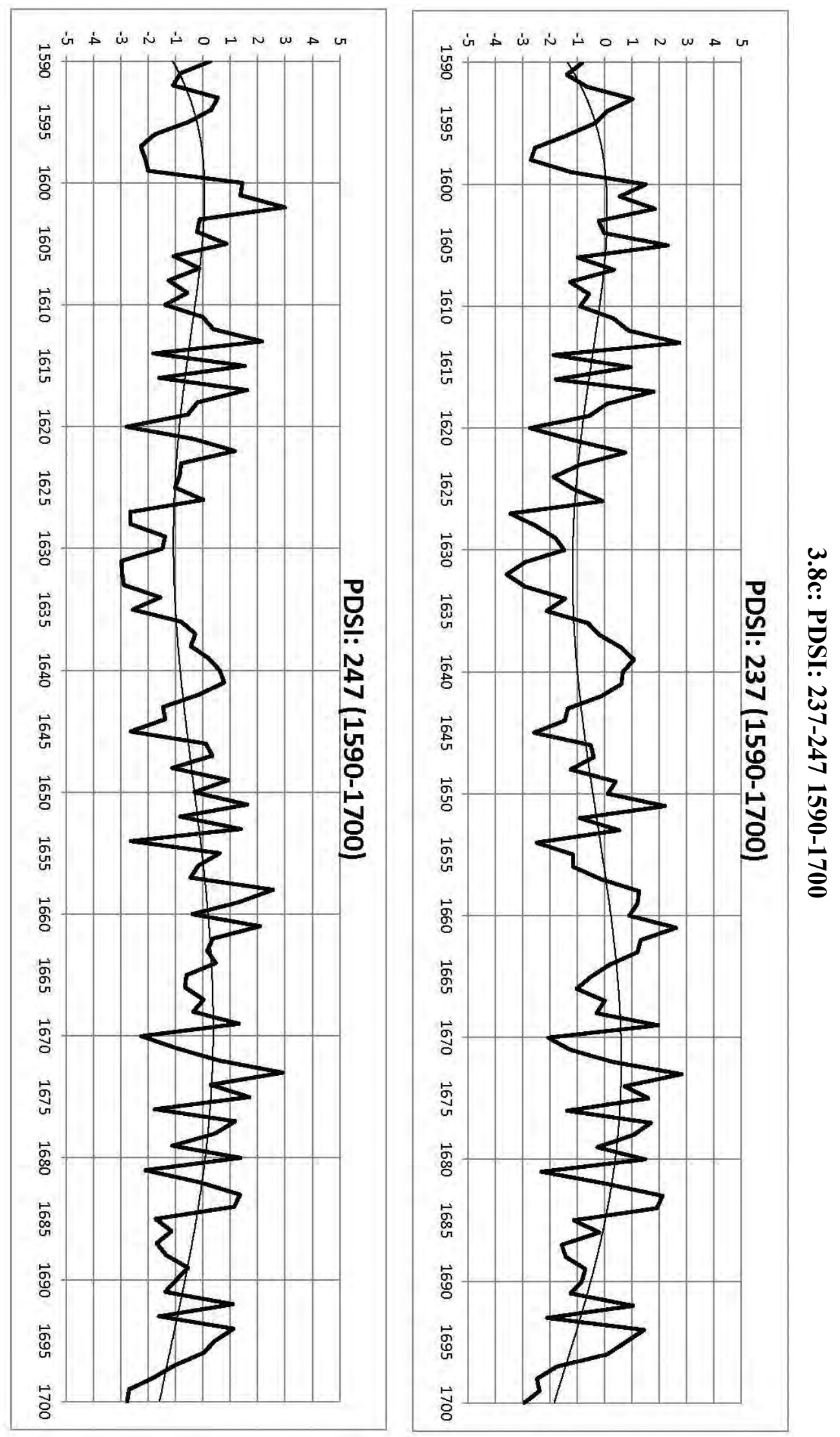
3.8d: PDSI: 237-247 1690-1760
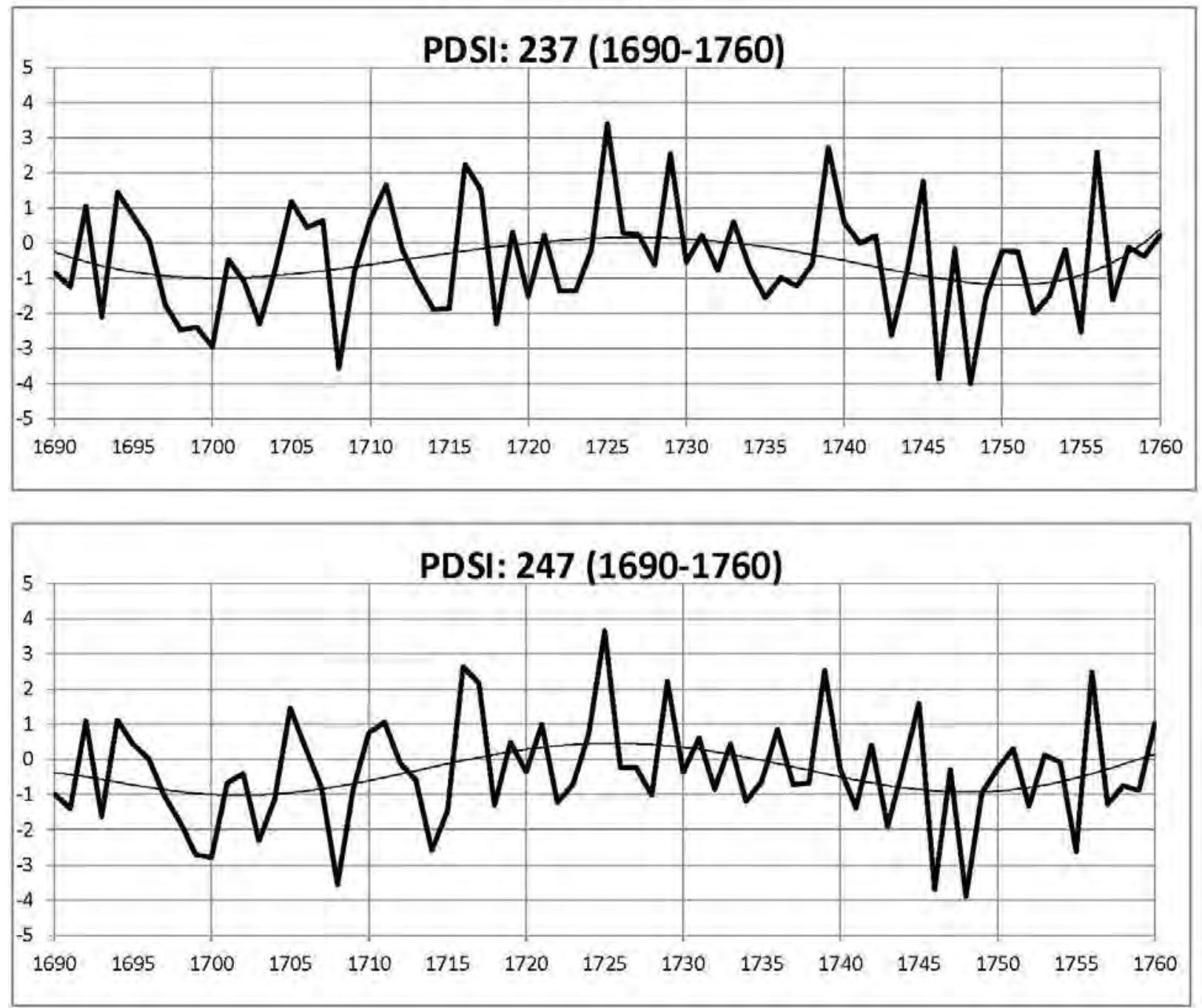

Notes: As indicated from the above graphs, the majority of the years between 1500-1760 were below the 1901-1970 baseline and much of the time was in medium to severe drought. The annual variability is espcially notable throughout the entire time period. 


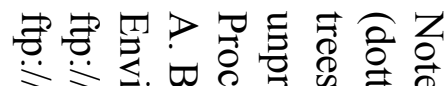

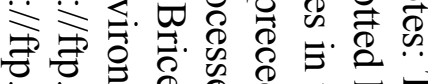

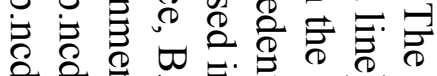
है है

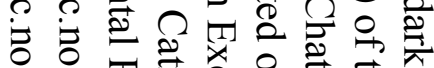

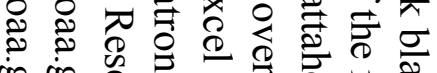

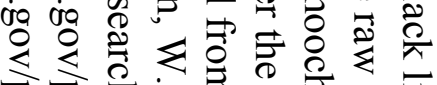

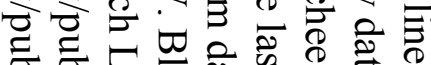

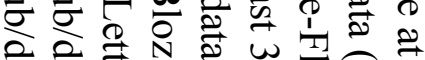

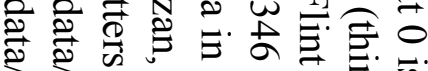
政的 递

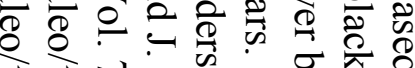

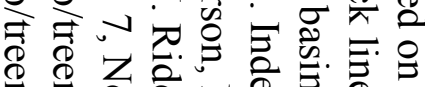

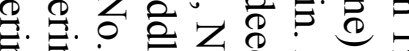

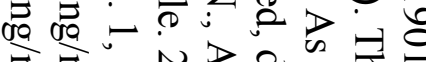

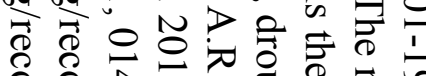
ᄋ

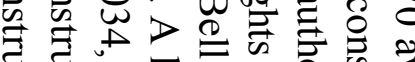
든 .

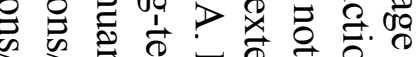

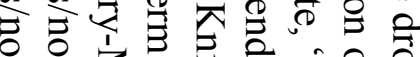

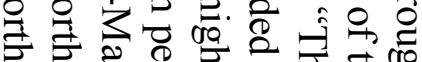

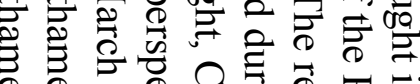
๑.

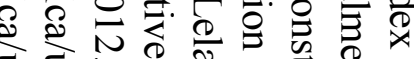

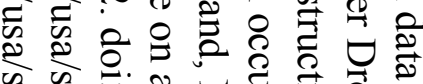

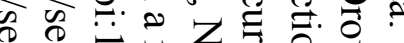
制

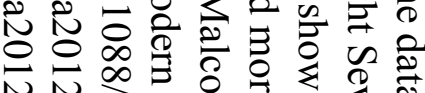

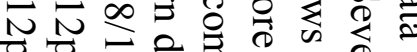

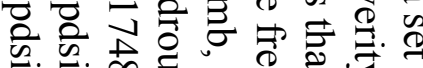
‥

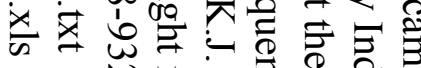
NE;

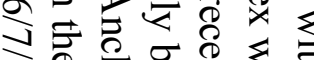
흉ㅎㅇ 융

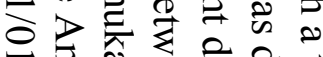
责 论

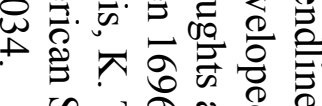
थै 苍谷官

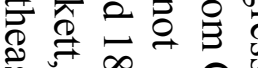

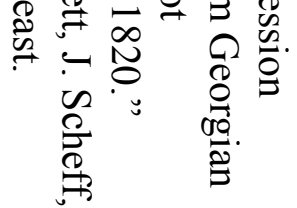

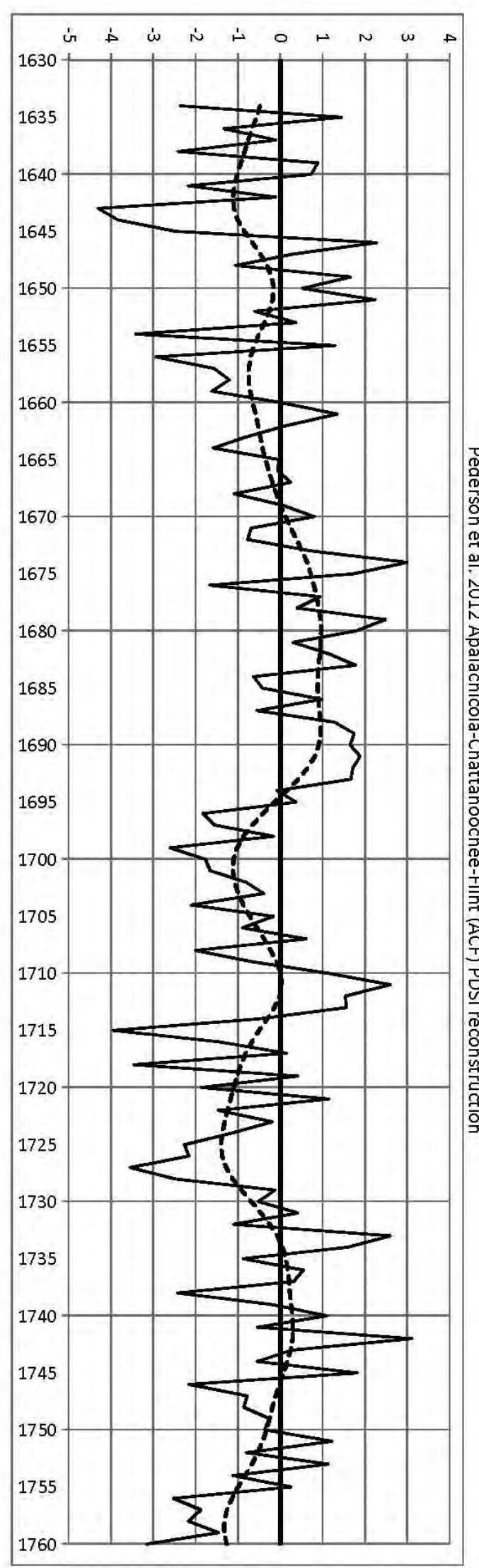



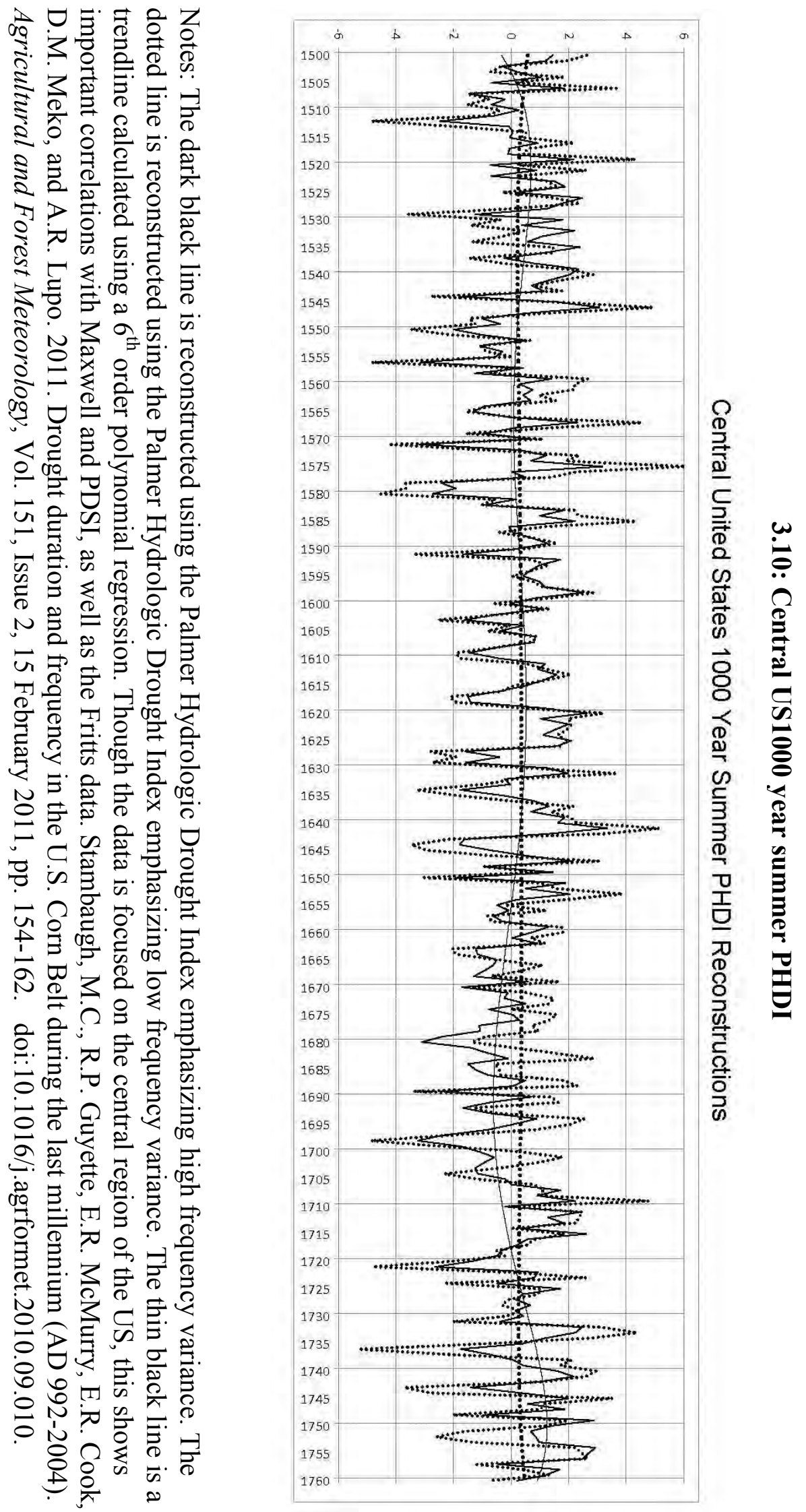

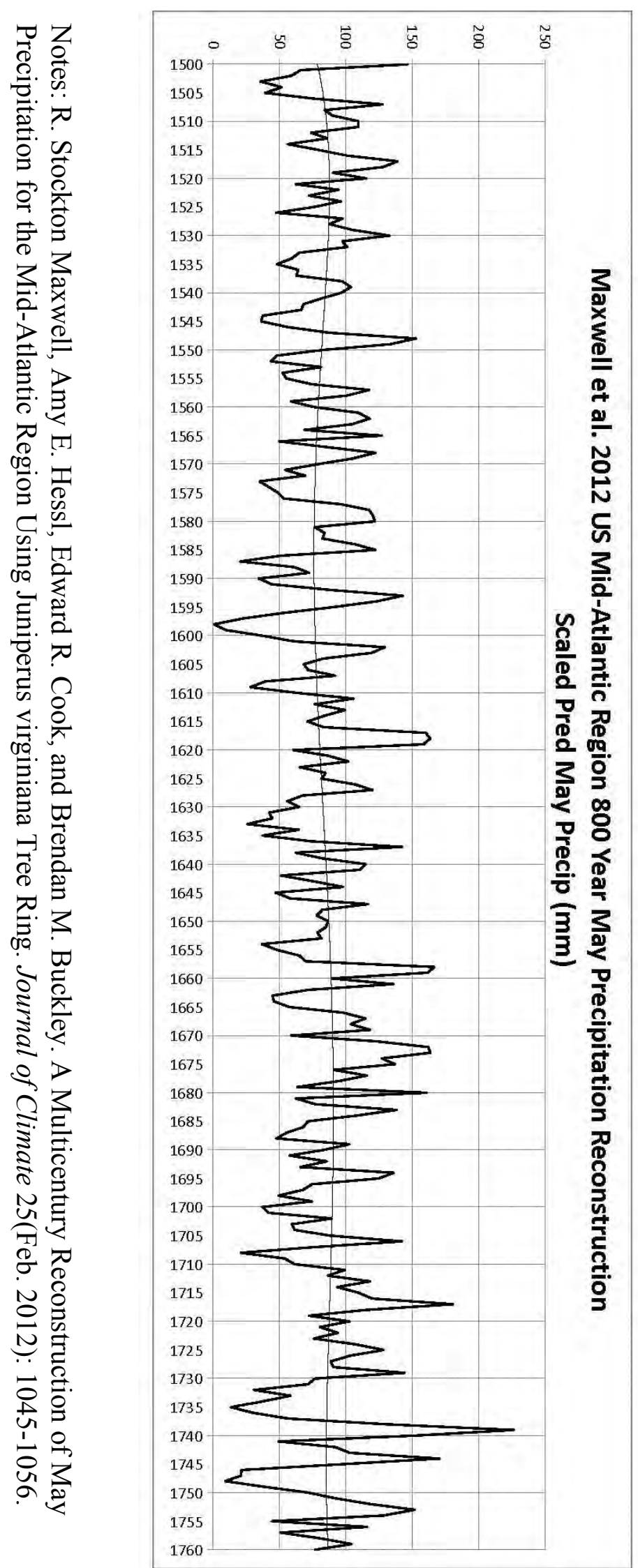

בְ' 
3.12a: Solomon paper: Global Temperature Anomaly: 0-2000

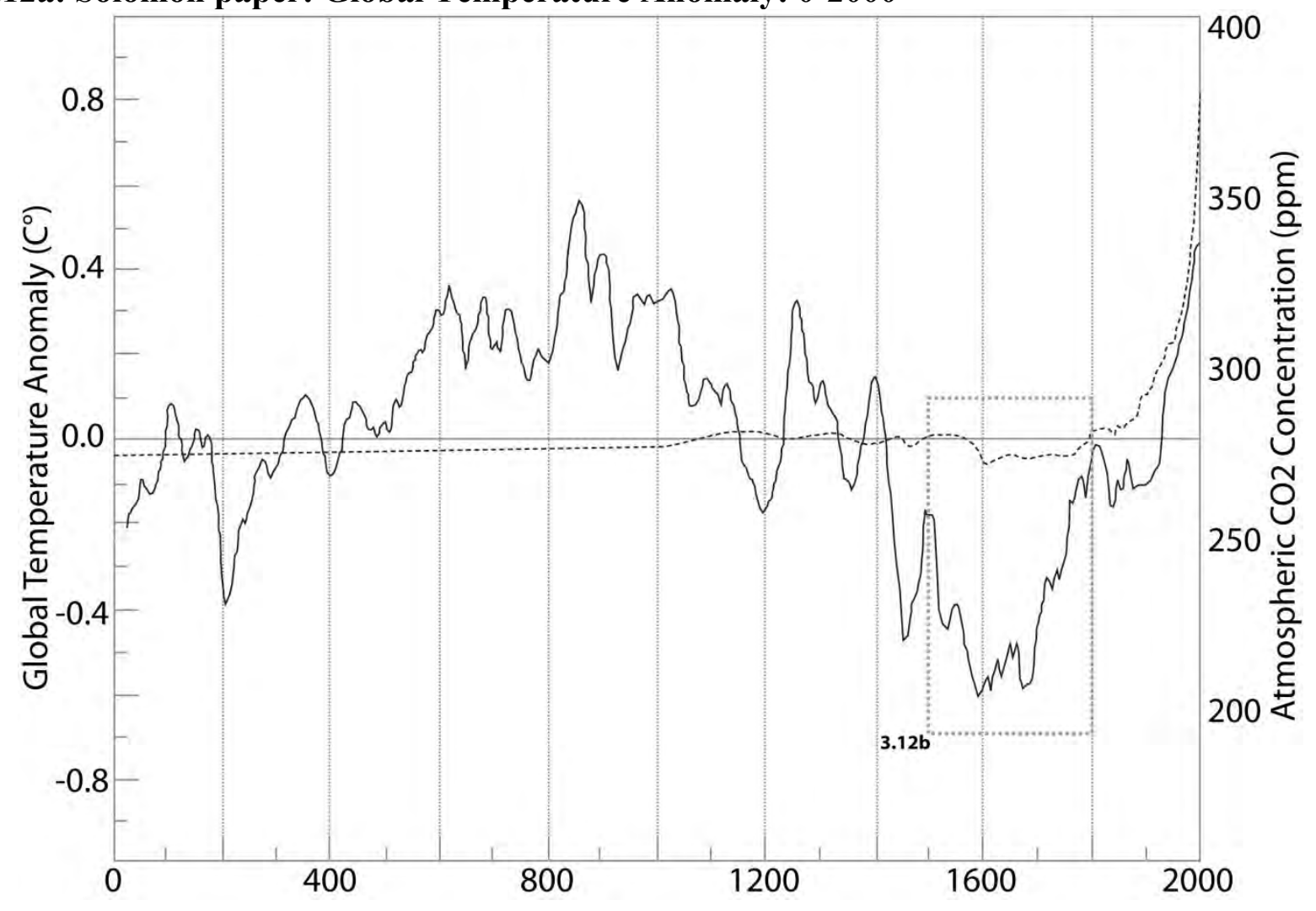

3.12b: Solomon paper: Global Temperature Anomaly: 1500-1800

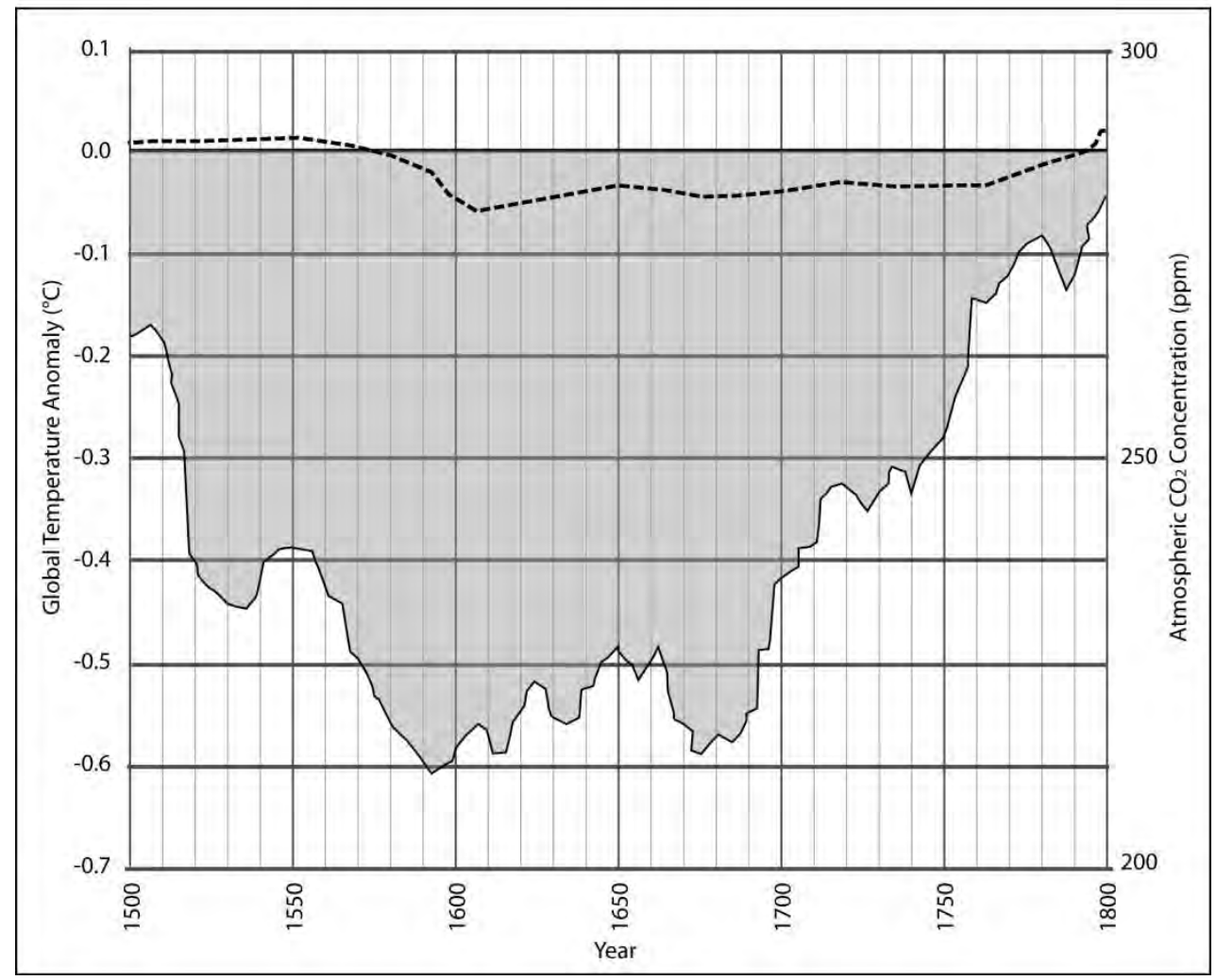



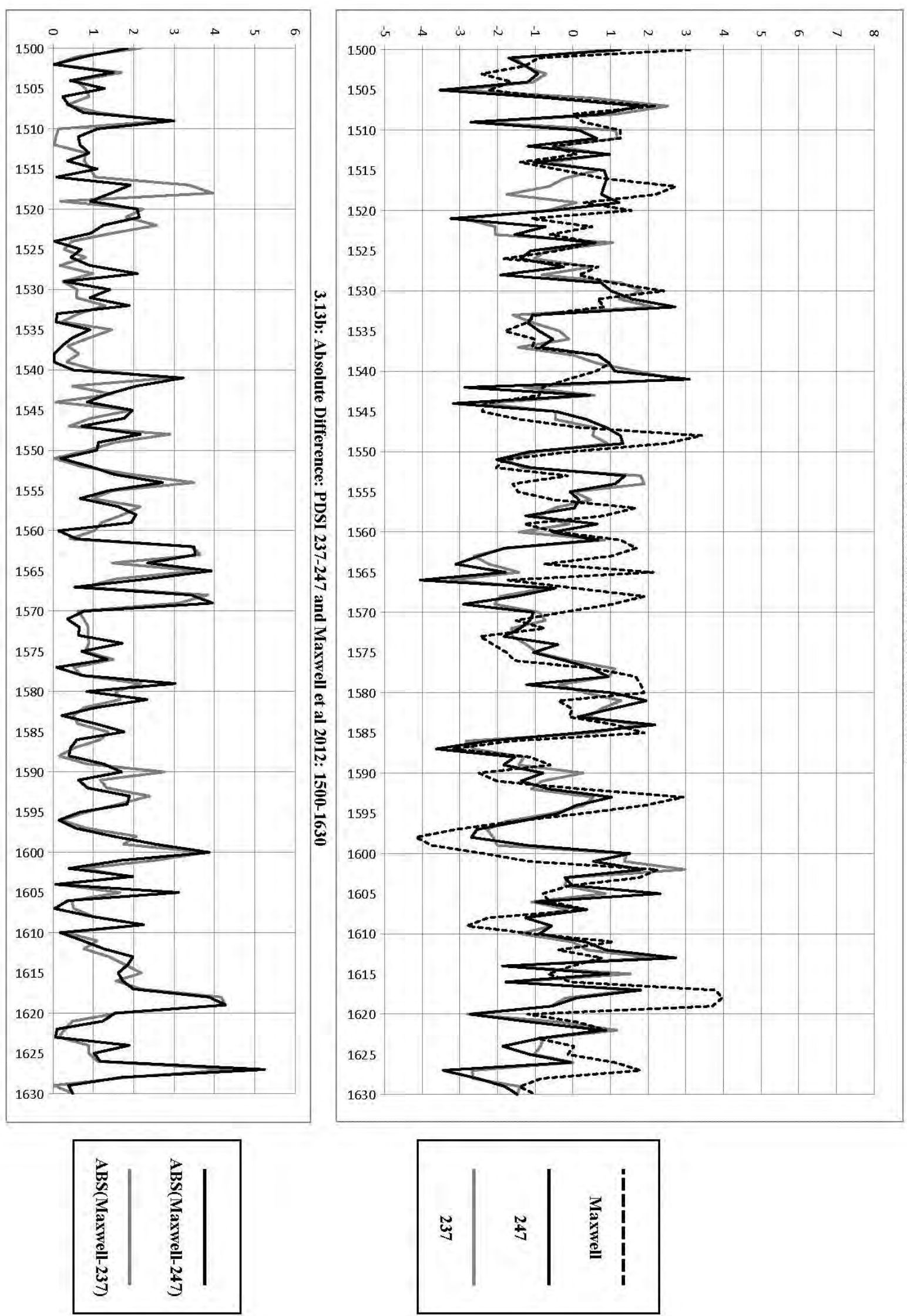

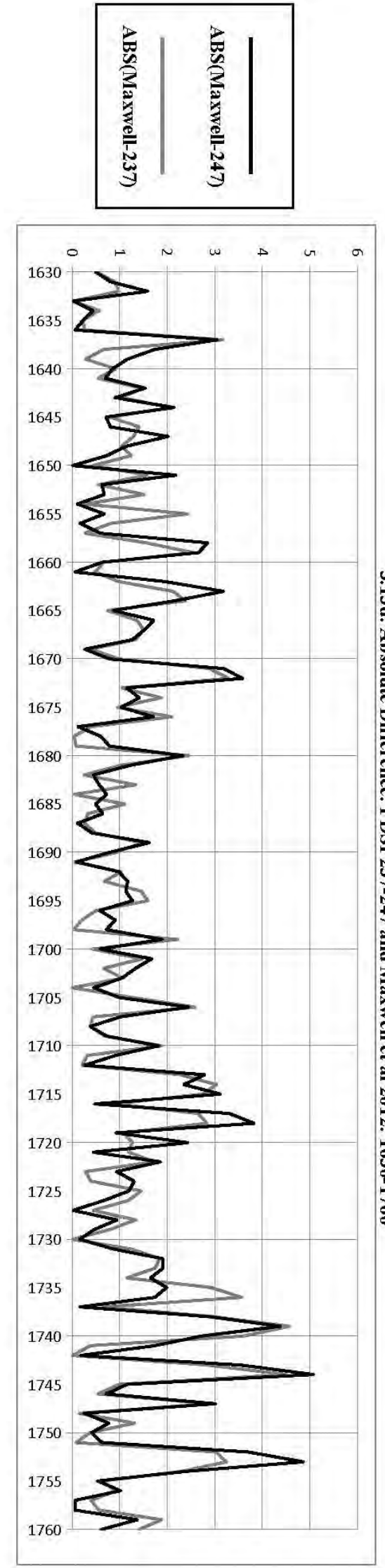

$:||||$

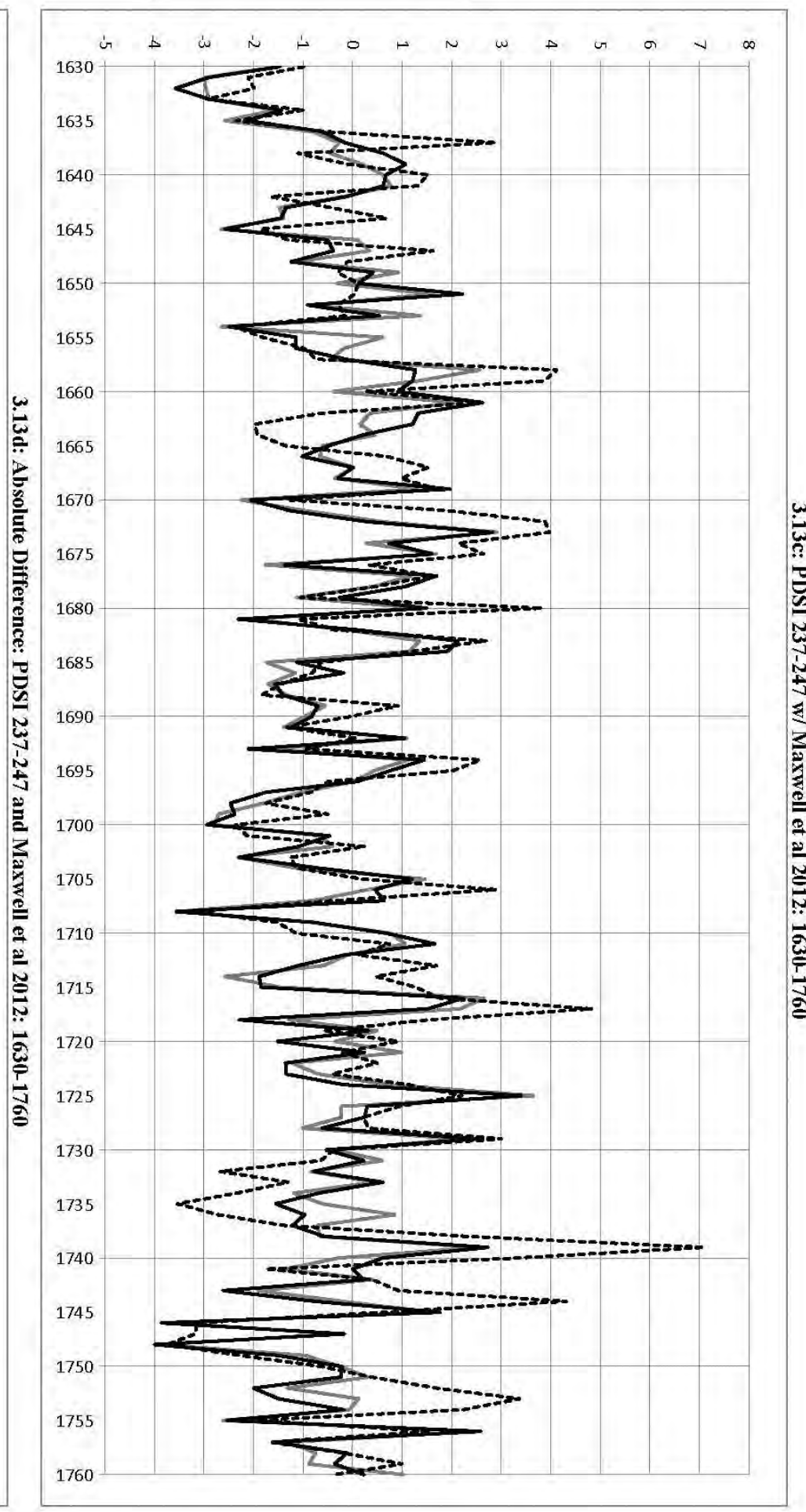




\subsection{3a-d: PDSI 237-247 w/ Maxwell et al 2010: 1500-1760: Notes}

Notes: I wanted to compare the data from the Mid-Atlantic tree-ring data from Maxwell et al data was recorded in $\mathrm{mm}$ to the PDSI anomalies. The differences between the two data sets could be numerically adjusted for comparison. The Maxwell data was altered using the following formula: $\Sigma=(\mathrm{M}-84.4) / 20, \Delta=|\Sigma-\mathrm{P}| . \mathrm{M}$ is the maxwell data. $\mathrm{P}$ is the PDSI data. $84.4 \mathrm{~mm}$ is the 1901-1970 base-line average for the regional precipitation for May. I divided the data by 20 to normalize data to make it comparable to PDSI 237-247. Then for comparison, I calculated the absolute value of the difference between Maxwell ad the PDSI raw values. The data shows a great deal of variation between the two data sets. 
3.14a: NDCD Draft 36: Observed US Temp. Change 1901-1960 vs 1991-2011

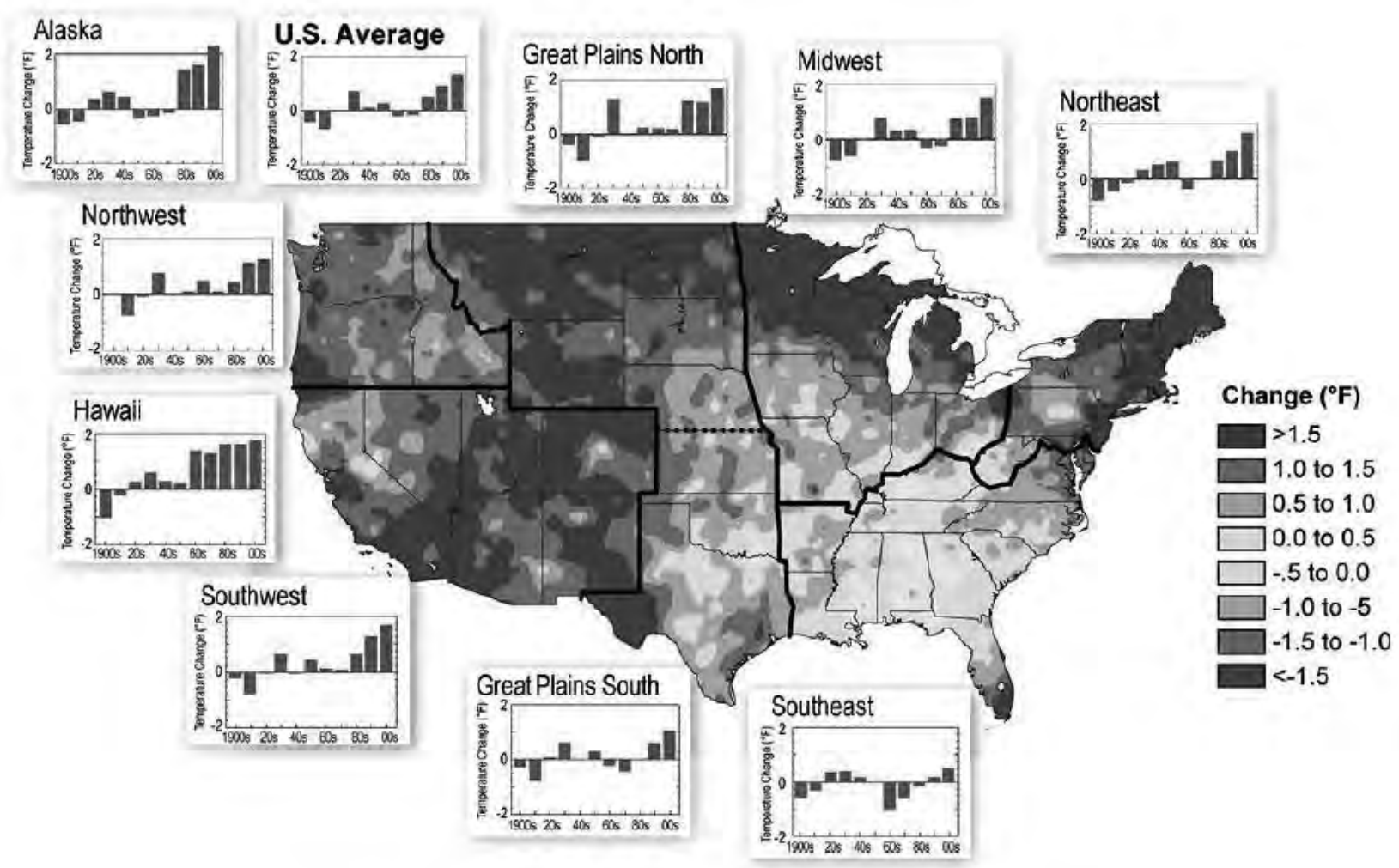

3.14b NCDC Draft 1604: 1700 Years Global Temp. Proxy Data 300-2000AD

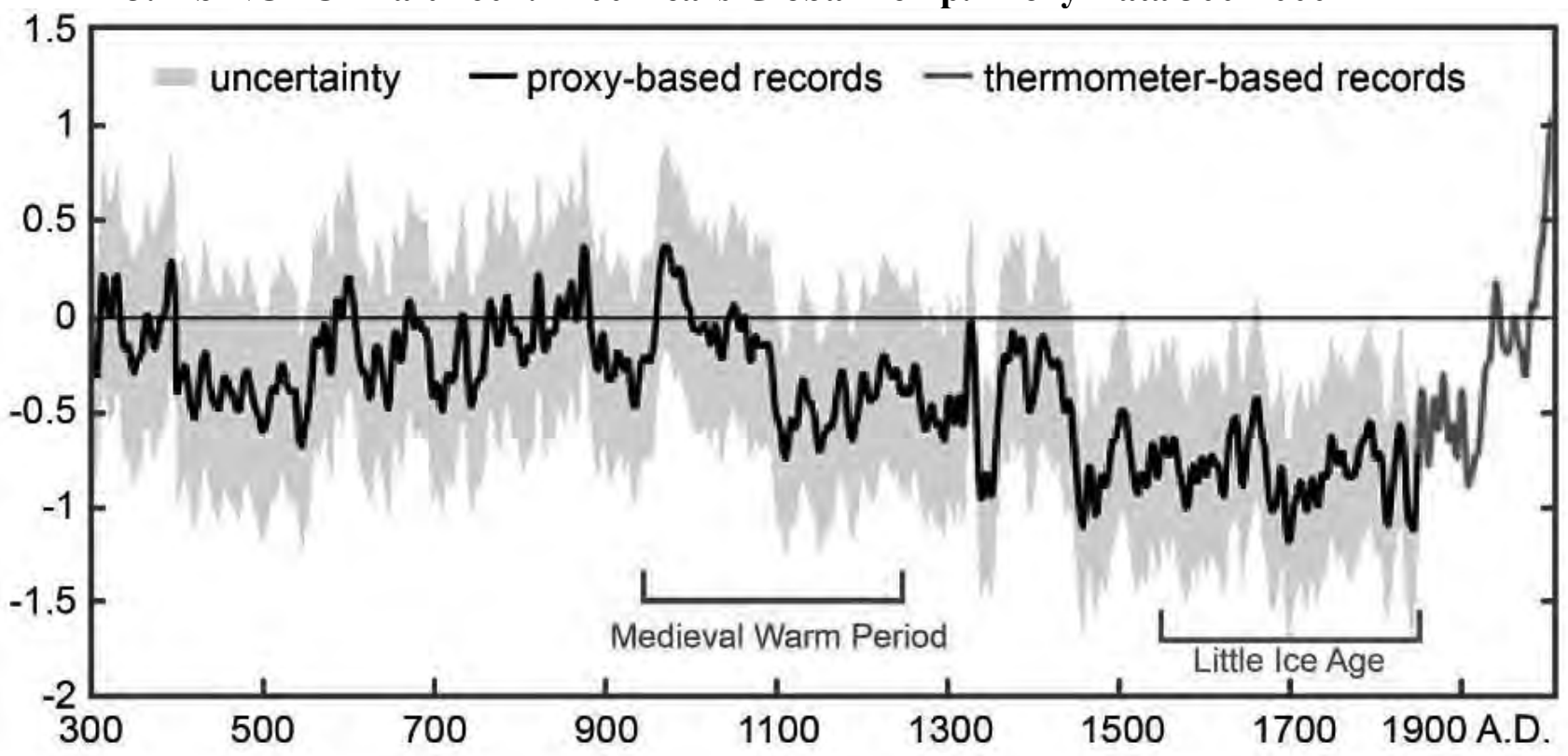

Both 3.14 came from National Climate Assessment and Development Advisory Committee Report January 2013 Draft for Public Comment. Melillo, Jerry M., Terese (T.C.) Richmond, and Gary W. Yohe, Eds., 2014: Climate Change Impacts in the United States: The Third National Climate Assessment. U.S. Global Change Research Program, 841 pp. doi:10.7930/J0Z31WJ2: (3.14a) 36, (3.14b) 1064. 


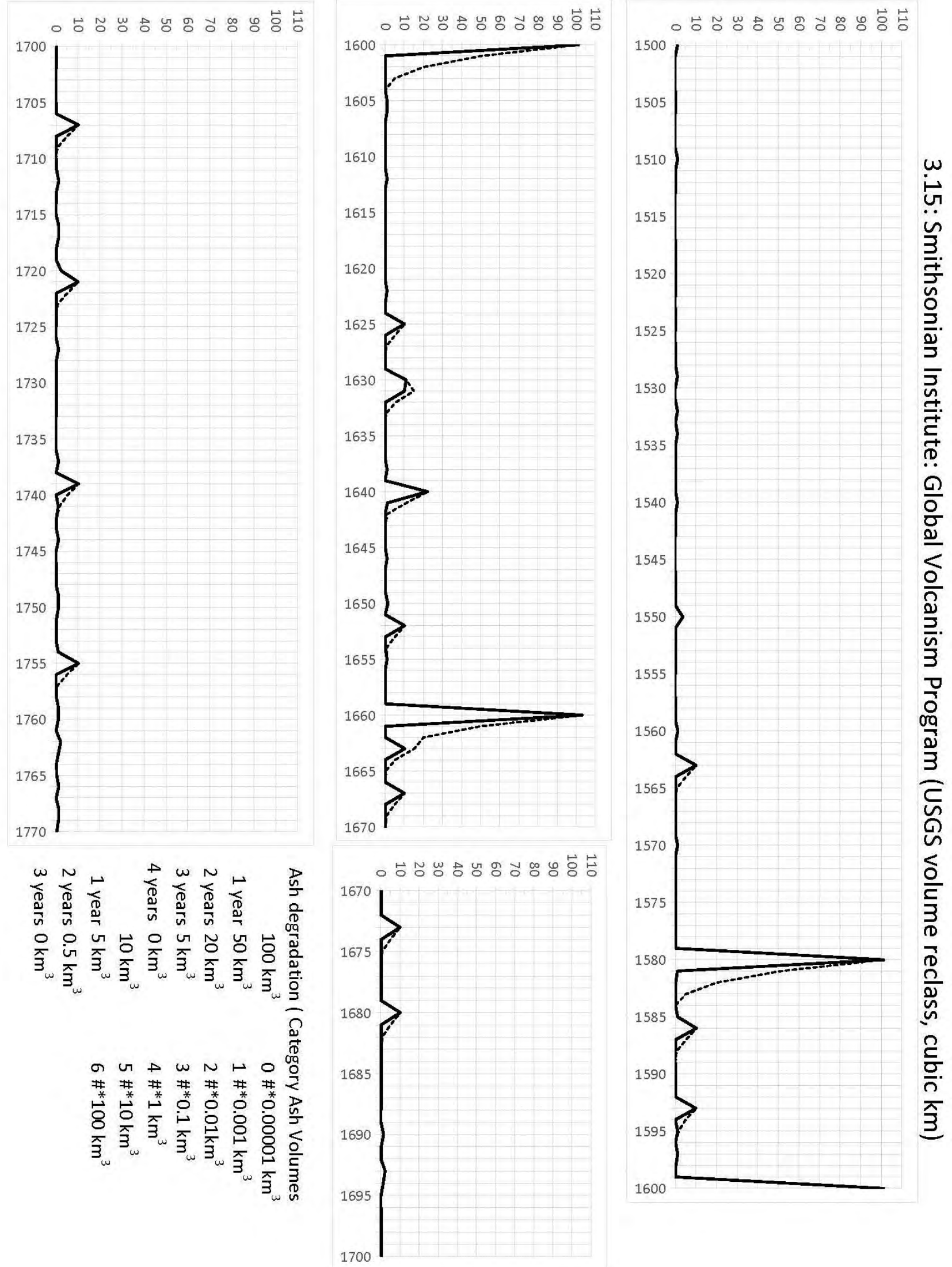


3.15: Smithsonian Institute: Global Volcanism Program (USGS volume reclass, cubic km) Notes: I developed this graph by calculating the volume of volcanic ash based off the Volcano Explosivity Index for each Volcano in the historical database, then aggregating each eruption volume for the year. This is the dark black line. The dotted line marks the estimated remaining and cumulative ash over subsequent years with major eruptions leaving significant ash in the upper atmosphere for up to three years. The effects of ash have recently came under closer examination through LiDar scanning of upper atmosphere which suggested that even small particulate can have a significant long-term cooling effect.

1. Smithsonian Institute: Global Volcanism Program - Volcanoes of the World 4.3.1, Downloaded on 18 Oct 2014 at 09:36 PM, http://www.volcano.si.edu/search_eruption_results.cfm.

2. Measuring Explosiveness: The Volcano Explosivity Index (VEI), Accessed 02/23/2015, 8:28pm. http://www.geology.sdsu.edu/how volcanoes_work/Variability.html

3. Ridley, David; S. Solomon, J.E. Barnes, V.D. Burlakov, T. Deshler, S. I. Dolgii, A. B. Herber, T. Nagai, R. R. Neely III, A. V. Nevzorov, C. Ritter, T. Sakai, B. D. Santer, M. Sato, A. Schmidt, O. Uchino, J. P. Vernier. Total volcanic stratospheric aerosol optical depths and implications for global climate change. American Geophysical Union. 18 November 2014. 


$\begin{array}{ll}\text { Abbreviations } & \\ \text { AHR } & \text { American Historical Review } \\ \text { AM } & \text { Archives of Maryland } \\ \text { CRNC } & \text { Colonial Records of North Carolina } \\ \text { CRSC } & \text { Colonial Records of South Carolina } \\ \text { EJCCV } & \text { Executive Journals of the Council of Colonial Virginia } \\ \text { JGCSC } & \text { Journals of the Grand Council of South Carolina } \\ \text { JR } & \text { Jesuit Relations } \\ M P C P & \text { Minutes of the Provincial Council of Pennsylvania } \\ \text { NYCD } & \text { Documents Relative to the Colonial History of the State of New York } \\ P A & \text { Pennsylvania Archives } \\ \text { WMHB } & \text { Virginia Magazine of History and Biography } \\ \text { WJ } & \text { Papers of William Johnson } \\ \text { WVA } & \text { West Virginia Archaeologist } \\ \text { WMQ } & \text { William and Mary Quarterly }\end{array}$

\section{Bibliography}

\section{Primary Sources}

A new collection of voyages, discoveries and travels... Vol. II. London: J. Knox, 1767.

A Treaty Held at the Town of Lancaster, By the Honourable the Lieutenant Governor of the Province, and the Honourable the Commissioners for the Province of Virginia and Maryland, with the Indians of the Six Nations in June, 1744 in Indian Treaties Printed by Benjamin Franklin, 1736-1762, eds. C.Van Doren, and Boyd, J. P. (Philadelphia, PA: The Historical Society of Pennsylvania, 1938, 41-79.

Acts of the General Assembly, October 1646, Thomas Jefferson Papers, Series 8, Volume 7, Library of Congress. Accessed online August 10, 2012: http://www.virginiamemory.com/online_classroom/shaping_the_ constitution/doc/treaty.

A Treaty, held at the town of Lancaster, in Pennsylvania, by the Honourable the lieutenant-governor of the province, and the Honourable the commissioners for the provinces of Virginia and Maryland, with the Indians of the Six Nations, in June, 1744. Philadelphia: B. Franklin. 1744. ECCO: W029577.

Adair, James. History of the American Indians. London: Edward and Charles Dilly, 1775. From ECCO, 2008. Alexander, Edward P. “An Indian Vocabulary from Fort Christanna, 1716.” VMHB 79:3 (Jul. 1971): 303-313. Alsop, George. A character of the province of Maryland. Cleveland: Burrows Brothers Company, [1666] 1902. Alvord, Clarence W., and Lee Bidgood. The First Explorations of the Trans-Allegheny Region by the Virginians, 1650-1674. Cleveland: Arthur H. Clarke Co., 1912.

Annual Register or a View of the History, Politicks, and Literature, for the Year 1763. London: 1764.

Archives of Maryland. Proceedings of the Council of Maryland. (Baltimore: Maryland Historical Society, 1883), 2: 196, 5: 245, 8: 534.

Armenius, Theophilus. The First Discovery of Kentucky, Feb. 10, 1820. Methodist Magazine 3 (1820): 384-389.

Atkin, Edmond, and Wilbur R. Jacobs. The Appalachian Indian frontier; the Edmond Atkin report and plan of 1755. Lincoln: University of Nebraska Press 1967, 1954.

Augustine, Herman, Map of Virginia and Maryland. London, 1670 in Virginia-Maryland Boundary Report, 1873.

Bailey, David. Copy of David Bailey's Document Concerning Indian Affairs. 1919. From ECCO 2010.

Bandera, Juan de la. "Proceedings for the Account Which Captain Juan Pardo Gave of the Entrance Which He Made into the Land of the Floridas." Translated by Paul Hoffman, in The Juan Pardo Expeditions: Explorations of the Carolinas and Tennessee, 1566-1568, Charles Hudson, (Washington, DC.: Smithsonian Institution Press, 1990).

Barnwell, John. "Journal of John Barnwell.” VMHB 5:4 (Apr., 1898): 391-402.

Beverley, Robert. The History and Present State of Virginia. Richmond: J.W. Randolph, 1705.

Brock, R. A., ed. The Official Records of Robert Dinwiddie. Vol. 1-2. Richmond: Virginia Historical Society, 1883.

Byrd, William. The Westover Manuscripts: containing The History of the Dividing Line Betwixt Virginia and North Carolina. Petersburg: Edmund and Julian C. Ruffin, 1841.

Candler, Allen D., ed. The colonial records of the state of Georgia. Vol. 1-2. Atlanta: Franklin, 1904-1916. 
Carroll, B. R., comp., Historical Collections of South Carolina: Embracing many rare and Valuable Pamphlets and other Documents Relating to the history of that State... to ... 1776, 2 vols. New York, 1836.

Celeron de Bienville, Pierre Joseph. "Celeron's Journal.” Edited by A. A. Lambling. Ohio Archaeological and Historical Society Quarterly 29:3 (July 1920): 335-396.

Chalkley, Thomas. A journal or historical account of the life, travels, and Christian experiences, of that antient, faithful servant of Jesus Christ, Thomas Chalkley. $3^{\text {rd }}$ ed. London: Luke Hinde, 1751. ECCO: N029101.

Clark, Walter, and William Laurence Saunders, eds. The State records of North Carolina. Vols. 1-2. Raleigh: P.M. Hale, 1886-1907.

Chaussegros de Léry, Gaspard-Joseph. Journal of Gaspard-Joseph Chaussegros de Léry, Northwestern Pennsylvania Historical Series, edited by Sylvester K. Stevens and Donald H. Hunt. 1940.

Colden, Cadwallader. The history of the five Indian nations of Canada, which are dependent on the province of New-York in America. $3^{\text {rd }}$ ed. London: Lockyer Davis; J. Wren; and J. Ward, 1755. ECCO: T144799. V 1.

Cumming, William P. The Southeast in Early Maps. Chapel Hill: University of North Carolina Press, 1998.

Darlington, W. M., ed. Christopher Gist's Journals, with Historical, Geographical and Ethnological Notes. Pittsburgh, 1893.

Davis, R. P. Stephen, Jr., ed. "The Travels Of James Needham And Gabriel Arthur Through Virginia, North Carolina, And Beyond, 1673-1674.” Southern Indian Studies 39 (1990): 31-55.

DeHass, Wills. History of the Settlement and Indian Wars of Western Virginia: An Account of the Various Expeditions in the West, Previous to 1795. Wheeling, WV: H. Hoblitzell, 1851.

Doddridge, Joseph. Notes on the settlement and Indian wars of the Western parts of Virginia and Pennsylvania from 1763 to 1783. Pittsburgh, Pa.: John S. Ritenour and William T. Lindsay, 1912.

Fallam, Robert. "Explorations beyond the Mountains." William and Mary Quarterly, 1st ser. 15, 1907.

Feest, Christian F. “Another French Account of Virginia Indians by John Lederer.” VMHB 83:2 (Apr. 1975): 150159.

Foster, Emily, ed. The Ohio frontier: an anthology of early writings. Lexington, Ky.: University Press of Kentucky, 1996.

French policy defeated. Being, an account of all the hostile proceedings of the French, against the inhabitants of the British colonies in North America, for the last seven years. ... Embellished with two curious maps. London: M. Cooper, 1755. ECCO: T098592.

Frost, John. Border Wars of the West: Comprising the Frontier Wars of Pennsylvania, Virginia, Kentucky, Ohio, Indiana, Illinois, Tennessee, and Wisconsin...” New York: Miller, Orton \& Mulligan, 1856.

Galbreath, C. B. ed. Expedition of Celoron to the Ohio Country in 1749. Republished for Ohio Archaeological and Historical Quarterly. Columbus, OH: F. J. Heer Printing Co. 1921.

Gallay, Alan, ed. Voices of the South: Eyewitness Accounts, 1528-1861. Athens: University of Georgia Press, 1994.

Galloway, Patricia, ed. Mississippi Provincial Archives, 1729-1748, French Dominion. Baton Rouge: Louisiana State University Press, 1984.

Gibson, John Arthur. "Concerning the League: The Iroquois League Tradition as Dictated in Onondaga." Ed. And Trans. Hanni M. Woodbury, in collaboration with Reg Henry and Harry M. Webster. Algonquian and Iroquoian Linguistics Memoir No. 9. Winnipeg: University of Manitoba, 1992: 459-60.

Hall, James. Sketches of History, Life, Manners in the West. Philadelphia : Harrison Hall, 1834.

Hamilton, Milton W., ed. The papers of William Johnson. Albany: The University of the State of New York, 1962.

Harrison, Fairfax. "The Virginians on the Ohio and the Mississippi in 1742." VMHB 30:2 (April 1922), 203-222.

Harrison, William Henry, col. A discourse on the aborigines of the Ohio Valley, in which the opinions of its conquest in the seventeenth century, by the Iroquois or Six Nations, supported by Cadwallader Colden... are examined and contested; to which are prefixed some remarks on the study of history. Prepared for Historical Society of Ohio, Chicago: Fergus Printing Company, 1883.

Harvey, Henry. History of the Shawnee Indians, from the year 1681 to 1854, inclusive. Cincinnati: E. Morgan \& Sons, 1855.

Hazard, Samuel, ed. Pennsylvania Archives. 12 vols. Philadelphia: Joseph Severens \& Co., 1852-1856.

Heckewelder, John Gottlieb Ernestus, and William Cornelius Reichel. Account of the history, manners, and customs of the Indian nations History, manners, and customs of the Indian nations who once inhabited Pennsylvania and the neighbouring states. (by the Rev. John Heckewelder; with an introduction and notes by the Rev. William C. Reichel) (Bowie, MD: Heritage Books, 1990). Originally published: New and rev. ed. Philadelphia: Historical Society of Pennsylvania, v. 12, 1876. 
Hennepin, Louis. A new discovery of a vast country in America: extending above four thousand miles, between New France and New Mexico : with a description of the Great Lakes, cataracts, rivers, plants, and animals : also, the manners, customs, and languages of the several native Indians, and the advantage of commerce with those different nations : with a continuation, giving an account of the attempts of the Sieur de la Salle upon the mines of St. Barbe, \&c.: the taking of Quebec by the English, with the advantages of a shorter cut to China and Japan: both parts illustrated with maps and figures, and dedicated to His Majesty K. William. London: Printed for M. Bentley, J. Tonson, H. Bonwick, T. Goodwin, and S. Manship, 1698.

Hildreth, Dr. Notes on Ohio. American Journal of Science and Arts Vol. X (Feb. 1820): 152-162.

Horn, William Franklin. "Jacob Horn's Diary 1735-1777." The Horn papers; early westward movement on the Monongahela and upper Ohio, 1765-1795, by W. F. Horn. Waynesburg, Pa., Pub. for a committee of the Greene County Historical Society, by The Herald Press, Scottsdale, Pa., 1945.

Hutchinson, Thomas. A History of the Province of Massachusetts Bay ... Until the Year 1750. Boston, Thomas and John Fleet, 1767.

Indian Slaves $W M Q$ 6:4 (Apr. 1898): 214-215.

Indian Slaves $W M Q$ 8:3 (Jan. 1900): 165.

Johnston, J. Stoddard, ed. First Explorations of Kentucky: Journals of Dr. Thomas Walker, 1750, and Christopher Gist, 1751. Louisville, KY: John P. Morton and Company, The Filson Club, 1898.

Johnston, John L. Indian Trails, Two Typescript Narratives, 1925. West Virginia Collection, Morgantown, WV.

Jones, Rev. David. A Journal of Two Visits made to some Nations of Indians on the west side of the river Ohio, in the Years 1772 and 1773. Burlington: Isaac Collins, 1774.

Kellogg, Louise Phelps, ed. "Salling's Journey in the Mississippi Valley." The Mississippi Valley Historical Review 1:2 (Sept. 1914): 262-265.

Kenton, Edna, ed. The Jesuit relations and allied documents; travels and explorations of the Jesuit missionaries in North America (1610-1791). with an intro. by Reuben Gold Thwaites. New York: A. \& C. Boni, 1925.

Kercheval, Samuel. A History of the Valley of Virginia. Winchester: Samuel H. Davis, 1833.

Kinietz, V., and E W. Voegelin. "Shawanese Traditions: C. C. Trowbridge's Account." University of Michigan, Museum of Anthropology, Occasional Contributions, 9, 1939.

Knight, Vernon J., Jr. and Sherée L. Adams. "A Voyage to the Mobile and Tomeh in 1700, with Notes on the Interior of Alabama." Ethnohistory 28:2 (Spring 1981): 179-194.

Krieger, Alex D. Krieger, Margery H. "Núñez Cabeza de Vaca, Alvar." We Came Naked and Barefoot: The Journey of Cabeza de Vaca Across North America. Austin: University of Texas Press, 2002. "Appendix 2: Account of the Disasters (Relación de Los Naufragios) Alvar Núñez Cabeza de Vaca" 155-242.

Lahontan, Louis Armand de Lom d'Arce, Baron de. New voyages to North-America. Containing an account of the several nations of that vast continent; their customs, commerce, and way of navigation upon the lakes and rivers; ... Illustrated with twenty three mapps and cutts. Written in French by the Baron Lahontan, ... Done into English. In two volumes. London: H. Bonwicke; T. Goodwin, M. Wotton, B. Tooke; and S. Manship, 1703. ECCO: T043043. Vol. 1-2.

Langdon Cheves, comp., The Shaftesbury Papers and other records relating to Carolina and the first settlement on the Ashley River prior to the year 1676. Charleston, SC: South Carolina Historical Society [1897] 2010.

Lawson, John. A New Voyage to Carolina. ed. by Hugh T. Lefler. Chapel Hill: University of North Carolina Press, 1967.

Le Jau, Dr. Francis, and Frank Lingberg, ed. The Carolina Chronicle of Dr. Francis Le Jau, 1706-1717. University of California Publications in History, Vol 53. Berkeley, CA: University of California Press, 1956.

Le Page du Pratz. The history of Louisiana, or of the western parts of Virginia and Carolina: containing a description of the countries that lie on both sides of the river Missisippi: [sic] with an account of the settlements, ... Translated from the French of M. Le Page du Pratz; with some notes and observations. London: T. Becket, 1774. ECCO: T141264.

Leder, Lawrence H. The Livingston Indian Records, 1666-1723. Pennsylvania History, 1956.

Lederer, John, and William P. Cumming, ed. The discoveries of John Lederer: with unpublished letters by and about Lederer to Governor John Winthrop, Jr. Charlottesville: University of Virginia Press, 1958.

Lewis, Clifford M., and Albert J. Loomie. The Spanish Jesuit Mission in Virginia, 1570-1572. Chapel Hill: University of North Carolina Press, 1953.

Lewis, John. New Hope; on The Rescue. A Tale of the Great Kanawha. New York: Bince \& Brother, Pub., 1855.

Lieber, Oscar M. Vocabulary of the Catawba Language. Charleston: James and Williams, Printers, 1858.

Longe, Alexander, and David H. Corkran, ed. "Reproduction of Alexander Longe's original." Southern Indian Studies 21 (Oct. 1969): 3-49. 
Loskiel, George Henry. History of the mission of the United Brethren among the Indians in North America. In three parts. By George Henry Loskiel. Translated from the German by Christian Ignatius La Trobe. London Brethren's Society for the furtherance of the Gospel, and John Stockdale, 1794. ECCO: T088588.

The Luna Papers: Documents Relating to the Expedition of Don Tristán de Luna y Arellano for the Conquest of La Florida in 1559-1561. 2 vols. Trans. and ed. Herbert Ingram Priestley. Deland: Florida State Historical Society, 1928.

MacConald, William, ed. Select Charters and Other Documents Illustrative of American History: 1606-1775. London: MacMillan Comp, 1899.

Madison, Bishop James. "Bishop Madison's account of the Kanawha valley mounds and earthworks." from Transactions of the American Philosophical Society., n. xxvi, 132-142; in WVA 6(1):17 ([1804] May 1964): 48-59.

McDowell, William L. Documents relating to Indian affairs. Columbia: South Carolina Archives Dept., 1958-1970.

McIlwaine, H. R., Wilmer L. Hall, and Benjamin J. Hillman, eds. Executive Journals of the Council of Colonial Virginia. 6 vols. Richmond: Virginia State Library, 1925-1966.

McWhorter, L.V. Border settlers of Northwestern Virginia. Hamilton, OH: Republican Publishing Co, 1915.

Mereness, Newton D. Travels in the American Colonies. New York: Macmillan Company, 1916.

Moore, James. Letter, ca. 1692, to Philip Ludwell, Governor [of North and South Carolina] and to the Counc[i]l [of South Carolina?]. VHS Manuscripts Mss1 L51 f 7.

Mulkearn, Lois, ed. George Mercer Papers Relating to the Ohio Company of Virginia. Pittsburgh, 1954.

Nairne, Capt. Thomas, Alexander Moore, ed. Nairne's Muskhogean Journals: The 1708 Expedition to the Mississippi River. Jackson: University of Mississippi Press, 1988.

Needham, James, and Gabriell Arthur. "The Travels of James Needham and Gabriel Arthur through Virginia, North Carolina and Beyond, 1673-1674.” Ed. R. P. Stephen Davis, Jr. Southern Indian Studies 39 (1990): 31-55.

Neill, Edward D. The Founders Of Maryland As Portrayed In Manuscripts, Provincial Records And Early Documents, Albany: Joel Munsell, Microform, 1876.

Neill, Edward D. Virginia Carolorum: the colony under the rule of Charles the First and Second, A.D. 1625-A.D. 1685, based upon manuscripts and documents of the period. Albany, NY: J. Munsell's Sons, 1886.

New York, Province of. A Treaty with the Shawanese and Delaware Indians, living on and near the Susquehanna River. New York: J. Parker and W. Weyman, 1757.

O'Callaghan, M.D., E.B., ed. Documents Relative to the Colonial History of the State of New York. Albany: Weed, Parsons and Company, Printers. Assorted Vol., 1855.

Ohio Company. Instructions given Mr. Christopher Gist by the Committee of the Ohio Company the 11th Day of September 1750. 1880.

Oldmixon, John. The British Empire in America, containing the history of the discovery, settlement, progress and present state of all the British colonies, on the continent and islands of America. In two volumes.... With curious maps of the several places, done from the newest surveys. By Herman Moll, Geographer. London John Nicholson, Benjamin Tooke, and Richard Parker and Ralph Smith, 1708. ECCO: T135550. Vol. 1-2.

Palmer, William P., ed. Calendar of Virginia state papers: and other manuscripts; preserved in the Capitol at Richmond. Vol. 1: 1652 - 1781. New York: Kraus, 1968.

Pénicault, André, and Richebourg Gaillard McWilliams, ed. Fleur de Lys and Calumet: being the Pénicault narrative of French adventure in Louisiana. Baton Rouge: Louisiana State University Press, 1953.

Pennsylvania, Province of. A Treaty between ... Pennsylvania, and the Indians of Ohio, held at Philadelphia, Nov. 13 1747. Philadelphia: Franklin, 1748.

Pennsylvania, Province of. A Treaty held by Commissioners ... with soome Chiefs of the Six Nations at Ohio ... in ... July 1748. Philadelphia: Franklin, 1748.

Pennsylvania, Province of. Treaty held with the Ohio Indians, at Carlisle, in October 1753. Philadelphia: Franklin and Hall, 1753.

Pennsylvania, State of. Minutes of the Provincial Council of Pennsylvania: from the organization to the termination of the proprietary government. [Mar. 10, 1683-Sept. 27, 1775], Vol. 1-8: March 10, 1683- Oct. 4, 1762. J. Severns for State of Pennsylvania, 1852.

Pennsylvania. The Particulars of an Indian Treaty at Conestogoe. Philadephia, 1721, HEH Copy. Conestogoe: July $9^{\text {th }}$, 1721: Gov. William Keith.

Post, Christian Frederick. The second journal of Christian Frederick Post, on a message from the governor of Pensilvania to the Indians on the Ohio. London: J. Wilkie, 1759. ECCO: N022047. 
Preston, William. "Preston's Journal of the Sandy Creek Expedition" In The Thirty-Fifth State: A Documentary History of West Virginia, edited by Elizabeth Comfetti, and Festus P. Summers, 41-47. Morgantown, WV: West Virginia University Library, 1966.

Priestley, Herbert Ingram. Tristan de Luna: Conquistador of the Old South: A Study of Spanish Imperial Strategy. Glendale, CA: Arthur H. Clark Co., 1936.

Quaife, Milo M., ed. The Preston and Virginia Papers of the Draper Collection of Manuscripts. Madison: Pub. State Historical Society of Wisconsin, Calendar Series, Vol. 1, 1915.

Riddel, Frank S. The historical atlas of West Virginia. Morgantown: West Virginia University Press, 2008.

Rudes, Blair A. Tuscarora-English/English-Tuscarora Dictionary. Toronto: University of Toronto Press, 1999.

Sainsbury, W. Noel, ed. Calendar of State Papers, Colonial series, 1574-1660. London: Longman, Green, Longman, \& Roberts, 1860. Accessed at http://books.google.com/. November 2, 2009.

Sainsbury, William Noel,; Salley, A. S. Records in the British Public Record Office relating to South Carolina: 1663-1710. Great Britain, Public Record Office. Columbia: Historical Commission of South Carolina, 1928-1947.

Salley, Alexander S. Journals of the Grand Council of South Carolina, July 14, 1677, April 12, 1680, June 4 and 24, $1680,82-85$.

Salley, A. S. Jr., (Index.) Records in the British Public Record Office relating to South Carolina. Atlanta: Printed for the Historical Commission of South Carolina by Foote \& Davies Co., 1928-47. v. 1. 1663-1684.--v. 2. 1685-1690.--v. 3. 1691-1697.--[v. 4] 1698-1700.--[v. 5] 1701-1710.

Salley, Alexander S., ed. Narratives of Early Carolina, 1650-1708. New York: Charles Scribner's Sons, 1911.

Saunders, William Laurence, ed. The Colonial Records of North Carolina: 1662-1776. Raleigh: P.M. Hale, 1968.

Speck, Frank G. Catawba texts. New York: Columbia University Press, 1934.

State of the British and French colonies in North America, with respect to number of people, forces, forts, Indians, trade and other advantages. ... In two letters to a friend. London: A. Millar, 1755. ECCO: T045619.

Summers, Lewis Preston. History of Southwest Virginia, 1746-1870, Washington County, 1777-1870. Richmond: J. L. Hill Printing Co., 1903.

The Middle Plantation Treaty of 1677. http://www.powhatanmuseum.com/Historic_Documents.html, accessed March 9, 2015.

The speech of a Creek-Indians [sic], against the immoderate use of spirituous liquors. Delivered in a national assembly of the Creeks, upon the breaking out of the late war. To which are added, 1. A letter from Yariza, an Indian maid of the royal line of the Mohawks, ... 2. Indian songs of peace. 3. An American fable. Together with some remarks upon the characters and genius of the Indians. London: R. Griffiths, 1754. ECCO: T111212.

Thompson, Charles. An enquiry into the causes of the alienation of the Delaware and Shawanese Indians from the British interest, and into the measures taken for recovering their friendship. Extracted from the public treaties, ... Written in Pensylvania. London: J. Wilkie, 1759. ECCO: T032730.

Thomson, Charles. Causes of the alienation of the Delaware and Shawanese Indians from the British interest. Philadelphia: John Campbell, 1867.

Thwaites, Reuben G., ed., Jesuit Relations and Allied Documents, The Travels and Explorations of the Jesuit Missionaries in New France. Cleveland: Burrows Brothers. 73 Vols. 1896-1901. $\mathrm{http} / / /$ puffin.creighton.edu/ jesuit/relations/.

Thwaites, Reuben Gold, ed. The Jesuit relations and allied documents microform: travels and explorations of the Jesuit missionaries in New France, 1610-1791. http://puffin.creighton.edu/ jesuit/relations/.

Tonti, Henri De. An Account of Monsieur de la Salle's last expedition and discoveries in North America microform / presented to the French king, and published by the Chevalier Tonti, Governour of Fort St. Louis, in the province of Illinois ; made English from the Paris original ; also the adventures of the Sieur de Montauban, captain of the French buccaneers on the coast of Guinea, in the year 1695. Microform, London: Printed for J. Tonson, S. Buckly and R. Knaplock, 1698.

Traunter, Richard. The Travels of Richard Traunter on the main continent of America from Appomattox River in Virginia to Charles Town in South Carolina. In two journals; performed in the years 1698: and 1699. Wherein is contained the quality \& nature of the soyle, the disposition of the inhabitants, and the reception I had amongst them; also my making peace with several nations of Indians, to the great advantage of the Indian traders in those parts, by opening a way that had not been travell'd before; with what else remarkable occur'd in my way. VHS Manuscripts Mss5:9 T6945:1 
Treaty of 1646. Acts of the General Assembly, October 1646, Thomas Jefferson Papers, Series 8, Volume 7, Library of Congress. Accessed online August 10, 2012: http://www.virginiamemory.com/online_ classroom/shaping the constitution/doc/treaty.

Trollope. Domestic Manners of the Americans $4^{\text {th }}$ ed. London: Whittakerm Trecaher and Co., 1832.

Trowbridge, C. C. Shawnese Traditions. Edited by Vernon Kinietz and E. W. Voegelin. Occasional Contributions from the Museum of Anthropology, University of Michigan, No. 9. Ann Arbor: University of Michigan Press, 1939.

Virginia and Maryland. A Treaty held at the Town of Lancaster, ...of Virginia and Maryland, with the Indians of the Six nations, in june, 1744. Philadelphia: Franklin, 1744.

Virginia, Colony of. A Treaty held with the Catawba and Cherokee Indians, at the Catawba-Town and Broad-River, in the Months of February and March 1756. Williamsburg: W. Hunter, 1756.

Walker, Dr. Thomas, William Cabell Rives, ed. Journal of an Exploration in the Spring of the Year 1750. Boston: Little, Brown, and Company, 1888.

Washington, George. Washington's Tour to the Ohio. Old South Leaflets, No. 41. 1770.

William L. McDowell Jr., ed., Colonial Records of South Carolina: Documents Relating to Indian Affairs, 17541765. Columbia, SC: 1970.

Williams, Samuel C., ed. Adair's History of the American Indians. Johnson City, TN: The Watauga Press, 1930.

Williams, Samuel C., ed. Early travels in the Tennessee country, 1540-1800: with introductions, annotations and index. Johnson City, Tenn: Watauga Press, 1928.

Withers, Alexander Scott. Chronicles of Border Warfare: or a History of Settlement by the Whites, of North-western Virginia, and the Indians Wars and Massacres in that section of the state with Reflections, anecdotes, \&c. Cincinnati: The Robert Clarke Company, 1895.

Wraxall, Peter. An Abridgement of Indian Affairs: Contained in four folio volumes, transacted in the colony of New York, from the year 1678 to the year 1751. Cambridge: Harvard University Press, 1915.

Zeisberger, David. Indian Dictionary: English, German, Iroquois-The Onondaga and Algonquin-The Delaware. Cambridge: John Wilson and Son. 1887.

Zeisberger, David. Ziesberger's Diary, 1781-1798. Vol. 2-3 Historical and Philosophical Society of Ohio, 1885. 


\section{Secondary Sources}

Abler, Thomas S. "Beavers and Muskets: Iroquois Military Fortunes in the Face of European Colonization." In War in the Tribal Zone: Expanding States and Indigenous Warfare, edited by R. Brian Ferguson and Neil L. Whitehead, 151-174. Santa Fe: School of American Research Press, 1992.

Abrams, Marc D. and Gregory J. Nowacki. "Native Americans as active and passive promoters of mast and fruit trees in the eastern USA." The Holocene 18:7 (2008): 1123-1137.

Adams, Stephen. The best and worst country in the world: perspectives on the early Virginia landscape. Charlottesville: University Press of Virginia, 2001.

Adelman, Jeremy and Stephen Aron. "From Borderlands to Borders: Empires, Nation-States, and the Peoples in between in North American History." AHR 104:3 (June 1999): 814-841. . "Of Lively Exchanges and Larger Perspectives." AHR 104:4 (Oct. 1999): 1235-1239.

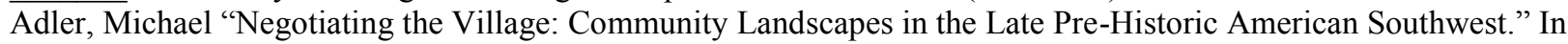
Inscribed Landscapes: Marking and Making Place, edited by Bruno David and Meredith Wilson, 200-218. Honolulu: University of Hawai'i Press, 2002.

Adovasio, J. M., and R. L. Andrews. "Basketry, Cordage and bark Impressions From the Northern Thorn Mound (46Mg78), Monongalia County, West Virginia." WVA 30 (1980): 33-72.

Adovasio, J.M., et al. The Prehistory of the Paintsville Reservoir, Johnson and Morgan Counties. Ethnology Monographs No. 6. Pittsburgh: Department of Anthropology, University of Pittsburgh Press, 1982.

Alden, John R. John Stewart and the Southern Colonial Frontier: A study of Indian Relations, War, Trade and Land Problems in the southern wilderness, 1754-1775. Ann Arbor: University of Michigan, 1944.

Aldrich, Serena R., Charles W. Lafon, Henri D. Grissino-Mayer, Georgina G. DeWeese, and Jennifer A. Hoss. "Three centuries of fire in montane pine-oak stands on a temperate forest landscape." Applied Vegetation Science 13 (2010): 36-46.

Allon, Gal, Athena S. Leoussi, and Anthony D Smith. The Call of the Homeland: Diaspora Nationalisms, Past and Present. Boston: 2010.

Alverson, William S., Donald M. Waller, and Stephen L. Solheim. "Forests Too Deer: Edge Effects in Northern Wisconsin." Conservation Biology 2:4 (December 1988): 348-358.

Ambler, Charles H. A History of Western Virginia, to 1861. Manuscript in WVU West Virginia Collection, Morgantown, WV, 1931.

Anderson, David G. "Climate and Culture Change in Prehistoric and Early Historic Eastern North America." Archaeology of Eastern North America 29 (2001): 143-186.

Anderson, David G., David W. Stahle, and Malcolm K. Cleaveland. "Paleoclimate and the Potential Food Reserves of Mississippian Societies: A Case Study from the Savannah River Valley." American Antiquity 60:2 (April 1995): 258-286.

Anderson, David G., and Steven D. Smith. Archaeology, History, and Predictive Modeling: Research at Fort Polk, 1972-2002. Tuscaloosa: University of Alabama, 2003.

Anderson, Fred. Crucible of War: The Seven Years' War and the Fate of the Empire in British North America, 175466. New York: 1st Vintage Books Edition, 2001.

Applegarth, J. D., et al. “46SU3 Revisited.” Pennsylvania Archaeologist 48:1 (1978, Special Issue): 1-103.

Aquila, Richard. "Down the Warriors Path: The Causes of the Southern Wars of the Iroquois." American Indian Quarterly 4 (August 1978): 211-221.

. The Iroquois Restoration: Iroquois Diplomacy on the Colonial Frontier, 1701-1754. Lincoln: University of Nebraska Press, 1997.

Ashcraft, A. Scott. "Pisgah Phase Palisades: Observations on the Spatial Evolution of Village Perimeters." In Upland Archaeology in the East: Symposium No. 6. Special Publication No. 38, Part 6. USDA, Forest Service, Archaeological Society of Virginia, 1996: 46-72.

Atkinson, George Wesley. History of Kanawha County. Charleston, WV: Office of West Virginia Journal, 1876.

Axtell, James. "At the Water's Edge: Trading in the Sixteenth Century." In After Columbus: Essays in the Ethnohistory of Colonial North America, 144-181. New York: Oxford University Press, 1988.

Baby, Raymond S. "Prehistoric Architecture: A Study of House Types in the Ohio Valley." The Ohio Journal of Science 71:4 (July 1971): 193-198.

Bache, Charles, and Linton Satterwaite, Jr. "The Excavation of Indian Mound at Beech Bottom, West Virginia." Museum Journal 21 (1930): 132-187.

Bailey, Kenneth P. "Christopher Gist and the Trans-Allegheny Frontier: A Phase of the Westward Movement." The Pacific Historical Review 14:1 (Mar. 1945) 45-56. 
Baker, Stanley W. "The Henderson Rocks Site (46-Ta-1): A Preliminary Look at Cultural Perseverance in the Rugged Uplands Region of Northern West Virginia." WVA 32 (Fall 1981): 1-23. . "Early Seventeenth Century Trade Beads from the Upper Ohio Valley." Ohio Archaeologist 36:4 (1986): 21-24. . "Neale's Landing Site Ceramics: A Perspective on the Protohistoric Period from Blennerhassett Island." WVA 40:2 (1988): 40-53.

Baker, Stanley W., and Daniel B. Fowler. "Archaeological Survey of Beech Fork Lake, Wayne and Cabell Counties, West Virginia." Unpublished manuscript, Archaeological section WVGES, Morgantown, WV, 1975.

Baldwin, C. C. Early Indian Migration in Ohio. Tract No. 47, Western Reserve and Ohio Historical Society, 1819. . The Iroquois in Ohio. Tract No. 40, Western Reserve and Ohio Historical Society, 1858.

Bamann, Susan, Robert Kuhn, James Molnar, and Dean Snow. "Iroquoian Archaeology." Annual Review of Anthropology 21 (1992): 435-460.

Barber, Michael B. "Prehistoric man Beyond the Blue Ridge: A Summary." Paper presented at The Blue Ridge Symposium, Roanoke College, February 1980.

. "Seventeenth Century Trade Goods Among the Roanoke River: Three Piedmont and Ridge and Valley Sites." In Upland Archaeology in the East: Symposium No. 6. Special Publication No. 38, Part 6. USDA, Forest Service, Archaeological Society of Virginia, 1996: 210-218. . "Prehistoric Rockshelter Use On Virginia's Appalachian Plateaus: Settlement Patterns, Looting, And Survivability." Archaeology of Eastern North America 33 (2005): 31-49.

Barber, Michael B., and Michael F. Barber. Emergency Excavations at the Sawyer Site (44Rn39), Area B: A Protohistoric Site in Roanoke County, Virginia. Research Report Series No. 14. Richmond: Virginia Department of Historic Resources, 2004.

Barnett, Roland E., and C. L. Paxton. "Notes on Glass and Shell Beads from 46-KA-9 (Marmet)." WVA 7 (July 1955): 31-33.

Barr, Juliana. "Geographies of Power: Mapping Indian Borders in the "Borderlands" of the Early Southwest." $W M Q$ $3^{\text {rd }}$ ser. 68:1 (Jan. 2011): 5-46.

Barth, Frederick. Ethnic Groups and Boundaries: The Social Organization of Culture Difference. London: Allen and Unwin, 1969.

Basso Keith. Wisdom Sits in Places: Landscape and Language among the Western Apache. Albuquerque: University of New Mexico Press, 1996.

Baugh, Timothy G., and Jonathon E. Ericson, eds. Prehistoric Exchange Systems in North America. New York: Plenum Press, 1994.

Bauxar, J Joseph. "Yuchi Ethnoarchaeology. Part I: Some Yuchi Identifications Reconsidered.” Ethnohistory 4:3 (Summer, 1957): 279-301.

Bauxar, J. Joseph. "Yuchi Ethnoarchaeology: Parts II-V.” Ethnohistory 4:4 (Autumn 1957): 369-464.

Beck, Robin A., Jr. "Catawba Coalescence and the Shattering of the Carolina Piedmont, 1540-1675." In Mapping the Mississippian Shatter Zone: The Colonial Indian Slave Trade and Regional Instability in the American South, edited by Robbie Ethridge and Sheri Shuck-Hall, 115-141. Lincoln: University of Nebraska Press, 2009.

Beck, Robin A., Jr., David G. Moore, and Christopher B. Rodning. "Identifying Fort San Juan: A Sixteenth-Century Spanish Occupation At The Berry Site, North Carolina.” Southeastern Archaeology 25:1 (Summer 2006): 65-77.

Becker, Marshall Joseph. "The Stature of a Susquehannock Population of the Mid-Sixteenth Century..." Pennsylvania Archaeologist 61:2 (1991): 73-88. . "An Analysis of Human Skeletal Remains from 46HM73: A Susquehannock Population of the MidSixteenth Century." WVA 39:2 (Fall 1987): 37-53. . "From the Seashore, To the Piedmont, To the Mountains Flecked with Snow: Native American Migrations Across Ecological Zones." In Upland Archaeology in the East: Symposium No. 6. Special Publication No. 38, Part 6. USDA, Forest Service, Archaeological Society of Virginia, 1996: 219-232.

Becker, Mary Druke. "Linking Arms: The Structure of Iroquois Intertribal Diplomacy." in Beyond the Covenant Chain: The Iroquois and Their Neighbors in Indian North America, 1600-1800 edited by Daniel K. Richter, and James H. Merrell, 29-39. University Park, PA: The Pennsylvania State University Press, 1987.

Beisaw, April M. "Memory, Identity, and NAGPRA in the Northeastern United States." American Anthropology 112:2 (2010): 244-256. . "Environmental History of the Susquehanna Valley around the Time of European Contact." Pennsylvania History: A Journal of Mid-Atlantic Studies 79:4 (2012), 366-376. 
Bellemare, Jesse, Glenn Motzkin, and David R. Foster. "Legacies of the Agricultural past in the forested present: an assessment of historical land-use effects on rich mesic forests." Journal of Biogeography 29 (2002): 14011420.

Benthall, Joseph L. Archaeological Investigation of the Shannon Site, Montgomery County, Virginia. Richmond: The Virginia State Library, 1969.

Betts, Colin M. "Pots and Pox: The Identification of Protohistoric Epidemics in the Upper Mississippi Valley." American Antiquity 71:2 (Apr. 2006): 233-259.

Binford, Lewis R. "Comments on the "Siouan Problem"” Ethnohistory 6:1 (Winter 1959): 28-41.

Biolsi, Thomas. "Imagined geographies: Sovereignty, indigenous space, and American Indian struggle." American Ethnologist 32:2 (2005): 239-259.

Bishop, Charles A. "The Emergence of Hunting Territories among the Northern Ojibwa." Ethnology 9:1 (Jan. 1970): $1-15$.

Black, Bryan A., and Marc D. Abrams. "Influences of Native Americans and Surveyor Biases on Metes and Bounds Witness-Tree Distribution." Ecology 82:9 (Sep. 2001): 2574-2586.

Black, Bryan A., Charles M. Ruffner, and Marc D. Abrams. "Native American influences on the forest composition of the Allegheny Plateau, northwest Pennsylvania." Canadian Journal of Forest Resources 36 (2006): 1266-1275.

Blair, Peggy J. Lament For a First Nation: The Williams Treaties of Southern Ontario. Vancouver: University of British Columbia Press, 1955.

Blanton, Dennis B., and Julia A. King, eds. Indian and European contact in context: the Mid-Atlantic Region. Gainesville: University Press of Florida, 2004.

Bloom, Jo Tice. "Cumberland Gap versus South Pass: The East or West in Frontier History." The Western Historical Quarterly 3:2 (Apr. 1972): 153-167.

Boback, John M. "Indian Warfare, Household Competency, and the Settlement of the Western Virginia Frontier, 1749 to 1794." Unpublished PhD Dissertation, West Virginia University, 2007.

Boisvert, Richard A. Kentucky Salt Licks: A Preservation Perspective. Lexington, Ky: Office of State Archaeology, University of Kentucky, 1984.

Booker, Karen M., and Charles M. Hudson, Robert L. Rankin. "Place Name Identification and Multilingualism in the Sixteenth-Century Southeast." Ethnohistory 39:4 (Autumn 1992): 399-451

Boulware, Tyler. Deconstructing the Cherokee Nation: Town, Region, and Nation Among Eighteenth-century Cherokees. Gainesville: University Press of Florida, 2011.

Bourdieu, Pierre. "Structures, habitus, practices." In The logic of practice edited by Pierre Bourdieu, 52-79. Stanford, CA: Stanford University Press, 1990.

Bossy, Denise Ileana. "Shattering Together, Merging Apart: Colonialism, Violence, and the Remaking of the Native South" $W M Q 3^{\text {rd }}$ ser. 71:4 (October 2014): 611-631.

Bowne, Eric E. The Westo Indians: Slave Traders of the Early Colonial South. Tuscaloosa: University of Alabama Press, 2005.

. “"A Bold and Warlike People”: the basis of Westo Power." In Light On The Path: The Anthropology and History of the Southeastern Indians, edited by Thomas J. Pluckhahn, and Robbie Ethridge,123-132. Tuscaloosa: University Of Alabama Press, 2006.

. "“Caryinge awaye their Corne and Children": The Effects of Westo Slave Raids on the Indians of the Lower South." In Mapping the Mississippian Shatter Zone: The Colonial Indian Slave Trade and Regional Instability in the American South edited by Robbie Ethridge and Sheri Shuck-Hall, 104-114. Lincoln: University of Nebraska Press, 2009.

Boyd, C, Clifford, Jr. "Prehistoric and Historic Human Adaptation in Appalachia: An Archaeological Perspective." Journal of Appalachian Studies Association 1 (1989): 15-27. . The Trigg Site (44MY3) and Other Late Woodland/Contact Period Sites Along the New River Valley in Southwest Virginia. Paper presented SEAC Conference, Raliegh, NC, November 1993.

Bradley, Raymond S. Paleoclimatology: Reconstructing Climates of the Quaternary, $2^{\text {nd }}$ ed. San Diego: Harcourt Academic Press, 1999.

Bradley et al. "Climate of the last millennium." In Paleoclimate, Global Change and the future edited by Keith D. Alverson, et al. Springer, 2003: 105-141.

Brain, J. P., and P. Phillips. Shell Gorgets of the Late Prehistoric and Protohistoric Southeast. Cambridge, Ma.: Peabody Museum Press, 1996.

Braley, Dean. Shaman's story: the West Virginia petroglyphs. St. Albans, WV: St. Albans Pub., 1993. 
Brandão, José A. "Ye fyres shall burn no more: Iroquois Policy toward New France and Its Native Allies to 1701. Lincoln: University of Nebraska Press, 1997.

Brandão, J. A., William A. Starna. "The Treaties of 1701: A Triumph of Iroquois Diplomacy." Ethnohistory 43:2 (Spring 1996): 209-244.

Brashler, Janet G., and David M. Reed. "Health and Status on the Eastern Periphery of Fort Ancient." WVA 42:1 (Spring 1990): 36-41.

Brashler, Janet G. and Ronald W. Moxley. "Late Prehistoric Engraved Shell Gorgets of West Virginia." WVA 42:1 (Spring 1990): 1-10.

Braund, Kathryn E. Holland. Deerskins and Duffels: Creek Indian Trade with Anglo-America, 1685-1815. Lincoln: University of Nebraska Press, 1993.

Briceland, Alan V. Westward from Virginia: The Exploration of the Virginia Carolina Frontier, 1650-1710. Charlottesville: University of Virginia Press, 1987. . "Batts and Fallam Explore the Backbone of the Continent." In Appalachian Frontier, edited by Robert D. Mitchell. 1991.

Brooke, John. "Ecology" in A Companion to Colonial America edited by Daniel Vickers, 44-75. Oxford: Blackwell Publishing, 2006.

Brose, David S. "Introduction to Eastern North America at the Dawn of European Colonization." In Societies in Eclipse: Archaeology of the Eastern Woodlands Indians, A. D. 1400-1700 edited by David S. Brose., C. Wesley Cowin, and Robert Mainfort, Jr., 1-7. Washington, D. C.: Smithsonian Institution Press, 2001.

Brose. David S., C. Wesley Cowin and Robert Mainfort, Jr., eds. Societies in Eclipse: Archaeology of the Eastern Woodlands Indians, A. D. 1400-1700. Washington, D. C.: Smithsonian Institution Press, 2001.

Brown, Douglas Summers. The Catawba Indians: The People of the River. Columbia: University of South Carolina Press, 1966.

Brown, Ian W. The Role of Salt in Eastern North American Prehistory. Anthropological Study No. 3. Baton Rouge, LA: Louisiana Archaeological Survey and Antiquities Commission, 1981. . "The Calumet Ceremony in the Southeast and Its Archaeological Manifestations." American Antiquity 54:2 (Apr. 1989): 311-331.

. "The Calumet Ceremony in the Southeast as Observed Archaeologically." In Powhatan's Mantle: Indians in Colonial Southeast edited by Peter H. Wood, Gregory A. Waselkov, and M. Thomas Hatley, 371-420. Lincoln: University of Nebraska Press, 1989.

Brown, Ralph M. "A Sketch of the Early History of South-Western Virginia.” WMQ, 2nd ser. 17:4 (Oct. 1937): 501513.

Broyles, Bettye J. "Kanawha Basin Comprehensive Study, Appendix L: Appraisal of archaeological and historical resources." Report submitted to the NPS, Washington, D.C., 1969.

Bruguier, Leonard R. The Yankton Sioux Tribe: People of the Pipestone, 1634-1888. Oklahoma State University Press, 1993.

Buchanan, William T., Jr. The Trigg Site, City of Radford, Virginia. Special Publication No. 14. Archaeological Society of Virginia, 1986.

Burns, Jonathan Allen. "Prehistoric Rockshelters Of Pennsylvania: Revitalizing Behavioral Interpretation From Archaeological Spatial Data." Unpublished Dissertation. Temple University, 2009.

Bushnell, Amy Turner. "Ruling "the Republic of Indians" in Seventeenth-Century Florida." In Powhatan's Mantle: Indians in Colonial Southeast edited by Peter H. Wood, Gregory A. Waselkov, and M. Thomas Hatley, 195-214. Lincoln: University of Nebraska Press, 1989.

Bushnell, David I., Jr. Native Villages and Village Sites East of the Mississippi. Smithsonian Institution Bureau of American Ethnology Bulletin 69. Government Printing Office, Washington, 1919.

Byers, A. Martin. From Cahokia to Larson to Madisonville: Death, World Renewal, and the Sacred in the Mississippian Social World of the Late Prehistoric Eastern Woodlands. Knoxville: University of Tennessee Libraries, Newfound Press, 2015.

Caldwell, Norman W. "The Southern Frontier During King George's War." The Journal of Southern History 7:1 (Feb. 1941): 37-54.

Callender, Charles. "Shawnee." In Handbook of North American Indians. Volume 15. Northeast, edited by William C. Sturtevant, and Bruce G Trigger, 622-635. Washington, D.C.: Smithsonian Institution, 1978.

Calloway, Colin G. "'We Have Always Been the Frontier': The American Revolution in Shawnee Country." American Indian Quarterly 16:1 (Winter 1992): 39-52. . New Worlds for All: Indians, Europeans, and the Remaking of Early America. Baltimore: Johns Hopkins University Press, 1997. 
Campbell, Lyle. "Areal linguistics.” Encyclopedia of Language and Lingustics. $2^{\text {nd }}$ ed. edited by Keith Brown. Oxford: Elsevier, 2006.

Campbell, William J. “An Adverse Patron: Land, Trade, And George Croghan.” Pennsylvania History 76:2 (Spring 2009): 117-140.

Carlos, Ann M., and Frank D. Lewis. "Indians, the Beaver, and the Bay: The Economics of Depletion in the Lands of the Hudson's Bay Company, 1700-1763.” The Journal of Economic History 53:3 (Sept. 1993): 465-494.

Carnes, Linda F. "Historic Artifacts." In Archaeology of the Historic Occaneechi Indians, edited by H. Trawick Ward and R. P. Stephen Davis, Jr. Southern Indian Studies 36-37 (Oct. 1988): 64-75.

Carocci, Max, and Stephanie Pratt. "Introduction: Contextualizing Native American Adoption, Captivity, and Slavery." In Native American Adoption, Captivity, and Slavery in Changing Contexts, edited by Max Caroccii and Stephanie Pratt, 1-22. New York: Palgrave MacMillan, 2012.

Carpenter, Charles. "West Virginia Buffalo Trails." West Virginia Review 8 (1931): 332-333, 348. . "Early maps of West Virginia territory." West Virginia Review 9 (1931): 152-153, 176. . "Prehistoric Stone and Earth Works in West Virginia." West Virginia Review 9:6 (March 1932): 274$275,280$.

Carr, Christopher, and Herbert Haas. "Beta-Count and AMS Radiocarbon Dates: Woodland and Fort Ancient Period Occupations in Ohio 1350 B.C. - A.D. 1650.” WVA 48:1-2 (Spring/Fall 1996): 19-53.

Carr, Christopher, and Robert F. Maslowski. "Cordage and Fabrics: Relating Form, Technology, and Social Processes." In Style, Society, and Person: Archaeological and Ethnological Perspectives, edited by Christopher Carr and Jill E. Neitzel, 297-343. New York: Plenum Press, 1995.

Carson, James Taylor. "Native Americans, the Market Revolution, and Culture Change: The Choctaw Cattle Economy, 1690-1830." Agricultural History 71:1 (Winter 1997): 1-18. . "Ethnogeography and the Native American Past." Ethnohistory 49:4 (Autumn 2002): 769-788. . "Teaching Amerindian Autohistory." American Indian Quarterly 27:1/2, Special Issue: Native Experiences in the Ivory Tower (Winter - Spring 2003): 155-159. . "American Historians and Indians." The Historical Journal 49:3 (Sep. 2006): 921-933. . Making an Atlantic world: circles, paths, and stories from the colonial South. Knoxville: University of Tennessee Press, 2007.

Caruso, John A. The Appalachian frontier: America's first surge westward. Knoxville: University of Tennessee Press, 2003.

Castle, R. Woodrow. "Batts and Fallam and the Kanawha." West Virginia History 3:4 (1942).

Cayton, Andrew R. L. "Land, Power, and Reputation: The Cultural Dimension of Politics in the Ohio Country." $W M Q$, 3rd ser. 47:2 (Apr. 1990): 266-286.

Cayton, Andrew R.L., and Fredrika J. Teute. "Introduction: On the Connection of Frontiers." In Contact Points: American Frontiers from the Mohawk Valley to the Mississippi, 1750-1830, edited by R.L. Andrew Cayton, and Fredrika J. Teute, 1-15. Chapel Hill: University of North Carolina Press, 1998.

Chafe, Wallace L. The Caddoan, Iroquoian and Siouan languages. The Hague: Mouton, 1976.

Chamberlain, Andrew T. Demography in archaeology, Cambridge Manuals in Archaeology. New York: Cambridge University Press, 2006.

Chambers, Ian. "Spatial Personas: A New Technique for Interpreting Colonial Encounters in Colonial North America." History Compass 6/4 (2008): 1164-1172.

Clark, Jerry E. "Shawnee Indian Migration: A Systems Analysis." Ph.D. Dissertation, University of Kentucky, 1974. . The Shawnee. Lexington, KY: University Press of Kentucky, 1993.

Clay, R. Berle, and Steven D. Creasman. "Middle Ohio Valley Late Woodland Nucleated Settlements: "Where's the Beef."' WVA 51:1-2 (Spring/Fall 1999): 1-10.

Clayton, Lawrence, Vernon James Knight Jr., and Edward C. Moore. De Soto Chronicles: Hernando de Soto to North America in 1539-1543. Tuscaloosa: University of Alabama Press, 1993.

Clifford, James. "Diasporas." Cultural Anthropology, Further Inflections: Toward Ethnographies of the Future 9:3 (Aug. 1994): 302-338.

Cobb, Charles R. "Archaeology and the "Savage Slot": Displacement and Emplacement in the Premodern World." American Anthropologist, New Series 107:4 (Dec. 2005): 563-574.

Cobb, Charles R., and Brian M. Butler. "The Vacant Quarter Revisited: Late Mississippian Abandonment of the Lower Ohio Valley." American Antiquity 67:4 (Oct. 2002): 625-641.

Coe, J. L. "Formative Cultures of the Carolina Piedmont." American Philosophical Society, Transactions, 54:5 (1964). 
Cohen, Robin. "Solid, ductile and liquid: changing notions of homeland and home in diaspora studies." QEH Working Paper Series: Working Paper Number 156, October 2007.

Cook, Edward R., David M. Meko, David W. Stahle, and Malcolm K. Cleaveland. "Drought Reconstructions for the Continental United States." Journal of Climate 12 (April 1999): 1145-1162

Cook, Edward R., et al. "North American Summer PDSI Reconstructions." IGBP PAGES/World Data Center for Paleoclimatology Data Contribution Series \# 2004-045. NOAA/NGDC Paleoclimatology Program, Boulder CO, USA. At ftp://ftp.ncdc.noaa.gov/pub/data/paleo/drought/pdsi2004/readme-pdsi-na2004.txt accessed 01/10/2011 11:30am.

Core, Earl L. "Ethnobotany of the Southern Appalachian aborigines." Economic Botany 21:3 (1967): 198-214.

Corkran, David H. The Cherokee Frontier: Conflict and Survival, 1740-62. Norman: University of Oklahoma Press, 1962.

. The Creek Frontier 1540-1783. Norman: University of Oklahoma Press, 1967.

$\overline{\text { Cowan, }}$ C. Wesley. From Foraging to Incipient Food Production: Subsistence Change and Continuity on the Cumberland Plateau of Eastern Kentucky. Vol. 1. Dissertation, University of Michigan, 1985.

. First Farmers of the Middle Ohio Valley: Fort Ancient Societies, A.D. 1000-1670. Cincinnati, Oh.: Cincinnati Museum of Natural History, 1987.

Crane, Verner W. The Southern Frontier: 1670-1732. Ann Arbor: Ann Arbor Paperbacks, 1964.

Crawford, B. Scott. "A Frontier of Fear: Terrorism and Social Tension along Virginia's Western Waters, 17421775." West Virginia History New Series, 2:2 (Fall 2008): 1-29.

Crawford, Rachel J. "Analysis Of Prehistoric Burials At The Snidow Site (46mc1), Mercer County, West Virginia." Unpublished Thesis. Marshall University, 2007.

Cronon, William. Changes in the land: Indians, colonists, and the ecology of New England. New York: Hill and Wang, 1983.

Crosby, Alfred W. "Virgin Soil Epidemics as a Factor in the Aboriginal Depopulation in America." WMQ 3rd Ser. 33:2. (Apr. 1976): 289-299.

Crumley, Carole L. "The Ecology of Conquest: Contrasting Agropastoral and Agricultural Societies' Adaptation to Climatic Change" in Historical Ecology: Cultural Knowledge and Changing Landscapes, edited by Carole L. Crumley, 183-202. Santa Fe: School of American Research Press, 1994.

Cumming, William Patterson. "Geographical Misconceptions of the Southeast in the Cartography of the Seventeenth and Eighteenth Centuries." The Journal of Southern History 4:4 (Nov. 1938): 476-492.

Custer, Jay F. "A Controlled Comparison of Late Woodland Settlement Patterns in the Appalachian Highlands." In Upland Archaeology in the East: Symposium No. 2. Special Publication No. 38, Part 2. USDA, Forest Service, Archaeological Society of Virginia, 1984: 75-101.

Dailey, Mark. "Cultural models of forests and ecological change on the Appalachian Plateau, 1750-1840." PhD diss., University of Georgia, 1999.

David, Bruno, and Meredith Wilson, eds. Inscribed Landscapes: Marking and Making Place. Honolulu: University of Hawai'I Press, 2002.

Davis, Donald Edward. Where there are Mountains: An Environmental History of the Southern Appalachians. Athens: University of Georgia Press, 2000.

Davis, R. P. Stephen, Jr. "The Tuscarora Migration and Evidence for the Tuscarora Near Martinsburg, Berkeley County, West Virginia." WVA 27 (1978): 1-15. . "Pottery." In Archaeology of the Historic Occaneechi Indians, edited by H. Trawick Ward and R. P.

Stephen Davis, Jr. Southern Indian Studies 36-37 (Oct. 1988): 31-63. . "The Evolution of Siouan Communities in Piedmont North Carolina." Southeastern Archaeology 10 (1991): 40-53.

Day, Gordon M. "The Indian as an Ecological Factor in the Northeastern Forest." Ecology 34 (1953): 329-46.

deBoer, Warren R. "Subterranean Storage and the Organization of Surplus: The View from Eastern North America." Southeastern Archaeology 7:1 (1988): 1-20.

Delcourt, Paul A., and Hazel R. Delcourt. "The Influence of Prehistoric Human-Set Fires on Oak-Chestnut Forests in the Southern Appalachians." Castanea 63:3 (Sep. 1998): 337-345. . Prehistoric Native Americans and Ecological Change. Cambridge: Cambridge University Press, 2004.

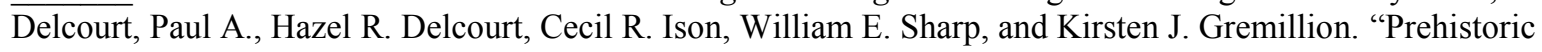
Human use of fire, the Eastern Agricultural Complex, and Appalachian Oak-Chestnut Forests: Paleoecology of Cliff Palace Pond, Kentucky." American Antiquity 63:2 (Apr. 1998): 263-278.

Deloria, Vine, Jr. "Ethnoscience and Indian realities." Winds of Change 7:3 (1992): 12-18. 
Demallie, Raymond J. "Tutelo and Neighboring Groups." In Southeast, Volume 14, Handbook of North American Indians, edited by William C. Sturtevant, 286-300. Smithsonian Institution, Washington, D.C., 2004.

Demeritt, David. "Agriculture, Climate, and Cultural Adaptation in the Prehistoric Northeast." Archaeology of Eastern North America 19 (1991): 183-202.

Denevan, William M. "The Pristine Myth: The Landscape of the Americas in 1492." Annals of the Association of American Geographers 82:3, The Americas before and after 1492: Current Geographical Research (Sep. 1992): 369-385.

Dennis, Matthew. Cultivating a Landscape of Peace: Iroquois-European Encounters in Seventeenth-Century America. Ithaca: Cornell University Press, 1993.

DePratter, Chester, Charles Hudson, and Marvin Smith. "Juan Pardo's Explorations in the Interior Southeast, 15661568." The Florida Historical Quarterly 62 (1983):125-158.

Diaz, Henry F., and David W. Stahle. "Climate and cultural history in the Americas: An overview." Climatic Change 83 (2007): 1-8.

Dickens, Roy S. "The Appalachian Summits Area A.D. 1000 to Bartram." Unpublished manuscript at VDHR. nd. "Mississippian Settlement Patterns in the Appalachian Summit Area: The Pisgah and Qualla Phases." In Mississippian Settlement Patterns, edited by Bruce D. Smith, 115-39. New York: Academic Press, 1978.

Dickens, Roy S., Jr., H. Trawick Ward, and R. P. Stephen Davis, Jr., eds. The Historic Occaneechi: An Archaeological Investigation Of Culture Change Final Report Of 1985 Investigations. Research Report No. 4. Research Laboratories of Anthropology, The University of North Carolina at Chapel Hill, May 15, 1986.

Dieterich-Ward, Allen. "The Changing Nature of Environmental History: An Interview Joel A. Tarr." Pennsylvania History: A Journal of Mid-Atlantic Studies 79:4 (2012): 331-344.

Dixon, Heriberto. "A Saponi by Any Other Name Is Still a Siouan.” American Indian Culture and Research Journal 26:3 (2002) 65-84.

Dobyns, Henry F. Their Number Become Thinned: Native American Population Dynamics in Eastern North America. Knoxville: University of Tennessee Press, 1983.

Dodge, Jacob R. Red Men of the Ohio Valley, An Aboriginal History of the Period Commencing A.D. 1650 and Ending at the Treaty of Grenville, A.D. 1795. Springfield, Ohio: Ruralist Publishing Co., 1860.

Dorsey, J. Owen. "Siouan Sociology: A Posthumous Paper." Fifteenth Annual Report of the Bureau of Ethnology to the Secretary of the Smithsonian Institution, 1893-1894, Government Printing Office, Washington, 1897. $1^{\text {st }}$ edition, ([1897] 2006): 205-244. Project Gutenberg EBook.

Dowd, Gregory Evans. "The Panic of 1751: The Significance of Rumors on the South Carolina- Cherokee Frontier." $W M Q$ 3rd ser. 53:3 Indians and Others in Early America (July 1996): 527-560.

Downes, Randolph C. Council Fires on the Upper Ohio: A Narrative of Indian Affairs in the Upper Ohio Valley until 1795. Pittsburgh: University of Pittsburgh Press, 1940.

Drooker, Penelope B. "Madisonville Metal and Glass Artifacts: Implications for Western Fort Ancient Chronology and Interaction." Midcontinental Journal of Archaeology, MCJA 21 (1996): 145-190.

. The View from Madisonville: Protohistoric Fort Ancient Interaction Patterns. Ann Arbor: Memoirs of the Museum of Anthropology, University of Michigan, No. 31, 1997.

“Approaching Fabrics Through Impressions On Pottery.” Unpublished manuscript. 2001.

"The Ohio Valley, 1550-1750: Patterns of Sociopolitical Coalescence and Dispersal." In The

Transformation of the Southeastern Indians, 1540-1760, edited by Robbie Ethridge, and Charles Hudson, 115-134. Jackson, MS: University Press of Mississippi, 2002.

Drooker, Penelope B., and C. Wesley Cowan. "Transformation of the Fort Ancient Cultures of the Central Ohio Valley." In Societies in Eclipse: Archaeology of the Eastern Woodlands Indians, A. D. 1400-1700 edited by David S. Brose, C. Wesley Cowin, and Robert Mainfort, Jr., 83-106. Washington, D. C.: Smithsonian Institution Press, 2001.

Dunnell, Robert C., Lee H. Hanson, and Donald L. Hardesty. "The Woodside Component of the Slone Site, Pike County, Kentucky.” Southeastern Archaeological Conference, Bulletin n. 14. Morgantown, 1971.

Durrett, S. F. "Artifacts from an Obliterated Site (46-Cb-10) in Huntington." WVA 5 (March 1952): 22-23.

Dye, David H. "Warfare in the Protohistoric Southeast: 1500-1700. In Between contacts and colonies: archaeological perspectives on the protohistoric Southeast, edited by Cameron B. Wesson, and Mark A. Rees, 126-141. Tuscaloosa: University of Alabama Press, 2002.

Dyer, James M. "Using witness trees to assess forest change in southeastern Ohio." Canadian Journal of Forest Resources 31 (2001): 1708-1718.

. "Land-use legacies in a central Appalachian forest: differential response of trees and herbs to historic agricultural practices." Applied Vegetation Science 13 (2010): 195-206. 
Eastman, Jane M. “The North Carolina Radiocarbon Date Study, Part 1.” Southern Indian Studies 42 (Oct. 1994): 167.

. "The North Carolina Radiocarbon Date Study, Part 2." Southern Indian Studies 43 (Oct. 1994): 1-121.

Eccles, W. J. "The Fur Trade and Eighteenth-Century Imperialism." The William and Mary Quarterly, 3rd. Ser. 40:3 (July 1983): 341-362.

Echo-Hawk, Roger C. "Ancient History in the New World: Integrating Oral Traditions and the Archaeological Record in Deep Time." American Antiquity 65:2 (Apr. 2000): 267-290.

Edwards, Brent Hayes. The Practice of Diaspora: Literature, Translation, and the Rise of Black Internationalism. Cambridge: Harvard University Press, 2003.

Eggan, Fred R. "The Ethnological Cultures and their Archaeology Backgrounds." In Archaeology of Eastern United States, edited by James B. Griffin, 35-45. Chicago: University of Chicago Press, 1952.

Egloff, Keith T. Ceramic Study of Woodland Occupation along the Clinch and Powell Rivers in Southwest Virginia. Virginia Division of Historic Landmarks, Research Report Series 3, Richmond, 1987. . "The Late Woodland Period in Southwestern Virginia." In Middle and Late Woodland Research in Virginia: A Synthesis, edited by Theodore R. Reinhart and Mary Ellen N. Hodges, 187-223. 1992.

Elmendorf, William W. "Item and Set Comparison in Yuchi, Siouan, and Yukian." International Journal of American Linguistics 30:4 (Oct. 1964): 328-340

Elmendorf, William W. "Yukian-Siouan Lexical Similarities." International Journal of American Linguistics 29:4 (Oct. 1963): 300-309.

Ely, William. The Big Sandy Valley, History of the People and Country, from the Earliest Settlement to the Present Time. Catlettsburg, Ky: Central Methodist Press, 1887.

Emerson, Thomas E., and Eve Hargrave. "Strangers In Paradise? Recognizing Ethnic Mortuary Diversity On The Fringes Of Cahokia." Southeastern Archaeology 19:1 (Summer 2000): 1-23.

Emrick, Isaac J. “The Monyton Diaspora: A History of the Middle Ohio River Valley, 1640-1700.” Unpublished master's thesis, West Virginia University, 2005.

Engelbrecht, William. Iroquoia: The development of a Native world. Syracuse, NY: Syracuse University Press, 2003.

Esarey, Duane. "Seasonal Occupation Patterns in Illinois History: A Case Study in the Lower Illinois River Valley." Illinois Archaeology: Journal of the Illinois Archaeological Survey 9:1-2 (1997): 164-219. . "Colonialism Before Contact: Interrogating theoretical limitations of contact period archaeology." Unpublished paper. SEAC 2008.

Essington, Joseph H. “Early Inhabitants of the Ohio Valley.” West Virginia History 13 (1952): 277-285.

Ethridge, Robbie. "Creating the shatter zone: Indian slave traders and the collapse of the southeastern chiefdoms." In Light On The Path: The Anthropology and History of the Southeastern Indians edited by Thomas J. Pluckhahn, and Robbie Ethridge, 207-218.Tuscaloosa: University Of Alabama Press, 2006. . "Introduction: Mapping the Mississippian Shatter Zone." In Mapping the Mississippian Shatter Zone: The Colonial Indian Slave Trade and Regional Instability in the American South edited by Robbie Ethridge and Sheri Shuck-Hall, 1-62. Lincoln: University of Nebraska Press, 2009. . "Afterword: Some Thoughts on Further Work." In Mapping the Mississippian Shatter Zone: The Colonial Indian Slave Trade and Regional Instability in the American South edited by Robbie Ethridge and Sheri Shuck-Hall, 418-424. Lincoln: University of Nebraska Press, 2009.

. From Chicaza to Chickasaw: The European Invasion and the Transformation of the Mississippian World, 1540-1715. Chapel Hill: University of North Carolina Press, 2010.

. "The Emergence of the Colonial South: Colonial Indian Slaving, the Fall of the Precontact Mississippian World, and the Emergence of a New Social Geography in the American South, 1540-1730" in Native American Adoption, Captivity, and Slavery in Changing Contexts edited by Max Caroccii and Stephanie Pratt, 47-64. New York: Palgrave MacMillan, 2012.

Ethridge, Robbie, and Charles Hudson, eds. The Transformation of the Southeastern Indians, 1540-1760. Jackson, MS: University Press of Mississippi, 2002.

Ethridge, Robbie, and Sheri Shuck-Hall, eds. Mapping the Mississippian Shatter Zone: The Colonial Indian Slave Trade and Regional Instability in the American South. Lincoln: University of Nebraska Press, 2009.

Fagan, Brian M. The Little Ice Age: how climate made history, 1300-1850. Basic Books, NY, 2002.

Everett, C. S. ““'They shalbe slaves for their lives” Indian Slavery in Colonial Virginia”, In Indian Slavery in Colonial America, edited by Alan Gallay, 67-108. Lincoln: University of Nebraska Press, 2009.

Ferguson, R. Brian and Neil L. Whitehead, eds. War in the Tribal Zone: Expanding States and Indigenous Warfare. Santa Fe: School of American Research Press, 1992. 
. "Preface." In War in the Tribal Zone: Expanding States and Indigenous Warfare, edited by R. Brian Ferguson and Neil L. Whitehead, xi-xiv. Santa Fe: School of American Research Press, 1992.

. "The Violent Edge of Empire." In War in the Tribal Zone: Expanding States and Indigenous Warfare edited by R. Brian Ferguson and Neil L. Whitehead, 1-30. Santa Fe: School of American Research Press, 1992.

Feit, H. "The ethno-ecology of the Waswanipi Cree or how hunters can manage their resources." In Cultural Ecology: Readings on the Canadian Indians and Eskimos edited by B. Cox, 115-125. Toronto: McCleeand and Stewart, 1973.

Fernow, Berthold. The Ohio Valley in Colonial days. New York: J. Munsell's Sons, Reprint, New York: Burt Franklin, (1890) 1971.

Fiedel, Stuart J. “Correlating Archaeology and Linguistics: The Algonquian Case.” Man in the Northeast 41 (Spring 1991): 9-32.

Filson, John, and Paul Royster, ed. The Discovery, Settlement and Present State of Kentucke (1784): An Online Electronic Text Edition. Electronic Texts in American Studies, University of Nebraska - Lincoln, 2006.

Findlow, Frank J. and Jonathon E. Ericson, eds. Catchment analysis: essays on prehistoric resource space. Los Angeles: Dept. of Anthropology, University of California, 1980.

Fitts, Mary E. "Mapping Catawba Coalescence." North Carolina Archaeology 55 (October 2006): 1-59.

Fitts, Mary Beth, Brett H. Riggs, and R. P. Stephen Davis, Jr. Summary Report Of 2007 Archaeological Investigations At Catawba Nassaw Town (38yk434), York County, South Carolina. Research Report No. 27. Research Laboratories of Archaeology, University of North Carolina at Chapel Hill, December 2007.

Fitzhugh, William, ed. Cultures in Contact: The Impacts of European Contacts on Native American Cultural Institutions, A . D. 100-1800. Washington, D.C.: Smithsonian Institution Press, 1985.

Fogelman, Gary L. Glass Trade Beads in the Northeast and Including Aboriginal Beads Industries. The Pennsylvania Artifact Series, Booklet 70, 1991.

Fosberg, F. R. "Geography, Ecology, and Biogeography." Annals of the Association of American Geographers 66:1 (Mar. 1976): 117-128.

Foster, H. Thomas, II. Archaeology of the Lower Muskogee Creek Indians, 1715-1836. Tuscaloosa: University of Alabama Press, 2007.

. "Evidence Of Historic Creek Indian Migration From A Regional And Direct Historic Analysis Of Ceramic Types." Southeastern Archaeology 23:1 (Summer 2004): 65-84.

Foster, H. Thomas, II, Bryan Black, Marc D. Abrams. "A Witness Tree Analysis of the Effects of Native American Indians on the Pre-European Settlement Forests in East-Central Alabama.” Human Ecology 32:1 (Feb. 2004): 27-47.

Foster, Michael K. "Language and the Culture History of North America." In Handbook of North American Indians, Volume 17: Languages, edited by William C. Sturtevant, 64-116. Government Printing Office, 1978.

Foster, William C. Climate and Culture Change in North America AD 900 to 1600. Austin: University of Texas Press, 2012.

Fowkes, Gerard. Archaeological History of Ohio: The Mound Builders and Later Indians. Columbus: Ohio State Archaeological and Historical Society, Fred J. Heer, 1902.

Fowler, Daniel B. "The Sheppard Gorget.” WVA 29 (1980) 42-45.

Fowler, Daniel B. “An Old Shawnee Town in West Virginia.” WVA 28 (1979): 24-29.

Fox, William A. "Events as Seen from the North: The Iroquois and Colonial Slavery." In Mapping the Mississippian Shatter Zone: The Colonial Indian Slave Trade and Regional Instability in the American South, edited by Robbie Ethridge and Sheri Shuck-Hall, 63-80.. Lincoln: University of Nebraska Press, 2009.

Frachtenberg, Leo J. “Contributions to a Tutelo Vocabulary.” American Anthropologist, New Series, 15:3 (Jul. Sep. 1913): 477-479.

Frachtenberg, Leo J., and John Dyneley Prince. Contributions to a Tutelo vocabulary. New York, 1913.

Fraterrigo, Jennifer M., Monica G. Turner, and Scott M. Pearson. "Previous land use alters plant allocation and growth in forest herbs." Journal of Ecology 94 (2006): 548-557.

Frank, Andrew K. Creeks \& Southerners: Biculturalism on the Early American Frontier. Lincoln: University of Nebraska Press, 2005.

Franklin, W. Neil. "Pennsylvania-Virginia Rivalry for the Indian Trade of the Ohio Valley." The Mississippi Valley Historical Review 20:4 (Mar. 1934): 463-480.

Fritts, Harold C. Reconstructing Large-Scale Climatic Patterns form Tree-Ring Data: A Diagnostic Analysis. Tucson: University of Arizona Press, 1991. 
Fuerst, David N. “Agricultural Intensification and Nucleation in the Lower New River Region.” Unpublished manuscript at VDHR, 2002.

Fuerst, David N. "Lower New River Chert Sources.” Unpublished manuscript. New River Gorge National River, 2002.

Fuerst, David N. "Communalism among the late Prehistoric-Protohistoric Intermontane and Monongahela culture." Archaeology of Eastern North America 33 (2005): 1-30.

. "On the Bluestone Phase of Southern West Virginia." Paper presented at the New River Symposium, Radford University, Virginia, June 1, 2007.

. "A Brief Retrospective on New River Series Pottery." Paper Presented to the Annual Meeting of the Archaeological Society of Virginia, Williamsburg, Virginia, October 13, 2007. . "Late Woodland Crab Orchard Series Pottery." Paper Presented to the 65th Annual Meeting of the Southeastern Archeological Conference, Charlotte, NC, November 13, 2008.

Furstenberg, Francois. "The Significance of the Trans-Appalachian Frontier in Atlantic History." AHR 113:3 (June 2008): 647-677.

Gallay, Alan. The Indian Slave Trade: The Rise of the English Empire in the American South, 1670-1717. New Haven: Yale University Press, 2002. . "Introduction." In Indian Slavery in Colonial America, edited by Alan Gallay, 1-32. Lincoln: University of Nebraska Press, 2009.

Galloway, Patricia K. Choctaw Genesis 1500-1700. Lincoln: University of Nebraska Press, 1995. . "Colonial Period Transformations in the Mississippi Valley: Disintegration, Alliance, Confederation, Playoff." In The Transformation of the Southeastern Indians, 1540-1760, edited by Robbie Ethridge, and Charles Hudson, 225-248. Jackson, MS: University Press of Mississippi, 2002. . Practicing Ethnohistory: Mining Archives, Hearing Testimony, Constructing Narrative. Lincoln: University of Nebraska Press, 2006.

Gardner, William M. "External Cultural Influences in the Western Middle Atlantic: A Neo-Diffusionist Approach or You Never Know What Went on Under the Rhododendron Bush Until You Look." In Upland Archaeology in the East. Symposium 2. Cultural Resources Report No. 5. June 1984: 118-141.

Gatschet, Albert S. A Migration Legend of the Creek Indians, with a Linguistic, Historic and Ethnographic Introduction. Vol. 1. Philadelphia: D. G. Brinton, 1884. . "The Yuchi Tribe of Indians, and Its Language." Science 5:112 (Mar. 27, 1885): 253. . "Some Mythic Stories of the Yuchi Indians." American Anthropologist, 6:3 (Jul. 1893): 279-282. . "Grammatic Sketch of the Catawba Language." American Anthropologist, New Series, 2:3 (Jul.-Sep., 1900): 527-549.

Geier, Clarence R. "Preliminary Observations on Aboriginal Settlement on Headwaters Streams of the James River; The Ridge and Valley Province of Virginia." In Upland Archaeology in the East: A Symposium, edited by Clarence R. Geier, Michael B. Barber, and George A. Tolley, 225-246. Harrisonburg, VA, 1981. . "Protohistoric Settlement in the Central Ridge and Valley Province Region of Western Virginia." In Upland Archaeology in the East. Symposium 2. Cultural Resources Report No. 5. June 1984: 166-177.

Genheimer, R.A. Cultures before Contact: The Late Prehistory of Ohio and the surrounding Regions. Columbus: Ohio Archaeological Council. 2000.

Given, Brian. A Pernicious Thing: Gun Trading and Native Warfare in the Early Contact period. Ottawa: Carlton University Press, 1994.

Glanville, Jim. "Unknown Holstonia: Southwest Virginia Before the Settling of Jamestown.” Unpublished paper from Second Virginia Forum on History, Library of Virginia, Richmond. April 14, 2007. . "Aboriginal and Remnant American Indians of Holstonia." Redbone Chronicles II:1 (March 2008): 20-52. . "Engraved Marine Shell Gorgets: A Review." Unpublished manuscript, 2010.

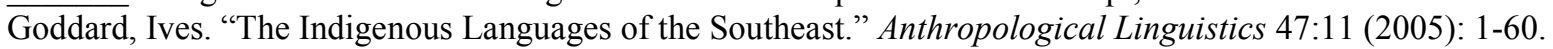
Gold, Debra L. The Bioarchaeology of Virginia Burial Mounds. Tuscaloosa: University of Alabama Press, 2004.

Goodman, Alan H., and Debra L. Martin. "Reconstructing Health Profiles from Skeletal Remains." In The Backbone of History: Health and Nutrition in the Western Hemisphere, edited by Richard H. Steckel, and Jerome C. Rose. Cambridge University Press, 2008: 11-60.

Gramly, Richard Michael. "Deerskins and Hunting Territories: Competition for a Scarce Resource of the Northeastern Woodlands." American Antiquity 42:4 (Oct. 1977): 601-605.

Graybill, Jeffrey R. "Carbonized Corn from the Roseberry Farm Site.” WVA 28 (1979): 50-53. . "The Eastern Periphery of Fort Ancient (A.D. 1050-1650): A Diachronic Approach to Settlement Variation." Ph.D. Dissertation, University of Washington, Seattle, 1981. 
. "The Eastern Periphery of Fort Ancient." Pennsylvania Archaeologist 54 (1984): 40-50.

. "Graybill: Late Prehistoric Study Unit." Unpublished manuscript on file at the West Virginia State Historic Preservation Office, Charleston, 1988.

Greenlee, Diana M. "Dietary Variation and Prehistoric Maize Farming in the Middle Ohio Valley." In Histories of Maize: Multidisciplinary Approaches to the Prehistory, Linguistics, Biogeography, Domestication, and Evolution of Maize, edited by John E. Staller, Robert H. Tykot, and Bruce F. Benz, 215-233. Academic Press, 2006.

Gregory, Ian N. A Place in History: A Guide to Using GIS in Historical Research. Oxford: Oxbow Books, 2003.

Gregory, Ian N., and Paul S. Ell. Historical GIS: Technologies, Methodologies and Scholarship. Cambridge: Cambridge University Press, 2007.

Gremillion, Kristen Johnson. "Plant Remains." In Archaeology of the Historic Occaneechi Indians, edited by H. Trawick Ward and R. P. Stephen Davis, Jr. Southern Indian Studies 36-37 (Oct. 1988): 95-117. . "Human Ecology at the Edge of History." In Between contacts and colonies: archaeological perspectives on the protohistoric Southeast, edited by Cameron B. Wesson, and Mark A. Rees, 12-31. Tuscaloosa: University of Alabama Press, 2002.

. "The Role of Plants in Southeastern Subsistence Economies" In The Subsistence Economies of Indigenous North American Societies: A Handbook, edited by Bruce D. Smith, 387-400. Washington, DC: Smithsonian Institution Scholarly Press, 2011.

Gremillion, Kristen J., and Kristin D. Sobolik. "Dietary Variability among Prehistoric Forager-Farmers of Eastern North America." Current Anthropology 37:3 (June 1996): 529-539.

Griffin, James B. "The Chronological position and ethnographical relationships of the Fort Ancient aspect." American Antiquity 2 (1937): 273-276.

. "On the Historic Location of the Tutelo and the Mohetan in the Ohio Valley." American Anthropologist, New Series 44:2 (Apr.-Jun. 1942): 275-280.

. "The Fort Ancient Aspect: Its cultural and Chronological position in Mississippi Valley Archaeology." University of Michigan, Museum of Anthropology, Anthropological Papers. n. 28, Ann Arbor, 1943. . "The De Luna Expedition and the 'Buzzard Cult' in the Southeast." Journal of the Washington Academy of Science. Menasha: 34:9 (1944): 299-303.

. "An Interpretation of Siouan Archaeology in the Piedmont of North Carolina and Virginia." American Antiquity 10:4 (Apr. 1945): 321-330.

. "Culture Periods in Eastern United States Archaeology." In Archaeology of Eastern United States edited by James B. Griffin, 352-368. Chicago: University of Chicago Press: 1952.

. "An Interpretation of the Place of Spiro in Southeastern Archaeology" In The Spiro Mound, edited by H. W. Hamilton. Missouri Archaeologist 14 (1952), 89-106.

. "Fort Ancient Has No Class: The Absence of an Elite Group in Mississippian Societies in the Central Ohio Valley." Archaeological Papers of the American Anthropological Association. 3:1 (January 1992):53-59.

Guilday, John E. Biological and archeological analysis of bones from a 17th century Indian village (46 PU 31), Putnam County, West Virginia. Morgantown, West Virginia Geological and Economic Survey, 1971.

Guilday, John E., and Donald P. Tanner. "Vertebrate remains from the Mount Carbon Site, (46-Fa-7), Fayette County, West Virginia." WVA 18 (July 1985): 1-14.

Gumperz, John J. “Types of Linguistic Communities.” Anthropological Linguistics 35:1/4, A Retrospective of the Journal Anthropological Linguistics: Selected Papers, 1959-1985 (1993): 130-142.

Gunderson, Lance, and C. S. Holling. Panarchy: Understanding Transformations in Systems of Humans and Nature. Island Press, 2001.

Gutié rez, Ramón A. When Jesus came, the Corn Mothers went away: marriage, sexuality, and power in New Mexico, 1500-1846. Stanford University Press, 1991.

Guyette, Richard P., Daniel C. Dey, and Michael C. Stambaugh. "Fire and Human History of a Barren-Forest Mosaic in Southern Indiana." American Midland Naturalist 149:1 (Jan. 2003): 21-34.

Haan, Richard L. "Covenant and Consensus: Iroquois and English, 1676-1760." In Beyond the Covenant Chain: The Iroquois and Their Neighbors in Indian North America, 1600-1800 edited by Daniel K. Richter, and James H. Merrell, 41-57. University Park, PA: The Pennsylvania State University Press, 1987.

Haefeli, Evan. "A Note on the Use of North American Borderlands." The American Historical Review 104:4. (Oct. 1999): 1222-1225.

Hagedorn, Nancy L. “'A Friend to go between Them': The Interpreter as Cultural Broker during Anglo-Iroquois Councils, 1740-70." Ethnohistory 35:1 (Winter 1988): 60-80.

Hahn, Steven C. The Invention of the Creek Nation, 1670-1763. Lincoln: University of Nebraska Press, 2004. 
. "They Look upon the Yuchis as Their Vassals': An Early History of Yuchi-Creek Political Relations." In Yuchi Indian Historian Before the Removal Era edited by Jason Baird Jackson, 123-154. Lincoln: University of Nebraska Press, 2012.

Hale, Horatio. "The Tutelo Tribe and Language." Proceedings of the American Philosophical Society, 21:114 (Mar. 1883a): 1-47.

. Indian migrations, as evidenced by language. Chicago: Jameson and Morse, Printers: $1883 \mathrm{~b}$. . The Tutelo language. Bristol, Pa.: Evolution Pub., (2001) 1883c.

Hall, Joseph M., Jr. Zamumo's Gifts: Indian-European Exchange in the Colonial Southeast. Philadelphia, University of Pennsylvania Press, 2009.

Hally, David J. ""As caves beneath the ground": Making Sense of Aboriginal House Form in the Protohistoric and Historic Southeast." In Between contacts and colonies: archaeological perspectives on the protohistoric Southeast, edited by Cameron B. Wesson, and Mark A. Rees, 90-109. Tuscaloosa: University of Alabama Press, 2002. . "Mississippian Shell Gorgets in Regional Perspective." In Southeastern Ceremonial Complex: Chronology, Content, Contest edited by Adam King, 185-231. Tuscaloosa: University of Alabama Press, 2007.

Hamilton, N. D., James M. Adovasio, J. Donahue. An Archaeological Reconnaissance of the Main Stem of the Big Sandy River, Wayne County, West Virginia; Boyd and Lawrence Counties, Kentucky and the Levisa Fork, Johnson County, Kentucky. Interim Report prepared for U.S. Army Corps of Engineers, Huntington District, 1983.

Hammett, Julia E. "Ethnohistory of Aboriginal Landscapes in the Southeastern United States." Southern Indian Studies 41 (Oct. 1992): 1-50.

Hanna, Charles A. The Wilderness Trail. Vol. 1 \&2. New York: G.P. Putnam's Sons, 1911.

Hanson, Lee H., Jr. The Buffalo Site, A Late $17^{\text {th }}$ Century Indian Village site (46PU31) in Putnam County, West Virginia. Morgantown: WVGES, Report of Archaeological Investgations, No. 5, 1975. . Preliminary excavations at the Slone Site in Pike County, Kentucky. Richmond: Dept. of the Interior, National Park Service, Region One, 1984.

Hanson, Lee H., Robert C. Dunnell, and Donald L. Hardesty. The Slone site, Pike County, Kentucky. Richmond: Dept. of the Interior, National Park Service, Southeastern Region, 1984.

Hantman, Jeffrey L. "Between Powhatan and Quirank: Reconstructing Monacan Culture and History in the Context of Jamestown." American Anthropologist, New Series 92:3 (Sep. 1990): 676-690.

. "Monacan Archaeology of the Virginia Interior, A.D. 1400-1700." In Societies in Eclipse: Archaeology of the Eastern Woodlands Indians, A. D. 1400-1700 edited by David S. Brose, C. Wesley Cowin, and Robert Mainfort, Jr., 107-123. Washington, D. C.: Smithsonian Institution Press, 2001.

Hare, Timothy S. "Using Measures of Cost Distance in the Estimation of Polity Boundaries in the Postclassic Yautepec Valley, Mexico.” Journal of Archaeological Science 31 (2004), 799-814.

Harkin, Michael E. "Sacred Places, Scarred Spaces." Wicazo Sa Review 15:1, The Secular Past, the Mythic Past, and the Impending Future (Spring 2000): 49-70.

Harris, Trevor M. "GIS in Archaeology” in Past Time, Past Place: GIS for History, edited by Anne Kelly Knowles, 131-144. Redlands, CA: ESRI, 2002.

Hart John P. "Storage and Monongahela Subsistence-Settlement Change." Archaeology of Eastern North America, Papers of the 1992 Monongahela Symposium. 23 (1995): 41-56.

Hatfield, April Lee. Atlantic Virginia: Intercolonial Relations in the Seventeenth Century. Philadelphia: University of Pennsylvania Press, 2004.

Hatley, Tom. "Cherokee Women Farmers Hold their Ground.” In Powhatan's Mantle: Indians in Colonial Southeast edited by Peter H. Wood, Gregory A. Waselkov, and M. Thomas Hatley, 305-336. Lincoln: University of Nebraska Press, 1989.

Hayes, Charles F., ed. Proceedings of the 1982 Glass Trade Bead Conference. Research Records no. 16. New York: Research Division, Rochester Museum and Science Center, 1983.

Heath, Charles L. "Catawba Militarism: An Ethnohistorical and Archaeological Overview." North Carolina Archaeology 53 (Oct. 2004): 80-120.

Hemmings, E. Thomas. "West Virginia Radiocarbon Dates and Prehistory." WVA 37:2 (Fall 1985): 35-44.

Henderson, A. Gwynn. “Chapter 7: Fort Ancient Period.” In The Archaeology of Kentucky: An Update. Vol. 2. edited by David Pollack, 739-902. Kentucky Heritage Council, State Historic Preservation Comprehensive, Plan Report No. 3, 2008. 
Henderson, A. Gwynn and Emanuel Breitburg. Fort Ancient cultural dynamics in the Middle Ohio Valley. Madison: Prehistory Press, 1992.

Henderson, A. Gwynn, and David Pollack. "Middle Fort Ancient Circular Village Organization." Paper presented at Constituting Social Life and Ritual in Circular Communities Across the Americas Symposium: Society for American Archaeology Annual Meeting, Montreal, Canada, April 2004.

Henderson, A. Gwynn, David Pollock, and Christopher A. Turnbow. "Chronology and Cultural Patterns." In Fort Ancient Cultural Dynamics in the Middle Ohio Valley, edited by A. Gwynn Henderson, 253-280. Monographs in World Archaeology No 8. Madison, Wisconsin: Prehistory Press, 1992.

Herman, Daniel J. "Romance on the Middle Ground." Journal of the Early Republic 19:2 (Summer 1999): 279-291.

Hessl, Amy E., Tom Saladyga, Thomas Schuler, Peter Clark, and Joshua Wixom. "Fire history from three species on a central Appalachian ridgetop." Canadian Journal of Forest Resources 41 (2011): 2031-2039.

Hildreth, S. P. Pioneer History: Being an Account of the First Examinations of the Ohio Valley, and the Early settlement of the Northwest Territory. Cincinnati: H.W. Derby and Co., 1848.

Hinderaker, Eric. Elusive Empires: Constructing Colonialism in the Ohio Valley, 1673-1800. Cambridge, 1997.

Hinderaker, Eric, and Peter C. Mancall. At the Edge of Empire: The Backcountry in British North America. Baltimore, Md: Johns Hopkins University Press, 2003.

Hoffman, Bernard G. "Ancient Tribes Revisited: A Summary of Indian Distribution and Movement in the Northeastern United States from 1534 to 1779. Parts I-III." Ethnohistory 14:1/2 (Winter - Spring 1967): 146.

Hoffman, Darla S. "From the Southeast to Fort Ancient: A Survey of Shell Gorgets in West Virginia." WVA (nd). . "From the Southeast to Fort Ancient: A Survey of Shell Gorgets in West Virginia." WVA 49:1-2 (1997): 140.

. "A Preliminary Analysis of Data from the Protohistoric Orchard Site (46Ms61) to Place it in the Cultural Temporal Sequence of Fort Ancient in the Upper Ohio Valley." Paper presented at the $66^{\text {th }}$ Annual Meeting of the Society of American Archaeology, New Orleans, 2000.

. "Corncob-Impressed Pottery at Late Prehistoric Sites in West Virginia." Paper presented at the $65^{\text {th }}$

Annual Southeastern Archaeological Conference (SEAC) meeting, Charlottesville, North Carolina, 2008.

Hoffman, Paul E., "Lucas Vazquez de Ayllon's Discovery and Colony." In The Forgotten Centuries: Indians and Europeans in the American South, 1521-1704, edited by Charles Hudson and Carmen Chaves Tesser, 3649. Athens: University of Georgia Press, 1994.

Hoffman, Paul E. "Narvaez and Cabeza de Vaca in Florida." In The Forgotten Centuries: Indians and Europeans in the American South, 1521-1704, edited by Charles Hudson and Carmen Chaves Tesser, 50-73. Athens: University of Georgia Press, 1994.

Hofstra, Warren R. "'The Extention of His Majesties Dominions': The Virginia Backcountry and the Reconfiguration of Imperial Frontiers." The Journal of American History 84:4 (March 1998): 1281-1312.

Holland, John D. "West Virginia Lithics of Potential Prehistoric Significance." WVA 53:1-2 (Spring-Fall 2001): 1924.

Holm, Mary Ann. "Faunal Remains." In Archaeology of the Historic Occaneechi Indians. Edited by H. Trawick Ward and R. P. Stephen Davis, Jr. Southern Indian Studies 36-37 (Oct. 1988): 85-94.

Hopkins, Kelly Yvonne. “A New Landscape: Changing Iroquois Settlement Patterns, Subsistence Strategies, and Environmental Use, 1630-1783.” Unpublished Dissertation. University of California, Davis, 2010.

Hornborg, Alf. "Ethnogenesis, Regional Integration, and Ecology in Prehistoric Amazonia Toward a System Perspective." Current Anthropology 46:4 (August-October 2005): 589-620.

Hranicky, William Jack, Irene Mitchell, and L. Dale Collins. "Mountain and Piedmont Solar Observatories in Prehistoric Virginia." In Upland Archaeology in the East: Symposium No. 6. Special Publication No. 38, Part 6. USDA, Forest Service, Archaeological Society of Virginia, 1996: 181-195.

Hudson, Charles. The Southeastern Indians. Knoxville: University of Tennessee Press, 1976. . "The Hernando de Soto Expedition, 1539-1543." In The Forgotten Centuries: Indians and Europeans in the American South, 1521-1704, edited by Charles Hudson and Carmen Chaves Tesser, 74-103. Athens: University of Georgia Press, 1994. . Knights of Spain, Warriors of the Sun; Hernando de Soto and the South's Ancient Chiefdoms. Athens: University of Georgia Press, 1997. . "Introduction." In The Transformation of the Southeastern Indians, 1540-1760 edited by Robbie Ethridge, and Charles Hudson, xi-xxxix. Jackson, MS: University Press of Mississippi, 2002.

Hudson, Charles, and Carmen Chaves Tesser, eds. The Forgotten Centuries: Indians and Europeans in the American South, 1521-1704. Athens: University of Georgia Press, 1994. 
. "Introduction." In The Forgotten Centuries: Indians and Europeans in the American South, 1521-1704, edited by Charles Hudson and Carmen Chaves Tesser, 1-16. Athens: University of Georgia Press, 1994.

Hudson, Charles, and Paul E. Hoffman. The Juan Pardo Expeditions: Exploration of the Carolinas and Tennessee, 1566-1568. 2nd edition. Tuscaloosa: University of Alabama Press, 2005.

Hudson, Charles, Marvin T. Smith, and Chester DePratter. "The Hernando De Soto Expedition: From Apalachee to Chiaha." Southeastern Archaeology 3(1984):65-77.

Huebner, Cynthia D., Steven L. Stephenson, Harold S. Adams, Gary W. Miller. "Short-Term Dynamics of SecondGrowth Mixed Mesophytic Forest Strata in West Virginia." Castanea 72: 2 (June 2007): 65-81.

Hufford, Mary, et al. "Ethnographic Overview And Assessment: New River Gorge National River and Gauley River National Recreation Area." Unpublished report. Boston, MA: The Center for Folklore and Ethnography, University of Pennsylvania, Northeast Region Ethnography Program, National Park Service, 2007.

Hulbert, Archer Butler. Indian Thoroughfares. Reprinted. AMS Press, New York, New York. Cleveland, Ohio: Arthur H. Clark Company, [1902] 1971. . Paths of the Mound-Building Indians and Great Game Animals. Reprinted. AMS Press, New York, New York. Cleveland, Ohio: Arthur H. Clark Company, [1902] 1971. . Portage Paths: The Keys to the Continent. Reprinted. AMS Press, New York, New York. Cleveland, Ohio: Arthur H. Clark Company, [1902] 1971.

Hunt, George T. The wars of the Iroquois; a study in intertribal relations. Madison, University of Wisconsin Press, 1940.

Hunter, William A. “The Ohio, The Indian's Land.” Pennsylvania History 21:4 (October, 1954): 338-350. . Forts on the Pennsylvania Frontier, 1753-1758. Harrisburg: Pennsylvania Historical and Museum Commision, 1960.

Huscher, Harold A. "Generic Western Names Identifiable in the Southeast." Southern Indian Studies 13 (Oct. 1961): 21-28.

Hyde, George E. Indians of the Woodlands: From Prehistoric Times to 1725. Norman, OK: University of Oklahoma, 1962.

Inghram, J. W. "The Tompkins Farm Site." WVA 6 (Feb. 1953): 43.

Inghram, J. W., Sigfus Olafson, and Edward McMichael. "The Mount Carbon Stone Walls: Description and History." WVA 13 (July 1955): 1-13.

Jaenen, Cornelius J. "French Expansion in North America." The History Teacher 34:2 (Feb. 2001): 155-164.

Jakle, John A. "Salt on the Ohio Valley Frontier, 1770-1820." Annals of the Association of American Geographers 59:4 (Dec. 1969): 687-709.

Jefferies, Richard W. "Living on the Edge: Mississippian Settlement in the Cumberland Gap Vicinity." In Archaeology of Appalachian Highlands edited by Lynn P. Sullivan, and Susan C. Prezzano, 198-221. Knoxville: University of Tennessee Press, 2001.

Jenkins, Ned J. "Tracing the Origins of the Early Creeks, 1050-1700 ce." In Mapping the Mississippian Shatter Zone: The Colonial Indian Slave Trade and Regional Instability in the American South edited by Robbie Ethridge and Sheri Shuck-Hall, 188-249. Lincoln: University of Nebraska Press, 2009.

Jennings, Francis. The Invasion of America: Indians, Colonialism, and the Cant of Conquest. Chapel Hill: University of North Carolina Press, 1975. . The Ambiguous Iroquois Empire. New York: W.W. Norton and Company, 1984. . "Pennsylvania Indians' and the Iroquois." In Beyond the Covenant Chain: The Iroquois and Their Neighbors in Indian North America, 1600-1800 edited by Daniel K. Richter, and James H. Merrell, 75-91. University Park, PA: The Pennsylvania State University Press, 1987. . Empire of Fortune: Crowns, Colonies \&Tribes in the Seven Years War in America. New York: W.W. Norton and Company, 1988.

Jennings, Francis, William Fenton, Mary Druke, David Miller, eds. The History and Culture Iroquois Diplomacy: An Interdisciplinary Guide to the Treaties of the Six Nations and Their League. Syracuse: Syracuse University Press, 1985.

Jennings, Matthew H. "Violence in a Shattered World." In Mapping the Mississippian Shatter Zone: The Colonial Indian Slave Trade and Regional Instability in the American South edited by Robbie Ethridge and Sheri Shuck-Hall, 272-294. Lincoln: University of Nebraska Press, 2009. . New Worlds of Violence: Cultures and Conquests in the Early American Southeast. Knoxville: University of Tennessee Press, 2011 
Jeter, Marvin D. "From Prehistory through Protohistory to Ethnohistory in and near the Northrn Lower Mississippi Valley." In The Transformation of the Southeastern Indians, 1540-1760, edited by Robbie Ethridge, and Charles Hudson, 177-223. Jackson, MS: University Press of Mississippi, 2002.

Jillson, Willard Rouse. The Big Sandy Valley: A Regional History Prior to the Year 1850. Louisville, KY: John P. Morton and Co., 1979.

Johnson, William C. "The Protohistoric Monongahela and the Case for an Iroquois Connection." In Societies in Eclipse: Archaeology of the Eastern Woodlands Indians, A. D. 1400-1700 edited by David S. Brose, C. Wesley Cowin and Robert Mainfort, Jr., 67-82. Washington, D. C.: Smithsonian Institution Press, 2001.

Johnson, William C., and Bernard K. Means. "The Late Prehistoric And Protohistoric Periods, A.D. 1150-1635, In The Lower Upper Ohio River Valley." Unpublished manuscript, 2006.

. "The World Beyond Jamestown: Reexamining the Massawomeck-Monongahela Connection." Unpublished Paper presented at $67^{\text {th }}$ meeting of the Archaeological Society of Virginia, Williamsburg, 2007.

Johnson, Michael F. "The evolution of the bifurcate hunting system in the interior piedmont of Fairfax County, Virginia." In Piedmont archaeology: recent research and results: proceedings from a Conference on Piedmont Archaeology, May 20-21, 1983, edited by J. Mark. Wittkofski, Lyle E. Browning, et al, 55-73. Richmond: Archeological Society of Virginia, 1983.

Johnston, David E. A History of The Middle New River Settlements and Contiguous Territory. Huntington, WV: Standard Printing and Publishing Co., 1908.

Johnston, John. "Account of the present state of the Indian tribes inhabiting Ohio." American Antiquarian Society, Transactions and Collections. 1 (1820): 269-299.

Jones, Charles C., Jr. Historical Sketch of Tomo-Chi-Chi, Mico of the Yamacraws. Albany: John Munsell, 1868.

Jones, Emory E., Jr. "Archaeological Investigations at the Snidow Site (46MC1), Mercer County, West Virginia." WVA 39:1 (Spring 1987): 1-20.

Jones, Glynis. "Garden Cultivation of Staple Crops and Its Implications for Settlement Location and Continuity." World Archaeology 37:2 Garden Agriculture (June 2005): 164-176.

Josephy, Jr., Alvin M., ed. America in 1492: The world of the Indian peoples before the Arrival of Columbus. New York: Knopf, 1992.

Judd, Carol M. and Arthur J. Ray, eds. Old Trails and New Directions: Papers of the Third North American Fur Trade Conference. Toronto: University of Toronto Press, 1980.

Judkins, Gabriel, Marissa Smith and Eric Keys. "Determinism within human-environment research and the rediscovery of environmental causation." The Geographical Journal 174:1 (March 2008): 17-29.

Jurgelski, William M. "Burning Seasons, Burning Bans: Fire in the Southern Mountains, 1750-2000." Appalachian Journal 35:3 (Spring 2008): 170-217.

Karklins, Karlis, and Roderick Sprague. "Glass Trade Beads in North America: An Annotated Bibliography." Historical Archaeology (1972): 87-101.

Karklins, Karlis. "Seventeenth Century Dutch Beads." Historical Archaeology (1974): 64-82.

Kay, Jeanne. "The Fur Trade and Native American Population Growth." Ethnohistory 31 (1984): 265-287. . "Native Americans in the Fur Trade and Wildlife Depletion" Environmental Review: ER 9:2, Special Issue: American Indian Environmental History (Summer, 1985): 118-130.

Keane, A. H. "On North Carolina Stone Carvings." The Journal of the Anthropological Institute of Great Britain and Ireland 12 (1883): 281-288

Keener, Craig S. "An Ethnohistorical Analysis of Iroquois Assault Tactics Used against Fortified Settlements of the Northeast in the Seventeenth Century." Ethnohistory 46:4, Warfare and Violence in Ethnohistorical Perspective (Autumn 1999): 777-807.

Kellogg, Louise Phelps. Early Narratives of the Northwest, 1634-1699. New York: Charles Scribner's Sons, 1917.

Kelly, Robert L., Lin Poyer, and Bram Tucker. "An Ethnoarchaeological Study of Mobility, Architectural Investment, and Food Sharing among Madagascar's Mikea." American Anthropologist 107:3 (Sept. 2005): 403-416.

Kelton, Paul. Epidemics and Enslavement: Biological Catastrophe in the Native Southeast 1492-1715. Lincoln: University of Nebraska Press, 2007.

Kenny, Hamill. West Virginia place names, their origin and meaning, including the nomenclature of the streams and mountains. Piedmont, W. Va.: The Place Name Press, 1945.

King, Adam, ed. Southeastern Ceremonial Complex: Chronology, Content, Contest. Tuscaloosa: University of Alabama Press, 2007. 
."The Southeastern Ceremonial Complex: From Cult to Complex." In Southeastern Ceremonial Complex: Chronology, Content, Contest edited by Adam King, 1-14.. Tuscaloosa: University of Alabama Press, 2007.

. "Whither SECC?" In Southeastern Ceremonial Complex: Chronology, Content, Contest edited by Adam King, 251-258. Tuscaloosa: University of Alabama Press, 2007.

King, Mary Elizabeth. "Analytical Methods and Prehistoric Textiles." American Antiquity 43:1 (Jan.1978): 89-96.

Kirby, Chester. "The English Game Law System." The American Historical Review 38:2 (Jan 1933): 240-262.

Kirby, Chester and Ethyn Kirby. "The Stuart Game Prerogative." The English Historical Review 46:182 (Apr. 1931): 239-254.

Knight, Vernon James, Jr. "The Formation of the Creeks." In The Forgotten Centuries: Indians and Europeans in the American South, 1521-1704, edited by Charles Hudson and Carmen Chaves Tesser, 373-392. Athens: University of Georgia Press, 1994.

. "Farewell To The Southeastern Ceremonial Complex." Southeastern Archaeology 25:1 (Summer 2006): $1-5$.

Knowles Anne K., ed. Past Time, Past Place: GIS for History. Redlands, CA: ESRI Press, 2002. . "Introducing Historical GIS" in Past Time, Past Place: GIS for History, edited by Anne Kelly Knowles, xi-xx. New York: ESRI, 2002. . "Conclusion: An Agenda for Historical GIS." In Placing History: How maps, Spatial Data, and GIS are Changing Historical Scholarship, edited by Anne K. Knowles, 267-274. Redlands, CA: ESRI Press, 2008. . Placing History: How maps, Spatial Data, and GIS are Changing Historical Scholarship. Redlands, CA: ESRI Press, 2008.

. "GIS in History." in Placing History: How Maps, Spatial Data, and GIS are Changing Historical Scholarship, edited by Anne Kelly Knowles, 1-26. Redlands, CA: ESRI, 2008.

Kowalewski, Stephen A. "Coalescent societies." In Light On The Path: The Anthropology and History of the Southeastern Indians edited by Thomas J. Pluckhahn, and Robbie Ethridge, 94-122. Tuscaloosa: University Of Alabama Press, 2006.

Kraft, Herbert C. "Sixteenth And Seventeenth Century Indian/White Trade Relations In The Middle Atlantic And Northeast Regions." Archaeology of Eastern North America, 17 (Fall 1989): 1-29.

Krech, Shepard, III. Indians, Animals, and the Fur Trade: A Critique of Keepers of the Game. Athens: University of Georgia Press, 1981.

. The Ecological Indian: Myth and History. New York: Norton, 1999.

Kuhman, Timothy R., Scott M. Pearson, and Monica G. Turner. "Agricultural land-use history increases non-native plant invasion in a southern Appalachian forest a century after abandonment." Canadian Journal of Forest Resources 41 (2011): 920-929.

Kuhn, Thomas, and Beverly Spurlock. "Lewis Old Town (46MS57): A Late Prehistoric Village Site in Mason County, West Virginia." WVA 33 (Spring 1982): 37-45.

Kupperman, Karen Ordahl. "Before 1607." WMQ 3rd ser. 72:1 (January 2015): 3-24.

Lacquement, Cameron H. Architectural Variability in the Southeast. Tuscaloosa: University of Alabama Press, 2007.

Lakomäki, Sami. Gathering Together: The Shawnee People through Diaspora and Nationhood, 1600-1870. New Haven: Yale University Press, 2014.

Lamarre, Lora A. "The Buffalo Site Ceramics: An Analysis of an Archaeological Assemblage from a Fort Ancient Village Site in West Virginia." Unpublished Masters Thesis, University of Cincinnati, Department of Anthropology, 1999.

Lapham, Heather A. "More Than "A Few Blew Beads": The Glass and Stone Beads from Jamestown Rediscovery's 1994-1997 Excavations." The Journal of the Jamestown Rediscovery Center 1 (Jan. 2001). . Hunting for Hides: Deerskins, Status, and Cultural Change in the Protohistoric Appalachians. Tuscaloosa, AL: University of Alabama Press, 2005.

Lapham, Heather A., and William C. Johnson. "Protohistoric Monongahela Trade Relations: Evidence from the Foley Farm Phase Glass Beads.” Archaeology of Eastern North America 30 (2002): 97-120.

Lauber, Almon Wheeler. Indian Slavery ion Colonial Times within the Present Limits of the United States. New York: Columbia University, Longman, Green and Co., 1913.

Leach, Douglas Edward. The Northern Colonial Frontier: 1607-1763. New York: Holt, Rinehart and Winston, 1966.

Lee, Elizabeth Oliver. “'Potomac's Valley shall become a domain we create:' Commercialism and the South Branch Valley, 1750-1800.” Unpublished PhD dissertation, West Virginia University, 2008. 
Lee, Wayne E. "Fortify, Fight, or Flee: Tuscarora and Cherokee Defensive Warfare and Military Culture Adaptation." The Journal of Military History 68:3 (Jul. 2004): 713-770.

Lewis, G. Malcolm. "Indian Maps." In Old Trails and New Directions: Papers of the Third North American Fur Trade Conference edited by Carol M. Judd, and Arthur J. Ray, 9-23. Toronto: University of Toronto Press, 1980.

Lewis, Ronald L. Transforming the Appalachian Countryside: Railroads, Deforestation, and Social Change in West Virginia, 1880-1920. Chapel Hill: University of North Carolina Press, 1998.

Lewis, R. Barry. Kentucky Archaeology. Lexington: University Press of Kentucky, 1996.

Lewis, Virgil A. History of West Virginia. Philadelphia: Hubbard Brothers, Publishers, 1889. . Life and Times of Anne Bailey, the Pioneer Heroine of the Great Kanawha Valley. Charleston, WV: Butler Printing Co., 1891.

Lightfoot, Kent G. "Culture Contact Studies: Redefining the Relationship between Prehistoric and Historical Archaeology." American Antiquity 60:2 (Apr. 1995): 199-217.

Lightfoot, Kent G., and Antoinette Martinez. "Frontiers and Boundaries in Archaeological Perspective." Annual Review of Anthropology 24 (1995): 471-492.

Little, Keith J. "Late Holocene Climate Fluctuations And Culture Change In Southeastern North America." Southeastern Archaeology 22:1 (Summer 2003): 9-32.

Lorimer, Craig G. "Historical and Ecological Roles of Disturbance in Eastern North American Forests: 9,000 Years of Change." Wildlife Society Bulletin 29:2 (Summer 2001): 425-439.

Lovis, William A., Kathryn C. Egan-Bruhy, Beverley A. Smith, and G. William Monaghan. "Wetlands and Emergent Horticultural Economies in the Upper Great Lakes: A New Perspective from the Schultz Site." American Antiquity 66:4 (Oct. 2001): 615-632.

Lustig, Mary Lou. The Imperial Executive in America: Sir Edmund Andros 1637-1714. Cranury, NJ: Associated University Presses, 2002.

MacCord, Howard A. "The Susquehannock Indians in West Virginia, 1630-77." WVA 13 (1952): 237-253. . "Archaeological Relationships Between West Virginia, Maryland, and Virginia." WVA 8 (May 1957): 3335 .

. "The Trigg Site, Radford, Virginia: A Resume." In Upland Archaeology in the East. Symposium 2. Cultural Resources Report No. 5. June 1984: 178-179.

MacCord, Howard, and William Buchanan. Trade Goods form the Trigg Site, Radford, Virginia. Unpublished report at VDHR. 1974.

. The Crab Orchard Site, Tazewell County, Virginia. Richmond: Archaeological Society of Virginia Special Publication No. 8, 1980.

Mahr, August C. "Shawnee Names And Migrations In Kentucky And West Virginia." The Ohio Journal Of Science 60:3 (May 1960): 155-164.

Mairs, O. L. "A Child Burial at Site 46 MS-61." WVA 3 (Oct. 1950): 1-4.

Makalani, Minkah. "Introduction: Diaspora and the Localities of Race" Social Text 98, Diaspora and the Localities of Race (Spring, 2009): 1-9

Manson, Carl, Howard A, MacCord. “An Historic Iroquois Site near Romney, West Virginia.” West Virginia History 2 (1941): 290-293.

Marks, P. L. "On the Origin of the Field Plants of the Northeastern United States." The American Naturalist 122: 2 (Aug. 1983): 210-228.

Maroukis, Thomas Constantine. Peyote and the Yankton Sioux: The Life and Times of Sam Necklace. University of Oklahoma Press, 2005.

Martin, Calvin. Keepers of the Game: Indian/Animal Relationship and the Fur trade. Berkeley: University of California Press, 1978.

Martin, Joel W. "Southeastern Indians and the English Trade in Skins and Slaves." In The Forgotten Centuries: Indians and Europeans in the American South, 1521-1704, edited by Charles Hudson and Carmen Chaves Tesser, 304-326. Athens: University of Georgia Press, 1994.

Marwitt, John P., K. Sauser, and R. Sterling. "1980 Excavations at the Childers Site (46MS121), Mason County, West Virginia." WVA 38:1 (Spring 1986): 1-23.

Maslowski, Robert F. "Protohistoric Villages in Southern West Virginia." Proceedings of the Upland Archaeology in the East Symposium 2 edited by Michael B. Barber, 148-161. Cultural Resources Report No. 5, US Department of Agriculture, Forest Service Southern Region, Atlanta, 1984. . "The Bluestone Monitor Pipe." WVA 7 (Spring 1985): 41. . "Woodland Settlement Patterns in the Mid and Upper Ohio Valley." WVA 37:2 (Fall 1985): 23-32. 
. "Archeology of the Great Kanawha Navigation.” Unpublished manuscript, 2003.

. "Cultural Affiliation Statement: New River Gorge National River and Gauley River National Recreation Area." Northeast Region NAGPRA Program, NPS, Boston, MA, June 2011

Maslowski, Robert F., Charles M. Niquette, and Derek M. Wingfield. "The Kentucky, Ohio and West Virginia Radiocarbon Database." WVA 47:1-2 (1995).

Maslowski, Robert F. and David L. Dawson. "Childers (46-Ms-121): A terminal Late Woodland Village." WVA 30 (1980): 4-32.

Maslowski, Robert F., and Mark F. Seeman. "Woodland Archaeology in the Mid-Ohio Valley: Setting Parameters for Ohio Main Stem/Tributary Comparisons." In Cultural Variability in Context: Woodland Settlements of the Mid-Ohio Valley edited by Mark F. Seeman, 10-14. MCJA Special Paper No. 7. Kent State University Press, 1992.

Maslowski, Robert F., and Penelope B. Drooker. "Fort Ancient Adaptations in the Mid Ohio Valley." 2009.

Mason, Carol Irwin. "Comments on Mouse Creek-Yuchi Identification.” American Antiquity 28:4 (Apr. 1963): 550551.

Maxwell, R. Stockton, Amy E. Hessl, Edward R. Cook, and Brendan M. Buckley. "A Multicentury Reconstruction of May Precipitation for the Mid-Atlantic Region Using Juniperus virginiana Tree Ring.” Journal of Climate 25 (Feb. 2012): 1045-1056.

Maxwell, Hu. "The Use and Abuse of Forests by the Virginia Indians." WMQ 19:2 (Oct. 1910): 73-103.

Maxwell, Moreau S. "The Archaeology of the Lower Ohio Valley." In Archaeology of Eastern United States, edited by James B. Griffin, 176-189. Chicago: University of Chicago Press, 1952.

Mayer-Oakes, William J. “Archaeological problems in the upper Ohio Valley.” Pennsylvania Archaeology 21 (1951): 53-56.

. Prehistory of the Upper Ohio Valley; and introductory archaeological study. Pittsburgh: Annals of Carnegie Museum, 1955.

Mazrim, Robert, and Duane Esarey. "Rethinking the Dawn of History: The Schedule, Signature, and Agency of European Goods in Protohistoric Illinois." Midcontinental Journal of Archaeology 32:2 (Fall 2007): 145200.

McBride, W. Steven and Kim A. “Chapter 8: Historic Period.” In The Archaeology of Kentucky: An Update. Vol. 2. edited by David Pollack, 903-1055. Kentucky Heritage Council, State Historic Preservation Comprehensive, Plan Report No. 3, 2008.

McCaa, Robert. "Paleodemography of the Americas: From Ancient Times to Colonialism and Beyond." In The Backbone of History: Health and Nutrition in the Western Hemisphere, edited by Richard H. Steckel, and Jerome C. Rose, 94-124. Cambridge University Press, 2008.

McCartney, Martha W. “Cockacoeske, Queen of Pamunkey, Diplomat and Suzeraine.” In Powhatan's Mantle: Indians in Colonial Southeast edited by Peter H. Wood, Gregory A. Waselkov, and M. Thomas Hatley, 243-266. Lincoln: University of Nebraska Press, 1989.

McColloch, Jane S. Springs of West Virginia. 50th Anniversary, revised edition. American Fisheries Society and The Conservation Fund, Inc. 1986.

McConnell, Michael N. "Peoples 'In Between': The Iroquois and the Ohio Indians, 1720-1768." In Beyond the Covenant Chain: The Iroquois and Their Neighbors in Indian North America, 1600-1800 edited by Daniel K. Richter, and James H. Merrell, 93-112. University Park, PA: The Pennsylvania State University Press, 1987.

. A Country Between: The Upper Ohio Valley and Its Peoples, 1724-1774. Lincoln: University of Nebraska Press, 1992.

McEwan, Ryan W., Neil Pederson, Adrienne Cooper, Josh Taylor, Robert Watts, and Amy Hruska. "Fire and gap dynamics over 300 years in an old-growth temperate forest." Applied Vegetation Science 17: 2 (Apr 2014): 312-322.

McGee, W. J. "The Siouan Indians: A Preliminary Sketch.” Fifteenth Annual Report of the Bureau of Ethnology to the Secretary of the Smithsonian Institution, 1893-1894, Government Printing Office, Washington, 1897. 1st edition, ([1897] 2006): 153-204.

McHargue, J. S. "Canebrakes in Prehistoric and Pioneer times in Kentucky." Annals of Kentucky Natural History, I (1941): 1-13.

McMicheal, Edward V. "Environment and culture in West Virginia." West Virginia Academy of Science Proc. 33:146-150, 1961. . "Archaeological problems in Central West Virginia." (abs.) East States Archaeological Federal Bulletin 21 (1962):14. 
. "Ethnobotanical material from the Ohio Valley." Southeastern Archaeological Conference Bulletin No. 3 Cambridge, MA, (1965): 36-37.

. Introduction to West Virginia Archeology. Morgantown: WVGES, 1968.

McReynolds, Theresa E. "Catawba Population Dynamics during the Eighteenth and Nineteenth Centuries." North Carolina Archaeology 53 (Oct. 2004): 42-59.

Means, Bernard K. Circular Villages of the Monongahela Tradition. Tuscaloosa: University of Alabama Press, 2007.

Mehta, Jayur. "Crossroads and Cosmologies: Diasporas and Ethnogenesis in the New World." Southeastern Archaeology 27:2 (Winter 2008): 294-295.

Meinig, D. W. The shaping of America: a geographical perspective on 500 years of history. New Haven: Yale University Press, 1986.

Melillo, Jerry M., Terese Richmond, and Gary W. Yohe, eds. National Climate Assessment and Development Advisory Committee Report January 2013 Draft for Public Comment, 2014: Climate Change Impacts in the United States: The Third National Climate Assessment. U.S. Global Change Research Program. doi:10.7930/J0Z31WJ2: 29.

Merchant, Carolyn. Ecological Revolutions: Nature, Gender, and Sciences in New England. Chapel Hill: University of North Carolina Press, 1989.

Merrell, James H. "Cultural Continuity among the Piscataway Indians of Colonial Maryland." WMQ, 3rd Ser. 36: 4 (October 1979): 548-570.

. "Reading "An Almost Erased Page": A Reassessment of Frank G. Speck's Catawba Studies." Proceedings of the American Philosophical Society 127:4 (1983): 248-262

. "The Indians' New World: The Catawba Experience.” WMQ 3rd Ser. 41:4 (Oct., 1984): 538-565.

. "Their Very Bones Shall Fight': The Catawba-Iroquois Wars." In Beyond the Covenant Chain: The

Iroquois and Their Neighbors in Indian North America, 1600-1800 edited by Daniel K. Richter, and James H. Merrell, 115-133. University Park, PA: The Pennsylvania State University Press, 1987.

. “'Our Bond of Peace" Patterns of Intercultural Exchange in the Carolina Piedmont, 1650-1750.” In Powhatan's Mantle: Indians in Colonial Southeast edited by Peter H. Wood, Gregory A. Waselkov, and M. Thomas Hatley, 267-304. Lincoln: University of Nebraska Press, 1989.

. The Indians New World: Catawbas and Their Neighbors from European Contact through the Era of Removal. Chapel Hill: Published for the Institute of Early American History and Culture, Williamsburg, Virginia, by the University of North Carolina Press, 1989.

. The Catawba. Indians of North America, Frank W. Porter III, ed. New York: Chelsea House Publishers, 1989a.

. Into the American Woods: Negotiators on the Pennsylvania Frontier. New York: W.W. Norton and Company, 1999.

. "Second Thoughts on Colonial Historians and American Indians" Forum: Colonial Historians and American Indians. $W M Q 3^{\text {rd }}$ ser. 69: 3 (July 2012): 451-512

Merritt, Jane T. "Metaphor, Meaning, and Misunderstanding: Language and Power on the Pennsylvania Frontier." in Contact Points: American Frontiers from the Mohawk Valley to the Mississippi, 1750-1830 edited by Andrew R.L. Cayton, and Fredrika J. Teute, 60-87. Chapel Hill: University of North Carolina Press, 1998. . At the Crossroads: Indians and Empires on a Mid-Atlantic Frontier, 1700-1763. Chapel Hill: University of North Carolina, 2003.

Meyers, Maureen S. “The Mississippian Frontier In Southwestern Virginia.” Southeastern Archaeology 21:2 (Winter 2002): 178-192.

. "From Refugees to Slave Traders: The Transformation of the Westo Indians." In Mapping the Mississippian Shatter Zone: The Colonial Indian Slave Trade and Regional Instability in the American South edited by Robbie Ethridge and Sheri Shuck-Hall, 81-103. Lincoln: University of Nebraska Press, 2009.

Miller, Carl F. "Revaluation of the Eastern Siouan Problem." Bulletins of the Bureau of American Ethnology. CLXIV, (1957): 115-212.

Milling, Chapman J. Red Carolinians. Chapel Hill, University of North Carolina Press, 1940.

Milner, George R. "Epidemic Disease In The Postcontact Southeast: A Reappraisal.” Midcontinental Journal of Archaeology 5:1 (1980): 39-56. 
Milner, George R., David G. Anderson, and Marvin T. Smith. "The Distribution of Eastern Woodlands Peoples at the Prehistoric and Historic Interface." In Societies in Eclipse: Archaeology of the Eastern Woodlands Indians, A. D. 1400-1700 edited by David S. Brose, C. Wesley Cowin and Robert Mainfort, Jr., 9-18. Washington, D. C.: Smithsonian Institution Press, 2001.

Miquelon, Dale. "Ambiguous Concession: What Diplomatic Archives Reveal about Article 15 of the Treaty of Utrecht and France's North American Policy." WMQ 3rd series 67:3 (July 2010): 459-486.

Minar, Cynthia Jill. "Impression Analysis of Cord-Marked Pottery, Learning Theory, and the Origins of the Alachua." Unpublished Dissertation, University of California, Riverside, 1999.

Mitchell, Robert D., ed. Appalachian Frontiers: Settlement, Society \& Development in the Preindustrial Era. Lexington: University of Kentucky Press, 1991.

Mooney, James. The Siouan Tribes of the East. Smithsonian Institution, Bureau of American Ethnography, bulletin no. 22. Washington, D.C.: Government Printing Office, 1894. . Myths of the Cherokees. Dover 1995 (1900). . James Mooney's History, Myths, and Sacred Formulas of the Cherokees. Edited by George Ellison. Asheville, NC: Historical Images, 1992.

Moore, David G. "Late Prehistoric and Early Historic Period Aboriginal Settlement in the Catawba Valley, North Carolina." PhD diss. Department of Anthropology, University of North Carolina, Chapel Hill, 1999. . Catawba Valley Mississippian: Ceramics, Chronology, and Catawba Indians. Tuscaloosa: University of Alabama Press, 2002.

Morgan, Richard G. "Outline of Cultures in the Ohio Region." In Archaeology of Eastern United States edited by James B. Griffin, 83-98. Chicago: University of Chicago Press, 1952.

Morrison, A. J. "The Virginia Indian Trade to 1673." WMQ 2nd ser. 1:4 (Oct. 1921): 217-236.

Moxley, Ronald W. "The Dennison Site (46LG16): A Mountaintop Site in Logan County." WVA 34 (Fall 1982): 3442.

. "Recent Excavations at the Man Site (46Lg5)." WVA 37 (Spring 1985): 44-46.

. "The Orchard Site: A Proto-Historic Fort Ancient Village Site in Mason County, West Virginia." WVA 40:1 (Spring 1988): 33-41.

. "The Rolfe Lee Site." Paper presented at the West Virginia Society annual meeting, Huntington. 1993.

Moxley, Ronald M., and James D. Bloemker. "The Man Site: A Preliminary Report on late Prehistoric Village in Logan County, West Virginia." WVA 37:2 (Fall 1985): 3-22.

Murphy, James L. "Faunal Remains from the Miller Site (46-Ja-55), Jackson County, West Virginia." WVA 31 (Spring 1981): 20-30.

Myers, William E. "Indian trails of the Southeast." $42^{\text {nd }}$ Annual Report of the Bureau of American Ethnology to Secretary of Smithsonian Institution. 1924-1925 (1928):735.

Nalbantis, I. "Evaluation of a Hydrological Drought Index." European Water 23/24 (2008): 67-77.

Nash, Carole. "Gaps in Our Knowledge: Hunter-Gatherers and High Elevation Blue Ridge Settlement." Uplands Archaeology in the East, Symposia VII \& IX, Archaeology Society of Virginia Special Pub. 2005: 89-102.

Nash, Carole L., and Michael B, Barber, eds. Uplands Archaeology in the East. Symposia VIII and IX. Archaeological Society of Virginia, Special Publication 38-7, nd.

Nash, Gary B. "The Image of the Indian in the Southern Colonial Mind." WMQ 3rd. Ser. 29:2 (April 1972): 197230.

Nass, J. P., Jr. "Subsistence-Settlement Change and Continuity in Western Pennsylvania." In Archaeology of Appalachian Highlands, edited by Lynn P. Sullivan, and Susan C. Prezzano, 177-197. Knoxville: University of Tennessee Press, 2001.

Nass, John Phillip, Jr. "Use-Wear Analysis And Household Archaeology: A Study Of The Activity Structure Of the Incinerator Site, an Anderson phase Fort Ancient community in Southwestern Ohio." Unpublished Dissertation. Ohio State University, 1987.

Naum, Magdalena. "Re-emerging Frontiers: Postcolonial Theory and Historical Archaeology of the Borderlands." Journal of Archaeological Method and Theory 17: 2 (June 2010): 101-131.

Navarro, Laetitia M. and Henrique M. Pereira. "Rewilding Abandoned Landscapes in Europe." Ecosystems 15 (2012): 900-912.

Nayar, P. Bhaskaran. "Sociological Implications of Language Contact." Anthropos 86:4/6 (1991): 528-535.

Niquette, Charles M. and Myra A. Hughes, eds. Late Woodland Archeology at the Parkline Site (46PU99), Putnam County, West Virginia (Contract Publication Series 90-93. Cultural Resource Analysts, Lexington, Kentucky, 1990. 
Niquette ,Charles M. and J.P. Kerr. "Late Woodland Archeology at the Parkline Site, Putnam County, West Virginia." WVA 45:1-2 (1993), 43-49.

Nobles, Gregory H. "Breaking into the Backcountry: New Approaches to the Early American Frontier, 1750-1800." WMQ 3rd. Ser. 46:4 (Oct. 1989): 641-670.

Noe, Randolph. The Shawnee Indians: an annotated bibliography. Lanham, Md.: Scarecrow Press, 2001.

O'Malley, Nancy. "Ceramics from the Childers and Woods Sites" In Childers and Woods: Two Late Woodland Sites in the Upper Ohio Valley, Mason County, West Virginia, edited by Michael J. Shott, 691- 815. University of Kentucky, Program for Cultural Resource Assessment Archeological Report No. 200, 1990.

Odell, George H. "Some Additional Perspectives on Appropriate Models and Analogs for Hunter-Gatherer Populations." American Antiquity 47:1 (Jan. 1982): 192-198.

Ogburn, Dennis E. "Assessing the Level of Visibility of Cultural Objects in Past Landscapes." Journal of Archaeological Science 33 (2006): 405-413.

Olafson, Sigfus. "The Painted Trees and the War Road: Paint Creek, Fayette Co. W. Va." WVA 10 (1958): 3-6. . "Gabriel Arthur and the Fort Ancient People." WVA 12 (1960): 32-42.

Oliverio, Giulia R. "A grammar and dictionary of Tutelo." PhD diss., University of Kansas, 1997.

Oliverio, Giulia R., and Robert Rankin. "On the Sub-grouping of the Virginia Siouan Languages." In Essays in Algonquian, Catawban and Siouan Linguistics in Memory of Frank T. Siebert, Jr. edited by Blair A. Rudes, and David J. Costa, 165-180. Algonquian and Iroquoian Linguistics. Memoir 16. Winnipeg: Algonquian and Iroquoian Linguistics, 2003.

Olwig, Kenneth R. "Reinventing Common Nature: Yosemite and Mount Rushmore-A Meandering Tale of Double Nature." In Uncommon Ground: Rethinking the Human Place in Nature, edited by William Cronon, 379408. New York: WW Norton Company, 1995.

Osborn, Alan J. "Ecological Aspects of Equestrian Adaptations in Aboriginal North America." American Anthropologist, New Series 85: 3 (Sep. 1983): 563-591.

Otto, John Solomon. "Forest Fallowing among the Appalachian Mountain Folk: An Ethnohistorical Study." Anthropologica 30:1 (1988): 3-22.

Parker, Bradley J. “Toward an Understanding of Borderland Processes.” American Antiquity 71:1 (Jan. 2006): 77-100.

Parmenter, Jon. "After the Mourning Wars: The Iroquois as Allies in Colonial North American Campaigns, 16761760." WMQ 64:1, Free to Enslave: Politics and the Escalation of Britain's Translantic (Jan. 2006): 39-76. . The Edge of the Woods: Iroquoia, 1534-1701. East Lansing: Michigan State University Press, 2010.

Paulett, Robert. An Empire of Small Places: Mapping the Southeastern Anglo-Indian Trade, 1732-1795. Atlanta: University of Georgia Press, 2012.

Pauketat, Timothy R. Chiefdoms and Other Archaeological Delusions. Lanham: AltaMira Press, 2007.

Pearson, Bruce L. "Savannah and Shawnee: The End of a Minicontroversy." International Journal of American Linguistics 53:2 (Apr. 1987): 183-193.

Pederson, N., A.R. Bell, T.A. Knight, C. Leland, N. Malcomb, K.J. Anchukaitis, K. Tackett, J. Scheff, A. Brice, B. Catron, W. Blozan, and J. Riddle. "A long-term perspective on a modern drought in the American Southeast.” Environmental Research Letters 7:1 (January-March 2012) 014034,. doi:10.1088/17489326/7/1/014034.

Pendergast, James F. "The Massawomeck: Raiders and Traders into the Chesapeake Bay in the Seventeenth Century." Transactions of the American Philosophical Society, New Series 81:2 (1991): 1-101.

Pendleton, Wm. C. History of Tazewell County and Southwest Virginia, 1748-1920. Richmond: WC Hill Printing, 1920.

Perdue, Theda. Slavery and the evolution of Cherokee society, 1540-1866. Knoxville: University of Tennessee Press, 1979.

Perttula, Timothy K. "Caddoan Area Protohistory and Archaeology." In Between contacts and colonies: archaeological perspectives on the protohistoric Southeast, edited by Cameron B. Wesson, and Mark A. Rees, 49-66. Tuscaloosa: University of Alabama Press, 2002.

Peyton, A. Lewis. History of Augusta County, Virginia. Staunton, VA: Samuel M. Yost \& Son, 1883.

Phillips, Donald L., and Donald J. Shure. "Patch-Size on early Succession in Southern Appalachian Forest." Ecology 71:1 (Feb. 1990): 204-212.

Piker, Joshua. Okfuskee: A Creek Indian Town in Colonial America. New York: Harvard University Press, 2006.

Plane, Mark R. "Catawba Ethnicity: Identity and Adaptation on the English Colonial Landscape." North Carolina Archaeology 53 (Oct. 2004): 60-79. 
Platt, Steven G., Christopher G. Brantley, and Thomas R. Rainwater. "Native American Ethnobotany of Cane (Arundinaria spp.) in the Southeastern United States: A Review." Castanea 74:3 (2009): 271-285.

Platt, Steven G., and Christopher G. Brantley. "Canebrakes: An Ecological and Historical Perspective." Castanea 62:1 (Mar. 1997): 8-21.

Pluciennik, Mark. "Archaeology, Anthropology and Subsistence." The Journal of the Royal Anthropological Institute 7:4 (Dec. 2001): 741-758.

Pluckhahn, Thomas J., and Robbie Ethridge, eds. Light On The Path: The Anthropology and History of the Southeastern Indians. Tuscaloosa: University Of Alabama Press, 2006.

Pluckhahn, Thomas J., Robbie Ethridge, Jerald T. Milanich, and Marvin T. Smith. "Introduction.” In Light On The Path: The Anthropology and History of the Southeastern Indians edited by Thomas J. Pluckhahn, and Robbie Ethridge, 1-25. Tuscaloosa: University Of Alabama Press, 2006.

Plytwyn, Victor "A Dish with one spoon: the shared hunting grounds agreement in the Great Lakes and St. Lawrence Valley Region." in Papers of the Twenty-eighth Algonquian Conference, edited by David $\mathrm{H}$. Pentland, 210-11. Winnipeg: University of Manitoba, 1997.

Pollack, David, C.D. Hockensmith, and T.N. Sanders, eds. Late Prehistoric Research in Kentucky. Frankfort: Kentucky Heritage Council, 1984.

Pollack, David, and A. Gwynn Henderson. "Toward a model of Fort Ancient Society." In Fort Ancient cultural dynamics in the Middle Ohio Valley edited by A. Gwynn Henderson, and Emanuel Breitburg, 281-294. Madison: Prehistory Press, 1992.

Pollack, David, and George Crothers, eds. Archaeological Overview And Assessment Of New River Gorge National River, West Virginia Part One: Overview And Context Development. Research Report No. 8. Louisville: University of Kentucky and the Kentucky Heritage Council, 2005. . Part Two: Archaeological Assessment Of Selected Areas Within The New River Gorge National River. Research Report No. 8. William S. Webb Museum of Anthropology, University of Kentucky and Kentucky Archaeological Survey, 2005.

Pollitzer, William S. "The Physical Anthropology and Genetics of Marginal People of the Southeastern United States." American Anthropologist, New Series 74:3 (Jun., 1972): 719-734.

Potter, Stephen R. "Early English Effects on Virginia Algonquian Exchange and Tribute in the Tidewater Potomac." In Powhatan's Mantle: Indians in Colonial Southeast edited by Peter H. Wood, Gregory A. Waselkov, and M. Thomas Hatley, 215-242. Lincoln: University of Nebraska Press, 1989. . Commoners, Tribute, and Chiefs: The Development of Algonquian Culture in the Potomac Valley. Charlottesville, VA: University Press of Virginia, 1993.

Preston, David L. The Texture of Contact: European and Indian Settler Communities on the Frontiers of Iroquoia, 1667-1783. Lincoln: University of Nebraska Press, 2009.

Pullins, Stevan C. "Late Woodland Settlement Organization in Southwest Virginia's Appalachian Plateau." WVA 53:1-2 (Spring-Fall 2001): 36-51.

Pullins, Stevan C., C. Michael Anslinger, Andrew Bradbury, Alexandra Bybee, Flora Church, Darla Spencer, and William D. Updike. Late Prehistoric, Late Woodland, And Late Archaic/Early Woodland Transitional Occupations At The Burning Spring Branch Site On The Kanawha River, West Virginia. Contract Publication Series WV08-22. Prepared for: U.S. Army Corps of Engineers, Huntington District. Prepared by: Cultural Resource Analysts, Inc. CRAI Project No. W04H004, September 5, 2008.

Purrington, Burton L. "The Status and Future of Archaeology and Native American Studies in the Southern Appalachians." Appalachian Journal 5 (Autumn 1977):40-54.

Quimby, George I., Indian Culture and European Trade Goods: The Archaeology of the Historic Period in the Western Great Lakes Region. Madison: University of Wisconsin Press, 1966.

Rafferty, Sean M. and Rob Mann. The Culture of Smoking: The Archaeology of Tobacco Pipes in Eastern North America. Knoxville: University of Tennessee Press, 2005.

Raitz, Karl B., Richard Ulack, Thomas Leinbach. Appalachia: A Regional Geography: Land, People and Development. Boulder: West View Press, 1984: 68.

Ramenofsky, Ann F. Vectors of Death: The Archaeology of European Contact. Albuquerque: University of New Mexico Press, 1987.

Randolph, J. Ralph. British Travelers Among the Southern Indians, 1660-1763. Norman: University of Oklahoma Press, 1973.

Rankin, Robert L. "Tutelo phonology revisited: the Sapir transcriptions." Abstracts, American Anthropological Association, Annual Meeting, Los Angeles, CA, December, 1981. 
. "On Some Ohio Valley Siouan and Illinois Algonquian Words for 'Eight'." International Journal of American Linguistics, Vol. 51, No. 4 (Oct., 1985), pp. 544-547.

. "Siouan languages." In The Encyclopedia of Languages and Linguistics, edited by R. E. Asher. Oxford, Pergamon Press 7 (1994): 39-54.

. "Siouan Tribal Contacts and Dispersions Evidenced in the Terminology for Maize and Other Cultigens."

In Histories of Maize: Multidisciplinary Approaches to the Prehistory, Linguistics, Biogeography, Domestication, and Evolution of Maize, edited by John E. Staller, Robert H. Tykot, and Bruce F. Benz, 563-575. Academic Press, 2006.

."Siouan Tribes of the Ohio Valley: "Where did all those Indians come from?"” Electronic document (2007) at http://hdf.handlenet/1811/28545. Accessed August 2007.

Rankin, Robert, John Boyle, Randolph Graczyk, and John Koontz. "Synchronic and Diachronic perspective on 'word' in Siouan." in Word: a cross-linguistic typology, edited by R. M. W. Dixon and Alexandra Y. Aikhenvald, 180-204. Cambridge: Cambridge University Press, 2002.

Reese, Ted. Soft Gold: A History of the Fur Trade in the Great Lakes Region and its Impact on Native American Culture. Bowie, MD: Heritage Books, Inc., 2001.

Reid, Jon Philip, A Better Kind of Hatchet: Law Trade and Diplomacy in the Cherokee nation During the Early Years of European Contact. University Park: Pennsylvania State University Press, 1976.

Reid, William H. "Prehistoric Settlement and Subsistence in the Cumberland Gap Region of Southwest Virginia." Unpublished dissertation, American University, 1996.

Rice, James D. Tales from a Revolution: Bacon's Rebellion and the Transformation of Early America. Oxford: Oxford University Press, 2012.

Renfrew, Colin. "Introduction: Peer Polity Interaction and Socio-Political Change.” In Peer Polity Interaction and Socio-Political Change, edited by Colin Renfrew and John F. Cherry, 1-18. New York: Cambridge University Press, 1986.

Renfrew, Colin, and Cherry, John F. eds. Peer Polity Interaction and Socio-Political Change. Cambridge: Cambridge University Press, 1986.

Reppert, R. S. Kanawha Black Flint: Its Occurrence and Extent in WV. Morgantown: WVGES, 1978.

Rhoades, Matthew L. “Assarigoa's Line: Anglo-Iroquois Origins of the Virginia Frontier, 1675-1774.” Unpublished Dissertation, Syracuse University, 2000. . "Blood and Boundaries Virginia Backcountry Violence and the Origins of the Quebec Act, 1758-1775." West Virginia History: A Journal of Regional Studies, New Series, 3:2 (Fall 2009): 1-22.

Rice, Jim. Wilderness Acts: Environmental Change, Land Use, and the Rise of Chiefdoms in the Potomac Valley, 700 A.D. - 1608. OIEAHC Colloquium Paper, Sept. 12, 2001.

Rice, Otis K. The Allegheny Frontier: West Virginia Beginnings, 1730-1830. Lexington: University Press of Kentucky, 1970.

Rice, Otis K. West Virginia: The State and Its People. Parsons, WV: McClain Printing Co., 1972.

Rice, Prudence M., E. Pendleton Banks, and Robert E. Pace. "Contact Zones and Eastern United States Prehistory: Evidence from a Piedmont Rock Shelter” Southern Indian Studies 24 (Oct. 1972): 42-53.

Richardson, James B., III, David A. Anderson and Edward R. Cook. "The Disappearance Of The Monongahela: Solved?" Archaeology of Eastern North America 30 (2002): 81-96.

Richter, Daniel K. "War and Culture: The Iroquois Experience.” WMQ 3d ser. 40 (1983): 529-537. . "Ordeals of the Longhouse: The Five Nations in Early American History." In Beyond the Covenant Chain: The Iroquois and Their Neighbors in Indian North America, 1600-1800, edited by Daniel K. Richter, and James H. Merrell, 11-27. University Park, PA: The Pennsylvania State University Press, 1987. . "Cultural Brokers and Intercultural Politics: New York-Iroquois Relations, 1664-1701." The Journal of American History 75: 1 (June 1988): 40-67.

. The Ordeal of the Longhouse: The Peoples of the Iroquois League in the Era of European Colonization. Chapel Hill: University of North Carolina Press, 1992.

. "Whose Indian History?" WMQ 3rd Ser. 50: 2 Early American History: Its Past and Future (Apr. 1993): 379-393. . Facing East from Indian Country: A Native History of Early America. Cambridge: Harvard University Press, 2001.

Richter, Daniel K. and James H. Merrell, eds. Beyond the Covenant Chain: The Iroquois and Their Neighbors in Indian North America, 1600-1800. University Park, PA: The Pennsylvania State University Press, 1987. 
Ridley, David, S. Solomon, J.E. Barnes, V.D. Burlakov, T. Deshler, S. I. Dolgii, A. B. Herber, T. Nagai, R. R. Neely III, A. V. Nevzorov, C. Ritter, T. Sakai, B. D. Santer, M. Sato, A. Schmidt, O. Uchino, J. P. Vernier. "Total volcanic stratospheric aerosol optical depths and implications for global climate change." American Geophysical Union. 18 November 2014.

Rights, Douglas L. "The Trading Path to the Indians.” Southern Indian Studies 38 (Oct. 1989): 49-73.

Riley, Thomas J., et al. "Cultigens in Prehistoric Eastern North America: Changing Paradigms [and Comments and Replies]." Current Anthropology 31:5 (Dec. 1990): 525-541.

Robbins, Louise M. "The Identification of the Prehistoric Shawnee Indians - The Description of the population of the Fort Ancient Aspect." Ph.D. dissertation, Indiana University, Bloomington, 1968.

Robbins, Louise M., and Georg K. Neumann. The Prehistoric People of the Fort Ancient Culture of the Central Ohio Valley. Anthropological Papers 47. Museum of Anthropology, University of Michigan, Ann Arbor, 1972.

Roberts, Strother E. "Changes in the Genre: A Brief Survey of Early Mid-Atlantic Environmental Histories." Pennsylvania History: A Journal of Mid-Atlantic Studies 79:4 (2012): 345-356.

Rockman, Marcy, and James Steele, eds. Colonization of Unfamiliar Landscapes: The Archaeology of Adaptation. London: Routledge, 2003.

Rodabaugh, James H. “American Indian Ethnohistorical Materials in Ohio.” Ethnohistory 8:3 (Summer 1961): 242255.

Rodning, Christopher B. "Reconstructing the Coalescence of Cherokee Communities in Southern Appalachia." In The Transformation of the Southeastern Indians, 1540-1760, Edited by Robbie Ethridge, and Charles Hudson, 155-176. Jackson, MS: University Press of Mississippi, 2002.

. "William Bartram and the Archaeology of the Appalachian Summit." In Between contacts and colonies: archaeological perspectives on the protohistoric Southeast, edited by Cameron B. Wesson, and Mark A. Rees, 67-89. Tuscaloosa: University of Alabama Press, 2002. . "Place, Landscape, and Environment: Anthropological Archaeology in 2009." American Anthropologist 112:2 (2010): 180-190.

. "Chapter 9: Community Aggregation through Public Architecture: Cherokee Townhouses" In From Prehistoric Villages to Cities: Settlement Aggregation and Community Transformation, edited by Jennifer Birch, New York: Taylor and Francis, 2013.

Rowland, Kate Mason. "The Ohio Company." WMQ 1: 4 (Apr., 1893): 197-203.

Rountree, Helen C, ed. Powhatan Foreign Relations 1500-1722. Charlottesville, VA: University Press of Virginia, 1993.

. "The Powhatans and the English: A Case of Multiple Conflicting Agendas" in Powhatan Foreign Relations 1500-1722, edited by Helen C. Rountree, 173-205. Charlottesville, VA: University Press of Virginia, 1993.

. "Trouble Coming Southward: Emanantions through and from Virginia, 1607-1675." In The

Transformation of the Southeastern Indians, 1540-1760 edited by Robbie Ethridge, and Charles Hudson, 65-78. Jackson, MS: University Press of Mississippi, 2002.

Ruffner, Charles M., and Marc D. Abrams. "Dendrochronological Investigation of Disturbance History for a Native American Site in Northwestern Pennsylvania.” Journal of the Torrey Botanical Society 129:3 (Jul. - Sep. 2002): 251-260.

Rumsey, David and Meredith Williams. "Historical Maps in GIS" In Past Time, Past Place: GIS for History, edited by Anne K. Knowles, 1-18. Redlands, CA: ESRI Press, 2002.

Rundstrom, R. A. "GIS, indigenous peoples, and epistemological diversity." Cartography and Geographic Information Systems 22:1 (1995): 45-57.

Sabo, George, III. “The Quapaw Indians of Arkansas, 1673-1803.” In Indians of the Greater Southeast: Historical Archaeology and Ethnohistory, edited by Bonnie G. McEwan, 178-203. Gainesville: University Press of Florida, 2000.

Salisbury, Neal. "Toward the Covenant Chain: Iroquois and Southern New England Algonquians, 1637-1684." In Beyond the Covenant Chain: The Iroquois and Their Neighbors in Indian North America, 1600-1800, edited by Daniel K. Richter, and James H. Merrell, 61-73. University Park, PA: The Pennsylvania State University Press, 1987.

. "The Indians' Old World: Native Americans and the Coming of Europeans." WMQ 3rd Ser. 53:3 Indians and Others in Early America (Jul. 1996): 435-458.

Salmón, Enrique. "Kincentric Ecology: Indigenous Perceptions of the Human-Nature Relationship." Ecological Applications 10:5 (Oct. 2000): 1327-1332. 
Sapart, C. J., et al. "Natural and anthropogenic variations in methane sources during the past two millennia." Nature 490 (4 Oct. 2012): 85-88.

Sapir, Edward. “A Tutelo Vocabulary.” American Anthropologist, New Series 15:2 (Apr.-Jun. 1913): 295-297.

Sapir, Edward, and Leo Joachim Frachtenberg. Minor vocabularies of Tutelo and Saponi. Bristol, Pa.: Evolution Pub., 2002, 1913.

Saunders, Rebecca. "Seasonality, Sedentism, Subsistence, and Disease in the Protohistoric: Archaeological versus Ethnohistoric Data along the Lower Atlantic Coast." In Between contacts and colonies: archaeological perspectives on the protohistoric Southeast, edited by Cameron B. Wesson, and Mark A. Rees, 32-48. Tuscaloosa: University of Alabama Press, 2002.

Saunt, Claudio. "The Indians' Old World." $W M Q 3^{\text {rd }}$ ser. Forum: Ethnogenesis. 68:2 (April 2011): 215-218.

Scaife, H. Lewis. History and Condition of the Catawba Indians of South Carolina. Philadelphia: Office of Indian Rights Association, 1896.

Scarry, C. Margaret and John F. Scarry. "Native American 'Garden Agriculture' in Southeastern North America." World Archaeology 37:2, Garden Agriculture (Jun. 2005): 259-274.

Schama, Simon. Landscape and Memory. New York: Vintage Books, 1995.

Schiavo, Anthony P. Jr., and Claudio R. Salvucci, eds. Iroquois Wars I: Extracts form the Jesuit Relations and primary sources from 1535 to 1650. Bristol, PA: Evolution Publishing, 2003.

Schmidt-Nowara, Christopher Ebert. "Borders and Borderlands of Interpretation." AHR 104:4 (Oct. 1999): 12261228.

Schutz, Noel William, Jr. "The Study of Shawnee Myth in an Ethnographic and Ethnohistorical Perspective." Unpublished disseration, Indiana University, 1975.

Sciulli, Paul W. "A Survey of Pathological Conditions in the Southwestern Pennsylvania Monongahela." Archaeology of Eastern North America 30 (2002): 39-57.

Scott, Gregory K. "A People of Consequence: The Shawnee, 1662-1789.” Unpublished PhD Dissertation, Syracuse University, 2007.

Rooney, Thomas P. "Deer impacts on forest ecosystems: a North American perspective." Forestry 74: 3 (2001) 201208.

Rooney, Thomas P., and Donald M. Waller. "Forest Dynamics and Ungulate Herbivory: From Leaf to Landscape: Direct and indirect effects of white-tailed deer in forest ecosystems." Forest Ecology and Management 181: 1-2 (3 August 2003): 165-176.

Seed, Patricia. "Taking Possession and Reading Texts: Establishing the Authority of Overseas Empires." $W M Q 3^{\text {rd }}$ Ser. 49: 2 (Apr. 1992): 183-209. . Ceremonies of Possession in Europe's Conquest of the New World, 1492-1640. New York: Cambridge University Press, 1995.

Seeman, M. F., and W.S. Dancey. "The Late Woodland Period in Southern Ohio: Basic Issues and Prospects" In Late Woodland Societies: Trade and Transformation Across the Midcontinent, edited by T.E. Emerson, D.L. McElrath, and A.C. Fortier, 583-611. Lincoln: University of Nebraska Press, 2000.

Sharp, Willam E. "Fort Ancient Farmers." In Kentucky Archaeology, edited by R. Barry Lewis, 161-182. Lexington: University Press of Kentucky, 1996.

Sheehan, Bernard. Savagism \& Civility: Indians and Englishmen in Colonial Virginia. New York: Cambridge University Press, 1980.

Shoemaker, Nancy. "How Indians Got to be Red." AHR (June 1997): 625-644. . "An Alliance between Men: Gender Metaphors in Eighteenth-Century American Indian Diplomacy East of the Mississippi." Ethnohistory 46:2 (Spring 1999): 239-263.

Shefveland, Kristalyn "Sic jurat transcendere montes ("Thus he swears to cross the mountains"): Alexander Spotswood, Virginian Exploration, and Native Diplomacy." Paper presented at American Society of Ethnohistory 59th Annual Meeting, 2012 New Orleans, La.

Shuck-Hall, Sheri M. "Alabama and Coushatta Diaspora and Coalescence in the Mississippian Shatter Zone." In Mapping the Mississippian Shatter Zone: The Colonial Indian Slave Trade and Regional Instability in the American South edited by Robbie Ethridge and Sheri Shuck-Hall, 250-271. Lincoln: University of Nebraska Press, 2009.

Sidbury, James and Jorge Cañizares-Esguerra. "Mapping Ethnogenesis in the Early Modern Atlantic." $W M Q 3^{\text {rd }}$ ser. Forum: Ethnogenesis 68: 2 (April 2011): 181-208. . "On the Genesis of Destruction, and Other Missing Subjects." $W M Q 3^{\text {rd }}$ ser. Forum: Ethnogenesis 68: 2 (April 2011): 240-246. 
Silver, Shirley, and Wick R. Miller. American Indian languages: cultural and social contexts. Tucson: University of Arizona Press, 1997.

Silver, Timothy. A new face on the countryside: Indians, colonists, and slaves in South Atlantic Forest, 1500-1800. Cambridge: Cambridge University Press, 1990.

Silverstein, Michael. "Dynamics of linguistic Contact." In Handbook of North American Indians, Volume 17: Languages, edited by William C. Sturtevant, 117-126. Government Printing Office, 1978.

Simpkins Daniel L. First Phase Investigations Of Late Aboriginal Settlement Systems In The Eno, Haw, And Dan River Drainages, North Carolina. Research Report No. 3. Research Laboratories of Anthropology and The University of North Carolina at Chapel Hill, 1985.

Simpkins, Daniel L., and Gary L. Petherick. Second Phase Investigations Of Late Aboriginal Settlement Systems In The Eno, Haw, And Dan River Drainages, North Carolina. Research Report No. 6. Research Laboratories of Anthropology and The University of North Carolina at Chapel Hill, 1986.

Simpson, Leanne. "Looking after Gdoo-naaganinaa: Precolonial Nishnaabeg Diplomatic and Treaty Relationships." Wicazo Sa Review 23:2 (Fall 2008): 29-42.

Simpson, Edward Gordon, Jr. "Pioneer Trails through Southeast Virginia." Unpublished Masters thesis for Virginia Polytechnic Institute and State University, Blacksburg, 1971.

Sioui, George, and Sheila Fischman, trans. For an Amerindian Autohistory: An Essay on the Foundations of a Social Ethic. Montreal: McGill Queen's University Press, 1992.

Smalley, Andrea L. ““'The Liberty of Killing a Deer”: Histories of Wildlife Use and Political Ecology in Early America.” Dekalb, IL: Northern Illinois University, unpublished Dissertation, 2005.

Smith, Brian D. "Introduction: Indigenous North American Societies and the Environment." In The Subsistence Economies of Indigenous North American Societies: A Handbook, edited by Bruce D. Smith, 1-10. Washington, DC: Smithsonian Institution Scholarly Press, 2011. . "Shaping the Natural World: Patterns of Human Niche Construction by Small-Scale Societies in North America." In The Subsistence Economies of Indigenous North American Societies: A Handbook edited by Bruce D. Smith, 593-610. Washington, DC: Smithsonian Institution Scholarly Press, 2011.

Smith, Eric Alden, and Mark Wishnie. "Conservation and Subsistence in Small-Scale Societies." Annual Review of Anthropology 29 (2000): 493-524.

Smith, Marvin T. Archaeology of Aboriginal Culture Change in the Interior Southeast: Depopulation during the Early Historic Period. Gainesville: University of Florida Press, 1987. . "Aboriginal Population Movements in the Early Historic Period Interior Southeast." In Powhatan's Mantle: Indians in Colonial Southeast edited by Peter H. Wood, Gregory A. Waselkov, and M. Thomas Hatley, 43-56. Lincoln: University of Nebraska Press, 1989. . "Aboriginal Depopulation in the Postcontact Southeast." In The Forgotten Centuries: Indians and Europeans in the American South, 1521-1704, edited by Charles Hudson and Carmen Chaves Tesser, 257275. Athens: University of Georgia Press, 1994.

. Coosa: The Rise And Fall Of A Southeastern Mississippian Chiefdom. Gainesville: University Press of Florida: 2000. . "Aboriginal Population Movements in the Postcontact Southeast." In The Transformation of the Southeastern Indians, 1540-1760, edited by Robbie Ethridge and Charles Hudson, 3-20. Jackson, MS: University Press of Mississippi, 2002.

Smithsonian Institute. "River Basin Survey, Bluestone Reservoir, West Virginia." Unpublished Manuscript, 2005.

Smithsonian Institute: Global Volcanism Program - Volcanoes of the World 4.3.1, Downloaded on 18 Oct 2014 at 09:36 PM, http://www.volcano.si.edu/search_eruption_results.cfm.

Snow, Dean R. "Wabanaki "Family Hunting Territories."” American Anthropologist, New Series 70:6 (Dec. 1968): $1143-1151$.

Snow, Dean R., and Kim M. Lamphear. "European Contact and Indian Depopulation in the Northeast: The timing of the first epidemics." Ethnohistory 35 (1988):15-33.

Snyder, Christina. Slavery in Indian Country: The Changing Face of Captivity in Early America. Cambridge, Harvard University Press, 2010.

Snyderman, George Simon. "Behind the tree of peace; a sociological analysis of Iroquois warfare." Unpublished master's thesis, University of Pennsylvania, 1948.

Solecki, Ralph S. "An Archaeological Survey of Two River basins in West Virginia." WVA 8 (May 1957): 3-28. Speck, Frank G. Ethnology of the Yuchi Indians. Originally published 1909. University of Nebraska Press, Lincoln, 2004. 
. "Mistassini Hunting Territories in the Labrador Peninsula." American Anthropologist, New Series 25:4 (Oct.-Dec. 1923): 452-471.

. "Siouan Tribes of the Carolinas as Known from Catawba, Tutelo, and Documentary Sources." American Anthropologist, New Series 37:2, Part 1 (Apr.-Jun., 1935): 201-225.

Speck, Frank G., and Claude E. Schaeffer. "The Deer and the Rabbit Hunting Drive in Virginia and the Southeast." Southern Indian Studies 2:1 (April 1950): 3-24.

. "Catawba Kinship and Social Organization with a Resume of Tutelo Kinship Terms." American Anthropologist, New Series, Vol. 44, No. 4, Part 1 (Oct. - Dec., 1942), pp. 555-575.

Spencer, Darla. "Corncob-Impressed Pottery in Southern West Virginia." Unpublished Manuscript, 2008. . "Evidence of Siouan Occupation" West Virginia Archaeologist (2009).

. "An Analysis of Late Prehistoric Pottery from Native American Villages in Southern West Virginia." Final Narrative Report, Grant No. 9022. Unpublished report, 2009. . "The Significance of Corncob-Impressed Pottery at Late Prehistoric Sites in Southern West Virginia." Unpublished manuscript, 2009.

Spencer, J. “Shawnee Folk-Lore.” The Journal of American Folklore 22:85. (Jul.-Sep. 1909): 319-326.

Spero, Laura Keenan. "'Stout, Bold, Cunning and the Greatest Travellers in America': The Colonial Shawnee Diaspora." Unpublished PhD Dissertation, University of Pennsylvania, 2010.

Sprague, Roderick. "Glass Trade Beads: A Progress Report.” Historical Archaeology 19 (197?): 87-105.

Squier, E.G. and Davis, E.H. "Ancient monuments of the Mississippi Valley Comprising Results of extensive Original Surveys and Explorations." Smithsonian Contributions to knowledge. V. 1. Washington D.C., 1848.

Stahle, David W., et al. "Tree-ring reconstructed megadroughts over North America since A.D. 1300." Climatic Change 83 (2007):133-149.

Stahle, David W., and Malcom K. Cleaveland. "Reconstruction and Analysis of Spring Rainfall over the Southeastern U.S. for the Past 1000 years." Bulletin of the American Meteorological Society 73:12 (Dec. 1992): 1947-1961.

Stahle, David W., Malcolm K. Cleaveland, Dennis B. Blanton, Matthew D. Therrell and David A. Gay. "The Lost Colony and Jamestown Droughts" Science, New Series, 280:5363 (Apr. 24, 1998), 564-567.

Stahle, David W., Falko K. Fye, Edward R. Cook, and R. Daniel Griffin. "Tree-ring reconstructed megadroughts over North America since A.D. 1300." Climate Change 83 (2007): 133-149.

Stark, William T. ed. The Archaeology of Social Boundaries. Washington, DC: Smithsonian Institution, 1998.

Starna,William A., George R. Hamell, and William L. Butts. "Northern Iroquoian Horticulture and Insect Infestation: A Cause for Village Removal.” Ethnohistory 31:3 (Summer 1984): 197-207.

Steckel, Richard H., Paul W. Sciulli, and Jerome C. Rose. "A Health Index from Skeletal Remains. " In The Backbone of History: Health and Nutrition in the Western Hemisphere, edited by Richard H. Steckel, and Jerome C. Rose, 61-93. Cambridge University Press, 2008.

Steele, Ian. Warpaths: Invasions of North America. New York: Oxford University Press, 1994. . "Shawnee Origins of Their Seven Years' War." Ethnohistory 53:4 (Fall 2006): 657-687.

Stojanowski, Christopher M. Bioarchaeology of Ethnogenesis in the Colonial Southeast. Gainesville: University Press of Florida, 2010.

Sturtevant, William C. "Siouan Languages in the East." American Anthropologist, New Series 60:4 (Aug. 1958): 738-743.

Sullivan, Lynne P., and Susan C. Prezzano. “A Conscious Appalachian Archaeology.” In Archaeology of Appalachian Highlands edited by Lynn P. Sullivan, and Susan C. Prezzano, 323-331. Knoxville: University of Tennessee Press, 2001.

Sullivan, Lynne P. "Shell Gorgets, Time, and the Southeastern Ceremonial Complex in Southeastern Tennessee." In Southeastern Ceremonial Complex: Chronology, Content, Contest edited by Adam King, 88-106. Tuscaloosa: University of Alabama Press, 2007.

Surface-Evans, Sarah L. "Hunter-gatherer cultural landscapes: A case study for a GIS-based reconstruction of the Shell Mound Archaic in the Falls of the Ohio Region of Indiana and Kentucky." Unpublished PhD dissertation, Michigan State University, 2009.

Sutton, Mark Q., and E. N. Anderson. Introduction to Cultural Ecology. Walnut Creek, CA: AltaMira Press, 2004. Swanton, John R. A New Siouan Dialect. Cedar Rapids, Iowa: The Torch press, 1909. . Early History of the Creek Indians and Their Neighbors. Originally published in 1922 by the Smithsonian Institution (Bureau of American Ethnology, Bulletin 73). The University Press of Florida, Gainesville, 1998. 
. "Siouan Tribes and the Ohio Valley." American Anthropologist 45 (1943): 49-66.

. The Indians of the Southeastern United States. Washington, D.C.: Smithsonian Institution, Bureau of American Ethnology, Bulletin 137, 1946.

Sweet, James H. "The Quiet Violence of Ethnogenesis." $W M Q 3^{\text {rd }}$ ser. Forum: Ethnogenesis 68: 2 (April 2011): 209-214.

Tamburro, Paul René. "Ohio Valley Native Americans Speak: Indigenous Discourse on the Continuity of Identity." Unpublished dissertation, Indiana University, 2006.

Tanner, Adrian. "The New Hunting Territory Debate: An Introduction to Some Unresolved Issues." Anthropologica, New Series, 28:1/2, À qui appartient le castor? Les régimes fonciers algonquins du nord remis en cause / Who Owns the Beaver? Northern Algonquian Land Tenure Reconsidered (1986): 19-36.

Tanner, Helen Hornbeck. "The Land and Water Communication Systems of the Southeastern Indians." In Powhatan's Mantle: Indians in Colonial Southeast edited by Peter H. Wood, Gregory A. Waselkov, and M. Thomas Hatley, 27-42. Lincoln: University of Nebraska Press, 1989.

Thomas, Cyrus. Catalog of Prehistoric Works East of the Rocky Mountains. Bulletin No. 12, Washington, D.C.: Bureau of American Ethnology, Smithsonian Institution, 1891.

Thomason, Sarah Grey. "Linguistic areas and language history." Revised version of presentation, Conference on Language Contacts in Groningen, Netherlands, November 1999.

Thornton, Russell. The Cherokees: A Population History. Lincoln: University of Nebraska, 1990.

Toffin, Gérard. "Ecology and Anthropology Of Traditional Dwellings." Traditional Dwellings and Settlements Review 5:2 (Spring 1994): 9-20.

Tooker, William Wallace. "The Algonquian Appellatives of the Siouan Tribes of Virginia.” American Anthropologist 8:4 (Oct. 1895): 376-392. . "The Problem of the Rechahecrian Indians of Virginia." American Anthropologist 11:9 (Sep. 1898): 261270.

. The Algonquian names of the Siouan tribes of Virginia: with historical and ethnological notes. New York: F.P. Harper, 1901.

Toupal, Rebecca S. "Cultural Affiliation Study: New River Gorge National River and Gauley River National Recreation Area, West Virginia." Prepared with: Bureau of Applied Research in Anthropology, University of Arizona, Northeast Region Ethnography Program, National Park Service. Boston, MA: February 2009.

Trelease, Allen W. Indian Affairs in Colonial New York: The Seventeenth Century. Lincoln: University of Nebraska Press, 1960.

Trudel, Marcel. Donald H. Kent, trans. "The Jumonville Affair, The French perspective of the Jumonville skirmish and the prelude to the Battle at Fort Necessity." Reprint from Pennsylvania History 21: 4 (October 1954), Fort Washington, PA: Eastern National, 1989.

Turgeon, Laurier. "The Tale of the Kettle: Odyssey of an Intercultural Object." Ethnohistory 44:1 (Winter 1997): 129.

Turner, E. Randolph. "The Archaeological Identification of Chiefdom Societies in Southwestern Virginia." In Upland Archaeology in the East: A Symposium, edited by Clarence R. Geier, Michael B. Barber, and George A. Tolley, 271-281. Harrisonburg, VA, 1981.

Turner, Monica G. Landscape Ecology in North America: Past, Present, and Future. Ecology 86: 8 (Aug. 2005): 1967-1974.

Unknown. An Indian Old Field in Washington's Round Bottom Lands. West Virginia Archaeologist 3 (Oct. 1950): 9-10.

Unkonwn. “Aboriginal Man in West Virginia.” WVA 1 (1949): 1.

Usner, Daniel H., Jr. “Borderlands.” In A Companion to Colonial America, edited by Daniel Vickers, 408-424. Malden, MA: Blackwell Publishing, 2006.

Van Kirk, Sylvia. Many Tender Ties: Women in Fur Trade Society, 1670-1870. Norman, Ok.: 1980.

Vecsey, Christopher. Iroquois Land Claims. Syracuse, NY: Syracuse University Press, 1988.

Vest, Jay Hansford C. "From Nansemond to Monacan: The Legacy of the Pochick-Nansemond among the Bear Mountain Monacan.” American Indian Quarterly 27:3/4, Special Issue: Urban American Indian Women's Activism (Summer-Autumn, 2003): 781-806. . "An Odyssey among the Iroquois: A History of Tutelo Relations in New York." American Indian Quarterly 29:1-2 (Winter-Spring 2005): 124-155. . "Crossing Paths Intersections between Louis Michel and Monacan Oral Traditions." Native South 2 (2009): 163-174. 
Voegelin, C. F., and E. W. Voegelin. "Shawnee Name Groups.” American Anthropologist, New Series 37:4, Part 1 (Oct.-Dec., 1935): 617-635.

Vojta, Jaroslav, and Lucie Drhovska. “Are abandoned wooded pastures suitable refugia for forest species?” Journal of Vegetation Science 23 (2012): 880-891.

Wagner, Gail E. "Fort Ancient Subsistence: The Botanical record." WVA 35:2 (Fall 1983): 27-39.

Wagner, Günter. Yuchi Tales. Vol. XIII. New York: G. E. Stechert and Co. 1931.

Wall, Helena M. "Confessions of a British North Americanist: Borderlands Historiography and Early American History." Reviews in American History 25:1 (Mar. 1997): 1-12.

Wall, Robert D. "Protohistoric Settlement of the Maryland Plateau Region: An Overview." In Upland Archaeology in the East. Symposium 2. Cultural Resources Report No. 5. June 1984: 180-189.

. "Archaeological Investigations at 46GB44 Greenbrier County, West Virginia.” WVA 41:2 (Fall 1989): 115.

Wallace, Anthony F. C. The Death and Rebirth of the Seneca. New York: Vintage Books, 1969.

Wallace, Paul A.W. Indian Paths of Pennsylvania. Harrisburg, PA: Pennsylvania Historical and Museum Commission, 1971.

. The Iroquois Book of Life: White Roots of Peace. Sante Fe, NM: Clear Light Publishers, 1994.

Ward, H. Trawick. "Burials, Features, and Structures." In Archaeology of the Historic Occaneechi Indians, edited by H. Trawick Ward and R. P. Stephen Davis, Jr. Southern Indian Studies 36-37 (Oct. 1988): 11-30.

Ward, H. Trawick and R. P. Stephen Davis, Jr. "Summary and Conclusions." In Archaeology of the Historic Occaneechi Indians, edited by H. Trawick Ward and R. P. Stephen Davis, Jr. Southern Indian Studies 3637 (Oct. 1988): 118-122. . Indian Communities on the North Carolina Piedmont: A.D. 1000 to 1700. Monongraph No. 2, Research Laboratories of Anthropology, the University of North Carolina, Chapel Hill, 1993.

. Time Before History: The Archaeology of North Carolina. Chapel Hill: The University of North Carolina Press, 1999.

. "Tribes and Traders on the North Carolina Piedmont, A.D. 1000-1710." In Societies in Eclipse: Archaeology of the Eastern Woodlands Indians, A. D. 1400-1700, edited by David S. Brose, C. Wesley Cowin, and Robert Mainfort, Jr., 125-141. Washington, D. C.: Smithsonian Institution Press, 2001.

Waring, Antonio J. "The DeLuna Expedition and Southeastern Ceremonial." American Antiquity 11:1 (1945): 5758.

Warren, Stephen. The Worlds the Shawnees Made: Migration and Violence in Early America. Chapel Hill: University of North Carolina Press, 2014.

Warren, Stephen, and Randolph Noe. "The Greatest Travelers in America”: Shawnee Survival in the Shatter Zone. In Mapping the Mississippian Shatter Zone: The Colonial Indian Slave Trade and Regional Instability in the American South edited by Robbie Ethridge, and Sheri Shuck-Hall, 163-187. Lincoln: University of Nebraska Press, 2009.

Waselkov, Gregory A. "Evolution Of Deer Hunting In The Eastern Woodlands.” Midcontinental Journal of Archaeology 3:1 (Spring 1978): 15-34.

. "Seventeenth Century Trade in the Colonial Southeast." Southeastern Archaeology 8 (1989): 117-33. . "Indian Maps of the Colonial Southeast." In Powhatan's Mantle: Indians in Colonial Southeast edited by Peter H. Wood, Gregory A. Waselkov, and M. Thomas Hatley, 435-502. Lincoln: University of Nebraska Press, 1989.

Webb, Stephen Saunders. 1676: The End of American Independence. Syracuse: Syracuse University Press, 1984.

Webb, William S., et al. "Prehistoric Indians of the Ohio Valley." Ohio State Archaeological History Quarterly 61 (1952): 173-195.

Welch, Paul D. "Political Economy in Late Prehistoric Southern Appalachia." In Archaeology of Appalachian Highlands, edited by Lynn P. Sullivan, and Susan C. Prezzano, 222-237. Knoxville: University of Tennessee Press, 2001.

Weslager, C. A. "Monongahela Woodland Culture and the Shawnee." Pennsylvania Archaeologist XVIII (1948): 19-22.

Wesson, Cameron B. "Prestige Goods, Symbolic Capital, and Social Power in the Protohistoric Southeast." In Between contacts and colonies: archaeological perspectives on the protohistoric Southeast, edited by Cameron B. Wesson, and Mark A. Rees, 110-125. Tuscaloosa: University of Alabama Press, 2002.

Wesson, Cameron B. and Mark A. Rees, eds. Between contacts and colonies: archaeological perspectives on the protohistoric Southeast. Tuscaloosa: University of Alabama Press, 2002. 
. "Protohistory and Archaeology: An Overview." In Between contacts and colonies: archaeological perspectives on the protohistoric Southeast, edited by Cameron B. Wesson, and Mark A. Rees, 1-11. Tuscaloosa: University of Alabama Press, 2002.

White, Richard. The Roots of Dependency: Subsistence, Environment, and Social Change among the Choctaws, Pawnees, and Navajos. University of Nebraska Press, 1983.

. Middle Ground: Indians, Empires, and Republics in the Great Lakes Region, 1650-1815. New York: Cambridge University Press, 1991.

. "Foreword." In Placing History: How Maps, Spatial Data, and GIS are Changing Historical Scholarship, edited by Anne Kelly Knowles, ix-xii. Redlands, CA: ESRI, 2008.

Whitehead, Neil L. "Tribes make States and States Make Tribes: Warfare and the Creation of Colonial Tribes and States in Northeastern South America." In War in the Tribal Zone: Expanding States and Indigenous Warfare, edited by R. Brian Ferguson and Neil L. Whitehead, 127-150. Santa Fe: School of American Research Press, 1992.

Whitney, G. G. "The History and Status of the Hemlock-Hardwood Forests of the Allegheny Plateau." Journal of Ecology 78:2 (Jun. 1990): 443-458.

Whitley, Thomas G., and Lacey M. Hicks. "A Geographic Information Systems Approach to Understanding Potential Prehistoric and Historic Travel Corridors." Southeastern Archaeology 22:1 (Summer 2003): 77 91.

Whyte, Thomas R. "Prehistoric Sedentary Agriculturalists in the Appalachian Summit of Northwestern North Carolina." North Carolina Archaeology 52 (Oct. 2003): 1-19.

Wilburn, Hiram C. "Nununyi, the Kituhwas, of Mountain Indians and the State of North Carolina." Southern Indian Studies 11:2 (Oct. 1950): 54-64.

Wilcox, Frank. Ohio Indian Trails. 2nd ed. Kent, Ohio: Kent State University Press, 1970.

Wilkins, Gary R. "Cultural ecology of prehistoric mountaintop sites in the Kanawha Basin, West Virginia." Unpublished manuscript, MA Thesis, Department of Anthropology, University of Arkansas, Fayetteville, AR, 1977.

. "Prehistoric Mountaintop Occupations of Southern West Virginia." Archaeology of Eastern North America 6 (Summer 1978): 13-39. . "The Miller Site 946-Ja-55): A Fort Ancient Component." WVA 31 (Spring 1981): 2-19.

Williams, John A. West Virginia: a History, $2^{\text {nd }}$ ed. Morgantown, WV: West Virginia University, 2001.

Williams, Mark, ed. Hitchiti: An Early Georgia Language. LAMAR Institute Publication 21, LAMAR Institute, 1992.

Williams, Robert A. Linking Arms Together: American Indian Treaty Visions of Law and Peace, 1600-1800. New York: Routledge, 1999.

Willoughby, Charles C. "The Virginia Indians in the Seventeenth Century." American Anthropologist, New Series 9:1 (Jan.-Mar. 1907): 57-86.

Wilson, Jack Hubert, Jr. "A Study Of The Late Prehistoric, Protohistoric, And Historic Indians of the Carolina and Virginia Piedmont: Structure, Process, and Ecology.” Unpublished Dissertation. University of North Carolina Chapel Hill, 1983.

Witgen, Michael. An Infinity of Nations: How the Native New World Shaped Early North America. Philadelphia: University of Pennsylvania Press, 2012.

Witthoft, John and William A. Hunter. "The Seventeenth-Century Origins of the Shawnee." Ethnohistory 2:1 (Winter 1955):42-57.

Wolf, Eric R. Europe and the People Without History. Berkeley: University of California Press, 1982.

Wood, Douglas McClure. "'I Have Now Made a Path to Virginia': Outacite Ostenaco and the Cherokee-Virginia Alliance in the French and Indian War." West Virginia History, New Series 2:2 (Fall 2008): 31-60.

Wood, George A. "Celoron de Blainville and French Expansion in the Ohio Valley." The Mississippi Valley Historical Review 9:4 (March 1923): 302-319.

Wood, Karenne, and Diane Shields. The Monacan Indians: our story. Madison Heights, VA: Monacan Indian Nation, 1999.

Wood, Karenne. Markings on earth. Tucson: University of Arizona Press, 2001.

Wood, Peter H. "The Changing Population of the Colonial South, An overview by race and region, 1685-1790." In Powhatan's Mantle: Indians in Colonial Southeast edited by Peter H. Wood, Gregory A. Waselkov, and M. Thomas Hatley, 57-132. Lincoln: University of Nebraska Press, 1989.

Wood, Peter H., Gregory A. Waselkov, and M. Thomas Hatley, eds. Powhatan's Mantle: Indians in Colonial Southeast. Lincoln: University of Nebraska Press, 1989. 
Worboys, Michael, and Matt Duckham. “Time.” In GIS: A Computing Perspective, $2^{\text {nd }}$ ed. Boca Raton, FL: CRC Press, 2004: 359-382.

Worth, John E. "The Lower Creeks: Origins and Early History." In Indians of the Greater Southeast: Historical Archaeology and Ethnohistory, edited by Bonnie G. McEwan, 265-298. Gainesville: University Press of Florida, 2000.

. "Bridging prehistory and history in the Southeast: evaluating the utility of the acculturation concept." In Light On The Path: The Anthropology and History of the Southeastern Indians edited by Thomas J. Pluckhahn, and Robbie Ethridge, 196-206. Tuscaloosa: University Of Alabama Press, 2006.

Wright, Henry T. "Past Action Present and Future." Native South 2 (2009): 121-125.

Wright, J. Leitch Jr. The Only Land They Knew: The tragic story of the American Indians in the Old South. New York: Free Press, 1981

Wright, Robin M. “Anthropological Presuppositions of Indigenous Advocacy.” Annual Review of Anthropology 17 (1988): 365-390.

Wunder, John R., and Pekka Hämäläinen. "Of Lethal Places and Lethal Essays.” AHR 104:4 (Oct. 1999): 12291234.

Wylie, Kenneth C. "The Uses and Misuses of Ethnohistory.” Journal of Interdisciplinary History 3:4 (Spring 1973): 707-720.

Yarnell, Richard A., Thomas O. Maher, and M. Jean Black. A Bibliography Of Aboriginal Archaeological Plant Food Remains From Eastern North America: 1901-1991. Research Report No. 11. Research Laboratories of Anthropology, University of North Carolina at Chapel Hill, 1993.

Young, Mary E. "The Dark and Bloody but Endlessly Inventive Middle Ground of Indian Frontier Historiography." Journal of the Early Republic 13:2 (Summer 1993): 193-205.

Youse, Hillis J. “Excavation at Rolf Lee Farm Site 46-Ms-51.” WVA 18 (July 1965): 15-24. . "The Man Site, 46Lo5." WVA 25 (1976): 15-19. . "Marmet Village - Archaeological Site 46KA9." WVA 40:1 (Spring 1988): 47-49. . "Hansford Ballfield Site - 46KA104." WVA 44:1-2 (Spring/Fall 1992): 40-56.

Youse, Hillis J., and Robin M. King. "Four Earth Cooking Pits in the Kanawha River Valley.” WVA 38:1 (Spring 1986): 38-40.

Yuan, May. "Mapping Text." In The Spatial Humanities: GIS and the Future of Humanities Scholarship, edited by David J. Bodenhamer, John Corrigan, and Trevor M. Harris, 109-123. Bloomington: Indiana University Press, 2010.

Zedeño, María Nieves. "Landscapes, Land Use, and the History of Territory Formation: An Example from the Puebloan Southwest." Journal of Archaeological Method and Theory 4:1 (Mar., 1997): 67-103. 